This report was prepared as an account of work sponsored by an agency of the United States Government. Neither the United States Government nor any agency thereof, nor any of their employees, makes any warranty, express or implied, or assumes any legal liability or responsibility for the accuracy, completeness, or usefulness of any information, apparatus, product, or process disclosed, or represents that its use would not infringe privately owned rights. Reference herein to any specific commercial product, process, or service by trade name, trademark, manufacturer, or otherwise does not necessarily constitute or imply its endorsement, recommendation, or favoring by the United States Government or any agency thereof. The views and opinions of authors expressed herein do not necessarily state or reflect those of the United States Government or any agency thereof.

INEL-95/0095

(formerly EGG-WM-11415)

Revision 1

\title{
Preliminary Parametric Performance Assessment of Potential Final Waste Forms for Alpha Low-Level Waste at the Idaho National Engineering Laboratory
}

\author{
T. H. Smith
}

M. E. Sussman

Lockheed Idaho Technologies Company

\author{
J. Myers \\ S. M. Djordjevic \\ T. A. DeBiase \\ M. T. Goodrich \\ D. DeWitt \\ IT Corporation \\ Albuquerque, New Mexico
}

Published August 1995

\section{Idaho National Engineering Laboratory Lockheed Idaho Technologies Company Idaho Falls, Idaho 83415}

\author{
Prepared for the \\ U.S. Department of Energy \\ Assistant Secretary for Environmental Management \\ Under DOE Idaho Operations Office \\ Contract DE-AC07-94ID13223
}




\section{DISCLAIMER}

Portions of this document may be illegible in electronic image products. Images are produced from the best available original document. 



\section{ABSTRACT}

This report presents a preliminary parametric performance assessment (PA) of potential waste disposal systems for alpha-contaminated, mixed, low-level waste (ALLW) currently stored at the Transuranic Storage Area of the Department of Energy's (DOE's) Idaho National Engineering Laboratory. The ALLW, which contains from 10 to $100 \mathrm{nCi} / \mathrm{g}$ of transuranic (TRU) radionuclides, is awaiting treatment and disposal.

The purpose of this study was to examine the effects of several parameters on the radiological-confinement performance (in terms of projected receptor doses) of potential disposal systems for the ALLW. The principal emphasis was on the performance of final waste forms (FWFs). Three categories of FWF (cement, glass, and ceramic) were addressed by evaluating the performance of two limiting FWFs for each category. Performance at five conceptual disposal sites was evaluated to illustrate the effects of site characteristics on the performance of the total disposal system. Other parameters investigated for effects on receptor dose included inventory assumptions, TRU radionuclide concentration, FWF fracture, disposal depth, water infiltration rates, subsurface-transport modeling assumptions, receptor well location, intrusion scenario assumptions, and the absence of waste immobilization. These and other factors were varied singly and in some combinations.

The results indicate that compliance of the treated and disposed ALLW with the performance objectives given in DOE Order 5820.2A, Chapter III, depends on the assumptions made, as well as on the FWF and the disposal site. Some combinations result in compliance, while others do not. The implications of these results for decisionmaking relative to treatment and disposal of the INEL ALLW are discussed.

The report compares the degree of conservatism in this preliminary parametric PA against that in four other PAs and one risk assessment. All of the assessments addressed the same disposal site, but different wastes.

The report also presents a qualitative evaluation of the uncertainties in the PA and makes recommendations for further study. 


\section{EXECUTIVE SUMMARY}

\section{Introduction and Background}

This report presents a preliminary parametric performance assessment (PA) of potential waste disposal systems for alpha-contaminated, mixed, low-level waste (ALLW) currently stored at the Transuranic Storage Area (TSA) of the Department of Energy's (DOE's) Idaho National Engineering Laboratory (INEL). The ALLW contains from 10 to $100 \mathrm{nCi} / \mathrm{g}$ of transuranic (TRU) radionuclides and was generated primarily from 1970 through 1989.

The containers of ALLW are stored together with similar containers of TRU waste having $>100 \mathrm{nCi} / \mathrm{g}$ of TRU contamination. The volume of ALLW is estimated to be $24,413 \mathrm{~m}^{3}$, about $40 \%$ of the total volume of $63,729 \mathrm{~m}^{3}$ of the waste stored at the TSA (ALLW plus TRU waste). The waste is awaiting retrieval from storage, segregation into TRU waste versus ALLW, treatment, and disposal.

This PA was conducted to help evaluate potential treatment and disposal of the ALLW. The treatment evaluations are in their early stages. Feasibility studies on private sector treatment have been performed, but a final waste form (FWF) and a disposal site for the ALLW have not yet been selected.

The purpose of this study was to provide preliminary evaluations of the radionuclideconfinement performance of treated ALLW in various FWFs, in various disposal locations, and under a variety of assumptions. The study examined the effects of several parameters on the performance of the overall disposal system (consisting of the FWF, container, engineered barriers, and disposal site). The performance was evaluated in terms of the projected receptor doses and the other performance objectives of DOE Order 5820.2A, Chapter III.

The principal emphasis was on the performance of potential FWFs for the ALLW. Three broad categories of FWF (cement, glass, and ceramic) were addressed by evaluating the performance of two limiting FWFs for each category.

Performance at five possible disposal sites was evaluated to illustrate the effects site characteristics would have on the performance of the total disposal system. Several other parameters were investigated, both singly and in some combinations, to determine the effects on the calculated receptor dose. Not every combination of parameters was evaluated, however.

This study is a preliminary parametric PA. It is preliminary in that it is not the formal PA that will be prepared after a disposal site and the FWF(s) have been selected. It is parametric in that several parameters were varied to observe their effects on the results, rather than examining in detail one FWF and one disposal site. At this early time in the treatment-selection process, the evaluation of a wide range of options was needed to provide guidance on the selection of a FWF(s).

The study was performed in three phases, all of which are reported herein. In the first phase, PA computer runs were performed using an initial set of assumptions and parameter 
values. In the second and third phases, the earlier results were evaluated, then additional runs were made using refined assumptions or expanded ranges for some parameter values. The complete set of earlier runs was not repeated using the revised assumptions or parameter values.

This study has several potential uses:

- It will help in determining the optimum degree of ALLW immobilization to satisfy the performance objectives of DOE Order 5820.2A, while minimizing cost

- The results indicate the margin of compliance with the performance objectives and how the margin depends on various parameters

- The study identifies key parameters for which better data are needed.

\section{The Waste}

Most of the INEL ALLW was generated at the Rocky Flats Plant; the remainder, at several other DOE facilities, including the INEL. The waste consists of a wide variety of solid materials (e.g., sludges, paper, metals) contaminated with small amounts of TRU radionuclides and other actinides. Some of the ALLW, particularly the small fraction that is remote handled, also contains fission products and activated metals.

Most of the ALLW is mixed waste; i.e., it contains chemically hazardous constituents per the Resource Conservation and Recovery Act (RCRA). Treatment will be required under the Land Disposal Restrictions of RCRA.

Shipping records for the waste are incomplete, particularly concerning radionuclide information. As a result of this situation and the uncertain split of the waste between ALLW and TRU waste, there is some uncertainty about the inventory of radionuclides in the ALLW. Based on a set of assumptions, a simplified, limiting inventory was developed for initial use in the PA. For the second phase, a refined inventory for part of the waste was used in some computer runs. For the third phase, an inventory with additional refinements for part of the waste was used in additional runs.

Glass, cement, and ceramic were considered logical candidates for the FWF that will be chosen for the ALLW. To evaluate a wide range of potential variations within these three categories, two limiting FWFs were selected for evaluation from each category. Of each pair, one represents the more favorable characteristics in terms of contaminant immobilization; the other represents the less favorable characteristics. Table ES-1 lists the FWFs evaluated.

\section{Disposal Sites}

The disposal location for the treated ALLW has not been selected. To illustrate the effects of disposal site characteristics on the performance of the disposal system, five sites were used. Characteristics that are representative of the following sites were chosen: the Subsurface Disposal Area at the INEL, Site 14 in the central part of the INEL, the Radioactive Waste 
Table ES-1. Final waste forms selected for parametric evaluation.

\begin{tabular}{lll}
$\begin{array}{c}\text { Category of } \\
\text { FWF }\end{array}$ & More favorable FWF & Less favorable FWF \\
\hline \multirow{2}{*}{ Cement } & FUETAP & PCC \\
Glass & ASG & BSG \\
Ceramic & IEB4
\end{tabular}

Abbreviations: FUETAP - formed under elevated temperature and pressure (cement)

PCC - Portland cement/concrete

ASG - aluminosilicate glass

BSG - borosilicate glass

IEB - iron-enriched basalt

IEB4 - enhanced iron-enriched basalt.

Management Site of the DOE's Nevada Test Site, the E-Area Vault Disposal Facility at the Savannah River Site, and the $200 \mathrm{~W}$ Area burial grounds at the Hanford Site. The sites are referred to herein as Sites A, B, C, D, and E, respectively.

Site A was studied because it is adjacent to the TSA. Site B was selected because its underlying sedimentary beds in the vadose zone are among the thickest at the INEL and would provide substantial retardation of radionuclides. Site $C$ was picked because it has virtually no groundwater flow. Site D was studied in order to illustrate the effects of disposal of the INEL waste at a humid site. Site $\mathrm{E}$ was selected for study to illustrate the effects at another relatively well characterized, semiarid site.

The study of a disposal site in this PA does not imply in any way that the site will be the actual disposal location for the INEL ALLW.

\section{Scenarios, Transport Pathways, and Exposure Routes}

To assess the performance of ALLW disposal systems, two scenarios were evaluated.

The first is the undisturbed-waste scenario, i.e., the scenario in which no intrusion occurs (see Figure ES-1). After $100 \mathrm{yr}$ of institutional control, members of the public were assumed to use a drinking water supply well located $100 \mathrm{~m}$ downgradient from the edge of the disposal unit.

The full range of transport pathways was considered for this scenario. However, based on other studies, it was concluded that (a) groundwater transport with a full range of exposure routes and (b) atmospheric transport of radon with outdoor inhalation exposure would be the dominant contributors to dose. These pathways were evaluated (see Figure ES-2). 


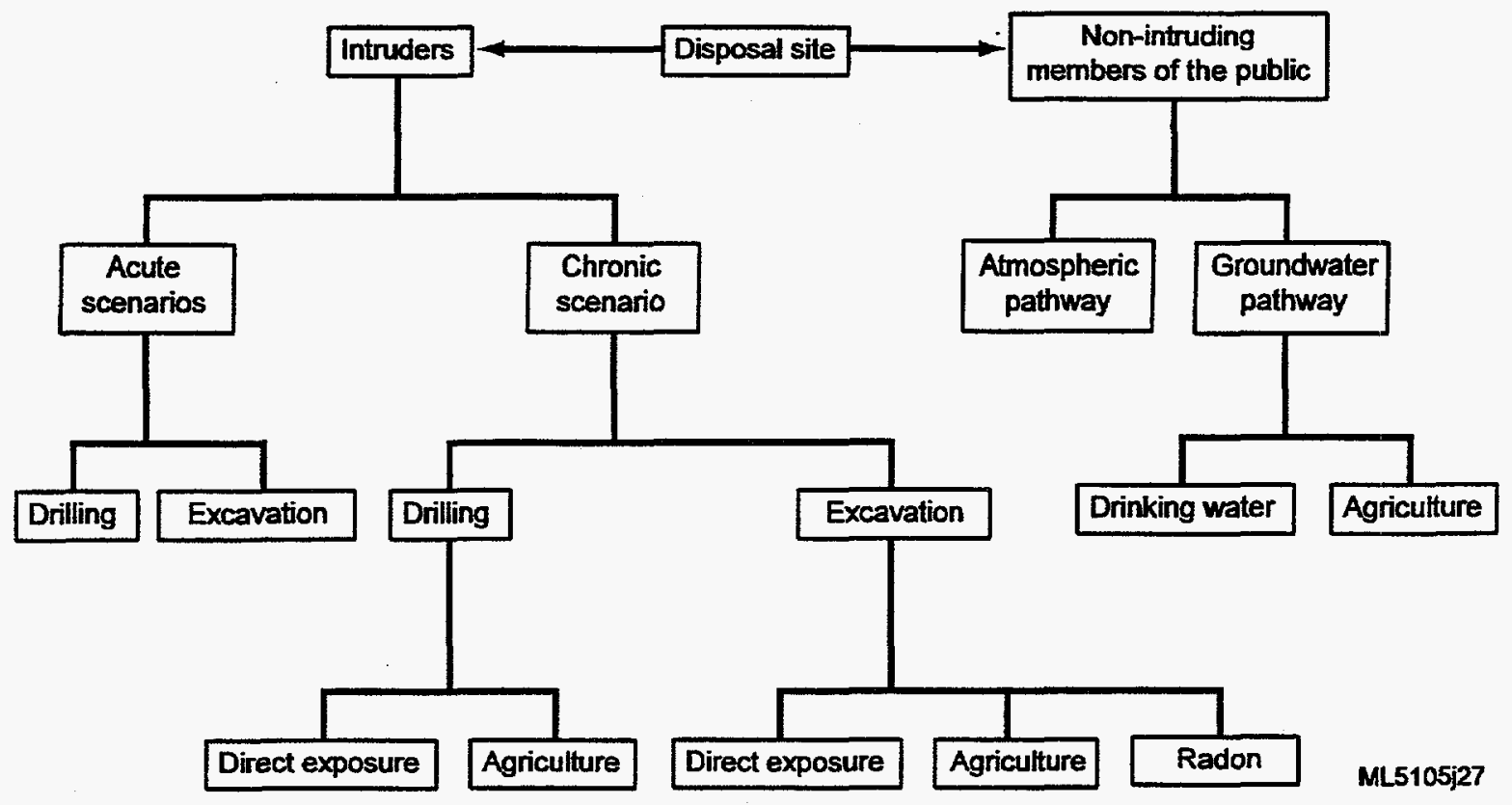

Figure ES-1. Scenarios evaluated.

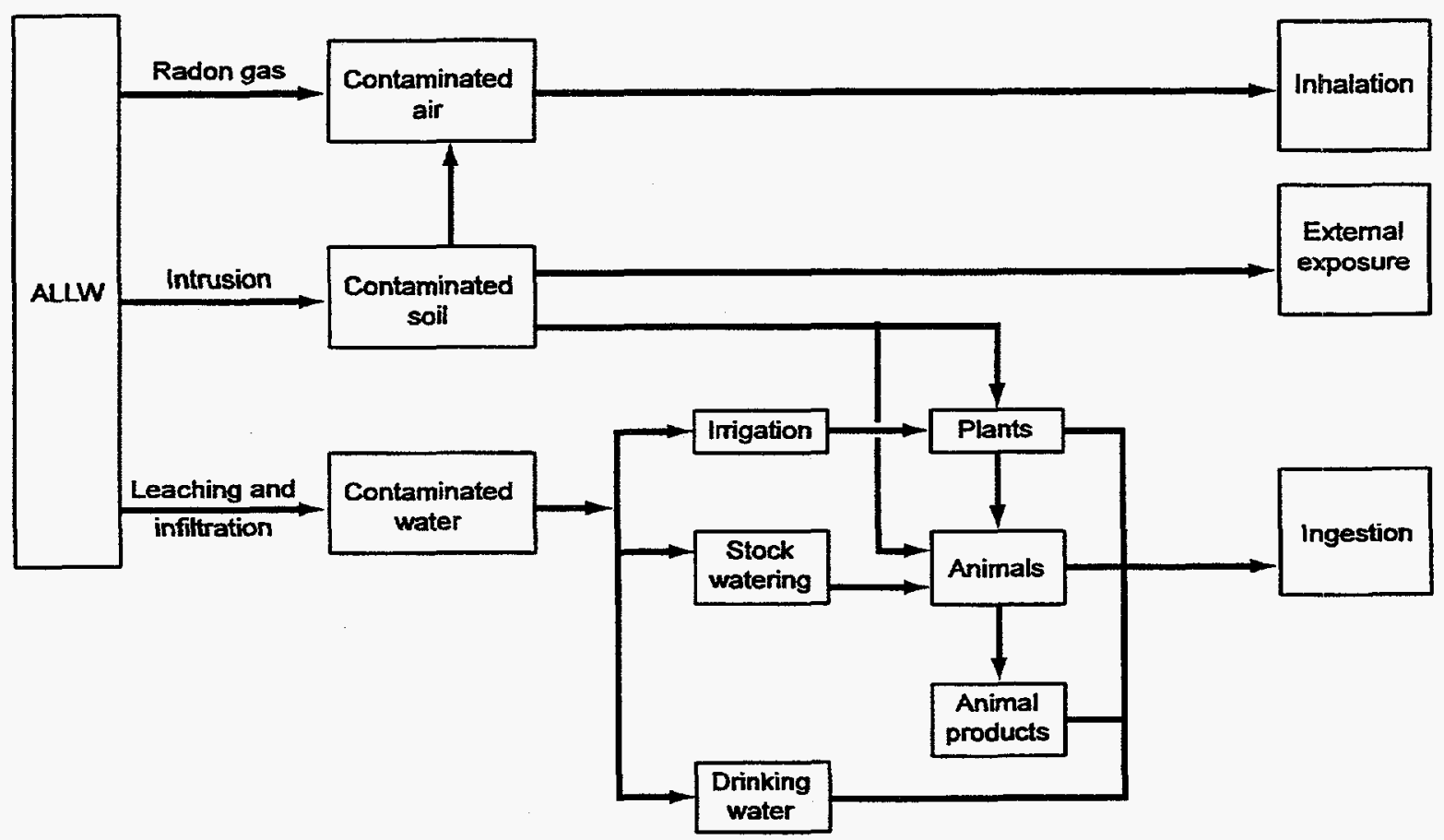

ML5051j27

Figure ES-2. Transport pathways and exposure routes evaluated. 
The groundwater transport simulations were continued until the peak radionuclide concentrations appeared at the receptor well, in some cases millions of years after closure of the disposal unit. The radon calculations covered times up to $167,000 \mathrm{yr}$, when the radon production rate peaks in this scenario.

The second scenario is the intrusion scenario, which is assumed to occur after the loss of institutional control. The scenario has four parts (see Figures ES-1 and ES-2). In the intruderdrilling scenario, an intruder drills a well directly through the source zone (the waste disposal unit). The drilling crew is exposed to the radionuclides in the exhumed waste/soil mixture from external radiation and inhalation. In the intruder-excavation scenario, waste/soil mixture is excavated during construction activities. Onsite workers are exposed by external radiation and inhalation. In the intruder-agriculture scenario, some of the waste/soil mixture is exhumed by the drilling or excavation activities just described. The mixture is spread over the ground surface, resulting in exposure by direct radiation and inhalation. In addition, radionuclides are taken up by crops and are ingested with foodstuffs of plant and animal origin. In the intruder-radon scenario, an intruder resides in a house with a basement that is constructed directly over the waste. Radon created by the radioactive decay of radionuclides in the waste is released from the FWF and diffuses through the soil and the concrete walls of the basement. The radon then circulates through the house and basement, where the indoor intruder receives a dose via the inhalation exposure route.

The waste was assumed to be buried in a large pit. The waste stack height was $22.7 \mathrm{ft}$ $(6.9 \mathrm{~m})$, corresponding to eight 55-gal drums. The top of the uppermost drums was either $5 \mathrm{ft}$ or $9 \mathrm{ft}$ belowgrade (two cases), with the void being backfilled with soil. An 11-ft-thick, multilayer, abovegrade cover was emplaced over the backfill. The cover was designed in accordance with Nuclear Regulatory Commission (NRC) and Environmental Protection Agency (EPA) guidelines to help ensure its integrity for $500 \mathrm{yr}$. After that time, it was assumed conservatively not to be present. (The belowgrade backfill was assumed to be present for all times.) Thus, the initial total thickness of geologic material over the waste was either $16 \mathrm{ft}$ or $20 \mathrm{ft}$, depending upon which of the two cases was being studied.

\section{Analysis of Performance}

Conceptual models were developed to describe the dominant physical and chemical processes that were assumed to occur in the various scenarios and transport pathways.

The conceptual models were implemented by a suite of numerical models. For the intruderradon scenario, the RESRAD computer code was used to perform the assessments. For the other intruder scenarios, the Generation-II (GENII) package of computer codes was used. For the groundwater-transport pathway in the undisturbed-waste scenario, the Variably Saturated 2-Dimensional Flow and Transport code (VS2DT) was used to model the flow of water through the source zone. The Disposal Unit Source Term (DUST) code was used to model the release of radionuclides and their transport within the source zone. Flow and transport in the vadose zone (below the waste disposal pit) and in the saturated zone were evaluated using analytical solutions. Finally, exposure routes were evaluated using the Dose Integrated Over Ten Thousand Years (DITTY) code of the GENII package. For radon transport in the undisturbed-waste scenario, analytical solutions were used. 
The performance-related characteristics of the six FWFs, such as leach rates, were estimated using a combination of the limited existing laboratory data and theoretical calculations. Site characteristics were estimated using a combination of the results of questionnaires completed by site representatives and data found in published reports.

For the undisturbed-waste scenario-groundwater transport pathway, one generic model was used to model radionuclide transport at the five sites, which have widely varying characteristics. Therefore, the uncertainties in the predicted doses via this pathway, in particular, are sizeable.

\section{Results and Conclusions}

About 120 runs were made, using the numerical models, to evaluate performance in the undisturbed-waste scenario and the intrusion scenarios. Because of the large volume of results, only the conclusions drawn from those results are presented here. Based on the cases studied, the conclusions are as listed below.

- Compliance with the performance objectives of DOE Order 5820.2A depends not only on the FWF and the disposal site, but also on the overall conservatism of the assumptions in the PA.

- For the undisturbed-waste scenario-atmospheric transport pathway:

- $\quad$ All FWFs at all sites would be expected to comply with the performance objectives. Although no existing standards apply to outdoor releases of radon from disposed ALLW, the predicted values for radon flux, concentration, and dose are much less than the nonapplicable standards.

- For the undisturbed-waste scenario-groundwater transport pathway, compliance with the performance objective on dose:

- At Site C, any FWF would be expected to comply.

- $\quad$ At Sites A and B, nearly all FWFs would be expected to comply under nearly all assumptions. Possible exceptions under very conservative assumptions are the untreated FWF and (if no credit is taken for the chemical interactions of the radionuclides with the cement) the PCC and FUETAP FWFs.

- $\quad$ At Sites D and E, only IEB4 at Site E satisfies the performance objective, and that by only a very small margin.

- The dominant radionuclide contributing to dose is generally the Am-241 decay chain for Sites A, B, and C. For Sites D and E, the dominant contributor is the U-233 decay chain in most cases.

- The results depend particularly on the assumed values for the leach rate of the FWF, the infiltration rate, and the $K_{d}$ values at the particular site. 
- For the undisturbed-waste scenario-groundwater transport pathway, compliance with the performance objective on groundwater protection:

- $\quad$ All FWFs pass at Sites A, B, and C.

- $\quad$ All FWFs fail at Sites D and E.

As stated previously, the use of one generic model for the groundwater pathway and the disposal unit design in addressing five sites with widely varying characteristics limits the accuracy to which the current method can predict radionuclide transport and dose via this pathway. Therefore, the conclusions should be viewed as scoping results only and subject to later confirmation by site-specific modeling.

- For the intrusion scenarios:

- To the accuracy of these analyses, the results of the intrusion scenario were assumed to be independent of the location of waste disposal.

- For the intruder-drilling scenario, all FWFs and burial depths studied satisfy the performance objective. (The one exception was the highly unlikely refinedinventory case in which the intruder drills into the remote-handled waste rather than into the contact-handled waste or an assumed homogeneous mixture of remote-handled and contact-handled waste.)

- For the intruder-excavation scenario, all FWFs and burial depths studied satisfy the performance objective. (The one exception was the case involving TRU waste, not ALLW).

- For the intruder-agricultural scenario with the 5-ft burial depth (16-ft total cover), all FWFs fail to satisfy the performance objective.

- For the intruder-agricultural scenario with the 9-ft burial depth (20-ft total cover), the PCC, FUETAP, BSG, ASG, and untreated waste satisfy the performance objective (assuming no intrusion into the remote-handled waste). The IEB and IEB4 FWFs pass if (a) the refined inventories are used or (b) a refined particle size distribution is used to reflect the breakup of the FWF as a result of the intrusion.

- $\quad$ For the intruder-radon scenario, all FWFs pass.

- The dominant radionuclides contributing to dose are Cs-137 and Am-241 during the early period studied (e.g., $100 \mathrm{yr}$ postclosure) and Am-241 and Pu-239 for the later period ( $500 \mathrm{yr}$ postclosure). Separate runs confirmed that the times of 100 yr and 500 yr are the times of peak dose.

- The results depend particularly on the depth of burial (belowgrade), cover longevity, and radionuclide concentration in the FWF. 
- Improved immobilization of the radionuclides into a more concentrated FWF can degrade the intrusion performance by concentrating the source term, unless credit is taken for the likely larger particle sizes of the improved FWF when subjected to drilling.

\section{Recommendations for Decisionmaking}

The following observations and recommendations are offered, based on the information developed in this preliminary parametric PA:

- PA considerations should continue to be part of the waste treatment project. As the project moves forward and focuses more closely on specific sites and specific FWFs, the PA studies should become more focused. Several topics meriting further study have been identified.

- Disposal of the INEL ALLW at Site D or Site E or other sites with similar characteristics is not expected to satisfy the performance objectives, regardless of the FWF. However, the uncertainties in the current generic modeling of groundwater transport are particularly sizeable at Sites D and E.

- It is expected that disposal of the INEL ALLW at Sites A, B, or C or other sites with similar characteristics can satisfy the performance objectives.

- Disposal will need to be at least $9 \mathrm{ft}$ below grade.

- Credit may need to be taken for the chemical interactions in the PCC and FUETAP FWFs to predict satisfactory performance in the undisturbed-waste scenario-groundwater transport pathway.

- The improved radionuclide inventory or the refined particle size distribution may have to be used for the IEB and IEB4 FWFs to predict satisfactory performance in the intruder-agricultural scenario.

- Special provisions are expected to be needed for disposal of the remote-handled ALLW. Disposal of such waste in conventional containers in pits is not expected to satisfy the performance objectives. Possible provisions include disposing of such waste by intermediate-depth disposal or at a deep geologic repository. 


\section{CONTENTS}

ABSTRACT $\ldots \ldots \ldots \ldots \ldots \ldots \ldots \ldots \ldots \ldots \ldots \ldots \ldots \ldots \ldots \ldots \ldots \ldots \ldots \ldots \ldots \ldots \ldots \ldots$

EXECUTIVE SUMMARY $\ldots \ldots \ldots \ldots \ldots \ldots \ldots \ldots \ldots \ldots \ldots \ldots \ldots \ldots \ldots \ldots$ v

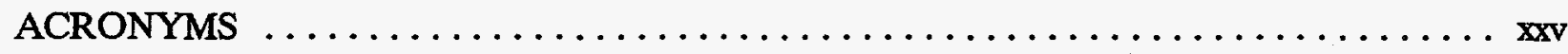

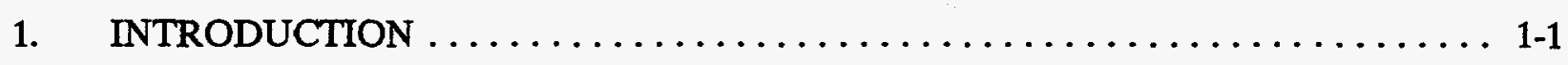

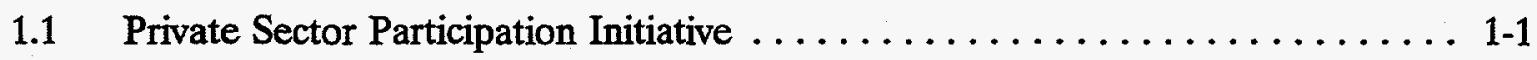

1.2 Purpose, Need for, Scope, and Use of Preliminary Parametric Performance

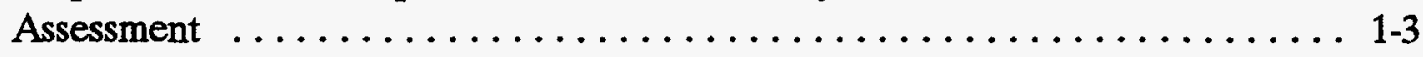

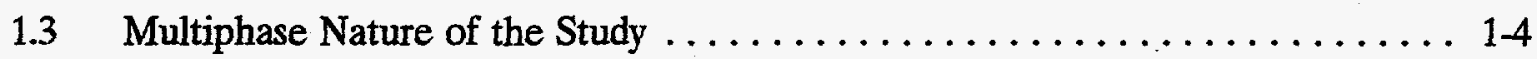

1.4 Requirements To Be Met in Formal Performance Assessment $\ldots \ldots \ldots \ldots$ 1-5

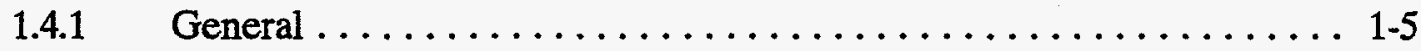

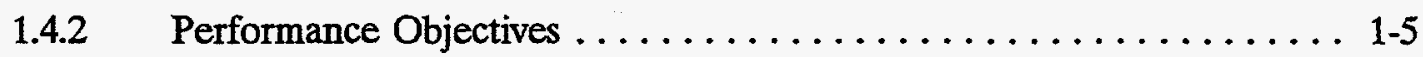

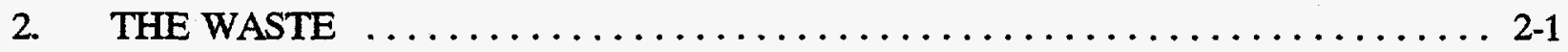

2.1 Radioactive Waste Management Complex $\ldots \ldots \ldots \ldots \ldots \ldots \ldots \ldots . . \ldots .1$

2.2 Brief Description of the Stored Alpha Low-Level Waste $\ldots \ldots \ldots \ldots \ldots$. $2-1$

2.3 Selection of Final Waste Forms for Parametric Evaluation $\ldots \ldots \ldots \ldots, 2-4$

2.4 Radionuclide Inventory in the ALLW $\ldots \ldots \ldots \ldots \ldots \ldots \ldots \ldots \ldots .4 .4$

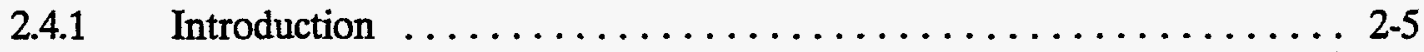

2.4.2 Simplified Radionuclide Inventory Used for Most of the

Computer Runs ......................... 2-6

2.4.3 Refined Inventory for Nonactinides ................ 2-11

2.4.4 Inventory with Additional Refinements for Nonactinides ....... 2-13

2.4.5 Refined Modeling of Untreated Waste $\ldots \ldots \ldots \ldots \ldots \ldots \ldots . . .15$

2.5 Radionuclide Screening of Nonactinides from Detailed Groundwater Pathway

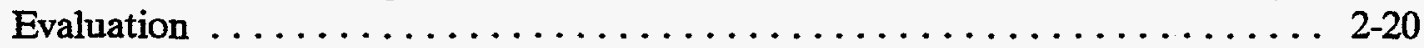

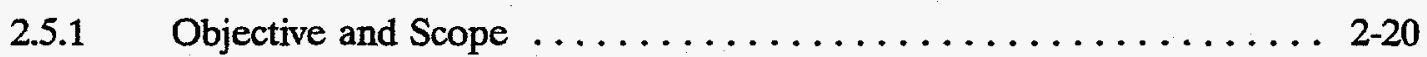

2.5.2 Approach and Generic Assumptions ................. 2-20

2.5.3 Screening Calculations for the Simplified Inventory .......... 2-21

2.5.4 Screening Calculations for the Inventory with Additional

Refinements ............................ 2-23 
3. THE DISPOSAL SITES $\ldots \ldots \ldots \ldots \ldots \ldots \ldots \ldots \ldots \ldots \ldots \ldots \ldots \ldots \ldots$

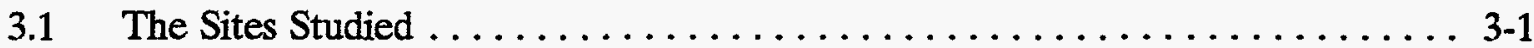

3.2 Site A (The Subsurface Disposal Area of the Radioactive Waste Management

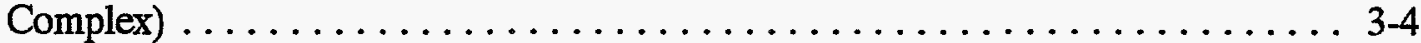

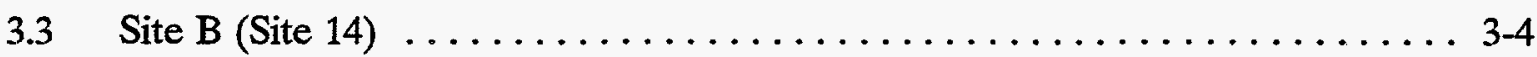

3.4 Site C (The Radioactive Waste Management Site at the Nevada Test Site) . . . 3-5

3.5 Site D (E-Area Vaults Disposal Facility at Savannah River Site) . . . . . . 3-5

3.6 Site E (200 W Area Burial Grounds at Hanford Site) $\ldots \ldots \ldots \ldots \ldots \ldots$

3.7 Sorption Coefficients for Radionuclides for Sites A, B, and C . . . . . . 3-6

3.8 Sorption Coefficients for Radionuclides for Site D . . . . . . . . . . 3-8

3.9 Sorption Coefficients for Radionuclides for Site $\mathrm{E} \ldots \ldots \ldots \ldots \ldots \ldots \ldots$

4. SCENARIOS, TRANSPORT PATHWAYS, AND EXPOSURE ROUTES

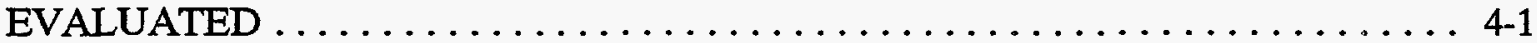

4.1 Introduction $\ldots \ldots \ldots \ldots \ldots \ldots \ldots \ldots \ldots \ldots \ldots \ldots \ldots \ldots \ldots \ldots \ldots$

4.2 Scenarios, Transport Pathways, Exposure Routes, and Receptors . . . . . . . . 4-2

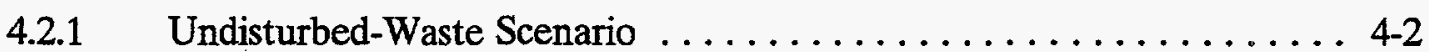

4.2.2 Intrusion Scenario . . . . . . . . . . . . . . . . $4-4$

$4.3 \quad$ Time Periods $\ldots \ldots \ldots \ldots \ldots \ldots \ldots \ldots \ldots \ldots \ldots \ldots \ldots \ldots \ldots$

5. EVALUATION OF PERFORMANCE-INTRODUCTION $\ldots \ldots \ldots \ldots \ldots \ldots . \ldots$

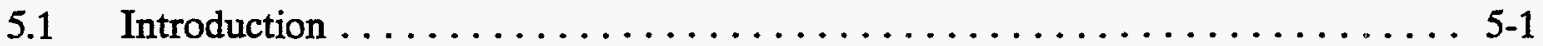

5.2 Model of Waste Disposal Pit $\ldots \ldots \ldots \ldots \ldots \ldots \ldots \ldots \ldots \ldots \ldots \ldots \ldots$

6. EVALUATION OF PERFORMANCE IN UNDISTURBED-WASTE SCENARIO-GROUNDWATER TRANSPORT PATHWAY $\ldots \ldots \ldots \ldots \ldots \ldots .6-1$

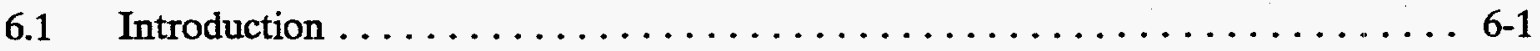

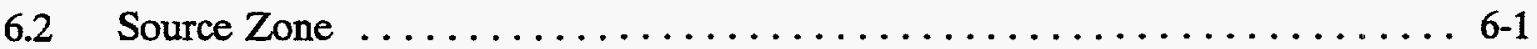


6.2.1 Conceptual Model for Flow and Transport $\ldots \ldots \ldots \ldots \ldots \ldots$ 6-1

6.2 .2 Numerical Model for Flow and Transport . . . . . . . . . . . . 6-4

6.2 .3 Assumptions and Parameter Values ................ 6-5

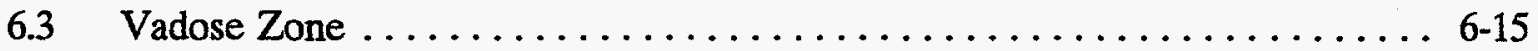

6.3.1 Conceptual Model for Flow and Transport $\ldots \ldots \ldots \ldots \ldots \ldots$ 6-15

6.3.2 Numerical Model for Flow and Transport .............. 6-15

6.3.3 Assumptions and Parameter Values ................ 6-16

6.4 Saturated Zone $\ldots \ldots \ldots \ldots \ldots \ldots \ldots \ldots \ldots \ldots \ldots \ldots \ldots \ldots \ldots$

6.4.1 Conceptual Model for Flow and Transport $\ldots \ldots \ldots \ldots \ldots \ldots$ 6-17

6.4.2 Numerical Model for Flow and Transport .............. 6-17

6.4.3 Assumptions and Parameter Values ................ 6-18

6.4.4 Handling of Radioactive Decay and Ingrowth During Groundwater

Transport ......................... 6-18

7. EVALUATION OF PERFORMANCE IN UNDISTURBED-WASTE

SCENARIO-EXPOSURE ROUTES FOR GROUNDWATER TRANSPORT

PATHWAY $\ldots \ldots \ldots \ldots \ldots \ldots \ldots \ldots \ldots \ldots \ldots \ldots \ldots \ldots \ldots \ldots \ldots \ldots \ldots \ldots \ldots \ldots \ldots$

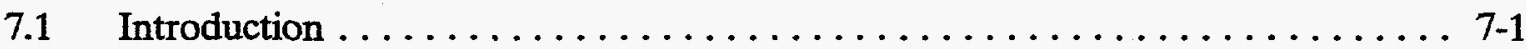

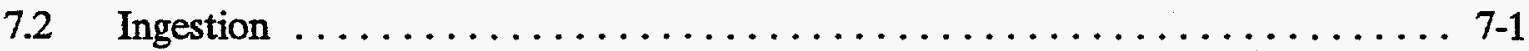

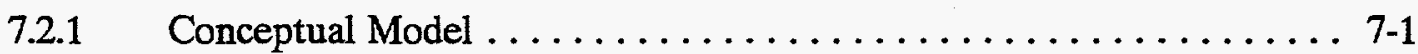

$7.2 .2 \quad$ Numerical Model . . . . . . . . . . . . . . . . . . . . . 7-1

7.2.3 Assumptions and Parameter Values ................ 7-2

7.2.4 Effective Dose Conversion Factors for Groundwater Pathway . . . . . . 7-3

8. EVALUATION OF PERFORMANCE IN UNDISTURBED-WASTE

SCENARIO-ATMOSPHERIC TRANSPORT PATHWAY (RADON TRANSPORT

AND RECEPTOR EXPOSURE) $\ldots \ldots \ldots \ldots \ldots \ldots \ldots \ldots \ldots \ldots \ldots \ldots \ldots \ldots$

$8.1 \quad$ Introduction $\ldots \ldots \ldots \ldots \ldots \ldots \ldots \ldots \ldots \ldots \ldots \ldots \ldots \ldots \ldots$

8.2 Conceptual Model $\ldots \ldots \ldots \ldots \ldots \ldots \ldots \ldots \ldots \ldots \ldots \ldots \ldots \ldots \ldots \ldots$

$8.3 \quad$ Numerical Model $\ldots \ldots \ldots \ldots \ldots \ldots \ldots \ldots \ldots \ldots \ldots \ldots \ldots \ldots . \ldots . \ldots . \ldots$

8.4 Assumptions and Parameter Values $\ldots \ldots \ldots \ldots \ldots \ldots \ldots \ldots \ldots . \ldots \ldots$

9. EVALUATION OF PERFORMANCE IN INTRUSION SCENARIOS ........ 9-1

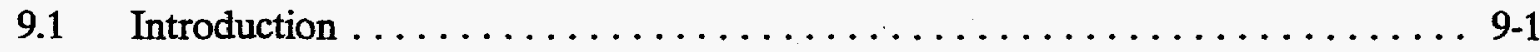


9.2.1 Conceptual Model . . . . . . . . . . . . . . . . . . 9-2

9.2.2 Numerical Model . . . . . . . . . . . . . . . . . . . .

9.2.3 Assumptions and Parameter Values ................ 9-3

9.3 Intruder-Excavation Scenario $\ldots \ldots \ldots \ldots \ldots \ldots \ldots \ldots \ldots \ldots$

9.3.1 Conceptual Model . . . . . . . . . . . . . . . . . . 9-4

9.3.2 Numerical Model . . . . . . . . . . . . . . . . . . . 9.4

9.3.3 Assumptions and Parameter Values ................ 9-5

9.4 Intruder-Agricultural Scenario $\ldots \ldots \ldots \ldots \ldots \ldots \ldots \ldots \ldots \ldots$

9.4.1 Conceptual Model . . . . . . . . . . . . . . . . . . 9-6

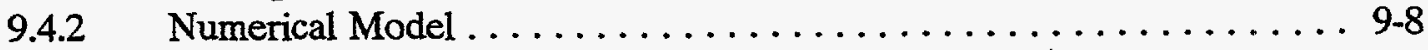

9.4.3 Assumptions and Parameter Values ................. 9-8

9.5 Intruder-Radon Scenario $\ldots \ldots \ldots \ldots \ldots \ldots \ldots \ldots \ldots \ldots \ldots \ldots$

9.5.1 Conceptual Model $\ldots \ldots \ldots \ldots \ldots \ldots \ldots \ldots \ldots \ldots \ldots \ldots \ldots . \ldots \ldots$

9.5.2 Numerical Model . . . . . . . . . . . . . . . . . . 9-11

9.5.3 Assumptions and Parameter Values ................ 9-11

9.5.4 Comparison of Calculational Method for Intruder-Radon Scenario against that for Radon in Undisturbed-Waste Scenario . . . . . . . 9-12

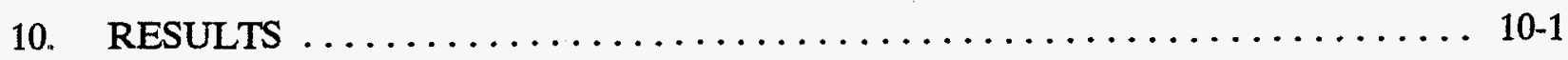

10.1 Introduction and Summary $\ldots \ldots \ldots \ldots \ldots \ldots \ldots \ldots \ldots \ldots \ldots \ldots \ldots$

10.2 Results for Undisturbed-Waste Scenario: Groundwater Pathway . . . . . . . 10-12

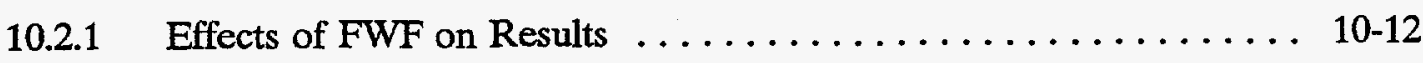

10.2.2 Effects of Disposal Site on Results ............... 10-13

10.2.3 Effects of TRU Radionuclide Activity Concentration on Results . . . 10-15

10.2.4 Effects of FWF Degradation on Results .............. 10-16

10.2.5 Effects of Water Infiltration Rate on Results . . . . . . . . . 10-18

10.2.6 Effects of Assumptions Concerning Vadose Zone Basalt on Results, Separately and Combined with Infiltration Rate . . . . . . . 10-19

10.2.7 Effects of Contaminant Sorption in Source Zone on Results, Separately and Combined with Infiltration Rate and Vadose Zone Basalt . . . . . . . . . . . . . . . . . . . . . . . 10-21

10.2.8 Effects of Far-Field Sorption Coefficients on Results . . . . . . . . 10-23

10.2.9 Effects of Distance to Receptor Well on Results . . . . . . . . . 10-25

10.2.10 Effects of Untreated Waste on Results ............... 10-25

10.2.11 Effects of FWF Leach Rates on Results . . . . . . . . . . . . 10-28

10.2.12 Effects of Time-Dependent Leach Rates on Results ......... 10-30 
10.2.13 Effects of Chemical Interactions within Cement Final Waste Forms on Results ............................ 10.31

10.2.14 Effects of Refined Inventory on Results .............. 10-34

10.2.15 Effects of Inventory with Additional Refinements on Results .... . 10-34

10.2.16 Effects of Revised Uranium and Thorium Inventories on Results .. 10-36

10.2.17 Effects of Vault-Type Disposal Facility on Results .......... 10-38

10.2.18 Reasons for Large Doses at Sites D and E ............. 10-39

10.2.19 Compliance with Performance Objective to Protect Groundwater Resources ........................... $10-46$

10.3 Results for Undisturbed-Waste Scenario: Atmospheric Pathway $\ldots \ldots \ldots$ 10-51

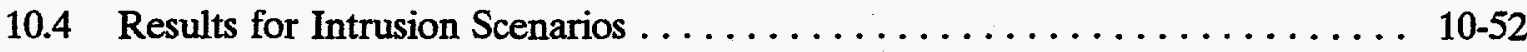

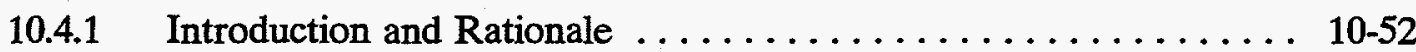

10.4.2 Effects of FWF on Results .................. 10-55

10.4.3 Effects of TRU Radionuclide Activity Concentration on Results ... 10-58

10.4.4 Effects of Disposal Depth on Results ............... 10-59

10.4.5 Effects of Untreated Waste on Results ............... 10-59

10.4.6 Effects of Refined Inventory on Results ............. 10-62

10.4.7 Effects of Inventory with Additional Refinements on Results . . . . . 10-63

10.4.8 Effects of Exposure Duration on Results for Intruder-Drilling

Scenario ........................... 10-65

10.4.9 Effects of Post-Disruption Particle Size Distribution of Final

Waste Form on Results .................... 10-66

10.4.10 Effects of Scenario Timing on Dose $\ldots \ldots \ldots \ldots \ldots \ldots \ldots \ldots$ 10-72

10.4.11 Dominant Radionuclide Contributors to Dose ............. 10-75

10.4.12 Results for Intruder-Radon Scenario . . . . . . . . . . . . . 10-82

10.5 Qualitative Prediction of the Effects of Secondary FWFs $\ldots \ldots \ldots \ldots \ldots 10-83$

11. CONCLUSIONS, AND IMPLICATIONS FOR DECISIONMAKING $\ldots \ldots \ldots \ldots$ 11-1

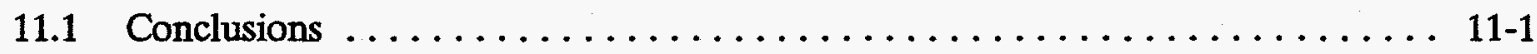

11.1.1 Undisturbed-Waste Scenario-Atmospheric Transport Pathway .... 11-1

11.1.2 Undisturbed-Waste Scenario-Groundwater Transport Pathway ..... 11-2

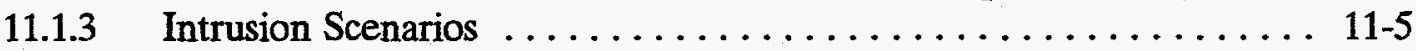

11.2 Implications for Decisionmaking $\ldots \ldots \ldots \ldots \ldots \ldots \ldots \ldots \ldots \ldots \ldots \ldots \ldots \ldots \ldots$

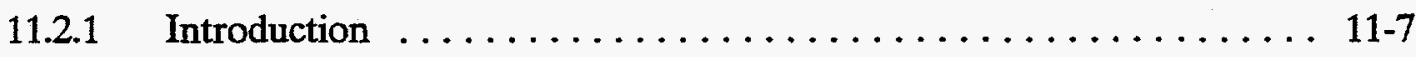

11.2.2 Observations and Recommendations $\ldots \ldots \ldots \ldots \ldots \ldots \ldots \ldots \ldots \ldots$

12. PERSPECTIVES ON THE ASSUMPTIONS AND PARAMETER VALUES USED: HOW CONSERVATIVE? . . . . . . . . . . . . . . . . . . . . . . . . . . 12-1 
12.1 Introduction

12.2 Comparisons against the Assumptions and Parameter Values Used in Related Assessments

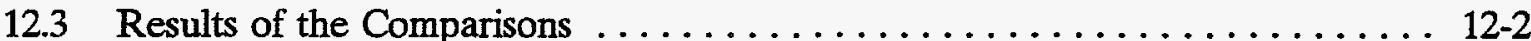

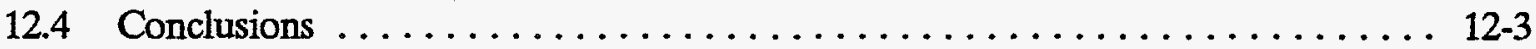

13. UNCERTAINTIES AND AREAS NEEDING FURTHER STUDY $\ldots \ldots \ldots \ldots$. . $13-1$

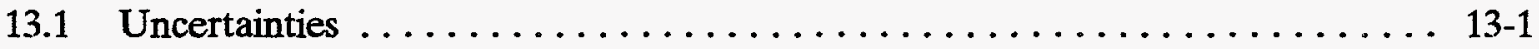

13.2 Areas Needing Further Study $\ldots \ldots \ldots \ldots \ldots \ldots \ldots \ldots \ldots \ldots \ldots \ldots$. . . . . . . . .

13.2.1 Areas that Are Sufficiently Well Defined Programmatically to be Considered for Further Study

13.2.2 Areas for Further Study

Appendix A-Estimating the Radionuclide Inventory in INEL-Stored Alpha

Low-Level Waste

Appendix B-Refined Model of Untreated Alpha-Contaminated Low-Level Waste Stored

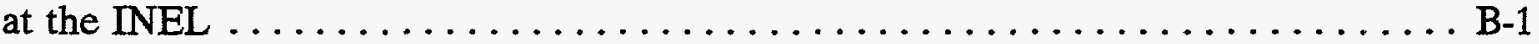

Appendix C-Completed Questionnaires Used to Obtain Geologic and Hydrologic

Properties of Disposal Locations A, B, and C

Appendix D-Description of Preprocessor and Postprocessor Programs . . . . . . . . . D-1

Appendix E-Description of Computer Programs $\ldots \ldots \ldots \ldots \ldots \ldots \ldots \ldots \ldots \ldots \ldots$ E-1

Appendix F-Verification and Validation of Computer Programs $\ldots \ldots \ldots \ldots \ldots \ldots \ldots$ F-1

Appendix G-Final Waste Form Characteristics $\ldots \ldots \ldots \ldots \ldots \ldots \ldots \ldots \ldots \ldots \ldots$

Appendix H-Detailed Comparison of Assumptions and Parameter Values Used in

Performance Assessments and Risk Assessments Related to the RWMC

Subsurface Disposal Area

\section{FIGURES}

2-1. Location and simplified layout of the Radioactive Waste Management Complex at the INEL . . . . . . . . . . . . . . . . . . . . . . . . . $2-2$

3-1. INEL disposal locations used in the study. 
4-1. Scenarios evaluated.

4-2. Transport pathways and exposure routes evaluated. ............... 4-3

4-3. Time periods of the waste disposal facility. $\ldots \ldots \ldots \ldots \ldots \ldots \ldots \ldots \ldots \ldots$

5-1. Conceptual layout of waste disposal pit. $\ldots \ldots \ldots \ldots \ldots \ldots \ldots \ldots \ldots \ldots$

6-1. Simplified depiction of the conceptual model of groundwater flow and transport in the source zone, vadose zone, and saturated zone $\ldots \ldots \ldots \ldots \ldots \ldots \ldots \ldots \ldots .2$

8-1. Simplified depiction of conceptual model for radon transport and receptor exposure. (Until $500 \mathrm{yr}$ postclosure, an 11-ft abovegrade cover was also

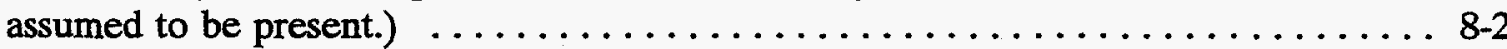

9-1. Exposure routes evaluated in the intruder scenarios. . . . . . . . . . . . 9-1

9-2. Disposal pit layout for intruder-drilling scenario, $100 \mathrm{yr}$ postclosure. (At $500 \mathrm{yr}$ postclosure, no credit would be taken for the abovegrade portion of the cover.) ... 9-5

9-3. Disposal pit layout for intruder-excavation scenario, 500-yr postclosure with 9-ft belowgrade backfill.

9-4. Disposal pit layout for intruder-excavation scenario, 500-yr postclosure with 5-ft belowgrade backfill. . . . . . . . . . . . . . . . . . . . . . .

9-5. Disposal pit and house layout for intruder-radon scenario, $>500 \mathrm{yr}$ postclosure with $9-\mathrm{ft}$ belowgrade backfill. . . . . . . . . . . . $\ldots \ldots \ldots \ldots \ldots \ldots \ldots$

11-1. Semiquantitative plot of compliance with performance objective for dose in undisturbed-waste scenario-groundwater transport pathway for Sites A, B, and C . . 11-3

\section{TABLES}

1-1. Summary of radiological performance objectives applicable to the ALLW performance

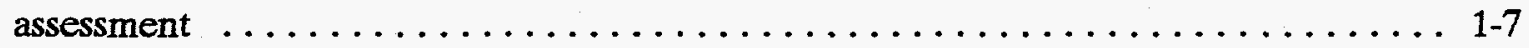

2-1. Volumes used for waste stored in the TSA. $\ldots \ldots \ldots \ldots \ldots \ldots \ldots \ldots$

2-2. Final waste forms selected for parametric evaluation $\ldots \ldots \ldots \ldots \ldots \ldots$

2-3. Total simplified inventory, assuming $100 \mathrm{nCi} / \mathrm{g}$ TRU radionuclides. . . . . . . . 2-8

2-4. Comparison of simplified inventory (assuming upper limit of $100 \mathrm{nCi} / \mathrm{g}$ TRU radionuclides) against inventory developed from Apel et al. (1993) by Tozer (1993). . . 2-9 
2-5. Volumetric concentrations of each radionuclide in each final waste form, in $\mathrm{Ci} / \mathrm{m}^{3}$, assuming $100 \mathrm{nCi} / \mathrm{g}$ TRU radionuclides for cement. . . . . . . . . . . 2-12

2-6. Refined inventory of nonactinides for $\mathrm{CH}$ ALLW. .............. 2-14

2-7. Refined inventory of nonactinides for RH ALLW. . . . . . . . . . . . 2-14

2-8. Nonactinide inventory with additional refinements for $\mathrm{CH} A L L W . \ldots \ldots \ldots$

2-9. Nonactinide inventory with additional refinements for RH ALLW. . . . . . . . . 2-16

2-10. Nonactinide inventory with additional refinements for $\mathrm{CH}$ plus RH ALLW. . . . . 2-17

2-11. Refined model of the untreated ALLW. . . . . . . . . . . . . . . . 2-19

2-12. Screening of nonactinides from the simplified inventory before detailed evaluation of groundwater transport-Sites A, B, and C. . . . . . . . . . . . . 2-22

2-13. Screening of nonactinides from the simplified inventory before detailed evaluation of groundwater transport-Sites $\mathrm{A}, \mathrm{B}$, and $\mathrm{C}$ with minimum groundwater travel time of $6.3 \mathrm{yr}$

2-14. Screening of nonactinides from the inventory with additional refinements before detailed evaluation of groundwater transport-Site $C$ (most favorable). . . . . . 2-25

2-15. Screening of nonactinides from the inventory with additional refinements before detailed evaluation of groundwater transport-Site D (least favorable).

2-16. Screening of nonactinides from the simplified inventory before detailed evaluation of groundwater transport-Site D (least favorable).

3-1. Values used for geologic and hydrologic properties of disposal locations.

3-2. Values used for sorption coefficients at Sites A, B, and C. . . . . . . . .

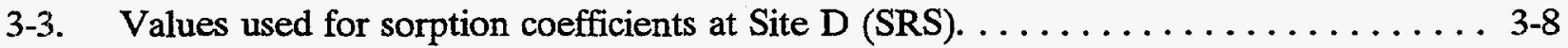

3-4. Values used for sorption coefficients at Site E (Hanford). . . . . . . . . . 3-9

5-1. Summary of conceptual models and numerical models selected for simulating processes in the performance assessment model

6-1. van Genuchten parameters used in VS2DT unsaturated flow model for source zone .. 6-6

6-2. Effective diffusion coefficients of nuclides in a cement FWF $\ldots \ldots \ldots \ldots \ldots \ldots$ 
6-3. Comparison of calculated versus measured diffusion coefficients for a portland cement FWF (values in $\mathrm{cm}^{2} / \mathrm{sec}$ ) ....................... 6.10

6-4. Values for ceramic FWF dissolution rates $\ldots \ldots \ldots \ldots \ldots \ldots \ldots \ldots \ldots \ldots \ldots \ldots$

6-5. Values for glass FWF dissolution rates $\ldots \ldots \ldots \ldots \ldots \ldots \ldots \ldots \ldots \ldots \ldots$

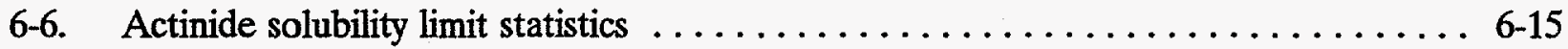

7-1. Parameter values for the DITTY code of the GENII package used for undisturbed-waste scenario

7-2. Effective dose conversion factors for the various radionuclides used in DECAYDOS

9-1. Parameter values for intruder-drilling scenario $\ldots \ldots \ldots \ldots \ldots \ldots \ldots \ldots$

9-2. Parameter values for intruder-excavation scenario for cases involving $1-\mathrm{m}(3-\mathrm{ft})$

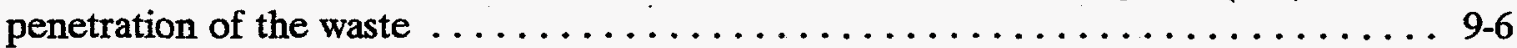

9-3. Parameter values for intruder-agricultural scenario $\ldots \ldots \ldots \ldots \ldots \ldots \ldots \ldots$

9-4. Fractional leach rates used in the intruder-radon scenario. $\ldots \ldots \ldots \ldots \ldots \ldots . \ldots 9$

9-5. Parameters used in intruder-radon scenario. $\ldots \ldots \ldots \ldots \ldots \ldots \ldots \ldots \ldots$

9-6. Similarities and differences in the methods for evaluating radon transport and exposure . . . . . . . . . . . . .

10-1. Performance objectives and top-level results $\ldots \ldots \ldots \ldots \ldots \ldots \ldots \ldots \ldots \ldots \ldots$ 10-2

10-2. Compilation of results for the undisturbed-waste scenario-groundwater transport pathway

10-3. Compilation of results for the intrusion scenarios $\ldots \ldots \ldots \ldots \ldots \ldots \ldots$

10-4. Effects of FWF on performance at Site B $\ldots \ldots \ldots \ldots \ldots \ldots \ldots \ldots \ldots \ldots \ldots$

10-5. Effects of disposal site on performance $\ldots \ldots \ldots \ldots \ldots \ldots \ldots \ldots \ldots \ldots \ldots$

10-6. Effects of FWF and saturated-zone groundwater velocity on performance at Site C.

10-7. Effects of TRU activity concentration on performance of IEB at Site B . . . . 10-15

10-8. Effects of FWF degradation on performance at Site B 
10-9. Effects of infiltration rate on performance of PCC at Sites A, B, D, and E . . . . 10-19

10-10. Combined effects of high infiltration rate and no credit for travel time through vadose zone basalt on performance at Site $\mathrm{A} \ldots \ldots \ldots \ldots \ldots \ldots \ldots \ldots \ldots \ldots$

10-11. Effects of adsorption of radionuclides by backfill within the disposal unit $\ldots \ldots \ldots 10-22$

10-12. Effects of reduced $\mathrm{K}_{\mathrm{d}}$ values on performance $\ldots \ldots \ldots \ldots \ldots \ldots \ldots \ldots \ldots \ldots$

10-13. Effects of distance to receptor well on performance $\ldots \ldots \ldots \ldots \ldots \ldots \ldots \ldots$

10-14. Effects of disposing of untreated waste $\ldots \ldots \ldots \ldots \ldots \ldots \ldots \ldots \ldots \ldots \ldots \ldots$

10-15. Effects of assumed release mechanism for untreated waste $\ldots \ldots \ldots \ldots \ldots \ldots$ 10-27

10-16. Leach rates for the final waste forms . . . . . . . . . . . . . . . . 10-29

10-17. Effects of leach rates on performance $\ldots \ldots \ldots \ldots \ldots \ldots \ldots \ldots \ldots \ldots \ldots$

10-18. Recommended and selected values for the two-stage leach rate model, $\mathrm{g} / \mathrm{m}^{2}$-day $\ldots \quad 10-30$

10-19. Effects of time-dependent FWF leach rates on performance $\ldots \ldots \ldots \ldots \ldots$ 10-31

10-20. Effects of chemical interactions of radionuclides with cement $\ldots \ldots \ldots \ldots \ldots$

10-21. Effects of inventory with additional refinements on performance $\ldots \ldots \ldots \ldots$

10-22. Effects of possible increases in U-233 and Th-232 inventory on performance . . . 10-37

10-23. Effects of vault-type facility for given disposal sites $\ldots \ldots \ldots \ldots \ldots \ldots \ldots$

10-24. Comparison of assumptions and results of PA runs involving Sites D and E $\ldots \ldots 10-41$

10-25. New runs to help clarify the large differences in PA runs for INEL ALLW disposed of at Sites D and E. (All runs involve INEL ALLW. Because of the complex, focused nature of the set of runs listed here, they are not included in 10-2.) . . . 10-45

10-26. Compliance with performance objective to protect groundwater resources . . . . 10-47

10-27. Dose from radon release $\ldots \ldots \ldots \ldots \ldots \ldots \ldots \ldots \ldots \ldots \ldots \ldots \ldots \ldots \ldots$

10-28. Burial depths and intrusion times evaluated for the intrusion scenarios $\ldots \ldots \ldots 10-54$

10-29. Cases evaluated for the intrusion scenarios. . . . . . . . . . . . . $10-56$

10-30. Effects of FWF on performance in intrusion scenarios $\ldots \ldots \ldots \ldots \ldots$ 10-57 
10-31. Effects of TRU activity concentration in IEB on performance in intrusion scenarios

10-32. Effects of burial depth on performance in intrusion scenarios

10-33. Intrusion scenario results for untreated waste

10-34. Intruder scenario doses for refined inventory $10-63$

10-35. Intruder scenario doses for inventory with additional refinements $10-64$

10-36. Effects of exposure duration in the intruder-drilling scenario $10-66$

10-37. Effects of particle size distribution on results for intruder-drilling scenario for 20 -ft cover, $100 \mathrm{yr}$

10-38. Effects of particle size distribution on results for intruder-agricultural scenario for 20-ft cover, $100 \mathrm{yr}$.

10-39. Time dependence of dose in intruder-drilling scenario with 16-ft soil cover $10-73$

10-40. Time dependence of dose in intruder-excavation scenario with 16-ft soil cover

10-41. Time dependence of dose in intruder-agricultural scenario initiated by drilling with 16-ft soil cover

10-42. Time dependence of dose in intruder-agricultural scenario initiated by excavation with 16-ft soil cover

10-43. Time dependence of dose in intruder-agricultural scenario initiated by drilling with 20 -ft soil cover

10-44. Dominant radionuclides contributing to dose for the intrusion scenarios $10-77$

10-45. Results for the intruder-radon scenario $10-83$

10-46. Regulatory requirements and results for intruder-radon scenario $10-84$

12-1. Degree of conservatism of the most important assumptions and parameter values used in this study

13-1. Key uncertainties in this study. 


\section{ACRONYMS}

\begin{tabular}{|c|c|}
\hline ALLW & alpha low-level waste \\
\hline ASG & aluminosilicate glass \\
\hline BDAT & best demonstrated available technology \\
\hline BSG & borosilicate glass \\
\hline C\&SB & Certified and Segregated Waste Storage Building \\
\hline CEDE & committed effective dose equivalent \\
\hline CERCLA & Comprehensive Environmental Response, Compensation, and Liability Act \\
\hline CFR & Code of Federal Regulations \\
\hline $\mathrm{CH}$ & contact-handled \\
\hline DITTY & Dose Integrated Over Ten Thousand Years (computer program) \\
\hline DOE & (U.S.) Department of Energy \\
\hline DUST & Disposal Unit Source Term (computer program) \\
\hline EAVDF & E-Area Vault Disposal Facility \\
\hline EDE & effective dose equivalent \\
\hline EPA & (U.S.) Environmental Protection Agency \\
\hline FFA/CO & Federal Facility Agreement and Consent Order \\
\hline FUETAP & formed under elevated temperature and pressure \\
\hline FWF & final waste form \\
\hline GENII & Generation-II (computer program) \\
\hline IEB & iron-enriched basalt \\
\hline IEB4 & enhanced iron-enriched basalt \\
\hline ILTSF & Intermediate-Level Transuranic Storage Facility \\
\hline INEL & Idaho National Engineering Laboratory \\
\hline IWPF & Idaho Waste Processing Facility \\
\hline LANL & Los Alamos National Laboratory \\
\hline LDR & land disposal restriction \\
\hline LLW & low-level waste \\
\hline MAP & mixed activation products \\
\hline MFP & mixed fission products \\
\hline & maximum permissible concentration \\
\hline
\end{tabular}


NRC

(U.S.) Nuclear Regulatory Commission

NTS

Nevada Test Site

P.A

performance assessment

PCC

Portland cement/concrete

PSPI

Private Sector Participation Initiative

RCRA

Resource Conservation and Recovery Act

RFP

Rocky Flats Plant

$\mathrm{RH}$

remote-handled

RWMC

Radioactive Waste Management Complex

RWMIS

Radioactive Waste Management Information System

RWMS

Radioactive Waste Management Site

SDA

Subsurface Disposal Area

SRS

Savannah River Site

SWEPP

Stored Waste Examination Pilot Plant

TRU

transuranic

TSA

Transuranic Storage Area

TSCA

Toxic Substances Control Act

UTR

untreated waste

VS2DT

Variably Saturated Two-Dimensional Flow and Transport (computer program)

WIPP

Waste Isolation Pilot Plant

ANS

American Nuclear Society 


\section{Preliminary Parametric Performance Assessment of Potential Final Waste Forms for Alpha Low-Level Waste at the Idaho National Engineering Laboratory}

\section{INTRODUCTION}

This document presents a preliminary parametric performance assessment (PA) concerning the eventual disposal of mixed alpha low-level waste (ALLW) currently stored at the Idaho National Engineering Laboratory (INEL). The study was performed in three phases. The first two phases were performed for the Private Sector Participation Initiative (PSPI). The third phase was performed as part of the continuing effort to develop and implement methods for the ultimate disposition of the ALLW.

Section 1.1 provides background information concerning the PSPI. Section 1.2 discusses the purpose, need for, scope, and use of the results of this study. Section 1.3 discusses the multiphase nature of the study. Finally, Section 1.4 lists the performance objectives for radionuclide isolation with which a formal PA addressing the INEL ALLW must eventually demonstrate compliance.

\subsection{Private Sector Participation Initiative}

The Department of Energy (DOE) has a need for treatment of waste stored at the INEL. Private sector services for treating the waste are being evaluated (DOE 1995). The PSPI supports the DOE in the technical aspects of this possible procurement.

Beginning in 1970, actual or suspected transuranic (TRU) waste ${ }^{\mathrm{a}}$ has been retrievably stored at the Radioactive Waste Management Complex (RWMC) of the INEL. The total amount

a. The current definition of transuranic (TRU) waste is as follows, as stated in DOE Order 5820.2A, "Radioactive Waste Management:"

Transuranic (TRU) waste-Without regard to source or form, waste that is contaminated with alphaemitting transuranium radionuclides with half-lives greater than $20 \mathrm{yr}$ and concentrations greater than $100 \mathrm{nCi} / \mathrm{g}$ at the time of assay.

Some of the suspected TRU waste eventually will be determined to be low-level waste (LLW):

Low-level waste-Waste that contains radioactivity and is not classified as high-level waste, transuranic waste, spent nuclear fuel or 11 (2) by-product material. . . .

Before 1984, the lower limit of transuranic radionuclide activity for defining TRU waste was $10 \mathrm{nCi} / \mathrm{g}$, rather than the currently specified $100 \mathrm{nCi} / \mathrm{g}$.

Much of the LLW and TRU waste stored in the Transuranic Storage Area (TSA) is mixed waste: waste containing both radioactive and hazardous chemical components as defined by the Atomic Energy Act and the Resource Conservation and Recovery Act (RCRA), respectively.

At the INEL, the following additional definition is used:

Alpha low-level waste (ALLW)-LLW that is contaminated with alpha-emitting transuranium radionuclides with half-lives greater than $20 \mathrm{yr}$ and concentrations $>10$ and $\leq 100 \mathrm{nCi} / \mathrm{g}$ at the time of assay.

ALLW can be either mixed or not mixed. In this document, the term ALLW refers to both the mixed and the non-mixed ALLW, unless otherwise indicated. 
of: this stored waste is $63,729 \mathrm{~m}^{3}$ (Raivo et al. 1993). An estimated $24,413 \mathrm{~m}^{3}$, or almost $40 \%$ of the waste, is ALLW (Raivo et al. 1993). ${ }^{\mathrm{b}}$ This waste is the subject of the PSPI and of this study.

Because most of the ALLW is considered a mixed waste, disposal of the waste may be restricted by the land disposal restrictions (LDRs) of the U.S. Environmental Protection Agency (EPA). Also, some of the ALLW may contain constituents regulated under the Toxic Substances Control Act (TSCA).

Appropriate treatment and disposal of the ALLW is being planned to ensure long-term protection of human health and the environment. The treatment must ensure that the final waste form (FWF) will satisfy the applicable disposal requirements.

The current strategy for the portion of the stored waste determined by radioassay to be TRU waste is as follows:

- Retrieve the waste

- $\quad$ Perform minimal processing to meet the acceptance criteria of the Waste Isolation Pilot Plant (WIPP)

- $\quad$ Ship it when WIPP is approved to receive such waste.

The ALLW is expected to be segregated from the TRU waste by means of the radioassay results. The ALLW is excluded from disposal at WIPP. It is also currently excluded from disposal at the RWMC Subsurface Disposal Area (SDA).

The current strategy for addressing the ALLW is as follows:

- Fund and evaluate several feasibility studies on private sector solutions for treatment of the waste

- Procure production-scale waste treatment services (use of private-sector treatment services is expected to be more rapid and cost effective)

- Select a suitable disposal location for the treated waste.

The feasibility studies have been completed and are undergoing evaluation.

The above strategies are subject to modification as the evaluations of management alternatives for the TRU waste and ALLW continue.

b. The estimates given in Raivo et al. (1993) were the best available at the time this study began. Subsequent evaluations have resulted in slightly different estimates. The differences are not expected to have a substantial effect on the results of the current study. 


\subsection{Purpose, Need for, Scope, and Use of Preliminary Parametric Performance Assessment}

The purpose of this preliminary parametric PA was to provide preliminary evaluations of the performance of the treated ALLW-in various FWFs, in various disposal locations, and under various assumptions.

Not only must treatment of the ALLW satisfy EPA requirements, but the waste disposal system must also satisfy performance objectives in DOE Order 5820.2A. The performance objectives are stated in terms of the projected radiological doses to members of the public and to inadvertent intruders after the loss of institutional control. The performance objectives also require the protection of groundwater resources, consistent with regulatory requirements. See Section 1.4 for details. The disposal system consists of the FWF, the packaging materials, any engineered barriers, and the geological environment of the disposal site. The evaluation of the projected performance is called a PA. Thus, eventually a formal PA must be prepared addressing the performance of the treated INEL ALLW in the chosen disposal setting.

It is too early in the PSPI project to prepare a formal PA. However, this study fulfills a related need: early, preliminary projections of whether a given FWF at a given disposal site might be expected to satisfy the performance objectives, and if so, by how much.

Implementing the PSPI or any other large-scale treatment operation involves the commitment of large amounts of funding. The treatment method(s) selected must provide the appropriate degree of immobilization of the radionuclides. If the treatment provides insufficient immobilization, the disposal system (including the FWF) will not comply with the performance objectives. If the treatment provides an unnecessary degree of immobilization, more funding may be expended than is necessary. Thus, the selection of a FWF is a crucial decision. This preliminary parametric PA provides vital early indications of the extent of immobilization that may be necessary. This study also examines the interactions among the FWF, the waste disposal location, and the other parameters that affect the performance of the waste disposal system.

This study is termed a preliminary, parametric PA:

- It is preliminary in that it is not the PA that will be prepared for formal approval in accordance with DOE Order 5820.2A At present, only a preliminary PA can be prepared because, among other reasons, the FWF and disposal location have not been selected.

- It is parametric in that several parameters were varied to observe their effect on the performance of the disposal system. Included were the FWF, the disposal location, the depth of burial, the degree of conservatism of the assumed values of geohydrologic parameters, etc. The study did not examine one FWF and one disposal location in detail. A parametric approach was selected because, at this early time in the PSPI program, a wide range of options required evaluation. 
This study has several potential uses:

- It will help guide program managers in determining the optimum degree of immobilization for the ALLW to satisfy the performance objectives while minimizing cost

- The results indicate the margin of compliance with the performance objectives and how it depends on various parameters

- It identifies key parameters that have a major effect on the performance and for which better data are needed to support decisions.

Two related evaluations of waste disposal performance at the SDA provided much of the input information concerning disposal performance in the SDA. Maheras et al. (1994) is the formal PA that supports ongoing disposal of LLW at the RWMC SDA. It addresses LLW buried or projected to be buried from 1984 through a potential closure date of 2020 . It was prepared pursuant to DOE Order 5820.2A. Various drafts of the formal PA, extending back as far as 1990 (Case et al. 1990), were consulted.

Loehr et al. (1994) is a preliminary scoping risk assessment. It was prepared pursuant to the Comprehensive Environmental Response, Compensation, and Liability Act (CERCLA) and an EPA/State of Idaho/DOE agreement [the Federal Facility Agreement and Consent Order (FFA/CO)] concerning possible remediation of part of the SDA. It addresses all waste buried belowgrade from 1952 through 1983. Follow-on risk assessments will extend the 1983 cutoff through 1994.

\subsection{Multiphase Nature of the Study}

This study was performed in three phases, all of which are reported herein. In the first phase, PA computer runs were performed using an initial set of assumptions and parameter values. In the second and third phases, the results obtained with the initial assumptions and parameter values were evaluated to identify topics needing further study. Additional runs were then made using refined assumptions or expanded ranges for some parameter values. The complete set of initial runs was not repeated using the revised assumptions or parameter values.

The multiphase nature of the study added complexity that was manifest in several ways. For example, in some cases, determining the effects of changing only one parameter at a time necessitated using, as a reference for comparison, early combinations of parameter values that had been determined later to be less than optimum. As another example, not every interesting combination of parameter values could be studied because of the large number of such combinations.

Some aspects of this report reflect the fact that the study was performed in successive phases and was an iterative process. The text reflects some revisiting of early results that was necessary because of knowledge gained in later phases. Also, the large number of runs with various 
combinations of values required elaborate tables to track the input values used for each run so the individual results could be interpreted in the proper context.

In spite of the added complexity, the study produced a wide range of useful information on the intricate dependencies of the many parameters that affect a PA.

\subsection{Requirements To Be Met in Formal Performance Assessment}

\subsubsection{General}

Chapter III of DOE Order 5820.2A deals with the management of LLW, under which the INEL ALLW is categorized. Paragraph $3 b(1)$ of Chapter III requires each DOE field organization with a disposal site to "prepare and maintain a site-specific radiological performance assessment for the disposal of waste for the purpose of demonstrating compliance with the performance objectives stated in paragraph 3a." The formal review process for PAs is also described in the order.

\subsubsection{Performance Objectives}

Paragraph 3a of Chapter III lists the performance objectives for DOE LLW not disposed of before issue of the Order on September 26, 1988. The objectives are as follows:

1. Protect public health and safety in accordance with standards specified in applicable $\mathrm{EH}$ orders and other DOE orders.

2. Ensure that external exposure to the waste and concentrations of radioactive material which may be released into surface water, groundwater, soil, plants and animals results in an effective dose equivalent $(\mathrm{EDE})^{\mathrm{c}}$ that does not exceed $25 \mathrm{mrem} / \mathrm{yr}$ to any member of the public. Releases to the atmosphere shall meet the requirements of 40 Code of Federal Regulations (CFR) 61 (EPA 1992a). Reasonable effort should be made to maintain releases of radioactivity in effluents to the general environment as low as is reasonably achievable.

3. Ensure that the committed effective dose equivalents (CEDE) received by individuals who inadvertently may intrude into the facility after the loss of active institutional control (100 yr) will not exceed $100 \mathrm{mrem} / \mathrm{yr}$ for continuous exposure or $500 \mathrm{mrem}$ for a single acute exposure.

4. Protect groundwater resources, consistent with Federal, State, and local requirements.

Item 2 above cites 40 CFR 61, "National Emission Standards for Hazardous Air Pollutants (Clean Air Act)," wherein the following performance objective is given:

c. Hereafter, the term dose or, where appropriate, peak annual dose is generally used in place of the effective dose equivalent or peak annual EDE. 
- The airborne effluent pathway shall not result in any member of the public receiving, in a year, a dose equivalent $>10$ mrem EDE.

Item 4 above, related to the protection of groundwater resources, was interpreted here to mean that concentrations of radionuclides should not exceed the standards for public drinking water supplies as established by the EPA. The National Primary Drinking Water Regulations in 40 CFR 141 (EPA 1992b) state that all community drinking water systems that have at least 15 connections or serve at least 25 people must meet the following requirements:

- Beta and photon (gamma) emitters, $s 4 \mathrm{mrem} / \mathrm{yr}$

- Total alpha emitters, $\leq 15 \mathrm{pCi} / \mathrm{L}$ (including $\mathrm{Ra}-226$, but excluding uranium and radon)

- Combined Ra-226 and $\mathrm{Ra}-228, \leq 5 \mathrm{pCi} / \mathrm{L}$.

The standard used for uranium in water is that given in a proposed rule-making (EPA 1991) to 40 CFR 141:

- Uranium, $\leq 30 \mathrm{pCi} / \mathrm{L}$.

The following criterion (EPA 1987) was used for radon in air:

- Indoor radon concentration, $\leq 4 \mathrm{pCi} / \mathrm{L}$.

In addition, State regulations may apply to the ALLW disposal system and must be at least as stringent as the Federal regulations. In the case of Idaho, the requirements are the same as the Federal requirements. No search was made of the requirements of other states in which the INEL ALLW could conceivably be disposed.

For convenience, the performance objectives are summarized in Table 1-1.

Proposed revisions to DOE Order 5820.2A have been drafted. The performance objectives that will appear in the final revision of the order are not known at this time. It seems prudent to use the current performance objectives in the interim.

Although this preliminary parametric PA was not prepared for the formal approval of a waste disposal system, the same performance objectives were used as will be used for the formal PA. The intent is that this study facilitate a smooth transition later to the formal PA. 
Table 1-1. Summary of radiological performance objectives applicable to the ALLW performance assessment.

\begin{tabular}{|c|c|c|c|c|}
\hline Regulation & Exposure group & $\begin{array}{c}\text { Performance objectives } \\
\text { limit }\end{array}$ & Compliance point & $\begin{array}{c}\text { Relevant } \\
\text { compliance period }\end{array}$ \\
\hline \multicolumn{5}{|l|}{ DOE Orders } \\
\hline \multirow[t]{3}{*}{$5820.2 \mathrm{~A}, \mathrm{Ch} . \mathrm{III}$} & Public & $\begin{array}{l}25 \text { mrem/yr EDE (all } \\
\text { pathways but air) }\end{array}$ & $\begin{array}{l}\text { Point } 100 \mathrm{~m} \text { downgradient } \\
\text { from disposal unit } \\
\text { boundary }\end{array}$ & $\begin{array}{l}\text { During post- } \\
\text { institutional } \\
\text { control }\end{array}$ \\
\hline & $\begin{array}{l}\text { Inadvertent } \\
\text { intruder }\end{array}$ & $\begin{array}{l}100 \text { mrem/yr EDE } \\
\text { (chronic exposure) }\end{array}$ & Disposal unit & $\begin{array}{l}\text { During post- } \\
\text { institutional } \\
\text { control }\end{array}$ \\
\hline & & $\begin{array}{l}500 \text { mrem EDE (acute } \\
\text { exposure) }\end{array}$ & & \\
\hline \multicolumn{5}{|l|}{ EPA } \\
\hline $\begin{array}{l}40 \text { CFR } 61 \\
\text { subpart } H\end{array}$ & Public & $\begin{array}{l}10 \text { mrem/yr EDE (air } \\
\text { emissions) }\end{array}$ & $\begin{array}{l}\text { Point of maximum annual } \\
\text { air concentration in an } \\
\text { unrestricted area where } \\
\text { the public resides or } \\
\text { abides }\end{array}$ & All periods \\
\hline \multirow[t]{4}{*}{$40 \mathrm{CFR} 141$} & Public & $\begin{array}{l}4 \text { mrem/yr from beta } \\
\text { emitters and photon } \\
\text { emitters }\end{array}$ & $\begin{array}{l}\text { Any community drinking } \\
\text { water system at point } \\
100 \mathrm{~m} \text { downgradient from } \\
\text { disposal unit boundary }\end{array}$ & All periods \\
\hline & & $\begin{array}{l}15 \mathrm{pCi} / \mathrm{L} \text { total alpha } \\
\text { emitters (including } \\
\text { Ra-226, excluding } \mathrm{U} \\
\text { and } \mathrm{Rn} \text { ) }\end{array}$ & & \\
\hline & & $\begin{array}{l}5 \mathrm{pCi} / \mathrm{L} \text { combined } \\
\mathrm{Ra}-226 \text { and } \mathrm{Ra}-228\end{array}$ & & \\
\hline & & $30 \mathrm{pCi} / \mathrm{L} \mathrm{U}$ & & \\
\hline EPA (1987) & $\begin{array}{l}\text { Inadvertent } \\
\text { intruder }\end{array}$ & $\begin{array}{l}4 \mathrm{pCi} / \mathrm{Ln} \\
\text { concentration in indoor } \\
\text { air }\end{array}$ & $\begin{array}{l}\text { Hypothetical residence } \\
\text { overlying disposal unit }\end{array}$ & $\begin{array}{l}\text { During post- } \\
\text { institutional } \\
\text { control }\end{array}$ \\
\hline
\end{tabular}




\section{References for Section 1}

Case, M. J., S. J. Maheras, M. A. McKenzie-Carter, M. E. Sussman, and P. Voilleque, 1990, Radioactive Waste Management Complex Performance Assessment (Draft) EG\&G Idaho, Inc., EGG-WM-8773, June.

DOE, 1995, Evaluation of Feasibility Studies for Private Sector Treatment of Alpha and TRU Mixed Wastes, U.S. Department of Energy, Idaho Operations Office, DOE/ID-10512, May.

EPA, 1987, Interim Protocols for Screening and Follow-up Radon and Radon Decay Product Measurements, EPA 520/1-86-014-1, U.S. Environmental Protection Agency, Office of Radiation Programs.

EPA, 1991, "National Primary Drinking Water Regulations: Radionuclides," Federal Register, Vol. 56, No. 138 (56 FR 33050), U.S. Environmental Protection Agency.

EPA, 1992a, "National Emission Standards for Hazardous Air Pollutants (Clean Air Act)," 40 CFR 61, U.S. Environmental Protection Agency.

EPA, 1992b, "National Primary Drinking Water Regulations," 40 CFR 141, U.S. Environmental Protection Agency.

Loehr, C. A., B. H. Becker, D. E. Burns, R. M. Huntley, S. M. Rood, P. Sinton, and T. H. Smith, 1994, Preliminary Scoping Risk Assessment for Waste Pits, Trenches, and Soil Vaults at the Subsurface Disposal Area, Idaho National Engineering Laboratory, EG\&G Idaho, Inc., EGG-WM-11181, May.

Maheras, S. J., A. S. Rood, S. O. Magnuson, M. E. Sussman, and R. N. Bhatt, 1994, Radioactive Waste Management Complex Low-Level Waste Radiological Performance Assessment, EG\&G Idaho, Inc., EGG-WM-8773, May.

Raivo, B. D., T. L. Eddy, and G. L. Anderson, 1993, Statement of Work: Commercial Transport and Treatment of Alpha-Contaminated Mixed Low-level Radioactive Waste (draft), Attachment 1 to Solid Alpha-Contaminated Low-level Radioactive Waste Transport/Treatment Services Request for Proposal, SP-SOW-01, June. 


\section{THE WASTE}

This section first describes the RWMC, where the subject waste is located. It discusses where, when, and how the waste was generated, and how it is currently stored. Most of the section is devoted to explaining how the radionuclide inventory in the waste was estimated before and after treatment. Finally, this section discusses radionuclide screening to simplify the evaluation of radionuclide transport via the groundwater pathway.

\subsection{Radioactive Waste Management Complex ${ }^{a}$}

The RWMC is located in the southwest portion of the INEL, which is located in southeastern Idaho. The RWMC consists of the 97-acre SDA, the 58-acre TSA, and the Administrative Area. See Figure 2-1.

Since 1952, solid low-level waste has been disposed of in pits, trenches, and soil vaults in the SDA. From 1954 through 1970, solid TRU waste also was disposed of in the SDA. Although the remaining disposal space is somewhat limited, the SDA is one possible location for disposal of the ALLW after any necessary treatment.

The TSA opened in 1970 for the storage of TRU waste and suspect TRU waste. It consists primarily of the TSA pads and the Intermediate-Level Transuranic Storage Facility (ILTSF), which was added in 1976. The ALLW is stored at the TSA. The manner of storage is discussed in Section 2.2.

In the 1970s, two programs demonstrated experimental retrieval of part of the waste buried in the SDA. The volume of waste retrieved was $4,346 \mathrm{~m}^{3}$. Most of the retrieved waste was placed into storage in the TSA.

The Stored Waste Examination Pilot Plant (SWEPP) is also located at the TSA. The mission of SWEPP is to certify, by nondestructive means, containers of TRU waste to meet the waste acceptance criteria of the WIPP repository. Waste processed through SWEPP is placed in the Certified and Segregated Waste Storage Building (C\&SB). SWEPP includes radiological assay equipment to measure the TRU content of waste containers, thereby allowing them to be designated as either TRU waste or ALLW.

\subsection{Brief Description of the Stored Alpha Low-Level Waste}

Storage of newly received TRU waste and suspect TRU waste at the TSA began in $1970 .^{\mathrm{b}}$ About $80 \%$ of the waste was generated at the Rocky Flats Plant, as residue from the production of nuclear weapons. The remainder was generated at several other DOE sites, including the

a. Most of the discussion in Section 2.1 is taken from EG\&G Idaho 1985.

b. As stated in Section 2.1, some waste was retrieved from burial in the SDA and placed on the TSA Most of that waste had been disposed of in 1970, although a small amount had been disposed of from 1955 through 1963. 


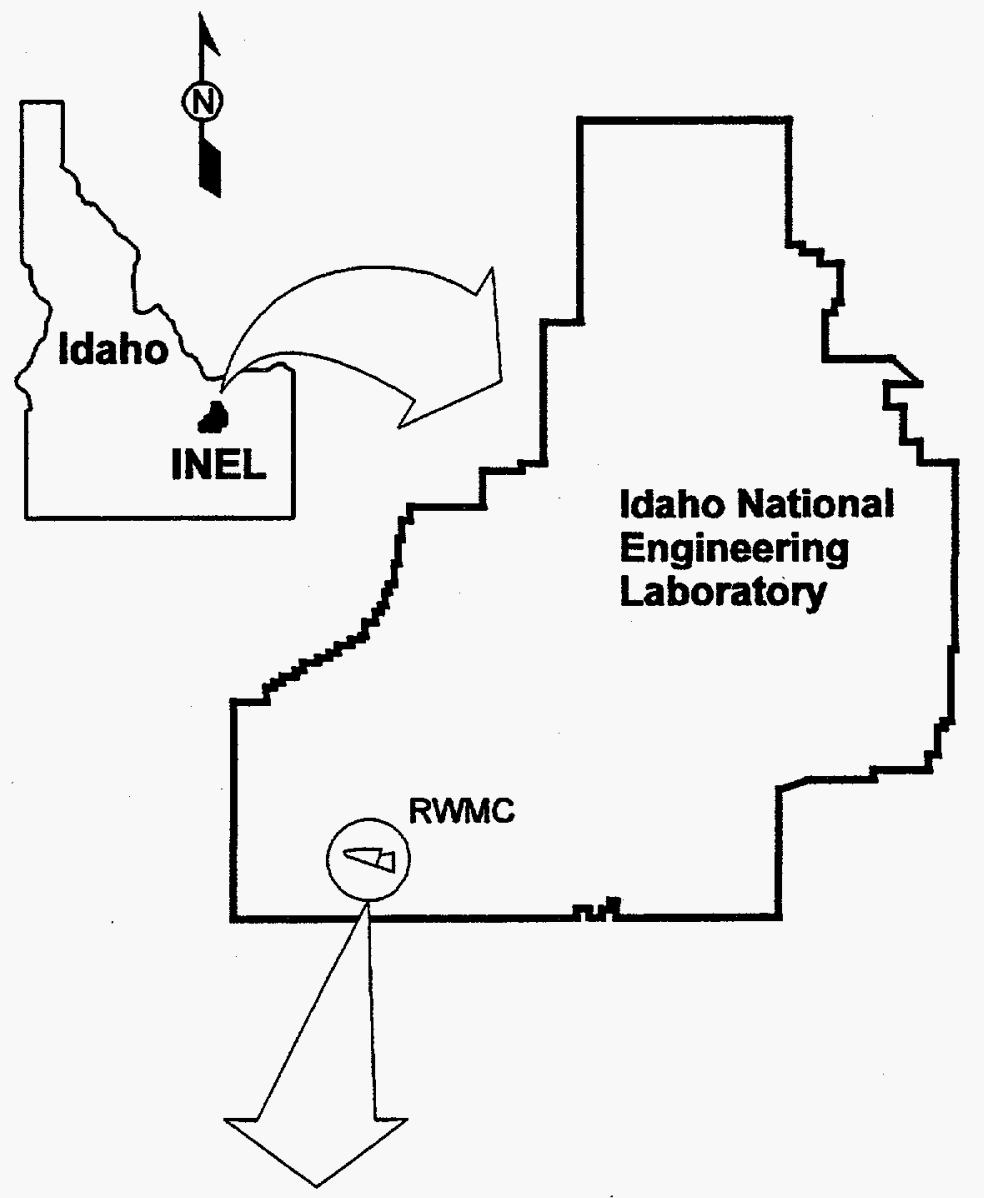

Radioactive Waste Management Complex (RWMC)

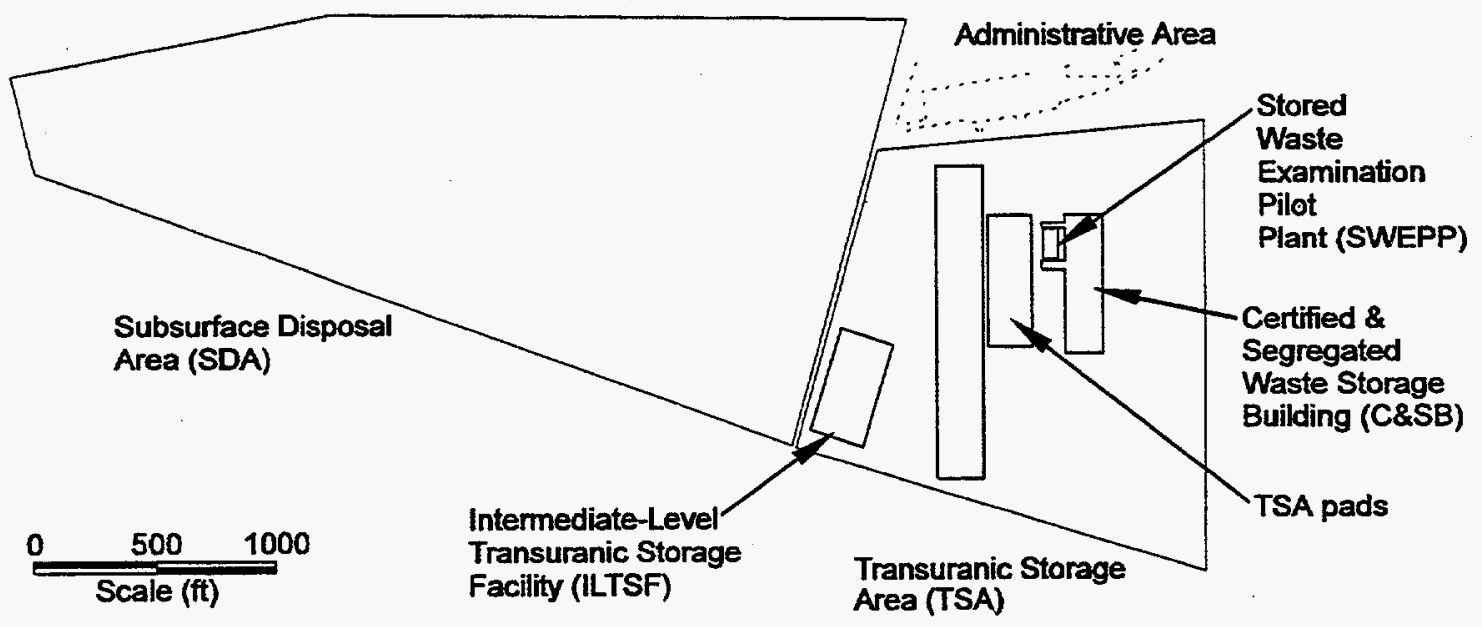

ML5107

Figure 2-1. Location and simplified layout of the Radioactive Waste Management Complex at the INEL. 
INEL, as a result of various operations and research programs. Most of the waste was generated from 1970 through 1989. Current receipt rates are greatly reduced from those during that period.

The waste consists of a wide variety of solid materials (e.g., sludges, paper, rags, metals, wood, soil) contaminated with small amounts of TRU radionuclides. Some of the waste, particularly that with higher radiation levels, also contains fission products and activated metals.

The contact-handled $(\mathrm{CH})$ waste, defined as that with dose rates $\leq 200 \mathrm{mrem} / \mathrm{hr}$ at the container surface, is contained in steel drums, plywood boxes, and steel bins. Most of the drums have rigid polyethylene liners, and most of the boxes are reinforced with plastic-impregnated fiberglass.

The $\mathrm{CH}$ waste was placed on two aboveground asphalt storage pads in the TSA. See Figure 2-1. The stacked waste containers were then covered with plywood, nylon-reinforced polyvinyl sheeting, and soil.

The remote-handled (RH) waste, defined as that with dose rates $>200 \mathrm{mrem} / \mathrm{hr}$ at the container surface, is contained primarily in steel drums or inserts. Because of the relatively high radiation levels, it is placed in belowgrade, steel-and-concrete vaults in the ILTSF. See Figure 2-1.

The total volume of stored waste in the TSA is well defined: $63,729 \mathrm{~m}^{3}$ (Raivo et al. 1993). See Table 2-1.

Estimating which of the stored waste is actually TRU waste and which is not TRU waste (i.e., ALLW) is less certain. The shipping records for the waste are incomplete, particularly in radionuclide information. Furthermore, during much of the time when the waste was generated,

Table 2-1. Volumes used for waste stored in the TSA.

\begin{tabular}{lr} 
Waste type & $\begin{array}{c}\text { Volume } \\
\left(\mathrm{m}^{3}\right)\end{array}$ \\
\cline { 2 - 2 } ALLW & 21,623 \\
Mixed & 2,790 \\
Nonmixed & 24,413 \\
Total & \\
TRU waste & 38,195 \\
Mixed & 1,121 \\
Nonmixed & 39,316 \\
Total & 63,729 \\
Grand total &
\end{tabular}


the technology for determining radionuclide inventories was not as advanced as it is today. The determination of TRU content will be made by assaying the containers in SWEPP when they are retrieved for certification or treatment. The containers of treated waste will be reassayed because the effects of treatment on the activity distribution cannot be projected with confidence. Thus, only estimates of the breakdown into TRU waste vs. ALLW can be made at present. The estimates are based on the (incomplete) information in the shipping records and a limited amount of assay data from SWEPP. Table 2-1 shows the division of waste used here (Raivo et al. 1993).

The division into mixed waste and nonmixed waste is also uncertain. (It does not have a direct effect on this study). The values from Raivo et al. 1993 are used here.

Thus, as shown in Table 2-1, the total volume assumed here to be ALLW, whether mixed or not, is $24,413 \mathrm{~m}^{3}$.

\subsection{Selection of Final Waste Forms for Parametric Evaluation}

The FWFs selected for parametric evaluation are introduced here, along with the reasons for their selection. Radionuclide concentrations for these FWFs are presented in Section 2.4. Assumed values for the physical and chemical characteristics of the FWFs are discussed in Sections 6.2.3.3 through 6.2.3.6.

Most of the ALLW is expected to be classified as mixed waste per RCRA. Disposal of the waste may also be restricted under the LDRs due to the presence of constituents such as lead, mercury, and organics such as carbon tetrachloride. Waste containing LDR constituents must be treated using the best demonstrated available technology (BDAT) before land disposal.

The BDAT for waste contaminated with LDR organics is thermal treatment followed by solidification of the resulting ash. Options for solidification of the ash to produce the FWF include cement, glass, and ceramic waste forms. The BDAT for waste contaminated with volatile metals that are not compatible with thermal treatment, such as lead and mercury, is solidification. Options for solidification of this waste include cementation.

Glass, cement, and (non-porous) ceramic are thus considered logical candidates for the FWF of the ALLW. To evaluate a wide range of potential FWFs, two FWFs from each of these three categories were evaluated. Of each pair, one was selected so as to represent the more favorable contaminant-immobilization characteristics of that category of waste form. The other one was selected to represent the less favorable characteristics. Table 2-2 lists the six FWFs selected for parametric evaluation.

In addition, a limited number of evaluations were performed with untreated waste (UTR) as a benchmark for comparison. Because the preimmobilization treatment methods are not known, the waste evaluated was pretreatment, not preimmobilization. 
Table 2-2. Final waste forms selected for parametric evaluation.

\begin{tabular}{llc}
$\begin{array}{l}\text { Category } \\
\text { of FWF }\end{array}$ & $\begin{array}{c}\text { More } \\
\text { favorable FWF }\end{array}$ & $\begin{array}{c}\text { Less } \\
\text { favorable FWF }\end{array}$ \\
\hline Cement & FUETAP & PCC \\
Glass & ASG & BSG \\
Ceramic & IEB4 & IEB \\
& & \\
Abbreviations: & FUETAP-formed under elevated temperature and pressure (cement) \\
& PCC-Portland cement/concrete & \\
ASG-aluminosilicate glass & \\
BSG-borosilicate glass & \\
IEB-iron-enriched basalt & \\
IEB4-enhanced iron-enriched basalt. & \\
\hline
\end{tabular}

\subsection{Radionuclide Inventory in the ALLW}

\subsubsection{Introduction}

The methods used to develop the radionuclide inventories for this study are described in detail in Appendix A.

As stated in Section 2.2, available information on the radionuclide inventory in the stored waste is incomplete. The available information does not allow the radionuclide inventory of the ALLW to be calculated with certainty. However, approximate inventories were developed for this study by (a) using the radionuclide information in the shipping records and in the Radioactive Waste Management Information System (RWMIS) database of those records, and (b) making some assumptions, performing analyses, and obtaining inventory information from sources other than RWMIS.

Section 1.3 stated that the present parametric study was conducted in three phases. Broad assumptions were made for the first phase. Based on the results of the first phase, important parameters meriting additional study were identified. For the second and third phases, either refined assumptions or a range of assumptions was made for several of those parameters.

The waste inventory assumptions were of this type. Additional inventory information was developed, both internal and external to this study, as the study progressed. Therefore, the inventory was refined for some of the evaluations in the second and third phases.

Three successive approximations of the radionuclide inventory were developed and used for PA runs involving treated ALLW. Each approximation was more detailed and is expected to be more accurate than its predecessor. 
The first version of the inventory is called the "simplified inventory." It was developed by means of the simplified approach described briefly in Section 2.4.2 and in detail in Sections A-1 through A-8 of Appendix A. It was used for all computer runs in the first phase of the study and for most of the runs in the second and third phases. Unless otherwise stated, this was the inventory used.

For the second phase, a "refined inventory," described briefly in Section 2.4.3 and in detail in Section A-9 of Appendix A, was developed and used for a limited number of runs. Those runs are so identified in the presentation of results.

For the third phase, an "inventory with additional refinements," described briefly in Section 2.4.4 and in detail in Section A-10 of Appendix A, was developed and used for a limited number of runs. Those runs are so identified in the presentation of results.

In the second phase, a refined model of the untreated waste, described briefly in Section 2.4.5 and in detail in Appendix B, was developed and used in a limited number of computer runs. Those runs are so designated in the presentation of results.

\subsubsection{Simplified Radionuclide Inventory Used for Most of the Computer Runs}

2.4.2.1 General. The method described below in Sections 2.4.2.2 through 2.4.2.6 was used in developing the simplified inventory for most of the computer runs.

In addition to many assumptions discussed later, three broad, simplifying assumptions were made:

- In addressing each of the six FWFs (one at a time), all waste is in the same FWF

- Within a given FWF, the radionuclide concentrations are homogeneous throughout the posttreatment waste

- All radionuclides that enter treatment with the waste stay with the treated waste.

Two groups of radionuclides are present in the waste; they were evaluated separately. The first group consists of the radionuclides with atomic number 289 and their progeny. This group of radionuclides is referred to here as the actinides. The second group consists of all other radionuclides and is referred to as the nonactinides.

For both actinides and nonactinides, the starting point for the evaluation was the shipping record-based inventory for all waste emplaced in the TSA. This pretreatment inventory is found in the RWMIS database and was decayed to 1993 by Atwood and Schlafman (1993).

Because the inventory of radionuclides in the ALLW has significant uncertainties, upperlimit and lower-limit inventories of actinides were developed to bound the actual inventory. Nearly all of the runs were made with the upper-limit inventory. For the nonactinides, the inventory is a best estimate. 
2.4.2.2 Actinides, A simplified, upper-limit inventory of the actinides in the ALLW was developed by

- Assuming that their respective activities in the ALLW have the same ratio to one another as in the TSA waste as a whole

- Scaling the posttreatment inventory of actinides to an upper-limit value of $100 \mathrm{nCi}$ of TRU radionuclides ${ }^{c}$ per gram of waste, the maximum possible concentration for ALLW; this step is discussed further in Section 2.4.2.6

- Screening out radionuclides with very small activities.

This inventory is conservative in that it reflects the maximum possible TRU radionuclide concentration for ALLW.

The minimum possible concentration of $10 \mathrm{nCi} / \mathrm{g}$ of TRU radionuclides in the ALLW was used to create a lower-limit inventory of actinides. Finally, a case was analyzed based on an assumption of $1,000 \mathrm{nCi} / \mathrm{g}$ of TRU radionuclides. This case actually represents TRU waste, not ALLW.

2.4.2.3 Nonactinides. A simplified inventory of nonactinides in the ALLW was developed by

- Assuming all of the nonactinides at the TSA are located in the (untreated) RH TRU waste and RH ALLW

- Assuming that the activity fraction of the nonactinide inventory that is in the RH ALLW is the same as the volume fraction of RH waste $(50 \% \pm 20 \%)$ that is ALLW; that is, the concentration of nonactinide activity was assumed to be independent of the concentration of TRU activity

- Spreading the nonactinide activity evenly over all of the treated ALLW (RH and CH)

- Screening out radionuclides with very low activities [the screening was confirmed using the method of Seitz and Kocher (1993) for the groundwater pathway and using computer runs for the intrusion scenarios]

- Assigning specific radionuclides for generic entries such as mixed fission products.

A best estimate of the nonactinide inventory was developed because there was no basis for estimating upper-limit and lower-limit inventories.

c. Hereafter, TRU radionuclide generally refers to those radionuclides cited in DOE Order $5820.2 \mathrm{~A}$ for the definition of TRU waste, i.e., those that are alpha-emitters and have half-lives greater than $20 \mathrm{yr}$. 
2.4.2.4 Total Inventory. Table 2-3 lists the total simplified inventory (as of 1993) that was used for most of the computer runs. Radioactive decay and ingrowth after 1993 was handled in the individual schemes for transport pathway modeling and exposure route modeling.

The TRU activity is the upper limit of $100 \mathrm{nCi} / \mathrm{g}$ for ALLW. (That is, if the total TRU activity of $2,990 \mathrm{Ci}$ is divided by the total mass of the waste after treatment, the result is $100 \mathrm{nCi} / \mathrm{g}$.)

For computer runs with $10 \mathrm{nCi} / \mathrm{g}$ or $1,000 \mathrm{nCi} / \mathrm{g}$ of TRU, the activities of all actinides were, respectively, divided by 10 or multiplied by 10 .

2.4.2.5 Comparison Against the Inventory Developed in Other PSPI Studies. While this study was under way, other PSPI activities included detailed evaluations of the known shipping information and SWEPP assay data on untreated waste expected to be classified as ALLW (Apel et al. 1993, Apel et al. 1994). The simplified inventory in Table 2-3 was used in this study because (a) the studies by Apel et al. were not available when the PA work started and (b) those evaluations did not identify any nonactinides in the ALLW.

Table 2-3. Total simplified inventory, assuming $100 \mathrm{nCi} / \mathrm{g}$ TRU radionuclides.

\begin{tabular}{lrc} 
& $\begin{array}{c}\text { Inventory in } 1993 \\
\text { Radionuclide }\end{array}$ & $\begin{array}{c}\text { TRU radionuclide inventory } \\
\text { (Ci) }\end{array}$ \\
\hline Ba-137m & 1,125 & - \\
Co-60 & 47 & - \\
Cs-137 & 1,125 & - \\
Sr-90 & 1,013 & - \\
Y-90 & 1,013 & - \\
Am-241 & 1,340 & 1,340 \\
Cm-244 & 8 & - \\
Pu-238 & 906 & 906 \\
Pu-239 & 598 & 598 \\
Pu-240 & 147 & 147 \\
Pu-241 & 2,401 & - \\
U-233 & 13 & - \\
U-238 & 0.0017 & - \\
Total & 9,736 & 2,990 \\
& &
\end{tabular}

Note: Totals may not match exactly because of rounding. 
The inventory studies by Apel et al. addressed different information about the ALLW (e.g., characterizing untreated waste rather than treated waste). Nevertheless, comparing the current simplified inventory against that developed in the Apel studies was useful as a rough check (Smith 1993, Tozer 1993).

Table 2-4 compares the two inventories. The simplified inventory has a higher total activity and higher entries for almost all radionuclides than does the inventory compiled from Apel et al. (1993) in Tozer (1993).

The simplified inventory lists $5,413 \mathrm{Ci}$ of actinides if $100 \mathrm{nCi} / \mathrm{g}$ TRU (the upper limit for ALLW) is assumed. If $10 \mathrm{nCi} / \mathrm{g}$ (the lower limit for ALLW) is assumed, the result is $541.3 \mathrm{Ci}$ of actinides. These two limiting cases bound the $1,898 \mathrm{Ci}$ of actinides in the inventory derived from Apel et al. (1993).

Table 2-4. Comparison of simplified inventory (assuming upper limit of $100 \mathrm{nCi} / \mathrm{g}$ TRU radionuclides) against inventory developed from Apel et al. (1993) by Tozer (1993).

\begin{tabular}{lrc}
\hline Radionuclide & $\begin{array}{r}\text { Simplified inventory } \\
(\mathrm{Ci})\end{array}$ & $\begin{array}{c}\text { Inventory from Tozer 1993 } \\
(\mathrm{Ci})\end{array}$ \\
\hline Ba-137m & 1,125 & - \\
Co-60 & 47 & - \\
Cs-137 & 1,125 & - \\
Sr-90 & 1,013 & - \\
Y-90 & 1,013 & 8.86 \\
Am-241 & 1,340 & - \\
Cm-244 & 8 & $4 \mathrm{E}-06$ \\
Pu-236 & - & 126 \\
Pu-238 & 906 & 227 \\
Pu-239 & 598 & 49.7 \\
Pu-240 & 147 & 1,330 \\
Pu-241 & 2,401 & 0.06 \\
Pu-242 & - & 0.475 \\
Th-232 & - & 155 \\
U-233 & 13 & 0.013 \\
U-235 & - & 0.42 \\
U-238 & 0.0017 & 1,898 \\
Total & 5,413 & 1,898 \\
Total actinides & &
\end{tabular}

Note: Totals may not match exactly because of rounding. 
As stated previously, the inventory in Apel et al. (1993) does not show any nonactinides.

With one exception, the only radionuclides for which the Apel inventory gives higher values than does the simplified inventory are all $<1 \mathrm{Ci}$ in activity.

The one exception is U-233. The simplified inventory lists $13 \mathrm{Ci}$, whereas Tozer's compilation from Apel et al. (1993) gives $155 \mathrm{Ci}$. The more recent Apel el al. (1994) lists approximately $865 \mathrm{Ci}$ of U-233. In addition, Apel et al. (1994) lists approximately $2.5 \mathrm{Ci}$ of Th-232, an increase over the $0.475 \mathrm{Ci}$ in Apel et al. (1993). Because of questions about the effects of the increased activities of U-233 and Th-232, special computer runs for the groundwater pathway were made using the most recent (highest) values of U-233 and Th-232 from Apel et al. (1994). The results, discussed in Section 10, show that, for the one site studied (the SDA), the total doses increase by only about $0.1 \%$ at the most, if the highest values of U-233 and Th-232 activity are used. Thus, the larger activity of U-233 and Th-232 in Apel et al. (1994) did not have a substantial effect on the dose for that site.

A check was also made on the importance of the $0.42 \mathrm{Ci}$ of U-238 in Apel et al. (1993). Although the activity is $<1 \mathrm{Ci}$, the half-life of $\mathrm{U}-238$ is extremely long at 4.47 billion years. A groundwater run was made for the U-238 assuming a Portland cement/concrete (PCC) FWF disposed of at the SDA. Although the U-238 produces a substantial secondary peak dose at a later time, the overall maximum dose was not increased by the larger activity of the U-238.

In conclusion, the rough comparison against the Apel inventories confirmed that the simplified inventory generally provides reasonable, bounding values for the radionuclide activities in the treated ALLW.

\subsubsection{Treated Waste.}

\section{General and Baseline}

As Section 2.4.2.2 indicated, the scaling step for actinides is discussed in more detail here.

One general assumption was that all radionuclides that enter treatment with the waste stay with the treated waste. Therefore, the radionuclide inventory, in $\mathrm{Ci}$, derived for untreated waste applies also to treated waste.

The upper-limit actinide inventory was developed for the situation in which all containers of treated waste have $100 \mathrm{nCi} / \mathrm{g}$ of TRU radionuclides. In this situation, the inventory depends on the total mass of the treated waste. (The mass of the empty containers is not considered in this analysis.) To complicate things, the posttreatment mass (a) differs from the pretreatment mass and (b) depends on the treatment method.

The estimated pretreatment mass is based on a waste volume of $24,413 \mathrm{~m}^{3}$ for the ALLW (Table 2-1) and an average waste density of $652 \mathrm{~kg} / \mathrm{m}^{3}$ from evaluations conducted in the INEL Idaho Waste Processing Facility (IWPF) Project. The result is an estimated pretreatment mass of $1.59 \mathrm{E}+10 \mathrm{~g}$. 
For simplicity in examining the effects on activity concentration, waste treatment can be considered to consist of two types of operations. The first type includes those that reduce the mass of the waste. For example, incineration reduces the mass of the combustible portion of the waste. However, the estimated fraction of the ALLW that is combustible is a maximum of only 25-30\% (by mass), per the IWPF Project. Suppose that $25 \%$ of the waste mass were essentially eliminated (reduced to a negligible mass of ash), as a result of incineration, offgassing, etc.

Therefore, each pretreatment unit of mass would be reduced to approximately 0.75 unit mass.

The second type of treatment covers operations that increase the mass of the waste. Immobilization increases the mass, by the addition of immobilization agents. Waste loadings for the FWFs (defined as mass of waste/total mass of FWF) considered range from 30 to $60 \%$.

It was calculated that, for the FWFs considered, the midpoint of the extreme values of the total posttreatment mass of the ALLW corresponds to a $40 \%$ waste loading. (Posttreatment mass is proportional to the inverse of the waste loading.) Because it was the midpoint, this value was used as a baseline for calculational purposes. (This midpoint loading happens to correspond to that for cement, both PCC and FUETAP. The effects for other FWFs are discussed later in this section.) Thus, in this case, each unit mass of postincineration ALLW that undergoes (cement) immobilization increases to about 2.5 unit mass of FWF.

The cumulative effect of the two types of processes is an increase in mass from 1 unit mass of waste before treatment to approximately $0.75 \times 2.5=1.88$ unit mass of FWF after treatment. Therefore, the posttreatment mass is approximately $1.88 \times 1.59 \mathrm{E}+10=2.99 \mathrm{E}+10 \mathrm{~g}$.

At the upper-limit concentration of $100 \mathrm{nCi} / \mathrm{g}$, the $2.99 \mathrm{E}+10 \mathrm{~g}$ has a total TRU radionuclide activity of $100 \mathrm{nCi} / \mathrm{g} \times 2.99 \mathrm{E}+10 \mathrm{~g} \times \mathrm{E}-9 \mathrm{Ci} / \mathrm{nCi}=2,990 \mathrm{Ci}$. Therefore, the individual actinide activities were scaled to produce a total activity of $2,990 \mathrm{Ci}$ of TRU radionuclides. Complete details are given in Appendix A.

\section{Specific to Each FWF}

Table 2-5 gives the volumetric concentration of activity for each radionuclide in each FWF. This information is needed because the amount of radioactivity released in the intrusion scenarios is proportional to the volumetric concentration of radioactivity. The table entries were developed by dividing the activities given in Table $2-3$ by the estimated total volume of each FWF. Estimation of the posttreatment volumes is described in Section A-8 of Appendix A.

For computer runs in which the mass concentration of TRU radionuclides was 10 or $1,000 \mathrm{nCi} / \mathrm{g}$, the values in Table $2-5$ were changed as follows. For all actinides, the radioactivity and the volumetric concentration of radioactivity were decreased or increased, respectively, by a factor of $\mathbf{1 0}$. For all nonactinides, the values were not changed.

\subsubsection{Refined Inventory for Nonactinides}

The computer runs in the first phase of the study identified that the assumptions concerning the nonactinides in the inventory had a considerable effect on the calculated doses for some intrusion scenarios. Therefore, a refined inventory of the nonactinides was developed during the 
Table 2-5. Volumetric concentrations of each radionuclide in each final waste form, in $\mathrm{Ci} / \mathrm{m}^{3}$, assuming $100 \mathrm{nCi} / \mathrm{g}$ TRU radionuclides for cement.

\begin{tabular}{lccccc}
\hline & $\begin{array}{c}\text { More favorable and } \\
\text { less favorable cement } \\
\text { (FUETAP and PCC) }\end{array}$ & $\begin{array}{c}\text { More favorable } \\
\text { glass } \\
\text { (ASG) }\end{array}$ & $\begin{array}{c}\text { Less favorable } \\
\text { glass } \\
\text { (BSG) }\end{array}$ & $\begin{array}{c}\text { More favorable } \\
\text { ceramic } \\
\text { (IEB4) }\end{array}$ & $\begin{array}{c}\text { Less } \\
\text { favorable } \\
\text { ceramic } \\
\text { (IEB) }\end{array}$ \\
\hline Bal-137m & $7.34 \mathrm{E}-02$ & $1.50 \mathrm{E}-01$ & $7.49 \mathrm{E}-02$ & $1.98 \mathrm{E}-01$ & $1.70 \mathrm{E}-01$ \\
$\mathrm{C0}-60$ & $3.07 \mathrm{E}-03$ & $6.26 \mathrm{E}-03$ & $3.13 \mathrm{E}-03$ & $8.27 \mathrm{E}-03$ & $7.09 \mathrm{E}-03$ \\
Cs-137 & $7.34 \mathrm{E}-02$ & $1.50 \mathrm{E}-01$ & $7.49 \mathrm{E}-02$ & $1.98 \mathrm{E}-01$ & $1.70 \mathrm{E}-01$ \\
Sr-90 & $6.61 \mathrm{E}-02$ & $1.35 \mathrm{E}-01$ & $6.74 \mathrm{E}-02$ & $1.78 \mathrm{E}-01$ & $1.53 \mathrm{E}-01$ \\
Y-90 & $6.61 \mathrm{E}-02$ & $1.35 \mathrm{E}-01$ & $6.74 \mathrm{E}-02$ & $1.78 \mathrm{E}-01$ & $1.53 \mathrm{E}-01$ \\
Arn-241 & $8.74 \mathrm{E}-02$ & $1.78 \mathrm{E}-01$ & $8.92 \mathrm{E}-02$ & $2.36 \mathrm{E}-01$ & $2.02 \mathrm{E}-01$ \\
$\mathrm{Cnn}-244$ & $5.22 \mathrm{E}-04$ & $1.07 \mathrm{E}-03$ & $5.33 \mathrm{E}-04$ & $1.41 \mathrm{E}-03$ & $1.21 \mathrm{E}-03$ \\
Pu-238 & $5.91 \mathrm{E}-02$ & $1.21 \mathrm{E}-01$ & $6.03 \mathrm{E}-02$ & $1.59 \mathrm{E}-01$ & $1.37 \mathrm{E}-01$ \\
Pu-239 & $3.90 \mathrm{E}-02$ & $7.96 \mathrm{E}-02$ & $3.98 \mathrm{E}-02$ & $1.05 \mathrm{E}-01$ & $9.02 \mathrm{E}-02$ \\
Pu-240 & $9.59 \mathrm{E}-03$ & $1.96 \mathrm{E}-02$ & $9.79 \mathrm{E}-03$ & $2.59 \mathrm{E}-02$ & $2.22 \mathrm{E}-02$ \\
Pu-241 & $1.57 \mathrm{E}-01$ & $3.20 \mathrm{E}-01$ & $1.60 \mathrm{E}-01$ & $4.22 \mathrm{E}-01$ & $3.62 \mathrm{E}-01$ \\
U-233 & $8.48 \mathrm{E}-04$ & $1.73 \mathrm{E}-03$ & $8.66 \mathrm{E}-04$ & $2.29 \mathrm{E}-03$ & $1.96 \mathrm{E}-03$ \\
U-238 & $1.11 \mathrm{E}-07$ & $2.26 \mathrm{E}-07$ & $1.13 \mathrm{E}-07$ & $2.99 \mathrm{E}-07$ & $2.56 \mathrm{E}-07$ \\
Total & $6.35 \mathrm{E}-01$ & $1.30 \mathrm{E}+00$ & $6.48 \mathrm{E}-01$ & $1.71 \mathrm{E}+00$ & $1.47 \mathrm{E}+00$
\end{tabular}

Note: Totals may not match exactly because of rounding.

second phase of the study, and a few computer runs were made using this refined inventory. The inventory of actinides was not changed from that in Table 2-3. The details of developing the refined inventory are given in Section A-9 of Appendix A. An overview is given below.

In developing the simplified inventory, conservative assumptions were made concerning nonactinides in the treated ALLW. One key assumption was spreading the nonactinide activity evenly over all of the treated ALLW. The simplified approach tends to overestimate the concentrations of nonactinides in the $\mathrm{CH}$ ALLW and underestimate the concentration of nonactinides in the RH ALLW. For the refined inventory, this assumption was replaced by a more realistic assumption. The CH ALLW was assumed to be treated separately from the RH ALLW, and the nonactinide inventories were estimated separately. It was no longer assumed that all of the nonactinides are in the RH waste. Most of the other assumptions used to develop the refined nonactinide inventory were the same as those for the simplified nonactinide inventory discussed in Section 2.4.2.3. 
It was assumed again that the distribution of nonactinides is independent of the distribution of TRU radionuclides. Thus, since $38 \%$ of the volume of the $\mathrm{CH}$ waste is $\mathrm{CH}$ ALLW, $38 \%$ of each nonactinide in the $\mathrm{CH}$ waste was assumed to be in the CH ALLW. The same assumption was made for the RH waste, although the fraction is $41 \%$. (The refined value differs somewhat from the earlier estimate of $50 \% \pm 20 \%$ used in the simplified model.)

Separate RWMIS printouts (covering the combined ALLW and TRU waste) were produced for the CH waste and for the RH waste. The RWMIS inventory of each nonactinide in the waste was multiplied by 0.38 for the $\mathrm{CH}$ waste or 0.41 for the $\mathrm{RH}$ waste.

The refined inventory of nonactinides is given in Table 2-6 for the $\mathrm{CH}$ portion of the ALLW and in Table 2-7 for the RH portion.

Comparison of Table 2-6 with Table 2-3 shows a large reduction in the nonactinide inventory in the CH ALLW. (The reduction for Co-60 is small and is the only exception.) The list of radionuclides that survived the screening is unchanged. The volume of the CH ALLW is virtually identical to that of the total ALLW (24,382 $\mathrm{m}^{3}$ versus $\left.24,413 \mathrm{~m}^{3}\right)$. Therefore, the concentrations of the nonactinides in the refined inventory for $\mathrm{CH} A L L W$ are reduced in proportion to their respective reductions in radioactivity.

Comparison of Table 2-7 with Table 2-3 shows that the activities of most radionuclides in the RH ALLW are slightly smaller. (One exception is Co-60, which is much smaller-only about $14 \%$ of its earlier value.) This result was expected because (a) the activity in the CH ALLW was addressed separately from the RH ALLW and (b) the volume (and activity) of the RH ALLW was assumed to be only $41 \%$, rather than the $50 \%$ used previously, of the total for the RH waste.

The volume of the RH ALLW is only about $0.13 \%$ of the total ALLW $\left(31 \mathrm{~m}^{3}\right.$ versus $\left.24,413 \mathrm{~m}^{3}\right)$. Therefore, the concentrations of the nonactinides obtained using the refined assumptions are about $1 / 0.0013=770$ times larger than the values developed using the simplified method.

The refined assumptions result in the activity and the activity concentration of the nonactinides generally decreasing by factors of 20 to 30 (depending on the radionuclide) for the CH ALLW. This decrease would be expected to reduce the receptor dose substantially for the intruder scenarios.

For the RH ALLW, the refined assumptions result in little change in the nonactinide activity inventory but an increase by a factor of about 770 in the activity concentration. This increase would be expected to increase the receptor dose substantially for intruder scenarios in which penetration of the RH waste occurs.

\subsubsection{Inventory with Additional Refinements for Nonactinides}

During the third phase of the study, a nonactinide "inventory with additional refinements" was developed and a few computer runs were made using this inventory. The inventory of actinides was not changed from that in Table 2-3. 
Table 2-6. Refined inventory of nonactinides for CH ALLW.

\begin{tabular}{lc} 
Radionuclide & $\begin{array}{c}\text { Radioactivity } \\
\text { (Ci) }\end{array}$ \\
\hline Ba-137m & 54.3 \\
Co-60 & 29.6 \\
Cs-137 & 54.3 \\
Sr-90 & 30.9 \\
Y-90 & 30.9 \\
Total & 200 \\
\hline
\end{tabular}

Table 2-7. Refined inventory of nonactinides for RH ALLW.

\begin{tabular}{lc} 
Radionuclide & $\begin{array}{c}\text { Radioactivity } \\
\text { (Ci) }\end{array}$ \\
\hline Ba-137m & 882 \\
Co-60 & 6.8 \\
Cs-137 & 882 \\
Sr-90 & 798 \\
Y-90 & 798 \\
Total & 3,367
\end{tabular}

Note: Totals may not match exactly because of rounding.

The details of developing the inventory with additional refinements are given in Section A-10 of Appendix A. An overview is given below. As with the refined inventory, the $\mathrm{CH}$ waste and RH waste were addressed separately.

Two investigations provided the new information for the inventory with additional refinements:

- One investigation was directed toward obtaining a more accurate split of the nonactinides between the TRU waste and the ALLW, and between the $\mathrm{CH}$ waste and the RH waste. The two previous inventories were based on very broad assumptions 
concerning these questions. In the new investigation, the RWMIS entries for each waste shipment containing nonactinides totaling $>1 \mathrm{Ci}$ were examined to determine whether the containers in the shipment would be expected to be TRU waste or ALLW, and $\mathrm{CH}$ waste or $\mathrm{RH}$ waste. To be conservative, any shipments with a TRU activity $<200 \mathrm{nCi} / \mathrm{g}$ were included in the ALLW. The division into the $\mathrm{CH}$ waste and $\mathrm{RH}$ waste was accomplished using separate RWMIS printouts for the $\mathrm{CH}$ waste on the TSA pads and the RH waste in the ILTSF. All individual nonactinide entries $>0.1 \mathrm{Ci}$ were then summed over all such shipments. Based on these new determinations, revisions were made to the estimate of the ALLW nonactinide inventory.

- In the other investigation, additional information on the nonactinide inventory was obtained from sources other than RWMIS. Based on various letters and reports, the following nonactinide activity (as of the time of disposal) that is not in RWMIS was identified:

- As much as 149 Ci of H-3 in waste from Rocky Flats Plant (RFP)

- An additional $64 \mathrm{Ci}$ of $\mathrm{Co}-60$ and $10 \mathrm{Ci}$ of $\mathrm{H}-3$ in radiation sources from RFP.

In addition, an estimate was made of the ALLW activity of three nonactinides that are often not reported or are underreported because of measurement difficulties. The three nonactinidesC-14, Tc-99, and I-129-are widespread in radioactive waste from non-weapons-related operations. Though very small in relative activity, they are often of interest in PAs because of their very long half-lives and relatively high mobility in the environment, once released from confinement. Using scaling factors derived for the buried waste at the SDA (Lockheed Idaho 1995), the following conservative estimates were made of the activities of these actinides:

- $\quad 1.0 \mathrm{Ci}$ of $\mathrm{C}-14$

- $\quad 0.05 \mathrm{Ci}$ of Tc-99

- $\quad$ 1.8E-05 Ci of I-129.

The results of the above three efforts were subjected to screening to eliminate nonactinides of very small activity that will not affect the calculated doses, then were decayed to 1993 . The product is the nonactinide inventory with additional refinements. The $\mathrm{CH}$ inventory, $\mathrm{RH}$ inventory, and combined inventory are presented in Tables 2-8, 2-9, and 2-10, respectively.

For comparison purposes, the corresponding entries from the simplified inventory and the refined inventory are also given in Tables 2-8 through 2-10. Table 2-10 shows that, with each successive inventory, the trend in total nonactinide activity has been downward.

\subsubsection{Refined Modeling of Untreated Waste}

In the second phase of the study, the performance of the untreated waste was evaluated as a benchmark for comparison. This necessitated developing a model of the untreated waste, in terms of the radionuclide inventory and release mechanisms. 
Table 2-8. Nonactinide inventory with additional refinements for CH ALLW.

\begin{tabular}{ccc}
\hline Radionuclide & $\begin{array}{c}\text { Activity in inventory } \\
\text { with additional } \\
\text { refinements } \\
(\mathrm{Ci})\end{array}$ & $\begin{array}{c}\text { Activity in refined } \\
\text { inventory } \\
(\mathrm{Ci})\end{array}$ \\
\hline Ba-137m & 67.3 & 54.3 \\
C-14 & 1.0 & - \\
Co-60 & 8.1 & 29.6 \\
Cs-137 & 67.3 & 54.3 \\
H-3 & 55.8 & - \\
I-129 & $1.8 \mathrm{E}-5$ & - \\
Sr-90 & 54.1 & 30.9 \\
Tc-99 & 0.05 & - \\
Y-90 & 54.1 & 30.9 \\
Total & 307.7 & 200 \\
& & \\
\hline \multirow{2}{*}{ a. Taken from Table 2-6. } & & \\
\hline
\end{tabular}

Table 2-9. Nonactinide inventory with additional refinements for RH ALLW.

\begin{tabular}{ccc}
\hline Radionuclide & $\begin{array}{c}\text { Activity in inventory } \\
\text { with additional } \\
\text { refinements } \\
(\mathrm{C} \text { ) }\end{array}$ & $\begin{array}{c}\text { Activity in refined } \\
\text { inventory } \\
(\mathrm{C})\end{array}$ \\
\hline Ba-137m & 140.5 & 882 \\
C-14 & 1.0 & - \\
Co-60 & 5.82 & 6.8 \\
Cs-134 & 5.5 & - \\
Cs-137 & 140.5 & 882 \\
I-129 & $1.8 \mathrm{E}-5$ & - \\
Sr-90 & 100.2 & 798 \\
Tc-99 & 0.05 & - \\
Y-90 & 100.2 & 798 \\
Total & 493.8 & 3366.8 \\
\cline { 2 - 3 } & & \\
\hline
\end{tabular}


Table 2-10. Nonactinide inventory with additional refinements for $\mathrm{CH}$ plus RH ALLW.

\begin{tabular}{lccc}
\hline Radionuclide & $\begin{array}{c}\text { Activity in inventory } \\
\text { with additional } \\
\text { refinements } \\
(\mathrm{Ci})\end{array}$ & $\begin{array}{c}\text { Activity in refined } \\
\text { inventory } \\
(\mathrm{Ci})\end{array}$ & $\begin{array}{c}\text { Activity in } \\
\text { simplified } \\
\text { inventory } \\
\text { (Ci) }\end{array}$ \\
\hline Ba-137m & 207.8 & 936.3 & 1125 \\
C-14 & 1.0 & - & - \\
Co-60 & 13.92 & 36.4 & 47 \\
Cs-134 & 5.5 & - & - \\
Cs-137 & 207.8 & 936.3 & 1125 \\
H-3 & 55.8 & - & - \\
I-129 & $1.8 \mathrm{E}-5$ & - & - \\
Sr-90 & 154.3 & 828.9 & 1013 \\
Tc-99 & 0.05 & - & - \\
Y-90 & 154.3 & 828.9 & 1013 \\
Total & 800.5 & 3566.8 & 4323 \\
& & & \\
\hline a. Taken from Tables 2-6 and 2-7. & & & \\
b. Taken from Table 2-3. & & &
\end{tabular}

NOTE: As discussed in Section 2.3, RCRA regulations are expected to require thermal treatment of most of the ALLW, followed by immobilization of the ash and other residuals. As a simplification, untreated waste was modeled here, rather than unimmobilized waste that had been through thermal treatment.

The model is referred to here as "refined" because it is slightly more sophisticated than the simplified one described in Section 2.4.2. However, it is still a very rudimentary model. It places all the untreated ALLW into three categories, with homogeneous properties within a category.

The details of the refined model for the untreated ALLW are given in Appendix B. An overview is provided below.

The refined radionuclide inventory used for modeling the untreated ALLW coincides with that presented in Table 2-3 for the actinides and Tables 2-6 and 2-7 (the refined inventory) for the nonactinides. Thus, the present discussion does not involve a new radionuclide inventory but a regrouping of the same inventory. 
After treatment, the INEL ALLW is expected to be fairly homogeneous, depending on the operational practices at the treatment facility. By contrast, the untreated ALLW is highly heterogeneous in its physical, chemical, and radiological characteristics.

No waste description of manageable complexity for this study can describe the ALLW precisely. Therefore, an approximate model representing the radiological inventory and release characteristics of the waste was developed. Grouping the untreated waste into categories with similar characteristics was necessary, together with assuming homogeneity of the waste within a category.

It was decided to group the ALLW packages first by INEL identification (ID) number. For mixed ALLW, there are 18 INEL ID numbers-groups of content codes ${ }^{\text {d }}$ that are based primarily on physical similarities. Examples of INEL ID numbers are those for cemented sludges (six content codes), resins (three), metals (five), and combustibles (seven). For nonmixed ALLW, there are eight INEL ID numbers.

The INEL ID numbers were then grouped into a smaller number of waste categories. The characteristics of the waste within each category were then evaluated and compared against the characteristics of the other categories.

Waste records in the form of detailed descriptions of the waste within a content code (Apel et al. 1993, supplemented by Apel et al. 1994 as necessary) were used to arrive at appropriate categories for modeling the waste. Those descriptions provide a large amount of information on the waste, although they are incomplete for many content codes, particularly concerning the radionuclide quantities and distributions.

As described in Appendix B, the data from Apel were used only for scaling the actinide content among content codes, ID numbers, and categories. The actinide inventory used was that developed in Appendix A and discussed in Section 2.4.2.2. The nonactinide activity used was that developed in Section A-9 of Appendix A and discussed in Section 2.4.3, as adapted for the untreated waste.

Table 2-11 summarizes the refined model of the untreated waste. Five ID numbers and part of another one relate to waste in the form of sludges, resins, and salts. They are combined into category 1: sludges, etc. For more than $99 \%$ of the actinide activity in this category, the release mechanism is assumed to be diffusion. The release parameters were assumed to match those for content code 2, second-stage sludge, the dominant content code in terms of actinide inventory for this category.

All but one of the 21 remaining ID numbers were grouped into category 2 , the nonsludges. Most of the actinides in category 2 are located on the surfaces of paper, rags, and metals. For most of the radioactivity in this category, the release mechanism is surface washoff. That mechanism was assumed for all ALLW in this category.

d. Each container of waste stored at the INEL is categorized under a specific content code, which provides a general description of the containerized waste. There are approximately 90 content codes. 
Table 2-11. Refined model of the untreated ALLW.

\begin{tabular}{|c|c|c|c|c|c|c|c|}
\hline Category & $\begin{array}{l}\text { Volume } \\
\left(\mathrm{m}^{3}\right)\end{array}$ & \multicolumn{2}{|c|}{$\begin{array}{l}\text { Actinide inventory } \\
\text { (Ci) }\end{array}$} & \multicolumn{2}{|c|}{$\begin{array}{l}\text { Nonactinide inventory } \\
\text { (Ci) }\end{array}$} & \multirow{2}{*}{$\begin{array}{c}\begin{array}{c}\text { Release } \\
\text { mechanism }\end{array} \\
\text { Diffusion }\end{array}$} & \multirow{2}{*}{$\begin{array}{c}\begin{array}{c}\text { Content code for other } \\
\text { properties }\end{array} \\
2 \text { (second-stage sludge) }\end{array}$} \\
\hline \multirow[t]{8}{*}{ 1-Sludges, etc. } & 3,904 & Am-241 & 214 & $\mathrm{Ba}-137 \mathrm{~m}$ & 8.70 & & \\
\hline & & $\mathrm{Cm}-244$ & 1.28 & $\mathrm{Co}-60$ & 4.74 & & \\
\hline & & $\mathrm{Pu}-238$ & 145 & Cs-137 & 8.70 & & \\
\hline & & $\mathrm{Pu}-239$ & 95.7 & Sr-90 & 4.95 & & \\
\hline & & $\mathrm{Pu}-240$ & 23.8 & Y-90 & 4.95 & & \\
\hline & & $\mathrm{Pu}-241$ & 384 & & & & \\
\hline & & $\mathrm{U}-233$ & 2.08 & & & & \\
\hline & & $\mathrm{U}-238$ & 0.0003 & & & & \\
\hline \multirow[t]{8}{*}{ 2-Nonsludges } & 20,455 & Am-241 & 1,124 & $\mathrm{Ba}-137 \mathrm{~m}$ & 45.6 & Surface & 330 (dry paper and \\
\hline & & $\mathrm{Cm}-244$ & 6.71 & $\mathrm{Co}-60$ & 24.9 & washoff & rags) \\
\hline & & $\mathrm{Pu}-238$ & 760 & Cs-137 & 45.6 & & \\
\hline & & $\mathrm{Pu}-239$ & 502 & Sr-90 & 25.9 & & \\
\hline & & $\mathrm{Pu}-240$ & 123 & $Y-90$ & 25.9 & & \\
\hline & & $\mathrm{Pu}-241$ & 2,014 & & & & \\
\hline & & U-233 & 10.9 & & & & \\
\hline & & U-238 & 0.0014 & & & & \\
\hline \multirow[t]{8}{*}{ 3-Remote-handled } & $31^{a}$ & Am-241 & 1.647 & $\mathrm{Ba}-137 \mathrm{~m}$ & 882 & Surface & None appropriate; \\
\hline & & $\mathrm{Cm}-244$ & 0.010 & $\mathrm{Co}-60$ & 6.8 & washoff & assume particulate on \\
\hline & & $\mathrm{Pu}-238$ & 1.15 & Cs-137 & 882 & & filters or rags \\
\hline & & $\mathrm{Pu}-239$ & 0.735 & Sr-90 & 798 & & \\
\hline & & $\mathrm{Pu}-240$ & 0.181 & Y-90 & 798 & & \\
\hline & & $\mathrm{Pu}-241$ & 2.950 & & & & \\
\hline & & U-233 & 0.016 & & & & \\
\hline & & U-238 & 0 & & & & \\
\hline \multirow[t]{8}{*}{ Total } & $24,390^{2}$ & Am-241 & 1,340 & $\mathrm{Ba}-137 \mathrm{~m}$ & 936 & NA & NA \\
\hline & & $\mathrm{Cm}-244$ & 8 & $\mathrm{Co}-60$ & 36.4 & & \\
\hline & & $\mathrm{Pu}-238$ & 906 & Cs-137 & 936 & & \\
\hline & & $\mathrm{Pu}-239$ & 598 & Sr-90 & 829 & & \\
\hline & & $\mathrm{Pu}-240$ & 147 & Y-90 & 829 & & \\
\hline & & $\mathrm{Pu}-241$ & 2,401 & & & & \\
\hline & & U-233 & 13 & & & & \\
\hline & & U-238 & 0.0017 & & & & \\
\hline
\end{tabular}

a. For consistency with other parametric studies in this document, the volume of the RH waste was assumed to be $31 \mathrm{~m}^{3}$, as given in RWMIS and discussed in Appendix A, rather than the $54 \mathrm{~m}^{3}$ given in Raivo et al. 1993. The total volume over all categories is, therefore, $23 \mathrm{~m}^{3}$ less than the $24,413 \mathrm{~m}^{3}$ in Raivo et al. 1993 . This volume difference of less than $0.1 \%$ is not significant for developing the radiological inventory and was neglected. 
The last ID number contains all of the RH ALLW. The waste with this ID number was assigned to category 3 , the RH waste. The available information on physical and chemical form is not detailed; a surface washoff release mechanism was assumed because most of the waste is combustibles and (apparently) nonactivated metals.

\subsection{Radionuclide Screening of Nonactinides from Detailed Groundwater Pathway Evaluation}

\subsubsection{Objective and Scope}

The calculations of groundwater transport of radionuclides using the models applied in this study are complex. In addition, separate model runs are required for each radionuclide whose contribution to the total dose is evaluated. Therefore, simple screening calculations were performed. The objective was to eliminate from detailed groundwater transport calculations the radionuclides that could make only negligible contributions to the dose.

This section describes how the screening was applied to the nonactinides in each of the three radionuclide inventories: simplified, refined, and with additional refinements. All of the actinides, the activities of which are identical in the three inventories, were retained for the detailed evaluations of groundwater transport.

This screening applies only to the groundwater pathway. Radionuclides identified as being insignificant dose contributors via that pathway may still make important contributions to dose in the intrusion scenarios. Therefore, the complete inventories in Table 2-3, in Tables 2-6 and 2-7, and in Tables 2-8 through 2-10 were retained for the evaluation of the intruder scenarios.

\subsubsection{Approach and Generic Assumptions}

The screening model of Seitz and Kocher (1993) was used to establish trigger levels for radionuclide concentrations in the waste. The trigger levels indicate what constitutes a potentially important concentration of a given radionuclide in the FWF, based on potential groundwater concentrations that could exceed drinking water standards established by the Nuclear Regulatory Commission (NRC) in 10 CFR Part 20 (NRC 1989). If the concentration of a given radionuclide in the FWF is below the trigger level, then that radionuclide will not make an important contribution to dose. Further calculations or data-collection efforts are not required for that radionuclide.

The starting point for the analysis was the following screening equation proposed by Seitz and Kocher (1993): 


$$
T_{i}=\frac{D_{s t d_{i}} \theta R_{d_{i}}}{D_{i n g_{i}} C_{r} e^{-\lambda_{i} t}}
$$

where

$$
\begin{array}{ll}
\mathrm{T}_{\mathrm{i}} & =\text { trigger level for radionuclide } \mathrm{i}\left(\mathrm{Ci} / \mathrm{m}^{3}\right) \\
\mathrm{D}_{\text {std }_{\mathrm{i}}} & =\text { dose limit for radionuclide } \mathrm{i}(\mathrm{mrem} / \mathrm{yr}) \\
\mathrm{D}_{\text {ing }_{\mathrm{i}}} & =\text { ingestion dose conversion factor for radionuclide } \mathrm{i}(\mathrm{mrem} / \mathrm{Ci}) \\
\mathrm{C}_{\mathrm{r}} & =\text { consumption rate }\left(\mathrm{m}^{3} / \mathrm{yr}\right) \\
\mathrm{t} & =\text { time at which consumption takes place }(\mathrm{yr}) \\
\theta & =\text { porosity of the aquifer (dimensionless) } \\
\mathrm{R}_{\mathrm{d}_{\mathrm{i}}} & =\text { retardation coefficient for radionuclide } \mathrm{i} \text { in the aquifer (dimensionless) } \\
\lambda_{\mathrm{i}} & =\text { decay constant for radionuclide } \mathrm{i}(1 / \mathrm{yr})=(\ln 2) / \mathrm{t}_{7 / \mathrm{i}} \text { with } \mathrm{t}_{1 / \mathrm{i}}=\text { half-life of }
\end{array}
$$

Equation (2-1) assumes that the entire volume of the waste inventory is deposited in an equal volume of aquifer at time $t$. The factor $D_{\text {std }} /\left(D_{\text {ing }}, C_{r}\right)$ is equivalent to a concentration limit of radionuclide $i$ in the groundwater. This factor, br concentration limit, will be denoted by the variable $\mathrm{C}_{\mathrm{i}}$ and has the units of $\mathrm{Ci} / \mathrm{m}^{3}$.

The following generic assumptions were used for the screening on all three inventories:

1. No credit was taken for any radionuclide immobilization provided by the FWF. The approach assumed that the entire radionuclide inventory is initially dissolved in the pore water within the disposal unit.

2. The time, $t$, was conservatively assumed to be the product of the vadose zone pore water travel time and the retardation coefficient for each radionuclide.

3. Conservatively, the value of $R_{d_{i}}$ listed explicitly in Equation (2-1) was set to the minimum value of 1.0 .

4. The concentration limit of radionuclide $i$ in the groundwater, $C_{i}$, was assumed to be equal to the smallest value of the maximum permissible concentration (MPC) for public drinking water listed for radionuclide $i$ in "Standards for Protection Against Radiation," Appendix B in 10 CFR Part 20 (NRC 1989). 
5. The half-life of $\mathrm{Y}-90(64 \mathrm{hr})$ was conservatively assigned the value for the half-life of Sr-90 (about $29 \mathrm{yr}$ ) in order to maintain secular equilibrium with the progenitor radionuclide. The same approach was used with Ba-137m and Cs-137.

6. The concentration of radionuclides in the FWF was conservatively selected to be equal to the concentration in IEB4 (the more favorable ceramic FWF), since this FWF has the highest waste loading.

\subsubsection{Screening Calculations for the Simplified Inventory}

During the first phase of the study, the screening calculations were performed on the simplified nonactinide inventory in Table 2-3. The calculations were applied to groundwater transport at Sites A, B, and C.

A groundwater travel time of $400 \mathrm{yr}$ was used. This value was the smallest value for any of the three sites, as shown later in Section 3. An aquifer porosity of 0.1 was used. The retardation coefficient $R_{d}$ for each radionuclide was calculated conservatively by using (a) one-tenth of the smaller $K_{d}$ values listed later in Table $3-2$ and (b) a bulk density of $1.5 \mathrm{~g} / \mathrm{cm}^{3}$ and porosity of 0.06 for the vadose zone, where nearly all of the travel time occurs.

By means of the screening method just described, the five nonactinides in the simplified inventory, Co-60, Y-90, Sr-90, Ba-137m, and Cs-137, were determined to be insignificant dose contributors via the groundwater pathway. They were deleted from detailed analysis for that pathway. The remaining radionuclides (the actinides) were analyzed in detail using the groundwater transport model, because they are progenitors of long-half-life decay chains.

Table 2-12 shows the bases for those conclusions. The second column lists the concentration of each nonactinide radionuclide in the FWF, as taken from Table 2-5. The third column lists the radionuclide half-lives. The fourth column lists the decay constant $\left(\lambda_{\mathrm{i}}\right)$ for each radionuclide.

The fifth column in the table lists the MPC in drinking water, as stipulated in $10 \mathrm{CFR}$ Part 20 (NRC 1989).

Table 2-12. Screening of nonactinides from the simplified inventory before detailed evaluation of groundwater transport-Sites A, B, and C.

\begin{tabular}{lcccccc}
\hline & $\begin{array}{c}\text { Concentration in } \\
\text { FWF } \\
\left(\mathrm{Ci}^{3} / \mathrm{m}^{3}\right)\end{array}$ & $\begin{array}{c}\text { Half-life } \\
(\mathrm{yr})\end{array}$ & $\begin{array}{c}\text { Lambda } \\
(1 / \mathrm{yr})\end{array}$ & $\begin{array}{c}\text { MPC drinking } \\
\text { water } \\
\left(\mathrm{Ci} / \mathrm{m}^{3}\right)\end{array}$ & $\begin{array}{c}\text { Trigger } \\
\text { level } \\
\left(\mathrm{Ci} / \mathrm{m}^{3}\right)\end{array}$ & $\begin{array}{c}\text { Concentration in } \\
\text { FWF/trigger level }\end{array}$ \\
\hline Co-60 & $8.27 \mathrm{E}-03$ & 5.3 & 0.131 & $3 \mathrm{E}-05$ & $>1 \mathrm{E}+200$ & $<1 \mathrm{E}-200$ \\
$\mathrm{Sr}-90$ & $1.78 \mathrm{E}-01$ & 29 & 0.0239 & $3 \mathrm{E}-07$ & $6.7 \mathrm{E}+17$ & $7.4 \mathrm{E}-19$ \\
$\mathrm{Y}-90$ & $1.78 \mathrm{E}-01$ & $29^{\mathrm{a}}$ & 0.0239 & $2 \mathrm{E}-05$ & $4.5 \mathrm{E}+19$ & $1.1 \mathrm{E}-20$ \\
$\mathrm{Ba}-137 \mathrm{~m}$ & $1.98 \mathrm{E}-01$ & $30.2^{\mathrm{a}}$ & 0.0230 & $2 \mathrm{E}-05$ & $>1 \mathrm{E}+200$ & $<1 \mathrm{E}-200$ \\
$\mathrm{Cs}-137$ & $1.98 \mathrm{E}-01$ & 30.2 & 0.0230 & $2 \mathrm{E}-05$ & $7.0 \mathrm{E}+197$ & $2.8 \mathrm{E}-199$
\end{tabular}

a. See text for explanation of half-life used. 
The sixth column lists the calculated trigger level for each radionuclide, with the variable $\mathrm{C}$ replacing the ratio $D_{\text {std }} /\left(D_{\text {ing }} C_{r}\right)$, using the values of the variables listed earlier. Entries in the sixth column designated by $>1 \mathrm{E}+200$ indicate that the denominator approaches zero, based on the large values for the time $(t)$ for the radionuclide to reach the saturated zone relative to the half-life. Since the denominator approaches zero, the trigger level approaches very large values, and the radionuclide is not of concern. The final column lists the ratio of the radionuclide concentration in the FWF to that of the trigger level for each radionuclide. If a value is greater than 1.0, that radionuclide justifies detailed evaluation of groundwater transport. All values listed are many orders of magnitude less than 1.0, so further groundwater transport evaluation of the nonactinides in this inventory was not necessary.

The additional nonactinides Ce-144, Cs-134, Kr-85, Ni-63, Pm-147, and Pr-144 that were excluded initially from the simplified inventory, in Table A-2, based on experience, were subjected later to the above screening analysis. The results showed that these radionuclides, at their assumed inventories in Table A-2, do not contribute substantially to the dose for the groundwater pathway.

These analyses show that the nonactinides in the simplified inventory would not contribute substantially to the dose via groundwater transport in this study. These radionuclides were retained, however, for the analysis of the intrusion scenarios.

As will be shown later in Section 10, a limited number of runs were made with groundwater travel times considerably shorter than the original values. For Sites A, B, and C, the shortest time was $6.3 \mathrm{yr}$ for some Site A runs. Overall, the shortest time was $1.5 \mathrm{yr}$ for one Site D run. The question arises as to whether the nonactinide screening conclusions drawn from Table 2-12, which was based on a 400-yr travel time, are still valid for the shorter travel times. Part of the answer is presented in Table 2-13. That table also includes the very small activities of C-14, Tc-99, I-129, and $\mathrm{H}-3$ given in RWMIS, as taken from Table A-2. For the minimum groundwater travel time of $6.3 \mathrm{yr}$ for Sites A, B, and C, the nonactinides Sr-90, Y-90, and Cs-137 now pass the screening.

Table 2-13. Screening of nonactinides from the simplified inventory before detailed evaluation of groundwater transport-Sites A, B, and C with minimum groundwater travel time of $6.3 \mathrm{yr}$.

\begin{tabular}{lclllll}
\hline & $\begin{array}{c}\text { Concentration in } \\
\text { FWF } \\
\left(\mathrm{Ci} / \mathrm{m}^{3}\right)\end{array}$ & $\begin{array}{c}\text { Half-life } \\
(\mathrm{yr})\end{array}$ & $\begin{array}{c}\text { Lambda } \\
(1 / \mathrm{yr})\end{array}$ & $\begin{array}{c}\text { MPC drinking } \\
\text { water } \\
\left(\mathrm{Ci} / \mathrm{m}^{3}\right)\end{array}$ & $\begin{array}{c}\text { Trigger } \\
\text { level } \\
\left(\mathrm{Ci} / \mathrm{m}^{3}\right)\end{array}$ & $\begin{array}{c}\text { Concentration in } \\
\text { FWF/trigger level }\end{array}$ \\
\hline Co-60 & $8.27 \mathrm{E}-03$ & 5.3 & 0.131 & $3 \mathrm{E}-05$ & $2.7 \mathrm{E}+84$ & $3.1 \mathrm{E}-87$ \\
$\mathrm{Sr}-90$ & $1.78 \mathrm{E}-01$ & 29.0 & 0.0239 & $3 \mathrm{E}-07$ & $7.3 \mathrm{E}-08$ & $2.4 \mathrm{E}+06$ \\
$\mathrm{Y}-90$ & $1.78 \mathrm{E}-01$ & 29.0 & 0.0239 & $2 \mathrm{E}-05$ & $4.9 \mathrm{E}-06$ & $3.6 \mathrm{E}+04$ \\
Ba-137m & $1.98 \mathrm{E}-01$ & 30.2 & 0.0230 & $2 \mathrm{E}-05$ & $6.5 \mathrm{E}+03$ & $3.1 \mathrm{E}-05$ \\
$\mathrm{Cs}-137$ & $1.98 \mathrm{E}-01$ & 30.2 & 0.0230 & $2 \mathrm{E}-05$ & $3.2 \mathrm{E}-03$ & 62 \\
$\mathrm{C}-14$ & $<1.76 \mathrm{E}-08$ & 5,720 & $1.21 \mathrm{E}-04$ & $8 \mathrm{E}-04$ & $8.0 \mathrm{E}-05$ & $<2.2 \mathrm{E}-04$ \\
$\mathrm{Tc}-99$ & $1.58 \mathrm{E}-07$ & $2.13 \mathrm{E}+05$ & $3.25 \mathrm{E}-06$ & $2 \mathrm{E}-04$ & $2.0 \mathrm{E}-05$ & $7.9 \mathrm{E}-03$ \\
$\mathrm{I}-129$ & 0 & $1.7 \mathrm{E}+07$ & $4.08 \mathrm{E}-08$ & $6 \mathrm{E}-08$ & $6.0 \mathrm{E}-09$ & 0 \\
$\mathrm{H}-3$ & $7.04 \mathrm{E}-05$ & 12.3 & $5.6 \mathrm{E}-02$ & $3 \mathrm{E}-03$ & $4.3 \mathrm{E}-04$ & 0.16 \\
\hline
\end{tabular}


Detailed groundwater runs were made for these three nonactinides to determine whether the maximum dose would be affected by the nonactinides in cases involving the shortest travel times. No maximum doses were affected.

Screening of the simplified inventory for application at Sites D and E is discussed at the end of Section 2.5.4 below. That section pertains to screening of the inventory with additional refinements, which was developed in the third phase of the study.

\subsubsection{Screening Calculations for the Inventory with Additional Refinements}

In the third phase of the study, the same screening method was applied to the inventory with additional refinements. The combined $\mathrm{CH}$ and $\mathrm{RH}$ inventory in Table $2-10$ was used.

Except as discussed here, the same screening assumptions were used as in Section 2.5.3.

The inventory with additional refinements was used for a limited number of runs at Sites A, $\mathrm{C}, \mathrm{D}$, and $\mathrm{E}$. Therefore, the screening considered all of these sites with their respective groundwater travel times and sorptive behaviors. Of the sites, the most favorable in terms of minimal groundwater transport is Site $\mathrm{C}$ and the least favorable is Site D. The other sites fall between the results for these two sites.

As will be discussed later in Section 3, for Site D, the groundwater travel time is $4.52 \mathrm{yr}$. For Site C, it is $2246 \mathrm{yr}$. These travel times are multiplied by the retardation coefficient of each radionuclide, which is calculated from the $\mathrm{K}_{\mathrm{d}} \mathrm{s}$.

The results of the screening are shown in Table 2-14 for the most favorable site and in Table 2-15 for the least favorable site.

The Cs-137, Ba-137m, Co-60, Sr-90, and Y-90 were screened out at both sites. The Cs-134 also was screened out at both sites. Because H-3, C-14, Tc-99, and I-129 could not be screened out, they were retained for detailed groundwater transport evaluations at all sites in the runs using this inventory. These radionuclides exceed the screening threshold at the least favorable site by factors ranging from 5.5 to 320 . Retention in the screening does not necessarily imply, however, that these radionuclides will be substantial contributors to dose in the detailed calculations.

Again, all of the radionuclides in the inventory were retained for the evaluations of the intrusion scenarios.

With completion of the screening in Table 2-15 for the inventory with additional refinements, the question of using the screened simplified inventory for runs at Sites D and E can now be addressed. The question is whether radionuclides in the simplified inventory that were screened out of detailed groundwater evaluations based on the characteristics of Sites A, B, and C should be included in the simplified inventory when applied to Sites D and E. The question was addressed by means of Table 2-15, combined with Table 2-5 and the unscreened ALLW inventory column in Table A-2, which is the precursor to Table 2-3. 
Table 2-14. Screening of nonactinides from the inventory with additional refinements before detailed evaluation of groundwater transport-Site C (most favorable).

\begin{tabular}{|c|c|c|c|c|c|c|}
\hline Radionuclide & $\begin{array}{l}\text { Concentration in } \\
\text { FWF } \\
\left(\mathrm{Ci} / \mathrm{m}^{3}\right)\end{array}$ & $\begin{array}{l}\text { Half-life } \\
\text { (yr) }\end{array}$ & $\begin{array}{l}\text { Lambda } \\
(1 / y r)\end{array}$ & $\begin{array}{c}\text { MPC drinking } \\
\text { water } \\
\left(\mathrm{Ci} / \mathrm{m}^{3}\right)\end{array}$ & $\begin{array}{c}\text { Trigger } \\
\text { level } \\
\left(\mathrm{Ci} / \mathrm{m}^{3}\right)\end{array}$ & $\begin{array}{l}\text { Concentration in } \\
\text { FWF/trigger level }\end{array}$ \\
\hline C-14 & $1.76 \mathrm{E}-04$ & 5720 & $1.21 \mathrm{E}-04$ & $8 \mathrm{E}-04$ & 8.4E-06 & 21 \\
\hline I-129 & $3.16 \mathrm{E}-09$ & 1.7E07 & $4.08 \mathrm{E}-08$ & $6 \mathrm{E}-08$ & $4.8 \mathrm{E}-10$ & 6.6 \\
\hline Tc-99 & 8.79E-06 & 2.12E05 & $3.25 \mathrm{E}-06$ & 2E-04 & $1.6 \mathrm{E}-06$ & 5.4 \\
\hline $\mathrm{Ba}-137 \mathrm{~m}$ & $3.65 \mathrm{E}-02$ & 30.2 & $2.3 \mathrm{E}-02$ & $3 E-08$ & $>E+200$ & $<$ E-200 \\
\hline $\mathrm{CO}-60$ & $2.45 \mathrm{E}-03$ & 5.3 & 0.13 & $3 \mathrm{E}-05$ & $>\mathrm{E}+200$ & $<\mathrm{E}-200$ \\
\hline Cs-134 & $9.74 \mathrm{E}-04$ & 2.1 & 0.34 & 9E-06 & $>E+200$ & $<\mathrm{E}-200$ \\
\hline Cs-137 & $3.65 \mathrm{E}-02$ & 30.2 & 2.3E-02 & $2 \mathrm{E}-05$ & $>E+200$ & $<\mathrm{E}-200$ \\
\hline Sr-90 & $2.71 \mathrm{E}-02$ & 29.0 & $2.4 \mathrm{E}-02$ & $3 \mathrm{E}-07$ & $>E+200$ & $<$ E-200 \\
\hline Y-90 & $2.71 \mathrm{E}-02$ & 29.0 & $2.4 \mathrm{E}-02$ & 2E-05 & $>\mathrm{E}+200$ & $<E-200$ \\
\hline $\mathrm{H}-3$ & 9.81E-03 & 12.3 & $5.6 \mathrm{E}-02$ & $3 E-03$ & $1.8 \mathrm{E}+50$ & $5.4 \mathrm{E}-53$ \\
\hline
\end{tabular}

Table 2-15. Screening of nonactinides from the inventory with additional refinements before detailed evaluation of groundwater transport-Site D (least favorable).

\begin{tabular}{lllllll}
\hline Radionuclide & $\begin{array}{c}\text { Concentration } \\
\text { in FWF } \\
\left(\mathrm{Ci} / \mathrm{m}^{3}\right)\end{array}$ & $\begin{array}{c}\text { Half-life } \\
(\mathrm{yr})\end{array}$ & $\begin{array}{c}\text { Lambda } \\
(1 / \mathrm{yr})\end{array}$ & $\begin{array}{c}\text { MPC drinking } \\
\text { water } \\
\left(\mathrm{Ci} / \mathrm{m}^{3}\right)\end{array}$ & $\begin{array}{c}\text { Trigger } \\
\text { level } \\
\left(\mathrm{Ci} / \mathrm{m}^{3}\right)\end{array}$ & $\begin{array}{c}\text { Concentration in } \\
\text { FWF/trigger level }\end{array}$ \\
\hline C-14 & $1.76 \mathrm{E}-04$ & 5720 & $1.21 \mathrm{E}-04$ & $8 \mathrm{E}-04$ & $6.5 \mathrm{E}-06$ & 27 \\
$\mathrm{I}-129$ & $3.16 \mathrm{E}-09$ & $1.7 \mathrm{E}+07$ & $4.08 \mathrm{E}-08$ & $6 \mathrm{E}-08$ & $4.8 \mathrm{E}-10$ & 6.6 \\
$\mathrm{Tc}-99$ & $8.79 \mathrm{E}-06$ & $2.13 \mathrm{E}+05$ & $3.25 \mathrm{E}-06$ & $2 \mathrm{E}-04$ & $1.6 \mathrm{E}-06$ & 5.5 \\
Ba-137m & $3.65 \mathrm{E}-02$ & 30.2 & $2.3 \mathrm{E}-02$ & $3 \mathrm{E}-08$ & $2.8 \mathrm{E}+33$ & $1.3 \mathrm{E}-35$ \\
Co-60 & $2.45 \mathrm{E}-03$ & 5.3 & 0.13 & $3 \mathrm{E}-05$ & $>\mathrm{E}+200$ & $<\mathrm{E}-200$ \\
$\mathrm{Cs}-134$ & $9.74 \mathrm{E}-04$ & 2.1 & 0.34 & $9 \mathrm{E}-06$ & $>\mathrm{E}+200$ & $<\mathrm{E}-200$ \\
Cs-137 & $3.65 \mathrm{E}-02$ & 30.2 & $2.3 \mathrm{E}-02$ & $2 \mathrm{E}-05$ & $9.1 \mathrm{E}+64$ & $4.0 \mathrm{E}-67$ \\
Sr-90 & $2.71 \mathrm{E}-02$ & 29.0 & $2.4 \mathrm{E}-02$ & $3 \mathrm{E}-07$ & $7.7 \mathrm{E}-02$ & 0.35 \\
Y-90 & $2.71 \mathrm{E}-02$ & 29.0 & $2.4 \mathrm{E}-02$ & $2 \mathrm{E}-05$ & 5.1 & $5.3 \mathrm{E}-03$ \\
H-3 & $9.8 \mathrm{E}-03$ & 12.3 & $5.6 \mathrm{E}-02$ & $3 \mathrm{E}-03$ & $3.1 \mathrm{E}-05$ & 320 \\
\hline
\end{tabular}

The results are given in Table 2-16. This table is based on the simplified inventory of nonactinides in Table A-2, including the very small activities of C-14, Tc-99, I-129, and H-3 given in RWMIS. Table 2-16 indicates that Sr-90 and H-3 survive the screening at Site D. As was the case with Sites A, B, and C, detailed groundwater runs with the simplified inventory were made for Site D using Sr-90 and H-3 and the shortest travel times. Again, the maximum doses were not affected by the nonactinides.

\subsubsection{Screening Calculations for the Refined Inventory}

No separate screening was done for the refined inventory. Instead, the conclusions drawn for the simplified inventory and for the inventory with additional refinements were applied, based on the following rationale. 
Table 2-16. Screening of nonactinides from the simplified inventory before detailed evaluation of groundwater transport-Site D (least favorable).

\begin{tabular}{|c|c|c|c|c|c|c|}
\hline R.adionuclide & $\begin{array}{c}\text { Concentration } \\
\text { in } \mathrm{FWF} \\
\left(\mathrm{Ci} / \mathrm{m}^{3}\right)\end{array}$ & $\begin{array}{l}\text { Half-life } \\
\text { (yr) }\end{array}$ & $\begin{array}{l}\text { Lambda } \\
(1 / y r)\end{array}$ & $\begin{array}{c}\text { MPC drinking } \\
\text { water } \\
\left(\mathrm{Ci} / \mathrm{m}^{3}\right)\end{array}$ & $\begin{array}{c}\text { Trigger } \\
\text { level } \\
\left(\mathrm{Ci} / \mathrm{m}^{3}\right)\end{array}$ & $\begin{array}{l}\text { Concentration in } \\
\text { FWF/trigger level }\end{array}$ \\
\hline C-14 & $1.76 \mathrm{E}-08$ & 5720 & $1.21 \mathrm{E}-04$ & $8 E-04$ & $6.5 \mathrm{E}-06$ & $<2.7 \mathrm{E}-03$ \\
\hline $\mathrm{I}-129$ & $\mathbf{0}$ & $1.7 \mathrm{E}+07$ & $4.08 \mathrm{E}-08$ & $6 \mathrm{E}-08$ & $4.8 \mathrm{E}-10$ & 0 \\
\hline Tc-99 & 1.58E-07 & $2.13 E+05$ & $3.25 \mathrm{E}-06$ & 2E-04 & $1.6 \mathrm{E}-06$ & 0.099 \\
\hline $\mathrm{Ba}-137 \mathrm{~m}$ & $1.98 \mathrm{E}-01$ & 30.2 & $2.3 \mathrm{E}-02$ & $3 E-08$ & $2.8 \mathrm{E}+33$ & 7.1E-35 \\
\hline $\mathrm{Co}-60$ & 8.27E-03 & 5.3 & 0.13 & $3 \mathrm{E}-05$ & $>E+200$ & $<$ E-200 \\
\hline Cs-134 & $9.68 \mathrm{E}-03$ & 2.1 & 0.34 & $9 E-06$ & $>E+200$ & $<\mathrm{E}-200$ \\
\hline Cs-137 & $1.98 \mathrm{E}-01$ & 30.2 & 2.3E-02 & $2 \mathrm{E}-05$ & $9.1 E+64$ & $2.2 \mathrm{E}-66$ \\
\hline Sr-90 & $1.78 \mathrm{E}-01$ & 29.0 & $2.4 \mathrm{E}-02$ & $3 E-07$ & 7.7E-02 & 2.3 \\
\hline Y-90 & $1.78 \mathrm{E}-01$ & 29.0 & $2.4 \mathrm{E}-02$ & $2 \mathrm{E}-05$ & 5.1 & 0.035 \\
\hline $\mathrm{H} \cdot 3$ & 7.04E-05 & 12.3 & $5.6 \mathrm{E}-02$ & $3 \mathrm{E}-03$ & 3.1E-05 & 2.3 \\
\hline
\end{tabular}

Tables 2-6 and 2-7 present the refined inventory. The groundwater pathway evaluation was done for the combined $\mathrm{CH}$ plus $\mathrm{RH}$ waste; thus, for each nonactinide, the sum of the entries on the two tables is of interest. For each of the five nonactinides listed in those two tables, the total activity is less than that for the simplified inventory in Table 2-3. Because those five radionuclides were screened out from detailed groundwater transport evaluation in Table 2-12 and Section 2.5.3, the smaller activities in the refined inventory were also screened out.

The activities of Cs-137, Sr-90, and Y-90 in the refined inventory are smaller than in the simplified inventory. Detailed groundwater runs with the simplified inventory showed that these three radionuclides did not affect the maximum doses for the cases with the shortest travel times. Therefore, they would not be expected to affect the maximum doses for the refined inventory. 


\section{References for Section 2}

Apel, M. L., M. T. Muneta-Bradford, A. L. Robert, J. C. Tozer, M. D. Argyle, and G. K. Becker, 1993, Waste Description Information Package for Alpha Low-level Mixed Waste and Alpha Low-level Waste (draft), Attachment 2 to Solid Alpha-Contaminated Low-Level Radioactive Waste Transport/Treatment Services Request for Proposal, SP-SOW-01, July.

Apel, M. L., G. K. Becker, Z. K. Ragan, J. Frasure, B. D. Raivo, L. G. Gale, and D. P. Pace, 1994, Radiological, Physical, and Chemical Characterization of Low-level Alpha-Contaminated Wastes Stored at the Idaho National Engineering Laboratory for Use in Conducting Feasibility Studies for Treatment Services, EG\&G Idaho, EGG-RWMC-11189, March.

Atwood, C. L., and M. J. Schlafman, 1993, Empirical Distributions of Radionuclides from RWMIS Data, EG\&G Idaho, Inc., EGG-RAAM-10741, April.

EG\&G Idaho, 1985, $A$ History of the Radioactive Waste Management Complex at the Idaho National Engineering Laboratory, WM-F1-81-003, Rev. 3, July.

Lockheed Idaho, 1995, A Comprehensive Inventory of Radiological and Nonradiological Contaminants in Waste Buried in the Subsurface Disposal Area of the INEL RWMC During the Years 1984-2003, Lockheed Idaho Technologies Company, INEL-95/0135, May.

NRC, 1989, "Standards for Protection Against Radiation," 10 CFR 20, Appendix B, U.S. Nuclear Regulatory Commission.

Raivo, B. D., T. L. Eddy, and G. L. Anderson, 1993, Statement of Work: Commercial Transport and Treatment of Alpha-Contaminated Mixed Low-Level Radioactive Waste (draft), Attachment 1 to Solid Alpha-Contaminated Low-Level Radioactive Waste Transport/Treatment Services Request for Proposal, SP-SOW-01, June.

Seitz, R. R., and D. C. Kocher, 1993, "On Establishing Waste Concentration Limits for Low-level Radioactive Waste Disposal," Proceedings of the Symposium on Waste Management, Tucson, Arizona, March.

Smith, T. H., 1993, "Comparison of Two Estimates of Radionuclide Inventories in Alpha LLW and Alpha LLMW," EG\&G Idaho, Inc., letter to G. L. Anderson, THS-13-93, August.

Tozer, J. C., 1993, "Estimated Total Quantity of Nuclides in ALLW and ALLMW," EG\&G Idaho, Inc., letter to M. L. Apel, JCT-16-93, July. 


\section{EVALUATION OF PERFORMANCE IN UNDISTURBED-WASTE SCENARIO-EXPOSURE ROUTES FOR GROUNDWATER TRANSPORT PATHWAY}

\subsection{Introduction}

For the assessment of the groundwater transport pathway in the undisturbed-waste scenario, the exposure was assumed to occur by the use of groundwater from a well drilled $100 \mathrm{~m}$ from the downgradient edge of the disposal facility. (No disturbance of the waste zone occurs in this scenario.) The assumed well screen thickness is $15 \mathrm{~m}$. The well is used for drinking water, irrigating crops, and watering livestock that may be consumed by humans.

The transport pathways and exposure routes for the undisturbed-waste scenario are depicted in the lower portion of Figure 4-2. Several pathways lead to the ingestion exposure route. (Section 4.2.1 discussed why other transport pathways and exposure routes were considered for this scenario but were not evaluated. One exception is radon transport, which is discussed in Section 8.) The details of the evaluation of the ingestion exposure route are given in Section 7.2.

An additional groundwater receptor location was evaluated in connection with Site A. A well was assumed to be drilled $215 \mathrm{~km}$ downgradient for one of the simulations (Run 1LDW). At that location, potentially contaminated groundwater may discharge to springs or other surfacewater bodies. The same transport pathways and exposure routes were evaluated as for the $100-\mathrm{m}$ well.

\subsection{Ingestion}

\subsubsection{Conceptual Model}

The conceptual model of the ingestion exposure route for the groundwater transport pathway assumed that a receptor resides near the disposal facility and uses a well located $100 \mathrm{~m}$ downgradient from the edge of the disposal unit as the major source of water. The receptor drinks contaminated groundwater, eats leafy vegetables and produce irrigated with contaminated groundwater, and consumes milk, meat, and eggs from livestock and poultry that consume contaminated groundwater and pasture grass irrigated with contaminated groundwater.

Secondary and indirect pathways within the groundwater pathway, such as inhalation of contaminated irrigation water and inhalation of contaminated dust remaining after evaporation of the irrigation water, were omitted from the conceptual model. These pathways would contribute relatively minor doses compared with those from more direct pathways, such as direct ingestion of contaminated water.

\subsubsection{Numerical Model}

The GENII dose assessment software package (Napier et al. 1988) was used to implement the conceptual model and to perform dose calculations based on the methods recommended by the International Committee on Radiation Protection (ICRP), as described in publications 
ICRP 26 and 30. The long-term environmental dosimetry portion of the package consists of the DITTY code, which calculates population exposures from waste disposal sites over long time periods. The timeframe for the calculations in DITTY is any 10,000-yr period. This period is divided into 143 periods of $70 \mathrm{yr}$ each. The DITTY code calculates the lifetime cumulative EDE and dose to critical organs for each time period and the annual EDEs for the period of maximum dose. The activity present during any period is the sum of the material released during that period plus the residual material in the environment from releases in previous periods.

The use of the DITTY code is adequate for calculating the maximum annual EDE within a 10,000 -yr time-of-compliance period and comparing the predictions with the 25 -mrem/yr performance objective. However, because the decay and in-growth of long-lived radionuclides may exceed the 10,000-yr time period, the maximum dose may be realized hundreds of thousands to millions of years after facility closure. For the analyses presented in this report, the maximum dose has been calculated irrespective of a time-of-compliance period. These maximum doses were calculated through the following sequence of calculations:

- Based on a conservative screening model (discussed in Section 2.5), several of the shorter-lived radionuclides were eliminated from further detailed analyses.

- The DUST code predicted the source terms for long-lived radionuclides (discussed in Section 6.2).

- The WELLC code predicted concentrations of the progenitor radionuclides at the receptor well (discussed in Section 6.4).

- The DECAYDOS program calculated the decay and in-growth of each radionuclide using the Bateman decay equations. Since the concentrations of the parent and progeny were calculated at the receptor well, this assumes identical sorption coefficients (and hence transport rates) for parent and progeny. Although radionuclides with lower sorption coefficients would arrive at the receptor well earlier, the annual EDE would be less than for the conservative assumed case of parent and progeny arriving at the receptor well simultaneously. Using as input the time-dependent concentration of each progenitor and progeny radionuclide and the groundwater usage environmental parameter values discussed in Section 7.2.3, the DITTY code calculated an annual EDE (in mrem/yr) for each radionuclide. The environmental parameter values assumed that the well water was used as the source of drinking water, as well as the source of irrigation water. The values used are summarized in Section 7.2.3, while the effective dose conversion factors for each radionuclide are summarized in Section 7.2.4.

- The doses were summed across all radionuclides that are part of a single decay chain. Thus, a dose-versus-time curve was derived for each chain.

\subsubsection{Assumptions and Parameter Values}

The required environmental parameter values encompass food-chain parameters and consumption rates. The parameter values used to evaluate the undisturbed-waste scenario with the DITTY code of the GENII package are provided in Table 7-1. Every effort was made to 
Table 7-1. Parameter values for the DITTY code of the GENII package used for undisturbedwaste scenario.

Parameter Value

Drinking water consumption rate

Consumption rate of leafy vegetables

Consumption rate of other vegetables

Consumption rate of eggs

Consumption rate of milk

Consumption rate of beef

Consumption rate of pork

Consumption rate of poultry

Growing period for leafy vegetables

Growing period for other vegetables

Grain growing time for animal consumption

Duration irrigation is used on crops

Irrigation rate for each crop
$730.5 \mathrm{~L} / \mathrm{yr}^{\mathrm{a}}$

$11 \mathrm{~kg} / \mathrm{yr}^{\mathrm{a}} \times 0.25^{\mathrm{b}}=2.8 \mathrm{~kg} / \mathrm{yr}$

$166 \mathrm{~kg} / \mathrm{yr}^{\mathrm{a}} \times 0.25^{\mathrm{b}}=42 \mathrm{~kg} / \mathrm{yr}$

$10 \mathrm{~kg} / \mathrm{yr}^{2}$

$103 \mathrm{~kg} / \mathrm{yr}^{2}$

$59 \mathrm{~kg} / \mathrm{yr}^{\mathrm{a}}$

$30 \mathrm{~kg} / \mathrm{yr}^{\mathrm{a}}$

$9 \mathrm{~kg} / \mathrm{yr}^{\mathrm{a}}$

45 days $^{\mathrm{a}}$

90 days $^{a}$

45 days $^{\mathrm{a}}$

6 months $/ \mathrm{yr}^{2}$

$63.33 \mathrm{~L} / \mathrm{m}^{2} / \mathrm{yr}^{\mathrm{a}}$

a. Source: Kennedy and Strenge 1992.

b. Based on the results of a U.S. Department of Agriculture survey, only $25 \%$ of the vegetables in the exposed individual's diet is derived from a residential garden (Aaberg and Kennedy 1990, Kennedy and Strenge 1992).

ensure that the parameter values supplied as input have referenceable sources to the extent of the available literature values. The majority of the parameter values were based on those cited by Kennedy and Strenge (1992). The values provided in that report are based on extensive U.S. Department of Agriculture consumption studies. Values for the other parameters are based on the recommended values supplied in the GENII package.

\subsubsection{Effective Dose Conversion Factors for Groundwater Pathway}

Table 7-2 presents the effective dose conversion factors for the groundwater pathway for the various radionuclides used in DECAYDOS. The effective dose conversion factors were obtained by running the DITTY routine of GENII with a unit concentration $\left(1 \mathrm{Ci} / \mathrm{m}^{3}\right)$ of each radionuclide in well water and with the parameter values in Table 7-1. These effective dose conversion factors differ from standard ingestion dose conversion factors in that they sum the doses from multiple environmental pathways. Included are the ingestion of $2 \mathrm{~L} /$ day of water, the consumption of leafy and other vegetables irrigated with contaminated water, and the consumption of vegetables, beef, poultry, pork, eggs, and milk obtained from animals that consumed contaminated water. 
Table 7-2. Effective dose conversion factors for the various radionuclides used in DECAYDOS.

\begin{tabular}{|c|c|c|c|}
\hline Radionuclide & $\begin{array}{c}\text { Effective } \\
\text { dose conversion factor } \\
(\mathrm{rem} / \mathrm{yr}) /\left(\mathrm{Ci} / \mathrm{m}^{3}\right)\end{array}$ & Radionuclide & $\begin{array}{c}\text { Effective } \\
\text { dose conversion factor } \\
(\mathrm{rem} / \mathrm{yr}) /\left(\mathrm{Ci} / \mathrm{m}^{3}\right)\end{array}$ \\
\hline Am-241 & $1.7 \times 10^{6}$ & Ac- 227 & $6.9 \times 10^{6}$ \\
\hline $\mathrm{Pu}-240$ & $3.4 \times 10^{4}$ & Ac-225 & $7.0 \times 10^{4}$ \\
\hline Pu-239 & $3.4 \times 10^{4}$ & Ra-228 & $5.1 \times 10^{5}$ \\
\hline $\mathrm{Pu}-238$ & $3.1 \times 10^{4}$ & $\mathrm{Ra}-226$ & $7.7 \times 10^{5}$ \\
\hline $\mathrm{Np}-237$ & $1.3 \times 10^{7}$ & Ra-225 & $1.4 \times 10^{5}$ \\
\hline U-238 & $1.9 \times 10^{4}$ & Ra-224 & $7.9 \times 10^{4}$ \\
\hline U-236 & $2.0 \times 10^{4}$ & $\mathrm{Ra}-223$ & $1.7 \times 10^{5}$ \\
\hline $\mathrm{U}-235$ & $2.7 \times 10^{4}$ & $R n-222$ & $1.6 \times 10^{1}$ \\
\hline $\mathrm{U}-234$ & $2.1 \times 10^{4}$ & $\mathrm{Bi}-212$ & $9.2 \times 10^{2}$ \\
\hline U-233 & $2.1 \times 10^{4}$ & $\mathrm{Bi}-210$ & $5.6 \times 10^{3}$ \\
\hline Th-234 & $8.7 \times 10^{3}$ & $\mathrm{~Pb}-212$ & $3.8 \times 10^{4}$ \\
\hline Th-232 & $1.3 \times 10^{6}$ & $\mathrm{~Pb}-210$ & $3.8 \times 10^{6}$ \\
\hline Th-231 & $8.3 \times 10^{2}$ & Po-210 & $1.4 \times 10^{6}$ \\
\hline $\mathrm{Th}-230$ & $2.8 \times 10^{5}$ & Cs-137 & $8.5 \times 10^{4}$ \\
\hline Th-229 & $1.8 \times 10^{6}$ & $\mathrm{I}-129$ & $3.5 \times 10^{5}$ \\
\hline Th-228 & $2.5 \times 10^{5}$ & Tc-99 & $4.5 \times 10^{3}$ \\
\hline Th-227 & $2.5 \times 10^{4}$ & $Y-90$ & $2.0 \times 10^{3}$ \\
\hline $\mathrm{Pa}-234$ & $1.4 \times 10^{3}$ & $\mathrm{Sr}-90$ & $2.4 \times 10^{5}$ \\
\hline $\mathrm{Pa}-233$ & $2.4 \times 10^{3}$ & C-14 & $7.5 \times 10^{3}$ \\
\hline $\mathrm{Pa}-231$ & $6.2 \times 10^{6}$ & $\mathrm{H}-3$ & $7.0 \times 10^{1}$ \\
\hline Ac-228 & $1.3 \times 10^{3}$ & - & - \\
\hline
\end{tabular}

These factors yield doses in rem/yr for each radionuclide, based on the use of groundwater with a concentration of $1 \mathrm{Ci} / \mathrm{m}^{3}$ for each radionuclide. To provide actual doses, the factors need to be adjusted for the actual concentration of each radionuclide in the groundwater.

The standard dose conversion factors upon which these effective dose conversion factors are based are from the GENII library, which uses the most conservative dose conversion factors contained in DOE $1988 \mathrm{a}$ and DOE $1988 \mathrm{~b}$. 


\section{References for Section 7}

Aaberg, R. L., and W. E. Kennedy, 1990, Definition of Intrusion Scenarios and Example Concentration Ranges for the Disposal of Near-Surface Waste at the Hanford Site, PNL-6312, Pacific Northwest Laboratories.

DOE, 1988a, External Dose-Rate Conversion Factors for Calculation of Dose to the Public, DOE/EH-0070, U.S. Department of Energy, March.

DOE, 1988b, Internal Dose-Rate Conversion Factors for Calculation of Dose to the Public, DOE/EH-0071, U.S. Department of Energy, July.

Kennedy, W. E., and D. L. Strenge, 1992, Residual Radioactive Contamination from Decommissioning: Technical Basis for Translating Contamination Levels to Annual Total Effective Dose Equivalent, NUREG/CR-5512, Pacific Northwest Laboratory.

Napier, B. A. R. A. Peloquin, D. L. Strenge, and J. V. Ramsdell, 1988, GENII-The Hanford Environmental Radiation Dosimetry Software System: Conceptual Representation, PNL-6584, Vol. 1, Pacific Northwest Laboratory. 


\section{EVALUATION OF PERFORMANCE IN UNDISTURBED- WASTE SCENARIO-ATMOSPHERIC TRANSPORT PATHWAY (RADON TRANSPORT AND RECEPTOR EXPOSURE)}

\subsection{Introduction}

Section 4.2.1 discussed why the doses from other atmospheric pathways in the undisturbedwaste scenario were considered negligible compared with those from the transport of gaseous radionuclides. Radon from the decay of actinides is expected to be the only gaseous radionuclide meriting evaluation and is discussed in this section. Other gaseous radionuclides are present (e.g., $\mathrm{Kr}-85$ ), but the activities are extremely small. In addition, those radionuclides either decay relatively quickly or will tend to partition into the gas phase during thermal treatment and not be incorporated into the FWF.

Three radionuclides of radon, $R n-219, R n-220$, and $R n-222$, will be produced as decay products of actinides in the inventory. $\mathrm{Rn}-222$, which grows in from the decay of $\mathrm{Pu}-238$ and U-238 in the inventory, has a half-life of about 3.8 days, the longest half-life of the three radon radionuclides. Production rates of $\mathrm{Rn}-222$ were calculated using the DECAYDOS routine, with the conservative assumption that no leaching of the parent radionuclides by groundwater occurs.

In the assumed absence of leaching, the short-lived radon produced by decay within a nonporous FWF (such as glass or ceramic) will not exist long enough as a gas for transport to the land surface. Only the radon produced from parent actinides that are in a porous FWF or are already released from the FWF has the potential to exist long enough to be transported to the surface. Therefore, only the transport of Rn-222 from a cement FWF was evaluated.

The remainder of Section 8 describes the evaluation of the transport of $R \mathbf{n}-222$ and the resulting dose from the inhalation of $\mathrm{Rn}-222$ and its short-lived decay products ( $\mathrm{Po}-218, \mathrm{~Pb}-214$, $\mathrm{Bi}-214$, and Po-214) that are generated post-inhalation. The approach was to develop a conceptual model of the transport pathway and the exposure route. An analytical solution was then used to implement the conceptual model.

\subsection{Conceptual Model}

Figure 8-1 presents a sketch of the assumed transport pathway for radon exposure in the undisturbed-waste scenario. The only exposure route is inhalation.

The radon is produced by the radioactive decay of Pu-238 and U-238 contained in a PCC FWF within a 22.7 -ft-thick layer of waste. Conservatively, the more shallow of the two burial depths was assumed. That is, the waste is overlain by a 16-ft layer of soil ( $5 \mathrm{ft}$ of belowgrade backfill plus $11 \mathrm{ft}$ of abovegrade cover that is conservatively assumed to be all soil). The abovegrade cover erodes instantaneously at a time $500 \mathrm{yr}$ postclosure. One dose calculation was performed just before $500 \mathrm{yr}$ postclosure, when the aboveground cover is still present. A second dose was calculated for a time 167,000 yr postclosure, when the radon concentration in the PCC FWF was determined by means of DECAYDOS to be a maximum. 


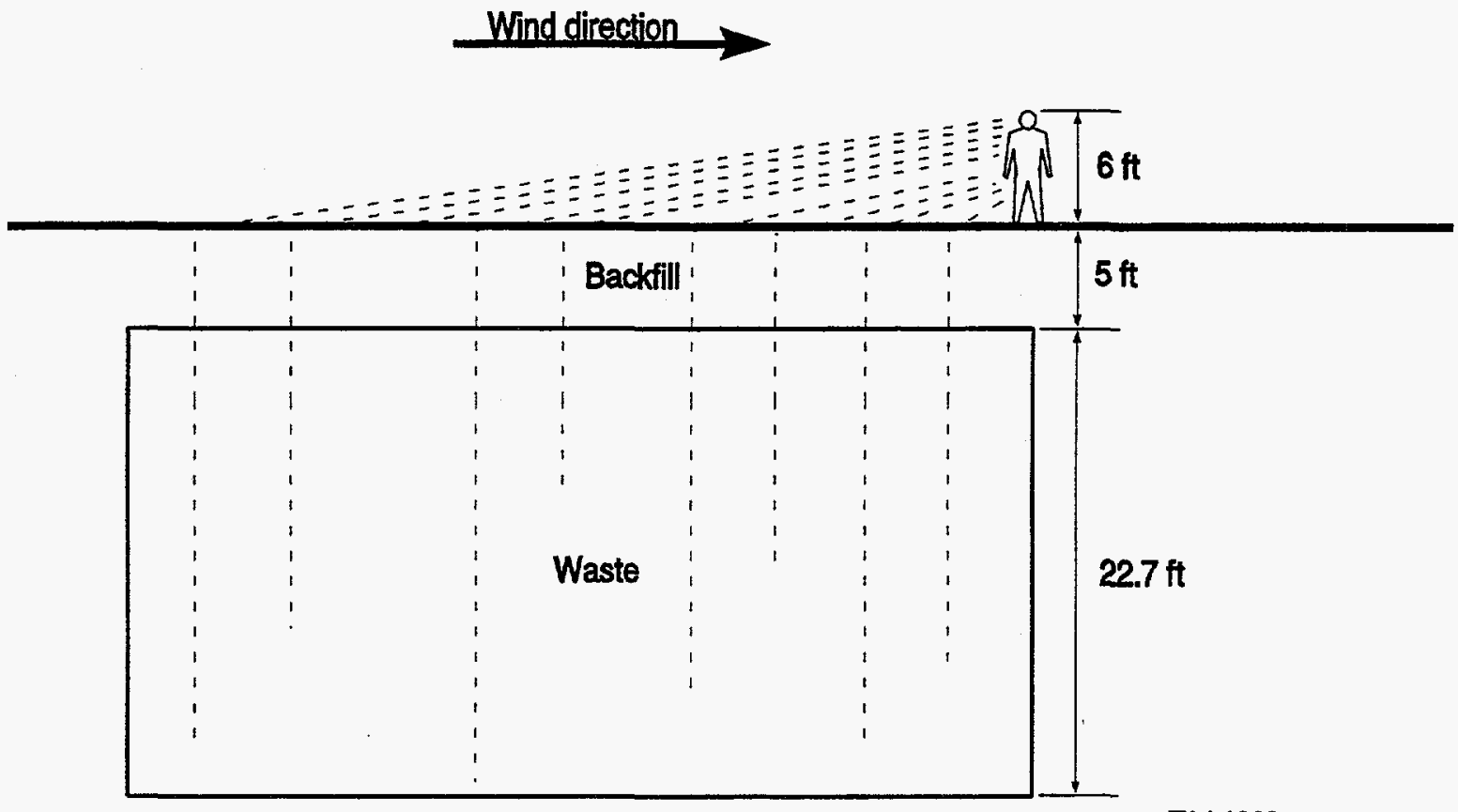

T94 1003

Figure 8-1. Simplified depiction of conceptual model for radon transport and receptor exposure. (Until 500 yr postclosure, an 11-ft abovegrade cover was also assumed to be present.)

The radon diffuses through the air-filled porosity within the PCC to the FWF surface and then diffuses through the air-filled soil porosity toward the land surface. At the land surface, the radon is diluted and transported by air currents to a receptor located at the downwind edge of the waste pit. The receptor becomes exposed by breathing the contaminated air.

\subsection{Numerical Model}

For simplicity, an analytical solution was used to calculate the Rn-222 emissions. The flux of $\mathrm{Rn}-222$ from the FWF was estimated based on the equation (Case et al. 1990):

$J_{o}=10,000 D_{e} C_{R n}\left(\frac{\lambda \epsilon}{D_{e}}\right)^{1 / 2}$

where

$$
\begin{aligned}
& \mathrm{J}_{\mathrm{o}} \quad=\text { radon flux from the FWF }\left(\mathrm{pCi} / \mathrm{m}^{2} \bullet \mathrm{sec}\right) \\
& 10,000=\text { conversion factor }\left(\mathrm{cm}^{2} / \mathrm{m}^{2}\right) \\
& \mathrm{D}_{\mathrm{e}}=\text { effective diffusion coefficient in the FWF }\left(\mathrm{cm}^{2} / \mathrm{sec}\right)
\end{aligned}
$$


$\mathrm{C}_{\mathrm{Rn}}=$ concentration of $\mathrm{Rn}-222$ in the void spaces of the FWF, defined below $\left(\mathrm{pCi} / \mathrm{cm}^{3}\right)$

$\lambda=$ decay constant for $\mathrm{Rn}-222\left(2.097 \times 10^{-6} / \mathrm{sec}\right)$

$\epsilon=$ void fraction of the FWF.

The concentration of Rn-222 in the void spaces is related to the concentration in the waste form, $\mathrm{C}_{\mathrm{Rn}}(\mathrm{FWF})$, by the equation $\mathrm{C}_{\mathrm{Rn}_{n}}$ (void space) $=\mathrm{C}_{\mathrm{Rn}}(\mathrm{FWF}) / \epsilon$. The DECAYDOS program calculated the radon concentration $\mathrm{C}_{\mathrm{Rn}}(\mathrm{FWF})$ using the Bateman decay equations.

The effective diffusion coefficient, $D_{e}$, was calculated based on the equation $D_{e}=\epsilon D$, where $D$ is the diffusion coefficient for radon in the air space of the FWF. D was calculated based on the diffusion coefficient for radon in air and the tortuosity of the PCC FWF, which was assumed to be 200 .

Using the definitions of variables outlined above, equation (8-1) can be reduced to the following:

$J_{o}=10,000 C_{R n}(\lambda D)^{1 / 2}$

where

$\mathrm{C}_{\mathrm{Rn}}$ is now the concentration of $\mathrm{Rn}-222$ in the FWF itself.

The radon flux through the soil cover was calculated based on the equation:

$J=J_{o} f_{s} e^{\left(-\alpha_{s} x_{s}\right)}$

where

$\mathrm{J}=\operatorname{radon}$ flux from the ground surface above the disposal facility $\left(\mathrm{pCi} / \mathrm{m}^{2} \cdot \mathrm{sec}\right)$

$\mathrm{J}_{\mathrm{o}} \quad=\quad$ radon flux from the waste $\left(\mathrm{pCi} / \mathrm{m}^{2} \cdot \mathrm{sec}\right)$

$\mathrm{f}_{\mathrm{s}} \quad=$ correction factor for the soil cover (dimensionless)

$\alpha_{\mathrm{s}} \quad=\left(\lambda \in / \mathrm{D}_{\mathrm{e}}\right)_{\mathrm{s}}^{1 / 2}$ for soil $(\mathrm{s})(\mathrm{cm})^{-1}$

$\mathrm{x}_{\mathrm{s}}=$ thickness of soil cover $(\mathrm{cm})$.

Given a radon flux from the ground surface above the disposal facility (J), the concentration of radon for a receptor directly above the disposal facility was calculated using an Eulerian box model, which is recommended for sites where the contaminant emission rate is relatively constant over an extended period of time (EPA 1991). For this application, the receptor was located at 
the downwind edge of the disposal facility in order to maximize the radon concentration in the "box" reaching the receptor. The general equation for the box model is:

$$
C_{x}=\frac{J L}{U \sigma_{x}}
$$

where

$$
\begin{array}{ll}
\mathrm{C}_{\mathrm{x}} & =\text { concentration of contaminant at the receptor }\left(\mathrm{pCi} / \mathrm{m}^{3}\right) \\
\mathrm{J} & =\text { flux of contaminant from the ground surface }\left(\mathrm{pCi} / \mathrm{m}^{2} \bullet \mathrm{sec}\right) \\
\mathrm{L} & =\text { travel distance }(\mathrm{m}) \\
\mathrm{U} & =\text { wind speed in the mixing zone }(\mathrm{m} / \mathrm{sec}) \\
\sigma_{\mathrm{x}} & =\text { mean vertical mixing height }(\mathrm{m}) .
\end{array}
$$

\subsection{Assumptions and Parameter Values}

As mentioned previously, it was assumed that the thickness of the waste layer is $22.7 \mathrm{ft}$. The cover above the waste is a total of $16 \mathrm{ft}$ thick until $500 \mathrm{yr}$ postclosure, after which time the cover thickness is only the $5 \mathrm{ft}$ of backfill.

The inventory of Rn-222 was calculated by decaying the 1993 inventories of Pu-238 and U-238, which are provided in Appendix A, Table A-3.

The values assigned for $f_{s}$ and $\epsilon / D_{e}$ were 0.86 and 40 , respectively, based on values provided by Case et al. (1990). Values assigned for $U$ and $\sigma_{x}$ were $2.25 \mathrm{~m} / \mathrm{sec}$ and $2 \mathrm{~m}$, respectively, based on default values provided by the EPA (1987). 


\section{References for Section 8}

Case, M. J., S. J. Maheras, M. A. McKenzie-Carter, M. E. Sussman, and P. Voilleque, 1990, Radioactive Waste Management Complex Performance Assessment, draft, EG\&G Idaho, Inc., EGG-WM-8773, June.

EPA, 1987, Interim Protocols for Screening and Follow-up Radon and Radon Decay Product Measurements, U.S. Environmental Protection Agency, Office of Radiation Programs, EPA 520/1-86-014-1.

EPA, 1991, Risk Assessment Guidance for Superfund: Volume 1-Human Health Evaluation Manual (Part B, Development of Risk-based Preliminary Remediation Goals), U.S.

Environmental Protection Agency, Interim Publication 9285.7-01B, PB92-963333, December. 


\section{EVALUATION OF PERFORMANCE IN INTRUSION SCENARIOS}

\subsection{Introduction}

Four intrusion scenarios were evaluated:

- Intruder-drilling (acute dose)

- Intruder-excavation (acute dose)

- Intruder-agricultural (chronic dose)

- Intruder-radon (chronic dose).

In the intruder-drilling scenario, a well is drilled directly through the waste. The drilling crew suffers acute exposure to a portion of the waste from external radiation and inhalation by handling the drill cuttings. In the intruder-excavation scenario, a portion of the waste is excavated during construction activities. Again, the onsite workers are acutely exposed. The intruderagricultural scenario is an extension of the drilling and excavation scenarios. It involves an agricultural pathway and results in chronic exposure. This scenario assumes that a portion of the waste is exhumed through drilling or construction activities (whichever type of activity exhumes the larger amount of waste for the assumed conditions). The waste is then spread and plowed around the site where crops are grown, resulting in chronic exposure by inhalation and direct exposure as well as ingestion of contaminated foodstuffs. In the intruder-radon scenario, an intruder occupies a house with a basement constructed above the waste. The intruder receives an inhalation dose by exposure to radon from the waste that diffuses into the basement.

The specific exposure routes analyzed in these intrusion scenarios are shown in Figure 9-1.

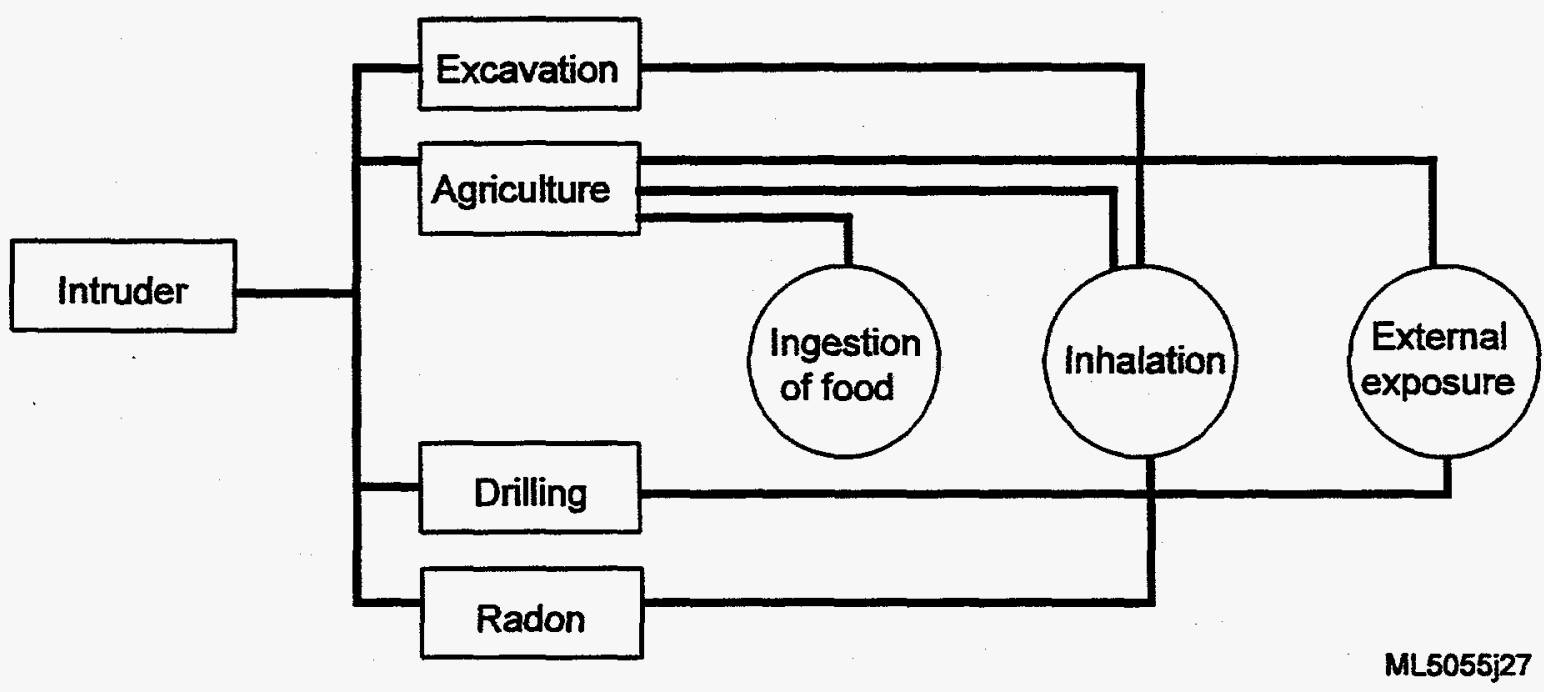

Figure 9-1. Exposure routes evaluated in the intruder scenarios. 
The results of the acute intruder-drilling and acute intruder-excavation scenarios were compared against the 500-mrem acute exposure performance objective in DOE Order 5820.2A. The result of the chronic intruder-agriculture scenario was compared against the 100 -mrem/yr continuous exposure performance objective in DOE Order 5820.2A. These scenarios are comparable to the scenarios used by the NRC in 10 CFR 61 to evaluate the land disposal of LLW in commercially operated facilities.

The results of the chronic intruder-radon scenario were compared against two performance objectives. One was the 100 -mrem/yr continuous exposure performance objective in DOE Order 5820.2A. The other was the concentration limit of radon in indoor air from EPA (1987).

The effects of radioactive decay and ingrowth were accounted for in all cases. It was also assumed that depletion of the inventory by leaching did not occur, except for the intruder-radon scenario, in which leaching was accounted for. Not considering the effects of leaching produces conservative results. In reality, a portion of the inventory may be leached and transported to a depth where it can no longer be brought to the surface by intruder events.

The radionuclide inventories used in the intruder scenarios are described in Appendices $\mathrm{A}$ and B. A homogeneous inventory was used in most cases, wherein it was assumed that the concentrations of radionuclides in the exhumed waste were representative of the average inventory. Additional runs were performed that simulated the effects of separate intrusions into the $\mathrm{CH}$ and $\mathrm{RH}$ fractions of the refined inventory developed in Appendix A, Section A-9 and of the inventory with additional refinements developed in Appendix A, Section A-10.

To within the level of detail in this study, the intrusion scenarios were assumed to be independent of the disposal location.

The conceptual models, numerical models, assumptions, and parameter values used to calculate doses from the intruder-drilling, intruder-excavation, intruder-agricultural, and intruderradon scenarios are provided in Sections $9.2,9.3,9.4$, and 9.5 respectively.

\subsection{Intruder-Drilling Scenario}

\subsubsection{Conceptual Model}

The intruder-drilling scenario assumes that an inadvertent intruder drills a water-supply well through the disposal pit and intercepts a column of waste. The intercepted waste is brought to the surface as cuttings. These radioactive cuttings are mixed with (and diluted by) clean cuttings derived from soil that was originally present in the drill hole above the waste. The cuttings were then assumed to be spread in a thin layer over an area surrounding the drill hole and mixed with native surface soil.

The presence of the exhumed waste at the surface results in acute exposure to the drill crew by inhalation of airborne particulates and by direct exposure to penetrating radiation. Predicted doses are affected by the volume of waste excavated, radionuclide concentration, dilution of the waste at the surface, and duration of inhalation and direct exposure. Since decay and ingrowth 
are considered in the model, the predicted doses are also a function of the time at which the intrusion occurs.

\subsubsection{Numerical Model}

Doses from the intruder-drilling scenario were calculated using the short-term environmental dosimetry option of the GENII code (Napier et al. 1988). This numerical model implements the NRC-recommended methodology for exposure pathway assessment and performs the ICRP-recommended dose calculation methodology as described in ICRP 26 and 30. The dose conversion factors used by GENII to calculate dose are based on the most conservative factors contained in DOE 1988a and DOE 1988b. A description of the GENII code is provided in Appendix E.

\subsubsection{Assumptions and Parameter Values}

This section describes the assumptions and parameter values used in simulating the intruder-drilling scenario. Specific parameter values are provided in Table 9-1. Figure 5-1 shows the layout of the waste disposal pit.

Calculated doses were based on the assumption that a $30-\mathrm{cm}$-diameter residential water supply well was drilled at the site. Drillers were on site for a total of $40 \mathrm{hr}$, during which time they were subject to direct exposure from the cuttings, and an additional hour of inhalation exposure, during which time the drill bit intersected the waste.

One supplemental run was performed that extended the 1-hr inhalation exposure time to $8 \mathrm{hr}$. This supplemental run was performed to examine the possibility that it may take more than $1 \mathrm{hr}$ to drill through a dense ceramic FWF.

Two facility designs were simulated (see Figure 5-1). One design had a 16-ft layer of soil overlying the waste ( $5 \mathrm{ft}$ of belowgrade backfill plus $11 \mathrm{ft}$ of abovegrade multilayer cover that was conservatively assumed to be all soil). The other design had a $20-\mathrm{ft}$ cover of soil overlying the waste ( $9 \mathrm{ft}$ of backfill plus the 11-ft cover). The thickness of the soil cover affects intruderdrilling doses by varying the volume of clean soil within the drill hole that is mixed with the waste.

It was further assumed that the exhumed portions of the FWFs are ground totally into respirable particulates by the drilling process. This is a conservative assumption for brittle glass or ceramic FWFs, which tend to fracture into larger pieces. The use of water or mud as a drilling fluid may also significantly reduce the generation of respirable particulates relative to the conservative modeling assumptions. In a limited number of runs that are so identified, particle size distributions that are more realistic were assumed.

The detailed rationale for the intruder-drilling cases evaluated is given in Section 10.4.1.2. The intruder-drilling scenario was conservatively assumed to occur $100 \mathrm{yr}$ after closure of the facility, corresponding to the start of the postinstitutional control period. Previous performance assessments (Maheras et al. 1994) have concluded that the dominant contributors to dose in this type of intruder scenario are nonactinides such as Cs-137. The inventories of these radionuclides during the postinstitutional control period are highest at the beginning of this period. 
Table 9-1. Parameter values for intruder-drilling scenario.

\begin{tabular}{lc}
\hline \multicolumn{1}{c}{ Parameter } & Value \\
\hline Inhalation exposure duration while drilling & $1 \mathrm{hr}$ \\
Mass loading factor during drilling process & $1 \times 10^{-4} \mathrm{~g} / \mathrm{m}^{3}$ \\
Intrusion scenario well diameter & $30 \mathrm{~cm}$ \\
$\begin{array}{l}\text { Length of time an individual is externally exposed to } \\
\text { contaminated surface soils }\end{array}$ & $40 \mathrm{hr}$ \\
$\begin{array}{l}\text { Volume of clean surface soil mixed with the drill core of waste } \\
\text { and backfill }\end{array}$ & $0.34 \mathrm{~m}^{3 \mathbf{a}}$ \\
\hline $\begin{array}{l}\text { a. Based on 16-ft cover (5-ft belowgrade backfill plus 11-ft-thick abovegrade engineered cover) and } \\
\text { 30-cm-diameter well. }\end{array}$ \\
Source: Aaberg and Kennedy 1990.
\end{tabular}

The multilayer cover has an assumed design life of $500 \mathrm{yr}$ (see Section 5.2). Therefore, it was assumed to be intact $100 \mathrm{yr}$ after closure.

Figure 9-2 illustrates the layout of the disposal pit for the intruder-drilling scenarios $100 \mathrm{yr}$ postclosure.

\subsection{Intruder-Excavation Scenario}

\subsubsection{Conceptual Model}

The intruder-excavation scenario assumes that an inadvertent intruder moves onto the site and excavates a basement for a residence. A portion of that excavation disturbs the waste and brings part of it to the surface. The waste brought to the surface is then assumed to be spread in a layer over an area surrounding the excavation site and mixed with native surface soil.

The presence of the exhumed waste at the surface results in acute exposure to the construction crew by inhalation of airborne particulates and by direct exposure to penetrating radiation. Predicted doses are affected by the volume of waste excavated, radionuclide concentration, dilution of the waste at the surface, and duration of inhalation and direct exposure. Since decay and ingrowth are considered in the model, predicted doses are also a function of the time at which intrusion occurs.

\subsubsection{Numerical Model}

Doses from the intruder-excavation scenario were calculated with the GENII code using the short-term environmental dosimetry option. This model is identical to the one used for the intruder-drilling scenario except for different values of certain input parameters. The GENII model (Napier et al. 1988) implements the NRC-recommended methodology for exposure 


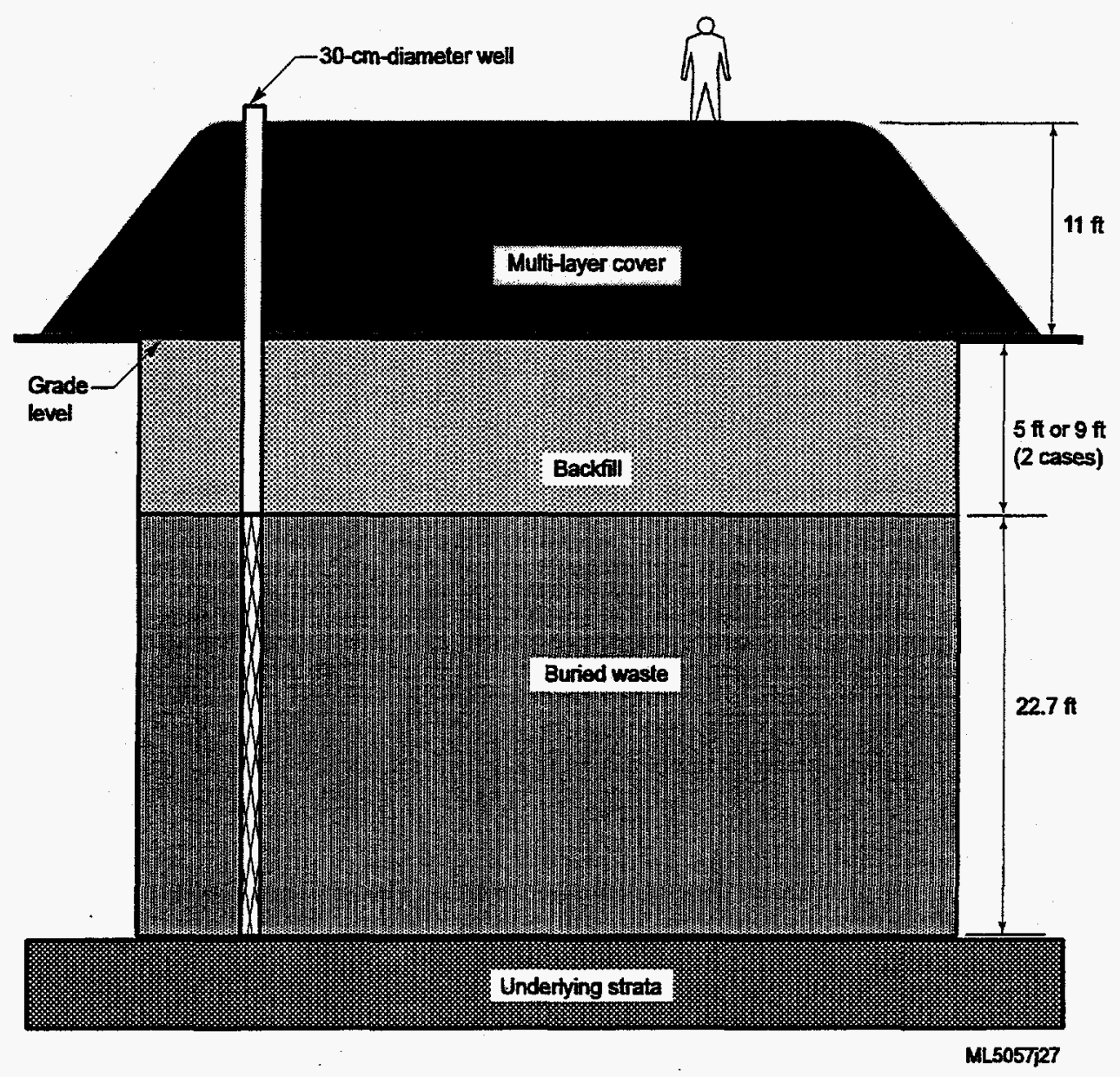

Figure 9-2. Disposal pit layout for intruder-drilling scenario, $100 \mathrm{yr}$ postclosure. (At $500 \mathrm{yr}$ postclosure, no credit would be taken for the abovegrade portion of the cover.)

pathway assessment and performs the ICRP-recommended dose calculations as described in ICRP 26 and 30. The dose conversion factors used by GENII to calculate dose are based on the most conservative factors contained in DOE 1988a and DOE 1988b. A description of the GENII code is provided in Appendix E.

\subsubsection{Assumptions and Parameter Values}

This section describes the assumptions and parameter values used in simulating the intruderexcavation scenario. Specific parameter values are provided in Table 9-2.

The detailed rationale for the intruder-excavation cases evaluated is given in Section 10.4.1.3. The facility has a total of 16 or $20 \mathrm{ft}$ of soil (two cases) overlying the waste. This soil cover is present at facility closure and maintained during the 100-yr period of institutional control. Excavation of an 8-ft-deep basement in this cover material at $100 \mathrm{yr}$ will not disturb the waste in either of the two cases and will result in an insignificant acute dose.

It was assumed that the $11-\mathrm{ft}$ abovegrade cover has a 500-yr lifetime. Excavation of a basement in the cover material at $500 \mathrm{yr}$ is assumed to disturb a layer of waste that is $3 \mathrm{ft}$ thick 
Table 9-2. Parameter values for intruder-excavation scenario for cases involving 1-m (3-ft) penetration of the waste.

\begin{tabular}{|c|c|}
\hline Parameter & Value \\
\hline Inhalation and external exposure duration & $\begin{array}{l}80 \mathrm{hr} \\
\text { (two workweeks) }\end{array}$ \\
\hline $\begin{array}{l}\text { Mass loading factor for the top layer of soil available for } \\
\text { resuspension }\end{array}$ & $5 \times 10^{-3} \mathrm{~g} / \mathrm{m}^{3}$ \\
\hline Volume of waste and backfill excavated & $100 \mathrm{~m}^{3}$ \\
\hline $\begin{array}{l}\text { Volume of clean surface soil mixed with the excavated waste and } \\
\text { backfill volume }\end{array}$ & $152 \mathrm{~m}^{3} \mathrm{a}$ \\
\hline \multicolumn{2}{|c|}{ 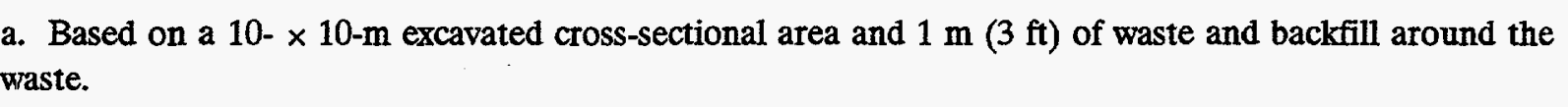 } \\
\hline Source: Aaberg and Kennedy 1990. & \\
\hline
\end{tabular}

for the shallower burial case ( $8 \mathrm{ft}$ excavation minus $5 \mathrm{ft}$ backfill equals a 3 -ft penetration into the waste). For the deeper burial case, the 8-ft excavation was assumed not to penetrate the top of the waste, which is $9 \mathrm{ft}$ belowgrade. See Figures 9-3 and 9-4, which depict the situation for the two burial depths at $500 \mathrm{yr}$.

It was assumed in this scenario that the durations of inhalation and external exposure are both equal to $80 \mathrm{hr}$, which is the equivalent of two work weeks for a maximally exposed member of the construction crew. The mass loading factor used to calculate doses from inhalation was assumed to be $5 \times 10^{-3} \mathrm{~g} / \mathrm{m}^{3}$, which is considerably higher than the value of $1 \times 10^{-4} \mathrm{~g} / \mathrm{m}^{3}$ used in the intruder-drilling scenario. The higher value was used here based on the assumption that excavation equipment generates more respirable fines than does well-drilling equipment.

\subsection{Intruder-Agricultural Scenario}

\subsubsection{Conceptual Model}

The intruder-agricultural scenario assumes that waste is brought to the surface by either an intruder-drilling scenario or an intruder-excavation scenario. (Both of these initiating events were included as appropriate for the assumed cover conditions at the time of intrusion.) The waste removed from the well or excavation is then spread and plowed around the site where crops are grown, resulting in chronic exposure by inhalation and direct exposure. In addition, the waste is leached into the root zone, and uptake of nuclides by the crops occurs. The crops are then consumed directly by humans and used to feed livestock, which are then consumed by humans.

The chronic exposure routes include inhalation; direct exposure; and consumption of leafy vegetables, root vegetables, grains, fruit, eggs, milk, beef, pork, and poultry. A maximally exposed 


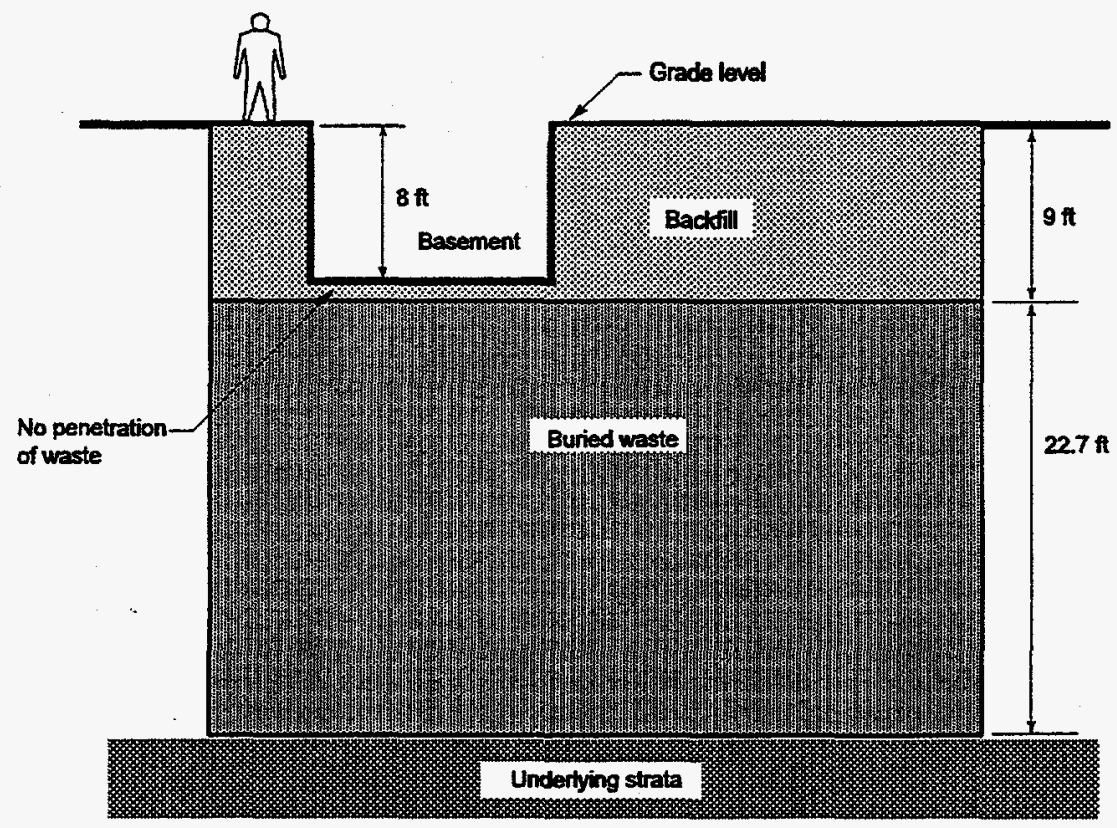

MLO5A/27

Figure 9-3. Disposal pit layout for intruder-excavation scenario, 500-yr postclosure with 9-ft belowgrade backfill.

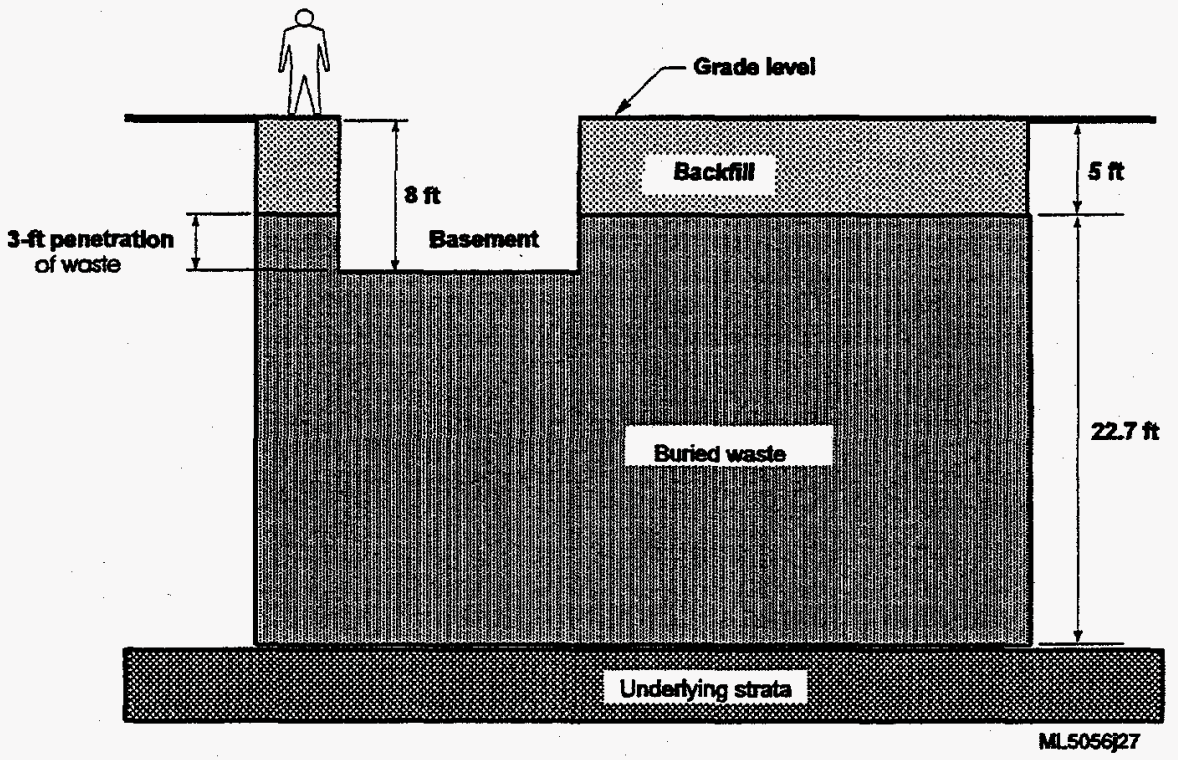

Figure 9-4. Disposal pit layout for intruder-excavation scenario, 500-yr postclosure with 5-ft belowgrade backfill. 
individual is assumed to reside at the site, consume contaminated foodstuffs, and be subject to the inhalation and direct exposure routes on a near-full-time basis, resulting in chronic rather than acute doses.

\subsubsection{Numerical Model}

Doses from the intruder-agricultural scenario were calculated using the inhalation, direct exposure, and food chain exposure pathways of the GENII code (Napier et al. 1988). This model is identical to the one used for the intruder-drilling and intruder-excavation scenarios, with the exceptions of the addition of food chain pathways and the calculation of chronic rather than acute doses. The GENII model implements the NRC-recommended methodology for exposure pathway assessment and performs the ICRP-recommended dose calculations as described in ICRP 26 and 30. The dose conversion factors used by GENII to calculate dose are based on the most conservative factors contained in DOE 1988a and DOE 1988b. A description of the GENII code is provided in Appendix $\mathrm{E}$.

\subsubsection{Assumptions and Parameter Values}

This section describes the assumptions and parameter values used in simulating the intruderagricultural scenario. Specific parameter values are provided in Table 9-3. Where agricultural and other parameters appear in Table 9-3 that correspond to those for the undisturbed-waste scenario in Table 7-1, the values used were identical.

Two separate types of intruder-agricultural scenarios were evaluated and used as appropriate for the assumed disposal conditions. The first type is initiated by an intruder-drilling event in which drill cuttings are the source of the contaminated material. The second type is initiated by an intruder-excavation event in which the excavated soil/waste mixture is the source of the contaminated material. Parameter values related to these initiating events, such as the volume of waste exhumed, mass loading factors, and the waste-to-soil dilution factors, are identical to the values used in the respective intruder-drilling and intruder-excavation scenarios.

The detailed rationale for the intruder-agricultural cases evaluated is given in Section 10.4.1.4. Intruder-agricultural scenarios were considered for both $16-\mathrm{ft}$ and 20 -ft soil cover designs and at both $100 \mathrm{yr}$ and $500 \mathrm{yr}$ postclosure. These times are expected to produce the peak doses for this scenario.

The agricultural exposures for the $100 \mathrm{yr}$ postclosure case were assumed to be initiated by a drilling event through the waste pit (see Figure 9-2) because, for either cover, an excavation event would not penetrate the waste at $100 \mathrm{yr}$. For the same reason, the agricultural exposures for the case with the 20 -ft cover at 500 yr were assumed to be initiated by a drilling event through the waste pit.

For the case with the 16-ft cover at $500 \mathrm{yr}$, the agricultural exposures were assumed to be initiated by an excavation event, because excavation would bring much more waste to the surface than would drilling. The event would penetrate the waste, as explained in Section 9.3.3 and illustrated in Figure 9-4. 
Table 9-3. Parameter values for intruder-agricultural scenario.

\section{Parameter}

Weighted-average inhalation exposure duration

Weighted-average mass loading factor

Weighted-average external exposure duration

Volume of waste and backfill mixed with clean surface soil

Volume of clean surface soil mixed with contaminated volume of waste and backfill

Growing period for hay consumed by milk cows

Length of growing season for leafy vegetables

Food holdup time between harvest and consumption of leafy vegetables

Human consumption rate of leafy vegetables

Length of growing season for root vegetables

Food holdup time between harvest and consumption of root vegetables

Human consumption rate of root vegetables

Length of growing season for grains

Food holdup time between harvest and consumption of grains

Human consumption rate of grains

Length of growing season for fruit

Food holdup time between harvest and consumption of fruit

Human consumption rate of fruit

Leafy-vegetable-yield value

Other-vegetable-yield value

Eggs-yield value

Milk-yield value

Beef-yield value

Pork-yield value

Poultry-yield value

Consumption rates of feed or forage by beef cattle

Consumption rates of feed or forage by milk cows

Consumption rates of feed or forage by poultry

Consumption rate of drinking water by beef cattle

Consumption rate of drinking water by milk cows

Consumption rate of drinking water by poultry

Food holdup time for beef

Food holdup time for pork

Food holdup time for poultry

Food holdup time for milk
Value

6,570 hr/yr

$1.0 \times 10^{-4} \mathrm{~g} / \mathrm{m}^{3 \mathrm{a}}$

$5,825 \mathrm{hr} / \mathrm{yr}$

$0.34 \mathrm{~m}^{3 \mathrm{a}}$

$2,500 \mathrm{~m}^{2} \times 0.15 \mathrm{~m}=375 \mathrm{~m}^{3}$

45 days

45 days

1 day

$11 \mathrm{~kg} / \mathrm{yr} \times 0.25^{\mathrm{b}}=2.8 \mathrm{~kg} / \mathrm{yr}$

90 days

14 days

$51 \mathrm{~kg} / \mathrm{yr} \times 0.25^{\mathrm{b}}=12.75 \mathrm{~kg} / \mathrm{yr}$

90 days

14 days

$69 \mathrm{~kg} / \mathrm{yr} \times 0.25^{b}=17.25 \mathrm{~kg} / \mathrm{yr}$

90 days

14 days

$46 \mathrm{~kg} / \mathrm{yr} \times 0.25^{\mathrm{b}}=11.5 \mathrm{~kg} / \mathrm{yr}$

$2.0 \mathrm{~kg} / \mathrm{m}^{2}$

$4.0 \mathrm{~kg} / \mathrm{m}^{2}$

$1.0 \mathrm{~kg} / \mathrm{m}^{2}$

$1.2 \mathrm{~kg} / \mathrm{m}^{2}$

$1.2 \mathrm{~kg} / \mathrm{m}^{2}$

$0.8 \mathrm{~kg} / \mathrm{m}^{2}$

$1.0 \mathrm{~kg} / \mathrm{m}^{2}$

$44 \mathrm{~kg} /$ day

$67 \mathrm{~kg} /$ day

$0.22 \mathrm{~kg} /$ day

$50 \mathrm{~L} /$ day

$60 \mathrm{~L} /$ day

$0.3 \mathrm{~L} /$ day

20 days

34 days

1 day

1 day 
Table 9-3. (continued).

\begin{tabular}{|c|c|}
\hline Parameter & Value \\
\hline Food holdup time for eggs & 1 day \\
\hline Human consumption rate of milk & $103 \mathrm{~kg} / \mathrm{yr}$ \\
\hline Human consumption rate of beef & $59 \mathrm{~kg} / \mathrm{yr}$ \\
\hline Human consumption rate of pork & $30 \mathrm{~kg} / \mathrm{yr}$ \\
\hline Human consumption rate of poultry & $9 \mathrm{~kg} / \mathrm{yr}$ \\
\hline Human consumption rate of eggs & $10 \mathrm{~kg} / \mathrm{yr}$ \\
\hline \multicolumn{2}{|c|}{$\begin{array}{l}\text { a. Values used for initiation of the intruder-agricultural scenario by a drilling event. If the scenario is initiated by an } \\
\text { excavation event, the corresponding values are } 5 \times 10^{-3} \mathrm{~g} / \mathrm{cm}^{3} \text { for the weighted-average mass loading factor and } \\
100 \mathrm{~m}^{3} \text { for the volume of waste and backfill mixed with clean surface soil. }\end{array}$} \\
\hline \multicolumn{2}{|c|}{$\begin{array}{l}\text { b. Based on the results of a U.S. Department of Agriculture survey, only } 25 \% \text { of the vegetables in the exposed } \\
\text { individual's diet is derived from a residential garden (Aaberg and Kennedy 1990; Kennedy and Strenge 1992). }\end{array}$} \\
\hline Sources: Aaberg and Kennedy 1990; Kennedy and Strenge 1992. & \\
\hline
\end{tabular}

Residents were assumed to reside on site and be subject to inhalation for $6,570 \mathrm{hr} / \mathrm{yr}$ (75\% of continuous occupancy), and direct exposure for $5,825 \mathrm{hr} / \mathrm{yr}$ ( $66 \%$ of continuous occupancy).

Consumption rates of contaminated fruit, grains, and vegetables were based on the assumption that $25 \%$ of these categories of food in the diet of the exposed individuals is from a residential garden (Aaberg and Kennedy 1990; Kennedy and Strenge 1992).

\subsection{Intruder-Radon Scenario}

Section 8 discussed how the transport and chronic inhalation of radon were evaluated for the undisturbed-waste scenario. This section discusses the analogous methodology used for the chronic intruder-radon scenario, which was evaluated in the third phase of the study. The methodology is similar to that used by Maheras et al. (1994).

\subsubsection{Conceptual Model}

The conceptual model assumes that an inadvertent intruder moves onto the disposal site at least $500 \mathrm{yr}$ postclosure, when the abovegrade portion of the cover has disappeared. The intruder resides in a house with a basement, which is constructed directly over the waste. See Figure 9-5 for the assumed layout of the disposal pit and the house.

Figure 9-5 indicates that, in the case analyzed, the bottom of the 8-ft basement is $1 \mathrm{ft}$ above the top of the waste. This situation corresponds to the deeper burial case in Figure 5-1, with $9 \mathrm{ft}$ of backfill. The more shallow burial case, with only $5 \mathrm{ft}$ of backfill, was considered but was not evaluated for the following reason: In the case with only $5 \mathrm{ft}$ of backfill, the calculated doses for the intruder-agricultural scenario exceed the performance objective by a large margin. The outcome of evaluating the intruder-radon scenario would not alter the conclusion about the 
inadequacy of the more shallow burial. The dose from radon would simply add to the dose from the agricultural pathways; the latter dose already exceeds the performance objective. Therefore, only the case with deeper burial was evaluated here.

As in the undisturbed-waste scenario, $\mathrm{Rn}-222$ and its decay products result from the radioactive decay of Pu-238 and U-238. The two FWFs considered in the scenario, PCC and IEB4, release radionuclides by different mechanisms. The radon generated in the PCC is released by diffusion; that generated in the IEB4 is released by dissolution of the FWF. After the radon is released from the FWF, it diffuses through the soil and through the concrete walls of the basement. The radon then circulates through the house and basement, where the indoor intruder receives a dose via the inhalation exposure route.

\subsubsection{Numerical Model}

The RESRAD computer code (Gilbert et al. 1989), Version 5.19, was used to perform the dose assessments for this scenario.

\subsubsection{Assumptions and Parameter Values}

Figure 9-5 shows most of the assumptions concerning the disposal unit and the house. The areal dimensions of the house and basement were $30.5 \mathrm{ft}$ by $30.5 \mathrm{ft}$. RESRAD does not have the capability to model separate radon exposures in the basement and on the main floor of the house, so a total room height of $17.2 \mathrm{ft}$ was used to account for the combined exposure in both areas.

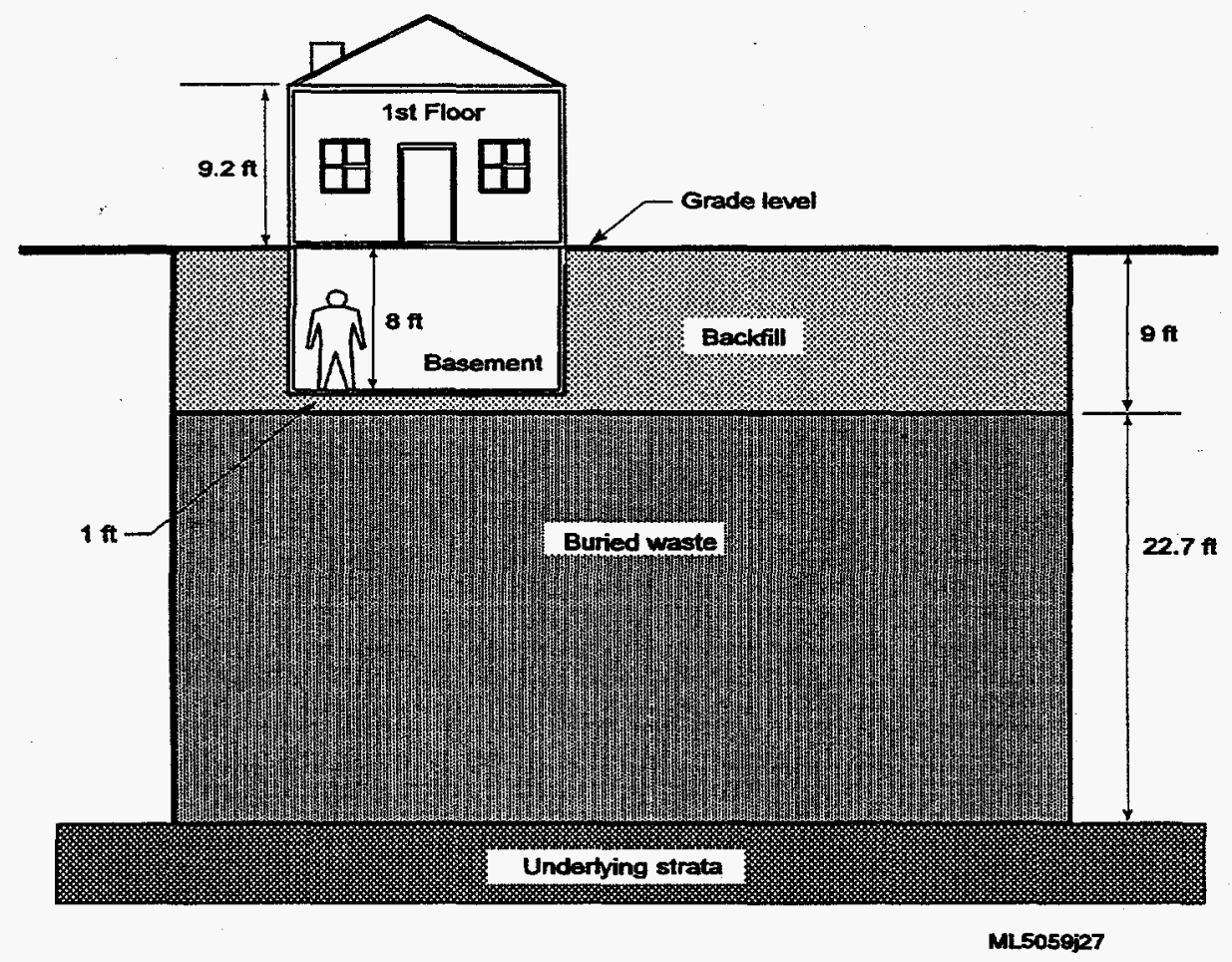

Figure 9-5. Disposal pit and house layout for intruder-radon scenario, $>500 \mathrm{yr}$ postclosure with 9-ft belowgrade backfill. 
RESRAD requires a fractional $\left(\mathrm{yr}^{-1}\right)$ leach rate for each radionuclide. The fractional leach rate for PCC was determined by using the DUST computer code (Sullivan 1993) to calculate a flux out of the disposal facility. By 3,000 yr after the end of institutional control, the flux had decreased to essentially zero $\left(<10^{-10} \mathrm{Ci} / \mathrm{cm}^{2}\right.$-yr). The initial activities of Pu-238 and U-238 were divided by $3,000 \mathrm{yr}$ to give a constant release rate for each radionuclide in $\mathrm{Ci} / \mathrm{yr}$. This release was then divided by the initial activity to give the fractional leach rate. For the PCC FWF, the resulting leach rates of the long-lived progenitors of $\mathrm{Rn}-222$ are shown in Table 9-4.

For the IEB4 FWF, the uniform dissolution rate of $5.0 \times 10^{-6} \mathrm{~g} / \mathrm{cm}^{2}$-day from Table $6-4$ was converted to a fractional leach rate by using the surface area of a waste drum and the concentrations of the radionuclides in the waste. For the IEB4 FWF, the resulting fractional leach rates of the long-lived $\mathrm{Rn}-222$ progenitors are shown in Table 9-4.

The assumed properties of the concrete used to construct the basement are based on data from two instrumented basement structures located at Colorado State University in Fort Collins, Colorado (Gadd 1993).

The data in Konz et al. (1989) were used to estimate that the intruder living in the house would spend $68 \%$ of the time at home and indoors.

Table 9-5 lists additional parameters used in evaluating the intruder-radon scenario.

\subsubsection{Comparison of Calculational Method for Intruder-Radon Scenario against that for Radon in Undisturbed-Waste Scenario}

The method for evaluating the intruder-radon scenario is both similar to and different from the method for evaluating radon transport and exposure in the undisturbed-waste scenario in Section 8. Table 9-6 lists several items for comparison. Where the scenarios were similar, an effort was made to use identical assumptions and parameter values. On many points, however, the differences in the scenarios justified the use of different assumptions and parameter values.

Table 9-4. Fractional leach rates used in the intruder-radon scenario.

\begin{tabular}{cccccc} 
Waste form & $\begin{array}{c}\text { Pu-238 } \\
\text { fractional } \\
\text { leach rate } \\
(1 / \mathrm{yr})\end{array}$ & $\begin{array}{c}\text { U-238 } \\
\text { fractional } \\
\text { leach rate } \\
(1 / \mathrm{yr})\end{array}$ & $\begin{array}{c}\text { U-234 } \\
\text { fractional } \\
\text { leach rate } \\
(1 / \mathrm{yr})^{\mathrm{a}}\end{array}$ & $\begin{array}{c}\text { Th-230 } \\
\text { fractional } \\
\text { leach rate } \\
(1 / \mathrm{yr})^{\mathrm{a}}\end{array}$ & $\begin{array}{c}\text { Ra-226 } \\
\text { fractional } \\
\text { leach rate } \\
(1 / \mathrm{yr})^{\mathrm{b}}\end{array}$ \\
\hline PCC & 0.0003 & 0.0003 & 0.0003 & 0.0003 & 0.0006 \\
IEB4 & 0.00005 & 0.00005 & 0.00005 & 0.00005 & 0.0001 \\
\hline a. Leach rate set equal to value for U-238 (Maheras et al. 1994). & \\
b. Leach rate is two times value for U-238 (Maheras et al. 1994).
\end{tabular}


Table 9-5. Parameters used in intruder-radon scenario.

\begin{tabular}{lcl}
\hline \multicolumn{1}{c}{ Parameter } & Value & \multicolumn{1}{c}{ Reference } \\
\hline Thickness of foundation & $0.1 \mathrm{~m}$ & Gadd (1993) \\
Bulk density of foundation & $2.1 \mathrm{~g} / \mathrm{cm}^{3}$ & Gadd (1993) \\
Porosity of foundation & 0.13 & Gadd (1993) \\
Diffusion coefficient of radon in cover & $3.0 \times 10^{-6} \mathrm{~m}^{2} / \mathrm{s}$ & Gilbert et al. (1989) \\
Diffusion coefficient of radon in foundation & $2.5 \times 10^{-8} \mathrm{~m}^{2} / \mathrm{s}$ & Gadd (1993) \\
Height of room (two levels) & $5.25 \mathrm{~m}$ & - \\
Building depth below grade & $2.44 \mathrm{~m}$ & - \\
Emanation fraction & 0.17 & Gadd (1993) \\
\hline
\end{tabular}

Table 9-6. Similarities and differences in the methods for evaluating radon transport and exposure.

\begin{tabular}{|c|c|c|c|}
\hline Item & $\begin{array}{c}\text { Assumption for radon } \\
\text { in undisturbed-waste } \\
\text { scenario }\end{array}$ & $\begin{array}{l}\text { Assumption for } \\
\text { intruder-radon scenario }\end{array}$ & Discussion \\
\hline $\begin{array}{l}\text { Location of } \\
\text { receptor }\end{array}$ & $\begin{array}{l}\text { Outdoors at } \\
\text { downwind edge of } \\
\text { disposal unit }\end{array}$ & $\begin{array}{l}\text { Indoors directly above } \\
\text { waste }\end{array}$ & Differences in scenarios \\
\hline $\begin{array}{l}\text { Thickness of } \\
\text { cover }\end{array}$ & $\begin{array}{l}5 \mathrm{ft} \text { of belowgrade } \\
\text { backfill; } 11 \mathrm{ft} \text { of } \\
\text { abovegrade cover for } \\
\text { runs }<500 \mathrm{yr} \\
\text { postclosure; no } \\
\text { abovegrade cover } \\
\text { thereafter }\end{array}$ & $\begin{array}{l}9 \mathrm{ft} \text { of belowgrade } \\
\text { backfill; abovegrade } \\
\text { cover eroded away }\end{array}$ & $\begin{array}{l}\text { Value in undisturbed-waste } \\
\text { scenario selected to give worst- } \\
\text { case dose; value in intruder- } \\
\text { radon scenario selected because } \\
\text { dose from agricultural pathways } \\
\text { for shallow-burial case already } \\
\text { failed performance objective }\end{array}$ \\
\hline $\begin{array}{l}\text { Excavation into } \\
\text { waste }\end{array}$ & No excavation & $\begin{array}{l}\text { Excavation of basement } \\
\text { to depth } 1 \mathrm{ft} \text { above top } \\
\text { of waste }\end{array}$ & Differences in scenarios \\
\hline $\begin{array}{l}\text { Sources of } \\
\text { radon }\end{array}$ & $\begin{array}{l}\mathrm{Pu}-238 \text { and } \mathrm{U}-238 \\
\text { decay chains }\end{array}$ & $\begin{array}{l}\mathrm{Pu}-238 \text { and } \mathrm{U}-238 \\
\text { decay chains }\end{array}$ & Same in both scenarios \\
\hline $\begin{array}{l}\text { Radon decay } \\
\text { chain evaluated }\end{array}$ & $\begin{array}{l}\text { Rn- } 222 \text { and short- } \\
\text { lived decay products } \\
\text { generated post- } \\
\text { inhalation }\end{array}$ & $\begin{array}{l}\text { Rn-222 and short-lived } \\
\text { decay products } \\
\text { generated post- } \\
\text { inhalation }\end{array}$ & Same in both scenarios \\
\hline $\begin{array}{l}\text { FWFs } \\
\text { evaluated }\end{array}$ & PCC & PCC, IEB4 & $\begin{array}{l}\text { Undisturbed-waste scenario } \\
\text { assumed no leaching; with this } \\
\text { assumption, Rn-222 would exit as } \\
\text { a gas from only porous FWFs, so } \\
\text { only PCC was evaluated }\end{array}$ \\
\hline
\end{tabular}


Table 9-6. (continued).

\begin{tabular}{|c|c|c|c|}
\hline Item & $\begin{array}{l}\text { Assumption for radon } \\
\text { in undisturbed-waste } \\
\text { scenario }\end{array}$ & $\begin{array}{l}\text { Assumption for } \\
\text { intruder-radon scenario }\end{array}$ & Discussion \\
\hline $\begin{array}{l}\text { Mechanism for } \\
\text { release from } \\
\text { FWF }\end{array}$ & Diffusion from PCC & $\begin{array}{l}\text { Diffusion from PCC; } \\
\text { dissolution of IEB4 }\end{array}$ & $\begin{array}{l}\text { Different release mechanisms for } \\
\text { different FWFs }\end{array}$ \\
\hline $\begin{array}{l}\text { Transport } \\
\text { through } \\
\text { subsurface }\end{array}$ & Diffusion through soil & $\begin{array}{l}\text { Diffusion through soil; } \\
\text { diffusion through } \\
\text { concrete walls of } \\
\text { basement }\end{array}$ & $\begin{array}{l}\text { Different transport pathways in } \\
\text { different scenarios }\end{array}$ \\
\hline $\begin{array}{l}\text { Airborne } \\
\text { transport } \\
\text { analysis }\end{array}$ & Simple box model & $\begin{array}{l}\text { Model in RESRAD } \\
\text { code, which } \\
\text { incorporates several } \\
\text { airborne transport } \\
\text { processes }\end{array}$ & $\begin{array}{l}\text { Different transport pathways in } \\
\text { different scenarios }\end{array}$ \\
\hline $\begin{array}{l}\text { Source term } \\
\text { reduction as a } \\
\text { result of } \\
\text { leaching and } \\
\text { groundwater } \\
\text { transport }\end{array}$ & $\begin{array}{l}\text { Conservatively } \\
\text { neglected }\end{array}$ & $\begin{array}{l}\text { FWF leaching and } \\
\text { corresponding inventory } \\
\text { reduction, in addition } \\
\text { to source zone } \\
\text { sorption, as addressed } \\
\text { by RESRAD }\end{array}$ & $\begin{array}{l}\text { Intruder-radon method selected } \\
\text { to include evaluation of FWF } \\
\text { leaching, and to be similar to } \\
\text { that in Maheras et al. } 1994\end{array}$ \\
\hline Dose model & $\begin{array}{l}\text { Dose conversion } \\
\text { factors taken from } \\
\text { DOE } 1988 \mathrm{~b}\end{array}$ & $\begin{array}{l}\text { Dose conversion factors } \\
\text { in RESRAD }\end{array}$ & None \\
\hline $\begin{array}{l}\text { Times } \\
\text { evaluated, yr } \\
\text { postclosure }\end{array}$ & $\begin{array}{l}500 \text { yr, to show effect } \\
\text { of abovegrade cover; } \\
167,000 \text { yr for } \\
\text { maximum dose as } \\
\text { determined with } \\
\text { DECAYDOS }\end{array}$ & $\begin{array}{l}4600 \text { yr for maximum } \\
\text { dose for PCC and } \\
20,000 \text { yr for maximum } \\
\text { dose for IEB } 4 \text {, as } \\
\text { determined with } \\
\text { RESRAD }\end{array}$ & $\begin{array}{l}\text { Factoring in leaching and } \\
\text { sorption leads to maximum dose } \\
\text { for PCC occurring earlier in } \\
\text { intruder-radon scenario than in } \\
\text { undisturbed-waste scenario; } \\
\text { radon escapes from IEB } 4 \text { more } \\
\text { slowly than from PCC, so } \\
\text { maximum dose occurs later }\end{array}$ \\
\hline
\end{tabular}




\section{References for Section 9}

Aaberg, R. L., and W. E. Kennedy, 1990, Definition of Intrusion Scenarios and Example Concentration Ranges for the Disposal of Near-Surface Waste at the Hanford Site, PNL-6312 UC-702, Pacific Northwest Laboratory.

DOE, 1988a, External Dose-Rate Conversion Factors for Calculation of Dose to the Public, DOE/EH-0070, U.S. Department of Energy, March.

DOE, 1988b, Internal Dose-Rate Conversion Factors for Calculation of Dose to the Public, DOE/EH-0071, U.S. Department of Energy, July.

EPA, 1987, Interim Protocols for Screening and Follow-up Radon and Radon Decay Product Measurements, Office of Radiation Programs, EPA 520/1-86-014-1, U.S. Environmental Protection Agency.

Gadd, M. S., 1993, The Origins and Pathways of ${ }^{222}$ Rn Entering into Basement Structures, Ph.D. Dissertation, Colorado State University, Fort Collins, Colorado.

Gilbert, T. L., C. Yu, Y. C. Yuan, A. J. Zielen, M. J. Jusko, and A. Wallo III, 1989, A Manual for Implementing Residual Radioactive Material Guidelines, ANL/ES-160, DOE/CH/8901.

Kennedy, W. E., and D. L. Strenge, 1992, Residual Radioactive Contamination from Decommissioning: Technical Basis for Translating Contamination Levels to Annual Total Effective Dose Equivalent, NUREG/CR-5512, Pacific Northwest Laboratory.

Konz, J. J., K. Lisi, E. Friebele, and D. A. Dixon, 1989, Exposure Factors Handbook, EPA/600/889/043, U.S. Environmental Protection Agency, July.

Maheras, S. J., A. S. Rood, S. O. Magnuson, M. E. Sussman, and R. N. Bhatt, 1994, Radioactive Waste Management Complex Low-Level Waste Radiological Performance Assessment, EG\&G Idaho, Inc., EGG-WM-8773, May.

Napier, B. A., R. A. Peloquin, D. L. Strenge, and J. V. Ramsdell, 1988, GENII-The Hanford Environmental Radiation Dosimetry Software System: Conceptual Representation, PNL-6584, Vol. 1, Pacific Northwest Laboratory.

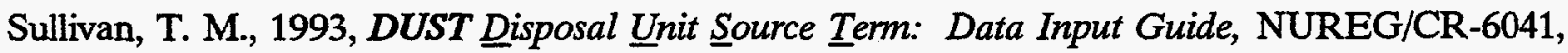
BNL-NUREG-52375, Brookhaven National Laboratory, April. 
9-16 


\section{RESULTS}

\subsection{Introduction and Summary}

This section provides the results of the evaluations, which covered a range of assumptions and parameter values. This preliminary parametric PA evaluated briefly the effects of several factors on predicted doses to members of the public and inadvertent intruders. The study is not a detailed evaluation of one specific set of conditions.

The effects on the dose as a result of many factors were investigated in various combinations. Not all combinations were considered, but the ones that were selected show most efficiently the effects of these factors on the results. The approach was basically to perform a group of runs (Runs 1 through 4,6, and 8 through 19) using an original set of assumptions and parameter values, then to investigate the effects of changes in the assumptions and parameter values, taken one, two, or three at a time.

Table 10-1 lists the performance objectives and the top-level PA results. As expected, compliance with each performance objective varies from one FWF to another and from one disposal site to another.

The results for the undisturbed-waste scenario-groundwater pathway are presented in Section 10.2. Because a large number of runs were performed, the results of each run are compiled in Table 10-2 for convenience. The purpose of each run is given under the description in the last column. Detailed information regarding each run is provided in the section whose number is listed in the next-to-last column of the table.

The results for the undisturbed-waste scenario-atmospheric pathway are presented in Section 10.3.

The results for the intrusion scenarios are presented in Section 10.4. Again, because a large number of runs were performed, the results of each run are compiled in Table 10-3 for convenience. The results of runs to confirm the assumed time of peak intrusion dose, however, are not included in the table.

As stated previously, to a first approximation, the results of the intrusion scenarios are independent of the disposal site. Therefore, no site dependence of the results is indicated in Table 10-3.

Because the calculational scheme for the intruder-radon scenario differed from that for the other intrusion scenarios, the results are given in Section 10.4.12, rather than in Table 10-3.

Section 10.5 provides a qualitative prediction of the effects of secondary FWFs on the performance of the disposal system. 
Table 10-1. Performance objectives and top-level results.

\begin{tabular}{|c|c|c|c|}
\hline Regulation & $\begin{array}{l}\text { Exposure } \\
\text { group }\end{array}$ & $\begin{array}{l}\text { Performance } \\
\text { objectives limit }\end{array}$ & Top-level results \\
\hline \multicolumn{4}{|l|}{ DOE Orders } \\
\hline \multirow[t]{3}{*}{$\begin{array}{l}5820.2 \mathrm{~A} \\
\text { Cl. III }\end{array}$} & Public & $\begin{array}{l}25 \mathrm{mrem} / \mathrm{yr} \mathrm{EDE} \\
\text { (all pathways but air) }\end{array}$ & $\begin{array}{l}\text { For Sites B and C, all FWFs pass. For Site } \\
\text { A, all FWFs pass except for PCC and } \\
\text { untreated waste under very conservative } \\
\text { assumptions. For Site D, all FWFs fail. For } \\
\text { Site E, all FWFs except IEB4 fail. }\end{array}$ \\
\hline & $\begin{array}{l}\text { Inadvertent } \\
\text { intruder }\end{array}$ & $\begin{array}{l}100 \mathrm{mrem} / \mathrm{yr} \mathrm{EDE} \\
\text { (chronic exposure) }\end{array}$ & $\begin{array}{l}\text { With 9-ft backfill plus } 11-\mathrm{ft} \text { cover, all FWFs } \\
\text { pass if refined assumptions are made on } \\
\text { particle size distribution or on nonactinide } \\
\text { inventory for IEB and IEB4 FWFs. With 5- } \\
\text { ft backfill plus 11-ft cover, all FWFs fail } \\
\text { intruder-agricultural scenario. }\end{array}$ \\
\hline & & $\begin{array}{l}500 \text { mrem EDE } \\
\text { (acute exposure) }\end{array}$ & $\begin{array}{l}\text { For intruder-drilling and intruder-excavation } \\
\text { scenarios, all FWFs pass except for RH } \\
\text { portion. }\end{array}$ \\
\hline \multicolumn{4}{|l|}{ EPA } \\
\hline $\begin{array}{l}40 \text { CFR } 61 \\
\text { Subpart H }\end{array}$ & Public & $\begin{array}{l}10 \mathrm{mrem} / \mathrm{yr} \mathrm{EDE} \\
\text { (air emissions) }\end{array}$ & $\begin{array}{l}\text { Dose expected to be much less than limit in } \\
\text { all cases, based on results in Maheras et al. } \\
\text { (1994). }\end{array}$ \\
\hline \multirow[t]{4}{*}{40 CFR 141} & Public & $\begin{array}{l}4 \text { mrem/yr from beta } \\
\text { emitters and photon } \\
\text { emitters }\end{array}$ & $\begin{array}{l}\text { For Sites A, B, and C, all FWFs pass. For } \\
\text { Sites D and E, all FWFs except IEB4 fail. }\end{array}$ \\
\hline & & $\begin{array}{l}15 \mathrm{pCi} / \mathrm{L} \text { total alpha } \\
\text { emitters (including } \\
\text { Ra-226, excluding } \mathrm{U} \\
\text { and } \mathrm{Rn} \text { ) }\end{array}$ & $\begin{array}{l}\text { For Sites A, B, and C, all FWFs pass. For } \\
\text { Sites D and E, all FWFs fail. }\end{array}$ \\
\hline & & $\begin{array}{l}5 \mathrm{pCi} / \mathrm{L} \text { combined } \\
\mathrm{Ra}-226 \text { and } \mathrm{Ra}-228\end{array}$ & All FWFs pass at all sites. \\
\hline & & $30 \mathrm{pCi} / \mathrm{L} \mathrm{U}$ & $\begin{array}{l}\text { For Sites A, B, and C, all FWFs pass. for } \\
\text { Sites D and E, all FWFs except IEB4 fail. }\end{array}$ \\
\hline EPA (1987) & $\begin{array}{l}\text { Inadvertent } \\
\text { intruder }\end{array}$ & $\begin{array}{l}4 \mathrm{pCi} / \mathrm{L} \mathrm{Rn} \\
\text { concentration in } \\
\text { indoor air }\end{array}$ & $\begin{array}{l}\text { All FWFs pass for intruder-radon scenario. } \\
\text { Limit is not applicable for undisturbed-waste } \\
\text { scenario because intruder is not indoors. }\end{array}$ \\
\hline
\end{tabular}


Table 10-2. Compilation of results for the undisturbed-waste scenario-groundwater transport pathway.

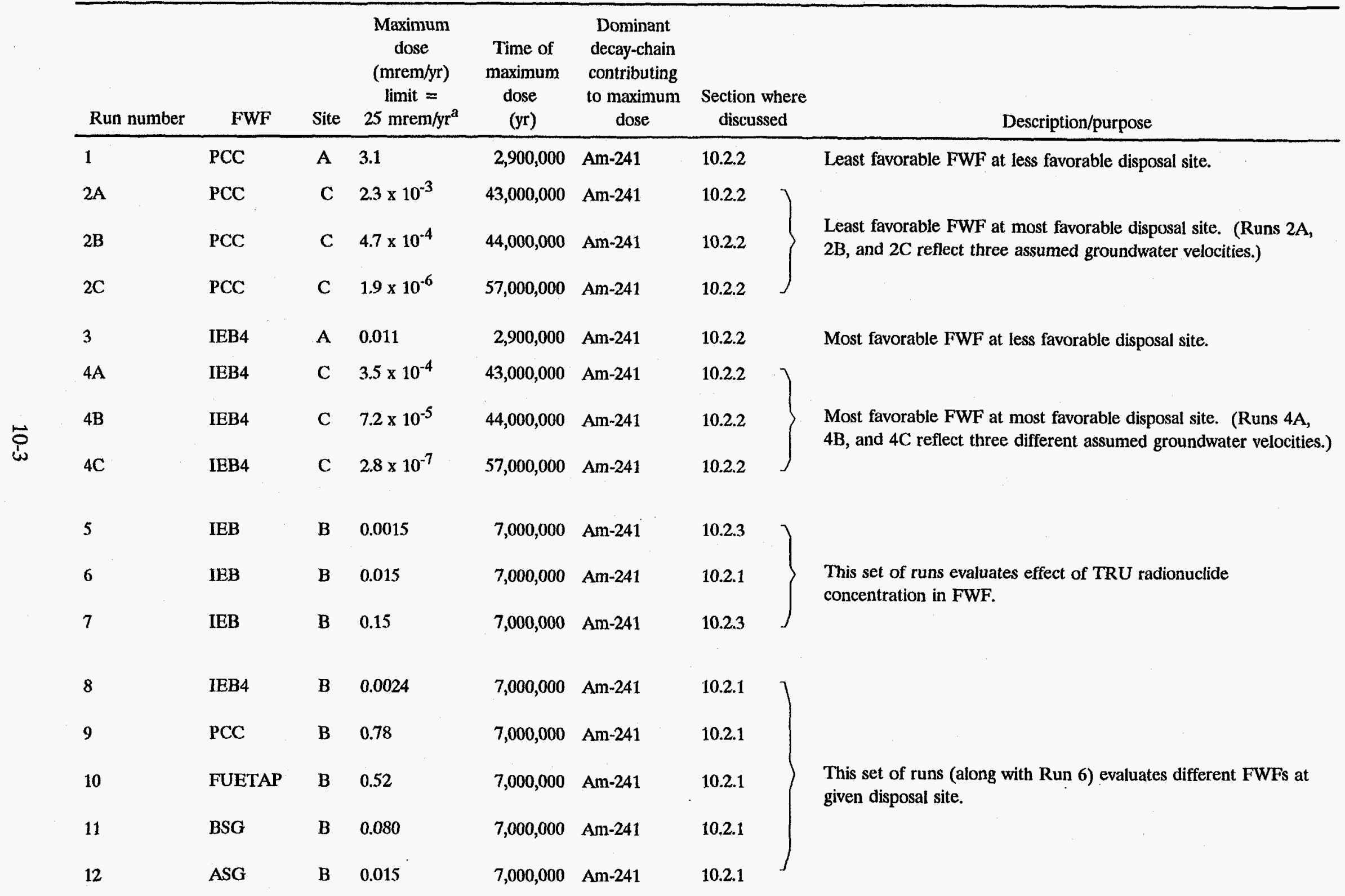


Table 10-2. (continued).

\begin{tabular}{|c|c|c|c|c|c|c|c|}
\hline Run number & FWF & Site & $\begin{array}{c}\text { Maximum } \\
\text { dose } \\
\text { (mrem/yr) } \\
\text { limit }= \\
25 \mathrm{mrem} / \mathrm{yr}^{\mathrm{a}}\end{array}$ & $\begin{array}{l}\text { Time of } \\
\text { maximum } \\
\text { dose } \\
(y r)\end{array}$ & $\begin{array}{c}\text { Dominant } \\
\text { decay-chain } \\
\text { contributing } \\
\text { to maximum } \\
\text { dose }\end{array}$ & $\begin{array}{l}\text { Section where } \\
\text { discussed }\end{array}$ & Description/purpose \\
\hline 13 & PCC & D & $1,100^{\mathrm{b}}$ & 9,200 & U-233 & 10.2 .2 & \multirow{4}{*}{$\begin{array}{l}\text { This set of runs (along with Runs } 1,2,3,4,8 \text {, and 9) evaluates } \\
\text { different disposal sites. }\end{array}$} \\
\hline 14 & PCC & $\mathbf{E}$ & $3,400^{b}$ & 470 & U-233 & 10.2 .2 & \\
\hline 15 & IEB4 & D & $44^{b}$ & 16,000 & U-233 & 10.2 .2 & \\
\hline 16 & IEB4 & $\mathbf{E}$ & 20 & 10,000 & U-233 & 10.2 .2 & \\
\hline 17 & ASG & A & 0.066 & $2,900,000$ & Am-241 & 10.2.11 & Most favorable glass at less favorable disposal site. \\
\hline 18 & IEB & A & 0.067 & $2,900,000$ & Am-241 & 10.2 .11 & Least favorable ceramic at less favorable disposal site. \\
\hline 17RLR & ASG & A & 0.12 & $2,900,000$ & Am-241 & 10.2.11 & Same as Run 17 , except that revised leach rates are used. \\
\hline 18RLR & IEB & A & 0.083 & $2,900,000$ & Am-241. & 10.2 .11 & Same as Run 18 , except that revised leach rates are used. \\
\hline 3RLR & IEB4 & A & 0.023 & $2,900,000$ & Am-241 & 10.2.11 & Same as Run 3, except that revised leach rates are used. \\
\hline 12RLR & ASG & B & 0.027 & $7,000,000$ & Am-241 & 10.2 .11 & Same as Run 12 , except that revised leach rates are used. \\
\hline 6RLR & IEB & $\mathbf{B}$ & 0.02 & $7,000,000$ & Am-241 & 10.2 .11 & Same as Run 6, except that revised leach rates are used. \\
\hline 8RLR & IEB4 & $\mathbf{B}$ & 0.0054 & $7,000,000$ & Am-241 & 10.2.11 & Same as Run 8 , except that revised leach rates are used. \\
\hline 18TDLR & IEB & A & $2.1 \times 10^{-3}$ & $2,900,000$ & Am-241 & 10.2.12 & Same as Run 18 , except that time-dependent leach rates are used. \\
\hline 6TDLR & IEB & $\mathbf{B}$ & $4.7 \times 10^{-4}$ & $7,000,000$ & Am-241 & 10.2.12 & Same as Run 6, except that time-dependent leach rates are used. \\
\hline $1 \mathrm{~K} 1$ & PCC & A & 12 & 950,000 & Am-241 & 10.2.8 & Same as Run 1, except that $K_{d}$ values are lowered by factor of 3 . \\
\hline $1 \mathrm{~K} 2$ & PCC & A & $28^{\mathrm{b}}$ & 290,000 & Am-241 & 10.2 .8 & Same as Run 1, except that $K_{d}$ values are lowered by factor of 10 . \\
\hline $9 \mathrm{~K} 1$ & PCC & B & 7.4 & $2,300,000$ & Am-241 & 10.2 .8 & Same as Run 9, except that $K_{d}$ values are lowered by factor of 3 . \\
\hline $9 \mathrm{~K} 2$ & PCC & B & 24 & 700,000 & Am-241 & 10.2 .8 & Same as Run 9, except that $K_{d}$ values are lowered by factor of 10 . \\
\hline
\end{tabular}


Table 10-2. (continued).

\begin{tabular}{|c|c|c|c|c|c|c|c|}
\hline Run number & FWF & Site & $\begin{array}{c}\text { Maximum } \\
\text { dose } \\
(\mathrm{mrem} / \mathrm{yr}) \\
\text { limit }= \\
25 \mathrm{mrem} / \mathrm{yr}^{\mathrm{a}}\end{array}$ & $\begin{array}{c}\text { Time of } \\
\text { maximum } \\
\text { dose } \\
(\mathrm{yr})\end{array}$ & $\begin{array}{c}\text { Dominant } \\
\text { decay-chain } \\
\text { contributing } \\
\text { to maximum } \\
\text { dose }\end{array}$ & $\begin{array}{l}\text { Section where } \\
\text { discussed }\end{array}$ & Description/purpose \\
\hline 13K1 & PCC & $\mathbf{D}$ & $1,800^{b}$ & 8,300 & Pu-239 & 10.2 .8 & Same as Run 13 , except that $K_{d}$ values are lowered by factor of 3 . \\
\hline $13 \mathrm{~K} 2$ & PCC & $\mathbf{D}$ & $6,800^{b}$ & 2,900 & Pu-239 & 10.2 .8 & $\begin{array}{l}\text { Same as Run } 13 \text {, except that } K_{d} \text { values are lowered by factor of } \\
10 \text {. }\end{array}$ \\
\hline $14 \mathrm{~K} 1$ & PCC & $\mathbf{E}$ & $5,400^{b}$ & 880,000 & Am-241 & 10.2 .8 & Same as Run 14, except that $K_{d}$ values are lowered by factor of 3 . \\
\hline $14 \mathrm{~K} 2$ & PCC & $\mathbf{E}$ & $14,000^{b}$ & 270,000 & Am-241 & 10.2 .8 & $\begin{array}{l}\text { Same as Run } 14 \text {, except that } K_{d} \text { values are lowered by factor of } \\
10 .\end{array}$ \\
\hline 6GC1 & IEB & B & 0.052 & $7,000,000$ & Am-241 & 10.2 .4 & $\begin{array}{l}\text { Same as Run 6, except that FWF surface area is increased by } \\
\text { factor of } 10 \text {. }\end{array}$ \\
\hline $6 \mathrm{GC2}$ & IEB & $\mathbf{B}$ & 0.29 & $7,000,000$ & Am-241 & 10.2 .4 & $\begin{array}{l}\text { Same as Run 6, except that FWF surface area is increased by } \\
\text { factor of } 100 \text {. }\end{array}$ \\
\hline $6 \mathrm{GC} 3$ & IEB & B & 0.65 & $7,000,000$ & Am-241 & 10.2 .4 & $\begin{array}{l}\text { Same as Run 6, except that FWF surface area is increased by } \\
\text { factor of } 1,000 \text {. }\end{array}$ \\
\hline $6 \mathrm{GC} 4$ & IEB & B & 1.2 & $7,000,000$ & Am-241 & 10.2 .4 & $\begin{array}{l}\text { Same as Run 6, except that FWF surface area is increased by } \\
\text { factor of } 10,000 \text {. }\end{array}$ \\
\hline $6 G C 5$ & IEB & B & 1.2 & $7,000,000$ & Am-241 & 10.2 .4 & $\begin{array}{l}\text { Same as Run 6, except that FWF surface area is increased by } \\
\text { factor of } 100,000 \text {. }\end{array}$ \\
\hline $9 \mathrm{C} 1$ & PCC & B & 1.1 & $7,000,000$ & Am-241 & 10.2 .4 & $\begin{array}{l}\text { Same as Run 9, except that FWF diffusion path length is } \\
\text { decreased by factor of } 10 \text {. }\end{array}$ \\
\hline $9 \mathrm{C} 2$ & PCC & $\mathbf{B}$ & 1.1 & $7,000,000$ & Am-241 & 10.2 .4 & $\begin{array}{l}\text { Same as Run } 9 \text {, except that FWF diffusion path length is } \\
\text { decreased by factor of } 100 \text {. }\end{array}$ \\
\hline 1IR1 & PCC & A & 6.1 & 760,000 & $A m-241$ & 10.2 .5 & Same as Run 1 , except that infiltration rate of $5 \mathrm{~cm} / \mathrm{gr}$ is used. \\
\hline 1IR2 & PCC & $\mathbf{A}$ & 6.8 & 380,000 & Am-241 & 10.2 .5 & Same as Run 1, except that infiltration rate of $10 \mathrm{~cm} / \mathrm{yr}$ is used. \\
\hline 9IR1 & $\mathrm{PCC}$ & B & 4.4 & $1,700,000$ & Am-241 & 10.2 .5 & Same as Run 9, except that infiltration rate of $5 \mathrm{~cm} / \mathrm{gr}$ is used. \\
\hline 9IR2 & PCC & B & 5.7 & 840,000 & Am-241 & 10.2 .5 & Same as Run 9, except that infiltration rate of $10 \mathrm{~cm} / \mathrm{yr}$ is used. \\
\hline
\end{tabular}


Table 10-2. (continued).

\begin{tabular}{|c|c|c|c|c|c|c|c|}
\hline Run number & FWF & Site & $\begin{array}{c}\text { Maximum } \\
\text { dose } \\
\text { (mrem/yr) } \\
\text { limit = } \\
25 \mathrm{mrem} / \mathrm{yr}^{\mathrm{a}}\end{array}$ & $\begin{array}{l}\text { Time of } \\
\text { maximum } \\
\text { dose } \\
(y r)\end{array}$ & $\begin{array}{c}\text { Dominant } \\
\text { decay-chain } \\
\text { contributing } \\
\text { to maximum } \\
\text { dose }\end{array}$ & $\begin{array}{l}\text { Section where } \\
\text { discussed }\end{array}$ & Description/purpose \\
\hline 13IR2 & PCC & D & $970^{b}$ & 7,500 & U-233 & 10.2 .5 & Same as Run 13 , except that infiltration rate of $80 \mathrm{~cm} / \mathrm{yr}$ is used. \\
\hline 13IR2 & PCC & D & $920^{\mathrm{b}}$ & 6,900 & U-233 & 10.2 .5 & Same as Run 13, except that infiltration rate of $120 \mathrm{~cm} / \mathrm{yr}$ is used. \\
\hline 14IR1 & PCC & $\mathbf{E}$ & $2,900^{b}$ & 270,000 & Am-241 & 10.2 .5 & Same as Run 14, except that infiltration rate of $5 \mathrm{~cm} / \mathrm{yr}$ is used. \\
\hline 14IR2 & PCC & $\mathbf{E}$ & $3,000^{b}$ & 130,000 & Am-241 & 10.2 .5 & Same as Run 14, except that infiltration rate of $10 \mathrm{~cm} / \mathrm{yr}$ is used. \\
\hline 1LDW & PCC & A & 0.0012 & $3,400,000$ & Am-241 & 10.2 .9 & Same as Run 1, except that receptor well is $215 \mathrm{~km}$ downgradient. \\
\hline 1UTR & Untreated & A & 3.6 & $2,900,000$ & Am-241 & 10.2 .10 & Same as Run 1 , except that waste is untreated. \\
\hline 9UTR & Untreated & B & 0.92 & $7,000,000$ & Am-241 & 10.2.10 & Same as Run 9, except that waste is untreated. \\
\hline 13UTR & Untreated & D & $780^{\mathrm{b}}$ & 9,500 & U-233 & 10.2 .10 & Same as Run 13 , except that waste is untreated. \\
\hline 14UTR & Untreated & $\mathrm{E}$ & $7,000^{b}$ & 470 & U-233 & 10.2.10 & Same as Run 14, except that waste is untreated. \\
\hline 1 NB & $\mathrm{PCC}$ & A & 6.2 & 720,000 & Am-241 & 10.2 .6 & $\begin{array}{l}\text { Same as Run 1, except that no credit is taken for vadose zone } \\
\text { basalt travel time. }\end{array}$ \\
\hline 1IR2NB & PCC & A & 7.7 & 140,000 & $\mathbf{U}-233$ & 10.2.6 & $\begin{array}{l}\text { Same as Run 1IR2, except that no credit is taken for vadose zone } \\
\text { basalt travel time. }\end{array}$ \\
\hline 1SZS & PCC & A & 0.23 & $2,900,000$ & Am-241 & 10.2.7 & Same as Run 1, except that source-zone sorption is used. \\
\hline 9SZS & PCC & B & $5.5 \times 10^{-2}$ & $7,000,000$ & Am-241 & 10.2 .7 & Same as Run 9, except that source-zone sorption is used. \\
\hline 13SZS & PCC & $\mathrm{D}$ & $1,100^{b}$ & 9,200 & U-233 & 10.2.7 & Same as Run 13, except that source-zone sorption is used. \\
\hline 14SZS & PCC & $\mathrm{E}$ & $3,400^{b}$ & 470 & U-233 & 10.2 .7 & Same as Run 14, except that source-zone sorption is used. \\
\hline 1IR2NBSZS & PCC & A & 2.9 & 140,000 & U-233 & 10.2 .7 & Same as Run 1IR2NB, except that source-zone sorption is used. \\
\hline $1 \mathrm{TBF}$ & PCC & A & $2.3 \times 10^{-2}$ & $2,900,000$ & Am-241 & 10.2 .7 & Same as Run 1, except that tailored backfill is assumed. \\
\hline
\end{tabular}


Table 10-2. (continued).

\begin{tabular}{|c|c|c|c|c|c|c|c|}
\hline Run number & FWF & Site & $\begin{array}{c}\text { Maximum } \\
\text { dose } \\
\text { (mrem/yr) } \\
\text { limit }= \\
25 \mathrm{mrem} / \mathrm{yr}^{\mathrm{a}}\end{array}$ & $\begin{array}{l}\text { Time of } \\
\text { maximum } \\
\text { dose } \\
\text { (yr) }\end{array}$ & $\begin{array}{c}\text { Dominant } \\
\text { decay-chain } \\
\text { contributing } \\
\text { to maximum } \\
\text { dose }\end{array}$ & $\begin{array}{l}\text { Section where } \\
\text { discussed }\end{array}$ & Description/purpose \\
\hline 9TBF & PCC & B & $4.8 \times 10^{-3}$ & $7,000,000$ & Am-241 & 10.2 .7 & Same as Run 9, except that tailored backfill is assumed. \\
\hline $18 \mathrm{TBF}$ & IEB & A & $3.7 \times 10^{-5}$ & $2,900,000$ & $A m-241$ & 10.2 .7 & Same as Run 18 , except that tailored backfill is assumed. \\
\hline $6 \mathrm{TBF}$ & IEB & $\mathbf{B}$ & $6.6 \times 10^{-6}$ & $7,000,000$ & Am-241 & 10.2 .7 & Same as Run 6, except that tailored backfill is assumed. \\
\hline 1IR2NBTBF & PCC & $\mathbf{A}$ & 0.25 & 840,000 & $\mathbf{U}-233$ & 10.2 .7 & Same as Run 1IR2NB, except that tailored backfill is assumed. \\
\hline 1IR2NBUTR & Untreated & A & 8.5 & 140,000 & $\mathrm{U}-233$ & 10.2 .10 & Same as Run 1IR2NB, except that waste is untreated. \\
\hline 1UTRTORT & Untreated & A & 3.7 & $2,900,000$ & Am-241 & 10.2 .10 & $\begin{array}{l}\text { Same as Run } 1 \text { UTR, except that higher diffusion coefficient for } \\
\text { sludge is used. }\end{array}$ \\
\hline 1UTRDIFF & Untreated & $\mathbf{A}$ & 2.8 & $2,900,000$ & Am-241 & 10.2 .10 & $\begin{array}{l}\text { Same as Run } 1 \mathrm{UTR} \text {, except that radionuclides are assumed to be } \\
\text { released by diffusion mechanism. }\end{array}$ \\
\hline 1UTRSUR & Untreated & $\mathbf{A}$ & 3.7 & $2,900,000$ & Am-241 & 10.2 .10 & $\begin{array}{l}\text { Same as Run } 1 \text { UTR, except that radionuclides are assumed to be } \\
\text { released by surface washoff mechanism. }\end{array}$ \\
\hline 1UTH & $\mathrm{PCC}$ & $\mathbf{A}$ & 3.1 & $2,900,000$ & Am-241 & 10.2 .16 & $\begin{array}{l}\text { Same as Run 1, except that } \mathrm{U}-233 \text { and Th- } 232 \text { inventories are } \\
\text { increased. }\end{array}$ \\
\hline 3UTH & IEB4 & A & 0.011 & $2,900,000$ & Am-241 & 10.2 .16 & $\begin{array}{l}\text { Same as Run 3, except that U-233 and Th-232 inventories are } \\
\text { increased. }\end{array}$ \\
\hline IINT & PCC & $\mathbf{A}$ & 0.025 & $2,900,000$ & Am-241 & 10.2 .13 & $\begin{array}{l}\text { Same as Run 1, except that chemical interactions between } \\
\text { radionuclides and PCC FWF are included. }\end{array}$ \\
\hline 9INT & PCC & B & 0.0066 & $7,000,000$ & Am-241 & 10.2 .13 & $\begin{array}{l}\text { Same as Run } 9 \text { except that chemical interactions between } \\
\text { radionuclides and PCC FWF are included. }\end{array}$ \\
\hline 1IAR & PCC & A & 3.1 & $2,900,000$ & Am-241 & 10.2 .15 & $\begin{array}{l}\text { Same as Run } 1 \text {, except that inventory with addition refinements is } \\
\text { used. }\end{array}$ \\
\hline
\end{tabular}


Table 10-2. (continued).

\begin{tabular}{|c|c|c|c|c|c|c|c|}
\hline Run number & FWF & Site & $\begin{array}{c}\text { Maximum } \\
\text { dose } \\
(\mathrm{mrem} / \mathrm{yr}) \\
\text { limit }= \\
25 \mathrm{mrem} / \mathrm{yr}^{\mathrm{a}}\end{array}$ & $\begin{array}{l}\text { Time of } \\
\text { maximum } \\
\text { dose } \\
(y r)\end{array}$ & $\begin{array}{c}\text { Dominant } \\
\text { decay-chain } \\
\text { contributing } \\
\text { to maximum } \\
\text { dose }\end{array}$ & $\begin{array}{l}\text { Section where } \\
\text { discussed }\end{array}$ & Description/purpose \\
\hline 13IAR & PCC & D & $1100^{\mathrm{b}}$ & 9,200 & $\mathrm{U}-233$ & 10.2 .15 & $\begin{array}{l}\text { Same as Run } 13 \text {, except that inventory with addition refinements is } \\
\text { used. }\end{array}$ \\
\hline 14LAR & PCC & $\mathbf{E}$ & $3400^{b}$ & 470 & U-233 & 10.2 .15 & $\begin{array}{l}\text { Same as Run } 14 \text {, except that inventory with addition refinements is } \\
\text { used. }\end{array}$ \\
\hline 4AIAR & IEB4 & C & 0.75 & 3,200 & C-14 & 10.2.15 & $\begin{array}{l}\text { Same as Run } 4 \mathrm{~A} \text {, except that inventory with addition refinements } \\
\text { is used. }\end{array}$ \\
\hline IUTRLAR & Untreated & A & 3.7 & $2,900,000$ & Am-241 & 10.2 .15 & $\begin{array}{l}\text { Same as Run 1UTR, except that inventory with addition } \\
\text { refinements is used. }\end{array}$ \\
\hline 1VTF & PCC & A & 2.9 & $2,900,000$ & Am-241 & 10.2 .17 & Same as Run 1, except that vault type disposal facility is assumed. \\
\hline 9VTF & PCC & B & 0.72 & $7,000,000$ & Am-241 & 10.2.17 & Same as Run 9, except that vault type disposal facility is assumed. \\
\hline $14 \mathrm{VTF}$ & PCC & E & $2100^{\mathrm{b}}$ & 470 & U-233 & 10.2.17 & Same as Run 14 , except that vault type disposal facility is assumed. \\
\hline $18 \mathrm{VTF}$ & IEB & A & 0.068 & $2,900,000$ & Am-241 & 10.2 .17 & Same as Run 18 , except that vault type disposal facility is assumed. \\
\hline 6VTF & IEB & B & 0.017 & $7,000,000$ & Am-241 & 10.2 .17 & Same as Run 6, except that vault type disposal facility is assumed. \\
\hline 19 & IEB & $\mathbf{E}$ & $150^{\mathrm{b}}$ & 22,000 & U-233 & 10.2.17 & IEB FWF at Site E. \\
\hline $19 \mathrm{VTF}$ & IEB & $\mathbf{E}$ & $150^{b}$ & 22,000 & U-233 & 10.2.17 & Same as Run 19 , except that vault type disposal facility is assumed. \\
\hline
\end{tabular}

a. Source: DOE Order $5820.2 \mathrm{~A}$.

b. EDE exceeds the limit set forth in DOE Order 5820.2A. 
Table 10-3. Compilation of results for the intrusion scenarios.

\begin{tabular}{|c|c|c|c|c|c|c|c|c|}
\hline $\begin{array}{l}\text { Final } \\
\text { waste } \\
\text { form }\end{array}$ & Inventory $^{a}$ & $\begin{array}{c}\text { Special } \\
\text { conditions }\end{array}$ & $\begin{array}{c}\text { Intruder-drilling } \\
\text { scenario } \\
\text { 16-ft soil cover } \\
\text { intrusion occurs at } \\
100 \mathrm{yr} \\
(\mathrm{mrem}) \\
\text { limit }=500 \mathrm{mrem}^{b}\end{array}$ & $\begin{array}{c}\text { Intruder-drilling } \\
\text { scenario } \\
20-\mathrm{ft} \text { soil cover } \\
\text { intrusion occurs at } \\
100 \mathrm{yr} \\
\quad(\mathrm{mrem}) \\
\text { limit }=500 \text { mrem }^{b}\end{array}$ & $\begin{array}{c}\text { Intruder-excavation } \\
\text { scenario } \\
16 \text {-ft soil cover } \\
\text { intrusion occurs at } \\
500 \mathrm{yr} \\
(\mathrm{mrem}) \\
\text { limit }=500 \mathrm{mrem}^{b}\end{array}$ & $\begin{array}{c}\text { Intruder-agricultural } \\
\text { scenario } \\
\text { 16-ft soil cover } \\
\text { intrusion occurs at } \\
500 \mathrm{yr} \\
(\mathrm{mrem}) \\
\text { limit }=100 \mathrm{mrem} / \mathrm{yr}^{b}\end{array}$ & $\begin{array}{c}\text { Intruder-agricultural } \\
\text { scenario } \\
20 \text {-ft soil cover } \\
\text { intrusion occurs at } \\
100 \mathrm{yr} \\
(\mathrm{mrem}) \\
\text { limit }=100 \mathrm{mrem} / \mathrm{yr}^{b}\end{array}$ & $\begin{array}{c}\text { Intruder-agricultural } \\
\text { scenario } \\
20 \text {-ft soil cover } \\
\text { intrusion occurs at } \\
500 \mathrm{yr} \\
(\mathrm{mrem}) \\
\text { limit }=100 \mathrm{mrem} / \mathrm{yr}^{b}\end{array}$ \\
\hline $\mathrm{PCC}$ & Simplified & NA & 23 & 18 & 96 & $1,400^{c}$ & 46 & $\mathrm{NE}$ \\
\hline FUETAP & Simplified & NA & 23 & 18 & 96 & $1,400^{c}$ & 46 & $\mathrm{NE}$ \\
\hline \multirow[t]{3}{*}{ IEB } & Simplified & NA & 49 & 42 & 220 & $3,100^{c}$ & $110^{c}$ & 22 \\
\hline & $\begin{array}{l}\text { Simplified } \\
\text { with } 10 \\
\text { nCi/g TRU }\end{array}$ & NA & 45 & 39 & 22 & $310^{c}$ & 47 & $\mathrm{NE}$ \\
\hline & $\begin{array}{l}\text { Simplified } \\
\text { with } 1000 \\
\text { nCi/g TRU }\end{array}$ & NA & 84 & 72 & $2,200^{c}$ & $31,000^{c}$ & $690^{c}$ & NE \\
\hline IEB4 & Simplified & NA & 59 & 49 & 260 & $3,600^{c}$ & $120^{c}$ & 25 \\
\hline BSG & Simplified & NA & 23 & 18 & 96 & $1,400^{c}$ & 46 & NE \\
\hline ASG & Simplified & NA & 46 & 36 & 190 & $2,700^{c}$ & 92 & $\mathrm{NE}$ \\
\hline UTR & $\begin{array}{l}\text { Refined- } \\
\text { Combined }\end{array}$ & NA & 12 & 9.6 & 58 & $820^{c}$ & 24 & $\mathrm{NE}$ \\
\hline PCC & $\begin{array}{l}\text { Refined- } \\
\text { RH }\end{array}$ & NA & $13,000^{c}$ & NE & 92 & $1,300^{c}$ & NE & $\mathrm{NE}$ \\
\hline PCC & $\begin{array}{l}\text { Refined- } \\
\mathrm{CH}\end{array}$ & NA & 2.7 & NE & 96 & $1,300^{c}$ & $\mathrm{NE}$ & NE \\
\hline PCC & $\begin{array}{l}\text { Refined- } \\
\text { Combined }\end{array}$ & NA & 19 & $\mathrm{NE}$ & 96 & $1,300^{c}$ & $\mathrm{NE}$ & NE \\
\hline IEB & $\begin{array}{l}\text { Refined- } \\
\text { RH }\end{array}$ & NA & $29,000^{c}$ & $\mathrm{NE}$ & 210 & $3,100^{c}$ & $\mathrm{NE}$ & $\mathrm{NE}$ \\
\hline IEB & $\begin{array}{l}\text { Refined- } \\
\mathrm{CH}\end{array}$ & NA & 6.2 & $\mathrm{NE}$ & 220 & $3,000^{c}$ & $\mathrm{NE}$ & $\mathrm{NE}$ \\
\hline IEB & $\begin{array}{l}\text { Refined- } \\
\text { combined }\end{array}$ & NA & 43 & NE & 220 & $3,000^{c}$ & 97 & 22 \\
\hline IEB4 & $\begin{array}{l}\text { Refined- } \\
\text { combined }\end{array}$ & NA & $\mathrm{NE}$ & NE & $\mathrm{NE}$ & NE & $110^{c}$ & 25 \\
\hline
\end{tabular}


Tabie 10-3. (continued).

\begin{tabular}{|c|c|c|c|c|c|c|c|c|}
\hline $\begin{array}{l}\text { Final } \\
\text { waste } \\
\text { form }\end{array}$ & Inventory ${ }^{a}$ & $\begin{array}{c}\text { Special } \\
\text { conditions }\end{array}$ & $\begin{array}{c}\text { Intruder-drilling } \\
\text { scenario } \\
\text { 16-ft soil cover } \\
\text { intrusion occurs at } \\
100 \mathrm{yr} \\
\quad(\mathrm{mrem}) \\
\text { limit }=500 \mathrm{mrem}^{b}\end{array}$ & $\begin{array}{c}\text { Intruder-drilling } \\
\text { scenario } \\
\text { 20-ft soil cover } \\
\text { intrusion occurs at } \\
100 \mathrm{yr} \\
\quad(\mathrm{mrem}) \\
\text { limit }=500 \mathrm{mrem}^{b}\end{array}$ & $\begin{array}{c}\text { Intruder-excavation } \\
\text { scenario } \\
16-\mathrm{ft} \text { soil cover } \\
\text { intrusion occurs at } \\
500 \mathrm{yr} \\
\quad(\mathrm{mrem}) \\
\text { limit }=500 \mathrm{mrem}^{b}\end{array}$ & $\begin{array}{c}\text { Intruder-agricultural } \\
\text { scenario } \\
\text { 16-ft soil cover } \\
\text { intrusion occurs at } \\
500 \mathrm{yr} \\
\quad(\mathrm{mrem}) \\
\text { limit }=100 \mathrm{mrem} / \mathrm{yr}^{b}\end{array}$ & $\begin{array}{c}\text { Intruder-agricultural } \\
\text { scenario } \\
20-\mathrm{ft} \text { soil cover } \\
\text { intrusion occurs at } \\
100 \mathrm{yr} \\
(\mathrm{mrem}) \\
\text { limit }=100 \mathrm{mrem} / \mathrm{yr}^{b}\end{array}$ & $\begin{array}{c}\text { Intruder-agricultural } \\
\text { scenario } \\
20-\mathrm{ft} \text { soil cover } \\
\text { intrusion occurs at } \\
500 \mathrm{yr} \\
(\mathrm{mrem}) \\
\text { limit }=100 \mathrm{mrem} / \mathrm{yr}^{b}\end{array}$ \\
\hline PCC & $\begin{array}{l}\text { Additional } \\
\text { refinements } \\
\text {-RH }\end{array}$ & NA & $2,000^{c}$ & $1,700^{c}$ & 96 & $1,400^{c}$ & $1,700^{c}$ & 10 \\
\hline PCC & $\begin{array}{l}\text { Additional } \\
\text { refinements } \\
-\mathrm{CH}\end{array}$ & NA & 3 & 2.5 & 96 & $1,300^{c}$ & 29 & 9.9 \\
\hline PCC & $\begin{array}{l}\text { Additional } \\
\text { refinements } \\
\text {-combined }\end{array}$ & NA & 5.4 & 3.6 & 96 & $1,300^{c}$ & 31 & 9.9 \\
\hline $\begin{array}{l}\overrightarrow{0} \\
\stackrel{0}{0}\end{array}$ & $\begin{array}{l}\text { Additional } \\
\text { refinements } \\
-\mathrm{RH}\end{array}$ & NA & $4,500^{c}$ & $3,600^{c}$ & 220 & $3,100^{c}$ & $3,800^{c}$ & 23 \\
\hline IEB & $\begin{array}{l}\text { Additional } \\
\text { refinements } \\
\text {-CH }\end{array}$ & NA & 6.7 & 5.7 & 220 & $3,000^{c}$ & 67 & 22 \\
\hline IEB & $\begin{array}{l}\text { Additional } \\
\text { refinements } \\
\text {-combined }\end{array}$ & NA & 15 & 12 & 220 & $3,100^{c}$ & 75 & 22 \\
\hline IEB4 & $\begin{array}{l}\text { Additional } \\
\text { refinements } \\
-\mathrm{RH}\end{array}$ & NA & $5,500^{c}$ & $4,500^{c}$ & 260 & $3,600^{c}$ & $4,400^{c}$ & 26 \\
\hline IEB4 & $\begin{array}{l}\text { Additional } \\
\text { refinements } \\
-\mathrm{CH}\end{array}$ & NA & 8.4 & 6.6 & 260 & $3,600^{c}$ & 78 & 26 \\
\hline IEB4 & $\begin{array}{l}\text { Additional } \\
\text { refinements } \\
\text {-combined }\end{array}$ & NA & 21 & 17 & 260 & $3,600^{c}$ & 83 & 26 \\
\hline IEB & Simplified & $\begin{array}{l}\text { Increased } \\
\text { exposure } \\
\text { time during } \\
\text { drilling }\end{array}$ & NE & 44 & $\mathrm{NE}$ & NE & $\mathrm{NE}$ & $\mathrm{NE}$ \\
\hline
\end{tabular}


Table 10-3. (continued).

\begin{tabular}{|c|c|c|c|c|c|c|c|c|}
\hline $\begin{array}{l}\text { Final } \\
\text { waste } \\
\text { form }\end{array}$ & Inventory ${ }^{a}$ & $\begin{array}{c}\text { Special } \\
\text { conditions }\end{array}$ & $\begin{array}{c}\text { Intruder-drilling } \\
\text { scenario } \\
16-\mathrm{ft} \text { soil cover } \\
\text { intrusion occurs at } \\
100 \mathrm{yr} \\
\quad(\mathrm{mrem}) \\
\text { limit }=500 \mathrm{mrem}^{b}\end{array}$ & $\begin{array}{c}\text { Intruder-drilling } \\
\text { scenario } \\
20-\mathrm{ft} \text { soil cover } \\
\text { intrusion occurs at } \\
100 \mathrm{yr} \\
\quad(\mathrm{mrem}) \\
\text { limit }=500 \mathrm{mrem}^{b}\end{array}$ & $\begin{array}{c}\text { Intruder-excavation } \\
\text { scenario } \\
16-\mathrm{ft} \text { soil cover } \\
\text { intrusion occurs at } \\
500 \mathrm{yr} \\
(\mathrm{mrem}) \\
\text { limit }=500 \mathrm{mrem}^{b}\end{array}$ & $\begin{array}{c}\text { Intruder-agricultural } \\
\text { scenario } \\
16-\mathrm{ft} \text { soil cover } \\
\text { intrusion occurs at } \\
500 \mathrm{yr} \\
(\mathrm{mrem}) \\
\text { limit }=100 \mathrm{mrem} / \mathrm{yr}^{b}\end{array}$ & $\begin{array}{c}\text { Intruder-agricultural } \\
\text { scenario } \\
20-\mathrm{ft} \text { soil cover } \\
\text { intrusion occurs at } \\
100 \mathrm{yr} \\
(\mathrm{mrem}) \\
\text { limit }=100 \mathrm{mrem} / \mathrm{yr}^{b}\end{array}$ & $\begin{array}{c}\text { Intruder-agricultural } \\
\text { scenario } \\
20 \text {-ft soil cover } \\
\text { intrusion occurs at } \\
500 \mathrm{yr} \\
\text { (mrem) } \\
\text { limit }=100 \mathrm{mrem} / \mathrm{yr}^{b}\end{array}$ \\
\hline IEB & Simplified & $\begin{array}{l}\text { Refined } \\
\text { particle-size } \\
\text { distribution }\end{array}$ & NE & 42 & NE & NE & 30 & NE \\
\hline ASG & Simplified & $\begin{array}{l}\text { Refined } \\
\text { particle-size } \\
\text { distribution }\end{array}$ & NE & 36 & NE & NE & 26 & NE \\
\hline IEB4 & Simplified & $\begin{array}{l}\text { Refined } \\
\text { particle-size } \\
\text { distribution }\end{array}$ & NE & 49 & NE & NE & 37 & NE \\
\hline BSG & Simplified & $\begin{array}{l}\text { Refined } \\
\text { particle-size } \\
\text { distribution }\end{array}$ & NE & 18 & NE & NE & 14 & $\mathrm{NE}$ \\
\hline $\begin{array}{l}\text { PCC or } \\
\text { FUETAP }\end{array}$ & Simplified & $\begin{array}{l}\text { Refined } \\
\text { particle-size } \\
\text { distribution }\end{array}$ & NE & 18 & $\mathrm{NE}$ & NE & 13 & $\mathrm{NE}$ \\
\hline \multicolumn{9}{|c|}{ Note: Intruder runs are not site-specific. } \\
\hline \multicolumn{9}{|c|}{ b. Source: DOE Order $5820.2 A$. } \\
\hline \multicolumn{9}{|c|}{ c. EDE exceeds the limit set forth in DOE Order $5820.2 \mathrm{~A}$. } \\
\hline \multicolumn{9}{|c|}{ NA $=$ Not applicable. } \\
\hline $\mathrm{NE}=\mathbf{N c}$ & luated. & & & & & & & \\
\hline
\end{tabular}




\subsection{Results for Undisturbed-Waste Scenario: Groundwater Pathway}

This section discusses the results of simulating exposure from the groundwater pathway for the undisturbed-waste scenario. The predicted performance of the various disposal systems is discussed in terms of the effects of key parameters on the predicted maximum annual EDEs.

As discussed in Section 4.2.1, performance was evaluated based on the maximum EDE to a receptor withdrawing groundwater from a well drilled $100 \mathrm{~m}$ (328 ft) from the downgradient edge of the disposal facility. The one exception was for the analysis of the effect of distance to the receptor well, which was evaluated on the maximum EDE at a receptor well $215 \mathrm{~km}$ (134 mi) from the downgradient edge of the disposal facility.

No time limit was imposed on the occurrence of the maximum EDE.

\subsubsection{Effects of FWF on Results}

In the initial runs, all six treated FWFs were evaluated at Site B. Table 10-4 shows the results of the six runs.

In all cases, the predicted maximum EDE is well below the regulatory limit of $25 \mathrm{mrem} / \mathrm{yr}$. Differences in maximum EDEs are the result primarily of differences in radionuclide release rates from the FWFs. A higher dissolution rate (or higher diffusion constants in the case of PCC and FUETAP) causes the FWF to release its inventory over a shorter time period, which results in higher doses. The time of maximum dose was delayed only about $4,000 \mathrm{yr}$ (out of about $7,000,000 \mathrm{yr}$ ) for the FWF having the best immobilization characteristics, compared with the FWF having the poorest immobilization characteristics.

An additional parameter that affects dose is the radionuclide availability. All waste forms were assumed to have a $100 \%$ availability, except for IEB4, which has a $30 \%$ availability for the actinides and Sr-90. This reduced availability contributes to lower doses from IEB4.

Table 10-4. Effects of FWF on performance at Site B.

\begin{tabular}{clcc}
$\begin{array}{c}\text { Run } \\
\text { number }\end{array}$ & FWF & $\begin{array}{c}\text { Maximum EDE } \\
(\text { mrem/yr }) \\
\text { limit }=25 \mathrm{mrem} / \mathrm{yr}\end{array}$ & $\begin{array}{c}\text { Time of maximum } \\
\text { dose } \\
(\mathrm{yr})\end{array}$ \\
\hline 9 & PCC & 0.78 & $7.0 \mathrm{E}+06$ \\
10 & FUETAP & 0.52 & $7.0 \mathrm{E}+06$ \\
11 & BSG & 0.080 & $7.0 \mathrm{E}+06$ \\
12 & ASG & 0.015 & $7.0 \mathrm{E}+06$ \\
6 & IEB & 0.015 & $7.0 \mathrm{E}+06$ \\
8 & IEB4 & 0.0024 & $7.0 \mathrm{E}+06$ \\
\hline
\end{tabular}




\subsubsection{Effects of Disposal Site on Results}

The effect of the choice of disposal site on the results was evaluated primarily in two sets of runs. Runs 1, 9, 2, 13, and 14 evaluated the performance of PCC at Sites A, B, C, D, and E, respectively. Runs $3,8,4,15$, and 16 evaluated the performance of IEB4 at Sites A, B, C, D, and $\mathrm{E}$, respectively. Of all the treated FWFs evaluated, IEB4 has the best immobilization characteristics for groundwater transport, while PCC has the poorest.

For both FWFs, Sites A, B, and C provided acceptable performance with respect to the 25-mrem/yr EDE limit. At Site D, both FWFs exceed the 25-mrem/yr limit. At Site E, PCC exceeds the limit and IEB4 is just barely within the limit. The results are shown in Table 10-5 and discussed below.

Sites $\mathbf{A}$ and $\mathbf{B}$. The results show that, for these preliminary assumptions and parameter values, both Sites A and B are acceptable with respect to the 25-mrem/yr standard. Site B offers the better performance of the two. The differences in site performance are attributed to the site hydrologic properties. Site B doses are lower than those from Site A due to the presence of $80 \mathrm{~m}$ of sediment within the vadose zone at Site B. Although the vadose zone at Site A consists of $167 \mathrm{~m}$ of fractured basalt plus $9 \mathrm{~m}$ of sediment, the $80 \mathrm{~m}$ of sediment at Site B provides a significantly greater degree of retardation. This results in a radionuclide travel time about 2.4 times that at Site A. This increased travel time allows for more radionuclide decay before reaching the water table.

Table 10-5. Effects of disposal site on performance.

\begin{tabular}{cllll}
\hline $\begin{array}{c}\text { Run } \\
\text { number }\end{array}$ & FWF & Site & limit $=25$ mrem/yr & $\begin{array}{c}\text { Maximum EDE } \\
\text { (mrem/yr) } \\
\text { maximum dose } \\
\text { (yr) }\end{array}$ \\
\hline 1 & PCC & A & 3.1 & $2.9 \mathrm{E}+06$ \\
9 & PCC & B & 0.78 & $7.0 \mathrm{E}+06$ \\
2 & PCC & C & $2.3 \times 10 \mathrm{E}-03$ to & $4.3 \mathrm{E}+07$ to \\
& & & $1.9 \times 10 \mathrm{E}-06^{\mathrm{a}}$ & $5.7 \mathrm{E}+07$ \\
13 & PCC & D & 1,100 & $9.2 \mathrm{E}+03$ \\
14 & PCC & E & 3,400 & $4.7 \mathrm{E}+02$ \\
3 & IEB4 & A & 0.011 & $2.9 \mathrm{E}+06$ \\
8 & IEB4 & B & 0.0024 & $7.0 \mathrm{E}+06$ \\
4 & IEB4 & C & $3.5 \times 10 \mathrm{E}-04$ to & $4.3 \mathrm{E}+07$ to \\
15 & & & $2.8 \times 10 \mathrm{E}-07^{\mathrm{a}}$ & $5.7 \mathrm{E}+07$ \\
16 & IEB4 & D & 44 & $1.6 \mathrm{E}+04$ \\
& IEB4 & E & 20 & $1.0 \mathrm{E}+04$
\end{tabular}

a. Range of doses reflects impact of range of very small values assumed for the near-zero groundwater velocity. 
Site C. Prediction of doses at Site $\mathrm{C}$ via this pathway is complicated by uncertainties concerning the groundwater velocity within the saturated zone. Saturated-zone velocities are reported to be near zero or below the limits of measurement. Two sets of runs were performed to assess the effects of varying the saturated-zone groundwater velocity on dose. The first set, consisting of Runs $2 \mathrm{~A}, 2 \mathrm{~B}$, and $2 \mathrm{C}$, considered the disposal of $\mathrm{PCC}$ at Site $\mathrm{C}$. The other set, consisting of Runs $4 \mathrm{~A}, 4 \mathrm{~B}$, and $4 \mathrm{C}$, considered the disposal of IEB4 at Site C. Groundwater velocities of $1.0,0.1$, and $0.01 \mathrm{~m} / \mathrm{yr}$ (asymptotically approaching zero) were used to assess the impact on the dose. The results are shown in Table 10-6.

The doses at Site $C$ are between 4 and 8 orders of magnitude below the 25 -mrem/yr limit, indicating that Site $\mathrm{C}$ offers the best performance of the sites evaluated. The very long travel times are a result primarily of the travel time through the vadose zone.

Flow within the saturated zone contributes an additional increment of travel time, depending upon the choice of groundwater velocity. The transport model for the saturated zone considers the combined effects of advection, adsorption, dispersion, and diffusion. When groundwater velocities are extremely small, diffusion dominates transport within the saturated zone. The doses and travel times are similar for the least favorable FWF (PCC) and the most favorable FWF (IIEB4), indicating that the doses at Site $\mathrm{C}$ are dominated by flow-path processes rather than by leaching processes.

Site $D$. Site $\mathrm{D}$ has a high infiltration rate and a relatively thin vadose zone. These characteristics combine to give Site $D$ a relatively short groundwater travel time. In addition, the $\mathrm{K}_{\mathrm{dl}}$ for uranium at Site $\mathrm{D}$ is lower than at Sites $\mathrm{A}, \mathrm{B}$, and $\mathrm{C}$.

The maximum dose for Site $D$ is from the U-233 decay chain and, as shown in Table 10-5, occurs at $9,200 \mathrm{yr}$ for PCC and $16,000 \mathrm{yr}$ for IEB4. For Sites A and B, the maximum dose is from the Am-241 decay chain and occurs at 2.9 and 7 million yr, respectively, for either PCC or IEB4. This difference in travel time for uranium is the reason Site D exceeds the performance objective.

Table 10-6. Effects of FWF and saturated-zone groundwater velocity on performance at Site C.

\begin{tabular}{|c|c|c|c|c|}
\hline $\begin{array}{c}\text { Run } \\
\text { number }\end{array}$ & FWF & $\begin{array}{l}\text { Groundwater } \\
\text { velocity } \\
(\mathrm{m} / \mathrm{yr})\end{array}$ & $\begin{array}{c}\text { Maximum EDE } \\
(\mathrm{mrem} / \mathrm{yr}) \\
\text { limit }=25 \mathrm{mrem} / \mathrm{yr}\end{array}$ & $\begin{array}{c}\text { Time of } \\
\text { maximum dose } \\
(y r)\end{array}$ \\
\hline $2 \mathrm{~A}$ & PCC & 1.0 & $2.3 \times 10^{-3}$ & $4.3 E+07$ \\
\hline $2 \mathrm{~B}$ & PCC & 0.1 & $4.7 \times 10^{-4}$ & $4.4 \mathrm{E}+07$ \\
\hline $2 \mathrm{C}$ & PCC & 0.01 & $1.9 \times 10^{-6}$ & $5.7 \mathrm{E}+07$ \\
\hline $4 \mathrm{~A}$ & IEB4 & 1.0 & $3.5 \times 10^{-4}$ & $4.3 E+07$ \\
\hline $4 B$ & IEB4 & 0.1 & $7.2 \times 10^{-5}$ & $4.4 \mathrm{E}+07$ \\
\hline $4 \mathrm{C}$ & IEB4 & 0.01 & $2.8 \times 10^{-7}$ & $5.7 \mathrm{E}+07$ \\
\hline
\end{tabular}


Site E. Site $E$ is a semiarid site with travel time and infiltration rate similar to Sites A and $B$, except that the $K_{d}$ values at Site $E$ are much smaller than at the other sites. The $K_{d}$ of $U$. 233 is zero, so it takes only about $450 \mathrm{yr}$ to reach the well. This short radionuclide travel time allows very little decay before the U-233 reaches the well and is the reason for the high dose at Site E.

Reasons for Differences. Some of the performance comparisons between the sites studied were presented in this section. Additional site-specific effects are evident in several other parts of Section 10. The reasons for the differences, which are often quite large if comparing doses at Sites $A$ and $B$ against corresponding doses at Sites D and E, are discussed in more detail in Section 10.2.18. In addition, the caution stated in Section 6.1, about the use of generic models for predictions of site-specific performance, is reiterated.

\subsubsection{Effects of TRU Radionuclide Activity Concentration on Results}

The effects of the concentration of TRU radionuclide activity in FWFs were evaluated in Runs 5, 6, and 7. These runs assumed an IEB FWF disposed of at Site B. All parameters were held constant in these three runs except for the TRU activity in the IEB, which was set at 10 , 100 , and $1,000 \mathrm{nCi} / \mathrm{g}$, respectively.

The case with $100 \mathrm{nCi} / \mathrm{g}$ corresponds to the actinide inventory used throughout this study. This concentration of TRU radionuclides is the maximum possible for INEL ALLW. The concentration of $10 \mathrm{nCi} / \mathrm{g}$ is the minimum possible for INEL ALLW. Waste with a $1,000 \mathrm{nCi} / \mathrm{g}$ TRU concentration would be managed as TRU waste, not ALLW. This concentration was used only for the purpose of the parametric evaluations.

Results are shown in Table 10-7.

The predicted peak annual EDEs are 1.5E-03, 1.5E-02, and 1.5E-01 mrem/yr, corresponding to TRU concentrations of 10,100 , and $1,000 \mathrm{nCi} / \mathrm{g}$. In all three cases, the peak dose was from the Am-241 decay chain and occurred at 7.0E+06 yr. This trend in EDEs is reasonable, since a dose from a given radionuclide should be linearly proportional to the activity concentration of that radionuclide in the FWF, as long as all other parameters are held constant. The arrival times were constant because the IEB dissolution rate was held constant for all three TRU concentrations.

Table 10-7. Effects of TRU activity concentration on performance of IEB at Site B.

\begin{tabular}{|c|c|c|c|}
\hline $\begin{array}{l}\text { Run } \\
\text { number }\end{array}$ & $\begin{array}{l}\text { TRU activity } \\
\text { (nCi/g) }\end{array}$ & $\begin{array}{c}\text { Maximum EDE } \\
(\mathrm{mrem} / \mathrm{yr}) \\
\text { limit }=25 \mathrm{mrem} / \mathrm{yr}\end{array}$ & $\begin{array}{c}\text { Time of } \\
\text { maximum dose } \\
(\mathrm{yr})\end{array}$ \\
\hline 5 & 10 & 0.0015 & $7.0 \mathrm{E}+06$ \\
\hline 6 & 100 & 0.015 & $7.0 \mathrm{E}+06$ \\
\hline 7 & 1,000 & 0.15 & $7.0 \mathrm{E}+06$ \\
\hline
\end{tabular}




\subsubsection{Effects of FWF Degradation on Results}

Except as indicated otherwise, all of the results presented in this report are based on the assumption that the radionuclide release rate from each FWF is constant until the inventory is depleted. At that time the release rate goes to zero. In reality, the release rate changes with time as a result of two factors. One factor is the change in the diffusion coefficients (in the case of cements) or the dissolution rate (in the case of ceramics and glasses). This factor relates to the complex changes in chemical processes occurring over time. For ceramics and glasses, this factor is addressed in Section 10.2.12.

The second factor relates to the physical degradation of the FWF over time. This factor leads to a reduced length of the diffusion path (in the case of the cements) or an increased surface area (in the case of the ceramics and glasses). This factor was investigated here.

Two sets of evaluations were performed to simulate the performance of degraded FWFs at Site B. The first set consisted of Runs 9, 9C1, and 9C2. Run 9 assumed a monolithic PCC FWF in the shape of a 55-gal drum. Run 9C1 assumed that the original shape was broken into pieces so that the diffusion path length was reduced by a factor of 10 . In Run $9 \mathrm{C2}$, the diffusion path length was reduced by an additional factor of 10 . The diffusion-limited release model discussed in Section 6.2.3.3 was used in these three runs, each of which had a different average length of the diffusion path, corresponding to the size of the pieces of the FWF.

The second set of analyses consisted of Runs $6,6 \mathrm{GC1}, 6 \mathrm{GC2}, 6 \mathrm{GC3}, 6 \mathrm{GC4}$, and $6 \mathrm{GC}$. Run 6 assumed a monolithic IEB FWF in the shape of a 55-gal drum. Run 6GC1 assumed breakup of the monolith into pieces so that the surface area increased by a factor of 10 . The sequence of assumptions continued up to Run $6 \mathrm{GC5}$, in which the surface area was increased by a factor of 100,000 . For the IEB, the dissolution-limited release model discussed in Section 6.2.3.4, which considered the surface area of the waste form, was used.

The results are shown in Table 10-8. In all cases, the predicted maximum EDE is well below the limit of $25 \mathrm{mrem} / \mathrm{yr}$ in the performance objective. The IEB FWF results show, as expected, an initial increase in dose as the surface area was increased, reaching a peak dose of $1.2 \mathrm{mrem} / \mathrm{yr}$ when the surface area was increased by a factor of 10,000 relative to the 55-gal drum shape. Increasing the surface area further to a factor of 100,000 relative to the shape also yielded a dose of $1.2 \mathrm{mrem} / \mathrm{yr}$, showing that an asymptote had been reached where further degradation of the FWF no longer increased the dose.

The time of maximum dose decreased slightly as the surface area was increased. However, the decrease was too small to appear in the two significant digits to which the times of peak dose are reported.

Results for the PCC FWF in Table 10-8 show that an asymptote of $1.1 \mathrm{mrem} / \mathrm{yr}$ is reached similarly when the diffusion path length of the FWF is decreased by a factor of only 10 relative to the original shape. The slight difference between the 1.2-mrem/yr asymptote for IEB and the 1.1-mrem/yr asymptote for PCC is the result of differences between a diffusion-limited release model for porous FWFs, such as PCC, and a dissolution-limited release model for nonporous FWFs, such as IEB. 
Table 10-8. Effects of FWF degradation on performance at Site B.

\begin{tabular}{|c|c|c|c|c|}
\hline $\begin{array}{c}\text { Run } \\
\text { number }\end{array}$ & FWF & $\begin{array}{l}\text { Dimensional } \\
\text { change }^{\mathbf{a}}\end{array}$ & $\begin{array}{c}\text { Maximum EDE } \\
(\mathrm{mrem} / \mathrm{yr}) \\
\text { limit }=25 \mathrm{mrem} / \mathrm{yr}\end{array}$ & $\begin{array}{c}\text { Time of maximum } \\
\text { dose } \\
(\mathrm{yr})\end{array}$ \\
\hline 9 & PCC & $\begin{array}{l}\text { Original diffusion } \\
\text { path length }\end{array}$ & 0.78 & $7.0 \mathrm{E}+06$ \\
\hline $9 \mathrm{C} 1$ & PCC & $\begin{array}{l}\text { Original diffusion } \\
\text { path length/10 }\end{array}$ & 1.1 & $7.0 \mathrm{E}+06$ \\
\hline $9 \mathrm{C} 2$ & PCC & $\begin{array}{l}\text { Original diffusion } \\
\text { path length/100 }\end{array}$ & 1.1 & $7.0 \mathrm{E}+06$ \\
\hline 6 & IEB & $\begin{array}{l}\text { Original surface } \\
\text { area }\end{array}$ & 0.015 & $7.0 \mathrm{E}+06$ \\
\hline $6 \mathrm{GC1}$ & IEB & $\begin{array}{l}\text { Original surface } \\
\text { area } \times 10\end{array}$ & 0.052 & $7.0 \mathrm{E}+06$ \\
\hline $6 \mathrm{GC2}$ & IEB & $\begin{array}{l}\text { Original surface } \\
\text { area } \times 100\end{array}$ & 0.29 & $7.0 \mathrm{E}+06$ \\
\hline $6 \mathrm{GC3}$ & IEB & $\begin{array}{l}\text { Original surface } \\
\text { area } \times 1,000\end{array}$ & 0.65 & $7.0 \mathrm{E}+06$ \\
\hline $6 \mathrm{GC} 4$ & IEB & $\begin{array}{l}\text { Original surface } \\
\text { area } \times 10,000\end{array}$ & 1.2 & $7.0 \mathrm{E}+06$ \\
\hline $6 \mathrm{GC5}$ & IEB & $\begin{array}{l}\text { Original surface } \\
\text { area } \times 100,000\end{array}$ & 1.2 & $7.0 \mathrm{E}+06$ \\
\hline
\end{tabular}

a. The size and shape of a 55-gal drum were retained for the FWF for all runs, with varying degrees of fracturing. 
Again, the decrease in the time of maximum dose was too small to appear in the table.

Once the FWF is degraded to the point that most of the inventory is released from the FWF during the first few time steps of the source-term model, further degradation of the FWF will not increase the dose. Under these conditions, the dose is controlled by the processes along the flowpath (decay, adsorption, dispersion, etc.) rather than by the processes controlling the release rate of radionuclides from the FWF.

\subsubsection{Effects of Water Infiltration Rate on Results}

Parametric evaluations were performed to assess the effects that varying the rate of infiltration of water through the disposal unit and vadose zone would have on predicted maximum EDEs and arrival times at Sites A, B, D, and E (see Table 10-9). Site C was not considered because of its insignificant groundwater pathway.

Twelve simulations were performed as part of this analysis. Runs 1, 1IR1, and 1IR2 simulated the performance of a PCC FWF at Site A using infiltration rates of $1.32 \mathrm{~cm} / \mathrm{yr}$ (the original case), $5 \mathrm{~cm} / \mathrm{yr}$, and $10 \mathrm{~cm} / \mathrm{yr}$, respectively. Runs 9, 9IR1, and 9IR2 simulated the performance of a PCC FWF at Site B using infiltration rates of $1.2 \mathrm{~cm} / \mathrm{yr}$ (the original case), $5 \mathrm{~cm} / \mathrm{yr}$, and $10 \mathrm{~cm} / \mathrm{yr}$, respectively. Runs 13, 13IR1, and 13IR2 simulated the performance of a PCC FWF at Site D using infiltration rates of $40 \mathrm{~cm} / \mathrm{yr}$ (the original case), $80 \mathrm{~cm} / \mathrm{yr}$, and $120 \mathrm{~cm} / \mathrm{yr}$, respectively. Runs 14, 14IR1, and 14IR2 simulated the performance of a PCC FWF at Site E using infiltration rates of $0.5 \mathrm{~cm} / \mathrm{yr}$ (the original case), $5 \mathrm{~cm} / \mathrm{yr}$, and $10 \mathrm{~cm} / \mathrm{yr}$, respectively. The rationale for using these infiltration rates is discussed in Section 6.2.3.2.

In Table 10-9, the doses at Sites A and B are primarily from the Am-241 decay chain and result in maximum EDEs below the 25 -mrem/yr limit in the performance objective. As expected, the doses increase with increasing infiltration rates, albeit on a diminishing-returns basis.

At Sites $\mathrm{D}$ and $\mathrm{E}$, the doses actually decrease in most cases with increasing infiltration rate. At Site D, the dominant contributor in Runs 13, 13IR1, and 13IR2 is the U-233 decay chain. Since U-233 has a long half-life (157,000 yr), the U-233 does not generate significant decay products during the short travel times at Site $D$. The U-233 has passed by the well by the time substantial ingrowth occurs. Thus, with an increasing infiltration rate that tends to shorten travel times, the dose decreases.

At Site E, the dominant contributor for Run 14 is the U-233 decay chain. For Runs 14IR1 and 14IR2, the dominant contributor is the Am-241 decay chain. With the increased infiltration rate in Runs 14IR1 and 14IR2, U-233 again passes by the well, so the U-233 decay chain dose is lowered and the Am-241 decay chain becomes the dominant contributor to dose. The Am-241 dose increases with the increasing infiltration dose. The time of maximum dose is inversely proportional to the infiltration rate, because the vadose zone travel time is inversely proportional to the infiltration rate. However, this relationship is true only for a given decay chain. The relationship between infiltration rate and predicted maximum EDEs is nonlinear because of the complex relationship between travel time and radioactive chain decay. 
Table 10-9. Effects of infiltration rate on performance of PCC at Sites A, B, D, and E.

\begin{tabular}{|c|c|c|c|c|c|c|}
\hline $\begin{array}{c}\text { Run } \\
\text { number }\end{array}$ & Site & $\begin{array}{l}\text { Infiltration } \\
\text { rate } \\
(\mathrm{cm} / \mathrm{yr})\end{array}$ & $\begin{array}{l}\text { Vadose } \\
\text { zone travel } \\
\text { time } \\
\text { (yr) }\end{array}$ & $\begin{array}{c}\text { Maximum } \\
\text { EDE } \\
\text { (mrem/yr) } \\
\text { limit }=25 \\
\text { mrem/yr }\end{array}$ & $\begin{array}{c}\text { Time of } \\
\text { maximum } \\
\text { dose (yr) }\end{array}$ & $\begin{array}{c}\text { Dominant decay } \\
\text { chain contributing } \\
\text { to dose }\end{array}$ \\
\hline 1 & A & 1.32 & 933 & 3.1 & $2.9 \mathrm{E}+06$ & Am-241 \\
\hline 1IR1 & A & 5 & 246 & 6.1 & $7.6 \mathrm{E}+05$ & Am-241 \\
\hline 1IR2 & A & 10 & 123 & 6.8 & $3.8 \mathrm{E}+05$ & Am-241 \\
\hline 9 & B & 1.2 & 400 & 0.78 & $7.0 \mathrm{E}+06$ & Am-241 \\
\hline 9IR1 & B & 5 & 96 & 4.4 & $1.7 \mathrm{E}+06$ & Am-241 \\
\hline 9IR2 & B & 10 & 48 & 5.7 & $8.4 \mathrm{E}+05$ & Am-241 \\
\hline 13 & $\mathrm{D}$ & 40 & 4.52 & 1,100 & $9.2 E+03$ & U-233 \\
\hline 13IR1 & $\mathrm{D}$ & 80 & 2.3 & 970 & $7.5 E+02$ & U-233 \\
\hline 13IR2 & $\mathrm{D}$ & 120 & 1.5 & 920 & $6.9 \mathrm{E}+03$ & U-233 \\
\hline 14 & $\mathrm{E}$ & 0.5 & 450 & 3,400 & $4.7 \mathrm{E}+02$ & U-233 \\
\hline 14IR1 & $\mathrm{E}$ & 5 & 45 & 2,900 & $2.7 \mathrm{E}+05$ & Am-241 \\
\hline 14IR2 & $\mathrm{E}$ & 10 & 22 & 3,000 & $1.3 E+05$ & Am-241 \\
\hline
\end{tabular}

10.2.6 Effects of Assumptions Concerning Vadose Zone Basalt on Results, Separately and Combined with Infiltration Rate

Groundwater flow and radionuclide transport through the fractured vadose zone basalts at Site $\mathrm{A}$ were simulated by a simple equivalent-porous-medium approach.

It is difficult to determine a priori whether the equivalent-porous-medium approach used here is realistic or conservative on balance. To address that question, additional simulations were 
performed to determine the importance of unsaturated flow and transport through fractured geologic units, by ignoring the presence of the fractured basalt layers at Site $\mathrm{A}$.

For this purpose, a run designated 1NB (no basalt) was compared with Run 1, which simulated the performance of a PCC FWF at Site A. Sites B, D, and E were not considered for this analysis because there is no vadose zone basalt. Site $C$ was not considered because the groundwater pathway was insignificant.

Run 1 used the simple equivalent-porous-medium approach, whereas Run 1NB completely ignored travel time through vadose zone basalts by assigning a zero thickness to these units. Run 1NB assumed a total vadose zone thickness of $9 \mathrm{~m}$ (see Table 3-1), the sediment thickness at Site A.

The revised assumption concerning the vadose zone basalt resulted in a travel time to the aquifer of $48 \mathrm{yr}$, compared with $933 \mathrm{yr}$ in Run 1. The results are shown in Table 10-10. The dose doubles from 3.1 to $6.2 \mathrm{mrem} / \mathrm{yr}$, and the time to peak dose decreases from 2.9 million yr to 0.72 million yr.

Additional runs were performed that considered the simultaneous effects of ignoring vadose zone basalts and increasing the infiltration rate. Run 1IR2NB was performed using a PCC FWF and the combination of a high infiltration rate of $10 \mathrm{~cm} / \mathrm{yr}$ at Site A (Run 1IR2) and no credit for vadose zone basalt travel time (Run 1NB). The results, shown in Table 10-10, indicate no substantial synergistic effects when assumptions of a high infiltration rate and no basalt travel time were combined in Run 1IR2NB. When the infiltration rate is raised to $10 \mathrm{~cm} / \mathrm{yr}$, the presence or absence of fractured vadose zone basalts does not affect predicted doses substantially.

Comparison with Run 1 shows that the conservative assumptions of a high infiltration rate and no basalt travel time increase the predicted doses by approximately a factor of 2 to 2.5 , whether these assumptions are applied individually or are combined.

In Run 1IR2NB, the peak dose occurs from the U-233 decay chain at a time of $140,000 \mathrm{yr}$. By comparison, the peak dose in Runs 1, 1IR2, and 1NB is attributed to the Am-241 decay chain.

Table 10-10. Combined effects of high infiltration rate and no credit for travel time through vadose zone basalt on performance at Site $A$.

\begin{tabular}{|c|c|c|c|c|c|}
\hline $\begin{array}{c}\text { Run } \\
\text { number }\end{array}$ & $\begin{array}{l}\text { Infiltration } \\
\text { rate } \\
(\mathrm{cm} / \mathrm{yr})\end{array}$ & $\begin{array}{c}\text { Credit } \\
\text { taken for } \\
\text { vadose zone } \\
\text { basalt? }\end{array}$ & $\begin{array}{l}\text { Vadose } \\
\text { zone travel } \\
\text { time } \\
\text { (yr) }\end{array}$ & $\begin{array}{c}\text { Maximum } \\
\text { dose } \\
\text { (mrem/yr) }\end{array}$ & $\begin{array}{c}\text { Time of } \\
\text { maximum dose } \\
(\mathrm{yr})\end{array}$ \\
\hline 1 & 1.32 & Yes & 933 & 3.1 & $2.9 \mathrm{E}+06$ \\
\hline 1IR2 & 10 & Yes & 123 & 6.8 & $3.8 \mathrm{E}+05$ \\
\hline $1 \mathrm{NB}$ & 1.32 & No & 48 & 6.2 & $7.2 \mathrm{E}+05$ \\
\hline 1IR2NB & 10 & No & 6.3 & 7.7 & $1.4 \mathrm{E}+05$ \\
\hline
\end{tabular}




\subsubsection{Effects of Contaminant Sorption in Source Zone on Results, Separately and Combined with Infiltration Rate and Vadose Zone Basalt}

As discussed in Sections 6.3 and 6.4 , the radionuclides were assumed to be retarded by physical and chemical interactions with the geologic media in the vadose zone and the saturated zone. In the source zone (disposal facility), however, it was conservatively assumed that there was no retardation $\left(K_{d}=0\right)$.

A limited number of simulations were performed to assess the effects of sorption of radionuclides on soil or other backfill material in the source zone. Two cases were considered for the amount of sorption. In the first case, termed source-zone sorption, it was assumed that the geologic material in the source zone was not selected with sorptive capabilities in mind. In such backfill material, the values of the $\mathrm{K}_{\mathrm{d}} \mathrm{s}$ were conservatively assumed to be one-tenth of their values in the native sediments. In the second case, called tailored backfill, it was assumed that the geologic material was selected with sorptive capabilities in mind. In such backfill material, the values of the $\mathrm{K}_{d} \mathrm{~s}$ were conservatively assumed to equal those of the native sediments.

To assess the effects of sorption in the source zone, eight additional runs, designated 1SZS, 9SZS, 13SZS, and 14SZS (source-zone sorption) and 1TBF, 9TBF, 18TBF, and 6TBF (tailored backfill), were performed and compared with previous Runs $1,9,13,14,18$, and 6, which did not consider this sorption in the source zone. Runs 1, 1SZS, and 1TBF considered PCC FWF disposed of at Site A, as did Runs 1IR2NB, 1IR2NBSZS, and 1IR2NBTBF. Runs 9, 9SZS, and 9TBF considered PCC FWF disposed of at Site B. Runs 13 and 13SZS considered PCC FWF disposed of at Site D. Runs 14 and 14SZS considered PCC FWF disposed of at Site E. Runs 18, 18TBF, 6, and 6TBF considered IEB FWF disposed of at Sites A and B, respectively. Once again, Site $\mathrm{C}$ was not considered because of its low infiltration rate and insignificant groundwater pathway.

The sorption coefficient $\left(\mathrm{K}_{\mathrm{d}}\right)$ values used for the source zone in the SZS runs were conservatively taken to be one-tenth the values used in Tables 3-2, 3-3, and 3-4 for the vadose zone sediments. The values used for the source zone in the TBF runs were considered the same as used in Table 3-2 for the vadose zone sediments.

The results of these 17 runs are shown in Table 10-11. The doses decrease for Sites A and $B$ if adsorption within the disposal unit is considered, although the time of maximum dose is not substantially affected. The maximum doses are approximately inversely proportional to the $K_{d}$ values used for the disposal unit backfill. The $\mathrm{K}_{\mathrm{d}} \mathrm{s}$ in Run 1TBF are 10 times greater than in Run 1SZS. This results in the dose being lower by about a factor of 10 . This same effect can be seen with Runs 9SZS and 9TBF. The effect of source zone sorption is very pronounced for the runs with an IEB waste form. Run 18TBF has a dose that is about 3 orders of magnitude less than Run 18. A similar effect is seen when comparing Runs 6 and 6TBF.

Source-zone sorption has little effect on the dose at Sites D and E. The radionuclide $\mathrm{K}_{d} s$ at these two sites are generally low, so taking one-tenth of the far-field $K_{d}$ provides for very little additional retardation in the source zone. At Site $\mathrm{E}$, the $\mathrm{K}_{\mathrm{d}}$ for uranium is zero, so there is no effect from source-zone sorption. 
Table 10-11. Effects of adsorption of radionuclides by backfill within the disposal unit.

\begin{tabular}{|c|c|c|c|c|c|c|c|c|}
\hline Run number & FWF & Site & $\begin{array}{l}\text { Infiltration } \\
\text { rate } \\
(\mathrm{cm} / \mathrm{yr})\end{array}$ & $\begin{array}{c}\text { Credit taken } \\
\text { for vadose } \\
\text { zone basalt? }\end{array}$ & $\begin{array}{c}\text { Credit taken } \\
\text { for source } \\
\text { zone sorption? }\end{array}$ & $\begin{array}{l}\text { Vadose } \\
\text { zone travel } \\
\text { time } \\
\text { (yr) }\end{array}$ & $\begin{array}{c}\text { Maximum } \\
\text { dose } \\
\text { (mrem/yr) }\end{array}$ & $\begin{array}{c}\text { Time of } \\
\text { maximum } \\
\text { dose } \\
(y r)\end{array}$ \\
\hline 1 & PCC & A & 1.32 & Yes & $\mathrm{No}$ & 933 & 3.1 & $2.9 E+06$ \\
\hline 1SZS & PCC & A & 1.32 & Yes & Yes & 933 & $2.3 \times 10 \mathrm{E}-01$ & $2.9 \mathrm{E}+06$ \\
\hline 1TBF & PCC & A & 1.32 & Yes & Yes & 933 & $2.3 \times 10 \mathrm{E}-02$ & $2.9 \mathrm{E}+06$ \\
\hline 1IR2NB & PCC & A & 10 & No & No & 6.3 & 7.7 & $1.4 \mathrm{E}+05$ \\
\hline 1IR2NBSZS & PCC & A & 10 & No & Yes & 6.3 & 2.9 & $1.4 \mathrm{E}+05$ \\
\hline 1IR2NBTBF & PCC & A & 10 & No & Yes & 6.3 & 0.25 & $8.4 \mathrm{E}+05$ \\
\hline 9 & PCC & B & 1.2 & Yes & No & 400 & 0.78 & $7.0 \mathrm{E}+06$ \\
\hline 9SZS & PCC & B & 1.2 & Yes & Yes & 400 & $5.5 \times 10 \mathrm{E}-02$ & $7.0 \mathrm{E}+06$ \\
\hline 9TBF & PCC & B & 1.2 & Yes & Yes & 400 & $4.8 \times 10 \mathrm{E}-03$ & $7.0 \mathrm{E}+06$ \\
\hline 13 & PCC & D & 40 & N/A & No & 4.52 & 1,100 & $9.2 E+03$ \\
\hline 13SZS & PCC & D & 40 & N/A & Yes & 4.52 & 1,100 & $9.2 \mathrm{E}+03$ \\
\hline 14 & PCC & E & 0.5 & N/A & No & 450 & 3,400 & 4.7E+02 \\
\hline 14SZS & PCC & $\mathrm{E}$ & 0.5 & N/A & Yes & 450 & 3,400 & $4.7 \mathrm{E}+02$ \\
\hline 18 & IEB & A & 1.32 & Yes & No & 933 & $6.7 \times 10 \mathrm{E}-02$ & $2.9 \mathrm{E}+06$ \\
\hline $18 T B F$ & IEB & A & 1.32 & Yes & Yes & 933 & $3.7 \times 10 \mathrm{E}-05$ & $2.9 E+06$ \\
\hline 6 & IEB & B & 1.2 & Yes & No & 400 & $1.5 \times 10 \mathrm{E}-02$ & $7.0 \mathrm{E}+06$ \\
\hline $6 \mathrm{TBF}$ & IEB & B & 1.2 & Yes & Yes & 400 & $6.6 \times 10 \mathrm{E}-06$ & $7.0 \mathrm{E}+06$ \\
\hline
\end{tabular}


Two final groundwater simulations (Runs 1IR2NBSZS and 1IR2NBTBF) were performed for Site $A$; these combined the two conservative assumptions of high infiltration rate and no basalt travel time but also assumed sorption of radionuclides within the source zone. The dose was reduced to $2.9 \mathrm{mrem} / \mathrm{yr}$ when routine source zone sorption was considered and to $0.25 \mathrm{mrem} / \mathrm{yr}$ when tailored backfill was assumed, compared with $7.7 \mathrm{mrem} / \mathrm{yr}$ without sorption in Run 1IR2NB.

It can be concluded by comparing Runs 1IR2NBSZS and 1IR2NBTBF with Run 1 that source zone sorption is a somewhat more important factor than infiltration rate or vadose zone basalt travel time or even the two combined.

The principal contributor to dose for Sites A and B is generally the Am-241 decay chain. For Runs 1IR2NB and 1IR2NBSZS, the principal contributor is the U-233 decay chain.

\subsubsection{Effects of Far-Field Sorption Coefficients on Results}

The values of sorption coefficients for given species in a given disposal environment are subject to considerable uncertainty. Therefore, parametric evaluations were performed to assess the effects of $K_{d} s$ along the flow paths on predicted EDEs and arrival times. The initial values of the $\mathrm{K}_{\mathrm{d}} \mathrm{s}$ are listed in Sections 3.7, 3.8, and 3.9.

Four sets of simulations were performed. Runs $1,1 \mathrm{~K} 1$, and $1 \mathrm{~K} 2$ simulated the performance of PCC at Site $A$ using the initial values of $K_{d}$ (Run 1), those $K_{d} s$ reduced by a factor of 3 (Run $1 \mathrm{~K} 1$ ), and the $\mathrm{K}_{\mathrm{d}} \mathrm{s}$ reduced by a factor of 10 (Run $1 \mathrm{~K} 2$ ). The second set of simulations consisted of Runs 9,9K1, and 9K2, which simulated the performance of $\mathrm{PCC}$ at Site B using the same sequence of $K_{d}$ values just discussed. Site $C$ was not considered because of its insignificant groundwater pathway. The third and fourth sets of simulations consist of Runs 13,13K1, and $13 \mathrm{~K} 2$, and Runs $14,14 \mathrm{~K} 1$, and $14 \mathrm{~K} 2$, which simulated the performance of PCC at Sites D and E, respectively, using the same sequence of $K_{d}$ values just discussed.

The results of these twelve runs are shown in Table 10-12. The results show that both the dose and the time of peak dose are strongly affected by the choice of $K_{d}$ values.

At Sites $A$ and $B$, reduction of the initial $K_{d} s$ by factors of 3 and 10 causes reductions in peak dose arrival times by almost exactly the same factors. At Sites $D$ and $E$, the dose for the initial $\mathrm{K}_{\mathrm{d}}$ is dominated by U-233; however, the other runs are dominated by Am-241 or Pu-239. For Runs $13 \mathrm{~K} 1$ and $13 \mathrm{~K} 2$, the Pu-239 decay chain dominates the dose, whereas for Runs $14 \mathrm{~K} 1$ and $14 \mathrm{~K} 2$, the Am-241 decay chain dominates the dose. For Runs $13 \mathrm{~K} 1$ and $13 \mathrm{~K} 2$ and for Runs $14 \mathrm{~K} 1$ and $14 \mathrm{~K} 2$, the arrival times are reduced by the same factors as the $K_{d} s$.

The predicted doses increase with decreasing $K_{d} s$ in direct response to the decreased travel time, which reduces the time allowed for decay. Run $1 \mathrm{~K} 2$ exceeded the 25 -mrem/yr performance objective limit by $3 \mathrm{mrem} / \mathrm{yr}$, and Run 9K2 was only $1 \mathrm{mrem} / \mathrm{yr}$ below the limit.

At Sites $D$ and $E$, all of the doses exceeded the performance objective. 
Table 10-12. Effects of reduced $\mathrm{K}_{\mathrm{d}}$ values on performance.

\begin{tabular}{|c|c|c|c|c|c|c|}
\hline $\begin{array}{c}\text { Run } \\
\text { number }\end{array}$ & FWF & Site & $\mathrm{K}_{\mathrm{d}}$ values $^{\mathrm{a}}$ & $\begin{array}{c}\text { Maximum EDE } \\
\text { (mrem/yr) } \\
\text { limit }=25 \\
\text { mrem/yr }\end{array}$ & $\begin{array}{c}\text { Time of } \\
\text { maximum dose } \\
(\mathrm{yr})\end{array}$ & $\begin{array}{l}\text { Dominant } \\
\text { decay chain } \\
\text { contributing } \\
\text { to dose }\end{array}$ \\
\hline 1 & PCC & A & Initial values & 3.1 & $2.9 \mathrm{E}+06$ & Am-241 \\
\hline $1 \mathrm{~K} 1$ & PCC & A & Initial values $\beta$ & 12 & $9.5 \mathrm{E}+05$ & Am-241 \\
\hline $1 \mathrm{~K} 2$ & PCC & A & Initial values /10 & 28 & $2.9 \mathrm{E}+05$ & Am-241 \\
\hline 9 & $\mathrm{PCC}$ & B & Initial values & 0.78 & $7.0 \mathrm{E}+06$ & Am-241 \\
\hline $9 \mathrm{~K} 1$ & $\mathrm{PCC}$ & B & Initial values $\mathcal{B}$ & 7.4 & $2.3 E+06$ & Am-241 \\
\hline $9 \mathrm{~K} 2$ & PCC & B & Initial values $/ 10$ & 24 & $7.0 \mathrm{E}+05$ & Am-241 \\
\hline 13 & PCC & $\mathrm{D}$ & Initial values & 1,100 & $9.2 \mathrm{E}+03$ & U-233 \\
\hline $13 \mathrm{~K} 1$ & $\mathrm{PCC}$ & $\mathrm{D}$ & Initial values $\boldsymbol{B}$ & 1,800 & $8.3 E+03$ & Pu-239 \\
\hline $13 \mathrm{~K} 2$ & PCC & $\mathrm{D}$ & Initial values $/ 10$ & 6,800 & $2.9 \mathrm{E}+03$ & Pu-239 \\
\hline 14 & PCC & $\mathrm{E}$ & Initial values & 3,400 & $4.7 E+02$ & $\mathrm{U}-233$ \\
\hline $14 \mathrm{~K} 1$ & $\mathrm{PCC}$ & $\mathrm{E}$ & Initial values $/ 3$ & 5,400 & $8.8 \mathrm{E}+05$ & Am-241 \\
\hline $14 \mathrm{~K} 2$ & $\mathrm{PCC}$ & $\mathrm{E}$ & Initial values $/ 10$ & 14,000 & $2.7 E+05$ & Am-241 \\
\hline
\end{tabular}




\subsubsection{Effects of Distance to Receptor Well on Results}

The effects of the distance to the receptor well on performance were evaluated in Runs 1 and 1LDW, assuming a PCC FWF at Site A. Run 1 assumed that the receptor well was located $100 \mathrm{~m}(328 \mathrm{ft})$ from the downgradient edge of the facility, while Run 1LDW assumed that the well was located $215 \mathrm{~km}(134 \mathrm{mi})$ downgradient. At this location, the groundwater may discharge to springs or other surface-water bodies.

The results of the evaluation are presented in Table 10-13. The predicted doses for the well located $215 \mathrm{~km}$ downgradient are approximately 2,500 times smaller than the doses for the well located at $100 \mathrm{~m}$. This is a direct result of the considerable dispersion that occurs along the migration pathway and the radionuclide decay that occurs during the longer travel times.

\subsubsection{Effects of Untreated Waste on Results}

The other portions of Section 10 discuss the performance of various treated FWFs. This section presents the results of additional evaluations that predict the performance of untreated waste. The results are compared against those for a PCC FWF. Although the ALLW in storage at the INEL will probably be immobilized by some method before disposal, the projected doses from untreated waste serve as a point of a comparison against which the relative effectiveness of proposed waste treatment options can be judged.

For the untreated waste, the total refined inventory was divided into three categories, as discussed in Section 2.4.5 and Appendix B: sludge, nonsludge, and RH waste. The specific radionuclide inventories and volumes associated with each of the three categories are given in Table 2-11.

The radionuclide inventory associated with the sludge fraction was assumed initially to be released by diffusion, and the inventories associated with the nonsludge and $\mathrm{RH}$ fractions were assumed to be released by a surface washoff mechanism. Additional runs were performed that (a) varied the diffusion constants for releases from the sludge, (b) considered release of the entire inventory by a diffusion mechanism, and (c) considered release of the entire inventory by surface washoff.

The sludge fraction, which occupies $16 \%$ of the total waste volume, consists of a wide variety of cemented and noncemented chemical precipitates (oxides, hydroxides, oxyhydroxides, and nitrate salts) in a solid or semisolid form. The radionuclides are present in these sludges as either soluble salts or as ions dissolved in the residual pore water.

Table 10-13. Effects of distance to receptor well on performance.

\begin{tabular}{llccc}
$\begin{array}{c}\text { Run } \\
\text { number }\end{array}$ & FWF & $\begin{array}{c}\text { Distance to } \\
\text { receptor well }\end{array}$ & $\begin{array}{c}\text { Maximum EDE } \\
\text { (mrem/yr) } \\
\text { limit }=25 \mathrm{mrem} / \mathrm{yr}\end{array}$ & $\begin{array}{c}\text { Time of } \\
\text { maximum dose } \\
(\mathrm{yr})\end{array}$ \\
\hline 1 & PCC & $100 \mathrm{~m}$ & 3.1 & $2.9 \mathrm{E}+06$ \\
$1 \mathrm{LDW}$ & PCC & $215 \mathrm{~km}$ & $1.2 \times 10 \mathrm{E}-03$ & $3.4 \mathrm{E}+06$ \\
\hline
\end{tabular}


The nonsludge and RH fractions, which together occupy $84 \%$ of the total waste volume, consist mostly of common materials such as paper, plastic, wood, sheet metal, plexiglass, tools, and laboratory glassware that have surface contamination. Radionuclides are released from the surface of these materials by surface washoff in water that infiltrates through the disposal unit.

The results for untreated waste at Sites A (Run 1UTR), B (Run 9UTR), D (Run 13UTR), and $E$ (Run 14UTR) are shown in Table 10-14 along with the results of Run 1 (PCC at Site A), Run 9 (PCC at Site B), Run 13 (PCC at Site D), and Run 14 (PCC at Site E) for comparison. The predicted peak annual dose from the untreated waste at Site $A$ was $3.6 \mathrm{mrem} / \mathrm{yr}$, which is slightly higher than the predicted dose $(3.1 \mathrm{mrem} / \mathrm{yr})$ from the PCC FWF at Site A. At Site B, the predicted maximum dose from the untreated waste was $0.92 \mathrm{mrem} / \mathrm{yr}$, which is slightly higher than the dose from PCC FWF at Site B. The increases for Sites A and B were a result of the higher radionuclide release rates assumed for the nonsludge and $\mathrm{RH}$ fractions.

The dose at Site $\mathrm{D}$ from untreated waste is $780 \mathrm{mrem} / \mathrm{yr}$; this is less than the dose from the PCC FWF at this site. The dose from untreated waste is lower because the volume of untreated waste is greater than the volume of PCC waste. Since the volume is greater, the facility is larger and its center is farther from the well. This results in longer travel times and more radioactive decay.

Table 10-14. Effects of disposing of untreated waste.

\begin{tabular}{|c|c|c|c|c|}
\hline Run number & FWF & Site & $\begin{array}{l}\text { Maximum } \\
\text { dose } \\
(\mathrm{mrem} / \mathrm{yr})\end{array}$ & $\begin{array}{c}\text { Time of } \\
\text { maximum dose } \\
(y r)\end{array}$ \\
\hline 1 & PCC & A & 3.1 & $2.9 E+06$ \\
\hline 1UTR & Untreated & $\mathrm{A}$ & 3.6 & $2.9 E+06$ \\
\hline 1UTRTORT & Untreated & A & 3.7 & $2.9 \mathrm{E}+06$ \\
\hline 1IR2NB & $\mathrm{PCC}$ & A & 7.7 & $1.4 \mathrm{E}+05$ \\
\hline 1IR2NBUTR & Untreated & A & 8.5 & $1.4 E+05$ \\
\hline 9 & PCC & B & 0.78 & $7.0 \mathrm{E}+06$ \\
\hline 9UTR & Untreated & B & 0.92 & $7.0 \mathrm{E}+06$ \\
\hline 13 & PCC & $\mathrm{D}$ & 1,100 & $9.2 E+03$ \\
\hline 13UTR & Untreated & $\mathrm{D}$ & 780 & $9.5 \mathrm{E}+03$ \\
\hline 14 & $\mathrm{PCC}$ & $\mathrm{E}$ & 3,400 & $4.7 \mathrm{E}+02$ \\
\hline 14UTR & Untreated & $\mathrm{E}$ & 7,000 & $4.7 \mathrm{E}+02$ \\
\hline
\end{tabular}


At Site E, the dose from untreated waste is $7,000 \mathrm{mrem} / \mathrm{yr}$, more than double the dose from PCC waste. The dose from untreated waste is high because of the short travel times at Site E. The initial release of waste resulting from surface washoff does not get diluted over this relatively short travel time. Also, the $\mathrm{K}_{\mathrm{d}} \mathrm{s}$ at Site $\mathrm{E}$ are low, so the facility size has little effect on dose.

A similar comparison was made for the situation in which more conservative assumptions were used for the infiltration rate and the basalt travel time. Run 1IR2NB used a PCC FWF, with a high infiltration rate of $10 \mathrm{~cm} / \mathrm{yr}$ and no credit for vadose zone basalt travel time. The groundwater travel time with the higher infiltration rate and without credit for the basalt was $6.3 \mathrm{yr}$, compared with $933 \mathrm{yr}$ with basalt and the lower infiltration rate. Run 1IR2NBUTR was the same as Run IIR2NB but the waste was untreated. Again, the untreated run gives a slightly higher dose than the corresponding PCC case: $8.5 \mathrm{mrem} / \mathrm{yr}$ versus $7.7 \mathrm{mrem} / \mathrm{yr}$.

Run 1UTR assumed that the sludge had diffusion coefficients equal to those of a PCC waste form. Run 1UTRTORT used a comparative tortuosity of 1.0, which makes the diffusion coefficient the same value as that for the radionuclide diffusing in free water. No credit is taken in this case for any retention by the sludge. The groundwater scenario is not very sensitive to diffusion coefficients in this range, and the maximum dose approaches an asymptote as the diffusion coefficient increases. The higher diffusion coefficient case (Run 1UTRTORT) gives only a slightly higher dose than Run 1UTR: 3.7 versus $3.6 \mathrm{mrem} / \mathrm{yr}$. The predicted doses for untreated waste and PCC are both an order of magnitude less than the performance objective of 25 mrem/yr.

Since the characteristics of the untreated waste are uncertain, additional runs were performed to examine the sensitivity of the dose to two different release mechanisms: diffusion and surface washoff. Runs 1UTRDIFF and 1UTRSUR, respectively, simulate these two mechanisms. For Run 1UTRDIFF, the radionuclides in all of the waste were assumed to be released by diffusion. The diffusion coefficient used was the same as that for PCC. For Run 1UTRSUR, the radionuclides in all of the waste were assumed to be released by surface washoff. The results are shown in Table 10-15. The maximum EDEs are not very sensitive to the different mechanisms. Surface washoff gives the highest dose because most of the inventory is available for immediate release. Diffusion gives a lower dose because the release is spread out over a longer time period than in the surface washoff run. As shown in Table 10-15, the doses fall on either side of those for Run 1UTR, which uses a combination of these two release mechanisms.

Table 10-15. Effects of assumed release mechanism for untreated waste.

\begin{tabular}{lllcc}
\hline Run number & FWF & \multicolumn{1}{c}{ Mechanism } & $\begin{array}{c}\text { Maximum dose } \\
(\mathrm{mrem} / \mathrm{yr})\end{array}$ & $\begin{array}{c}\text { Time of } \\
\text { maximum dose } \\
(\mathrm{yr})\end{array}$ \\
\hline 1UTRDIFF & Untreated & Diffusion & 2.8 & $2.9 \mathrm{E}+06$ \\
1UTRSUR & Untreated & Surface washoff & 3.7 & $2.9 \mathrm{E}+06$ \\
1UTR & Untreated & Surface washoff plus diffusion & 3.6 & $2.9 \mathrm{E}+06$ \\
\hline
\end{tabular}




\subsubsection{Effects of FWF Leach Rates on Results}

An extensive amount of laboratory leach rate data exists for a variety of glass and ceramic FWF compositions. A common characteristic of these laboratory data is a large amount of scatter in test results. The scatter is a result of several factors including:

- Variations in FWF composition (alkali content, waste loading, etc.)

- Differences in FWF processing conditions (melt temperature, cool-down rate, annealing temperature, etc.)

- Differences between leach test protocols (temperature; surface area; leachant composition; static, dynamic, or flow-through test conditions; etc.).

Selecting the most appropriate data on which to base assigned leach rates in PA runs is a challenging task. The leach rates used for most of the PA runs were obtained from a survey of existing 28-day MCC-1 leach rate data, predominantly from Lutze and Ewing (1988) with the exception of bulk leach rates for IEB4, the more favorable ceramic. The leach rates appear in Table G-1.

Recent experiments at the INEL have provided new leach rate data for three FWFs. See the January 18, 1995, letter from T. L. Eddy in Appendix G. The new data are tabulated in Table 10-16. The new values, referred to as "revised leach rates," are slightly larger than the previous values. The revised values are based on the bulk release rate of silica during MCC-1 leach testing of ASG, IEB, and IEB4 FWFs. The leach rates for the radionuclides are typically smaller than the bulk or silica leach rate by a substantial margin, so use of the indicated values is conservative. The availability factors for ASG and IEB remain at $100 \%$ and the availability factor for IEB4 remains at $30 \%$.

Six sets of evaluations were performed to simulate the long-term performance of three FWFs with the revised leach rates. These sets were for ASG, IEB, and IEB4 at Sites A and B.

The results for the runs with the revised leach rates (designated by run numbers ending in RLR) are as shown in Table 10-17. In all cases, the predicted peak doses were dominated largely by the Am-241 decay chain. The Pu-238 and Pu-239 decay chains were also contributors, but yielded much smaller doses than the Am-241 chain and the peaks occurred at a much later time. The results were compared with the doses obtained for the original leach rates. The peak doses showed a slight increase because of the small increase in the leach rates for the three FWFs. This result is expected because the radionuclide release rate increases with an increase in leach rate. The time for maximum dose did not change, because the leach rate would affect only the concentration of radionuclides released and would not change the time of peak occurrence at the receptor well.

All of the indicated doses are at least 2 orders of magnitude below the performance objective of $25 \mathrm{mrem} / \mathrm{yr}$. The doses calculated with the revised leach rates differ by no more than a factor of 2 from the corresponding doses calculated with the original leach rates. Therefore, the precise value of the leach rate for these three FWFs does not appear to be an important 
Table 10-16. Leach rates for the final waste forms.

\begin{tabular}{ccc}
\hline Final waste form & $\begin{array}{c}\text { Original leach rate } \\
\left(\mathrm{g} / \mathrm{m}^{2} \text {-day }\right)\end{array}$ & $\begin{array}{c}\text { Revised leach rate }^{\mathrm{b}} \\
\left(\mathrm{g} / \mathrm{m}^{2} \text {-day }\right)\end{array}$ \\
\hline ASG & 0.07 & 0.13 \\
IEB & 0.08 & 0.10 \\
IEB4 & 0.05 & 0.11 \\
a. From Table G-1. & \\
b. From the January 18, 1995, letter by T. L. Eddy in Appendix G. \\
\hline
\end{tabular}

Table 10-17. Effects of leach rates on performance.

\begin{tabular}{|c|c|c|c|c|c|}
\hline Run no. & $\begin{array}{c}\text { Final waste } \\
\text { form }\end{array}$ & Site & $\begin{array}{l}\text { Leach rate } \\
\left(\mathrm{g} / \mathrm{m}^{2} \text {-day }\right)\end{array}$ & $\begin{array}{l}\text { Peak dose } \\
(\mathrm{mrem} / \mathrm{yr})\end{array}$ & $\begin{array}{c}\text { Time of } \\
\text { peak dose } \\
\left(10^{6} \mathrm{yr}\right)\end{array}$ \\
\hline 17 & ASG & $\mathrm{A}$ & 0.07 (b) & 0.066 & 2.9 \\
\hline 17RLR & ASG & A & $0.13(r)$ & 0.12 & 2.9 \\
\hline 18 & IEB & A & $0.08(b)$ & 0.067 & 2.9 \\
\hline 18RLR & IEB & A & 0.10 (r) & 0.083 & 2.9 \\
\hline 3 & IEB4 & A & 0.05 (b) & 0.011 & 2.9 \\
\hline 3RLR & IEB4 & A & $0.11(r)$ & 0.023 & 2.9 \\
\hline 12 & ASG & B & 0.07 (b) & 0.015 & 7.0 \\
\hline 12RLR & ASG & B & $0.13(r)$ & 0.027 & 7.0 \\
\hline 6 & IEB & B & 0.08 (b) & 0.015 & 7.0 \\
\hline 6RLR & IEB & B & $0.10(\mathrm{r})$ & 0.02 & 7.0 \\
\hline 8 & IEB4 & B & 0.05 (b) & 0.0024 & 7.0 \\
\hline 8RLR & IEB4 & B & $0.11(\mathrm{r})$ & 0.0054 & 7.0 \\
\hline
\end{tabular}


consideration in selecting a FWF, under the assumptions used herein and for Sites $A$ and $B$. The same general conclusion holds for the BSG FWF, for which no new leach rate data were identified.

\subsubsection{Effects of Time-Dependent Leach Rates on Results}

Leach rates for FWFs are time-dependent. When glass or ceramic FWFs are initially in contact with water, the leach rate is at a maximum value. As leaching proceeds, the concentrations of the major constituents in the waste form increase in the leachant, which reduces the driving force for dissolution. In the case of BSG, for example, as the concentration of silica in the leachant approaches the solubility of amorphous silica, the dissolution rate of the waste form approaches a very low value. In some long-term tests, secondary phases such as cristobalite $\left(\mathrm{SiO}_{2}\right)$ and zeolites (hydrated $\mathrm{Na}$-Ca-aluminosilicates) have been observed to precipitate from the leachant. These precipitates act to buffer the silica concentration at a constant value corresponding to the solubility limit of the secondary phase assemblage. Under these conditions, the release rate of radionuclides from the glass is indirectly controlled by the rate of growth of the secondary phases and is also affected by the influx rate of fresh water, which dilutes the saturated leachant.

Leaching of glass can thus be considered as a two-stage process. Stage one proceeds until the silica concentration approaches a saturated value and is characterized by a relatively high release rate. Stage two proceeds from this point until the waste form is completely dissolved and is characterized by a lower steady-state rate. Ceramics generally exhibit similar behavior.

The use of short-term leach rate to model releases occurring over many thousands of years can be quite conservative. Therefore, leach rate data were examined so that a two-stage release model for glasses and ceramics could be used in a limited number of runs.

A March 14, 1995, letter from T. L. Eddy (see Appendix G) documents the basis for recommending the values for the two-stage leach rate model. The recommended values are given in Table 10-18.

PA runs with the two-stage leach model were made only for the IEB FWF. For conservatism, the Stage 2 leach rate value selected for the IEB runs matched that for the FWF with the largest value for Stage 2 leaching, namely, the value of $0.0025 \mathrm{~g} / \mathrm{m}^{2}$-day for BSG.

Table 10-18. Recommended and selected values for the two-stage leach rate model, $\mathrm{g} / \mathrm{m}^{2}$-day.

\begin{tabular}{cccc}
\hline Final waste form & $\begin{array}{c}\text { Stage 1 } \\
0<\mathrm{t}<1 \mathrm{yr}\end{array}$ & $\begin{array}{c}\text { Stage 2 recommended } \\
\mathrm{t}>1 \mathrm{yr}\end{array}$ & $\begin{array}{c}\text { Stage 2 selected } \\
\mathrm{t}>1 \mathrm{yr}\end{array}$ \\
\hline BSG & 0.4 & 0.0025 & No runs \\
ASG & 0.07 & 0.00044 & No runs \\
IEB & 0.08 & 0.00050 & 0.0025 \\
IEB4 & 0.05 & 0.00031 & No runs \\
\hline
\end{tabular}


Two simulations were performed to evaluate the effects of a two-stage leach process. The performance of IEB at Sites A and B was evaluated using a 0 to 1-yr leach rate corresponding to the baseline value used in previous runs, followed by the lower leach rate as shown in Table 10-18. Because of the large uncertainties in long-term leach rates, the results should be viewed as illustrative rather than definitive.

Results of the time-dependent leach rate simulations (Runs 18TDLR and 6TDLR) are shown in Table 10-19, along with the corresponding fixed-leach-rate runs (numbered 18 and 6) for comparison. The doses at both Sites A and B are reduced by more than an order of magnitude.

Doses at both sites are dominated by the lower leach rate because of the relatively short duration of the high-leach-rate period. The pulse of radionuclides released during this 1 -yr period is dispersed along the travel path, so the peak is attenuated before arrival at the receptor well. There probably exists some critical duration of the period with the initial high leach rate, beyond which the doses are dominated by the higher rather than the lower leach rate. This critical duration is apparently $>1 \mathrm{yr}$ at Sites $\mathrm{A}$ and $\mathrm{B}$.

\subsubsection{Effects of Chemical Interactions within Cement Final Waste Forms on Results}

Nearly all of the runs that evaluated the performance of cement FWFs considered only the physical retardation of radionuclides within the FWF and did not consider the effects of chemical retardation (see Section 6.2.3.3). This section considers chemical as well as physical retardation within the cement matrix and the consequent effects on the predicted doses.

The release of radionuclides from a cement waste form will be largely diffusion-controlled as long as the cement is intact. For the purposes of these analyses, it was assumed that the cement is intact until all of the radionuclides are released by diffusion. For the runs without chemical interaction, the radionuclide inventory is released from the cement matrix in about 5,500 yr. For the runs with chemical interaction, the nuclides are released by a combination of diffusion and desorption in about 100,000 yr. The estimated life of the cement is uncertain. It depends on the waste, treatment parameters, residual stresses, temperature and moisture cycles, and groundwater chemistry. Published estimates (e.g., Brandstetter et al. 1994) suggest the initiation of substantial cracking in 100 to $1,000 \mathrm{yr}$, and large-scale breakup in 500 to 5,000 yr. Even with large-scale breakup, however, the concrete pieces could provide considerable retardation of radionuclides.

Table 10-19. Effects of time-dependent FWF leach rates on performance.

\begin{tabular}{cccccc}
\hline Run no. & Final waste form & Site & $\begin{array}{c}\text { Leach rate } \\
\left(\mathrm{g} / \mathrm{m}^{2} \text {-day }\right)\end{array}$ & $\begin{array}{c}\text { Peak dose } \\
(\mathrm{mrem} / \mathrm{yr})\end{array}$ & $\begin{array}{c}\text { Time of peak } \\
\text { dose }\left(10^{6} \mathrm{yr}\right)\end{array}$ \\
\hline 18 & IEB & A & 0.08 & 0.067 & 2.9 \\
18 TDLR & IEB & A & Time-dependent & 0.0021 & 2.9 \\
6 & & & & & \\
6 & IEB & B & 0.08 & 0.015 & 7.0 \\
6 6TDLR & IEB & B & Time-dependent & $4.7 \times 10 \mathrm{E}-04$ & 7.0 \\
\hline
\end{tabular}


Nevertheless, the 100,000 yr required for the last radionuclides to exit the cement FWF, when credit is taken for chemical interactions, is far beyond the expected life of the cement. Thus, the accompanying analysis of chemical interactions may provide a lower bound on the dose, in that credit is taken for the concrete structure long after it may have eroded or crumbled into small pieces.

The radionuclide migration behavior within the cement matrix will be strongly affected by the chemical composition of the pore water within the matrix. Critical pore water parameters include $\mathrm{pH}$, redox, and ionic strength. The chemical environment within portland-type cement/concrete is characterized by high $\mathrm{pH}$ and high total dissolved solids. The $\mathrm{pH}$ can range from 11.5 for a low-alkali formulation to over 13 for high alkali formulations. This high $\mathrm{pH}$ is maintained by the presence of portlandite $\left[\mathrm{Ca}(\mathrm{OH})_{2}\right]$, which will buffer the $\mathrm{pH}$ above 11.5 for as long as the portlandite remains within the matrix. The presence of $\mathrm{Na}_{2} \mathrm{O}$ and $\mathrm{K}_{2} \mathrm{O}$, which hydrolyze to $\mathrm{NaOH}$ and $\mathrm{KOH}$ in the matrix environment, will raise the $\mathrm{pH}$ to values above the portlandite buffer (Glasser et al. 1985).

Published information on chemical retardation in cement waste forms, such as Allard (1985), provides values that are calculated from laboratory data. These calculated values lump all sorption and precipitation processes together and express the net effects of these processes as a $\mathrm{K}_{\mathrm{d}}$ without distinguishing between the exact mechanisms. This approach does not explain the mechanisms responsible for chemical retardation, but it is adequate for assessing the general effects of chemical retardation.

The solubilities of the actinide elements are several orders of magnitude lower at these high $\mathrm{pH}$. conditions than at neutral $\mathrm{pH}$ values. Radionuclides released from the FWF matrix will encounter high $\mathrm{pH}$ pore fluid and precipitate as hydroxide or oxyhydroxide phases (Allard 1985). The presence of these phases will maintain the concentrations of actinides in the pore fluid at low values corresponding to the solubility limits of the precipitated phases. This control on the release rate of actinides will persist until either the radionuclides or the $\mathrm{pH}$-controlling phase is completely leached. Adsorption of radionuclides within the cement matrix can also occur, which can reduce the effective rate of diffusion through the waste form. Specific sorption processes such as chemisorption, electrostatic interaction, and ion exchange can contribute to chemical retardation. Precipitation or solubility control is not, strictly speaking, a sorptive process, but its effects can be treated, from a modeling standpoint, as retardation.

Based on the aforementioned assumptions, Equation 6-5 was used to determine the effective diffusion coefficients of the radionuclides within the cement waste forms:

$$
D_{i}^{e}=\frac{D_{i}^{o}}{R_{f} \tau}
$$

where

$$
D_{i}^{e}=\text { effective diffusion coefficient of radionuclide } i\left(\mathrm{~cm}^{2} / \mathrm{sec}\right)
$$




$$
\begin{aligned}
& D_{\mathrm{i}}^{\circ}=\text { diffusion coefficient of radionuclide } \mathrm{i} \text { in water, }\left(\mathrm{cm}^{2} / \mathrm{sec}\right) \\
& \mathrm{R}_{\mathrm{f}}=\text { chemical retardation factor (dimensionless) } \\
& \tau=\text { physical retardation factor or tortuosity (dimensionless). }
\end{aligned}
$$

The physical retardation factor was assumed to be 200 for the PCC FWF (see Section 6.2.3.3). The chemical retardation factor was calculated using $\mathrm{K}_{\mathrm{d}} \mathrm{s}$ for radionuclides in a cement matrix (Allard 1985). Equation 10-1 was used to determine the retardation coefficient $R_{\mathrm{f}}$ :

$R_{f}=1+(\rho / \phi) K_{d}$

where

$$
\begin{aligned}
& \rho=\text { density of the waste form }=1.95 \mathrm{~g} / \mathrm{cm}^{3} \text { for PCC } \\
& \phi=\text { porosity of the waste form }=0.22 \text { for PCC. }
\end{aligned}
$$

The $\mathrm{K}_{\mathrm{d}}$ value used for americium, plutonium, and uranium is $5,000 \mathrm{~cm}^{3} / \mathrm{g}$ (Allard 1985), yielding a chemical retardation of 44,300 . The effective diffusion coefficients are thus reduced by this same factor.

For PCC at Sites A and B, Table 10-20 shows the results of runs with chemical interactions, along with the runs that included only physical retardation due to the tortuosity of the diffusion paths in the cement. The results indicate that the doses decrease by approximately 2 orders of magnitude when chemical interactions within the cement waste form are considered. In fact, the doses in runs 1INT and 9INT are within a factor of three of the corresponding doses for the IEB4 FWF in Runs 3 and 8, respectively.

Table 10-20. Effects of chemical interactions of radionuclides with cement.

\begin{tabular}{lcccccc}
\hline & & & \multicolumn{4}{c}{ Maximum } \\
Run number & FWF & Site & $\begin{array}{c}\text { EDE } \\
\text { interaction } \\
\text { considered? }\end{array}$ & $\begin{array}{c}\text { Chemical } \\
\text { interaction } \\
\text { considered? }\end{array}$ & $\begin{array}{c}\text { (mrem/yr) } \\
\text { limit }=25 \\
\text { mrem/yr }\end{array}$ & $\begin{array}{c}\text { Time of } \\
\text { maximum dose } \\
\text { (yr) }\end{array}$ \\
\hline 1 & PCC & A & Yes & No & 3.1 & $2.9 \mathrm{E}+06$ \\
$1 \mathrm{IINT}$ & PCC & A & Yes & Yes & 0.025 & $2.9 \mathrm{E}+06$ \\
9 & PCC & B & Yes & No & 0.78 & $7.0 \mathrm{E}+06$ \\
$9 \mathrm{INT}$ & PCC & B & Yes & Yes & 0.0066 & $7.0 \mathrm{E}+06$ \\
\hline
\end{tabular}




\subsubsection{Effects of Refined Inventory on Results}

During the second and third phases of the investigation, evaluations were performed in which the total waste volume and radionuclide inventory were subdivided into a $\mathrm{CH}$ fraction and an. RH fraction. This refined inventory is discussed in Section 2.4 .3 and in Section A-9 of Appendix A.

Evaluations were performed assuming an IEB FWF disposed of at Site B. These evaluations were identical to Run 6, except that separate evaluations were performed for the $\mathrm{CH}$ and $\mathrm{RH}$ fractions of the waste. Additional evaluations were performed assuming PCC and IEB FWFs disposed of at Site D.

Detailed evaluations of groundwater transport for these cases at Site B were not necessary, however, for the following reason. The dominant radionuclides at Site B were determined in previous runs to be the actinides. In deriving the refined inventory in Appendix $A$, the volumetric concentration of actinides was assumed to be identical in both the $\mathrm{CH}$ and $\mathrm{RH}$ fractions, and the $\mathrm{RH}$ fraction occupies only $31 \mathrm{~m}^{3}$, or $0.13 \%$ of the total combined inventory volume. Therefore, predicted doses from the groundwater scenario are highly insensitive to the RH waste, which contains most of the nonactinide activity. The exclusion or segregation of the RH waste fraction from the $\mathrm{CH}$ waste fraction does not affect the predicted doses from groundwater transport at Site B because the long travel times provide ample time for the $\mathrm{RH}$ nonactinides to decay before reaching the receptor well.

Detailed evaluations of groundwater transport were performed for the $\mathrm{CH}$ and $\mathrm{RH}$ fractions disposed of as PCC and IEB at Site D because the shorter groundwater travel time at SRS raised the possibility that doses from the nonactinides in the RH fraction might be significant. Although groundwater travel times at SRS are shorter than the groundwater travel times at the semiarid sites, the use of higher site-specific adsorption coefficients for several nonactinides (e.g., Sr-90 and Cs-137) at SRS relative to those at the semiarid sites resulted in long ( $-20,000$-yr $)$ radionuclide travel times. Under these conditions, the RH nonactinides have ample time to decay before reaching the receptor well. As a result, the doses at Site D from the RH fraction are approximately $0.1 \%$ of the doses from the $\mathrm{CH}$ fraction, which corresponds to the $\mathrm{RH}$-versus-CH volumetric percent.

It can be concluded from these evaluations that the inclusion or deletion of the RH fraction of the ALLW waste has an inconsequential effect on the doses from the groundwater scenario, as long as the radionuclide travel times at the site are long enough to allow for substantial decay of the shorter-lived $\mathrm{RH}$ nonactinides. Thus, no nonintrusion results showing the effects of the refined inventory are included in Table 10-2.

\subsubsection{Effects of Inventory with Additional Refinements on Results}

In the inventory with additional refinements, four nonactinides (H-3, C-14, Tc-99, and I-129) were not screened out from detailed groundwater transport calculations (see Sections 2.4 .4 and 2.5.4). In groundwater transport calculations involving the preceding two inventories, the nonactinides were screened out. 
Additional groundwater simulations were performed that included these nonactinides in addition to the actinide inventory. Runs 1, 13, 14, 4A, and 1UTR do not include the nonactinide inventory, whereas Runs 1IAR, 13IAR, 14IAR, 4AIAR, and 1UTRIAR include the four nonactinides listed above.

The results of these runs are shown in Table 10-21. Between Runs 1 and 1IAR, the inventory with additional refinements produces about a $1.0 \%$ increase in dose; between Runs 13 and 13IAR, a $0.7 \%$ increase; between Runs 14 and 14IAR, a $0.5 \%$ increase. These increases are not evident in Table 10-21 because the results are reported to only two significant figures. Between Runs 1UTR and 1UTRIAR, the nonactinides provide a 3.0\% increase in dose.

In all of these runs, the actinides dominate the dose. Of the nonactinides, $\mathrm{C}-14$ makes the greatest contribution to dose. In Runs 1IAR, 14IAR, and 1UTRIAR, C-14 has a sorption coefficient of 0.0 , which results in a retardation coefficient of 1.0. This lack of retardation results in relatively short travel times for $\mathrm{C}-14$. Because it has low concentrations $\left(1.18 \times 10^{-9} \mathrm{Ci} / \mathrm{m}^{3}\right.$ in PCC) in the FWFs, I-129 contributes very little dose. Tc-99 also has a relatively low concentration $\left(3.27 \times 10^{-6} \mathrm{Ci} / \mathrm{m}^{3}\right.$ in PCC) in the FWFs. H-3 has retardation coefficients that are about the same as those for $\mathrm{C}-14$, but $\mathrm{H}-3$ has a short (12.3 yr) half-life, whereas the half-life of C-14 is 5,730 yr. For Run 13IAR, C-14 has a retardation coefficient of 43 , but C-14 still dominates the nonactinides because it has a relatively high (when compared to the other nonactinides) concentration $\left(6.54 \times 10^{-5} \mathrm{Ci} / \mathrm{m}^{3}\right.$ in PCC) in the FWFs. This higher retardation coefficient for C-14 is based on sorption coefficients from Martin Marietta (1994).

Table 10-21. Effects of inventory with additional refinements on performance.

\begin{tabular}{llccc}
\hline $\begin{array}{c}\text { Run } \\
\text { number }\end{array}$ & FWF & Site & $\begin{array}{c}\text { Maximum dose } \\
\text { (mrem/yr) } \\
\text { limit }=25 \\
\text { mrem/yr }\end{array}$ & $\begin{array}{c}\text { Time of } \\
\text { maximum } \\
\text { dose } \\
\text { (yr) }\end{array}$ \\
\hline 1 & PCC & A & 3.1 & $2.9 \mathrm{E}+06$ \\
1 1IAR & PCC & A & 3.1 & $2.9 \mathrm{E}+06$ \\
13 & PCC & D & 1,100 & 9,200 \\
13IAR & PCC & D & 1,100 & 9,200 \\
14 & PCC & E & 3,400 & 470 \\
14IAR & PCC & E & 3,400 & 470 \\
4A & IEB4 & C & $3.5 \times 10 \mathrm{E}-04$ & $4.3 \mathrm{E}+07$ \\
4AIAR & IEB4 & C & 0.75 & 3,200 \\
& & & & $2.9 \mathrm{E}+06$ \\
1UTR & Untreated & A & 3.6 & $2.9 \mathrm{E}+06$ \\
1UTRIAR & Untreated & A & 3.7 & \\
\hline
\end{tabular}


Between Runs 4A and 4AIAR, the increased dose is dominated by the nonactinides because of their short travel times. Run 4AIAR is the only run in which the nonactinides dominate the total dose. At Site $\mathrm{C}$, the shortest actinide travel time is about 35 million yr, compared with the shortest nonactinide travel time of about 3,200 yr. Because of the reasons given in the previous paragraph, C-14 dominates the dose for Run 4AIAR.

Thus, the nonactinides, especially $\mathrm{C}-14$, contribute to total dose, but the contribution to dose is overshadowed by the contribution from the actinide inventory. The one exception is at Site $\mathrm{C}$, where the actinides have extremely long travel times compared with the nonactinide travel times.

The predicted contributions from C-14, Tc-99, and I-129 should be considered upper bounds because it is unlikely that these nuclides will remain in any of the FWFs (other than untreated waste) considered in this report. The cement, glass, and ceramic waste forms result from the cementation, vitrification, or crystallization of ash from the thermal treatment of the waste. The volatile nature of these elements makes it likely that they will partition into the off-gas system.

\subsubsection{Effects of Revised Uranium and Thorium Inventories on Results}

The simplified actinide inventory used in virtually all runs in this study (Table 2-3) contained $13 \mathrm{Ci}$ of U-233 and no Th-232. Recent data from Apel et al. (1994) suggest the presence of $865 \mathrm{Ci}$ of U-233 and $2.5 \mathrm{Ci}$ of Th-232 (see Section 2.4.2.5).

The larger values for U-233 and Th-232 were used in Runs 1UTH and 3UTH to assess the potential importance of these two radionuclides in FWFs. These additional runs calculated doses from the disposal at Site A of a PCC FWF (Run 1UTH) and an IEB4 FWF (Run 3UTH), both of which contained the higher U-233 and Th-232 inventories. The results were then compared with the performance of these two FWFs using the original actinide inventory.

The total activity of Am-241 used in both inventories for this particular simplified comparison was 3,741 $\mathrm{Ci}$. [The $3741 \mathrm{Ci}$ includes the $1340 \mathrm{Ci}$ of Am-241 and the $2401 \mathrm{Ci}$ of its comparatively short-lived parent $\mathrm{Pu}-241$. Because the half-life of $\mathrm{Pu}-241$ is much less than that of Am-241, it can be shown (Glasstone and Sesonke 1967, for example) that the addition of the two activities is a valid approximation in this case.] Each radionuclide was run separately in order to compute the dose attributable to each parent radionuclide initially. present in the inventory.

The predicted doses for the groundwater pathway based on the higher actinide inventory are shown in Table 10-22. The doses for Run 1 (PCC at Site A) and Run 3 (IEB4 at Site A), both of which used the simplified actinide inventory, are listed for comparison.

For Run 1UTH, the maximum doses for U-233 and Th-232 were approximately 5 orders of magnitude lower than the dose for Am-241. For Run 3UTH, the maximum dose for U-233 was again about 5 orders of magnitude less than the Am-241 dose, and the maximum dose for Th-232 was about 3 orders of magnitude less than the Am-241 dose. 
Table 10-22. Effects of possible increases in U-233 and Th-232 inventory on performance.

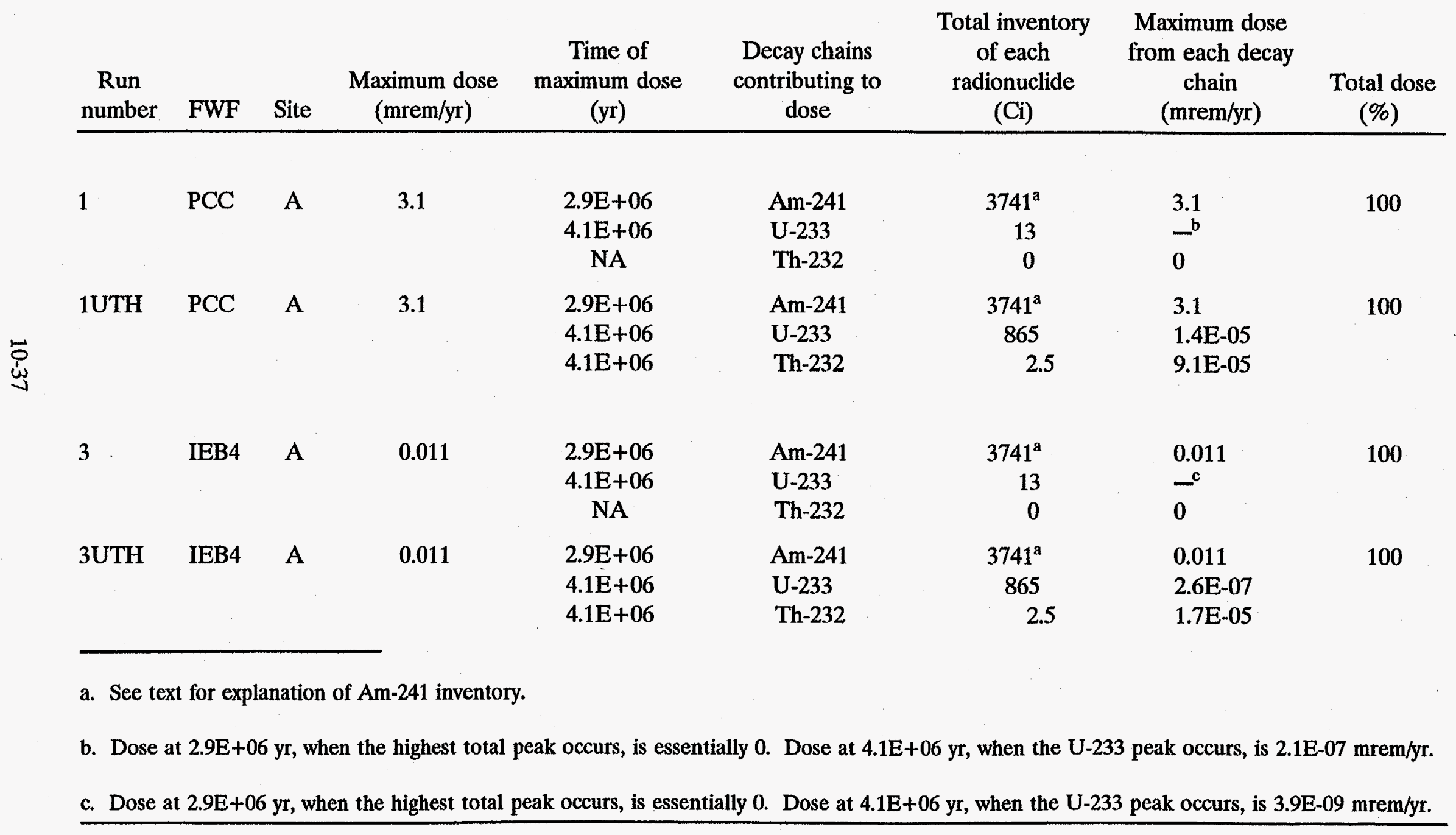


In both Run $1 \mathrm{UTH}$ and Run $3 \mathrm{UTH}$, the Am-241 contributed $100 \%$ of the total dose when rounded to the nearest percent. In both runs, the maximum doses for U-233 and Th-232 occurred at 4.1 million yr, compared with 2.9 million yr for Am-241. This is because U-233 and Th-232 have the same $K_{d}$ value and will arrive at the receptor well at the same time, whereas the $K_{d}$ value for Am-241 is lower, resulting in an earlier arrival time.

In summary, the predicted doses were unchanged by the assumed potential increases of U-233 and Th-232.

\subsubsection{Effects of Vault-Type Disposal Facility on Results}

Analyses were performed to assess the long-term performance of a vault-type disposal facility at the SDA (Site A), Site 14 (Site B), and Hanford (Site E). Preliminary design plans are based on the Center de Stockage de l'Aube disposal facility in France, which is a concrete vault facility with waste packages stabilized with concrete or gravel backfill, and a multi-layered barrier for a closure cap.

The important parameters considered for the analyses are the facility lifetime and the infiltration rate during the facility lifetime. The design lifetime for the l'Aube facility is $300 \mathrm{yr}$ after closure, during which time the facility remains intact. The requirements established by the $\mathrm{NRC}$ in the regulations of $10 \mathrm{CFR} 61$ include waste form stability for $300 \mathrm{yr}$ and intrusion protection for $500 \mathrm{yr}$. Based on these requirements, a facility lifetime of $500 \mathrm{yr}$ was assumed, during which time the facility remains intact. While the facility is intact, the infiltration rate was assumed conservatively to be reduced by roughly a factor of 10 . After the facility lifetime of 500 $\mathrm{yr}$, it was assumed that the facility instantly fails, and the infiltration rate returns to the normal value. For Sites $A$ and $B$, the infiltration rate with the intact facility was $0.1 \mathrm{~cm} / \mathrm{yr}$. The infiltration rates at Sites $A$ and $B$ after the failure of the facility were 1.32 and $1.2 \mathrm{~cm} / \mathrm{yr}$, respectively. At Site $E$, the infiltration rate prior to facility failure was $0.05 \mathrm{~cm} / \mathrm{yr}$; after failure, it was $0.5 \mathrm{~cm} / \mathrm{yr}$. Simulations were performed for PCC and IEB FWFs.

The assumptions used here for vault lifetime and infiltration rates differ somewhat from those in Section 5.2 that were used to evaluate the conceptual disposal of the INEL ALLW at Site D. For Site D, the present study simply followed the assumptions in the Site D PA (Martin Marietta 1994). In this section, the vault lifetime assumption is based on compliance with the NRC guidelines. The infiltration rate assumption was a conservative estimate based on professional judgment.

The results for runs 1VTF, 9VTF, 14VTF, 18VTF, 6VTF, and 19VTF with the vault type facility are provided in Table 10-23 and compared with the corresponding Runs 1, 9, 14, 18, 6, and 19. Runs 1, 1VTF, 9, 9VTF, 14, and 14VTF considered PCC FWFs for Sites A, B, and E, respectively. Runs $18,18 \mathrm{VTF}, 6,6 \mathrm{VTF}, 19$, and 19VTF considered IEB FWFs for Sites A, B, and $\mathrm{E}$ respectively.

For the PCC FWF, the reduction in dose offered by the vault barrier is minimal (a few percent) at sites that have relatively long travel times for radionuclides. The only site where a significant reduction in dose $(38 \%)$ was predicted was Site E, where the radionuclide travel times are relatively short. 
Doses for IEB at the sites evaluated were essentially unchanged by the presence of a vault barrier. For the IEB FWF, the releases occur over longer time periods than for PCC, so the doses are unaffected by changes in the release rate during the first $500 \mathrm{yr}$ after closure. Runs 18 VTF and 6VTF have slightly higher doses than Runs 18 and 6, respectively. The small increase in dose is due to a very small increase in travel times, caused by the presence of the vaults. The increase in travel time allows more decay of the Am-241 chain into decay products with higher dose-conversion factors.

Separate intruder analyses were not performed with a vault-type facility because of the following rationale. For any scenario initiated by drilling, it was assumed that the drill bit would bore through the vault and exhume the waste. This assumption was also applied to any scenario initiated by excavation; hence, the intruder would excavate the waste regardless of the presence of the vault. Also, the intruder analyses assumed that there was no leaching of radionuclides out of the facility, so the vault would not affect the release of radionuclides during the intruder scenarios.

\subsubsection{Reasons for Large Doses at Sites D and E}

10.2.18.1 Introduction. All of the groundwater transport runs involving hypothetical disposal of the INEL ALLW at Site D or E predict a much larger dose than for disposal of the same waste at Site A, B, or C. For corresponding cases, the doses at Sites D and E are typically 2 to 4 orders of magnitude larger than at Sites $A$ and $B$ and sometimes even larger. Comparing the doses at Sites $\mathrm{D}$ and $\mathrm{E}$ against the corresponding doses at Site $\mathrm{C}$ results in still larger differences. In addition, the doses at Sites $\mathrm{D}$ and $\mathrm{E}$ are above the limit in the performance objective in all cases but one: IEB4 at Site E.

The question arises as to why these doses for the INEL ALLW at Sites D and E are so high, in spite of the fact that

- Where feasible, the parameter values used herein for Sites D and E were those used in the respective PAs prepared for those sites for the disposal of their own LLW

- Those PAs concluded that the disposal of the waste generated at their own sites would comply with the performance objectives.

The remainder of Section 10.2.18 is directed toward answering that question.

This section explores some of the reasons for the much higher calculated doses at Sites D and E. Discussions with a preparer of the Hanford PA indicate that still other factors are affecting the calculated doses, e.g., inhomogeneities of contaminant distribution within the waste coupled with solubility limits for dose-controlling radionuclides. Only a point-by-point comparison of the two methods would reveal all of the important differences, which is beyond the scope of this study.

10.2.18.2 Comparisons of Results from Runs Already Made. To explore the above question, several key runs were examined that had already been made for waste disposal at Sites $\mathrm{D}$ and $\mathrm{E}$. Some of the runs were for INEL ALLW, as evaluated in this study. The other runs 
Table 10-23. Effects of vault-type facility for given disposal sites.

\begin{tabular}{cccccc}
$\begin{array}{c}\text { Run } \\
\text { number }\end{array}$ & FWF & Site & $\begin{array}{c}\text { Maximum dose } \\
\text { (mrem/yr) }\end{array}$ & $\begin{array}{c}\text { Time of } \\
\text { maximum dose } \\
\text { (yr) }\end{array}$ & $\begin{array}{c}\text { Dominant } \\
\text { contributor to } \\
\text { dose } \\
\text { (decay chain) }\end{array}$ \\
\hline 1 & PCC & A & 3.1 & $2.9 \mathrm{E}+6$ & Am-241 \\
1 VTF & PCC & A & 2.9 & $2.9 \mathrm{E}+6$ & Am-241 \\
9 & PCC & B & 0.78 & $7.0 \mathrm{E}+6$ & Am-241 \\
9 VTF & PCC & B & 0.72 & $7.0 \mathrm{E}+6$ & Am-241 \\
14 & PCC & E & 3,400 & 470 & U-233 \\
14 VTF & PCC & E & 2,100 & 470 & U-233 \\
18 & IEB & A & 0.067 & $2.9 \mathrm{E}+6$ & Am-241 \\
$18 \mathrm{VTF}$ & IEB & A & 0.068 & $2.9 \mathrm{E}+6$ & Am-241 \\
& & & & & \\
6 & IEB & B & 0.015 & $7.0 \mathrm{E}+6$ & Am-241 \\
6 VTF & IEB & B & 0.017 & $7.0 \mathrm{E}+6$ & Am-241 \\
19 & & & & & \\
$19 \mathrm{VTF}$ & IEB & E & 150 & 22,000 & U-233 \\
\hline
\end{tabular}

were for specific inventories of SRS LLW and Hanford LLW disposed of at their own sites, as evaluated in their respective PAs (Martin Marietta 1994 and Wood et al. 1994).

The results of these comparisons appear in Table 10-24. The objective of the table was to list the key assumptions and parameter values wherein the PA runs differed, so that the reasons for the large differences in dose could be better understood.

The first column of the table simply provides an item number to simplify this discussion. Run numbers are also given for the runs made in this study. The next four columns indicate the waste evaluated, the inventory of the key dose contributors, the conceptual location of the disposal, and the FWF studied. The next two columns list the assumptions made for the FWF release process and the assumed $K_{d}$ values for the key dose contributors. The groundwater travel time in the vadose zone is listed next, followed by the calculated maximum value of the groundwater dose. 
Table 10-24. Comparison of assumptions and results of PA runs involving Sites D and E.

\begin{tabular}{|c|c|c|c|c|c|c|c|c|}
\hline $\begin{array}{c}\text { Item } \\
\text { (run no.) }\end{array}$ & Waste & $\begin{array}{c}\text { Inventory of key dose } \\
\text { contributors }\end{array}$ & $\begin{array}{c}\text { Location of } \\
\text { disposal }\end{array}$ & $\begin{array}{l}\text { Final } \\
\text { waste } \\
\text { form }\end{array}$ & $\begin{array}{c}\text { Assumptions } \\
\text { concerning release } \\
\text { process }\end{array}$ & $\begin{array}{c}\text { Assumed values } \\
\text { for } \mathbf{K}_{\mathrm{d}} \mathrm{s}\end{array}$ & $\begin{array}{l}\text { Groundwater } \\
\text { travel time in } \\
\text { vadose zone } \\
\text { (yr) }\end{array}$ & $\begin{array}{c}\text { Peak } \\
\text { groundwater } \\
\text { dose } \\
(\text { mrem/yr) }\end{array}$ \\
\hline 1 & Hanford LLW & $\begin{array}{l}5.23 \mathrm{Ci} \mathrm{C}-14 \\
0.22 \mathrm{Ci} \mathrm{I}-129 \\
1.69 \mathrm{Ci} \mathrm{Tc}-99 \\
31 \mathrm{Ci} \text { Uranium } \\
\text { (nuclide not specified) }\end{array}$ & Hanford & Cement & $\begin{array}{l}\text { Realistic-Release } \\
\text { rate limited by } \\
\text { solubility of elements } \\
\text { in cement pore water }\end{array}$ & $\begin{array}{l}\text { C, I, Tc 0; } \\
\text { Am } 100 \\
\text { U } 0\end{array}$ & 450 & 0.47 \\
\hline $\begin{array}{l}2 \\
\text { (Run 14) }\end{array}$ & INEL ALLW & $\begin{array}{l}1340 \text { Ci Am-241 } \\
2401 \text { Ci Pu-241 } \\
13 \text { Ci U-233 }\end{array}$ & Hanford & Cement & $\begin{array}{l}\text { Conservative } \rightarrow \text { no } \\
\text { chemical adsorption } \\
\text { in cement }\end{array}$ & $\begin{array}{l}\text { Am } 100 \\
\text { U } 0\end{array}$ & 450 & 3400 \\
\hline $\begin{array}{l}3 \\
\text { (Run 16) }\end{array}$ & INEL ALLW & $\begin{array}{l}1340 \text { Ci Am-241 } \\
2401 \text { Ci Pu-241 } \\
13 \text { Ci U-233 }\end{array}$ & Hanford & IEB4 & Realistic-dissolution & $\begin{array}{l}\text { Am } 100 \\
\mathrm{U} 0\end{array}$ & 450 & 20 \\
\hline 4 & SRS LLW & $\begin{array}{l}\text { back-calculated: } \\
\text { Am-241 } 1000 \\
\text { Np-237 0.2 } \\
\text { I-129 5.3E-4 } \\
\text { Cs-135 } 19 \\
\text { Sr-90 3E13 } \\
\text { etc. }\end{array}$ & SRS & Cement & $\begin{array}{l}\text { Realistic-Release } \\
\text { rate limited by } \\
\text { solubility of elements } \\
\text { in cement pore water }\end{array}$ & $\begin{array}{l}\text { Am } 1900 / 150^{\mathrm{a}} \\
\text { Np } 5 / 10 \\
\text { U } 35 / 50 \\
\text { I } 1.0 / 0.6 \\
\text { Sr } 15 / 10 \\
\text { Cs } 280 / 100\end{array}$ & 4.52 & $\begin{array}{l}25 \text {, by } \\
\text { constraint }\end{array}$ \\
\hline $\begin{array}{l}5 \\
\text { (Run 13) }\end{array}$ & INEL ALLW & $\begin{array}{l}1340 \mathrm{Ci} \mathrm{Am-241} \\
2401 \mathrm{Ci} \mathrm{Pu}-241 \\
13 \mathrm{Ci} \mathrm{U}-233\end{array}$ & SRS & Cement & $\begin{array}{l}\text { Conservative-no } \\
\text { chemical adsorption } \\
\text { in cement }\end{array}$ & $\begin{array}{l}\text { Am 1900/150 } \\
\text { U 35/50 }\end{array}$ & 4.52 & 1100 \\
\hline $\begin{array}{l}6 \\
\text { (Run 15) }\end{array}$ & INEL ALLW & $\begin{array}{l}1340 \mathrm{Ci} \mathrm{Am-241} \\
2401 \mathrm{Ci} \mathrm{Pu}-241 \\
13 \mathrm{Ci} \mathrm{U}-233\end{array}$ & SRS & IEB4 & Realistic-dissolution & $\begin{array}{l}\text { Am } 1900 / 150 \\
\text { U } 35 / 50\end{array}$ & 4.52 & 44 \\
\hline $\begin{array}{l}7 \\
\text { (Run 1) }\end{array}$ & INEL ALLW & $\begin{array}{l}1340 \mathrm{Ci} \mathrm{Am}-241 \\
2401 \mathrm{Ci} \mathrm{Pu}-241 \\
13 \mathrm{Ci} \mathrm{U}-233\end{array}$ & INEL SDA & Cement & $\begin{array}{l}\text { Conservative-no } \\
\text { chemical adsorption } \\
\text { in cement }\end{array}$ & $\begin{array}{l}\text { Am } 700 / 70^{b} \\
\text { U 1000/100 }\end{array}$ & 933 & 3.1 \\
\hline $\begin{array}{l}8 \\
\text { (Run } \\
\text { 1IR2NB) }\end{array}$ & INEL ALLW & $\begin{array}{l}1340 \mathrm{Ci} \mathrm{Am}-241 \\
2401 \mathrm{Ci} \mathrm{Pu}-241 \\
13 \mathrm{Ci} \mathrm{U}-233\end{array}$ & INEL SDA & Cement & $\begin{array}{l}\text { Conservative-no } \\
\text { chemical adsorption } \\
\text { in cement }\end{array}$ & $\begin{array}{l}\text { Am 700/70 } \\
\text { U 1000/100 }\end{array}$ & $6.3^{c}$ & 7.7 \\
\hline
\end{tabular}


Table 10-24. (continued).

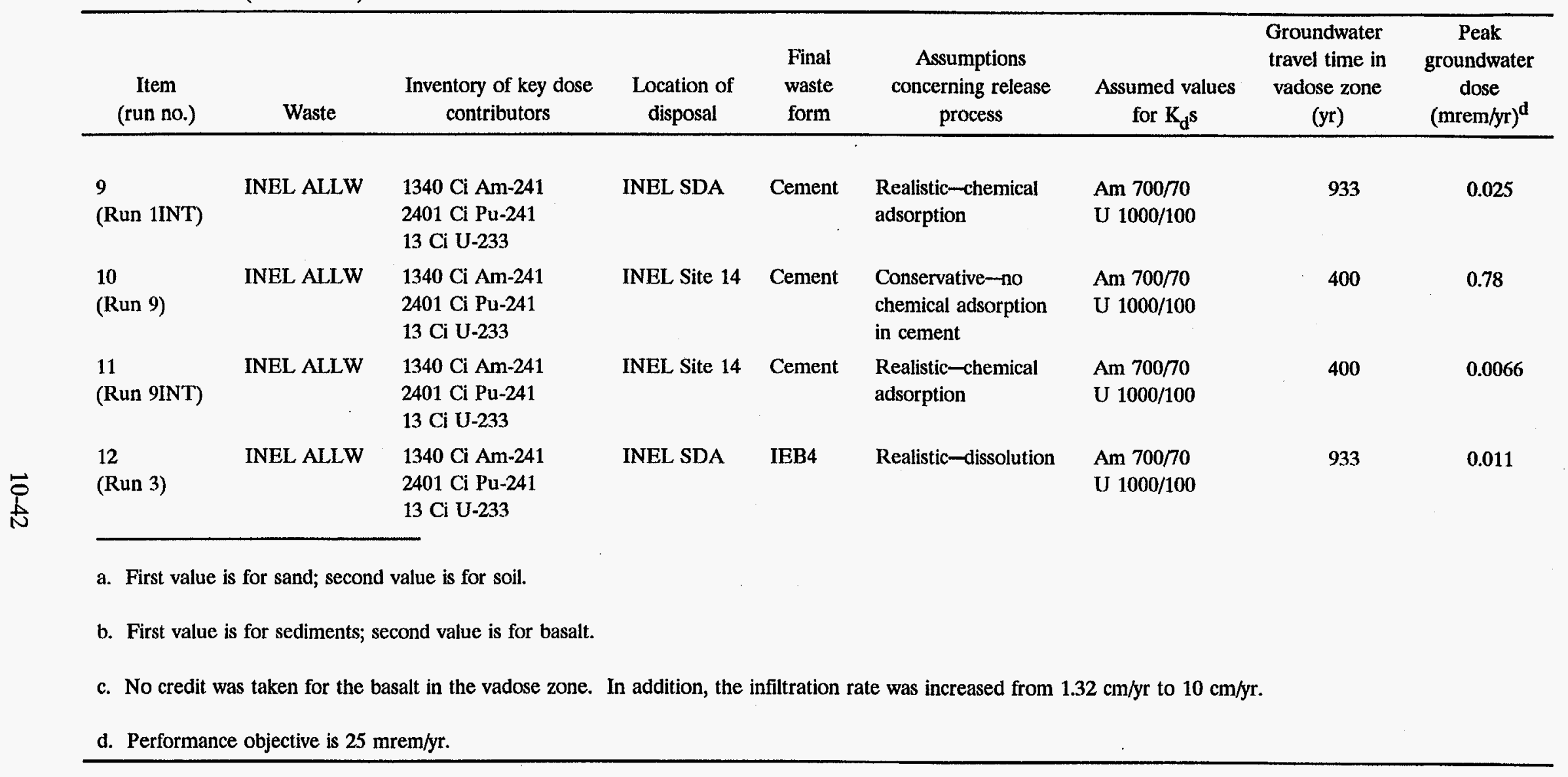


The following observations were made from the entries in Table 10-24:

- The inventories in the SRS waste and Hanford waste differed somewhat from that used in this study. The INEL ALLW tends to be dominated by the Am-241, Pu-239, and U233 decay chains. The Hanford waste was dominated by $U$, the specific isotopic composition of which is not known to the authors. The SRS inventory, which had been back-calculated to derive limits for various radionuclides, tended to be dominated by Am-241, Np-237, and certain nonactinides.

- The $\mathrm{K}_{\mathrm{d}}$ values used at Site D were generally similar to those used for Sites $\mathrm{A}, \mathrm{B}$, and $C$, although much lower for $U$. The values at Site $E$ were considerably lower than those at the other sites, especially for $U$. The extent to which the differences reflect different geochemical interactions at the various sites versus differences in conservatism of the assumptions is not known.

- At the SDA, increasing the assumed infiltration rate to the maximum and taking no credit for the underlying basalt layers increases the dose by only about a factor of $21 / 2$, in spite of decreasing the vadose zone travel time from $933 \mathrm{yr}$ to $6.3 \mathrm{yr}$ (see items 7 and 8).

- At either the SDA or Site 14, including the chemical adsorption in the cement lowers the dose by about 2 orders of magnitude (see items 7 and 9, and items 10 and 11, respectively). In fact, including the chemical adsorption reduces the dose for cement to only a factor of about 3 larger than that for IEB4 (see items 9 and 12).

- For the INEL ALLW in a cement FWF with no chemical adsorption, the dose at SRS is about 350 times higher than that at the SDA and fails the performance objective by a very large margin (see items 5 and 7). Even if the INEL vadose zone travel time were reduced from $933 \mathrm{yr}$ to $6.3 \mathrm{yr}$, close to the $4.52 \mathrm{yr}$ at SRS, the dose at SRS is still about 140 times higher than at the SDA (see items 5 and 8). Evidently, the much lower value of $K_{d}$ for $U$ (35 in SRS sediments versus 1,000 in INEL sediments, a difference of a factor of almost 30 ) is the controlling parameter.

- For the INEL ALLW at SRS, even an IEB4 FWF fails the performance objective (see item 6). Thus, with these assumptions, no FWF would pass the performance objective when disposing of the INEL ALLW at SRS.

- For the INEL ALLW in a cement FWF with no chemical adsorption, the dose at Hanford is about 1,100 times higher than that at the SDA and fails the performance objective by a very large margin (see items 2 and 7). Even if the INEL vadose zone travel time were reduced from $933 \mathrm{yr}$ to $6.3 \mathrm{yr}$ (Hanford's is $450 \mathrm{yr}$ ), the dose at Hanford is still about 440 times higher than at the SDA (see items 2 and 8). Evidently, the much lower value of $\mathrm{K}_{\mathrm{d}}$ for $\mathrm{U}$ ( 0 at Hanford versus 1,000 in INEL sediments) is the controlling factor.

- $\quad$ For the INEL ALLW in an IEB4 FWF at Hanford, the dose barely satisfies the performance objective (see item 3 ). 
10.2.18.3 Results of Additional Runs. Based on the above observations, additional runs were made to (a) substantiate that the differences are actual and not due to a calculational error and (b) explore briefly the reasons for the large differences. Detailed evaluation of the reasons for the differences is beyond the scope of this study.

The following conclusions were drawn from the results of the new runs, which are presented in Table 10-25. The first three conclusions involve the PCC FWF. The fourth conclusion involves the IEB4 FWF.

- Taking credit for the chemical adsorption of INEL ALLW radionuclides in a PCC FWF at Site D or E reduces the dose by about 2 orders of magnitude. This can be seen by comparing the results of Run 14INT against item 2 (Run 14) in Table 10-24, and by comparing Run 13INT against item 5 (Run 13) in Table 10-24. This fractional dose reduction of about 2 orders of magnitude is the same as that found for disposal of $P C C$ at Sites A and B in Section 10.2.13. Thus, taking credit for the chemical adsorption in the PCC accounts for much of the large difference in dose at Sites D and E. The PAs for Hanford and the SRS took credit for the chemical interactions between the radionuclides and the cement, although a detailed analysis of how the chemical interactions were modeled at those sites is beyond the scope of these comparisons.

- For purposes simply of illustrating the sensitivity of dose to $K_{d}$ values, use of the less conservative values of the $\mathrm{K}_{\mathrm{d}} \mathrm{s}$-the INEL values-for the migration of INEL ALLW radionuclides in PCC at Site D or E reduces the dose by about 3 orders of magnitude at Site $E$ and 1 order of magnitude at Site $D$. This can be seen by comparing the results of Run 14INELKD against item 2 (Run 14) in Table 10-24, and by comparing Run 13INELKD against item 5 (Run 13) in Table 10-24. Thus, the difference in $K_{d}$ values explains much of the difference in dose.

- Combining the effects of chemical adsorption of radionuclides in the PCC and the use of different values of $\mathrm{K}_{\mathrm{d}} \mathrm{s}$ reduces the dose even more. The dose is reduced by about 4 orders of magnitude at Site $E$ and 2 to 3 orders of magnitude at Site D. This can be seen by comparing the results from Run 14INT/INELKD against item 2 (Run 14) in Table 10-24, and by comparing Run 13INT/INELKD against item 5 (Run 13) in Table 10-24.

- Using less conservative values of the $\mathrm{K}_{\mathrm{d}} \mathrm{s}$-the INEL values-for the migration of INEL ALLW radionuclides in IEB4 at Site D or E has a much smaller effect than was the case for PCC. With IEB4, the dose reduction is only a factor of about 70 at Site E and a factor of about 8 at Site D. This can be seen by comparing the results of Run 16INELKD against item 3 (Run 16) in Table 10-24, and by comparing Run 15INELKD against item 6 (Run 15) in Table 10-24. The reduced effect in this case is because the IEB4 FWF has a larger effect than does PCC in reducing the release rate. 
Table 10-25. New runs to help clarify the large differences in PA runs for INEL ALLW disposed of at Sites D and E. (All runs involve INEL ALLW. Because of the complex, focused nature of the set of runs listed here, they are not included in Table 10-2.)

\begin{tabular}{|c|c|c|c|c|c|c|c|c|}
\hline Run No. & $\begin{array}{c}\text { Item in Table } 10-24 \\
\text { to which results are } \\
\text { compared }\end{array}$ & $\begin{array}{c}\text { Location } \\
\text { of disposal }\end{array}$ & $\begin{array}{l}\text { Final waste } \\
\text { form }\end{array}$ & $\begin{array}{c}\text { Assumptions } \\
\text { concerning release } \\
\text { process } \\
\end{array}$ & $\begin{array}{c}\text { Assumed values for } \\
\mathrm{K}_{\mathrm{d}} \mathrm{s}\end{array}$ & $\begin{array}{c}\text { Groundwater } \\
\text { travel time in } \\
\text { vadose zone } \\
\text { (yr) }\end{array}$ & $\begin{array}{l}\text { Maximum dose } \\
\text { (mrem/yr) }\end{array}$ & $\begin{array}{c}\text { Time of } \\
\text { maximum dose } \\
\text { (yr) }\end{array}$ \\
\hline $14 \mathrm{INT}$ & 2 (Run 14) & Hanford & PCC & $\begin{array}{l}\text { Realistic-chemical } \\
\text { adsorption in } \\
\text { cement }\end{array}$ & $\begin{array}{l}\text { Same as Run } 14 \\
\text { (standard values for } \\
\text { Hanford in this } \\
\text { study) }\end{array}$ & 450 & 18 & 470 \\
\hline $13 \mathrm{INT}$ & 5 (Run 13) & SRS & PCC & $\begin{array}{l}\text { Realistic-chemical } \\
\text { adsorption in } \\
\text { cement }\end{array}$ & $\begin{array}{l}\text { Same as Run } 13 \\
\text { (standard values for } \\
\text { SRS in this study) }\end{array}$ & 4.52 & 26 & 10,000 \\
\hline 14INELKD & 2 (Run 14) & Hanford & PCC & $\begin{array}{l}\text { Conservative-no } \\
\text { chemical } \\
\text { adsorption in } \\
\text { cement }\end{array}$ & Use INEL $\mathbf{K}_{\mathbf{d}} \mathbf{s}$ & 450 & 3.7 & $53,000,000$ \\
\hline $\begin{array}{l}\text { 14INT/ } \\
\text { INELKD }\end{array}$ & 2 (Run 14) & Hanford & PCC & $\begin{array}{l}\text { Realistic-chemical } \\
\text { adsorption in } \\
\text { cement }\end{array}$ & Use INEL $K_{d} s$ & 450 & 0.14 & $53,000,000$ \\
\hline 16INELKD & 3 (Run 16) & Hanford & IEB4 & $\begin{array}{l}\text { Realistic- } \\
\text { dissolution }\end{array}$ & Use INEL $K_{d} s$ & 450 & 0.29 & $53,000,000$ \\
\hline 13INELKD & 5 (Run 13) & SRS & PCC & $\begin{array}{l}\text { Conservative-no } \\
\text { chemical } \\
\text { adsorption in } \\
\text { cement }\end{array}$ & Use INEL $K_{d} \mathbf{s}$ & 4.52 & 53 & 120,000 \\
\hline $\begin{array}{l}\text { 13INT/ } \\
\text { INELKD }\end{array}$ & 5 (Run 13) & SRS & PCC & $\begin{array}{l}\text { Realistic-chemical } \\
\text { adsorption in } \\
\text { cement }\end{array}$ & Use INEL $\mathrm{K}_{\mathrm{d}} \mathrm{s}$ & 4.52 & 2.6 & 130,000 \\
\hline 15INELKD & 6 (Run 15) & SRS & IEB4 & $\begin{array}{l}\text { Realistic- } \\
\text { dissolution }\end{array}$ & Use INEL $\mathrm{K}_{\mathbf{d}} \mathrm{s}$ & 4.52 & 5.6 & 120,000 \\
\hline
\end{tabular}


10.2.18.4 Overall Conclusions. The doses calculated herein for the disposal of INEL AlLW at Sites D and E are very large on an absolute scale. They are also very large compared with the corresponding doses calculated for (a) disposal of INEL ALLW at Sites A, B, and C and for (b) disposal of the waste from Sites $D$ and $E$ at their respective sites. The dose differences appear to be caused primarily by the following differences in assumptions and parameter values:

- Different inventories for the waste from Sites D and E compared with the INEL ALLW

- Taking no credit for chemical adsorption of radionuclides in the cement FWF for most of the runs herein.

- Use of smaller values of $K_{d}$ at Sites $D$ and $E$

- The shorter vadose zone travel time of the groundwater at Site D.

As stated in Section 10.2.18.1, additional factors may have affected the calculations, particularly for Sites D and E. The above conclusions are based only on the factors investigated herein.

\subsubsection{Compliance with Performance Objective to Protect Groundwater Resources}

Section 1.4.1 listed the performance objectives to be complied with by the waste disposal system. One performance objective involves the protection of groundwater resources, consistent with federal, state, and local requirements. As shown in Tables 1-1 and 10-1, that performance objective was interpreted in this study to entail compliance with four EPA limits in 40 CFR 141 for radionuclides in community drinking water systems.

The study predicted the extent of compliance with the four EPA limits. Runs covering the original assumptions for the various FWFs at the various disposal sites were examined.

Tables 10-26a through 10-26d present the results, which can be summarized, respectively, as follows:

- $\quad$ Beta- and photon-emitters dose limit: For Sites A, B, and C, all FWFs pass. For Sites $D$ and $E$, all FWFs except IEB4 fail.

- Alpha-emitters concentration limit: For Sites A, B, and C, all FWFs pass. For Sites D and $\mathrm{E}$, all FWFs fail.

- Ra-226 and Ra-228 concentration limit: All FWFs pass at all sites.

- U concentration limit: For Sites A, B, and C, all FWFs pass. For Sites D and E, all FWFs except IEB4 fail.

The composite conclusion regarding compliance with these four limits is that all FWFs pass at Sites A, B, and C, but all FWFs fail at Sites D and E. 
Table 10-26. Compliance with performance objective to protect groundwater resources.

(a) Compliance with the objective to limit the dose from beta-emitters and photon-emitters in groundwater to 4 mrem/yr.

Runs with doses below the regulation

\begin{tabular}{cclc} 
Run & Site & FWF & $\begin{array}{c}\text { Dose from beta- } \\
\text { emitters and photon- } \\
\text { emitters } \\
\text { (mrem/yr) }\end{array}$ \\
\hline 1 & A & PCC & $4.3 \mathrm{E}-10$ \\
2 & C & PCC & $3.2 \mathrm{E}-13$ \\
3 & A & IEB4 & $1.5 \mathrm{E}-12$ \\
4 & C & IEB4 & $4.8 \mathrm{E}-14$ \\
6 & B & IEB & $2.0 \mathrm{E}-12$ \\
8 & B & IEB4 & $3.3 \mathrm{E}-13$ \\
9 & B & PCC & $1.1 \mathrm{E}-10$ \\
10 & B & FUETAP & $7.2 \mathrm{E}-11$ \\
11 & B & BSG & $1.1 \mathrm{E}-11$ \\
12 & B & ASG & $2.0 \mathrm{E}-12$ \\
15 & D & IEB4 & $3.0 \mathrm{E}+00$ \\
16 & E & IEB4 & $1.3 \mathrm{E}+00$ \\
17 & A & ASG & $9.0 \mathrm{E}-12$ \\
18 & A & IEB & $9.2 \mathrm{E}-12$ \\
$10 T R$ & A & UTR & $4.9 \mathrm{E}-10$ \\
9 ITR & B & UTR & $1.3 \mathrm{E}-10$
\end{tabular}

Runs with doses that exceed the regulation

\begin{tabular}{rccc} 
& & & $\begin{array}{c}\text { Dose from } \\
\text { beta-emitters and } \\
\text { photon-emitters } \\
\text { (mrem/yr) }\end{array}$ \\
\hline 13 & Site & FWF & $7.6 \mathrm{E}+01$ \\
14 & D & PCC & $1.9 \mathrm{E}+02$ \\
19 & E & PCC & $7.7 \mathrm{E}+00$ \\
13 UTR & E & IEB & $5.4 \mathrm{E}+01$ \\
14 UTR & D & UTR & $3.9 \mathrm{E}+02$
\end{tabular}


Table 10-26. (continued).

(b) Compliance with the objective to limit the total concentration of alpha-emitters to $15 \mathrm{PCi} / \mathrm{L}$ (including Ra-226, excluding $\mathrm{U}$ and $\mathrm{Rn}$ ).

Runs with concentrations below the regulation

\begin{tabular}{rllc} 
Run & Site & FWF & $\begin{array}{c}\text { Total concentration of } \\
\text { alpha-emitters }(\mathrm{pCi} / \mathrm{L})\end{array}$ \\
\hline 1 & A & PCC & $6.5 \mathrm{E}-01$ \\
2 & C & PCC & $4.8 \mathrm{E}-04$ \\
3 & A & IEB4 & $2.3 \mathrm{E}-03$ \\
4 & C & IEB4 & $7.2 \mathrm{E}-05$ \\
6 & B & IEB & $3.1 \mathrm{E}-03$ \\
8 & B & IEB4 & $5.0 \mathrm{E}-04$ \\
9 & B & PCC & $1.6 \mathrm{E}-01$ \\
10 & B & FUETAP & $1.1 \mathrm{E}-01$ \\
11 & B & BSG & $1.7 \mathrm{E}-02$ \\
12 & B & ASG & $3.1 \mathrm{E}-03$ \\
17 & A & ASG & $1.4 \mathrm{E}-02$ \\
18 & A & IEB & $1.4 \mathrm{E}-02$ \\
1 UTR & A & UTR & $7.4 \mathrm{E}-01$ \\
$9 U T R$ & B & UTR & $1.9 \mathrm{E}-01$
\end{tabular}

Runs with concentrations that exceed the regulation

\begin{tabular}{rclc} 
Run & Site & FWF & $\begin{array}{c}\text { Total concentration of } \\
\text { alpha-emitters }(\mathrm{pCi} / \mathrm{L})\end{array}$ \\
\hline 13 & D & PCC & $1.1 \mathrm{E}+03$ \\
14 & E & PCC & $2.7 \mathrm{E}+03$ \\
15 & D & IEB4 & $4.3 \mathrm{E}+01$ \\
16 & E & IEB4 & $1.9 \mathrm{E}+01$ \\
19 & E & IEB & $1.1 \mathrm{E}+02$ \\
13 UTR & D & UTR & $7.7 \mathrm{E}+02$ \\
$14 U T R$ & E & UTR & $5.6 \mathrm{E}+03$
\end{tabular}


Table 10-26. (continued).

(c) Compliance with the objective to limit the concentration of Ra-226 and Ra-228 combined to $5 \mathrm{pCi} / \mathrm{L}$

All runs predict concentrations below the regulation

\begin{tabular}{|c|c|c|c|}
\hline Run & Site & FWF & $\begin{array}{c}\text { Combined } \\
\text { concentration of } \\
\text { Ra-226 and Ra-228 } \\
(\mathrm{pCi} / \mathrm{L})\end{array}$ \\
\hline 1 & A & PCC & 4.6E-06 \\
\hline 2 & $\mathrm{C}$ & PCC & $<1 \mathrm{E}-10$ \\
\hline 3 & $\mathrm{~A}$ & IEB4 & $3.6 \mathrm{E}-08$ \\
\hline 4 & $\mathrm{C}$ & IEB4 & $<1 \mathrm{E}-10$ \\
\hline 6 & B & IEB & $3.8 \mathrm{E}-07$ \\
\hline 8 & B & IEB4 & 6.3E-08 \\
\hline 9 & B & PCC & $9.3 \mathrm{E}-06$ \\
\hline 20 & B & FUETAP & $7.0 \mathrm{E}-06$ \\
\hline 11 & B & BSG & 2.0E-07 \\
\hline 12 & B & ASG & 3.8E-06 \\
\hline 13 & $\mathrm{D}$ & $\mathrm{PCC}$ & $2.0 \mathrm{E}+00$ \\
\hline 14 & $\mathrm{E}$ & $\mathrm{PCC}$ & 6.8E-02 \\
\hline 15 & $\mathrm{D}$ & IEB4 & $4.2 \mathrm{E}-02$ \\
\hline 16 & $\mathrm{E}$ & IEB4 & $9.6 \mathrm{E}-05$ \\
\hline 17 & A & ASG & 2.1E-07 \\
\hline 18 & A & IEB & $2.2 \mathrm{E}-07$ \\
\hline 19 & $\mathrm{E}$ & IEB & $1.9 \mathrm{E}-03$ \\
\hline 1UTR & $A$ & UTR & 1.9E-05 \\
\hline 9UTR & $\mathrm{B}$ & UTR & 3.3E-05 \\
\hline 13UTR & $\mathrm{D}$ & UTR & $1.5 E+00$ \\
\hline 14UTR & $\mathrm{E}$ & UTR & 4.8E-02 \\
\hline
\end{tabular}


Table 10-26. (continued).

(d) Compliance with the objective to limit the concentration of uranium to $30 \mathrm{pCi} / \mathrm{L}$ Runs with concentrations below the regulation

\begin{tabular}{rllc} 
Run & Site & FWF & $\begin{array}{c}\text { Concentration of } \\
\text { uranium (pCi/L) }\end{array}$ \\
\hline 1 & A & PCC & $2.2 \mathrm{E}-01$ \\
2 & C & PCC & $1.7 \mathrm{E}-04$ \\
3 & A & IEB4 & $7.7 \mathrm{E}-04$ \\
4 & C & IEB4 & $2.5 \mathrm{E}-05$ \\
6 & B & IEB & $1.1 \mathrm{E}-03$ \\
8 & B & IEB4 & $1.7 \mathrm{E}-04$ \\
9 & B & PCC & $5.6 \mathrm{E}-02$ \\
10 & B & FUETAP & $3.7 \mathrm{E}-02$ \\
11 & B & BSG & $5.8 \mathrm{E}-03$ \\
12 & B & ASG & $1.1 \mathrm{E}-03$ \\
15 & D & IEB4 & $2.7 \mathrm{E}+01$ \\
16 & E & IEB4 & $1.6 \mathrm{E}+01$ \\
17 & A & ASG & $4.7 \mathrm{E}-03$ \\
18 & A & IEB & $4.8 \mathrm{E}-03$ \\
$1 \mathrm{ITR}$ & A & UTR & $2.5 \mathrm{E}-01$ \\
$9 \mathrm{UTR}$ & B & UTR & $6.6 \mathrm{E}-02$
\end{tabular}

Runs with concentrations that exceed the regulation

\begin{tabular}{rccc} 
Run & Site & FWF & $\begin{array}{c}\text { Concentration of } \\
\text { uranium }(\mathrm{pCi} / \mathrm{L})\end{array}$ \\
\hline 13 & D & PCC & $9.2 \mathrm{E}+02$ \\
14 & E & PCC & $3.1 \mathrm{E}+04$ \\
19 & E & IEB & $9.0 \mathrm{E}+01$ \\
$13 \mathrm{UTR}$ & $\mathrm{D}$ & UTR & $6.4 \mathrm{E}+02$ \\
$14 \mathrm{UTR}$ & E & UTR & $6.5 \mathrm{E}+04$ \\
\hline
\end{tabular}




\subsection{Results for Undisturbed-Waste Scenario: Atmospheric Pathway}

The methodology described in Section 8 was used to estimate the radon flux and the concentration at and dose to a receptor on the downwind edge of the disposal unit. A PCC FWF was assumed.

Two cases were considered: (a) the dose to a receptor just before $500 \mathrm{yr}$, and (b) the dose to a receptor at $167,000 \mathrm{yr}$. The first case included the presence of $16 \mathrm{ft}$ of soil $(11 \mathrm{ft}$ of abovegrade cover and $5 \mathrm{ft}$ of belowgrade backfill). The second case corresponded to the peak $\mathrm{Rn}-222$ production rate from the inventory and was modeled with only the $5 \mathrm{ft}$ of belowgrade backfill remaining.

The results are shown in Table 10-27. For the first case, the radon flux from the ground surface above the disposed waste was calculated to be $1.9 \mathrm{E}-05 \mathrm{pCi} / \mathrm{m}^{2}-\mathrm{sec}$. For the second case, the flux was estimated to be $0.84 \mathrm{pCi} / \mathrm{m}^{2}-\mathrm{sec}$.

No specific regulations exist for the control of radon emissions (radon flux) from a LLW disposal facility. The EPA has identified an emission limit of $20 \mathrm{pCi} / \mathrm{m}^{2}-\mathrm{sec}$ as a basis for remedial actions involving mill tailings for the Uranium Mill Tailings Remedial Action (UMTRA) project (DOE 1989). The two values calculated here are well below that limit.

Given a value of $1.9 \mathrm{E}-05 \mathrm{pCi} / \mathrm{m}^{2}-\mathrm{sec}$ for the 500-yr radon flux, the Eulerian box model yielded a value of $2.4 \mathrm{E}-07 \mathrm{pCi} / \mathrm{L}$ for the concentration of radon at the receptor, located outdoors. The resulting dose is $4.8 \mathrm{E}-05 \mathrm{mrem} / \mathrm{yr}$.

For the 167,000 -yr case, the Eulerian box model yielded a value of $1.1 \mathrm{E}-02 \mathrm{pCi} / \mathrm{L}$ for the concentration of radon at the receptor. The resulting dose is $2.1 \mathrm{mrem} / \mathrm{yr}$.

There are also no specific standards for the outdoor concentration of radon and the corresponding dose. The average concentration of radon in homes in the United States, resulting from naturally occurring radon, is about $1 \mathrm{pCi} / \mathrm{L}$. The resulting equivalent whole body dose is $200 \mathrm{mrem} / \mathrm{yr}$ (Lodge 1991). The EPA has established an action level for indoor radon of $4 \mathrm{pCi} / \mathrm{L}$, above which remedial action is recommended (EPA 1987). The EPA estimates the average outdoor radon level to be $0.4 \mathrm{pCi} / \mathrm{L}$ (Lodge 1991). Thus, the outdoor concentrations calculated here are less than one-tenth of the natural background concentrations of radon in outdoor air.

Table 10-27. Dose from radon release in undisturbed-waste scenario.

\begin{tabular}{lccccc}
\hline & $\begin{array}{c}\text { Concentration } \\
\text { of radon in } \\
\text { FWF } \\
(\mathrm{pCi} / \mathrm{L})\end{array}$ & $\begin{array}{c}\text { Total soil } \\
\text { cover } \\
(\mathrm{ft})\end{array}$ & $\begin{array}{c}\text { Flux from } \\
\text { ground } \\
\text { surface } \\
\left(\mathrm{pCi} / \mathrm{m}^{2}-\mathrm{sec}\right)\end{array}$ & $\begin{array}{c}\text { Concentration } \\
\text { at receptor } \\
(\mathrm{pCi} / \mathrm{L})\end{array}$ & $\begin{array}{c}\text { Dose rate } \\
\text { to receptor } \\
\text { (mrem/yr) }\end{array}$ \\
\hline Just less than 500 & 6.0 & 16 & $1.9 \mathrm{E}-05$ & $2.4 \mathrm{E}-07$ & $4.8 \mathrm{E}-05$ \\
167,000 & 12,000 & 5 & 0.84 & $1.1 \mathrm{E}-02$ & 2.1 \\
\hline
\end{tabular}


This evaluation was conservative for the following reasons:

- Leaching of the radon parents and migration to greater depths below the surface was neglected

- The most conservative values were used as inputs for the Eulerian box model, which resulted in the highest concentration of radon at the receptor.

\subsection{Results for Intrusion Scenarios}

Section 10.4 provides the results of the cases evaluated for the four intrusion scenarios. Section 10.4.1 provides an introduction and the rationale for the cases evaluated. Sections 10.4.2 through 10.4.11 discuss the effects on the results for the first three intrusion scenarios when several parameters and assumptions were changed. Section 10.4 .12 provides the results for the fourth scenario, intruder-radon.

\subsubsection{Introduction and Rationale}

10.4.1.1 General. To within the precision of this study, the results for the intrusion scenarios are independent of the location of the waste disposal site.

The intrusion results depend strongly upon the burial depth (belowgrade) and on the presence or absence of the abovegrade multi-layer, engineered cover. The latter depends, in turn, on the time at which the intrusion is assumed to occur. The reader is referred to Section 5.2 concerning the layout of the waste disposal pit and the abovegrade cover and to Section 4.3 concerning time periods.

For the intrusion scenarios, two different burial depths were evaluated at two different intrusion times, although not all of the combinations of these factors were evaluated in detail. One burial depth (termed for simplicity the "16-ft cover") initially has $5 \mathrm{ft}$ of backfill soil belowgrade plus an $11-\mathrm{ft}$ abovegrade engineered cover, totaling $16 \mathrm{ft}$ of material overlying the waste. The other burial depth (termed the "20-ft cover") initially has $9 \mathrm{ft}$ of backfill soil belowgrade plus the same 11-ft abovegrade engineered cover, totaling $20 \mathrm{ft}$ of material overlying the waste.

As discussed in Section 5.2, the cover was assumed to remain intact for all times up to but not including $500 \mathrm{yr}$ postclosure. At $500 \mathrm{yr}$ and later, no credit was taken for the abovegrade cover. The belowgrade backfill was assumed to be present at all times.

The total thickness of the soil cover affects the doses from a drilling event by varying the volume of clean soil within the drill hole that is mixed with the waste. The cover thickness also affects doses from an excavation event by varying the volume of waste (if any) that is excavated. By virtue of its effects on the drilling and excavation events, the total thickness of the cover affects the doses in the intruder-agricultural scenario. Finally, the thickness affects the doses in the intruder-radon scenario. 
Two different intrusion times were evaluated: $100 \mathrm{yr}$ and $500 \mathrm{yr}$ following closure of the disposal facility. The rationale for evaluating the performance at these times is discussed briefly in Section 4.3 and in detail in Sections 10.4.1.2 through 10.4.1.5.

Confirming runs were performed for numerous other times up through $100,000 \mathrm{yr}$ and are reported in Section 10.4.10. The results confirm that the arguments made below concerning the times of peak dose are valid.

The intruder-radon scenario was a special case. The doses were evaluated at the time of maximum radon concentration. These times were $4,600 \mathrm{yr}$ for PCC and 20,000 yr for IEB4.

The burial depths and scenario times evaluated for the intrusion scenarios are shown in Table 10-28. The detailed rationale for the selected combinations follows in Sections 10.4.1.2 through 10.4.1.5.

10.4.1.2 Rationale for Cases Evaluated in Intruder-Drilling Scenario. The intruderdrilling scenario was evaluated at $100 \mathrm{yr}$ with both the 16- and $20 \mathrm{ft}$ soil covers (see the " $\mathrm{D}$ " entries in Table 10-28).

Evaluations of the intruder-drilling scenario at $500 \mathrm{yr}$ were not performed because these would be expected to yield lower doses, based on the following rationale. Two factors affect the intruder-drilling dose at $500 \mathrm{yr}$ compared with the dose at $100 \mathrm{yr}$. The first factor is radioactive decay of the radionuclides that contribute most of the dose in this scenario. This first factor tends to decrease the dose as the time increases. Typically, $90 \%$ to $93 \%$ of the dose in the intruderdrilling scenarios at $100 \mathrm{yr}$ was found to be contributed by Cs-137. The remaining $7 \%$ to $10 \%$ was contributed by Am-241. At $500 \mathrm{yr}$, the Cs-137 inventory (half-life of about $30 \mathrm{yr}$ ) would have decayed by a factor on the order of 10,000 , so its contribution to dose would be negligible compared with that of the Am-241. The Am-241 is relatively long-lived (half-life of about $433 \mathrm{yr}$ ) and its first decay product, Np-237, is extremely long-lived. Thus, at $500 \mathrm{yr}$, the Am-241 would constitute most of the dose. Based on considering this factor only, the dose at $500 \mathrm{yr}$ would be expected to be less than one-tenth of the dose at $100 \mathrm{yr}$.

The second factor involves the loss of the abovegrade cover just before $500 \mathrm{yr}$. This loss results in decreasing the dilution factor for the drill cuttings by about one third, tending to increase proportionately the dose at $500 \mathrm{yr}$ compared to the dose at $100 \mathrm{yr}$.

The first factor predominates over the smaller second factor, so the intruder-drilling dose at $500 \mathrm{yr}$ is expected to be less than the dose at $100 \mathrm{yr}$.

10.4.1.3 Rationale for Cases Evaluated in Intruder-Excavation Scenario. The intruder-excavation scenario was evaluated only at $500 \mathrm{yr}$ and only with the $16-\mathrm{ft}$ cover (the " $\mathrm{E}^{n}$ entry in Table 10-28) for the following reasons. 
Table 10-28. Burial depths and intrusion times evaluated for the intrusion scenarios.

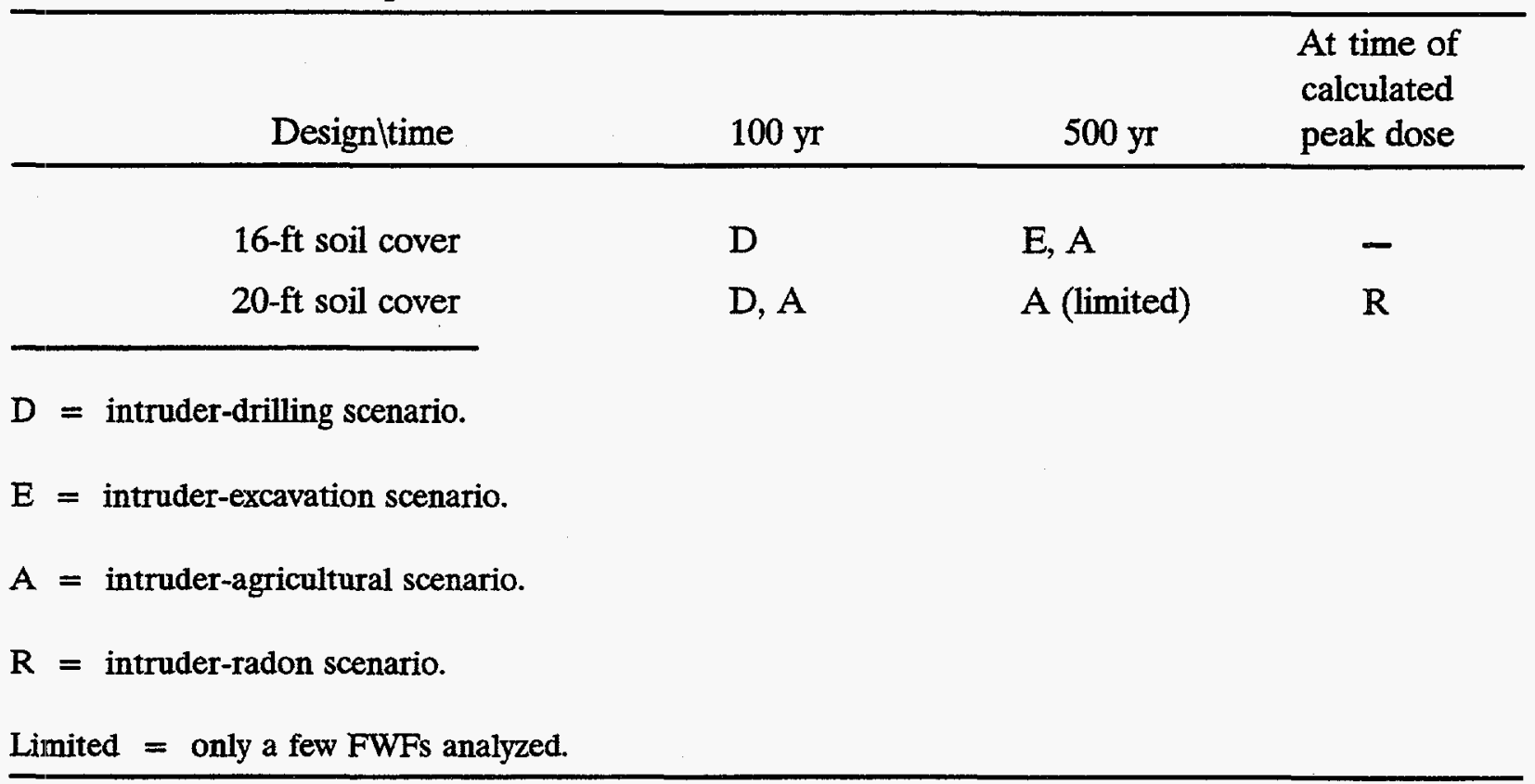

In the case of the $16-\mathrm{ft}$ cover, that cover will be present at facility closure and will be maintained during the 100-yr period of institutional control. Excavation of an 8-ft basement in this cover material at 100 yr will not disturb the waste and will therefore result in a minuscule acute dose. The 11-ft abovegrade cover overlying the $5 \mathrm{ft}$ of belowgrade soil has a 500 -yr design life, however. At the end of the design life, the abovegrade cover is assumed to disappear, leaving only the $5 \mathrm{ft}$ of belowgrade backfill soil. Excavation of a basement $8 \mathrm{ft}$ deep in this remaining material at $500 \mathrm{yr}$ was assumed to disturb a layer of waste $3 \mathrm{ft}$ thick (8-ft basement - 5$\mathrm{ft}$ backfill $=3 \mathrm{ft}$ of waste penetrated).

In the case of the $20-\mathrm{ft}$ cover, an intruder-excavation scenario at $500 \mathrm{yr}$ would result in a smaller acute dose, for the following reason. At $500 \mathrm{yr}$, no credit is taken for the abovegrade cover, so the $9 \mathrm{ft}$ of belowgrade backfill remains. The 8 - $\mathrm{ft}$ basement would not penetrate completely through the backfill, so no waste would be disturbed. Therefore, this case was not evaluated for the excavation scenario.

10.4.1.4 Rationale for Cases Evaluated in Intruder-Agricultural Scenario. The rationale for the cases evaluated in the intruder-agricultural scenario basically follows from the preceding rationale for the drilling and excavation scenarios. Those scenarios are the initiating events for the agricultural scenario.

- For the 16 -ft cover, the intruder-agricultural scenario dose at $500 \mathrm{yr}$ was evaluated because it is expected to be larger than the dose at $100 \mathrm{yr}$. At $100 \mathrm{yr}$, the abovegrade cover is intact and only the drilling event penetrates the waste (excavation does not). At $500 \mathrm{yr}$, no credit is taken for the abovegrade cover, so excavation penetrates the waste and a relatively large volume is exhumed. (Excavation exhumes about 200 times the volume of waste exhumed by drilling.) This much larger exhumation leads to an increased dose at $500 \mathrm{yr}$, compared with that at $100 \mathrm{yr}$. (The key dose contributors are 
the relatively long-lived Am-241 and Pu-239, so radioactive decay does not play a major role between 100 and $500 \mathrm{yr}$.) Thus, for the 16-ft cover, intrusion at $500 \mathrm{yr}$ was expected to result in the largest dose for the agricultural scenario and was evaluated.

- For the 20 -ft cover, excavation does not penetrate the waste at either $100 \mathrm{yr}$ or $500 \mathrm{yr}$. Drilling was assumed to be the initiating event. As discussed in Section 10.4.1.2, the radioactive decay in the key radionuclides between $100 \mathrm{yr}$ and $500 \mathrm{yr}$ is expected to reduce the dose at $500 \mathrm{yr}$ more than the loss of the abovegrade cover increases the dose (due to the reduced dilution of the cuttings). Therefore, the dose at an intrusion time of $100 \mathrm{yr}$ is expected to result in the largest agricultural dose for the 20 -ft cover and was the dose evaluated.

The "A" entries in Table 10-28 show that the intruder-agricultural scenario was evaluated for the $16-\mathrm{ft}$ cover at $500 \mathrm{yr}$ and for the $20-\mathrm{ft}$ cover at $100 \mathrm{yr}$. In addition, a limited number of cases were evaluated for the $20-\mathrm{ft}$ cover at $500 \mathrm{yr}$.

10.4.1.5 Summary of Cases Evaluated. Table 10-29 shows the different intrusion combinations (or cases) and which combinations were evaluated (an " $\mathrm{X}$ " means that the combination was evaluated). Not all combinations were evaluated, but those that were illustrate the effects of the various factors on the results.

\subsubsection{Effects of FWF on Results}

Table 10-30 lists the results by FWF for the cases evaluated for the three intrusion scenarios (drilling, excavation, and agricultural).

For both cases of the intruder-drilling scenario and for the intruder-excavation scenario, all FWFs satisfy the performance objective of 500 mrem acute exposure.

For the agricultural scenario with the $16-\mathrm{ft}$ cover, all FWFs fail at $500 \mathrm{yr}$. With the $20-\mathrm{ft}$ cover, all FWFs comply at 100 yr except for IEB and IEB4, which are slightly above the performance objective of $100 \mathrm{mrem} / \mathrm{yr}$ chronic exposure. ASG is only slightly under the limit.

The effects of FWF density and waste loading on the intrusion doses are evident from Table 10-30. The more concentrated, advanced FWFs exhibit the higher doses. This is because the product of the waste loading, FWF density, and volume of excavated waste equals the mass of waste brought to the surface.

Another key parameter affecting dose that was not varied here is related to facility design. These evaluations assumed a subsurface waste stack of eight 55-gal drums (22.7 ft) and total cover thicknesses of 16 or $20 \mathrm{ft}$. Reducing the stack height would proportionally reduce the predicted intruder doses from drilling events. 
Table 10-29. Cases evaluated for the intrusion scenarios.

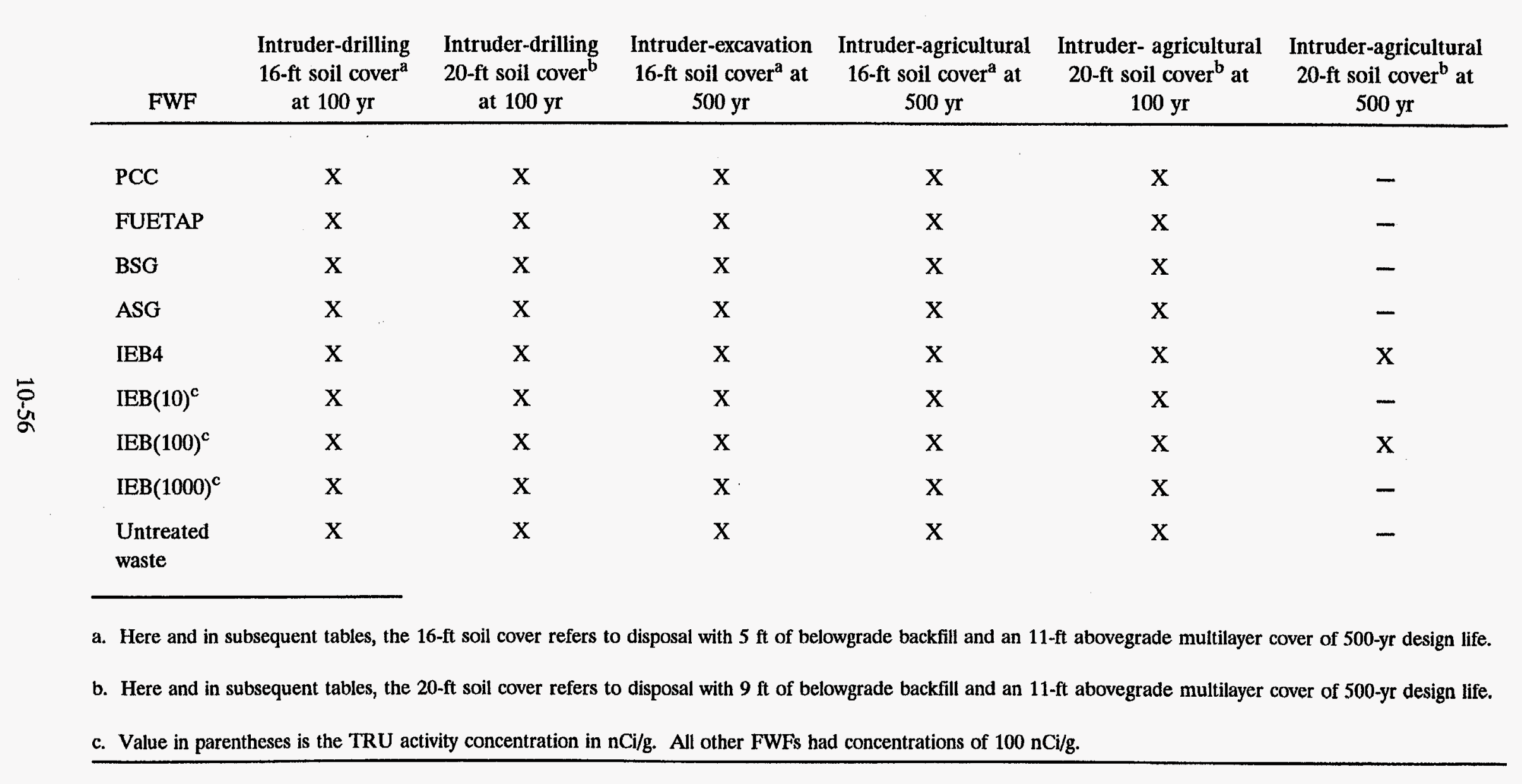


Table 10-30. Effects of FWF on performance in intrusion scenarios.

\begin{tabular}{|c|c|c|c|c|c|c|c|}
\hline FWF & $\begin{array}{c}\text { FWF } \\
\text { density } \\
\left(\mathrm{g} / \mathrm{cm}^{3}\right)\end{array}$ & $\begin{array}{c}\text { FWF waste } \\
\text { loading } \\
\text { (wt. \%) }\end{array}$ & $\begin{array}{c}\text { Intruder- } \\
\text { drilling 16-ft } \\
\text { soil cover at } \\
100 \mathrm{yr} \\
\text { (mrem) }\end{array}$ & $\begin{array}{l}\text { Intruder- } \\
\text { drilling } 20-\mathrm{ft} \\
\text { soil cover at } \\
100 \mathrm{yr} \\
\text { (mrem) }\end{array}$ & $\begin{array}{c}\text { Intruder- } \\
\text { excavation 16-ft } \\
\text { soil cover at } \\
500 \mathrm{yr} \\
(\mathrm{mrem})\end{array}$ & $\begin{array}{l}\text { Intruder- } \\
\text { agricultural } 20-\mathrm{ft} \\
\text { soil cover at } \\
100 \mathrm{yr} \\
(\mathrm{mrem} / \mathrm{yr})\end{array}$ & $\begin{array}{c}\text { Intruder- } \\
\text { agricultural } \\
\text { 16-ft cover at } \\
500 \mathrm{yr} \\
(\mathrm{mrem} / \mathrm{yr})\end{array}$ \\
\hline PCC & 1.95 & 40 & 23 & 18 & 96 & 46 & 1,400 \\
\hline FUETAP & 1.95 & 40 & 23 & 18 & 96 & 46 & 1,400 \\
\hline BSG & 2.65 & 30 & 23 & 18 & 96 & 46 & 1,400 \\
\hline ASG & 2.65 & 60 & 46 & 36 & 190 & 92 & 2,700 \\
\hline IEB & 3.00 & 60 & 49 & 42 & 220 & 110 & 3,100 \\
\hline IEB4 & 3.50 & 60 & 59 & 49 & 260 & 120 & 3,600 \\
\hline
\end{tabular}




\subsubsection{Effects of TRU Radionuclide Activity Concentration on Results}

Table 10-31 lists the results of the various cases evaluated for the intrusion scenarios wherein the concentration of TRU radionuclide activity in the IEB FWF was varied.

The results are nonlinear, due to combined contributions from actinides and nonactinides. For example, the intruder-drilling runs for a 20 -ft soil cover at $100 \mathrm{yr}$ yield acute doses of 39,42 , and $72 \mathrm{mrem}$ for the three concentrations of 10,100, and 1,000 $\mathrm{nCi} / \mathrm{g}$ TRU activity, respectively. The dominant radionuclide contributing to the dose is Cs-137, which gives a constant dose of about 39 mrem to the lungs from external exposure in all three cases. Added to this dose is a contribution from Am-241 (and to a lesser extent $\mathrm{Pu}-239$ ), which provides additional doses of $0.31,3.1$, and 31 mrem, respectively, to bone surfaces from inhalation. These results are a consequence of the inventory assumptions, which held the nonactinide inventory constant while varying the actinide inventory over 2 orders of magnitude.

For the intruder excavation scenario (16-ft soil cover, $500 \mathrm{yr}$ ), the doses are controlled by the inhalation route, with $\mathrm{Pu}-239, \mathrm{Pu}-240$, and $\mathrm{Am}-241$ as the dominant contributors. As expected, the dose increases linearly with TRU concentration, by virtue of the inventory assumptions.

For the intruder-agricultural scenario, only one case of which (20-ft soil cover, $100 \mathrm{yr})$ is shown in Table 10-31, the chronic doses were estimated at 47,110, and $690 \mathrm{mrem} / \mathrm{yr}$ for the three TRU radionuclide concentrations. Cs-137 provides a dose of $24 \mathrm{mrem} / \mathrm{yr}$ for all three runs. Sr-90 provides doses of about $15 \mathrm{mrem} / \mathrm{yr}$ in each of the three cases. In addition, Am-241 contributes 4.3, 43, and $430 \mathrm{mrem} / \mathrm{yr}$ for the three cases. Pu-239 and Pu-238 also contribute 110 and $76 \mathrm{mrem} / \mathrm{yr}$, respectively, for the TRU concentration of $1,000 \mathrm{nCi} / \mathrm{g}$ and proportionately smaller doses for the smaller concentrations. Other radionuclides contribute lesser portions of the dose. Table 10-3 includes the results for the other case evaluated (16-ft soil cover, $500 \mathrm{yr}$ ).

Table 10-31. Effects of TRU activity concentration in IEB on performance in intrusion scenarios.

\begin{tabular}{|c|c|c|c|c|}
\hline $\begin{array}{c}\text { TRU } \\
\text { activity } \\
\text { (nCi/g) }\end{array}$ & $\begin{array}{c}\text { Intruder-drilling } \\
\text { 16-ft soil cover } \\
100 \mathrm{yr} \\
(\mathrm{mrem})\end{array}$ & $\begin{array}{c}\text { Intruder-drilling } \\
20 \text {-ft soil cover } \\
100 \mathrm{yr} \\
\text { (mrem) }\end{array}$ & $\begin{array}{c}\text { Intruder- } \\
\text { excavation } \\
\text { 16-ft soil cover } \\
500 \mathrm{yr} \\
\text { (mrem) }\end{array}$ & $\begin{array}{c}\text { Intruder- } \\
\text { agricultural } \\
20 \text {-ft soil cover } \\
100 \mathrm{yr} \\
\text { (mrem/yr) }\end{array}$ \\
\hline 10 & 45 & 39 & 22 & 47 \\
\hline 100 & 49 & 42 & 220 & 110 \\
\hline 1,000 & 84 & 72 & 2200 & 690 \\
\hline
\end{tabular}




\subsubsection{Effects of Disposal Depth on Results}

Table 10-32 indicates the cases evaluated to investigate the effects of burial depth. As stated previously, two burial depths were evaluated. (Burial at a depth requiring $5 \mathrm{ft}$ of belowgrade backfill results in a 16-ft cover, including the 11-ft abovegrade cover. Burial at a depth requiring $9 \mathrm{ft}$ of belowgrade backfill results in a 20 -ft cover.)

A comparison of the intruder-drilling scenario results at $100 \mathrm{yr}$, assuming $16 \mathrm{ft}$ versus $20 \mathrm{ft}$ of total cover, shows an increase in acute dose of approximately $25 \%$ with the 16 - $\mathrm{ft}$ cover. This increased dose occurs because a smaller volume of clean material in the drill hole is mixed with the exhumed waste. In all cases, the predicted doses from the intruder-drilling scenarios are less than the performance objective limit of 500 mrem.

The effect of burial depth on the intruder-agricultural dose at $500 \mathrm{yr}$ was investigated briefly. The doses from the shallower burial (16-ft cover) exceeded the $100 \mathrm{mrem} / \mathrm{yr}$ limit for all FWFs. However, with the deeper burial (20-ft cover), the doses were dramatically reduced. The dose for IEB4 (the FWF with the largest dose) was reduced from 3,600 mrem/yr to $25 \mathrm{mrem} / \mathrm{yr}$. For IEB, the dose was reduced from 3,100 to 22 mrem/yr. Thus, all FWFs meet the $100 \mathrm{mrem} / \mathrm{yr}$ performance objective at $500 \mathrm{yr}$ if the deeper burial is implemented.

The explanation for the large reduction in agricultural dose when the burial depth is increased is as follows. With only $5 \mathrm{ft}$ of belowgrade backfill after the abovegrade cover is gone, an 8-ft excavation exhumes a relatively large amount of waste. With $9 \mathrm{ft}$ of belowgrade backfill, the excavation does not penetrate the waste. Only the drilling penetrates the waste, and the volume exhumed is much smaller.

\subsubsection{Effects of Untreated Waste on Results}

The results for the intrusion scenarios for untreated waste are shown in Table 10-33 (see Section 2.4.5 for the radionuclide inventory). The results for a PCC FWF are listed for comparison.

In these evaluations, the untreated waste was distributed uniformly throughout the disposal facility. Thus, each scenario exhumed equal fractions of the different types of untreated waste.

The doses in all of the intrusion scenarios are lower for the untreated waste than for PCC. The relative percentage of each radionuclide's contribution to dose is the same for both waste forms. The total radionuclide inventory is held constant. Since different treated and untreated waste forms have different densities and mass loadings of the waste, the radionuclide concentration also differs for each waste form. Intruder scenario doses are proportional to these radionuclide concentrations.

For the $100-\mathrm{yr}$ intruder-drilling scenario with a $16-\mathrm{ft}$ cover, the dose from untreated waste is 12 mrem, roughly half of the dose from PCC ( $23 \mathrm{mrem}$ ). The dominant dose contribution $(92 \%)$ is from Cs-137 and is a lung dose from external radiation. 
Table 10-32. Effects of burial depth on performance in intrusion scenarios.

\begin{tabular}{|c|c|c|c|c|}
\hline FWF & $\begin{array}{c}\text { Intruder-drilling } \\
\text { 16-ft soil cover at } \\
100 \mathrm{yr} \\
(\mathrm{mrem})\end{array}$ & $\begin{array}{c}\text { Intruder-drilling } \\
20 \text {-ft soil cover at } \\
100 \mathrm{yr} \\
(\mathrm{mrem})\end{array}$ & $\begin{array}{c}\text { Intruder- } \\
\text { agricultural } \\
\text { 16-ft soil cover } \\
\text { at } 500 \mathrm{yr} \\
\text { (mrem/yr) }\end{array}$ & $\begin{array}{c}\text { Intruder- } \\
\text { agricultural } \\
20 \text {-ft soil cover } \\
\text { at } 500 \mathrm{yr} \\
(\mathrm{mrem} / \mathrm{yr})\end{array}$ \\
\hline PCC & 23 & 18 & 1,400 & - \\
\hline FUETAP & 23 & 18 & 1,400 & - \\
\hline BSG & 23 & 18 & 1,400 & - \\
\hline ASG & 46 & 36 & 2,700 & - \\
\hline IEB & 49 & 42 & 3,100 & 22 \\
\hline IEB4 & 59 & 49 & 3,600 & 25 \\
\hline
\end{tabular}


Table 10-33. Intrusion scenario results for untreated waste.

\begin{tabular}{|c|c|c|c|c|}
\hline Scenario & $\begin{array}{c}\text { Dose from } \\
\text { untreated waste }\end{array}$ & $\begin{array}{l}\text { Dose from } \\
\text { PCC }\end{array}$ & $\begin{array}{c}\text { Radionuclides } \\
\text { contributing } \\
25 \% \text { of dose }\end{array}$ & $\begin{array}{c}\text { Radionuclide } \\
\text { contribution } \\
\text { (\%) }\end{array}$ \\
\hline $\begin{array}{l}\text { Intruder-drilling } \\
16 \text {-ft cover, } 100 \mathrm{yr}\end{array}$ & 12 mrem & 23 mrem & $\begin{array}{l}\mathrm{Cs}-137 \\
\mathrm{Am}-241\end{array}$ & $\begin{array}{c}92 \\
8\end{array}$ \\
\hline $\begin{array}{l}\text { Intruder-excavation } \\
16 \text {-ft cover, } 500 \text { yr }\end{array}$ & $58 \mathrm{mrem}$ & 96 mrem & $\begin{array}{l}\mathrm{Pu}-239 \\
\mathrm{Am}-241 \\
\mathrm{Pu}-240\end{array}$ & $\begin{array}{l}50 \\
36 \\
12\end{array}$ \\
\hline $\begin{array}{l}\text { Intruder-agricultural } \\
16 \text {-ft cover, } 500 \text { yr }\end{array}$ & $820 \mathrm{mrem} / \mathrm{yr}$ & $1,400 \mathrm{mrem} / \mathrm{yr}$ & $\begin{array}{l}\text { Am-241 } \\
\text { Pu-239 } \\
\text { Pu-240 }\end{array}$ & $\begin{array}{c}60 \\
32 \\
7\end{array}$ \\
\hline $\begin{array}{l}\text { Intruder-drilling } \\
20 \text {-ft cover, } 100 \mathrm{yr}\end{array}$ & 9.6 mrem & $18 \mathrm{mrem}$ & $\begin{array}{l}\text { Cs-137 } \\
\text { Am-241 }\end{array}$ & $\begin{array}{c}90 \\
9\end{array}$ \\
\hline $\begin{array}{l}\text { Intruder-agricultural } \\
20 \text {-ft cover, } 100 \mathrm{yr}\end{array}$ & 24 mrem & 46 mrem & $\begin{array}{l}\text { Am-241 } \\
\text { Sr-90 } \\
\text { Cs-137 } \\
\text { Pu-239 } \\
\text { Pu-238 }\end{array}$ & $\begin{array}{c}46 \\
14 \\
13 \\
13 \\
9\end{array}$ \\
\hline
\end{tabular}

The total volume of untreated waste is $24,390 \mathrm{~m}^{3}$. The total volume of the same inventory treated and encapsulated as a PCC waste form is $15,300 \mathrm{~m}^{3}$. From consideration of these volumes, one would expect the doses from untreated waste to be $63 \%$ rather than $48 \%$ of those from PCC. Revisions in the refined inventory of Cs-137 account for the difference (see Appendices A and B). The PCC analyses assumed a Cs-137 inventory of 1,125 $\mathrm{Ci}$. This assumption was refined to a value of $936.3 \mathrm{Ci}$ before performing the analysis of untreated waste. When the difference in total waste volume and the revision in Cs-137 inventory are taken into account, the results for untreated waste and PCC are consistent. Predicted doses for both waste forms are below the performance objective of 500 mrem for acute exposures.

For the 500-yr intruder-excavation scenario with a 16 -ft cover, the dose from untreated waste is $58 \mathrm{mrem}$, which is less than the dose from PCC (96 mrem). The dominant dose contribution (50\%) is from $\mathrm{Pu}-239$ delivered to lungs via inhalation. Other principal contributors are Am-241 and Pu-240, which provide doses through the same exposure route. Predicted doses for both waste forms are below the performance objective of 500 mrem for acute exposures.

For the 500-yr intruder-agricultural scenario with a $16-\mathrm{ft}$ cover, the dose from untreated waste is $820 \mathrm{mrem} / \mathrm{yr}$, which is less than the dose from PCC (1,400 mrem/yr). The dominant dose contribution (60\%) is from Am-241 delivered to bone surfaces from inhalation. Other contributors are $\mathrm{Pu}-239$ and $\mathrm{Pu}-240$, which provide doses through the same exposure route.

The other cases listed in Table 10-33 illustrate the same relationship between the doses from untreated waste and those from the PCC FWF. 


\subsubsection{Effects of Refined Inventory on Results}

Section 2.4.3 describes the refined radionuclide inventory, in which the $\mathrm{CH}$ waste and $\mathrm{RH}$ waste were modeled separately instead of being commingled as was the case in all the intrusion runs discussed thus far. Evaluations were performed using this refined inventory for the drilling, excavation, and agricultural intrusion scenarios.

These evaluations were identical to those performed previously, except that separate evaluations were performed for the $\mathrm{CH}$ and $\mathrm{RH}$ fractions of the FWF. Doses were calculated assuming an IEB or a PCC FWF.

Table 10-34 provides separate results for the $\mathrm{CH}, \mathrm{RH}$, and combined inventory fractions.

The doses from the intruder-drilling scenario with $16-\mathrm{ft}$ soil cover at $100 \mathrm{yr}$ are dominated by Cs-137, except in the $\mathrm{CH}$ cases. The majority (94\%) of the Cs-137 in the refined inventory is in the RH fraction, so direct interception of $\mathrm{RH}$ waste in a drilling scenario yields extremely high doses. Although probabilities are not considered in these analyses, it should be noted that the total volume of $\mathrm{RH}$ waste is only $31 \mathrm{~m}^{3}$, or $0.13 \%$ of the volume of the total combined inventory. The probability of a direct interception of $\mathrm{RH}$ waste by an intruder is extremely small.

The excavation scenario for the RH waste becomes rather incredible, since excavation of $100 \mathrm{~m}^{3}$ of waste and backfill is assumed, while the total $\mathrm{RH}$ waste volume is only $31 \mathrm{~m}^{3}$.

The doses from the intruder-excavation and intruder-agricultural scenarios at $500 \mathrm{yr}$ are dominated by Pu-239 and Am-241. At 500 yr, the Cs-137 (half-life of about $30 \mathrm{yr}$ ) has mostly decayed. The doses for these two 500-yr scenarios are similar for the $\mathrm{CH}, \mathrm{RH}$, and combined inventory fractions because the concentrations of $\mathrm{Pu}-239$ and $\mathrm{Am}-241$ are identical in the different waste fractions.

The intrusion doses from IEB are approximately 2.3 times higher than the doses from PCC because of the higher density and higher waste loading in IEB.

An additional run was made with IEB for the intruder-agricultural scenario at $100 \mathrm{yr}$ with the 20 - $\mathrm{ft}$ cover. The calculated dose for the combined $\mathrm{RH}$ and $\mathrm{CH}$ waste, using the refined inventory, was $97 \mathrm{mrem} / \mathrm{yr}$, just within the performance objective. This result is important because, with the simplified inventory and for IEB at $100 \mathrm{yr}$ with the 20 -ft soil cover, the dose was $110 \mathrm{mrem} / \mathrm{yr}$, just above the performance objective. Thus, the refined inventory moves the dose from just above the limit to just below the limit. A similar run for IEB4 at $100 \mathrm{yr}$ with the 20-ft cover gave a dose of $110 \mathrm{mrem} / \mathrm{yr}$.

Because the intruder doses from PCC are lower than those from IEB, the dose from PCC for the intruder-agricultural scenario at $100 \mathrm{yr}$ with the 20 -ft cover would be less than $97 \mathrm{mrem} / \mathrm{yr}$. The result would satisfy the performance objective. 
Table 10-34. Intruder scenario doses for refined inventory.

\begin{tabular}{|c|c|c|c|c|c|}
\hline FWF & $\begin{array}{l}\text { Waste } \\
\text { fraction }\end{array}$ & $\begin{array}{c}\text { Intruder-drilling } \\
\text { 16-ft soil cover } \\
100 \mathrm{yr} \\
\text { (mrem) }\end{array}$ & $\begin{array}{c}\text { Intruder- } \\
\text { excavation } \\
\text { 16-ft soil cover } \\
500 \mathrm{yr} \\
\text { (mrem) }\end{array}$ & $\begin{array}{c}\text { Intruder- } \\
\text { agricultural } \\
\text { 16-ft soil cover } \\
500 \mathrm{yr} \\
\text { (mrem/yr) }\end{array}$ & $\begin{array}{c}\text { Intruder- } \\
\text { agricultural } \\
20 \text {-ft soil cover } \\
100 \mathrm{yr} \\
\text { (mrem/yr) }\end{array}$ \\
\hline PCC & $\mathrm{CH}$ & 2.7 & 96 & 1,300 & $\mathrm{NE}^{\mathrm{a}}$ \\
\hline PCC & RH & 13,000 & 92 & 1,300 & NE \\
\hline $\mathrm{PCC}$ & Combined $^{\mathbf{b}}$ & 19 & 96 & 1,300 & $\mathrm{NE}$ \\
\hline IEB & $\mathrm{CH}$ & 6.2 & $220^{c}$ & 3,000 & NE \\
\hline IEB & RH & 29,000 & $210^{c}$ & 3,100 & NE \\
\hline IEB & Combined $^{\mathrm{b}}$ & 43 & $220^{c}$ & 3,000 & $97^{\mathrm{d}}$ \\
\hline \multicolumn{6}{|c|}{ a. $\mathrm{NE}=$ Not evaluated. } \\
\hline \multicolumn{6}{|c|}{$\begin{array}{l}\text { b. The } \mathrm{CH} \text { waste and } \mathrm{RH} \text { waste totals for the various nonactinides differed slightly from those in the } \\
\text { combined simplified inventory. Therefore, in some instances, the dose for the combined waste with the } \\
\text { refined inventory differs slightly from that for the simplified inventory. }\end{array}$} \\
\hline \multicolumn{6}{|c|}{$\begin{array}{l}\text { c. The small percentage differences in this column are due to rounding of radionuclide inventory values } \\
\text { in the calculations. }\end{array}$} \\
\hline
\end{tabular}

\subsubsection{Effects of Inventory with Additional Refinements on Results}

Section 2.4.4 describes the inventory with additional refinements. The inventory contains revised activities of the nonactinides, plus new entries for H-3, C-14, Tc-99, and I-129. All of the $\mathrm{H}-3$ is taken to be in the $\mathrm{CH}$ fraction. The C-14, Tc-99, and I-129 are assumed conservatively to have the same activities in the $\mathrm{CH}, \mathrm{RH}$, and combined inventories. Compared with the refined inventory discussed in Section 2.4.3, the inventory with additional refinements contains less nonactinide activity in the $\mathrm{RH}$ portion, slightly more in the $\mathrm{CH}$ portion, and less overall.

Doses were calculated for the intruder-drilling, intruder-excavation, and intruder-agricultural scenarios. The FWFs evaluated were PCC, IEB, and IEB4. The results are presented in Table 10-35. Separate results are shown for the $\mathrm{CH}, \mathrm{RH}$, and combined inventory fractions.

For comparison purposes, Table 10-35 also presents the results of the corresponding runs with the simplified inventory and the refined inventory. 
Table 10-35. Intruder scenario doses for inventory with additional refinements.

\begin{tabular}{|c|c|c|c|c|c|c|c|c|}
\hline FWF & Inventory ${ }^{a}$ & Waste fraction & $\begin{array}{c}\text { Intruder-drilling } \\
\text { scenario } \\
\text { 16-ft soil cover } \\
100 \mathrm{yr} \\
\text { (mrem) } \\
\end{array}$ & $\begin{array}{c}\text { Intruder-drilling } \\
\text { scenario } \\
20 \text {-ft soil cover } \\
100 \mathrm{yr} \\
\text { (mrem) } \\
\end{array}$ & $\begin{array}{c}\text { Intruder-excavation } \\
\text { scenario } \\
\text { 16-ft soil cover } \\
500 \mathrm{yr} \\
\text { (mrem) } \\
\end{array}$ & $\begin{array}{c}\text { Intruder-agricultural } \\
\text { scenario } \\
\text { 16-ft soil cover } \\
500 \mathrm{yr} \\
(\mathrm{mrem} / \mathrm{yr})^{b} \\
\end{array}$ & $\begin{array}{c}\text { Intruder-agricultural } \\
\text { scenanio } \\
20-\mathrm{ft} \text { soil cover } \\
100 \mathrm{yr} \\
\text { (mrem/yr) }^{b} \\
\end{array}$ & $\begin{array}{c}\text { Intruder-agricultural } \\
\text { scenario } \\
20-\mathrm{ft} \text { soil cover } \\
500 \mathrm{yr} \\
(\mathrm{mrem} / \mathrm{yr})^{b}\end{array}$ \\
\hline $\mathrm{PCC}$ & IAR & $\mathrm{CH}$ & 3 & 2.5 & 96 & 1,300 & 29 & 9.9 \\
\hline PCC & IAR & RH & 2,000 & 1,700 & 96 & 1,400 & 1,700 & 10 \\
\hline $\mathrm{PCC}$ & IAR & Combined & 5.4 & 3.6 & 96 & 1,300 & 31 & 9.9 \\
\hline PCC & $\mathrm{s}$ & $\mathrm{NA}^{c}$ & 23 & 18 & 96 & 1,400 & 46 & $\mathrm{NE}^{d}$ \\
\hline PCC & $\mathbf{R}$ & $\mathrm{CH}$ & 2.7 & NE & 96 & 1,300 & NE & NE \\
\hline PCC & $\mathbf{R}$ & RH & 13,000 & NE & 92 & 1,300 & NE & NE \\
\hline PCC & $\mathbf{R}$ & Combined & 19 & NE & 96 & 1,300 & $\mathrm{NE}$ & $\mathrm{NE}$ \\
\hline IEB & IAR & $\mathrm{CH}$ & 6.7 & 5.7 & 220 & 3,000 & 67 & 22 \\
\hline IEB & IAR & RH & 4,500 & 3,600 & 220 & 3,100 & $\mathbf{3 , 8 0 0}$ & 23 \\
\hline IEB & IAR & Combined & 15 & 12 & 220 & 3,100 & 75 & 22 \\
\hline IEB & $\mathbf{s}$ & NA & 49 & 42 & 220 & 3,100 & 110 & 22 \\
\hline IEB & $\mathbf{R}$ & $\mathrm{CH}$ & 6.2 & $\mathrm{NE}$ & 220 & 3,000 & $\mathrm{NE}$ & NE \\
\hline IEB & $\mathbf{R}$ & RH & 29,000 & $\mathrm{NE}$ & 210 & 3,100 & $\mathrm{NE}$ & $\mathrm{NE}$ \\
\hline IEB & $\mathbf{R}$ & Combined & 43 & $\mathrm{NE}$ & 220 & 3,000 & 97 & 22 \\
\hline IEB4 & IAR & $\mathrm{CH}$ & 8.4 & 6.6 & 260 & 3,600 & 78 & 26 \\
\hline IEB4 & IAR & RH & 5,500 & 4,500 & 260 & 3,600 & 4,400 & 26 \\
\hline IEB4 & IAR & Combined & 21 & 17 & 260 & 3,600 & 83 & 26 \\
\hline IEB4 & $s$ & NA & 59 & 49 & 260 & 3,600 & 120 & 25 \\
\hline IEB4 & $\mathbf{R}$ & Combined & $\mathrm{NE}$ & $\mathrm{NE}$ & $\mathrm{NE}$ & NE & 110 & 25 . \\
\hline $\begin{array}{l}\text { a. } \mathrm{S}= \\
\text { b. The } \\
\text { c. NA } \\
\text { d. NE }\end{array}$ & $\begin{array}{l}\text { lified; } R= \\
\text { I percentag } \\
\text { ot applicabl } \\
\text { ot evaluatec }\end{array}$ & $\begin{array}{l}\text { fined; } \text { IAR }=I t \\
\text { ifferences reflect }\end{array}$ & $\begin{array}{l}\text { ntory with additio } \\
\text { in this column are }\end{array}$ & $\begin{array}{l}\text { inements. } \\
\text { o rounding of radi }\end{array}$ & ide inventory value & the calculations. & & \\
\hline
\end{tabular}


The key conclusions and comparisons from the results in Table 10-35 are as follows:

- With either the refined inventory or the inventory with additional refinements, the RH portion of the waste does not comply with the performance objectives. However, the intrusion scenarios involving the $\mathrm{RH}$ waste again become rather incredible because of the small volume of this fraction of the ALLW.

- With the 20 -ft soil cover and the inventory with additional refinements, the $\mathrm{CH}$ portion and combined portions for all FWFs now comply with all intrusion performance objectives.

- For the inventory with additional refinements, the behavior in terms of dominant radionuclide contributors to dose is generally the same as that for the refined inventory, as discussed in Section 10.4.6.

- $\quad \mathrm{H}-3$ is not an important contributor to the intruder dose because of its relatively short (12.3-yr) half-life. C-14, Tc-99, and I-129 are not important contributors because of their extremely low activities in the INEL ALLW.

- The intruder doses from IEB are approximately 2.3 times higher than those from PCC, and the doses from IEB4 are still higher. This behavior is a consequence of the higher densities and higher waste loadings in these FWFs.

\subsubsection{Effects of Exposure Duration on Results for Intruder-Drilling Scenario}

The evaluations of the intruder-drilling scenario were based on the assumption that $1 \mathrm{hr}$ would be required to drill through the waste and $40 \mathrm{hr}$ to complete installation of a residential well. The drillers would be exposed to $1 \mathrm{hr}$ of inhalation during the penetration of the waste layer and $\mathbf{4 0} \mathrm{hr}$ of direct radiation from the drill cuttings. These assumptions are less conservative than the corresponding assumptions in Maheras et al. 1994. That assessment assumed $160 \mathrm{hr}$ of inhalation and $160 \mathrm{hr}$ of external exposure, based on construction of a large irrigation well. See Table H-1 in Appendix $\mathbf{H}$.

A run was performed with an IEB FWF to investigate the effects of more conservative values for the exposure times. The inhalation time was increased from $1 \mathrm{hr}$ to $8 \mathrm{hr}$. The exposure time for external radiation was left at $40 \mathrm{hr}$ to reflect a residential well.

The results of the run are compared with those from an IEB run with the shorter exposure time in Table 10-36. Both evaluations assume intrusion at $100 \mathrm{yr}$ postclosure, an IEB FWF, and a 20-ft soil cover.

The dose increased by only 2 mrem/yr, or about $5 \%$, when the inhalation exposure was lengthened. Most of the dose results from direct exposure from Cs-137, rather than inhalation of radionuclides (Am-241 being the primary contributor to inhalation dose). Therefore, the assumed duration of the inhalation has only a minor effect on the total dose from all exposure routes in the intruder-drilling scenario. 
Table 10-36. Effects of exposure duration in the intruder-drilling scenario. (Both runs are based on an IEB FWF, 20-ft soil cover, and a time of $100 \mathrm{yr}$ postclosure).

\begin{tabular}{lccc}
\hline Exposure duration & $\begin{array}{c}\text { Total dose } \\
\text { (mrem) }\end{array}$ & $\begin{array}{c}\text { Radionuclides contributing } \\
\text { z5\% of dose }\end{array}$ & $\begin{array}{c}\text { Radionuclide contribution } \\
(\%)\end{array}$ \\
\hline $1 \mathrm{hr}$ inhalation & 42 & Cs-137 & 93 \\
$40 \mathrm{hr}$ external & & Am-241 & 7 \\
& & & \\
$8 \mathrm{hr}$ inhalation & 44 & Cs-137 & 89 \\
$40 \mathrm{hr}$ external & & Am-241 & 9 \\
\hline
\end{tabular}

\subsubsection{Effects of Post-Disruption Particle Size Distribution of Final Waste Form on Results}

10.4.9.1 Introduction. The assumptions and parameter values used for the intrusion scenarios are discussed in Section 9. The size distribution of the particles produced by drilling through or excavation into the disposed waste is an important parameter in modeling those scenarios. Either drilling or excavation could disrupt a portion of the waste, grind it or shear it into smaller fragments, and bring a portion of the broken-up material to the surface.

The presence of the broken-up waste material at the surface is assumed to lead to acute exposure of the drilling and excavation crews by direct radiation and by inhalation. In addition, in the intruder-agricultural scenario, the exhumed material from drilling or excavation is spread over an area where crops are grown. This action results in chronic exposure by inhalation and direct exposure. It also results in chronic exposure by the pathway involving leaching of radionuclides from the FWF into the root zone, uptake of the radionuclides by crops, and human ingestion of the crops or of livestock that feed upon the crops.

10.4.9.2 General Effects of Particle Size. The following paragraphs discuss the general effects of FWF particle size in these three intrusion exposure routes-direct radiation, inhalation, and ingestion of foodstuffs.

For direct radiation exposure, the particle size distribution could have some effect on the dose by virtue of the differing degrees of self-shielding provided by the waste fragments. Large fragments would offer more self-shielding than would fine particulate. However, this effect is expected to be relatively minor, particularly since the fractured FWF would be mixed with surface soil to a depth of $15 \mathrm{~cm}$. This effect was not addressed further.

For inhalation, the particle size distribution could have a major effect on the dose. If the mechanical disruption due to the intrusion produces a large fraction of minute particulate, then a relatively high concentration of airborne, respirable particulate could be present in the air inhaled by the intruders. On the other hand, if the broken-up FWF exists primarily in larger chunks, very little might become airborne and respirable. A simplified evaluation of the effect was undertaken and is described in Section 10.4.9.4. 
For the ingestion exposure route, the particle size distribution could have a major effect on root uptake. If the FWF exists in large fragments, root uptake of the radionuclides in the FWF would be much less than if the FWF exists totally as fine particulate. The difference in uptake would be expected to be related to the comparative total surface area of the FWF. This effect would be quite difficult to evaluate by modeling, however. A simplified evaluation of the effect was undertaken and is described in Section 10.4.9.3.

10.4.9.3 Simplified Evaluation of Effects of Particle Size on Ingestion Dose. In the current methodology for intrusion evaluation, the radionuclide concentration in crops is calculated using a "soil-to-plant transfer factor" for each element and each food group. These factors relate the concentrations of elements in soil to the concentrations in agricultural products grown in that soil. For each element, there is a set of factors for leafy vegetables/fresh animal forage, root vegetables, grains/stored animal feed, and fruit. The factors are unitless parameters that can be thought of as ( $\mathrm{pCi} / \mathrm{g}$ in the plant/pCi/g in the soil). These factors have values that range from $10^{-4}$ to $10^{-1}$ for radionuclides of concern.

In the current methodology, the values of the factors are based on the radionuclides being freely available in the soil, e.g., as a powder mixed with the soil or even as a dissolved species. These conditions correspond to the maximum potential for uptake by plant roots.

More realistically, the FWF fragments in the intrusion scenario would range in size from large chunks to a relatively small fraction of fine particulate. Postulating plant root uptake from such an assumed distribution of particle sizes would be very complex. Therefore, to investigate the effect of this parameter on the calculated ingestion dose, the simple approach was used of reducing the soil-to-plant uptake factors by a factor of 10 for each FWF. A total of five runs were made with these reduced values. The five runs represent all six FWFs because the characteristics of PCC and FUETAP were assumed to be identical.

\subsubsection{Simplified Evaluation of Effects of Particle Size on Inhalation Dose.}

10.4.9.4.1 Current Calculational Method-Exposure via inhalation of suspended particulates in the intrusion scenarios is calculated using the GENII code. The dose to an individual from inhalation of contaminated air is calculated from the product of the concentration (activity) of each radionuclide in the air, ventilation (breathing) rate, exposure duration, and dose conversion factor. The doses from the various radionuclides are summed. The air activity can be calculated using either a time-dependent function or a constant mass loading factor. The latter choice is used, with a mass loading of $10^{-4} \mathrm{~g} / \mathrm{m}^{3}$ for drilling and $5 \times 10^{-3} \mathrm{~g} / \mathrm{m}^{3}$ for excavation.

The internal dosimetry model of GENII calculates the dose from inhalation of contamination air using a multicompartmental model. A value of 1.0 micron for the activity median aerodynamic diameter (AMAD) is assumed for all airborne material.

10.4.9.4.2 The Physical Nature of the Actions in the Intrusion Scenarios-In the intruder-drilling scenario, the buried containers of FWF are assumed to be stacked vertically as shown in Figure 5-1. The diameter of each container is approximately $60 \mathrm{~cm}$. A 30-cm-diameter drill bit is assumed to penetrate a column of containers vertically. Depending on the drilling process, the FWF is subjected to a shearing and grinding process, and possibly a pulverizing 
process, that generates fragments ranging in size from particulate to large chunks. The total volume of FWF fractured and removed is $\left(\pi[0.3 \mathrm{~m}]^{2} / 4\right)(6.9 \mathrm{~m})=0.49 \mathrm{~m}^{3}$. Bringing the fragments to the surface and spreading them out is not expected to alter the size distribution appreciably, but it would dilute the fragments with uncontaminated soil.

In the intruder-excavation scenario, the buried containers of FWF are subjected to a shearing process. The exact nature of the process depends on the excavation method. The extent of FWF breakup into fine particulate is expected to be less than that associated with drilling. For this reason and because penetration of the FWF during excavation can be excluded by disposal at the greater of the two depths studied, the current evaluation concentrated on the drilling action.

10.4.9.4.3 Available Data-No particulate data were identified for conditions that closely match those in the intruder-drilling scenario. Developing rigorous assumptions that cover all of the complexities associated with drilling through a FWF would require an extensive testing program, which is beyond the scope of the present study.

Data from impact testing are available from which a very rough, order-of-magnitude estimate can be developed of the respirable fraction that might result from drilling through a FWF. There is no certainty that the impact data bear a meaningful relationship to the data from drilling through a FWF. Nevertheless, the impact data can be used to illustrate the effects of particle size and airborne concentrations on the calculated doses.

Data are available for the particle size distribution from several FWFs subjected to impact (not shearing and grinding) actions. Smith and Ross (1975) subjected large (5-ft long) and smaller (4-in. long) steel canisters containing a glass FWF to impact at speeds of up to $117 \mathrm{ft} / \mathrm{sec}$. The resulting fraction of the FWF that was of respirable size (by convention, $<10$ microns) was on the order of $10^{-4}(0.02 \%)$ at the highest speed. The energy density at the highest speed was $1.4 \mathrm{~J} / \mathrm{cm}^{3}$.

Jardine et al. (1982) subjected small (approximately 40-g) specimens of several FWFs to impact from a large falling weight. The energy density for most of the tests was $10 \mathrm{~J} / \mathrm{cm}^{3}$. The respirable fractions were $0.43 \%$ for FUETAP cement, $0.14 \%$ to $0.18 \%$ for glasses, and $0.06 \%$ to $0.16 \%$ for ceramics. Limited tests at energy densities as low as $1.2 \mathrm{~J} / \mathrm{cm}^{3}$ suggested that the respirable size fraction increases approximately linearly with increasing density of impact energy. At an energy density of $1.2 \mathrm{~J} / \mathrm{cm}^{3}$, the respirable fraction from glass specimens was $0.016 \%$. Allowing for the uncertainties of about a factor of 2 upward or downward in the comparison, this value of $0.016 \%$ is close to the slightly higher value of $0.02 \%$ obtained by Smith and Ross (1975) at a slightly higher energy density.

Farnsworth et al. (1994) reported respirable fractions of $0.32 \%$ for PCC and 0 for IEB and IEB4, using the method of Jardine et al. (1982) with 40-g specimens. The energy density was the same $10 \mathrm{~J} / \mathrm{cm}^{3}$.

A compendium of data on accident-generated particulate materials (Sutter 1982) contains data from repeated impact of weights on small samples of concrete and glass. The energy density 
of the cumulative impacts was approximately 25 to $35 \mathrm{~J} / \mathrm{cm}^{3}$. No glass particles $<8$ microns were produced; for concrete, $0.1 \%$ to $0.2 \%$ of the mass was in particulate $<8$ microns.

\subsection{Simplified Method for Evaluating Effects of Particle Size-Accurate} modeling of the distribution of particle sizes inhaled in the intrusion scenarios would be extremely complex. The first step would involve estimating the size distribution of particulate matter produced during drilling, which depends on the FWF, the drill bit material and design, and the drilling procedure. The next step would involve modeling the process by which the particulates become airborne, which depends on the drilling procedure, the provisions for managing the drilling effluents and residues, the wind conditions, the nature of the ground surface, and many other parameters. The deposition of suspended particles, at a rate that depends on particle size, would also be modeled. The locations and work habits of the drilling personnel relative to the drilling apparatus would also be modeled. The result of this complex set of analyses would be a time-dependent, particle size-dependent air loading at the locations where the airborne particles could be inhaled by the drilling personnel. Unfortunately, only very simplified, approximate models of the above conditions are feasible. One such model is as follows.

Based on the impact tests, an order-of-magnitude estimate for the respirable fractions ( $<10$ microns) of FWF that might result from drilling through full-size containers of waste is $0.5 \%$ for the cements, $0.2 \%$ for the glasses, and $0.1 \%$ for ceramics. Based on the particle size distribution data of Smith and Ross (1975), the $<5$ micron fraction would be about a factor of 10 smaller than the $<10$ micron fraction, and the $<1$ micron fraction would be approximately a factor of 100 still smaller.

As shown in Smith and Ross (1975), most particles larger than 7 microns AMAD tend to be trapped in the nasopharyngeal region rather than in the lung (where the resulting dose would be maximized). As the particle size decreases, the portion of the particles trapped in the tracheobronchial and pulmonary (deep lung) compartments increases. For a simple scoping calculation, a fraction of $0.01 \%$ of the FWF, corresponding to the $<5$ micron fraction of ceramics, was used for all FWFs.

Sutter (1982) provides a comprehensive compilation of data on the resuspension factor, $\mathrm{k}$, for particulate matter under a wide range of conditions:

$\mathrm{k} \mathrm{m}^{-1}=$ airborne concentration $/ \mathrm{m}^{3} /$ surface contamination $/ \mathrm{m}^{2}$.

For outdoor, cleared sandy soil at wind speeds $<5 \mathrm{~m} / \mathrm{sec}$, $\mathrm{k}$ typically ranges from $10^{-10}$ to $10^{-6} \mathrm{~m}^{-1}$.

In GENII, the surface areas over which the excavated material is spread are assumed to be $5.5 \mathrm{~m}^{2}$ for the drilling scenario and $1,680 \mathrm{~m}^{2}$ for the excavation scenario.

The airborne concentration of $<5$ micron particles could be estimated in each scenario. For drilling, assuming an exhumed volume of $0.49 \mathrm{~m}^{3}$, the mass of the $<5$ micron fraction for IEB would be:

$0.49 \mathrm{~m}^{3} \times 10^{6} \mathrm{~cm}^{3} / \mathrm{m}^{3} \times 3 \mathrm{~g} / \mathrm{cm}^{3}$ (IEB density) $\times 10^{-4}$ (fraction respirable and trapped in lung) $=$ $147 \mathrm{~g}$ 
If this mass were spread over $5.5 \mathrm{~m}^{2}$ (the area for the drilling scenario), the concentration would be $26.7 \mathrm{~g} / \mathrm{m}^{2}$. Based on a resuspension factor of $10^{-7} \mathrm{~m}^{-1}$, the mass loading factor would be $2.7 \times$ $10^{-6} \mathrm{~g} / \mathrm{m}^{3}$, compared with $10^{-4} \mathrm{~g} / \mathrm{m}^{3}$ used previously. Similar calculations were done for the other FWFs by changing the density. For IEB4, BSG, ASG, and FUETAP (or PCC), the mass loading factors are $3.2 \times 10^{-6}, 2.4 \times 10^{-6}, 2.4 \times 10^{-6}$, and $1.8 \times 10^{-6} \mathrm{~g} / \mathrm{m}^{3}$, respectively. These mass loading factors were applied to both the drilling and agricultural scenarios.

10.4.9.5 Results of Runs to Evaluate Effects of Particle Size Distribution. Based on the revised values for the mass loading (from Section 10.4.9.4.4) and the plant-soil uptake factors (one tenth of the previous values), new runs were performed for IEB, ASG, IEB4, BSG, and FUETAP (or PCCF) FWFs, for the intruder-drilling and intruder-agricultural scenarios.

Table 10-37 presents the original and revised doses for the intruder-drilling scenario at $100 \mathrm{yr}$ with a 20 -ft cover. Table $10-38$ presents the original and revised doses for the intruderagricultural scenario for the same time and cover thickness. The doses for the revised runs were calculated using the revised mass-loading and plant-soil uptake factors.

Table 10-37. Effects of particle size distribution on results for intruder-drilling scenario for 20-ft cover, $100 \mathrm{yr}$.

\begin{tabular}{|c|c|c|c|c|c|c|c|c|}
\hline $\begin{array}{l}\text { Final } \\
\text { waste } \\
\text { form }\end{array}$ & Run & $\begin{array}{c}\text { Mass } \\
\text { loading } \\
\text { factor } \\
\left(\mathrm{g} / \mathrm{m}^{3}\right)\end{array}$ & $\begin{array}{c}\text { Inhalation } \\
\text { dose } \\
\text { (mrem) }\end{array}$ & $\begin{array}{l}\text { Ingestion } \\
\text { dose } \\
\text { (mrem) }\end{array}$ & $\begin{array}{c}\text { External } \\
\text { dose } \\
\text { (mrem) }\end{array}$ & $\begin{array}{c}\text { Total } \\
\text { dose } \\
(\text { mrem })^{a}\end{array}$ & $\begin{array}{l}\text { Radionuclides } \\
\text { contributing } \\
25 \% \text { of dose }\end{array}$ & $\begin{array}{c}\text { Radionuclide } \\
\text { contribution }^{\text {a }} \\
(\%)\end{array}$ \\
\hline \multirow[t]{2}{*}{$\overline{D E B}$} & Original & $10^{-4}$ & 0.25 & 0 & 42 & 42 & $\begin{array}{c}\text { Cs-137 } \\
\text { Am-241 }\end{array}$ & $\begin{array}{r}92 \\
7\end{array}$ \\
\hline & Revised & $2.7 \times 10^{-6}$ & $6.9 \times 10^{-3}$ & 0 & 42 & 42 & $\begin{array}{c}\text { Cs-137 } \\
\text { Am-241 }\end{array}$ & $\begin{array}{r}92 \\
7\end{array}$ \\
\hline \multirow[t]{2}{*}{$A S G$} & Original & $10^{-4}$ & 0.23 & 0 & 36 & 36 & $\begin{array}{c}\mathrm{Cs}-137 \\
\text { Am-241 }\end{array}$ & $\begin{array}{r}92 \\
7\end{array}$ \\
\hline & Revised & $2.4 \times 10^{-6}$ & $5.4 \times 10^{-3}$ & 0 & 36 & 36 & $\begin{array}{c}\mathrm{Cs}-137 \\
\mathrm{Am}-241\end{array}$ & $\begin{array}{r}92 \\
7\end{array}$ \\
\hline \multirow[t]{2}{*}{ IEB4 } & Original & $10^{-4}$ & 0.3 & 0 & 49 & 49 & $\begin{array}{c}\text { Cs-137 } \\
\text { Am-241 }\end{array}$ & $\begin{array}{r}90 \\
9\end{array}$ \\
\hline & Revised & $3.2 \times 10^{-6}$ & $9.7 \times 10^{-3}$ & 0 & 49 & 49 & $\begin{array}{c}\text { Cs-137 } \\
\text { Am-241 }\end{array}$ & $\begin{array}{r}90 \\
9\end{array}$ \\
\hline \multirow[t]{2}{*}{ BSG } & Original & $10^{-4}$ & 0.11 & 0 & 18 & 18 & $\begin{array}{c}\text { Cs-137 } \\
\text { Am-241 }\end{array}$ & $\begin{array}{r}93 \\
7\end{array}$ \\
\hline & Revised & $2.4 \times 10^{-6}$ & $2.7 \times 10^{-3}$ & 0 & 18 & 18 & $\begin{array}{c}\text { Cs-137 } \\
\text { Am-241 }\end{array}$ & $\begin{array}{r}93 \\
7\end{array}$ \\
\hline \multirow[t]{2}{*}{$\begin{array}{l}\text { FUETAP } \\
\text { or PCC }\end{array}$} & Original & $10^{-4}$ & 0.11 & 0 & 18 & 18 & $\begin{array}{c}\mathrm{Cs}-137 \\
\text { Am-241 }\end{array}$ & $\begin{array}{r}93 \\
7\end{array}$ \\
\hline & Revised & $1.8 \times 10^{-6}$ & $2.0 \times 10^{-3}$ & 0 & 18 & 18 & $\begin{array}{l}\text { Cs-137 } \\
\text { Am-241 }\end{array}$ & $\begin{array}{r}93 \\
7\end{array}$ \\
\hline
\end{tabular}

a. The sum of the individual doses may not equal the total dose due to rounding. 
Table 10-38. Effects of particle size distribution on results for intruder-agricultural scenario for 20 -ft cover, $100 \mathrm{yr}$.

\begin{tabular}{|c|c|c|c|c|c|c|c|c|}
\hline $\begin{array}{l}\text { Final } \\
\text { waste } \\
\text { form }\end{array}$ & Run & $\begin{array}{l}\text { Mass } \\
\text { loading } \\
\text { factor } \\
\left(\mathrm{g} / \mathrm{m}^{3}\right)\end{array}$ & $\begin{array}{c}\text { Inhalation } \\
\text { dose } \\
\text { (mrem) }\end{array}$ & $\begin{array}{l}\text { Ingestion } \\
\text { dose } \\
\text { (mrem) }\end{array}$ & $\begin{array}{l}\text { External } \\
\text { dose } \\
\text { (mrem) }\end{array}$ & $\begin{array}{c}\text { Total } \\
\text { dose } \\
(\text { mrem })^{a}\end{array}$ & $\begin{array}{l}\text { Radionuclides } \\
\text { contributing } \\
25 \% \text { of dose }\end{array}$ & $\begin{array}{c}\text { Radionuclide } \\
\text { contribution }^{\mathrm{a}} \\
(\%)\end{array}$ \\
\hline \multirow[t]{2}{*}{ IEB } & Original & $10^{-4}$ & 57 & 23 & 26 & 110 & $\begin{array}{c}\text { Am-241 } \\
\mathrm{Cs}-137 \\
\mathrm{Sr}-90 \\
\mathrm{Pu}-239 \\
\mathrm{Pu}-238\end{array}$ & $\begin{array}{r}40 \\
22 \\
14 \\
11 \\
7\end{array}$ \\
\hline & Revised & $2.7 \times 10^{-6}$ & 1.5 & 2.6 & 26 & 30 & $\begin{array}{c}\mathrm{Cs}-137 \\
\mathrm{Am}-241 \\
\mathrm{Sr}-90\end{array}$ & $\begin{array}{r}85 \\
10 \\
5\end{array}$ \\
\hline \multirow[t]{2}{*}{ ASG } & Original & $10^{-4}$ & 50 & 19 & 23 & 92 & $\begin{array}{c}\mathrm{Am}-241 \\
\mathrm{Cs}-137 \\
\mathrm{Sr}-90 \\
\mathrm{Pu}-239 \\
\mathrm{Pu}-238\end{array}$ & $\begin{array}{r}40 \\
23 \\
14 \\
12 \\
7\end{array}$ \\
\hline & Revised & $2.4 \times 10^{-6}$ & 1.2 & 2.2 & 23 & 26 & $\begin{array}{c}\text { Cs-137 } \\
\text { Am-241 } \\
\text { Sr-90 }\end{array}$ & $\begin{array}{r}84 \\
10 \\
5\end{array}$ \\
\hline \multirow[t]{2}{*}{ IEB4 } & Original & $10^{-4}$ & 66 & 25 & 32 & 120 & $\begin{array}{c}\text { Am-241 } \\
\mathrm{Cs}-137 \\
\mathrm{Sr}-90 \\
\mathrm{Pu}-239 \\
\mathrm{Pu}-238\end{array}$ & $\begin{array}{r}40 \\
25 \\
14 \\
11 \\
7\end{array}$ \\
\hline & Revised & $3.2 \times 10^{-6}$ & 2.1 & 2.9 & 32 & 37 & $\begin{array}{c}\text { Cs-137 } \\
\text { Am-241 } \\
\text { Sr-90 }\end{array}$ & $\begin{array}{r}83 \\
10 \\
5\end{array}$ \\
\hline \multirow[t]{2}{*}{ BSG } & Original & $10^{-4}$ & 25 & 9.9 & 12 & 46 & $\begin{array}{c}\text { Am-241 } \\
\text { Cs-137 } \\
\text { Sr-90 } \\
\text { Pu-239 } \\
\text { Pu-238 }\end{array}$ & $\begin{array}{r}39 \\
23 \\
14 \\
11 \\
7\end{array}$ \\
\hline & Revised & $2.4 \times 10^{-6}$ & 0.59 & 1.1 & 12 & 14 & $\begin{array}{c}\mathrm{Cs}-137 \\
\mathrm{Am}-241 \\
\mathrm{Sr}-90\end{array}$ & $\begin{array}{r}84 \\
10 \\
5\end{array}$ \\
\hline \multirow[t]{2}{*}{$\begin{array}{l}\text { FUETAP } \\
\text { or PCC }\end{array}$} & Original & $10^{-4}$ & 25 & 9.4 & 12 & 46 & $\begin{array}{c}\mathrm{Am}-241 \\
\mathrm{Cs}-137 \\
\mathrm{Sr}-90 \\
\mathrm{Pu}-239 \\
\mathrm{Pu}-238\end{array}$ & $\begin{array}{r}39 \\
24 \\
13 \\
11 \\
7\end{array}$ \\
\hline & Revised & $1.8 \times 10^{-6}$ & 0.44 & 1.0 & 12 & 13 & $\begin{array}{c}\mathrm{Cs}-137 \\
\mathrm{Am}-241 \\
\mathrm{Sr}-90\end{array}$ & $\begin{array}{r}84 \\
10 \\
5\end{array}$ \\
\hline
\end{tabular}

a. The sum of the individual doses may not equal the total dose due to rounding. 
For the intruder-drilling scenario (see Table 10-37), the decrease in the mass loading factor lowered the inhalation dose by a factor of about 40 . However, the total dose was dominated by the external dose, and the change in the inhalation dose did not have a substantial effect on the total dose. Hence, for this scenario, the total dose for each FWF was unchanged by the refined assumptions regarding size distribution.

For the intruder-agricultural scenario (see Table 10-38), the decreases in the plant-soil uptake factor and the mass loading factor had a substantial effect on the total doses for all the FWFs. The inhalation doses and ingestion doses decreased by approximately the same fraction as the reduction in the mass loading factors and the plant-soil uptake factor, respectively. These values were a factor of about 10 reduction in the ingestion dose and a factor of about 40 reduction in the inhalation dose. The external doses remained the same. Because the inhalation and ingestion doses were major contributors for this scenario, the total dose changed considerably.

The most important result of the refined treatment of particle size distribution is that the doses for all of the FWFs now satisfy the performance objectives. In particular, the intruderagricultural scenario doses for IEB and IEB4 were reduced from values $>100 \mathrm{mrem} / \mathrm{yr}$ to values substantially $<100 \mathrm{mrem} / \mathrm{yr}$.

\subsubsection{Effects of Scenario Timing on Dose}

10.4.10.1 Introduction. For all the previous intrusion scenarios, the time of intrusion was assumed to be either 100 or 500 yr after disposal of the waste and closure of the disposal facility. As explained in Section 10.4.1, the 100-yr time was chosen because it corresponds to the start of the postinstitutional control period. The 500-yr time represents the lifetime of the abovegrade cover over the waste. Additional intrusion simulations were performed at other times to confirm the validity of the assumption that the 100-yr and 500-yr times encompass the peak dose for all of the scenarios studied. The results are reported herein.

To determine when the peak intrusion doses occur, five sets of runs were performed. All five sets used the IEB4 FWF, since IEB4 is the most concentrated FWF of those considered and gives the highest dose.

For the first four sets of runs, the burial depth was $5 \mathrm{ft}$ below grade. This results in a total of $16 \mathrm{ft}$ of material over the waste for the first $500 \mathrm{yr}$ ( $5 \mathrm{ft}$ below grade and $11 \mathrm{ft}$ abovegrade). After $500 \mathrm{yr}$, only the $5 \mathrm{ft}$ of belowgrade material remains. For the fifth set of runs, the burial depth was $9 \mathrm{ft}$, resulting in a total thickness of $20 \mathrm{ft}$ for the first $500 \mathrm{yr}$ and $9 \mathrm{ft}$ thereafter.

GENII was used to model the three exposure pathways: external radiation, inhalation, and ingestion. However, at times of intrusion greater than $100,000 \mathrm{yr}$, the GENII computer model does not calculate inhalation or ingestion pathways; therefore, its results are not valid beyond this point.

For each radionuclide, GENII contains three separate dose conversion factors (one for each pathway). At intrusion times greater than $5,000 \mathrm{yr}$, doses for the INEL ALLW are dominated by Th-229 or Ac-225. Th-229 has higher dose conversion factors than Ac-225 for the inhalation and ingestion pathways, but Ac-225 has a higher dose conversion factor than Th-229 for the external 
pathway. The intruder-drilling scenario is dominated by the external pathway, so, at times of intrusion greater than 5,000 yr, Ac-225 dominates the dose. The intruder-excavation and intruderagricultural scenarios are dominated by the inhalation pathway, so, at times of intrusion greater than 5,000 yr, Th-229 dominates the dose.

10.4.10.2 Intruder-Drilling Scenario. The first set of runs is the intruder-drilling scenario. The original run for this set had a time of intrusion at 100 yr. Table 10-39 contains the results of nine runs at other intrusion times as well as the original run.

The maximum dose is from the original run, confirming the assumptions made in Section 10.4.1.2. The dose decreases rapidly as the time of intrusion increases. The dominant contributor in the original and 200-yr runs is Cs-137. Cs-137 has a half-life of $30 \mathrm{yr}$, so it decays relatively fast. By the next run at $300 \mathrm{yr}$, the Cs-137 has decayed sufficiently that it is no longer the dominant contributor. Am-241 is the dominant contributor for the intrusion times from 300 through 1,000 yr. After 1,000 yr, the Am-241 has decayed sufficiently that one of its progeny, Ac-225, dominates the dose for the rest of the runs. For the intruder-drilling scenario, the dose from external exposure is greater than the dose from inhalation.

Similar intruder-drilling runs over a range of times were not made for the case of the $20-\mathrm{ft}$ cover. The doses would be smaller than those with the $16-\mathrm{ft}$ cover, all of which complied with the performance objective.

10.4.10.3 Intruder-Excavation Scenario. The second set of runs is the intruderexcavation scenario. The original run for this set had a time of intrusion at $500 \mathrm{yr}$. Table 10-40 contains the results of nine runs at other intrusion times as well as the original run. No runs were

Table 10-39. Time dependence of dose in intruder-drilling scenario with $16-\mathrm{ft}$ soil cover.

\begin{tabular}{ccc}
\hline $\begin{array}{c}\text { Time of intrusion } \\
(\mathrm{yr})\end{array}$ & $\begin{array}{c}\text { Total dose } \\
(\mathrm{mrem})\end{array}$ & $\begin{array}{c}\text { Dominant contributor to } \\
\text { dose }\end{array}$ \\
\hline 100 (original run) & 59 & $\mathrm{Cs}-137$ \\
200 & 8.4 & $\mathrm{Cs}-137$ \\
300 & 3 & $\mathrm{Am}-241$ \\
400 & 2.1 & $\mathrm{Am}-241$ \\
500 & 1.6 & Am-241 \\
1,000 & 0.49 & Am-241 \\
5,000 & 0.021 & Ac-225 \\
10,000 & & (Am-241 decay chain) \\
50,000 & $9.6 \mathrm{E}-4$ & Ac-225 \\
& & (Am-241 decay chain) \\
100,000 & $1.3 \mathrm{E}-14$ & Ac-225 \\
& & (Am-241 decay chain) \\
& $3.6 \mathrm{E}-28$ & Ac-225 \\
& & (Am-241 decay chain) \\
\hline
\end{tabular}


Table 10-40. Time dependence of dose in intruder-excavation scenario with $16-\mathrm{ft}$ soil cover.

\begin{tabular}{ccc}
\hline $\begin{array}{c}\text { Time of simulation } \\
(\mathrm{yr})\end{array}$ & $\begin{array}{c}\text { Total dose } \\
(\mathrm{mrem})\end{array}$ & $\begin{array}{c}\text { Dominant contributor to } \\
\text { dose }\end{array}$ \\
\hline 500 (original run) & 260 & $\mathrm{Pu}-239$ \\
600 & 210 & $\mathrm{Pu}-239$ \\
700 & 180 & $\mathrm{Pu}-239$ \\
800 & 150 & $\mathrm{Pu}-239$ \\
900 & 120 & $\mathrm{Pu}-239$ \\
1,000 & 100 & $\mathrm{Pu}-239$ \\
5,000 & 0.61 & $\mathrm{Pu}-239$ \\
10,000 & $1.1 \mathrm{E}-2$ & $\mathrm{Th}-229$ \\
& & (Am-241 decay chain) \\
50,000 & $1.5 \mathrm{E}-13$ & Th-229 \\
& & (Am-241 decay chain) \\
100,000 & $4.1 \mathrm{E}-27$ & Th-229 \\
& & (Am-241 decay chain) \\
\hline
\end{tabular}

made for times $<500 \mathrm{yr}$ because the abovegrade cover would still be intact and the excavation would not penetrate the waste.

The maximum dose is from the original run, confirming the assumptions made in Section 10.4.1.3. The dose decreases as the time of intrusion increases. The dominant contributor in the original case is $\mathrm{Pu}-239 . \mathrm{Pu}-239$ dominates the dose in the simulations up to 10,000 yr. Beginning at the 10,000-yr time of intrusion, Th-229 dominates the dose. Th-229 is in the decay chain of Am-241 and has a half-life of 7,430 yr. For the intruder-excavation scenario, the dose from inhalation is the dominant exposure pathway.

Similar intruder-excavation runs were not made for the case of the $20-\mathrm{ft}$ cover because, even after loss of the abovegrade portion of the cover at $500 \mathrm{yr}$, the excavation would not penetrate the waste.

10.4.10.4 Intruder-Agricultural Scenario. The third set of runs is the intruderagricultural scenario initiated by drilling with a $16-\mathrm{ft}$ cover. The original run for this set had a time of intrusion at $100 \mathrm{yr}$. Table $10-41$ contains the results of three runs at later times as well as the original run.

The maximum dose is from the original run, confirming the assumptions made in Section 10.4.1.4. The dose decreases as the time of intrusion increases. The dose from the agricultural scenario initiated by drilling is always less than the dose from the agricultural scenario initiated by excavation (assuming the excavation penetrates the waste) because of the small volume of waste exhumed by the drill bit. The dominant contributor in these simulations is Am-241. For the intruder-agricultural scenario, inhalation is the dominant exposure pathway. 
Table 10-41. Time dependence of dose in intruder-agricultural scenario initiated by drilling with $16-\mathrm{ft}$ soil cover.

\begin{tabular}{ccc}
\hline $\begin{array}{c}\text { Time of simulation } \\
(\mathrm{yr})\end{array}$ & $\begin{array}{c}\text { Total dose } \\
(\mathrm{mrem} / \mathrm{yr})\end{array}$ & $\begin{array}{c}\text { Dominant contributor to } \\
\text { dose }\end{array}$ \\
\hline 100 (original run) & 120 & Am-241 \\
200 & 59 & Am-241 \\
300 & 43 & Am-241 \\
400 & 33 & Am-241 \\
\hline
\end{tabular}

The fourth set of runs is the intruder-agricultural scenario initiated by excavation with a $16-\mathrm{ft}$ cover. The original run for this set had a time of intrusion at $500 \mathrm{yr}$. Table 10-42 contains the results of five runs at longer times as well as the original run.

The maximum dose is from the original run, confirming the assumptions made in Section 10.4.1.4. The dose decreases rapidly as the time of intrusion increases. The dominant dose contributor of the original dose is from Am-241. For the 1,000- and 5,000-yr runs, Pu-239 dominates the dose. For the runs from 10,000 to $100,000 \mathrm{yr}$, Th-229 dominates the dose. Th-229 is produced by the Am-241 decay chain. For the intruder-agricultural scenario, inhalation is the dominant exposure pathway.

The fifth set of runs is the intruder-agricultural scenario initiated by drilling with a 20-ft cover. The original run for this set had a time of intrusion at 500 yr. Table 10-43 contains the results of nine runs at longer times as well as the original run.

The maximum dose is from the original run, confirming the assumptions made in Section 10.4.1.4. The dose decreases rapidly as the time of intrusion increases. The dominant dose contributor up through $500 \mathrm{yr}$ is Am-241. For the 1,000 and 5,000-yr runs, Pu-239 dominates the dose. For the runs from 10,000 to $100,000 \mathrm{yr}$, Th-229 dominates the dose. Inhalation, initiated by drilling, is the dominant exposure pathway.

Thus, all of these results confirmed the earlier reasoning in Section 10.4.1 that concluded the highest dose to intruders occurs at the 100-yr loss of institutional control or the 500-yr loss of the abovegrade portion of the cover, depending on the specific scenario.

\subsubsection{Dominant Radionuclide Contributors to Dose}

The dominant radionuclides contributing to dose for the three intrusion scenarios that have been the principal focus of Section 10.4 are shown in Table 10-44. Contributions rounded to the nearest whole percent are provided for each radionuclide that contributes $5 \%$ or more to the total dose.

To keep Table 10-44 to a manageable size, the detailed breakdowns of the dominant radionuclide contributors to dose are not listed for certain runs. This restriction applies to the runs made to determine the time to peak dose in Section 10.4.10; the one dominant contributor to each of these runs is given already in Tables 10-39 through 10-43. It also applies to the runs in 
Table 10-42. Time dependence of dose in intruder-agricultural scenario initiated by excavation with 16 -ft soil cover.

\begin{tabular}{ccc}
\hline $\begin{array}{c}\text { Time of intrusion } \\
\text { (yr) }\end{array}$ & $\begin{array}{c}\text { Total dose } \\
\text { (mrem/yr) }\end{array}$ & $\begin{array}{c}\text { Dominant contributor to } \\
\text { dose }\end{array}$ \\
\hline 500 (original run) & 3,600 & Am-241 \\
1,000 & 1,300 & Pu-239 \\
5,000 & 6.9 & Pu-239 \\
10,000 & $1.6 \mathrm{E}-1$ & Th-229 \\
& & (Am-241 decay chain) \\
50,000 & $2.2 \mathrm{E}-12$ & Th-229 \\
& & (Am-241 decay chain) \\
100,000 & $6.1 \mathrm{E}-26$ & Th-229 \\
& & (Am-241 decay chain) \\
\hline
\end{tabular}

Table 10-43. Time dependence of dose in intruder-agricultural scenario initiated by drilling with 20 -ft soil cover.

\begin{tabular}{ccc}
\hline $\begin{array}{c}\text { Time of simulation } \\
(\mathrm{yr})\end{array}$ & $\begin{array}{c}\text { Total dose } \\
(\mathrm{mrem} / \mathrm{yr})\end{array}$ & $\begin{array}{c}\text { Dominant contributor to } \\
\text { dose }\end{array}$ \\
\hline 100 (original run) & 120 & $\mathrm{Am}-241$ \\
200 & 59 & $\mathrm{Am}-241$ \\
300 & 43 & $\mathrm{Am}-241$ \\
400 & 33 & $\mathrm{Am}-241$ \\
500 & 25 & $\mathrm{Am}-241$ \\
1,000 & 9.1 & Pu-239 \\
5,000 & $4.9 \mathrm{E}-2$ & $\mathrm{Pu}-239$ \\
10,000 & $1.1 \mathrm{E}-3$ & Th-229 \\
& & (Am-241 decay chain) \\
50,000 & $1.6 \mathrm{E}-14$ & Th-229 \\
100,000 & & (Am-241 decay chain) \\
& $4.4 \mathrm{E}-28$ & Th-229 \\
& &
\end{tabular}


Table 10-44. Dominant radionuclides contributing to dose for the intrusion scenarios.

\begin{tabular}{|c|c|c|c|c|c|}
\hline $\begin{array}{l}\text { Final waste } \\
\text { form }\end{array}$ & Scenario & Inventory ${ }^{\mathbf{a}}$ & $\begin{array}{l}\text { Total dose } \\
\text { (mrem) } \\
\text { (mrem/yr for } \\
\text { agricultural) }\end{array}$ & $\begin{array}{l}\text { Radionuclides } \\
\text { contributing } \\
25 \% \text { of dose }\end{array}$ & $\begin{array}{c}\text { Radionuclide } \\
\text { contribution }^{c} \\
(\%)\end{array}$ \\
\hline $\begin{array}{l}\text { PCC or } \\
\text { FUETAP }\end{array}$ & $\begin{array}{l}\text { Intruder-drilling } \\
16 \text {-ft cover after } 100 \mathrm{yr}\end{array}$ & Simplified & 23 & $\begin{array}{l}\text { Cs-137 } \\
\text { Am-241 }\end{array}$ & $\begin{array}{r}93 \\
7\end{array}$ \\
\hline $\begin{array}{l}\text { PCC or } \\
\text { FUETAP }\end{array}$ & $\begin{array}{l}\text { Intruder-drilling } \\
20 \text {-ft cover after } 100 \mathrm{yr}\end{array}$ & Simplified & 18 & $\begin{array}{l}\text { Cs-137 } \\
\text { Am-241 }\end{array}$ & $\begin{array}{r}93 \\
7\end{array}$ \\
\hline $\begin{array}{l}\text { PCC or } \\
\text { FUETAP }\end{array}$ & $\begin{array}{l}\text { Intruder-excavation } \\
16 \text {-ft cover after } 500 \mathrm{yr}\end{array}$ & Simplified & 96 & $\begin{array}{l}\mathrm{Pu}-239 \\
\mathrm{Am}-241 \\
\mathrm{Pu}-240\end{array}$ & $\begin{array}{l}49 \\
36 \\
11\end{array}$ \\
\hline $\begin{array}{l}\text { PCC or } \\
\text { FUETAP }\end{array}$ & $\begin{array}{l}\text { Intruder-agricultural } \\
16 \text {-ft cover after } 500 \mathrm{yr}\end{array}$ & Simplified & 1,400 & $\begin{array}{l}\mathrm{Am}-241 \\
\mathrm{Pu}-329 \\
\mathrm{Pu}-240\end{array}$ & $\begin{array}{r}57 \\
31 \\
7\end{array}$ \\
\hline $\begin{array}{l}\text { PCC or } \\
\text { FUETAP }\end{array}$ & $\begin{array}{l}\text { Intruder-agricultural } \\
20 \text {-ft cover after } 100 \mathrm{yr}\end{array}$ & Simplified & 46 & $\begin{array}{l}\text { Am-241 } \\
\text { Cs-137 } \\
\text { Sr-90 } \\
\text { Pu-239 } \\
\text { Pu-238 }\end{array}$ & $\begin{array}{r}39 \\
24 \\
13 \\
11 \\
7\end{array}$ \\
\hline IEB & $\begin{array}{l}\text { Intruder-drilling } \\
16 \text {-ft cover after } 100 \mathrm{yr}\end{array}$ & Simplified & 49 & $\begin{array}{l}\text { Cs-137 } \\
\text { Am-241 }\end{array}$ & $\begin{array}{r}90 \\
7\end{array}$ \\
\hline IEB & $\begin{array}{l}\text { Intruder-drilling } \\
20 \text {-ft cover after } 100 \mathrm{yr}\end{array}$ & Simplified & 42 & $\begin{array}{l}\text { Cs-137 } \\
\text { Am-241 }\end{array}$ & $\begin{array}{r}93 \\
7\end{array}$ \\
\hline IEB & $\begin{array}{l}\text { Intruder-excavation } \\
16 \text {-ft cover after } 500 \mathrm{yr}\end{array}$ & Simplified & 220 & $\begin{array}{l}\mathrm{Pu}-239 \\
\mathrm{Am}-241 \\
\mathrm{Pu}-240\end{array}$ & $\begin{array}{l}50 \\
36 \\
11\end{array}$ \\
\hline IEB & $\begin{array}{l}\text { Intruder-agricultural } \\
16 \text {-ft cover after } 500 \mathrm{yr}\end{array}$ & Simplified & 3,100 & $\begin{array}{l}\text { Am-241 } \\
\text { Pu-239 } \\
\text { Pu-240 }\end{array}$ & $\begin{array}{r}58 \\
30 \\
7\end{array}$ \\
\hline IEB & $\begin{array}{l}\text { Intruder-agricultural } \\
20 \text {-ft cover after } 100 \mathrm{yr}\end{array}$ & Simplified & 110 & $\begin{array}{l}\text { Am-241 } \\
\text { Cs-137 } \\
\text { Sr-90 } \\
\text { Pu-239 } \\
\text { Pu-238 }\end{array}$ & $\begin{array}{r}40 \\
22 \\
14 \\
10 \\
7\end{array}$ \\
\hline IEB & $\begin{array}{l}\text { Intruder-agricultural } \\
20 \text {-ft cover after } 500 \mathrm{yr}\end{array}$ & Simplified & 22 & $\begin{array}{l}\text { Am-241 } \\
\mathrm{Pu}-239 \\
\mathrm{Pu}-240\end{array}$ & $\begin{array}{r}59 \\
30 \\
7\end{array}$ \\
\hline IEB & $\begin{array}{l}\text { Intruder-drilling } \\
\text { 16-ft cover after } 100 \mathrm{yr}\end{array}$ & $\begin{array}{l}\text { Simplified with } \\
10 \mathrm{nC} / \mathrm{g} \text { TRU }\end{array}$ & 45 & Cs- 137 & 98 \\
\hline IEB & $\begin{array}{l}\text { Intruder-drilling } \\
20 \text {-ft cover after } 100 \mathrm{yr}\end{array}$ & $\begin{array}{l}\text { Simplified with } \\
10 \mathrm{nCi} / \mathrm{g} \text { TRU }\end{array}$ & 39 & Cs-137 & 100 \\
\hline IEB & $\begin{array}{l}\text { Intruder-excavation } \\
16 \text {-ft cover after } 500 \mathrm{yr}\end{array}$ & $\begin{array}{l}\text { Simplified with } \\
10 \mathrm{nCi} / \mathrm{g} \text { TRU }\end{array}$ & 22 & $\begin{array}{l}\mathrm{Pu}-239 \\
\mathrm{Am}-241 \\
\mathrm{Pu}-240\end{array}$ & $\begin{array}{l}50 \\
36 \\
11\end{array}$ \\
\hline
\end{tabular}


Table 10-44. (continued).

\begin{tabular}{|c|c|c|c|c|c|}
\hline $\begin{array}{l}\text { Final waste } \\
\text { form }\end{array}$ & Scenario & Inventory ${ }^{2}$ & $\begin{array}{l}\text { Total dose } \\
\text { (mrem) } \\
\text { (mrem/yr for } \\
\text { agricultural) }\end{array}$ & $\begin{array}{l}\text { Radionuclides } \\
\text { contributing } \\
25 \% \text { of dose }\end{array}$ & $\begin{array}{c}\text { Radionuclide } \\
\text { contribution }^{c} \\
(\%)\end{array}$ \\
\hline IEB & $\begin{array}{l}\text { Intruder-agricultural } \\
16-\mathrm{ft} \text { cover after } 500 \mathrm{yr}\end{array}$ & $\begin{array}{l}\text { Simplified with } \\
10 \mathrm{nCi} / \mathrm{g} \text { TRU }\end{array}$ & 310 & $\begin{array}{l}\mathrm{Am}-241 \\
\mathrm{Pu}-239 \\
\mathrm{Pu}-240\end{array}$ & $\begin{array}{r}58 \\
31 \\
7\end{array}$ \\
\hline IEB & $\begin{array}{l}\text { Intruder-agricultural } \\
20 \text {-ft cover after } 100 \text { yr }\end{array}$ & $\begin{array}{l}\text { Simplified with } \\
10 \mathrm{nCi} / \mathrm{g} \text { TRU }\end{array}$ & 47 & $\begin{array}{l}\text { Cs-137 } \\
\text { Sr-90 } \\
\text { Am-241 }\end{array}$ & $\begin{array}{r}51 \\
32 \\
9\end{array}$ \\
\hline IIEB & $\begin{array}{l}\text { Intruder-drilling } \\
20 \text {-ft cover after } 100 \mathrm{yr}\end{array}$ & $\begin{array}{l}\text { Simplified with } \\
1000 \mathrm{nCi} / \mathrm{g} \text { TRU }\end{array}$ & 84 & $\begin{array}{l}\text { Cs-137 } \\
\text { Am-241 }\end{array}$ & $\begin{array}{l}52 \\
44\end{array}$ \\
\hline IEB & $\begin{array}{l}\text { Intruder-drilling } \\
20 \text {-ft cover after } 100 \mathrm{yr}\end{array}$ & $\begin{array}{l}\text { Simplified with } \\
1000 \mathrm{nCi} / \mathrm{g} \text { TRU }\end{array}$ & 72 & $\begin{array}{l}\text { Cs-137 } \\
\text { Am-241 }\end{array}$ & $\begin{array}{l}54 \\
43\end{array}$ \\
\hline IEB & $\begin{array}{l}\text { Intruder-excavation } \\
16 \text {-ft cover after } 500 \mathrm{yr}\end{array}$ & $\begin{array}{l}\text { Simplified with } \\
1000 \mathrm{nCi} / \mathrm{g} \text { TRU }\end{array}$ & 2,200 & $\begin{array}{l}\mathrm{Pu}-239 \\
\mathrm{Am}-241 \\
\mathrm{Pu}-240\end{array}$ & $\begin{array}{l}50 \\
36 \\
11\end{array}$ \\
\hline IEB & $\begin{array}{l}\text { Intruder-agricultural } \\
\text { 16-ft cover after } 500 \mathrm{yr}\end{array}$ & $\begin{array}{l}\text { Simplified with } \\
1000 \mathrm{nCi} / \mathrm{g} \text { TRU }\end{array}$ & 31,000 & $\begin{array}{l}\text { Am-241 } \\
\text { Pu-239 } \\
\mathrm{Pu}-240\end{array}$ & $\begin{array}{r}58 \\
31 \\
7\end{array}$ \\
\hline IEB & $\begin{array}{l}\text { Intruder-agricultural } \\
20 \text {-ft cover after } 100 \mathrm{yr}\end{array}$ & $\begin{array}{l}\text { Simplified with } \\
1000 \mathrm{nCi} / \mathrm{g} \text { TRU }\end{array}$ & 690 & $\begin{array}{l}\mathrm{Am}-241 \\
\mathrm{Pu}-239 \\
\mathrm{Pu}-238\end{array}$ & $\begin{array}{l}62 \\
16 \\
11\end{array}$ \\
\hline IEB4 & $\begin{array}{l}\text { Intruder-drilling } \\
\text { 16-ft cover after } 100 \mathrm{yr}\end{array}$ & Simplified & 59 & $\begin{array}{l}\text { Cs-137 } \\
\text { Am-241 }\end{array}$ & $\begin{array}{r}92 \\
7\end{array}$ \\
\hline IEB4 & $\begin{array}{l}\text { Intruder-drilling } \\
20 \text {-ft cover after } 100 \mathrm{yr}\end{array}$ & Simplified & 49 & $\begin{array}{l}\text { Cs-137 } \\
\text { Am-241 }\end{array}$ & $\begin{array}{r}90 \\
8\end{array}$ \\
\hline IEB4 & $\begin{array}{l}\text { Intruder-excavation } \\
16 \text {-ft cover after } 500 \mathrm{yr}\end{array}$ & Simplified & 260 & $\begin{array}{l}\mathrm{Pu}-239 \\
\mathrm{Am}-241 \\
\mathrm{Pu}-240\end{array}$ & $\begin{array}{l}46 \\
37 \\
11\end{array}$ \\
\hline IEB4 & $\begin{array}{l}\text { Intruder-agricultural } \\
16-\mathrm{ft} \text { cover at } 500 \mathrm{yr}\end{array}$ & Simplified & 3,600 & $\begin{array}{l}\text { Am-241 } \\
\text { Pu-239 }\end{array}$ & $\begin{array}{l}70 \\
30\end{array}$ \\
\hline IEB4 & $\begin{array}{l}\text { Intruder-agricultural } \\
20 \text {-ft cover after } 100 \mathrm{yr}\end{array}$ & Simplified & 120 & $\begin{array}{l}\text { Am-241 } \\
\text { Cs-137 } \\
\text { Sr-90 } \\
\text { Pu-239 } \\
\text { Pu-238 }\end{array}$ & $\begin{array}{r}40 \\
25 \\
14 \\
11 \\
7\end{array}$ \\
\hline IEB4 & $\begin{array}{l}\text { Intruder-agricultural } \\
20 \text {-ft cover after } 500 \mathrm{yr}\end{array}$ & Simplified & 25 & $\begin{array}{l}\text { Am-241 } \\
\text { Pu-239 } \\
\text { Pu-240 }\end{array}$ & $\begin{array}{r}60 \\
32 \\
8\end{array}$ \\
\hline BSG & $\begin{array}{l}\text { Intruder-drilling } \\
16 \text { - } \mathrm{ft} \text { cover at } 100 \mathrm{yr}\end{array}$ & Simplified & 23 & $\begin{array}{l}\text { Cs-137 } \\
\text { Am-241 }\end{array}$ & $\begin{array}{r}91 \\
7\end{array}$ \\
\hline
\end{tabular}


Table 10-44. (continued).

\begin{tabular}{|c|c|c|c|c|c|}
\hline $\begin{array}{l}\text { Final waste } \\
\text { form }\end{array}$ & Scenario & Inventory $^{\mathrm{a}}$ & $\begin{array}{l}\text { Total dose } \\
\text { (mrem) } \\
\text { (mrem/yr for } \\
\text { agricultural) }\end{array}$ & $\begin{array}{l}\text { Radionuclides } \\
\text { contributing } \\
25 \% \text { of dose }\end{array}$ & $\begin{array}{c}\text { Radionuclide } \\
\text { contribution }^{\mathrm{c}} \\
\text { (\%) }\end{array}$ \\
\hline BSG & $\begin{array}{l}\text { Intruder-drilling } \\
20 \text {-ft cover after } 100 \mathrm{yr}\end{array}$ & Simplified & 18 & $\begin{array}{l}\text { Cs-137 } \\
\text { Am-241 }\end{array}$ & $\begin{array}{r}93 \\
7\end{array}$ \\
\hline BSG & $\begin{array}{l}\text { Intruder-excavation } \\
16 \text {-ft cover after } 500 \mathrm{yr}\end{array}$ & Simplified & 96 & $\begin{array}{l}\mathrm{Pu}-239 \\
\mathrm{Am}-241 \\
\mathrm{Pu}-240\end{array}$ & $\begin{array}{l}49 \\
36 \\
11\end{array}$ \\
\hline BSG & $\begin{array}{l}\text { Intruder-agricuitural } \\
16-\mathrm{ft} \text { cover at } 500 \mathrm{yr}\end{array}$ & Simplified & 1,400 & $\begin{array}{l}\mathrm{Am}-241 \\
\mathrm{Pu}-239 \\
\mathrm{Pu}-240\end{array}$ & $\begin{array}{r}57 \\
31 \\
7\end{array}$ \\
\hline BSG & $\begin{array}{l}\text { Intruder-agricultural } \\
20 \text {-ft cover after } 100 \mathrm{yr}\end{array}$ & Simplified & 46 & $\begin{array}{l}\text { Am-241 } \\
\text { Cs-137 } \\
\text { Sr-90 } \\
\text { Pu-239 } \\
\text { Pu-238 }\end{array}$ & $\begin{array}{r}39 \\
23 \\
14 \\
11 \\
7\end{array}$ \\
\hline ASG & $\begin{array}{l}\text { Intruder-drilling } \\
\text { 16-ft cover after } 100 \mathrm{yr}\end{array}$ & Simplified & 46 & $\begin{array}{l}\text { Cs-137 } \\
\text { Am-241 }\end{array}$ & $\begin{array}{r}91 \\
7\end{array}$ \\
\hline ASG & $\begin{array}{l}\text { Intruder-drilling } \\
20 \text {-ft cover after } 100 \mathrm{yr}\end{array}$ & Simplified & 36 & $\begin{array}{l}\mathrm{Cs}-137 \\
\mathrm{Am}-241\end{array}$ & $\begin{array}{r}92 \\
7\end{array}$ \\
\hline ASG & $\begin{array}{l}\text { Intruder-excavation } \\
\text { 16-ft cover after } 500 \text { yr }\end{array}$ & Simplified & 190 & $\begin{array}{l}\mathrm{Pu}-239 \\
\mathrm{Am}-241 \\
\mathrm{Pu}-240\end{array}$ & $\begin{array}{l}50 \\
37 \\
11\end{array}$ \\
\hline ASG & $\begin{array}{l}\text { Intruder-agricultural } \\
16 \text {-ft cover after } 500 \text { yr }\end{array}$ & Simplified & 2,700 & $\begin{array}{l}\mathrm{Am}-241 \\
\mathrm{Pu}-239 \\
\mathrm{Pu}-240\end{array}$ & $\begin{array}{r}57 \\
31 \\
7\end{array}$ \\
\hline ASG & $\begin{array}{l}\text { Intruder-agricultural } \\
20 \text {-ft cover after } 100 \mathrm{yr}\end{array}$ & Simplified & 92 & $\begin{array}{l}\text { Am-241 } \\
\text { Cs-137 } \\
\text { Sr-90 } \\
\text { Pu-239 } \\
\text { Pu-238 }\end{array}$ & $\begin{array}{r}40 \\
23 \\
14 \\
12 \\
7\end{array}$ \\
\hline Untreated & $\begin{array}{l}\text { Intruder-drilling } \\
16 \text {-ft cover after } 100 \mathrm{yr}\end{array}$ & Refined & 12 & $\begin{array}{l}\text { Cs-137 } \\
\text { Am-241 }\end{array}$ & $\begin{array}{r}92 \\
8\end{array}$ \\
\hline Untreated & $\begin{array}{l}\text { Intruder-drilling } \\
20 \text {-ft cover after } 100 \mathrm{yr}\end{array}$ & Refined & 9.6 & $\begin{array}{l}\text { Cs-137 } \\
\text { Am-241 }\end{array}$ & $\begin{array}{r}90 \\
9\end{array}$ \\
\hline Untreated & $\begin{array}{l}\text { Intruder-excavation } \\
16 \text {-ft cover after } 500 \mathrm{yr}\end{array}$ & Refined & 58 & $\begin{array}{l}\text { Pu-239 } \\
\text { Am-241 } \\
\text { Pu-240 }\end{array}$ & $\begin{array}{l}50 \\
36 \\
12\end{array}$ \\
\hline Untreated & $\begin{array}{l}\text { Intruder-agricultural } \\
\text { 16-ft cover after } 500 \mathrm{yr}\end{array}$ & Refined & 820 & $\begin{array}{l}\text { Am-241 } \\
\text { Pu-239 } \\
\text { Pu-240 }\end{array}$ & $\begin{array}{r}60 \\
32 \\
7\end{array}$ \\
\hline
\end{tabular}


Table 10-44. (continued).

\begin{tabular}{|c|c|c|c|c|c|}
\hline $\begin{array}{l}\text { Final waste } \\
\text { form }\end{array}$ & Scenario & Inventory ${ }^{a}$ & $\begin{array}{l}\text { Total dose } \\
\text { (mrem) } \\
\text { (mrem/yr for } \\
\text { agricultural) }\end{array}$ & $\begin{array}{l}\text { Radionuclides } \\
\text { contributing } \\
25 \% \text { of dose }\end{array}$ & $\begin{array}{l}\text { Radionuclide } \\
\text { contribution } \\
\text { (\%) }\end{array}$ \\
\hline Untreated & $\begin{array}{l}\text { Intruder-agricultural } \\
20 \text {-ft cover after } 100 \mathrm{yr}\end{array}$ & Refined & 24 & $\begin{array}{l}\text { Am-241 } \\
\text { Sr-90 } \\
\text { Cs-137 } \\
\text { Pu-239 } \\
\text { Pu-238 }\end{array}$ & $\begin{array}{r}46 \\
14 \\
13 \\
13 \\
9\end{array}$ \\
\hline PCC & $\begin{array}{l}\text { Intruder-drilling } \\
\text { 16-ft cover after } 100 \mathrm{yr}\end{array}$ & Refined-RH & 13,000 & Cs-137 & 99 \\
\hline PCC & $\begin{array}{l}\text { Intruder-excavation } \\
16 \text {-ft cover after } 500 \mathrm{yr}\end{array}$ & Refined-RH & 92 & $\begin{array}{l}\text { Pu-239 } \\
\text { Am-241 } \\
\text { Pu-240 }\end{array}$ & $\begin{array}{l}48 \\
36 \\
12\end{array}$ \\
\hline PCC & $\begin{array}{l}\text { Intruder-agricultural } \\
\text { 16-ft cover after } 500 \mathrm{yr}\end{array}$ & Refined-RH & 1,300 & $\begin{array}{l}\text { Am-241 } \\
\text { Pu-239 } \\
\text { Pu-240 }\end{array}$ & $\begin{array}{r}57 \\
31 \\
7\end{array}$ \\
\hline PCC & $\begin{array}{l}\text { Intruder-drilling } \\
16 \text {-ft cover after } 100 \mathrm{yr}\end{array}$ & Refined-CH & 2.7 & $\begin{array}{l}\text { Am-241 } \\
\text { Cs-137 }\end{array}$ & $\begin{array}{l}59 \\
37\end{array}$ \\
\hline PCC & $\begin{array}{l}\text { Intruder-excavation } \\
16-\mathrm{ft} \text { cover after } 500 \mathrm{yr}\end{array}$ & Refined-CH & 96 & $\begin{array}{l}\mathrm{Pu}-239 \\
\mathrm{Am}-241 \\
\mathrm{Pu}-240\end{array}$ & $\begin{array}{l}49 \\
36 \\
11\end{array}$ \\
\hline PCC & $\begin{array}{l}\text { Intruder-agricultural } \\
16 \text {-ft cover after } 500 \mathrm{yr}\end{array}$ & Refined-CH & 1,300 & $\begin{array}{l}\text { Am-241 } \\
\mathrm{Pu}-239 \\
\mathrm{Pu}-240\end{array}$ & $\begin{array}{r}61 \\
33 \\
6\end{array}$ \\
\hline PCC & $\begin{array}{l}\text { Intruder-drilling } \\
16-\mathrm{ft} \text { cover after } 100 \mathrm{yr}\end{array}$ & Refined-combined & 19 & $\begin{array}{l}\text { Cs-137 } \\
\text { Am-241 }\end{array}$ & $\begin{array}{r}89 \\
8\end{array}$ \\
\hline PCC & $\begin{array}{l}\text { Intruder-excavation } \\
16-\mathrm{ft} \text { cover after } 500 \mathrm{yr}\end{array}$ & Refined-combined & 96 & $\begin{array}{l}\mathrm{Pu}-239 \\
\mathrm{Am}-241 \\
\mathrm{Pu}-240\end{array}$ & $\begin{array}{l}49 \\
36 \\
11\end{array}$ \\
\hline $\mathrm{PCC}$ & $\begin{array}{l}\text { Intruder-agricultural } \\
16-\mathrm{ft} \text { cover after } 500 \mathrm{yr}\end{array}$ & Refined-combined & 1,300 & $\begin{array}{l}\mathrm{Am}-241 \\
\mathrm{Pu}-239 \\
\mathrm{Pu}-240\end{array}$ & $\begin{array}{r}61 \\
33 \\
6\end{array}$ \\
\hline IEB & $\begin{array}{l}\text { Intruder-drilling } \\
16-\mathrm{ft} \text { cover after } 100 \mathrm{yr}\end{array}$ & Refined-RH & 29,000 & Cs-137 & 100 \\
\hline ПEB & $\begin{array}{l}\text { Intruder-excavation } \\
16-\mathrm{ft} \text { cover after } 500 \mathrm{yr}\end{array}$ & Refined-RH & 210 & $\begin{array}{l}\mathrm{Pu}-239 \\
\mathrm{Am}-241 \\
\mathrm{Pu}-240\end{array}$ & $\begin{array}{l}47 \\
36 \\
11\end{array}$ \\
\hline IEB & $\begin{array}{l}\text { Intruder-agricultural } \\
\text { RH-waste } \\
16 \text {-ft cover after } 500 \mathrm{yr}\end{array}$ & Refined-RH & 3,100 & $\begin{array}{l}\text { Am-241 } \\
\text { Pu-239 } \\
\text { Pu-240 }\end{array}$ & $\begin{array}{r}55 \\
30 \\
7\end{array}$ \\
\hline
\end{tabular}


Table 10-44. (continued).

\begin{tabular}{|c|c|c|c|c|c|}
\hline $\begin{array}{l}\text { Final waste } \\
\text { form }\end{array}$ & Scenario & Inventory $^{a}$ & $\begin{array}{l}\text { Total dose } \\
\text { (mrem) } \\
\text { (mrem/yr for } \\
\text { agricultural) }\end{array}$ & $\begin{array}{l}\text { Radionuclides } \\
\text { contributing } \\
25 \% \text { of dose }\end{array}$ & $\begin{array}{c}\text { Radionuclide } \\
\text { contribution } \\
\text { (\%) }\end{array}$ \\
\hline IEB & $\begin{array}{l}\text { Intruder-drilling } \\
16 \text {-ft cover after } 100 \mathrm{yr}\end{array}$ & Refined-CH & 6.2 & $\begin{array}{l}\text { Am-241 } \\
\text { Cs-137 }\end{array}$ & $\begin{array}{l}60 \\
35\end{array}$ \\
\hline IEB & $\begin{array}{l}\text { Intruder-excavation } \\
16 \text {-ft cover after } 500 \mathrm{yr}\end{array}$ & Refined-CH & 220 & $\begin{array}{l}\mathrm{Pu}-239 \\
\mathrm{Am}-241 \\
\mathrm{Pu}-240\end{array}$ & $\begin{array}{l}50 \\
36 \\
11\end{array}$ \\
\hline IEB & $\begin{array}{l}\text { Intruder-agricultural } \\
16 \text {-ft cover after } 500 \text { yr }\end{array}$ & Refined-CH & 3,000 & $\begin{array}{l}\text { Am-241 } \\
\text { Pu-239 } \\
\text { Pu-240 }\end{array}$ & $\begin{array}{r}60 \\
31 \\
7\end{array}$ \\
\hline IEB & $\begin{array}{l}\text { Intruder-drilling } \\
16 \text {-ft cover after } 100 \mathrm{yr}\end{array}$ & Refined-combined & 43 & $\begin{array}{l}\mathrm{Cs}-137 \\
\mathrm{Am}-241\end{array}$ & $\begin{array}{r}91 \\
9\end{array}$ \\
\hline IEB & $\begin{array}{l}\text { Intruder-excavation } \\
\text { 16-ft cover after } 500 \mathrm{yr}\end{array}$ & Refined-combined & 220 & $\begin{array}{l}\text { Pu-239 } \\
\text { Am-241 } \\
\text { Pu-240 }\end{array}$ & $\begin{array}{l}50 \\
36 \\
11\end{array}$ \\
\hline IEB & $\begin{array}{l}\text { Intruder-agricultural } \\
\text { 16-ft cover after } 500 \mathrm{yr}\end{array}$ & Refined-combined & 3,000 & $\begin{array}{l}\mathrm{Am}-241 \\
\mathrm{Pu}-239 \\
\mathrm{Pu}-240\end{array}$ & $\begin{array}{r}60 \\
31 \\
7\end{array}$ \\
\hline IEB & $\begin{array}{l}\text { Intruder-agricultural } \\
20 \text {-ft cover after } 100 \mathrm{yr}\end{array}$ & Refined-combined & 97 & $\begin{array}{l}\text { Am-241 } \\
\text { Cs-137 } \\
\text { Sr-90 } \\
\text { Pu-239 } \\
\text { Pu-238 }\end{array}$ & $\begin{array}{r}48 \\
14 \\
14 \\
13 \\
9\end{array}$ \\
\hline IEB & $\begin{array}{l}\text { Intruder-agricultural } \\
20 \text {-ft cover after } 500 \mathrm{yr}\end{array}$ & Refined-combined & 22 & $\begin{array}{l}\mathrm{Am}-241 \\
\mathrm{Pu}-239 \\
\mathrm{Pu}-240\end{array}$ & $\begin{array}{r}59 \\
30 \\
7\end{array}$ \\
\hline IEB4 & $\begin{array}{l}\text { Intruder-agricultural } \\
20 \text {-ft cover after } 100 \mathrm{yr}\end{array}$ & Refined-combined & 110 & $\begin{array}{l}\text { Am-241 } \\
\text { Sr-90 } \\
\text { Cs-137 } \\
\text { Pu-239 } \\
\text { Pu-238 }\end{array}$ & $\begin{array}{r}48 \\
15 \\
14 \\
14 \\
9\end{array}$ \\
\hline IEB4 & $\begin{array}{l}\text { Intruder-agricultural } \\
20 \text {-ft cover after } 500 \mathrm{yr}\end{array}$ & Refined-combined & 25 & $\begin{array}{l}\mathrm{Am}-241 \\
\mathrm{Pu}-239 \\
\mathrm{Pu}-240\end{array}$ & $\begin{array}{r}60 \\
32 \\
8\end{array}$ \\
\hline IEB & $\begin{array}{l}\text { Intruder-drilling } \\
20 \text {-ft cover after } 100 \mathrm{yr} \\
\text { increased exposure time }\end{array}$ & Simplified & 44 & $\begin{array}{l}\text { Cs-137 } \\
\text { Am-241 }\end{array}$ & $\begin{array}{r}89 \\
9\end{array}$ \\
\hline
\end{tabular}


Section 10.4.9 that evaluated the effects of particle size distribution, for the same reason. In addition, the dominant contributors for the runs in Section 10.4.7, using the inventory with additional refinements, are not given in Table 10-44. The key contributors are nearly the same as those for the corresponding runs made with the refined inventory.

The intrusion scenarios can be divided into two general categories with respect to the dominant radionuclides that contribute to dose. The doses resulting from intrusion scenarios assumed to occur at $100 \mathrm{yr}$ were dominated by Cs-137 and the Am-241 decay chain. Minor contributors in some scenarios included Sr-90 and the Pu-238, Pu-239, and Pu-240 decay chains. The doses resulting from intrusion scenarios assumed to occur at $500 \mathrm{yr}$ were dominated by the Am-241 chain and the Pu-239 chain. The Pu-240, Pu-238, and U-233 chains contributed lesser percentages, depending on the specific assumptions.

The separate analyses of $\mathrm{RH}$ and $\mathrm{CH}$ fractions for the refined inventory included the radionuclides Ce-144, Cs-134, Kr-85, Ni-63, Pm-147, and Pr-144, which were excluded in the other analyses. These additional radionuclides, however, contributed much less than $1 \%$ of the total dose. For the inventory with additional refinements, which included even more radionuclides, the conclusions were essentially the same.

\subsubsection{Results for Intruder-Radon Scenario}

Table 10-45 contains the results for the intruder-radon scenario. It indicates the time of maximum dose, the indoor $\mathrm{Rn}-222$ concentration at the time of maximum dose, and the maximum dose from radon inhalation for the PCC and IEB4 FWFs.

The maximum radon dose for the PCC FWF occurs at 4,600 yr. The maximum indoor radon concentration is $1.03 \times 10^{-3} \mathrm{pCi} / \mathrm{L}$. The IEB4 FWF maximum dose occurs at $20,000 \mathrm{yr}$, with a maximum indoor radon concentration of $1.7 \times 10^{-2} \mathrm{pCi} / \mathrm{L}$. The maximum doses for PCC and IEB4 are 0.19 and $3.16 \mathrm{mrem} / \mathrm{yr}$, respectively.

The time of maximum dose for IEB4 is much later than for PCC because of its much smaller leach rate. The radionuclides in the IEB4 FWF remain in the disposal facility much longer; therefore, the radionuclides undergo more decay and more radon is produced in the facility. This accounts for the higher dose from IEB4.

In Section 8, the peak radon concentration from PCC was found to occur at $167,000 \mathrm{yr}$, for an intruder standing at the surface. This peak time assumes no leaching of the radionuclides. Because the intruder-radon scenario includes leaching, no radionuclides remain in the facility at $167,000 \mathrm{yr}$.

In the case of PCC, it was assumed that all of the radon generated is available for transport via diffusion from the porous waste form toward the receptor. In the case of IEB4, the impermeable nature of the FWF prevents radon produced within the FWF from being released from the FWF before it decays into nongaseous products. Therefore, the source of radon for IEB4 was restricted to the inventory of radionuclides present in a leached form within the disposal unit. 
Table 10-45. Results for the intruder-radon scenario.

\begin{tabular}{|c|c|c|c|}
\hline Waste form & $\begin{array}{c}\text { Time of maximum dose } \\
(\mathrm{yr})\end{array}$ & $\begin{array}{c}\text { Indoor } \mathrm{Rn}-222 \\
\text { concentration at time of } \\
\text { maximum dose } \\
(\mathrm{pCi} / \mathrm{L})\end{array}$ & $\begin{array}{l}\text { Maximum dose } \\
(\mathrm{mrem} / \mathrm{yr})\end{array}$ \\
\hline $\mathrm{PCC}$ & 4,600 & $1.03 \times 10^{-3}$ & 0.19 \\
\hline IEB4 & 20,000 & $1.7 \times 10^{-2}$ & 3.16 \\
\hline
\end{tabular}

The PCC leach rate dictates that all the radionuclides are released from the FWF in about 3,300 yr. The maximum dose occurs after this time due to adsorption of radionuclides within the facility. The RESRAD code used for the intruder-radon scenario includes a desorption model to simulate leaching. Leach rates input to the code are converted to equivalent desorption coefficients that are applied equally to the waste, backfill, and vadose zone materials. Thus, sorption in the facility cannot be avoided, but in radon scenarios, incorporating the sorption produces conservative results.

Table 10-46 compares the calculated radon concentrations and doses against regulatory limits. The conclusion is that no limits would be exceeded.

\subsection{Qualitative Prediction of the Effects of Secondary FWFs}

The evaluations of the FWFs considered in this report are based on the simplifying assumption that all of the waste will be disposed of as a single FWF (PCC, FUETAP, BSG, ASG, IEB, IEB4, or untreated). The selected FWF will be produced by immobilization of the ash remaining after thermal treatment of the waste.

In reality, not all of the existing INEL ALLW waste can be incorporated into a single FWF. It is likely that multiple FWFs will be disposed of. It is also likely that a small fraction of the waste will not be susceptible to thermal treatment and will be incorporated into some secondary waste form not considered in this report. This section discusses the likely effects of such a secondary waste form on the performance of the disposal system.

The total volume of waste that may be incorporated into a secondary waste form (such as a cement waste form) is believed to be in the range of $1 \%$ to $5 \%-$ certainly less than $10 \%-$ of the total volume. Most of this material contains hazardous metals with low melting points, such as lead or mercury, that are not amenable to thermal treatment.

The TRU radionuclide concentration in INEL ALLW is limited, by definition, to a range from 10 through $100 \mathrm{nCi} / \mathrm{g}$. Because of this narrow range, the TRU activity does not concentrate to a great extent in any content code. Therefore, if $10 \%$ of the waste volume is present as a secondary waste form, this volume is expected to contain a similar percentage of the total TRU radionuclide inventory. 
Table 10-46. Regulatory requirements and results for intruder-radon scenario.

\begin{tabular}{llll}
\multicolumn{1}{c}{ Regulation } & Exposure group & \multicolumn{1}{c}{$\begin{array}{c}\text { Performance objective } \\
\text { limit }\end{array}$} & \multicolumn{1}{c}{ Results of evaluations } \\
\hline EPA (1987) & Inadvertent intruder & $\begin{array}{l}4 \mathrm{pCi} / \mathrm{L} \text { concentration } \\
\text { in indoor air }\end{array}$ & $\begin{array}{l}\text { Maximum indoor air } \\
\text { concentration of } 1.7 \times \\
10^{-2} \mathrm{pCi} / \mathrm{L} \text { for IEB4 }\end{array}$ \\
& & & Maximum dose of \\
DOE Order 5820.2A, & Inadvertent intruder & $100 \mathrm{mrem} / \mathrm{yr}$ EDE & (chronic exposure) \\
Ch. III & & $3.16 \mathrm{mrem} / \mathrm{yr}$ for IEB4 \\
\hline
\end{tabular}

The dose for the undisturbed-waste scenario-groundwater transport pathway depends on the FWF. For Site A, for example, the dose varies from $3.6 \mathrm{mrem} / \mathrm{yr}$ for untreated waste (Run 1UTR) to $0.011 \mathrm{mrem} / \mathrm{yr}$ for IEB4 (Run 3). These doses are all below the 25 -mrem/yr performance objective. If the secondary waste form contains $10 \%$ of the radionuclide inventory and performs at least as well as the untreated waste, then the presence of a secondary waste form should not pose any problem in demonstrating compliance with the performance objective.

The acute and chronic intrusion doses depend on the volumetric concentrations of radionuclides in the waste form. The concentration in a secondary waste form cannot realistically fall far outside the range of concentrations already considered in the six FWFs and untreated waste, while still meeting the definition of ALLW. Therefore, an inadvertent intrusion into a secondary waste form is expected to result in doses within the same range as the intrusion doses predicted herein.

In summary, the probable presence of a secondary waste form occupying up to $10 \%$ of the total waste volume will not significantly affect the overall performance of the disposal system unless the performance of the secondary waste form is a great deal worse than the performance of untreated waste. 


\section{References for Section 10}

Allard, B., 1985, Radionuclide Sorption on Concrete, Nationale Genossenschaft für die Lagerung radioaktiver Abfälle. NAGRA-NTB-85-21, November.

Apel, M. L., G. K. Becker, Z. K. Ragan, J. Frasure, B. D. Raivo, L. G. Gale, and D. P. Pace, 1994, Radiological, Physical, and Chemical Characterization of Low-level Alpha-contaminated Wastes Stored at the Idaho National Engineering Laboratory for Use in Conducting Feasibility Studies for Treatment Senvices, EG\&G Idaho, EGG-RWMC-11189, March.

Brandstetter, E.R., J.L. Lolcama, and S.R. Reed, 1994, "An Integrated Degradation and Structural Model for Predicting the Service Life of Buried Reinforced Concrete Structures for Low- and Intermediate-Level Radioactive Waste Disposal," Proceedings of the Symposium on Waste Management, Tucson, AZ, February 27-March 3, 1994, Vol. 1, pp. 89-97.

DOE, 1989, Technical Approach Document, UMTRA-DOE/AL 050425.0002, Rev. II, U.S. Department of Energy.

EPA, 1987, Interim Protocols for Screening and Follow-up Radon and Radon Decay Product Measurements, Office of Radiation Programs, EPA 520/1-86-014-1, U.S. Environmental Protection Agency.

Farnsworth, R. K. et al., 1994, "Properties Comparison for Mixed Waste Final Waste Forms," presented at the American Chemical Society Meeting, September 19-21.

Glasser, F. P., M. J. Angus, C. E. McCulloch, D. Macphee, and A. A. Rahman, 1985, "The Chemical Environment in Cements," Material Research Society Symposium Proceedings, Vol. 44, 1985, pp. 849-858.

Glasstone, S., and A. Sesonke, 1967, Nuclear Reactor Engineering, Van Nostrand Reinhold Company, New York, NY.

Jardine, L. J., G. T. Reedy, and W. J. Mecham, 1982, "Respirable Fines Produced by Impacts of Simulated Alternative High-Level Waste Materials," in The Scientific Basis for Nuclear Waste Management, S. V. Topp, ed., Elsevier Science Publishing Company, Inc., 1982, pp. 115-123.

Lodge, J. P., Jr., 1991, Methods of Air Sampling and Analysis, 3rd ed., Lewis Publishers, Inc., Chelsea, Michigan.

Lutze, W., and R. C. Ewing, 1988, Radioactive Waste Forms of the Future, North-Holland.

Maheras, S. J., A. S. Rood, S. O. Magnuson, M. E. Sussman, and R. N. Bhatt, 1994, Radioactive Waste Management Complex Low-Level Waste Radiological Performance Assessment, EGG-WM-8773, EG\&G Idaho, Inc., May. 
Martin Marietta Energy Systems, Inc. (Martin Marietta), 1994, EG\&G Idaho, Inc., and Westinghouse Savannah River Company, Radiological Performance Assessment for the E-Area Vaults Disposal Facility, prepared for Westinghouse Savannah River Company, Aiken, South Carolina, WSRC-RP-94-218, April.

Snith, T. H., and W. A. Ross, 1975, Impact Testing of Vitreous Simulated High-Level Waste in Canisters, Battelle Pacific Northwest Laboratories, BNWL-1903, May.

Sutter, S. L., 1982, Accident Generated Particulate Materials and Their Characteristics $-A$ Review of Background Information, Battelle Pacific Northwest Laboratories, NUREG/CR-2651, May.

Wood, M. I., R. Khaleel, P. D. Rittman, A. H. Lu, S. H. Finfrock, R. J. Serne, K. J. Cantrell, T. H. DeLorenzo, 1994, Performance Assessment for the Disposal of Low-Level Waste in the 200 West Area Burial Grounds, Westinghouse Hanford Company, Richland, Washington, WHC-EP-0645, November. 


\section{CONCLUSIONS, AND IMPLICATIONS FOR DECISIONMAKING}

Section 11.1 presents the key conclusions from this study. Section 11.2 discusses the implications of these conclusions on decisions to be made for managing the INEL ALLW.

\subsection{Conclusions}

Two release scenarios were evaluated in this study, the undisturbed-waste scenario and the intrusion scenario. The conclusions from the two scenarios are different and are discussed separately below.

The number of PA cases evaluated was quite large (about 120, depending on how one counts) but was still limited. To broaden their usefulness, the conclusions reflect some extrapolations. This allowed including the results expected from cases not specifically evaluated but believed to be predictable with a high degree of confidence, based on the results of closely related cases.

Because of the uncertainties in these evaluations (see Section 13.1), the doses reported herein should be considered approximate. More precise evaluations will be performed later for the particular FWF(s), site, and disposal unit design to be implemented.

\subsubsection{Undisturbed-Waste Scenario-Atmospheric Transport Pathway}

All FWFs at all sites would be expected to comply with the performance objectives of DOE Order 5820.2A for the undisturbed-waste scenario-atmospheric transport pathway.

- Only long-term release of radon would be expected to result in substantial effects via this pathway.

- To a first approximation, the effects are independent of disposal site.

- For the PCC FWF, the peak outdoor concentration of radon is $0.011 \mathrm{pCi} / \mathrm{L}$. The peak dose is $2.1 \mathrm{mrem} / \mathrm{yr}$.

- The dose would be lower for the other FWFs, which provide more resistance to radon diffusion.

- As discussed in Section 10.3, no standards apply to the flux, concentration, or dose from outdoor releases of radon from the disposed ALLW. However, (a) the peak radon flux from the ALLW is much less than that in the nonapplicable EPA standard, (b) the peak radon concentration is far below the EPA action level for indoor radon, and (c) the peak dose calculated for outdoor radon is about $1 \%$ of the $200-\mathrm{mrem} / \mathrm{yr}$ average dose for indoor radon in the United States. 


\subsubsection{Undisturbed-Waste Scenario-Groundwater Transport Pathway}

As stated previously, the use of one generic model for the groundwater pathway and the disposal unit design in addressing five sites with widely varying characteristics limits the accuracy to which the current method can predict radionuclide transport and dose via this pathway. Therefore, the conclusions should be viewed as scoping results only and subject to later confirmation by site-specific modeling.

11.1.2.1 Conclusions: Compliance with Performance Objective on Dose. Compliance with the performance objective on dose for the undisturbed-waste scenario-groundwater transport pathway depends on the FWF, disposal site, and overall conservatism of the assumptions made.

Although not every combination of FWF, site, assumptions, and parameter values was evaluated, enough runs were made to develop a semiquantitative display of the conclusions. See Figure 11-1.

The display was developed by examining how the calculated doses in Table 10-2 changed as the various factors were changed. The display is semiquantitative, in that it is useful for making comparisons to within a precision of about a factor of 10 . However, it is not a precise numerical plot because it presents a simplified composite of the many factors that were varied. Some of the factors have a nonlinear effect on the calculated dose.

Figure 11-1 is basically a mapping of the dose, in mrem/yr, as a function of the performance of the FWF and the performance of the disposal site. The magnitude of the dose can be imagined as extending out of the plane of the page. The doses are indicated primarily as contour lines of constant dose. Not all calculated doses are shown explicitly because of the impracticality of depicting many data points virtually on top of one another.

The horizontal axis of Figure 11-1 represents the relative performance of the FWF. Moving along the axis toward the left from one division mark to the next represents roughly a tenfold improvement in FWF performance and roughly a tenfold reduction in calculated dose, if all other factors are held constant.

Designators for the six FWFs plus untreated waste (UTR) are located on the horizontal axis so as to depict their effect on dose. It can be seen that the relative performance of IEB4 for this pathway is about $21 / 2$ factors of 10 (a factor of about 300 ) superior to that of UTR. That is, the dose from an IEB4 FWF would be about 1/300 that for untreated waste, if all other factors are held constant. FWF performance is a function of several variables, but the leach rate is principal among them.

The designator PCC-INT is used on Figure 11-1 to represent the performance of the PCC FWF when chemical interactions between the radionuclides and the cement are considered in the modeling and long-term integrity of the PCC is assumed. Based on the simplified modeling of chemical interactions, the performance of PCC-INT is far better than that of PCC and, at its best, lies between that of IEB and that of IEB4. 


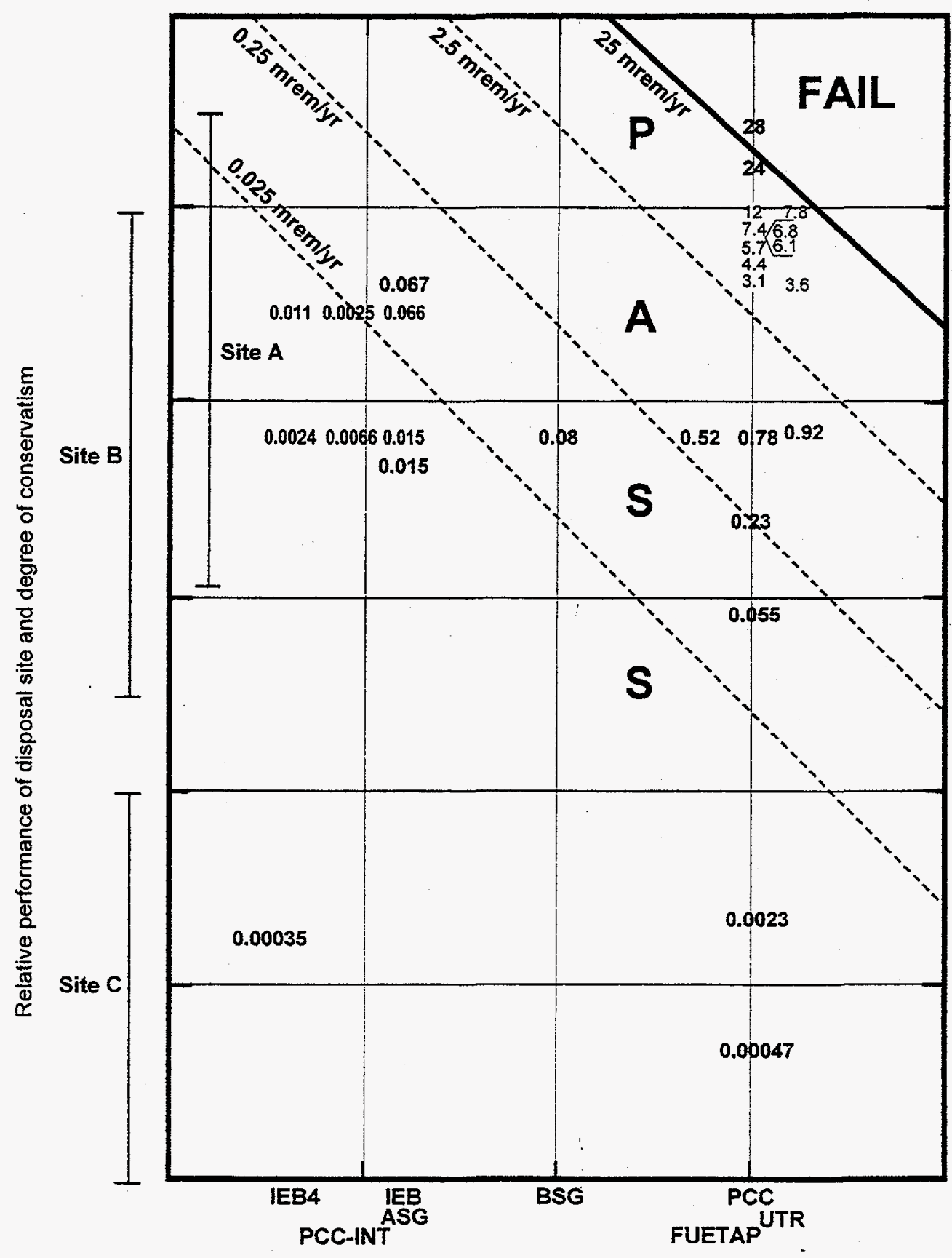

Relative performance of final waste form

Note:

Each mark on vertical and horizontal scales represents roughly a 10-fold effect on dose. Upper end of each vertical bar represents quite conservative assumptions. Lower end reoresents less conservative assumptions. Numbers on field of figure are calculated values of peak doses (mrem/yr) for combinations of FWF, site, and assumptions and parameter values.

ML5069i27

Figure 11-1. Semiquantitative plot of compliance with performance objective for dose in undisturbed-waste scenario-groundwater transport pathway for Sites A, B, and C. 
The vertical axis similarly represents the relative performance of the disposal site. Moving downward along the axis from one division mark to the next represents roughly a tenfold improvement in site performance and roughly a tenfold reduction in dose, if all other factors are held constant.

Performance levels representative of Sites A, B, and C are located on the vertical axis so as to depict their effects on dose. The performance is by far the best for a site exhibiting the characteristics of Site C; the characteristics used for Site B are somewhat more favorable than those used for Site A. Site performance is a function of many variables. Among the most important are the groundwater travel time in the vadose zone and the sorption coefficients.

The performance of each site is shown as a range with a vertical bar, rather than as a single point, for the following reason. Many of the assumptions and parameter values that were varied relate to site characteristics. Examples are $K_{d}$ values and infiltration rates. Because there is considerable uncertainty in such parameters, even for a given site, a range of values was investigated. One end of the range represents more conservative values; the other, less conservative values. Figure 11-1 accommodates this effect by use of a bar for each site; the length of the bar represents the range of the dose values resulting from differing (but realistic) degrees of conservatism. If truly extreme values-highly conservative or highly nonconservative-were pursued, the bars would be extended correspondingly in both directions.

The performances of Sites $D$ and $E$ are not shown on Figure 11-1. Except for one run involving IEB4 at Site $\mathrm{E}$ that barely satisfied the performance objective, all runs involving Sites D and $E$ failed by a very large margin. On Figure 11-1, vertical bars representing Sites D and E would have to be placed approximately 3 factors of 10 ( 3 division marks) higher than the bar for Site A. The additional vertical bars for Sites $D$ and $E$ would be off the top of the current chart.

The observations that can be drawn from Figure 11-1 and the above discussion include the following:

\section{Sites D and E}

- For Sites D and E, only IEB4 at Site E satisfies the performance objective, and that by only a very small margin ( $20 \mathrm{mrem} / \mathrm{yr}$ versus $25 \mathrm{mrem} / \mathrm{yr})$. Any additional conservatism in the assumptions or parameter values would push the resulting dose above the 25-mrem/yr limit.

\section{Sites A, B, and C}

- For the remaining site with the least favorable characteristics (Site A) and under very conservative assumptions, the less favorable FWFs (UTR, and PCC and FUETAP without credit taken for chemical interactions with the cement) may or may not ultimately fail the performance objective. The calculated doses are either slightly above the limit of $25 \mathrm{mrem} / \mathrm{yr}$ or within a factor of 10 below the limit. The pass-or-fail outcome depends on the conservatism of the specific assumptions used. Even though they pass in the current evaluations, these combinations are susceptible to failing when 
the detailed, formal PA is done because the current margin of compliance is smaller than the range of potential conservatism.

- All other combinations of FWF (including PCC and FUETAP with credit taken for chemical interactions in the cement), site, and degree of conservatism satisfy the performance objective. The margin by which these combinations pass ranges from a factor of about 10 to more than a factor of 1,000 . Thus, at sites with the characteristics of Site B or C, any waste form would probably satisfy the performance objectives, even untreated waste. The margin would be greater at Site $C$ than at Site B.

- The tradeoff of FWF performance against site performance is evident from the slope of the constant-dose lines in Figure 11-1. An excellent FWF will pass the performance objective at any of the three sites; an excellent site will pass with any FWF that was evaluated. It is noted that, compared with disposal site properties, the properties of FWFs are more readily tailored and more verifiable.

11.1.2.2 Conclusions: Compliance with Performance Objective on Groundwater Protection. Compliance with the performance objective on groundwater protection for the undisturbed-waste scenario-groundwater transport pathway depends on the site and the FWF.

- All FWFs pass at Sites A, B, and C

- All FWFs fail at Sites D and E.

11.1.2.3 Other Conclusions. In addition to the conclusions regarding compliance with the performance objectives, the following general conclusions can be drawn about system performance for the undisturbed-waste scenario-groundwater transport pathway:

- The results depend most strongly on the assumed values for the leach rate of the FWF, the infiltration rate, and the $\mathrm{K}_{\mathrm{d}} \mathrm{s}$.

- The results also depend strongly on whether credit is taken for radionuclide sorption in the source zone.

- In most cases, the dominant radionuclide contributing the greatest to the peak dose is the Am-241 decay chain, in particular, Np-237. However, for most runs with Sites D and $\mathrm{E}$ and for the most conservative runs at Site $\mathrm{A}$, the U-233 decay chain is the dominant contributor.

\subsubsection{Intrusion Scenarios}

To a first approximation, the intrusion doses calculated with the present methodology are independent of disposal site. Therefore, the evaluations focused on the FWF and on the assumptions made. 


\subsubsection{Conclusions: Compliance with Performance Objectives on Dose.}

Compliance with the performance objectives on dose for the intrusion scenarios depends on the FWF, disposal parameters, and overall conservatism of the assumptions made.

- For the intruder-drilling scenario, all FWFs and burial depths studied satisfy the performance objective, except for cases in which an intruder drills into the $\mathrm{RH}$ waste (an extremely unlikely situation) rather than into the $\mathrm{CH}$ waste or an assumed homogeneous mixture of the $\mathrm{RH}$ and $\mathrm{CH}$ waste.

- For the intruder-excavation scenario, all FWFs and burial depths studied satisfy the performance objective. The one exception was the case involving TRU waste, not ALLW.

- For the intruder-agricultural scenario with the 5-ft burial depth (16-ft total cover), all FWFs fail to satisfy the performance objective.

- For the intruder-agricultural scenario with the 9-ft burial depth ( $20-\mathrm{ft}$ total cover), all FWFs fail if an intruder drills into the RH waste (an extremely unlikely situation) rather than into the $\mathrm{CH}$ waste or an assumed homogeneous mixture of the $\mathrm{RH}$ and $\mathrm{CH}$ waste. If it is assumed that this does not occur, then:

- The PCC, FUETAP, BSG, ASG, and untreated FWFs pass

- The IEB FWF passes if (a) the refined inventory or the inventory with additional refinements is used or (b) the refined particle size distribution is used

- The IEB4 FWF passes if (a) the inventory with additional refinements is used or (b) the refined particle size distribution is used

- $\quad$ The TRU waste fails.

- For the intruder-radon scenario, all FWFs pass.

- In summary, satisfying the performance objectives for intrusion requires (a) burial at least $9 \mathrm{ft}$ deep (20-ft total cover), (b) special provisions for the RH ALLW, and (c) in the case of the IEB and IEB4 FWFs, either use of the improved inventory or use of the refined particle size distribution in the PA calculations.

11.1.3.2 Other Conclusions. In addition to the conclusions regarding compliance with the performance objectives, the following general conclusions can be drawn about system performance for the intrusion scenarios:

- The results depend particularly on the depth of burial (belowgrade), cover longevity, and radionuclide concentration in the FWF 
- Improved immobilization of the radionuclides into a more concentrated FWF can degrade the intrusion performance unless credit is taken for the likely larger particle sizes of the improved FWF when subjected to drilling

- The dominant radionuclides contributing to dose are Cs-137 and Am-241 during the early period studied (100 yr postclosure) and Am-241 and Pu-239 for the later period (500 yr postclosure)

- Separate runs confirmed that the peak doses to intruders are predicted to occur at $100 \mathrm{yr}$ and $500 \mathrm{yr}$ postclosure.

\subsection{Implications for Decisionmaking}

\subsubsection{Introduction}

Performance assessment is an important part of decisionmaking for the treatment and disposal of LLW. Selection of a FWF is a major decision involving very large funds, if the cost of implementing the decision is considered (facility construction and operation). If a FWF with inadequate performance is selected and implemented, the cost and schedule impacts from later discovery that the performance objectives are not met could be extremely serious. On the other hand, implementation of a FWF with an unnecessarily high level of performance could lead to excessive expenditures on waste treatment.

This section discusses briefly the implications of the information developed in this preliminary study upon the decisions to be made in the PSPI project. It draws primarily from the conclusions in Section 11.1. It draws also from the later discussions of the conservatism of the present study, found in Section 12, and the uncertainties and areas needing further study, discussed in Section 13.

The PSPI project is still in its early stages. Many future events and external factors may affect the future direction of the project. Therefore, the observations and recommendations presented here are an assessment of only the present situation and may not reflect future conditions.

\subsubsection{Observations and Recommendations}

The following observations and recommendations are offered, based on the information developed in this preliminary parametric PA:

- PA considerations should continue to be part of the waste treatment project. As the project moves forward and focuses more closely on specific sites and specific FWFs, the PA studies should become more focused. Several topics meriting further study have been identified.

- Disposal of the INEL ALLW at Site D or Site E or other sites with similar characteristics is not expected to satisfy the performance objectives, regardless of the 
FWF. However, the uncertainties in the current generic modeling of the groundwater pathway are particularly sizeable at Sites D and E.

- It is expected that disposal of the INEL ALLW at Sites A, B, or C or other sites with similar characteristics can satisfy the performance objectives.

- Disposal will need to be at least $9 \mathrm{ft}$ below grade.

- $\quad$ Credit may need to be taken for the chemical interactions in the PCC and FUETAP FWFs to predict satisfactory performance in the undisturbed-waste scenario-groundwater transport pathway.

- The improved radionuclide inventory or the refined particle size distribution may have to be used for the IEB and IEB4 FWFs to predict satisfactory performance in the intruder-agricultural scenario.

- Special provisions are expected to be needed for disposal of the remote-handled ALLW. Disposal of such waste in conventional containers in pits is not expected to satisfy the performance objectives. Possible provisions include disposing of such waste by intermediate-depth disposal or at a deep geologic repository. 


\section{PERSPECTIVES ON THE ASSUMPTIONS AND PARAMETER VALUES USED: HOW CONSERVATIVE?}

\subsection{Introduction}

In this preliminary parametric PA, a major emphasis was placed on investigating the effects that the assumptions and parameter values have on the results. The study was performed in three phases. Results from the first phase guided the selection of assumptions and parameters to be investigated in the second and third phases.

The results from the first phase indicated that the assumptions and parameter values strongly affected the results. In particular, the degree of conservatism in the assumptions and parameter values is important in projecting the acceptability of a FWF. A given FWF at a given disposal site could be projected to either pass or fail the performance objectives, depending simply on the assumptions and parameter values used in the PA.

One cannot predict the degree of conservatism that will be required ultimately by the personnel who review and approve the formal PA addressing disposal of the treated ALLW. If the reviewers require great conservatism, FWFs will tend to be pushed down the scale of acceptability. Some FWFs may fall below the limit of acceptability by failing the performance objectives.

If the assumptions and parameter values used in this study are quite conservative, the chances are reduced that future reviewers will push FWFs below the levels of acceptability arrived at herein. On the other hand, if this study is excessively conservative, attractive FWFs may be prematurely ruled out.

The question of the degree of conservatism of this study is, therefore, of considerable importance. That question was addressed (as explained in Section 12.2) by comparing the assumptions and parameter values used herein against those in five other PAs or risk assessments related to the SDA (Site A).

\subsection{Comparisons against the Assumptions and Parameter Values Used in Related Assessments}

Hundreds of assumptions and parameter values are used in a PA. Assumptions are necessary where data are unavailable. Assumptions are also necessary in cases where complex natural processes need to be simplified in order to allow simulation with computer models. Single values of parameters need to be selected from a range of possible and reasonable values. Making assumptions and selecting parameter values are intimately associated with the resulting uncertainties in the results of a PA. Only limited, broad direction (e.g., DOE 1994) is available on the assumptions and parameter values to be used in PAs prepared in response to DOE Order $5820.2 \mathrm{~A}$.

From among the hundreds of assumptions and parameter values used in a PA, a panel of technical personnel selected approximately 130 expected to be among those having the greatest effect on the calculated doses. 
For these approximately 130 parameters, the assumptions and values used in this study were compared systematically against those in five related PAs or risk assessments. The assessments are related in that they all dealt with various portions of the waste that either are now, or may be in the future, disposed of in the SDA (Site A). The assessments differed, however, in the specific waste addressed, purpose, level of detail, number of alternatives evaluated, and intended degree of conservatism. It is understandable, therefore, that the studies used a range of assumptions and parameter values.

The five other assessments are as follows:

- The formal RWMC Performance Assessment (Maheras et al. 1994), which addresses the LLW buried in the SDA from 1984 through 2020

- The Preliminary Scoping Risk Assessment (Loehr et al. 1994), prepared pursuant to CERCLA, which addresses both radiological and nonradiological contaminants in the TRU waste and LLW buried in the SDA from 1952 through 1983

- An informal PA (Rood 1992) on the waste buried in the SDA from 1954 through 1970, which was assumed to be retrieved, treated to produce an IEB FWF, and buried in the SDA

- An informal PA (Maheras et al. 1992) addressing the same situation as that immediately above, but with a concrete FWF

- An informal PA (Rood 1993) on the INEL ALLW (without the nonactinides), which was assumed to be disposed of in the SDA without treatment.

The last three assessments listed were less detailed than the first two.

The primary purpose of the comparisons was to assess the degree of conservatism in the first phase of this study, compared with that in the other five assessments, thereby identifying any additional computer runs needed for the second and third phases of this study. An additional purpose was to gain a better understanding of the important processes and parameters that control disposal system performance. A final benefit of the comparisons is that the resulting cornpilation may be helpful in preparing future PAs, risk assessments, and other environmental documents related to the SDA.

\subsection{Results of the Comparisons}

The detailed comparisons appear in Appendix $\mathrm{H}$.

Based on the results of the comparisons, additional computer runs were made in the second and third phases of this study to evaluate the effects of alternative assumptions or different parameter values. The new computer runs are discussed in Section 10. The comparisons in Appendix $\mathrm{H}$ were then updated to reflect the new computer runs. 
Table 12-1 is a simplified summary of Appendix H. The first column lists the most important of the approximately 130 parameters covered in the comparisons. As discussed in Appendix $\mathrm{H}$, "important" parameters are defined here as those for which (a) the values assumed in the six assessments had a large spread and (b) a substantial effect on the results was expected. The second column provides a simplified conclusion on whether the first-phase evaluations herein were in the conservative or nonconservative part of the spectrum of reasonable values. The last column of Table 12-1 discusses any new computer runs made and/or indicates the degree of conservatism after the second and third phases of the study.

Table 12-1 reflects a great simplification of Appendix $H$. For details, the latter should be consulted.

\subsection{Conclusions}

The degree of conservatism of a PA is difficult to assess in quantitative terms. In the present situation, even though six assessments addressed the same disposal area, many aspects of the assessments were so different that no rigorous conclusions can be drawn. Short of repeating the entire PA with the exact assumptions and parameter values used in other assessments, there is no way to give a quantitative answer to the question, "How conservative is this PA?"

Nevertheless, the comparisons performed here do provide a perspective on the degree of conservatism in this study. For the undisturbed-waste scenario, the first-phase evaluations tended to be conservative on the points of taking no credit for waste containers or for radionuclide sorption in the source zone. The evaluations tended to be nonconservative on some of the assumed infiltration rates and on the vadose zone travel time. These nonconservatisms were investigated in the second phase by making computer runs with more conservative assumptions and parameter values. Overall, the effects of the conservative vs. nonconservative assumptions tended to balance each other. For Site A, comparing the calculated dose for the second-phase Run 1IR2NBSZS with that for Run 1 shows that the effects almost exactly cancel out. (Run 1 used the lower infiltration rate, took credit for the basalt layers, but took no credit for sorption in the source zone. Run 1IR2NBSZS used the opposite assumptions-the higher infiltration rate, no credit for the basalt layers, but credit for sorption in the source zone.) The combined set of computer runs for the two phases provided relatively complete coverage for the important parameters.

For the intruder scenarios, the first-phase computer runs tended to be conservative, principally because of the assumption that spread the nonactinide inventory over all of the waste. The other assumptions tended to balance out one another, being comparatively conservative on some points and comparatively nonconservative on others. The second- and third-phase computer runs provided refined assumptions about the nonactinide distribution and reduced the conservatism in some cases.

The overall conclusion is that this study encompasses a suitable range of conservatism in the various computer runs. It seems unlikely that the required conservatism for the formal PA addressing disposal of the ALLW will fall outside the range of conservatism investigated here. 
Table 12-1. Degree of conservatism of the most important assumptions and parameter values used in this study.

\begin{tabular}{|c|c|c|}
\hline Assumption or parameter & $\begin{array}{l}\text { Degree of } \\
\text { conservatism in } \\
\text { first-phase } \\
\text { evaluations }\end{array}$ & $\begin{array}{l}\text { Degree of conservatism after } \\
\text { second- and third-phase evaluations }\end{array}$ \\
\hline Split of $\mathrm{CH}$ and $\mathrm{RH}$ waste & Conservative & $\begin{array}{l}\text { Refined analyses produced lower } \\
\text { doses in some cases and showed } \\
\text { that first-phase computer runs for } \\
\text { intrusion scenarios were very } \\
\text { conservative for } \mathrm{CH} \text { waste }\end{array}$ \\
\hline Degradation of FWF & Conservative & Covered full range of assumptions \\
\hline Credit for waste containers & Conservative & Conservative \\
\hline $\begin{array}{l}\text { Credit for contaminant adsorption } \\
\text { in cement }\end{array}$ & Conservative & Covered full range of assumptions \\
\hline Burial depth & Typical & Typical \\
\hline Cover integrity & Typical & Typical \\
\hline $\begin{array}{l}\text { Comprehensiveness of list of } \\
\text { transport pathways and exposure } \\
\text { routes for undisturbed-waste } \\
\text { scenario }\end{array}$ & $\begin{array}{l}\text { Less conservative, } \\
\text { but effect on } \\
\text { results is small }\end{array}$ & $\begin{array}{l}\text { Less conservative, but effect on } \\
\text { results is small }\end{array}$ \\
\hline Infiltration rate & Nonconservative & Covered full range of values \\
\hline $\begin{array}{l}\text { Credit for cover reducing } \\
\text { infiltration during institutional } \\
\text { control }\end{array}$ & Conservative & Conservative \\
\hline Vadose zone travel time & Nonconservative & Covered full range of assumptions \\
\hline Flooding scenario & $\begin{array}{l}\text { Typical but } \\
\text { nonconservative }\end{array}$ & Typical but nonconservative \\
\hline Sorption in waste zone & Conservative & Covered full range of assumptions \\
\hline $\begin{array}{l}\text { Transport pathways and exposure } \\
\text { routes for intrusion scenarios }\end{array}$ & $\begin{array}{l}\text { Approximately in } \\
\text { middle of range }\end{array}$ & Approximately in middle of range \\
\hline $\begin{array}{l}\text { Assumptions governing exposure } \\
\text { during intruder-drilling scenario }\end{array}$ & Nonconservative & Covered full range of assumptions \\
\hline
\end{tabular}


Table 12-1. (continued).

\begin{tabular}{|c|c|c|}
\hline Assumption or parameter & $\begin{array}{l}\text { Degree of } \\
\text { conservatism in } \\
\text { first-phase } \\
\text { evaluations }\end{array}$ & $\begin{array}{l}\text { Degree of conservatism after } \\
\text { second- and third-phase evaluations }\end{array}$ \\
\hline $\begin{array}{l}\text { Assumptions governing exposure } \\
\text { during intruder-excavation scenario }\end{array}$ & Conservative & Conservative \\
\hline $\begin{array}{l}\text { Assumptions governing exposure } \\
\text { during intruder-agricultural } \\
\text { scenario }\end{array}$ & $\begin{array}{l}\text { Approximately in } \\
\text { middle of range }\end{array}$ & Approximately in middle of range \\
\hline
\end{tabular}




\section{References for Section 12}

DOE, 1994, Performance Assessment Task Team Progress Report, U.S. Department of Energy, DOE/LLW-157, Rev. 1, May.

Loehr, C. A., B. H. Becker, D. E. Burns, R. M. Huntley, S. M. Rood, P. Sinton, and T. H. Smith, 1994, Preliminary Scoping Risk Assessment for Waste Pits, Trenches, and Soil

Vaults at the Subsurface Disposal Area, Idaho National Engineering

Laboratory, EG\&G Idaho, Inc., EGG-WM-11181, May.

Maheras, S. J., A. S. Rood, and R. Shuman, 1992, "A Performance Assessment of Radioactive Waste Encapsulated in Concrete and Disposed at the INEL," September (located in EG\&G Idaho, Inc., Engineering Design File IWPF-0028, Appendix 2).

Maheras, S. J., A. S. Rood, S. O. Magnuson, M. E. Sussman, and R. N. Bhatt, 1994, Radioactive Waste Management Complex Low-Level Waste Radiological Performance Assessment, EG\&G Idaho, Inc., EGG-WM-8773, May.

Rood, A S., 1992, "A Performance Assessment of Radioactive Waste Encapsulated in IronEnriched Basalt and Disposed at the Idaho National Engineering Laboratory's Radioactive Waste Management Complex", Proceedings of the International Topical Meeting on Nuclear and Hazardous Waste Management, Spectrum '92, August (located in EG\&G Idaho, Inc., Engineering Design File IWPF-0028, Appendix 3).

Rood, A. S., 1993, "A Limited Performance Assessment for the Idaho Waste Processing Facility: 1993 Update Using Revised Parameters and Limited Sensitivity Analysis", September 29, (located in EG\&G Idaho, Inc., Engineering Design File IWPF-0044). 


\section{UNCERTAINTIES AND AREAS NEEDING FURTHER STUDY}

\subsection{Uncertainties}

The identification and discussion of the uncertainties are important parts of a PA. The uncertainties include those related to the major areas of a PA: the radionuclide inventory, the release mechanisms and rates, the physical setting of the site, the scenarios, the conceptual and numerical models used to estimate transport, and the exposure parameters. The uncertainties can be classified into three broad categories (EPA 1994): scenario uncertainties, model uncertainties, and parameter uncertainties.

The variables and assumptions believed to contribute most of the uncertainty in the current study were identified. Most of the emphasis was placed on the modeling uncertainties and the parameter uncertainties. No attempt was made to list every uncertainty or to quantify precisely the total degree of uncertainty in the PA results.

Table 13-1 summarizes the key uncertainties. The potential effect of each entry is indicated in terms of possibly overestimating or underestimating the dose. Steps taken to investigate or reduce the uncertainty are listed. For example, many of the key uncertain parameters were varied over a range of values to determine the effect on the calculated dose. Finally, comments and conclusions are provided as appropriate.

\subsection{Areas Needing Further Study}

This section determines the areas listed in Table 13-1 and elsewhere for which further study is recommended at this time.

\subsubsection{Areas that Are Sufficiently Well Defined Programmatically to be Considered for Further Study}

Some areas related to the disposal of the INEL ALLW are fairly well defined programmatically at this time. Other areas are not yet well defined. Pursuing technical uncertainties in the latter may not be cost effective. This section distinguishes between the two types of areas.

The first paragraph in Section 13.1 listed the major areas of a PA. In an overview sense, the programmatic status of those areas is as follows:

- Radionuclide inventory

This area is comparatively well defined, in that the body of waste to be addressed has been identified. The programmatic uncertainties, such as (a) the lower limit of TRU concentration for ALLW, and (b) the exact details for dividing containers between those that are TRU waste and those that are ALLW, are not expected to cause major impacts on the PA. 
Tablle 13-1. Key uncertainties in this study.

\begin{tabular}{|c|c|c|c|}
\hline Uncertainty factor & $\begin{array}{l}\text { Potential effect } \\
\text { of uncertainty on } \\
\text { calculated dose }\end{array}$ & $\begin{array}{l}\text { Steps taken to investigate or } \\
\text { reduce uncertainty }\end{array}$ & Comments/conclusions \\
\hline $\begin{array}{l}\text { The activities of the } \\
\text { radionuclides in the } \\
\text { ALLW are uncertain, } \\
\text { due to limited data on } \\
\text { the waste, uncertainties } \\
\text { in the partitioning } \\
\text { between TRU waste } \\
\text { and ALLW, and } \\
\text { unknowns about the } \\
\text { effects of treatment. }\end{array}$ & $\begin{array}{l}\text { May overestimate } \\
\text { or slightly } \\
\text { underestimate } \\
\text { dose. }\end{array}$ & $\begin{array}{l}\text { Used conservative upper limit of } \\
100 \text { nCi/g TRU for most } \\
\text { computer runs. Performed } \\
\text { computer runs with } 10 \text { and } 1,000 \\
\text { nCi/g TRU to observe effects. } \\
\text { Used conservative values for } \\
\text { activity of nonactinides, in } \\
\text { particular Cs-137, which was } \\
\text { found to dominate intruder dose } \\
\text { in many cases. Examined effect of } \\
\text { separating vs. combining CH and } \\
\text { RH waste in the model. } \\
\text { Examined effect on dose if } \\
\text { activity of difficult-to-measure } \\
\text { radionuclides increased. }\end{array}$ & $\begin{array}{l}\text { This uncertainty is an important } \\
\text { factor. It was investigated rather } \\
\text { thoroughly here. The range of } \\
\text { values used is believed to bound } \\
\text { the actual values. }\end{array}$ \\
\hline $\begin{array}{l}\text { Very-small-activity } \\
\text { radionuclides were } \\
\text { screened out of the } \\
\text { evaluations. }\end{array}$ & $\begin{array}{l}\text { May slightly } \\
\text { underestimate } \\
\text { dose. }\end{array}$ & $\begin{array}{l}\text { Subsequent runs verified that the } \\
\text { screened-out radionuclides had a } \\
\text { negligible effect on the dase. }\end{array}$ & The uncertainty is quite small. \\
\hline $\begin{array}{l}\text { The modeling of } \\
\text { radionuclide release } \\
\text { mechanisms and } \\
\text { release rates was } \\
\text { greatly simplified. }\end{array}$ & $\begin{array}{l}\text { May overestimate } \\
\text { or underestimate } \\
\text { dose. }\end{array}$ & $\begin{array}{l}\text { Performed computer runs with } \\
\text { maximum and minimum release } \\
\text { parameter values for each } \\
\text { category of FWF (cement, } \\
\text { ceramic, glass). Performed runs } \\
\text { with fractured FWF. Performed } \\
\text { runs on untreated waste as a } \\
\text { benchmark for comparison. Took } \\
\text { no credit for waste container. }\end{array}$ & $\begin{array}{l}\text { This uncertainty is an important } \\
\text { factor. It was investigated rather } \\
\text { thoroughly here. The range of } \\
\text { values used is believed to bound } \\
\text { the actual values. }\end{array}$ \\
\hline $\begin{array}{l}\text { No credit was taken for } \\
\text { sorption of } \\
\text { contaminants in cement } \\
\text { FWFs in most runs. }\end{array}$ & $\begin{array}{l}\text { May overestimate } \\
\text { dose. }\end{array}$ & $\begin{array}{l}\text { Performed computer runs in } \\
\text { which sorption in the cement was } \\
\text { modeled using a simple method. }\end{array}$ & $\begin{array}{l}\text { The uncertainty is an important } \\
\text { factor. The range of assumptions } \\
\text { used is believed to bound the } \\
\text { actual values. }\end{array}$ \\
\hline $\begin{array}{l}\text { The timeline modeled } \\
\text { for ALLW treatment, } \\
\text { disposal, and facility } \\
\text { closure was simplified } \\
\text { by using an } \\
\text { unrealistically short } \\
\text { interval ( } 1 \text { yr). }\end{array}$ & $\begin{array}{l}\text { May overestimate } \\
\text { dose. }\end{array}$ & None. & $\begin{array}{l}\text { This uncertainty is believed to be } \\
\text { rather small. In most cases, the } \\
\text { dose is dominated by the long-lived } \\
\text { actinide decay chains, and a delay } \\
\text { of up to } 20 \text { or } 30 \mathrm{yr} \text { in the time } \\
\text { period modeled would have a } \\
\text { negligible effect. For many } \\
\text { intrusion scenarios, however, the } \\
\text { dose is dominated by Cs- } 137 \text {. The } \\
\text { same delay of } 20 \text { or } 30 \mathrm{yr} \text { could } \\
\text { result in a reduction of as much as } \\
50 \% \text { in the Cs-137 dose, due to } \\
\text { radioactive decay occurring before } \\
\text { closure of the disposal unit. }\end{array}$ \\
\hline
\end{tabular}


Table 13-1. (continued).

\begin{tabular}{|c|c|c|c|}
\hline Uncertainty factor & $\begin{array}{l}\text { Potential effect } \\
\text { of uncertainty on } \\
\text { calculated dose }\end{array}$ & $\begin{array}{l}\text { Steps taken to investigate or } \\
\text { reduce uncertainty }\end{array}$ & Comments/conclusions \\
\hline $\begin{array}{l}\text { The location of the } \\
\text { disposal site is } \\
\text { unknown. }\end{array}$ & $\begin{array}{l}\text { May overestimate } \\
\text { or underestimate } \\
\text { dose. }\end{array}$ & $\begin{array}{l}\text { Performed computer runs for } \\
\text { various FWFs at five possible } \\
\text { disposal sites with large } \\
\text { differences in characteristics. }\end{array}$ & $\begin{array}{l}\text { This uncertainty is an important } \\
\text { factor. The range of sites studied } \\
\text { is believed to provide a broad } \\
\text { perspective on the range of } \\
\text { potential behaviors of the site that } \\
\text { could conceivably be selected. }\end{array}$ \\
\hline $\begin{array}{l}\text { The disposal unit layout } \\
\text { (burial depth, backfill } \\
\text { thickness, engineered } \\
\text { barriers, cover) is } \\
\text { uncertain. }\end{array}$ & $\begin{array}{l}\text { May overestimate } \\
\text { or underestimate } \\
\text { dose. }\end{array}$ & $\begin{array}{l}\text { Performed computer runs with } \\
\text { different depths to top of waste } \\
\text { stack. Assumed a well-engineered } \\
\text { cover, which retains integrity for } \\
\text { its design life, then instantly } \\
\text { erodes totally. In most runs, took } \\
\text { no credit for engineered barriers. } \\
\text { Took no credit for sediment } \\
\text { underlayer in pit. }\end{array}$ & $\begin{array}{l}\text { The depth to the top of the waste } \\
\text { stack is an important factor for the } \\
\text { intrusion scenarios. The range of } \\
\text { values used is believed to bound } \\
\text { the actual values. The other } \\
\text { disposal unit variables are believed } \\
\text { to be less important. }\end{array}$ \\
\hline $\begin{array}{l}\text { Natural disturbances of } \\
\text { the waste zone (e.g., by } \\
\text { flooding) were not } \\
\text { evaluated. }\end{array}$ & $\begin{array}{l}\text { May } \\
\text { underestimate } \\
\text { dose. }\end{array}$ & None. & $\begin{array}{l}\text { The effects of natural disturbances } \\
\text { should be evaluated when specific } \\
\text { candidate sites have been identified } \\
\text { formally. }\end{array}$ \\
\hline $\begin{array}{l}\text { The infiltration rate for } \\
\text { precipitation at the } \\
\text { disposal units is } \\
\text { uncertain. }\end{array}$ & $\begin{array}{l}\text { May } \\
\text { underestimate } \\
\text { dose for some } \\
\text { computer runs. }\end{array}$ & $\begin{array}{l}\text { Infiltration rate for most } \\
\text { computer runs is probably } \\
\text { nonconservative. Performed } \\
\text { several runs with larger } \\
\text { infiltration rates, up to a large } \\
\text { upper limit. }\end{array}$ & $\begin{array}{l}\text { This uncertainty is an important } \\
\text { factor. The range of values } \\
\text { investigated is believed to bound } \\
\text { the actual values. }\end{array}$ \\
\hline $\begin{array}{l}\text { The modeling of the } \\
\text { subsurface structure, } \\
\text { flow, and transport was } \\
\text { greatly simplified. }\end{array}$ & $\begin{array}{l}\text { May overestimate } \\
\text { or underestimate } \\
\text { dose. }\end{array}$ & $\begin{array}{l}\text { Performed computer runs to } \\
\text { investigate effects of some of the } \\
\text { simplifications. Examples are } \\
\text { effects of taking no credit for } \\
\text { basalt layers at Site A, effects of } \\
\text { taking no credit for radionuclide } \\
\text { sorption in the waste zone. }\end{array}$ & $\begin{array}{l}\text { The scope of the study did not } \\
\text { allow detailed site-specific } \\
\text { modeling. This uncertainty is an } \\
\text { important factor. }\end{array}$ \\
\hline $\begin{array}{l}\text { The values of sorption } \\
\text { coefficients are } \\
\text { uncertain. }\end{array}$ & $\begin{array}{l}\text { May overestimate } \\
\text { or underestimate } \\
\text { dose. }\end{array}$ & $\begin{array}{l}\text { Used representative values for } \\
\text { most of the computer runs. } \\
\text { Performed runs with more } \\
\text { conservative values, also. }\end{array}$ & $\begin{array}{l}\text { This uncertainty is an important } \\
\text { factor. It was investigated rather } \\
\text { thoroughly here, at least for the } \\
\text { present level of detail of the study. } \\
\text { The range of values used is } \\
\text { believed to bound the actual } \\
\text { values. }\end{array}$ \\
\hline
\end{tabular}


Table 13-1. (continued).

\begin{tabular}{|c|c|c|c|}
\hline Uncertainty factor & $\begin{array}{l}\text { Potential effect } \\
\text { of uncertainty on } \\
\text { calculated dose }\end{array}$ & $\begin{array}{l}\text { Steps taken to investigate or } \\
\text { reduce uncertainty }\end{array}$ & Comments/conclusions \\
\hline $\begin{array}{l}\text { For groundwater } \\
\text { transport, it was } \\
\text { assumed that all } \\
\text { progeny arrive at the } \\
\text { receptor well at the } \\
\text { same time as the } \\
\text { parent. }\end{array}$ & $\begin{array}{l}\text { May overestimate } \\
\text { or underestimate } \\
\text { dose. }\end{array}$ & None. & $\begin{array}{l}\text { In reality, a chromatographic effect } \\
\text { will occur, with progeny arriving at } \\
\text { the receptor well at different times. } \\
\text { This spreading of the arrival times } \\
\text { will tend to reduce the peak dose. } \\
\text { On the other hand, progeny with } \\
\text { high dose conversion factors and } \\
\text { fast travel times are retarded so as } \\
\text { to travel with the parent in the } \\
\text { model, which may tend to } \\
\text { underestimate dose. }\end{array}$ \\
\hline $\begin{array}{l}\text { For the undisturbed- } \\
\text { waste scenario, only the } \\
\text { grcundwater transport } \\
\text { pathway and radon } \\
\text { transport via the } \\
\text { airborne pathway were } \\
\text { evaluated. }\end{array}$ & $\begin{array}{l}\text { May } \\
\text { underestimate } \\
\text { dose. }\end{array}$ & None. & $\begin{array}{l}\text { Results for other pathways from } \\
\text { Maheras et al. (1994) were used to } \\
\text { justify not evaluating the dose from } \\
\text { the other pathways. }\end{array}$ \\
\hline $\begin{array}{l}\text { The exposure routes } \\
\text { and receptor locations } \\
\text { are uncertain. }\end{array}$ & $\begin{array}{l}\text { May overestimate } \\
\text { or underestimate } \\
\text { dose. }\end{array}$ & $\begin{array}{l}\text { Performed computer runs using } \\
\text { generally conservative exposure } \\
\text { routes and conservative values of } \\
\text { the related parameters. } \\
\text { Performed one intrusion run } \\
\text { using a more conservative } \\
\text { scenario for drilling. }\end{array}$ & $\begin{array}{l}\text { The assumptions used are } \\
\text { somewhat conservative. If direct } \\
\text { intrusion into the waste does not } \\
\text { occur, the dose will have been } \\
\text { overestimated considerably. }\end{array}$ \\
\hline $\begin{array}{l}\text { The dose conversion } \\
\text { factors are uncertain. }\end{array}$ & $\begin{array}{l}\text { May overestimate } \\
\text { or underestimate } \\
\text { dose. }\end{array}$ & None. & Widely accepted values were used. \\
\hline
\end{tabular}


- Release mechanisms and rates

This area depends on the FWF(s) that will be selected and is thus not well defined. However, the FWF(s) selected will most likely represent one or more of the three major categories evaluated here: cement, glass, ceramic. The range of specific formulations for each category was substantially bounded by the choice of the six FWFs studied here.

- $\quad$ Physical setting of site

A formal list of candidate sites, from which the actual site will certainly be selected, has not been prepared. Thus, this area is not well defined. Pursuing site-specific details (e.g., $\mathrm{K}_{\mathrm{d}} \mathrm{s}$, infiltration rates), without assurance that the particular site is a formal candidate, may not be cost effective.

- Scenarios

Scenarios for PA evaluations are generally independent of programmatic considerations. Some aspects of scenarios are site-specific, however, and therefore not well defined programmatically.

- Conceptual and numerical models used to estimate transport

To a large extent, detailed models of radionuclide transport are site specific.

- Exposure parameters

Some exposure parameters are site specific.

Based on the above arguments, the areas that tend to be the best suited for additional study at this time are related to the radionuclide inventory and the release rates. The areas that tend to be the least suitable are any involving site-specific parameters.

\subsubsection{Areas for Further Study}

After consideration of the technical uncertainties from Table 13-1 and the program status from Section 13.2.1, the following areas are recommended for further study at this time.

- Better information is needed on the operational approach for dealing with $\mathrm{CH}$ vs. RH ALLW in treatment and disposal. In addition, a more precise estimate of the TRU content in the treated ALLW is needed to supplement the upper and lower limits used herein. Both of these items would be addressed by examining possible operational schemes for treatment and disposal, then considering the impacts on the radionuclide inventory in the treated ALLW.

- The simplified timeline used in this study (which assumed only one year for waste treatment, disposal, and site closure) represents a worst-case situation and is not realistic. 
Some computer runs should be made using a timeline that represents the current best judgment for the programmatic and operational timeline.

- Several simplifications were made in modeling the release mechanisms; the subject needs to be addressed in more detail as the selection of a FWF becomes better defined.

- This preliminary parametric PA produced an initial mapping of the projected compliance status of various combinations of FWFs and disposal sites, for various degrees of conservatism in the analysis (see Section 11). The mapping is not precise; it is only semiquantitative. It is intended to indicate the general behavior of the "compliance versus noncompliance" conclusion in the complex, multivariable space of possible disposal system combinations. The mapping is based on the results of the limited number of cases evaluated. The limited number of cases necessitated some extrapolation of results for cases that were not evaluated but were estimated based on results of similar cases.

Additional cases need to be evaluated to provide a more detailed and defensible mapping. 


\section{References for Section 13}

EPA, 1994, Exposure Assessment Guidelines, U.S. Environmental Protection Agency, EH-232-009/08/94, August.

Maheras, S. J., A. S. Rood, S. O. Magnuson, M. E. Sussman, and R. N. Bhatt, 1994, Radioactive

Waste Management Complex Low-Level Waste Radiological Performance Assessment, EG\&G Idaho Inc., EGG-WM-8773, May. 


\section{Appendix A}

Estimating the Radionuclide Inventory in INEL-Stored Alpha Low-Level Waste 
A-2 


\section{Appendix A}

\section{Estimating the Radionuclide Inventory in INEL-Stored Alpha Low-Level Waste}

Incomplete information is available from shipping records concerning the radionuclide inventory in the alpha low-level waste (ALLW) stored at the Idaho National Engineering Laboratory (INEL). Therefore, that information was supplemented with assumptions, analyses, and other sources of information to arrive at a suitable inventory for use in this study.

This appendix describes how the radionuclide inventory was estimated. The inventory is in terms of the activity (in $\mathrm{Ci}$ ) and the volumetric concentration of activity (in $\mathrm{Ci} / \mathrm{m}^{3}$ ) of each radionuclide.

Three successive approximations of the radionuclide inventory were developed and used for runs involving treated ALLW. Each approximation was more detailed and is expected to be more accurate than its predecessor.

The first version of the inventory is called the "simplified inventory." It was developed by means of the simplified approach described in Section A-1 through A-8. It was used for all of the computer runs in the first phase of the study and for most of the runs in the second and third phases. Unless otherwise stated, this was the inventory used.

For the second phase, a "refined inventory" (described in Section A-9) was developed and used for a limited number of computer runs. Those runs are so identified in the presentation of results.

For the third phase, an "inventory with additional refinements" (described in Section A-10) was developed and used for a limited number of computer runs. Those runs are so identified in the presentation of results.

Appendix B describes the refined model of the untreated ALLW used for a limited number of computer runs in the second phase of the study.

\section{A-1. BACKGROUND}

The posttreatment inventory of radionuclides in the ALLW cannot be estimated with a high degree of confidence before the treatment campaign is well underway. Several reasons exist for this uncertainty:

- The shipping records often did not provide complete lists of the radionuclides in the waste

- Determination of the plutonium in the waste was difficult because of measurement limitations 
- Measurement of some nonactinides in the waste was also difficult because the radionuclides are $\beta$-emitters that have no associated $\gamma$ radiation (e.g., Sr-90, Ni-63)

- In addition, the outcome of dividing the waste into waste that is $>100 \mathrm{nCi} / \mathrm{g}$ after treatment and waste that is $\leq 100 \mathrm{nCi} / \mathrm{g}$ after treatment is difficult to predict.

Thus, rigorous projection of the inventory of the radionuclides in the posttreatment waste is not possible.

In the absence of data to support rigorous inventory estimates, limiting or best-judgment inventories were developed based on several assumptions and simplifications. The result of the assumptions and simplifications was a simplified inventory (with later refinements) that allowed the performance assessment (PA) to proceed cost-effectively with the assurance that realistic, if not precise, values were used for the inventory.

Sections A-2 through A-8 discuss the basis for the simplified inventory and present the result.

\section{A-2. CONSTRAINTS}

The radionuclide inventory had to satisfy several constraints to be comprehensive and realistic:

- It had to include only the ALLW, not the transuranic (TRU) waste

- It had to include the waste from all generators, not just Rocky Flats Plant (RFP), which was the predominant generator

- It had to include all of the radionuclides in the waste, not just the actinides (the radionuclides with atomic number $\geq 89$ and their progeny are referred to here as the "actinides"; all other radionuclides are referred to here as the "nonactinides")

- It had to represent posttreatment conditions, not as-stored conditions in the Transuranic Storage Area (TSA) at the Radioactive Waste Management Complex (RWMC)

- It had to address the three broad categories (glass, ceramic, cement) of final waste forms (FWFs) under consideration, including the two extreme or limiting FWFs (more favorable and less favorable) for each category

- The list of radionuclides had to be complete enough to represent essentially all of the risk, but short enough to allow cost-effective, repeated parametric calculations of radionuclide transport.

The inventory of radionuclides in the ALLW has significant uncertainties. Therefore, for the actinides, upper-limit and lower-limit inventories were developed to bound the actual inventory. For the nonactinides, the inventory is a best estimate. 


\section{A-3. GENERAL ASSUMPTIONS}

Three very broad, simplifying assumptions were made:

- In addressing each of the six FWFs (one at a time), all waste is in the same FWF

- Within a given FWF, the radionuclide concentrations are homogeneous over all the posttreatment waste

- All radionuclides that enter treatment with the waste stay with the treated waste.

\section{A-4. ACTINIDES}

\section{A-4.1 Initial Steps}

The inventory of actinides was developed as explained below. As will be seen, the inventory of actinides used in most of the computer runs is an upper-limit inventory. Table A-1 shows the various steps in the process.

The starting point was the pretreatment inventory for all waste emplaced in the TSA through 1992, as found in the Radioactive Waste Management Information System (RWMIS) database of shipping records. The 1992 data were the most recent available at the time this study began. Only a very few drums of waste have been emplaced since 1992.

The first column of Table A-1 lists the radionuclides in the inventory that are actinides.

Some of the actinides fall within the definition of TRU radionuclides given in DOE Order 5820.2A: atomic number $>92$, alpha emitter, half-life $>20$ years. Some do not. See the second column of Table A-1. This division of actinides into TRU and non-TRU radionuclides is key to the approach used here.

Atwood and Schlafman (1993) decayed the RWMIS inventory data discussed above from the time of emplacement to 1993 . The decayed values appear in the third column of Table A-1.

\section{A-4.2 Screening}

The inventory in the third column was subjected to three screening steps to reduce the list of radionuclides to only those of potential importance. As a first step, radionuclides in the third column with $<0.1 \mathrm{Ci}$ activity were deleted. This step eliminated Ac-227, Am-242m, Bi-214, Bk-249, Cf-249, Cf-252, Cm-242, Cm-243, Cm-246, Cm-248, Pa-233, Pb-210, Pb-214, Po-214, Po-218, Pu-236, Ra-226, Ra-228, Rn-222, Th-230, Th-234, U-228, U-235, and U-236.

The next screening step was to delete the relatively small activities of eight progeny that had grown in during the average period of 15 years since the time of waste emplacement. The maximum activity of any of these progeny in 1993 was $26.55 \mathrm{Ci}$ in the TRU waste plus the 
Table A-1. Development of simplified inventory of actinides.

\begin{tabular}{|c|c|c|c|c|c|}
\hline Radionuclide & $\begin{array}{c}\text { TRU } \\
\text { radionuclide? }^{\mathrm{a}}\end{array}$ & $\begin{array}{l}\text { Inventory in } \\
\text { TRU waste } \\
\text { and ALLW in } \\
1993 \\
\text { (Ci) }\end{array}$ & $\begin{array}{c}\text { Screened } \\
\text { inventory } \\
\text { (Ci) }\end{array}$ & $\begin{array}{c}\text { Inventory } \\
\text { normalized to } \\
1 \text { Ci total for } \\
\text { TRU } \\
\text { radionuclides }\end{array}$ & $\begin{array}{c}\text { Inventory scaled } \\
\text { up to } 100 \mathrm{nCi} / \mathrm{g} \\
\text { (after treatment) } \\
\text { in all ALLW } \\
\text { (Ci) }\end{array}$ \\
\hline Ac-227 & $\mathrm{N}$ & 0.04 & - & - & - \\
\hline Am-241 & $\mathrm{Y}$ & 89,780 & 89,780 & 0.448 & 1,340 \\
\hline Am-242m & $\mathrm{Y}$ & 0.0003 & - & - & - \\
\hline Am-243 & $\mathrm{Y}$ & 0.38 & - & - & - \\
\hline Bi-212 & $\mathrm{N}$ & 26.55 & - & - & - \\
\hline Bi-214 & $\mathrm{N}$ & $<$ E-04 & - & - & - \\
\hline Bk-249 & $\mathrm{N}$ & 0.0006 & - & - & - \\
\hline Cf-249 & $\mathrm{Y}$ & 0.01 & - & - & - \\
\hline Cf-252 & $\mathrm{N}$ & 0.004 & - & - & - \\
\hline $\mathrm{Cnn}-242$ & $\mathrm{~N}$ & $<$ E-04 & - & - & - \\
\hline $\mathrm{Cnn}-243$ & $\mathrm{Y}$ & 0.015 & - & - & - \\
\hline $\mathrm{Cnn}-244$ & $\mathrm{~N}$ & 539 & 539 & 0.0027 & 8 \\
\hline Cnn-246 & $\mathrm{Y}$ & 0.002 & - & - & - \\
\hline $\mathrm{Cnn}-248$ & $\mathrm{Y}$ & $<$ E-04 & - & - & - \\
\hline $\mathrm{Np}-237$ & $\mathrm{Y}$ & 0.3552 & - & - & - \\
\hline $\mathrm{Pa}-233$ & $\mathrm{~N}$ & $<$ E-04 & - & - & - \\
\hline $\mathrm{Pb}-210$ & $\mathrm{~N}$ & 0.018 & - & - & - \\
\hline $\mathrm{Pb}-212$ & $\mathrm{~N}$ & 26.55 & - & - & - \\
\hline $\mathrm{Pb}-214$ & $\mathrm{~N}$ & $<$ E-04 & - & - & - \\
\hline Po-212 & $\mathrm{N}$ & 17.01 & - & - & - \\
\hline Po-214 & $\mathrm{N}$ & $<$ E-04 & - & - & - \\
\hline Po-216 & $\mathrm{N}$ & 26.55 & - & - & - \\
\hline Po-218 & $\mathrm{N}$ & $<$ E-04 & - & - & - \\
\hline $\mathrm{Pu}-236$ & $\mathrm{~N}$ & 0.015 & - & - & - \\
\hline $\mathrm{Pu}-238$ & $\mathrm{Y}$ & 60,800 & 60,800 & 0.303 & 906 \\
\hline $\mathrm{Pu}-239$ & $\mathrm{Y}$ & 40,150 & 40,150 & 0.200 & 598 \\
\hline $\mathrm{Pu}-240$ & $\mathrm{Y}$ & 9,825 & 9,825 & 0.049 & 147 \\
\hline $\mathrm{Pu}-241$ & $\mathrm{~N}$ & 161,100 & 161,100 & 0.803 & 2,401 \\
\hline $\mathrm{Pu}-242$ & $\mathrm{Y}$ & 0.9451 & - & - & - \\
\hline Ra-224 & $\mathrm{N}$ & 26.55 & - & - & - \\
\hline Ra:-226 & $\mathbf{N}$ & 0.048 & - & - & - \\
\hline Ral-228 & $\mathrm{N}$ & 0.03 & - & - & - \\
\hline Rn-220 & $\mathrm{N}$ & 26.55 & - & - & - \\
\hline$R n-222$ & $\mathrm{~N}$ & $<$ E-04 & - & - & - \\
\hline Th-228 & $\mathrm{N}$ & 26.55 & - & - & - \\
\hline Th-230 & $N$ & 0.02 & - & - & - \\
\hline Th-232 & $\mathrm{N}$ & 0.3301 & - & - & - \\
\hline Th-234 & $\mathrm{N}$ & $<$ E-04 & - & - & - \\
\hline T1-208 & $\mathrm{N}$ & 9.54 & - & - & - \\
\hline U-228 & $\mathrm{N}$ & $<$ E-04 & - & - & - \\
\hline
\end{tabular}


Table A-1. (continued).

\begin{tabular}{|c|c|c|c|c|c|}
\hline Radionuclide & $\begin{array}{c}\text { TRU } \\
\text { radionuclide? }^{\mathrm{a}}\end{array}$ & $\begin{array}{l}\text { Inventory in } \\
\text { TRU waste } \\
\text { and ALLW in } \\
1993 \\
\text { (Ci) }\end{array}$ & $\begin{array}{c}\text { Screened } \\
\text { inventory } \\
\text { (Ci) }\end{array}$ & $\begin{array}{c}\text { Inventory } \\
\text { normalized to } \\
1 \mathrm{Ci} \text { total for } \\
\text { TRU } \\
\text { radionuclides }^{\mathrm{b}}\end{array}$ & $\begin{array}{c}\text { Inventory scaled } \\
\text { up to } 100 \mathrm{nCi} / \mathrm{g} \\
\text { (after treatment) } \\
\text { in all ALLW } \\
\text { (Ci) }\end{array}$ \\
\hline U-232 & $\mathrm{N}$ & 26.04 & - & - & - \\
\hline U-233 & $\mathrm{N}$ & 898.5 & 898.5 & 0.0045 & 13 \\
\hline U-234 & $\mathbf{N}$ & 5.778 & - & - & - \\
\hline U-235 & $\mathrm{N}$ & 0.067 & - & - & - \\
\hline U-236 & $\mathrm{N}$ & 0.001 & - & - & - \\
\hline U-238 & $\mathrm{N}$ & 0.1171 & 0.1171 & $5.8 \mathrm{E}-7$ & 0.0017 \\
\hline Total & & $\overline{363,313}$ & $\overline{993}$ & NA & 5,413 \\
\hline
\end{tabular}

a. A TRU radionuclide is one with an atomic number greater than 92. The definition of TRU waste in DOE Order 5820.2A includes only TRU radionuclides that are alpha-emitters and have half-lives greater than 20 years. The additional stipulations in the DOE Order are reflected in the designation of TRU radionuclides in this table.

b. All entries in the preceding column were multiplied by the normalization constant of 4.986 E-06 to arrive at the entries in this column.

Note: Totals may not match exactly because of rounding.

ALLW. As will be seen shortly in the description of the scaling process, the $26.55 \mathrm{Ci}$ corresponds to an activity of $<0.4 \mathrm{Ci}$ for any of these progeny in the ALLW in 1993. (The performance assessment calculations will allow the ingrowth again of these same radionuclides. In a period of about 15 years, essentially the same activities of the progeny will reappear.) This step results in the temporary elimination of progeny $\mathrm{Bi}-212$, Pb-212, Po-212, Po-216, Ra-224, Rn-220, Th-228, and Tl-208, which were not present in the original inventory at the time of shipment.

The last screening step was to delete several additional radionuclides. After the scaling steps to be discussed shortly, the activities of Am-243, Np-237, Pu-242, Th-232, and U-234 would all be $<0.1 \mathrm{Ci}$. The activity of U-232 would be $<0.4 \mathrm{Ci}$. Therefore, these radionuclides were eliminated from further analysis.

The result of these screening steps was to reduce the number of actinides to be modeled from 46 to 8 . See the fourth column of Table A-1. The screening process decreased the total activity by less than $0.1 \%$. 


\section{A-4.3 Scaling Preliminaries}

Based on the screened inventory for actinides in the TRU waste plus ALLW, simplified upperlimit and lower-limit inventories were estimated for the ALLW alone by use of a scaling process. Unless indicated otherwise, all of the computer runs were made using the upper-limit inventory of actinides.

The scaling process was rather involved. The first step was to assume that the activities of the respective actinides in the ALLW have the same ratios to one another as they do in the TSA waste taken as a whole (ALLW plus TRU waste). The justification for this assumption is that the TSA waste generally derives from the same processes that deal with weapons-grade plutonium or heat-source plutonium, whether the waste is the higher-concentration TRU waste $(>100 \mathrm{nCi} / \mathrm{g})$ or the lower-concentration ALLW ( $\leq 100 \mathrm{nCi} / \mathrm{g})$.

With the above assumption, the screened inventory in the fourth column could then be scaled to produce limiting inventories of actinides in the ALLW. The largest potential inventory of actinides in the ALLW corresponds to the situation in which every package of treated waste contains $100 \mathrm{nCi} / \mathrm{g}$ of TRU radionuclides. (If the concentration were larger than $100 \mathrm{nCi} / \mathrm{g}$ of TRU radionuclides, the waste would be TRU waste, not ALLW.) Correspondingly, the smallest potential inventory of actinides in the ALLW corresponds to the situation in which every package of treated waste contains $10 \mathrm{nCi} / \mathrm{g}$ of TRU radionuclides. (If the concentration were smaller than $10 \mathrm{nCi} / \mathrm{g}$ of TRU radionuclides, the waste would be non-alpha LLW, not ALLW.) These two limiting cases represent the upper and lower limits on the actinide inventory in the treated waste.

One general assumption stated in Section A-3 was that all radionuclides that enter treatment with the waste stay with the treated waste. Therefore, the pretreatment inventory, in $\mathrm{Ci}$, can be used for the posttreatment inventory.

In preparation for scaling the screened actinide inventory to the limiting cases, the inventory was first normalized to a total of $1 \mathrm{Ci}$ of TRU radionuclides. All entries were multiplied by the normalization constant of $4.986 \mathrm{E}-06$. The constant is the inverse of the total activity of longlived, alpha-emitting transuranics in the fourth column. The result appears in the fifth column of Table A-1.

\section{A-4.4 Scaling, with the Effects of One Method of Treatment}

The upper-limit actinide inventory was developed for the situation in which all containers of treated waste have $100 \mathrm{nCi} / \mathrm{g}$ of TRU radionuclides. In this situation, the calculated inventory depends on the total mass of the treated waste. (The mass of the empty containers is not considered in this analysis.) To complicate things, the posttreatment mass (a) differs from the pretreatment mass and (b) depends on the treatment method.

The estimated pretreatment mass is based on a waste volume of $24,413 \mathrm{~m}^{3}$ for the ALLW (Raivo, Eddy, and Anderson 1993) and an average waste density of $652 \mathrm{~kg} / \mathrm{m}^{3}$ from evaluations conducted in the INEL Idaho Waste Processing Facility (IWPF) Project. The result is an estimated pretreatment mass of $1.59 \mathrm{E}+10 \mathrm{~g}$. 
For simplicity in examining the effects on activity concentration, waste treatment can be considered to consist of two types of operations. The first type of operation includes those that reduce the mass of the waste. For example, incineration reduces the mass of the combustible portion of the waste. However, the estimated fraction of the ALLW that is combustible is a maximum of only $25-30 \%$ (by mass), per the IWPF Project. Suppose that $25 \%$ of the ALLW mass were essentially eliminated (reduced to a negligible mass of ash), as a result of incineration, offgassing, etc. Each pretreatment unit of mass would therefore be reduced to approximately 0.75 unit mass.

The second type of treatment covers operations that increase the mass of the waste. Immobilization increases the mass, by the addition of immobilization agents. For the FWFs considered, waste loadings range from $30-60 \%$ by mass.

It was calculated that, for the FWFs considered, the midpoint of the extreme values of the total posttreatment mass of the ALLW corresponds to a $40 \%$ waste loading. (Posttreatment mass is proportional to the inverse of the waste loading.) Because it was the midpoint, this value was used as a baseline for calculational purposes. (This midpoint loading happens to correspond to the waste loading for cement, both Portland cement/concrete (PCC) and formed under elevated temperature and pressure (FUETAP). The effects for other FWFs are discussed in Section A-8, after the nonactinide inventory is developed.) Thus, in this case, each unit mass of postincineration ALLW that undergoes (cement) immobilization increases to about 2.5 unit mass of FWF.

The cumulative effect of the two types of processes is an increase in mass from 1 unit mass of waste before treatment to approximately $0.75 \times 2.5=1.88$ unit mass of FWF after treatment. The posttreatment mass is therefore approximately $1.88 \times 1.59 \mathrm{E}+10=2.99 \mathrm{E}+10 \mathrm{~g}$.

At the upper-limit concentration of $100 \mathrm{nCi} / \mathrm{g}$, the $2.99 \mathrm{E}+10 \mathrm{~g}$ has a total TRU radionuclide activity of $100 \mathrm{nCi} / \mathrm{g} \times 2.99 \mathrm{E}+10 \mathrm{~g} \times \mathrm{E}-09 \mathrm{Ci} / \mathrm{nCi}=2,990 \mathrm{Ci}$. Therefore, the normalized entries in the fifth column of Table A-1 (totaling $1 \mathrm{Ci}$ of TRU radionuclides) were scaled by multiplying by 2,990 . The result is the estimated posttreatment inventory of actinides for the ALLW at $100 \mathrm{nCi} / \mathrm{g}$, as indicated in the last column.

\section{A-5. NONACTINIDES}

For the nonactinides, the starting point for the inventory calculations was again the RWMIS data, as decayed by Atwood and Schlafman (1993). In this case, a best estimate of the nonactinide inventory was developed, because there was no basis for estimating upper-limit and lower-limit inventories.

\section{A-5.1 Basis}

An estimate had to be made about the location of the nonactinides in the TRU waste versus in the ALLW, and in the contact-handled $(\mathrm{CH})$ waste versus in the remote-handled (RH) waste. No exact analysis of the division of these radionuclides is possible at present, so assumptions and simplifications were necessary again. 
Almost all of the computer runs were made using a nonactinide inventory based on the following simplified analysis. A few runs in the second phase of the study were made with a relined inventory of nonactinides, described in Section A-9 of this appendix, that are more realistic. A few runs in the third phase were made with a nonactinide inventory with additional refinements, described in Section A-10 of this appendix.

In the simplified inventory it was assumed that, before waste treatment, $100 \%$ of the nonactinides at the TSA are located in the very small volumetric fraction of the TRU waste and ALLW that is RH.

For this untreated $\mathrm{RH}$ waste, it was assumed that the activity fraction of the nonactinide inventory that is in the ALLW is the same as the volume fraction of waste that is ALLW. That is, it was assumed that the concentration of nonactinide activity is independent of the concentration of TRU activity.

RWMIS indicates that about $41 \%$ by volume of the RH waste is believed to contain $<100 \mathrm{nCi} / \mathrm{g}$ of TRU radionuclides and would therefore be classified as ALLW. Other studies and estimates give values ranging from 27 to $70 \%$. For this simplified calculation, the value was assumed to be $50 \%( \pm 20 \%)$. Since the activity fraction was assumed to equal the volume fraction, $50 \%$ of the nonactinide activity was assumed to be in the RH ALLW.

It was assumed in this simplified approach that the nonactinide activity in the RH ALLW waste was spread uniformly throughout all of the posttreatment (RH and CH) ALLW.

Applying these assumptions led to the development of the inventory of nonactinides shown in Table A-2. The first two columns show the TRU waste plus ALLW inventory of nonactinides, as decayed by Atwood and Schlafman (1993) from the time of emplacement to 1993. That inventory was multiplied by 0.5 to give the ALLW nonactinide inventory in the third column.

\section{A-5.2 Screening}

The inventory in the third column was subjected to screening to reduce the number of radionuclides to only those of potential importance. First, all radionuclides with $\angle 1 \mathrm{Ci}$ of activity were deleted. C-14, Co-58, Cr-51, Eu-150, Eu-152, Eu-154, Eu-155, Fe-55, Fe-59, H-3, Mn-54, Nb-95, Ta-182, Tc-99, Zn-65, and Zr-95 were thereby eliminated. Then several radionuclides were deleted based on application of the screening method of Seitz and Kocher (1993) for the groundwater pathway and on computer runs for the intrusion scenarios. This step resulted in eliminating Ce-144, Cs-134, Kr-85, Ni-63, Pm-147, and Pr-144. The screened inventory appears in the fourth column of Table A-2 and has approximately $98 \%$ of the total activity listed in the unscreened inventory.

Two final steps were entailed in developing the nonactinide inventory. One step was to apportion the mixed fission products (MFP) and unidentified $\beta-\gamma$ entries, both of which were taken to be $50 \% \mathrm{Sr}-90$ and $50 \% \mathrm{Cs}-137$, and add the resulting activity to the respective radionuclides indicated. The extremely small activity $(0.64 \mathrm{Ci})$ of mixed activation products was neglected with respect to the much larger activity of Co-60, its most likely predominant constituent. The other step was to adjust the Ba-137m activity to match that of $\mathrm{Cs}-137$, and the 
$\mathrm{Y}-90$ activity to match that of Sr-90, based on decay equilibrium considerations. The result is in the last column of Table A-2.

\section{A-6. TOTAL INVENTORY, ASSUMING $100 \mathrm{nCi} / \mathrm{g}$ TRU RADIONUCLIDES}

Table A-3 lists the total simplified inventory (as of 1993) for the ALLW. The table is the result of adding the actinide entries from Table A-1 and the nonactinide entries from Table A- 2 . All of the waste is assumed to be in posttreatment waste packages with TRU radionuclide activity of $100 \mathrm{nCi} / \mathrm{g}$, the upper limit for ALLW. 
Table A-2. Development of simplified inventory of nonactinides.

\begin{tabular}{|c|c|c|c|c|}
\hline Radionuclide & $\begin{array}{l}\text { Inventory in TRU waste } \\
\text { and ALLW in } 1993 \\
\text { (Ci) }\end{array}$ & $\begin{array}{c}0.5 \text { times } \\
\text { inventory } \\
\text { (ALLW only) } \\
\text { (Ci) }\end{array}$ & $\begin{array}{l}\text { Screened } \\
\text { inventory } \\
\quad(\mathrm{Ci})\end{array}$ & $\begin{array}{l}\text { Same activity } \\
\text { after adjustment } \\
\text { (Ci) }\end{array}$ \\
\hline $\mathrm{Ba}-137 \mathrm{~m}$ & 2,246 & 1,123 & 1,123 & 1,125 \\
\hline C-14 & $<\mathrm{E}-04$ & $<$ E-04 & - & - \\
\hline Ce-144 & 27.06 & 13 & - & - \\
\hline Co-58 & $<$ E-04 & $<$ E-04 & - & - \\
\hline $\mathrm{Co}-60$ & 94.3 & 47 & 47 & 47 \\
\hline $\mathrm{Cr}-51$ & $<\mathrm{E}-04$ & $<$ E-04 & - & - \\
\hline Cs-134 & 110.7 & 55 & - & - \\
\hline Cs-137 & 2,003 & 1,001 & 1,001 & 1,125 \\
\hline Eu-150 & $<$ E-04 & $<$ E-04 & - & - \\
\hline Eu-152 & 0.068 & 0.034 & - & - \\
\hline Eu-154 & 0.71 & 0.35 & - & - \\
\hline Eu-155 & 0.19 & 0.1 & - & - \\
\hline $\mathrm{Fe}-55$ & 1.132 & 0.57 & - & - \\
\hline $\mathrm{Fe}-59$ & $<$ E-04 & $<$ E-04 & - & - \\
\hline $\mathrm{H}-3$ & 0.8 & 0.4 & - & - \\
\hline $\mathrm{Kr}-85$ & 6.857 & 3.4 & - & - \\
\hline MAP & 1.28 & 0.64 & - & - \\
\hline MFP & 483.3 & 242 & 242 & - \\
\hline Mn-54 & 0.23 & 0.12 & - & - \\
\hline $\mathrm{Nb}-95$ & $<$ E-04 & $<$ E-04 & - & - \\
\hline $\mathrm{Ni}-63$ & 3.572 & 1.79 & - & - \\
\hline Pm-147 & 27.26 & 14 & - & - \\
\hline Pr-144 & 27.18 & 14 & - & - \\
\hline Sr-90 & 1,778 & 889 & 889 & 1,013 \\
\hline Ta-182 & $<$ E-04 & $<$ E-04 & - & - \\
\hline Tc-99 & 0.0018 & 0.0009 & - & - \\
\hline Unid. $\beta-\gamma$ & 12.44 & 6 & 6 & - \\
\hline$Y-90$ & 2,019 & 1,010 & 1,010 & 1,013 \\
\hline $\mathrm{Zn}-65$ & $<$ E-04 & $<$ E-04 & - & - \\
\hline Zr-95 & $\leq \mathrm{E}-04$ & $\leq \mathrm{E}-04$ & - & - \\
\hline Total & 8,843 & 4,421 & 4,318 & 4,323 \\
\hline
\end{tabular}

Note: Totals may not match exactly because of rounding. 
Table A-3. Total simplified inventory, assuming $100 \mathrm{nCi} / \mathrm{g}$ TRU radionuclides.

\begin{tabular}{lrc} 
Radionuclide & $\begin{array}{r}\text { Inventory in 1993 } \\
(\mathrm{Ci})\end{array}$ & $\begin{array}{c}\text { TRU radionuclide inventory } \\
(\mathrm{C})\end{array}$ \\
\hline Ba-137m & 1,125 & - \\
Co-60 & 47 & - \\
Cs-137 & 1,125 & - \\
Sr-90 & 1,013 & - \\
Y-90 & 1,013 & 1,340 \\
Am-241 & 1,340 & - \\
Cm-244 & 8 & 906 \\
Pu-238 & 906 & 598 \\
Pu-239 & 598 & 147 \\
Pu-240 & 147 & - \\
Pu-241 & 2,401 & - \\
U-233 & 13 & - \\
U-238 & 0.0017 & 2,990 \\
Total & 9,736 & - \\
\hline & &
\end{tabular}

Note: Totals may not match exactly because of rounding. 


\section{A-7. TOTAL INVENTORY, ASSUMING $10 \mathrm{nCi} / \mathrm{g}$ OR $1,000 \mathrm{nCi} / \mathrm{g}$ TRU RADIONUCLIDES}

The preceding analysis yields an upper-limit inventory, the situation in which every container has $100 \mathrm{nCi} / \mathrm{g}$ of TRU radionuclides. This section scales those inventories to the following situations: (a) every container has $10 \mathrm{nCi} / \mathrm{g}$ of TRU radionuclides, a lower-limit inventory for the ALLW; (b) every container has $1,000 \mathrm{nCi} / \mathrm{g}$ of TRU radionuclides, a situation in which the waste is actually TRU waste, not ALLW.

For the $10 \mathrm{nCi} / \mathrm{g}$ situation, it was assumed that the activity of all the actinides was reduced by a factor of 10 . The nonactinide inventory was assumed not to change because of the manner in which the inventory was derived.

The results appear in Table A-4.

For the $1,000 \mathrm{nCi} / \mathrm{g}$ situation, it was assumed that the activity of all the actinides was increased by a factor of 10 . The nonactinide inventory again was assumed not to change because of the manner in which the inventory was derived.

The results appear in Table A-5.

\section{A-8. EFFECTS OF TREATMENT ON INVENTORY FOR VARIOUS FWFS}

\section{A-8.1 Results}

As stated in Section A-4.4, the midpoint waste loading, which happened to match that of the cernent FWFs, was used to develop a baseline actinide inventory. That inventory was established at $100 \mathrm{nCi}$ of TRU radionuclides/g as an upper limit for ALLW. This section develops the corresponding radionuclide inventory for all of the FWFs.

Table A-6 presents the values of the parameters used to develop the inventory for each FW/F. The parameters of waste loading, mass change associated with treatment, posttreatment density and volume, and the total inventory of radionuclides are indicated. The first column of Table A-6 also indicates in parentheses how each derived parameter was calculated.

Because the ranges of densities for the cements and for the glasses were relatively small, the respective average densities were used for these two waste categories. The density values are $1.95 \mathrm{~g} / \mathrm{cm}^{3}$ for the cements and $2.65 \mathrm{~g} / \mathrm{cm}^{3}$ for the glasses. This simplification was not used for the ceramics because the range of densities was larger.

As Table A-6 indicates, the same radionuclide inventory, in $\mathrm{C}$, was used for all FWFs. Because of the different posttreatment masses of the FWFs, the TRU radionuclide concentration by mass must vary from one FWF to another. Only for cement is the value $100 \mathrm{nCi} / \mathrm{g}$. The values for the other FWFs are either somewhat above or somewhat below $100 \mathrm{nCi} / \mathrm{g}$. Section A-8.2 discusses this situation and its implications. 
Table A-4. Total simplified inventory, assuming $10 \mathrm{nCi} / \mathrm{g}$ TRU radionuclides.

\begin{tabular}{lcc} 
Radionuclide & $\begin{array}{c}\text { Inventory in 1993 } \\
(\mathrm{Ci})\end{array}$ & $\begin{array}{c}\text { TRU radionuclide inventory } \\
(\mathrm{Ci})\end{array}$ \\
\hline Ba-137m & 1,125 & - \\
Co-60 & 47 & - \\
Cs-137 & 1,125 & - \\
Sr-90 & 1,013 & - \\
Y-90 & 1,013 & - \\
Am-241 & 134 & 134 \\
Cm-244 & 0.8 & - \\
Pu-238 & 91 & 91 \\
Pu-239 & 60 & 60 \\
Pu-240 & 15 & 15 \\
Pu-241 & 240 & - \\
U-233 & 1.3 & - \\
U-238 & 0.00017 & - \\
Total & 4,865 & 300
\end{tabular}

Note: Totals may not match exactly because of rounding.

Table A-5. Total simplified inventory, assuming $1,000 \mathrm{nCi} / \mathrm{g}$ TRU radionuclides.

\begin{tabular}{lcc} 
& $\begin{array}{c}\text { Inventory in } 1993 \\
\text { Radionuclide }\end{array}$ & $\begin{array}{c}\text { TRU radionuclide inventory } \\
(\mathrm{Ci})\end{array}$ \\
\hline Ba-137m & 1,125 & - \\
Co-60 & 47 & - \\
Cs-137 & 1,125 & - \\
Sr-90 & 1,013 & - \\
Y-90 & 1,013 & 13,400 \\
Am-241 & 13,400 & - \\
Cm-244 & 80 & 9,060 \\
Pu-238 & 9,060 & 5,980 \\
Pu-239 & 5,980 & 1,470 \\
Pu-240 & 1,470 & - \\
Pu-241 & 24,010 & - \\
U-233 & 130 & - \\
U-238 & 0.017 & 29,910 \\
Total & 58,453 & \\
\hline
\end{tabular}


Table A-6. Values of parameters used to develop inventory of ALLW in various final waste forms.

\begin{tabular}{|c|c|c|c|c|c|}
\hline Parameter & $\begin{array}{l}\text { More favorable and } \\
\text { less favorable } \\
\text { cement } \\
\text { (FUETAP and } \\
\text { PCC) }\end{array}$ & $\begin{array}{l}\text { More } \\
\text { favorable } \\
\text { glass } \\
\left(\mathrm{ASG}^{\mathrm{a}}\right)\end{array}$ & $\begin{array}{c}\text { Less } \\
\text { favorable } \\
\text { glass } \\
\left(\mathrm{BSG}^{\mathrm{b}}\right)\end{array}$ & $\begin{array}{l}\text { More } \\
\text { favorable } \\
\text { ceramic } \\
\left(\mathrm{IEB} 4^{\mathrm{C}}\right)\end{array}$ & $\begin{array}{l}\text { Less } \\
\text { favorable } \\
\text { ceramic } \\
\left(\text { IEB }^{\mathrm{d}}\right)\end{array}$ \\
\hline 1. Waste loading, $\%$ by mass & 40 & 60 & 30 & 60 & 60 \\
\hline $\begin{array}{l}\text { 2. Mass decrease factor due to } \\
\text { incineration, etc. }\end{array}$ & 0.75 & 0.75 & 0.75 & 0.75 & 0.75 \\
\hline $\begin{array}{l}\text { 3. Mass increase factor due to } \\
\text { immobilization (100/row 1) }\end{array}$ & 2.5 & 1.67 & 3.33 & 1.67 & 1.67 \\
\hline $\begin{array}{l}\text { 4. Mass change factor (row } 2 \times \\
\text { row } 3 \text { ) }\end{array}$ & 1.88 & 1.25 & 2.5 & 1.25 & 1.25 \\
\hline $\begin{array}{l}\text { 5. Posttreatment mass, } \mathrm{g} \\
(1.59 \mathrm{E}+10 \mathrm{~g} \text { pretreatment } \times \\
\text { row } 4)\end{array}$ & $2.99 \mathrm{E}+10$ & $1.99 \mathrm{E}+10$ & $3.98 \mathrm{E}+10$ & $1.99 \mathrm{E}+10$ & $1.99 \mathrm{E}+10$ \\
\hline 6. Posttreatment density, $\mathrm{g} / \mathrm{cm}^{3}$ & 1.95 & 2.65 & 2.65 & 3.5 & 3.0 \\
\hline $\begin{array}{l}\text { 7. Posttreatment volume, } \mathrm{m}^{3} \text { (row } \\
5 \times \text { E-06/row } 6 \text { ) }\end{array}$ & $1.53 E+04$ & $7.51 \mathrm{E}+03$ & $1.50 \mathrm{E}+04$ & $5.69 E+03$ & $6.63 \mathrm{E}+03$ \\
\hline 8. Radionuclide inventory, $\mathrm{Ci}$ & $\begin{array}{l}2,990 \text { TRU } \\
5,413 \text { total actinides } \\
4,323 \text { nonactinides } \\
9,736 \text { total }\end{array}$ & Same & Same & Same & Same \\
\hline $\begin{array}{l}\text { 9. TRU radionuclide conc. by } \\
\text { mass, nCi/g }(100 \times \\
2.99 \mathrm{E}+10 / \text { row } 5)\end{array}$ & 100 & 150 & 75 & 150 & 150 \\
\hline a. ASG-aluminosilicate glass. & & & & & \\
\hline b. BSG-borosilicate glass. & & & & & \\
\hline c. IEB-iron-enriched basalt. & & & & & \\
\hline d. HEB4-enhanced iron-enriched basalt. & & & & & \\
\hline
\end{tabular}


If the simplified inventory entries in Table A-3 are divided by the total volume for each FWF in row 7 of Table A-6, the volumetric concentration of each radionuclide in each FWF is obtained. The results are given in Table A-7. These results constitute the inventory inputs to the release scenario calculations for each FWF.

\section{A-8.2 An "Overspecified" System}

In parametric studies, a complex set of parameters and their values can inadvertently become "overspecified." Numerous parameters may be specified independently, whereas in reality, certain relationships constrain the values among the parameters. To generate comparable results from one parametric run to another, inconsistencies of lesser importance may be accepted so that more important parameters have consistent values. Such is the case with the radionuclide inventories and the radionuclide concentrations by mass and volume for the various FWFs.

Let us assume that parametric computer runs are being conducted for different FWFs. If the radionuclide inventory is fixed and if the FWFs have different posttreatment masses, then the concentrations of TRU radionuclides by mass in the various FWFs must differ. The equation "radioactivity per unit mass = radioactivity/mass" relates these three parameters. If two of the parameters are specified, the third is automatically determined and cannot be picked arbitrarily.

Thus, total matchup of the parametric computer runs for different FWFs is not possible. It was considered realistic and essential that the total radionuclide inventory, in curies, be constant across all FWFs. Because the masses of the FWFs differ, the $\mathrm{nCi} / \mathrm{g}$ of TRU radionuclides varies among the FWFs.

As discussed in Section A-4.4, a midpoint value of the waste loading was selected. The inventory was established so, for the FWFs that happened to have that waste loading, a value of $100 \mathrm{nCi} / \mathrm{g}$ of TRU radionuclides resulted. This is the conservative, upper-limit situation for the ALLW. The other FWFs have waste loadings somewhat higher or lower than that of the midpoint value, and posttreatment masses that vary correspondingly. Accordingly, the concentration of TRU radionuclides is somewhat higher or lower than $100 \mathrm{nCi} / \mathrm{g}$ for these FWFs. There is no way to match all of the values across the FWFs because the FWFs differ in waste loading, posttreatment mass, density, etc.

Both the intrusion scenarios and the groundwater scenario depend on the total radioactivity per unit volume of waste. The total radioactivity is identical for all FWFs. The FWF volumes differ, so the values of $\mathrm{Ci} / \mathrm{m}^{3}$ differ, but the comparisons are on an equal footing.

In reality, during the treatment campaign, the mass differences of the various FWFs will result in some containers of treated waste crossing the boundaries representing $10 \mathrm{nCi} / \mathrm{g}$ and $100 \mathrm{nCi} / \mathrm{g}$. In this sense, the parametric computer runs do not perfectly represent the realities of operational decisions that may change the classification of a given container from TRU waste to ALLW or from ALLW to LLW, for example. Nevertheless, the current runs are sufficiently consistent among the FWFs to provide results that are reasonably comparable. 
Table A-7. Volumetric concentrations of each radionuclide in each final waste form, in $\mathrm{Ci} / \mathrm{m}^{3}$, assuming $100 \mathrm{nCi} / \mathrm{g}$ TRU radionuclides for cement.

\begin{tabular}{|c|c|c|c|c|c|}
\hline Radionuclide & $\begin{array}{l}\text { More favorable } \\
\text { and less } \\
\text { favorable cement } \\
\text { (FUETAP and } \\
\text { PCC) }\end{array}$ & $\begin{array}{c}\text { More } \\
\text { favorable } \\
\text { glass } \\
\text { (ASG) }\end{array}$ & $\begin{array}{c}\text { Less } \\
\text { favorable } \\
\text { glass } \\
\text { (BSG) }\end{array}$ & $\begin{array}{c}\text { More } \\
\text { favorable } \\
\text { ceramic } \\
\text { (IEB4) }\end{array}$ & $\begin{array}{c}\text { Less } \\
\text { favorable } \\
\text { ceramic } \\
\text { (IEB) }\end{array}$ \\
\hline $\mathrm{Ba}-137 \mathrm{~m}$ & 7.34E-02 & $1.50 \mathrm{E}-01$ & 7.49E-02 & $1.98 \mathrm{E}-01$ & $1.70 \mathrm{E}-01$ \\
\hline Co-60 & 3.07E-03 & $6.26 \mathrm{E}-03$ & 3.13E-03 & 8.27E-03 & $7.09 \mathrm{E}-03$ \\
\hline Cs-137 & 7.34E-02 & $1.50 \mathrm{E}-01$ & $7.49 \mathrm{E}-02$ & $1.98 \mathrm{E}-01$ & $1.70 \mathrm{E}-01$ \\
\hline Sr-90 & 6.61E-02 & $1.35 \mathrm{E}-01$ & $6.74 \mathrm{E}-02$ & $1.78 \mathrm{E}-01$ & 1.53E-01 \\
\hline$Y-90$ & $6.61 \mathrm{E}-02$ & 1.35E-01 & $6.74 \mathrm{E}-02$ & $1.78 \mathrm{E}-01$ & $1.53 \mathrm{E}-01$ \\
\hline Am-241 & 8.74E-02 & $1.78 \mathrm{E}-01$ & 8.92E-02 & $2.36 \mathrm{E}-01$ & $2.02 E-01$ \\
\hline $\mathrm{Cm}-244$ & $5.22 \mathrm{E}-04$ & $1.07 \mathrm{E}-03$ & 5.33E-04 & 1.41E-03 & $1.21 \mathrm{E}-03$ \\
\hline Pu-238 & $5.91 \mathrm{E}-02$ & $1.21 \mathrm{E}-01$ & $6.03 \mathrm{E}-02$ & $1.59 \mathrm{E}-01$ & 1.37E-01 \\
\hline $\mathrm{Pu}-239$ & $3.90 \mathrm{E}-02$ & 7.96E-02 & $3.98 \mathrm{E}-02$ & $1.05 \mathrm{E}-01$ & $9.02 \mathrm{E}-02$ \\
\hline $\mathrm{Pu}-240$ & $9.59 \mathrm{E}-03$ & $1.96 \mathrm{E}-02$ & $9.79 \mathrm{E}-03$ & $2.59 \mathrm{E}-02$ & $2.22 E-02$ \\
\hline $\mathrm{Pu}-241$ & $1.57 \mathrm{E}-01$ & $3.20 \mathrm{E}-01$ & $1.60 \mathrm{E}-01$ & 4.22E-01 & $3.62 \mathrm{E}-01$ \\
\hline U-233 & $8.48 \mathrm{E}-04$ & $1.73 \mathrm{E}-03$ & $8.66 \mathrm{E}-04$ & $2.29 \mathrm{E}-03$ & $1.96 \mathrm{E}-03$ \\
\hline U-238 & $1.11 \mathrm{E}-07$ & $2.26 \mathrm{E}-07$ & $1.13 \mathrm{E}-07$ & $2.99 \mathrm{E}-07$ & $2.56 \mathrm{E}-07$ \\
\hline Total & $6.35 \mathrm{E}-01$ & $1.30 \mathrm{E}+00$ & $6.48 \mathrm{E}-01$ & $1.71 E+00$ & $1.47 E+00$ \\
\hline
\end{tabular}

\section{A-9. REFINED INVENTORY FOR NONACTINIDES}

\section{A-9.1 Introduction}

Section A-5 of this appendix described how the nonactinide inventory that was used in almost all of the PA calculations was developed. Runs performed during the first phase of the study indicated a considerable dependence of some intrusion doses on the nonactinide inventory. There was a large uncertainty in that nonactinide inventory.

This section describes an improved set of assumptions used to develop a refined nonactinide inventory that is more realistic. The latter approach was used for a few PA calculations to evaluate the effect of these particular inventory assumptions. The inventory of actinides was not altered from that in Table A-3.

The distinction between the two methods lies in whether the RH ALLW and CH ALLW are addressed jointly or separately. The approach in Section A-5 was basically to (a) assume that, 
before waste treatment, all nonactinides are in the $\mathrm{RH}$ waste, (b) note that about $50 \%$ of the $\mathrm{RH}$ waste volume is ALLW, (c) assume that $50 \%$ of the RH activity is therefore in the RH ALLW, and (d) spread the resulting activity uniformly over all posttreatment $\mathrm{CH}$ and RH ALLW. The simplified approach was useful for scoping evaluations. However, it tends to overestimate the concentration of nonactinides in the CH ALLW and underestimate the concentration of nonactinides in the RH ALLW. In the following refined analysis, the RH ALLW was assumed to be treated separately from the $\mathrm{CH} A L L W$, and the nonactinide inventories were estimated separately.

It was assumed again that the distribution of nonactinides is independent of the distribution of TRU radionuclides. Thus, if a given fraction by volume of the $\mathrm{CH}$ waste is CH ALLW, then the same fraction of the nonactinides in the $\mathrm{CH}$ waste is in the $\mathrm{CH}$ ALLW. The same assumption was made for the $\mathrm{RH}$ waste, although the fraction differs.

Separate RWMIS printouts (covering combined ALLW and TRU waste) were produced for the $\mathrm{CH}$ waste and for the $\mathrm{RH}$ waste.

\section{A-9.2 CH Waste}

The process for developing the $\mathrm{CH}$ inventory is depicted in Table A-8. The first two columns list the nonactinide inventory in the $\mathrm{CH}$ waste at the time of emplacement according to RWMIS.

The next column gives an approximate value for the activity decayed to 1993 . The values are approximate because, for the nonactinides, the ratios of decayed activity to emplaced activity derived in Atwood and Schlafman (1993) for the total stored waste inventory were assumed here to apply also to the $\mathrm{CH}$ and $\mathrm{RH}$ inventories individually. Basically, this simplifying assumption implies that the $\mathrm{CH}$ and $\mathrm{RH}$ were emplaced at the same rate, in terms of activity, from 1970 through 1993. The assumption was used in lieu of performing the detailed decay calculations for every year of waste emplacement, as was done by Atwood and Schlafman.

It was next assumed that, since the $\mathrm{CH}$ ALLW has approximately $38 \%$ of the total $\mathrm{CH}$ volume, ${ }^{a}$ it also has $38 \%$ of the total $\mathrm{CH}$ activity of nonactinides. Thus, the entries in the fourth column were produced by multiplying those in the third column by 0.38 .

The inventory was subjected to screening as in Section A-5 of this appendix to reduce the number of radionuclides to only those of potential importance. All radionuclides with $<1 \mathrm{Ci}$ of activity were deleted. C-14, Ce-144, Co-58, Cr-51, Cs-134, Eu-150, Eu-152, Eu-154, Eu-155, Fe-55, H-3, Mn-54, Ni-63, Tc-99, Zn-65, and Zr-95 were thereby eliminated. The last screening step was to delete the $8.78 \mathrm{Ci}$ of $\mathrm{Pm}-147$, based on application of the screening method of Seitz

a. The volume estimates are as follows, in $\mathrm{m}^{3}: \mathrm{RH}$ total= 76 (from $\mathrm{RWMIS}$ ); $\mathrm{RH}$ ALLW $=31$ (from RWMIS); $\mathrm{CH}$ total $=63,729$ (from Raivo et al. 1993) - 76 = 63,653; $\mathrm{CH} \mathrm{ALLW}=24,413$ (from Raivo et al. 1993) $-31=24,382$. Thus, the fraction of $\mathrm{CH}$ waste that is ALLW is $24,382 / 63,653=0.38$. The fraction of RH waste that is ALLW is $31 / 76=0.41$. 
Table A-8. Development of refined inventory of nonactinides for CH ALLW.

Inventory in $\mathrm{CH}$

TRU waste and $\mathrm{CH}$

ALLW at time of emplacement

Radionuclide

Ba-137m

$\mathrm{C}-14$

Ce-144

Co-58

Co-60

Cr-51

Cs-134

Cs-137

Eu-150

Eu-152

Eu-154

Eu-155

Fe-55

H-3

MAP

MFP

Mn-54

Ni-63

Pm-147

Sr-90

Tc-99

Unid. $\beta-\gamma$

Y-90

Zn-65

Zr-95

Total
(Ci)

0

$<$ E-04

9.021

0.83

192

1.45

0.002

72.94

$<$ E-04

0.17

0.0002

$<$ E-04

0.0006

1.95

1.75

195.4

0.14

0.0001

464

0.3

0.0018

14.89

0

0.001

66.8

1,021
61.75

$<$ E-04

0.06

$<$ E-04

77.8

$<$ E-04

0.0002

61.75

$<$ E-04

0.067

$<$ E-04

$<$ E-04

0.0002

0.80

0.39

149.9

0.0003

0.0001

23.1

0.25

0.0018

12.44

0.25

$<$ E-04

$\leq$ E-04

389
0.38 times inventory (ALLW only)

(Ci)

Screened inventory

23.5

29.6

$<$ E-04

$<$ E-04

23.5

23.5

$<$ E-04

0.025

0.17

$<$ E-04

$<$ E-04

0.30

0.15

57.0

0.0001

$<$ E-04

8.78

0.095

0.0007

4.7

0.095

$<$ E-04

$\leq \mathrm{E}-04$

148
(Ci)

23.5 54.3

-

-

29.6

29.6

Same activity after adjustment

(Ci)

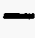

-
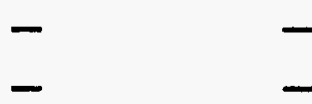

54.3

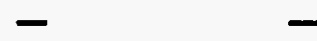


and Kocher (1993) for the groundwater pathway and on computer runs for the intrusion scenarios. The screened inventory appears in the fifth column of Table A-8. The total activity has been reduced from $148 \mathrm{Ci}$ to $139 \mathrm{Ci}$, primarily due to screening out the $8.78 \mathrm{Ci}$ of Pm-147.

Two final steps were involved in developing the refined nonactinide inventory for the $\mathrm{CH}$ ALLW. One step was to apportion the MFP and unidentified $\beta-\gamma$ entries, both of which were taken to be 50\% Sr-90 and 50\% Cs-137, and add the resulting activity to the respective radionuclides indicated. The extremely small activity $(0.15 \mathrm{Ci})$ of mixed activation products (MAP) was neglected compared to the much larger activity of Co-60, its most likely predominant constituent. The other step was to readjust the Ba-137m activity to match that of Cs-137, and the Y-90 activity to match that of Sr-90, based on decay equilibrium considerations. The result is in the last column of Table A-8.

Comparison of the last column of Table A-8 (the refined inventory for nonactinides) with the last column of Table A-2 (the simplified inventory for nonactinides) shows a large reduction in the nonactinide inventory in the CH ALLW. The Cs-137 activity is reduced to about $5 \%$ of its previous value; Sr-90, to about 3\%. (The Co-60 activity is still about $63 \%$ of its earlier value, however.) The list of radionuclides that survived the screening is unchanged.

The volume of the CH ALLW is virtually identical to that of the total ALLW $\left(24,382 \mathrm{~m}^{3}\right.$ versus $24,413 \mathrm{~m}^{3}$ ). Therefore, the concentrations of the nonactinides obtained in the refined inventory are reduced in proportion to their respective reductions in radioactivity.

\section{A-9.3 RH Waste}

The process for developing the $\mathrm{RH}$ waste inventory is similar to that for the $\mathrm{CH}$ waste and is depicted in Table A-9. The first two columns list the nonactinide inventory in the RH waste at the time of emplacement, according to RWMIS. The next column gives an approximate value for the activity decayed to 1993, using the approach described for the CH waste in Section A-9.2 of this appendix.

It was next assumed that, since the RH ALLW has approximately $41 \%$ of the total RH volume ( 31 of $76 \mathrm{~m}^{3}$, based on the RWMIS information), it also has $41 \%$ of the total RH activity of nonactinides. Thus, the entries in the fourth column were produced by multiplying those in the third column by 0.41 . (This fraction differs somewhat from the 0.5 value used for Table A-2 because it is based solely on the RWMIS value, which is probably the most reliable among the estimates that have been made.)

The inventory was subjected to screening (as in Section A-5 of this appendix) to reduce the number of radionuclides to only those of importance. All radionuclides with $\angle 1 \mathrm{Ci}$ of activity were deleted. Co-58, Cr-51, Eu-154, Eu-155, Fe-55, Fe-59, Mn-54, Nb-95, Rh-106, Ru-106, $\mathrm{Sb}-125, \mathrm{Ta}-182$, and $\mathrm{Zr}-95$ were thereby eliminated. The last screening step was to delete the Ce-144, Cs-134, Kr-85, Ni-63, and Pm-147 based on application of the screening method of Seitz and Kocher (1993) for the groundwater pathway and on computer runs for the intrusion scenarios. The screened inventory appears in the fifth column of Table A-9 and totals $98 \%$ of that before screening. 
Table A-9. Development of refined inventory of nonactinides for RH ALLW.

\begin{tabular}{|c|c|c|c|c|c|}
\hline Radionuclide & $\begin{array}{l}\text { Inventory in RH TRU } \\
\text { waste and RH ALLW } \\
\text { at time of emplacement } \\
\text { (Ci) }\end{array}$ & $\begin{array}{l}\text { Inventory } \\
\text { in } 1993 \\
\text { (Ci) }\end{array}$ & $\begin{array}{l}0.41 \text { times } \\
\text { inventory } \\
\text { (ALLW only) } \\
\text { (Ci) }\end{array}$ & $\begin{array}{c}\text { Screened } \\
\text { inventory } \\
\text { (Ci) }\end{array}$ & $\begin{array}{l}\text { Same activity } \\
\text { after } \\
\text { adjustment } \\
\text { (Ci) }\end{array}$ \\
\hline Ba- $137 m$ & 97.33 & 1,984 & 813 & 813 & 882 \\
\hline Ce-144 & 3,890 & 27 & 11.1 & - & - \\
\hline Co-58 & 112.4 & $<$ E-04 & $<$ E-04 & - & - \\
\hline Co-60 & 40.64 & 16.5 & 6.8 & 6.8 & 6.8 \\
\hline Cr-51 & 7.01 & $<$ E-04 & $<$ E-04 & - & - \\
\hline Cs-134 & 929.6 & 110.7 & 45.4 & - & - \\
\hline Cs-137 & 2,343 & 1,984 & 813 & 813 & 882 \\
\hline Eu-154 & 1.555 & 0.71 & 0.29 & - & - \\
\hline Eu-155 & 0.78 & 0.19 & 0.08 & - & - \\
\hline Fie-55 & 3.858 & 1.13 & 0.46 & - & - \\
\hline Fe-59 & 5.34 & $<$ E-04 & $<$ E-04 & - & - \\
\hline $\mathrm{Kr}-85$ & 9.362 & 6.86 & 2.81 & - & - \\
\hline MAP & 4.0 & 0.89 & 0.36 & - & - \\
\hline MFP & 434.5 & 333 & 137 & 137 & - \\
\hline Mn-54 & 115.4 & 0.23 & 0.09 & - & - \\
\hline $\mathrm{Nb}-95$ & 0.72 & $<$ E-04 & $<\mathrm{E}-04$ & - & - \\
\hline $\mathrm{Ni}-63$ & 3.694 & 3.572 & 1.46 & - & - \\
\hline F'm-147 & 84.13 & 4.18 & 1.71 & - & - \\
\hline Fh-106 & 1.3 & $<$ E-04 & $<$ E-04 & - & - \\
\hline Ru-106 & 105.4 & 0.19 & 0.08 & - & - \\
\hline $\mathrm{Sb}-125$ & 6.087 & 1.647 & 0.68 & - & - \\
\hline Sr-90 & 2,115 & 1,777 & 729 & 729 & 798 \\
\hline Ta-182 & 0.735 & $<$ E-04 & $<$ E-04 & - & - \\
\hline$Y-90$ & 101.8 & 1,777 & 729 & 729 & 798 \\
\hline Zrr-95 & 0.432 & $\leq \mathrm{E}-04$ & $<\mathrm{E}-04$ & - & - \\
\hline Total & 10,414 & 8,029 & 3,292 & 3,228 & 3,367 \\
\hline
\end{tabular}


Two final steps were involved in developing the refined nonactinide inventory for the RH ALLW. One step was to apportion the MFP, which were taken to be 50\% Sr-90 and 50\% Cs-137, and add the resulting activity to the respective radionuclides indicated. The extremely small activity $(0.36 \mathrm{Ci})$ of mixed activation products (MAP) was neglected compared to the much larger activity of Co-60, its most likely predominant constituent. The other step was to readjust the Ba-137m activity to match that of Cs-137, and the Y-90 activity to match that of Sr-90, based on decay equilibrium considerations. The result is in the last column of Table A-9.

The activity values in the last column of Table A-9 are slightly smaller than the corresponding values in the last column of Table A-2. (One exception is Co-60, which is much smaller-only about $14 \%$ of its earlier value.) This result was expected because (a) the activity in the CH ALLW was addressed separately from the RH ALLW and (b) the volume (and activity) of the RH ALLW was assumed to be only $41 \%$, rather than the $50 \%$ used previously, of the total for the RH waste.

The volume of the RH ALLW is only about $0.13 \%$ of the total ALLW (31 $\mathrm{m}^{3}$ versus $24,413 \mathrm{~m}^{3}$ ). Therefore, the concentrations of the nonactinides obtained using the refined assumptions are about $1 / 0.0013=770$ times larger than the values developed using the simplified methods described in Section A-5 of this appendix.

Tables A-8 and A-9 indicate that approximately $95 \%$ of the nonactinide activity in the TRU waste and ALLW in 1993 is in the RH waste: $8,029 /(8,029+389)$. The simplified assumption discussed in Section A-5.1 was $100 \%$.

\section{A-9.4 Conclusions}

The refined assumptions result in the activity and the activity concentration of the nonactinides generally decreasing by factors of 20 to 30 (depending on the radionuclide) for the CH ALLW. This decrease would be expected to reduce the receptor dose substantially for the intruder scenarios.

For the RH ALLW, the refined assumptions result in little change in the nonactinide activity inventory except an increase by a factor of about 770 in the activity concentration. This increase would be expected to substantially increase the receptor dose for intruder scenarios in which penetration of the waste occurs.

\section{A-10. ADDITIONAL REFINEMENTS TO NONACTINIDE INVENTORY}

\section{A-10.1 Introduction}

This section reports two investigations undertaken during the third phase of the study to produce "additional refinements" to the nonactinide inventory:

- In one investigation, the RWMIS entries for each untreated waste shipment to the TSA containing nonactinides totaling $>1 \mathrm{Ci}$ were examined to determine whether the 
containers in the shipment would be expected to be TRU waste or ALLW, and CH waste or RH waste. This was done rather than making broad assumptions about the distribution of nonactinides in TRU waste versus ALLW, and in $\mathrm{CH}$ waste versus RH waste, as had been done in the two preceding inventories. Based on these new determinations, the estimate of the ALLW nonactinide inventory was revised.

- In the other investigation, additional information on the nonactinide inventory was obtained from sources other than RWMIS.

The resulting "inventory with additional refinements" is described in this section. It was used in a limited number of runs that are so identified. The actinide inventory was not altered from that in Table A-3.

\section{A-10.2 Distribution of Nonactinides Between ALLW and TRU Waste Based on the Examination of the Records for Individual Shipments}

The RWMIS data on individual waste shipments were examined to identify the nonactinides that were believed to be in the ALLW, as opposed to the TRU waste. This search, which was performed at the level of waste shipments rather than at the level of individual waste containers, was performed as follows.

A search of the RWMIS database included all shipments of waste placed into storage at the TSA. Separate searches were conducted for $\mathrm{CH}$ waste, which was placed on the TSA pads, and RH waste, which was placed in the ILTSF.

All shipments with a total nonactinide inventory of $>1 \mathrm{Ci}$ were flagged. Shipments with this flag were then sorted into those expected to be assayed as TRU waste versus those expected to be ALLW. The sorting was done by calculating (in accordance with DOE Order 5820.2A) the total TRU activity in the shipment and dividing by the mass of the waste in the shipment. To be conservative, any shipments with an average activity of $<200 \mathrm{nCi}$ TRU/g of waste were included in the ALLW. Using $200 \mathrm{nCi} / \mathrm{g}$ rather than the prescribed cutoff of $100 \mathrm{nCi} / \mathrm{g}$ provided a conservatism of a factor of 2 in estimating which shipments are ALLW rather than TRU waste.

The number of $\mathrm{CH}$ waste shipments identified under the above criteria was 53 from five generators. For RH waste, the number of such shipments was 63 from three generators.

All individual nonactinide entries $>0.1 \mathrm{Ci}$ were then summed over all such shipments. The results are given in Tables $\mathrm{A}-10$ and $\mathrm{A}-11$ for $\mathrm{CH}$ waste and $\mathrm{RH}$ waste, respectively. As in Section A-5, entries listed as MFP or unidentified $\beta-\gamma$ were assumed to be $50 \%$ Cs-137 and $50 \%$ Sr-90. Also as in Section A-5, the activities of Ba-137m and Y-90 were adjusted to match those of $\mathrm{Cs}-137$ and $\mathrm{Sr}-90$, respectively. 
Table A-10. Nonactinide inventory assigned to CH ALLW by use of RWMIS records of individual shipments.

\begin{tabular}{lcc}
\hline Radionuclide & $\begin{array}{c}\text { Reported activity } \\
(\mathrm{Ci})\end{array}$ & $\begin{array}{c}\text { Activity after } \\
\text { adjustment } \\
(\mathrm{Ci})\end{array}$ \\
\hline Ba-137m & - & 88.6 \\
Ce-144 & 1.0 & 1.0 \\
Co-60 & 39.2 & 39.2 \\
Cs-137 & 16.5 & 88.6 \\
MFP & 137.8 & - \\
Sr-90 & - & 72.1 \\
Unid. $\beta-\gamma$ & 6.3 & - \\
Y-90 & - & 72.1 \\
Zr-95 & 11.9 & 11.9 \\
Total & 212.7 & 373.5 \\
\hline
\end{tabular}

Table A-11. Nonactinide inventory assigned to RH ALLW by use of RWMIS records of individual shipments.

\begin{tabular}{lcc}
\hline Radionuclide & $\begin{array}{c}\text { Reported activity } \\
(\mathrm{C})\end{array}$ & $\begin{array}{c}\text { Activity after } \\
\text { adjustment } \\
(\mathrm{Ci})\end{array}$ \\
\hline Ba-137m & - & 165.0 \\
Ce-144 & 165.4 & 165.4 \\
Co-58 & 13.2 & 13.2 \\
Co-60 & 1.4 & 1.4 \\
Cr-51 & 1.0 & 1.0 \\
Cs-134 & 58.1 & 58.1 \\
Cs-137 & 149.0 & 165.0 \\
Fe-59 & 1.3 & 1.3 \\
MFP & 32.0 & - \\
Mn-54 & 13.4 & 13.4 \\
Nb-95 & 0.3 & 0.3 \\
Sr-90 & 102.4 & 118.4 \\
Y-90 & - & 118.4 \\
Zr-95 & 0.2 & 0.2 \\
Total & 537.7 & 821.1 \\
\hline & & \\
\hline
\end{tabular}




\section{A-10.3 Additional Inventory Information from Sources other than RWMIS}

The shipping records and their compilation as the RWMIS database often provide incomplete information on the radionuclides in the waste. Other sources of information sometimes contain useful data on the identity and activity of the radionuclides. Several potential sources of information on the nonactinides in the ALLW were investigated. That new information is discussed below.

\section{A-10.3.1 Tritium}

Based on RWMIS data, Atwood and Schlafman (1993) listed an activity of only $1.95 \mathrm{Ci}$ of tritium (H-3) in the waste stored in the TSA. Radioactive decay had reduced the activity, recorded in 1977 , to $0.7978 \mathrm{Ci}$ by 1993 . Examination of the RWMIS entry indicates that the waste containing the H-3 is likely to be ALLW, not TRU waste.

As described below, the present task led to the conclusion that additional H-3, not reported in RWMIS, is in the stored waste.

Two incidents at the Rocky Flats Plant resulted in tritium-contaminated waste being sent to the TSA (Clements 1984). Nearly all of the tritium in the stored waste is believed to exist in waste generated during the cleanup and decontamination work stemming from these two incidents.

Information was compiled in Clements (1984) on the tritium-contaminated waste from these incidents, based primarily on operator interviews. That document was used to develop the following inventory of tritium in the ALLW.

Tritium-bearing waste associated with the first incident was shipped to the TSA in late 1973 and early 1974. The great majority of the tritium is located in a total of 11 drums. Very small amounts of tritium (possibly up to the $\mathrm{mCi}$ range) were in drums shipped later.

Of the 11 drums, 9 were shown by assay at Rocky Flats Plant to have at least $1 \mathrm{~g} \mathrm{Pu}$ and are almost certainly TRU waste, not ALLW. Two drums were shown by assay to have $<1 \mathrm{~g} \mathrm{Pu}$. These two drums could conceivably be ALLW. (For a 300-lb drum, for example, about $0.17 \mathrm{~g}$ of weapons-grade $\mathrm{Pu}$ would represent a concentration of $100 \mathrm{nCi}$ TRU/g.) Conservatively, it was assumed that these two drums were ALLW.

In the absence of more definitive information, the distribution of tritium throughout the 11 drums was assumed to be uniform. The activity of tritium in the two ALLW drums was thus estimated to be $2 / 11$ of the total of approximately $600-800 \mathrm{Ci}$ for the 11 drums, or $109-145 \mathrm{Ci}$. For the PA inventory, the conservative value assumed was $145 \mathrm{Ci}$ as of late 1973.

The waste form in one of the two assumed ALLW drums resulting from the first incident is wet combustibles. In the other drum, the waste form is leaded rubber gloves. A conservative assumption indicated that the release mechanism for tritium was surface washoff. If the tritium 
turns out to be a substantial contributor to dose in the PA, then a more realistic release mechanism, such as a dissolution process, may be used.

Tritium-bearing waste associated with the second incident is located in two drums shipped in 1981. These drums may or may not be ALLW. It was assumed here that both drums were ALLW. The amount of tritium in each of these drums was estimated to be $1 \mathrm{Ci}$, for a total of 2 $\mathrm{Ci}$. The waste is in the form of dry combustibles, and a surface washoff release mechanism was assumed.

Based on the above information, the total activity of tritium in the ALLW "inventory with additional refinements" was assumed conservatively to be $145+2+1.95=149 \mathrm{Ci}$ at the time of generation. An amount of $145 \mathrm{Ci}$ was generated in late 1973, plus $2 \mathrm{Ci}$ in 1981 , plus the $1.95 \mathrm{Ci}$ listed in RWMIS that was recorded in 1977. A surface washoff release mechanism was assumed for the initial performance evaluations. The drums containing $\mathrm{H}-3$ were assumed to be $\mathrm{CH}$ waste. No credit was taken for removal of $\mathrm{H}-3$ from the waste during waste treatment.

\section{A-10.3.2 Nonactinides in Radiation Sources}

Clements and Darnell's study (1994), which is based on studies performed in 1979 and 1980 , provides data that are not in RWMIS on radiation sources in RFP waste received at the RWMC. Separate listings are given for the larger and smaller sources. Some of these sources are in the stored waste, and some are in the buried waste. Of those in the stored waste, some may be in the ALLW and some in the TRU waste.

The data in Table A-12 on the nonactinides (plus Ra-226) in the radiation sources from RFP were obtained from Clements and Darnell (1994). All entries with an activity of $0.1 \mathrm{Ci}$ or greater were included.

Waste packages shipped before or during October 1970 are generally considered to have been buried in the SDA rather than stored in the TSA. Therefore, the drums in the first, third, and fourth entries were assumed to have been buried and are outside the scope of this study.

The second entry is probably not TRU waste because it appears that only radiation sources, lead, and concrete were placed into this drum. Apparently, these particular sources were placed in sole-purpose packages, rather than being added to existing drums already containing waste.

The only nonactinide listed in RWMIS for stored waste from Rocky Flats Plant is the 1.95 $\mathrm{Ci}$ of H-3 discussed in A-10.3.1. It is associated with waste retrieved from Pits 11 and 12 and placed into storage. Based on Card (1977), that waste was buried in Pits 11 and 12 in 1970. Therefore, the $1.95 \mathrm{Ci}$ of $\mathrm{H}-3$ from RFP that is listed in RWMIS does not include any of the H-3 sources in the fifth through ninth entries listed above.

Thus, all of the entries except the first, third, and fourth are (a) in the stored waste, (b) not included in the RWMIS printouts used in the previous ALLW PA inventories, and (c) because of the years in which they were shipped, not included in the H-3 discussed in Section A-10.3.1. 
Table A-12. Nonactinides plus Ra-226 in radiation sources received from the Rocky Flats Plant.

\begin{tabular}{|c|c|c|c|c|}
\hline Shipping date & Package number & Nonactinide activity & Form & TRU waste? \\
\hline $6-18-70^{a}$ & Drum 444-679 & $\begin{array}{l}174 \mathrm{Ci} \mathrm{Co}-60 \\
214 \mathrm{Ci} \mathrm{Cs}-137\end{array}$ & Lead shielded & Probably not \\
\hline $5-9-73$ & Drum $68-8$ & $64 \mathrm{Ci} \mathrm{Co}-60$ & Lead shielded & Probably not \\
\hline $10-70^{\mathrm{a}}$ & $\begin{array}{l}\text { Drum (no } \\
\text { number) }\end{array}$ & $0.36 \mathrm{H}-3$ & Unknown & Unknown \\
\hline $10-70^{a}$ & $\begin{array}{l}\text { Drum (no } \\
\text { number) }\end{array}$ & $0.1 \mathrm{Ci} \mathrm{Ra}-226$ & Unknown & Unknown \\
\hline 1975 & Box 1544-85251 & $5 \mathrm{Ci} \mathrm{H}-3$ & Unknown & Unknown \\
\hline 1975 & Drum 36-01846 & $0.25 \mathrm{Ci} \mathrm{H}-3$ & Scandium tritide & Unknown \\
\hline 1977 & Drum D05548 & $0.25 \mathrm{Ci} \mathrm{H}-3$ & Unknown & Unknown \\
\hline $3-31-77$ & Drum 742-25064 & $3.1 \mathrm{Ci} \mathrm{H}-3$ & Unknown & Unknown \\
\hline 8-78 & Drum 742-25667 & $1.5 \mathrm{Ci} \mathrm{H}-3$ & Scandium tritide & Unknown \\
\hline
\end{tabular}

a. Assumed to be in buried waste; not included in this study.

Based on the preceding discussion, the "inventory with additional refinements" was supplemented to include the activity listed in Table A-13.

The $64 \mathrm{Ci}$ of Co-60 were assumed to be in the ALLW. The containers totaling $10 \mathrm{Ci}$ of $\mathrm{H}-3$ were assumed to be in the ALLW. These activities do not reflect radioactive decay.

It was assumed that the $\mathrm{H}-3$ is in $\mathrm{CH}$ waste. For the Co-60, it was assumed that during treatment, the source will be removed from its lead-shielded $\mathrm{CH}$ drum and addressed with the RH waste.

\section{A-10.3.3 Possible Presence of Other Radionuclides}

The radionuclides C-14, I-129, and Tc-99 are often present in small activities in waste generated as a result of the operation of nuclear reactors. The activities of these radionuclides are difficult to measure; they are often not reported or underreported in waste shipping records.

Table A-13. Nonactinides in radiation sources in stored ALLW received from Rocky Flats Plant.

\begin{tabular}{lll}
\hline Radionuclide & Activity & \multicolumn{1}{c}{ Release mechanism for untreated waste } \\
\hline Co-60 & $64 \mathrm{Ci}$ & $\begin{array}{l}\text { Entrapped in metallic matrix } \\
\text { H.-3 }\end{array}$ \\
$10 \mathrm{Ci}$ & $\begin{array}{l}\text { Conservatively, surface washoff was assumed; if the H-3 impacts the } \\
\text { dose, a more realistic, corrosion-based mechanism involving } \\
\text { scandium tritide can be used }\end{array}$ \\
\hline
\end{tabular}


Activities of $4 \mathrm{E}-5 \mathrm{Ci}$ and $1.8 \mathrm{E}-3 \mathrm{Ci}$ for C-14 and Tc-99, respectively, were reported in RWMIS for the total of all waste (TRU waste plus ALLW) in the TSA (Atwood and Schlafman 1993). No I-129 was reported.

The radionuclides C-14, I-129, and Tc-99 are potentially of interest in PAs because they are very long-lived and are relatively mobile in groundwater. To project their potential effect on doses in this preliminary parametric PA, a conservative estimate of their possible activity in the ALLW was developed as follows.

The activities of these difficult-to-measure radionuclides are often estimated by comparing them with the activities of radionuclides that are readily measured. The activity of C-14 is compared with that of Co-60; the activities of I-129 and Tc-99 are compared with that of Cs-137. Typical values of these activity ratios, often called scaling factors, have been determined (EPRI 1987) by evaluating a large quantity of laboratory data. There is considerable scatter in the data for these three particular radionuclides.

The scaling factor approach has been used to attribute activities of these three radionuclides to some of the waste buried in the RWMC Subsurface Disposal Area (Lockheed Idaho 1995). The conservative estimates developed here were based on the use of scaling factors taken from that reference.

The scaling factor for C-14 in INEL buried waste typically ranges from $1 \mathrm{E}-3$ to $1 \mathrm{E}-2$ (Lockheed Idaho 1995), depending on the nature of the waste. If one conservatively multiplies the largest of these values, $1 \mathrm{E}-2$, by the estimated total activity of $104.6 \mathrm{Ci}$ of $\mathrm{Co}-60$ from Tables A-10, A-11, and A-13, the result is $1.0 \mathrm{Ci}$ of $\mathrm{C}-14$.

The scaling factor for Tc-99 in INEL buried waste typically ranges from 1E-5 to $2 \mathrm{E}-4$ (Lockheed Idaho 1995), depending on the nature of the waste. If one conservatively multiplies the largest of these values, $2 \mathrm{E}-4$, by the estimated total activity of $253.6 \mathrm{Ci}$ of $\mathrm{Cs}-137$ from Tables A-10, A-11, and A-13, the result is $0.05 \mathrm{Ci}$ of Tc-99.

The scaling factor for I-129 in INEL buried waste typically ranges from 3E-8 to 7E-8 (Lockheed Idaho 1995), depending on the nature of the waste. If one conservatively multiplies the largest of these values, 7E-8, by the estimated total activity of $253.6 \mathrm{Ci}$ of $\mathrm{Cs}-137$ from Tables A-10, A-11, and A-13, the result is $1.8 \mathrm{E}-5 \mathrm{Ci}$ of $\mathrm{I}-129$.

Despite their very small activities, C-14, Tc-99, and I-129 are potentially important contributors to the dose via the groundwater transport pathway. Therefore, the conservatively estimated activities of $1.0 \mathrm{Ci}, 0.05 \mathrm{Ci}$, and $1.8 \mathrm{E}-5 \mathrm{Ci}$, respectively, were retained for the groundwater pathway screening evaluation discussed in Section A-10.5. Because it is not known whether these three radionuclides could be in the $\mathrm{CH}$ waste or the $\mathrm{RH}$ waste, their activities were conservatively included in both types of waste but were counted only once in the total nonactinide inventory for the $\mathrm{CH}$ waste plus $\mathrm{RH}$ waste. 


\section{A-10.4 Nonactinide Inventory with Additional Refinements}

This section presents the tables for the "inventory with additional refinements" and describes how they were compiled.

The nonactinide "inventory with additional refinements" is presented in Table A-14 for the $\mathrm{CH}$ portion, Table A-15 for the RH portion, and Table A-16 for the combined $\mathrm{CH}$ and $\mathrm{RH}$ contributions. These nonactinide inventories, combined with the unchanged actinide inventory from Table A-3, were used in a limited number of runs that are so identified.

The second column of each table lists the activity of each radionuclide at the time of generation. These entries were compiled from Tables A-10, A-11, and A-13, and the discussion in Section A-10.3.3.

A simplified approach was used to estimate the radioactive decay of the nonactinides from the time of generation through 1993. The approach is indicated in the third and fourth columns of Tables A-14 and A-15. Nonactinides were identified in RWMIS in a total of 116 shipments of ALLW over a period of many years. Half of the radioactivity in the CH waste in the TSA had been received by about 1980; half of the radioactivity in the $\mathrm{RH}$ waste had been received by about 1985 (DOE 1994). As an approximation, the nonactinides in the $\mathrm{CH}$ waste were understood to have been generated in 1980 , and the nonactinides in the RH waste were understood to have been generated in 1985.

Exceptions to the above simplification involved a small number of additional ALLW shipments that, as discussed in Section A-10.3, contained H-3 or radiation sources and were not reported in RWMIS. For the shipments containing major entries of $\mathrm{H}-3$ or radiation sources, the exact years of generation were used herein to calculate radioactive decay. Approximations were used for the dates of generation of shipments containing the smaller activities.

The next column of Tables A-14 through A-16 shows the activity after screening out certain radionuclides from the inventory. If a radionuclide would make a negligibly small contribution to the groundwater transport dose and to the intrusion scenario doses, then the radionuclide was deleted from the inventory. The method for making this determination was as follows. Section 2.5 presents the screening evaluation for the dose from groundwater transport. In those evaluations, all nonactinides in the inventory with additional refinements were screened out except H-3, C-14, Tc-99, and I-129. These four radionuclides were retained in the inventory because of their potential contribution to the groundwater transport dose. Other radionuclides with activities <1 $\mathrm{Ci}$ in 1993 were deleted from the inventory because they were considered (a) not to be substantial contributors to the intrusion scenario dose and (b) not to be substantial contributors to the groundwater transport dose. This led to deleting Ce-144, Co-58, Cr-51, Fe-59, $\mathrm{Mn}-54, \mathrm{Nb}-95$, and $\mathrm{Zr}-95$ from the inventory. All other indicated nonactinides were retained for the intrusion evaluations. H-3, C-14, Tc-99, and I-129 were the only nonactinides included in the groundwater transport evaluations. The entries in this column of the table were used in the PA ruris. 
Table A-14. Nonactinide inventory with additional refinements for CH ALLW.

\begin{tabular}{|c|c|c|c|c|c|}
\hline Radionuclide & $\begin{array}{l}\text { Activity at } \\
\text { time of } \\
\text { generation } \\
\text { (Ci) }\end{array}$ & $\begin{array}{l}\text { Approximate } \\
\text { year of } \\
\text { generation }\end{array}$ & $\begin{array}{c}\text { Activity } \\
\text { in } 1993 \\
\text { (Ci) }\end{array}$ & $\begin{array}{l}\text { Activity after } \\
\text { screening } \\
\text { (Ci) }\end{array}$ & $\begin{array}{l}\text { Activity in refined } \\
\text { inventory as } \\
\text { of } 1993 \\
\text { (Ci) }\end{array}$ \\
\hline $\mathrm{Ba}-137 \mathrm{~m}$ & 88.6 & 1980 & 67.3 & 67.3 & 54.3 \\
\hline C-14 & $<1.0$ & 1980 & $<1.0$ & 1.0 & - \\
\hline Ce-144 & 1.0 & 1980 & 2.3E-5 & - & - \\
\hline $\mathrm{Co}-60$ & 39.2 & 1980 & 8.1 & 8.1 & 29.6 \\
\hline Cs -137 & 88.6 & 1980 & 67.3 & 67.3 & 54.3 \\
\hline $\mathrm{H}-3$ & 159 & $\begin{array}{l}145 \mathrm{Ci} \text { in } 1973 \\
5 \mathrm{Ci} \text { in } 1975 \\
7 \mathrm{Ci} \text { in } 1977 \\
2 \mathrm{Ci} \text { in } 1981\end{array}$ & 55.8 & 55.8 & - \\
\hline $\mathrm{I}-129$ & $<1.8 \mathrm{E}-5$ & 1980 & $<1.8 \mathrm{E}-5$ & $1.8 \mathrm{E}-5$ & - \\
\hline Sr-90 & 72.1 & 1980 & 54.1 & 54.1 & 30.9 \\
\hline Tc-99 & $<0.05$ & 1980 & $<0.05$ & 0.05 & - \\
\hline Y-90 & 72.1 & 1980 & 54.1 & 54.1 & 30.9 \\
\hline $\mathrm{Zr}-95$ & 11.9 & 1980 & $\approx 0$ & - & - \\
\hline Total & 533.5 & $\mathrm{NA}$ & 307.7 & 307.7 & 200 \\
\hline
\end{tabular}

a. Taken from Table A-8. 
Table A-15. Nonactinide inventory with additional refinements for RH ALLW.

\begin{tabular}{|c|c|c|c|c|c|}
\hline Radionuclide & $\begin{array}{l}\text { Activity at } \\
\text { time of } \\
\text { generation } \\
\text { (Ci) }\end{array}$ & $\begin{array}{c}\text { Approximate } \\
\text { year of } \\
\text { generation }\end{array}$ & $\begin{array}{c}\text { Activity } \\
\text { in } 1993 \\
\text { (Ci) }\end{array}$ & $\begin{array}{l}\text { Activity after } \\
\text { screening } \\
\text { (Ci) }\end{array}$ & $\begin{array}{l}\text { Activity in refined } \\
\text { inventory as } \\
\text { of } 1993 \\
\text { (Ci) }\end{array}$ \\
\hline Ba-137m & 165.0 & 1985 & 140.5 & 140.5 & 882 \\
\hline C-14 & $<1.0$ & 1985 & $<1.0$ & 1.0 & - \\
\hline Ce-144 & 165.4 & 1985 & 0.325 & - & - \\
\hline Co- 58 & 13.2 & 1985 & $\approx 0$ & - & - \\
\hline $\mathrm{Co}-60$ & 65.4 & $\begin{array}{l}64 \mathrm{Ci} \text { in } 1973 \\
1.4 \mathrm{Ci} \text { in } 1985\end{array}$ & 5.82 & 5.82 & 6.8 \\
\hline $\mathrm{Cr}-51$ & 1.0 & 1985 & $\approx 0$ & - & - \\
\hline Cs-134 & 58.1 & 1985 & 5.5 & 5.5 & - \\
\hline Cs-137 & 165.0 & 1985 & 140.5 & 140.5 & 882 \\
\hline $\mathrm{Fe}-59$ & 1.3 & 1985 & $\approx 0$ & - & - \\
\hline I-129 & $<1.8 \mathrm{E}-5$ & 1985 & $<1.8 \mathrm{E}-5$ & $1.8 \mathrm{E}-5$ & - \\
\hline$M n-54$ & 13.4 & 1985 & 0.046 & - & - \\
\hline $\mathrm{Nb}-95$ & 0.3 & 1985 & $\approx 0$ & - & - \\
\hline Sr-90 & 118.4 & 1985 & 100.2 & 100.2 & 798 \\
\hline Tc-99 & $<0.05$ & 1985 & $<0.05$ & 0.05 & - \\
\hline$Y-90$ & 118.4 & 1985 & 100.2 & 100.2 & 798 \\
\hline $2 x-95$ & 0.2 & 1985 & $\approx 0$ & - & - \\
\hline Total & 886.1 & $\mathrm{NA}$ & 494.1 & 493.8 & 3366.8 \\
\hline
\end{tabular}

a. Taken from Table A-9. 
Table A-16. Nonactinide inventory with additional refinements for $\mathrm{CH}$ plus RH ALLW.

\begin{tabular}{|c|c|c|c|c|c|}
\hline Radionuclide & $\begin{array}{l}\text { Activity at } \\
\text { time of } \\
\text { generation } \\
\text { (Ci) }\end{array}$ & $\begin{array}{l}\text { Activity } \\
\text { in } 1993 \\
\text { (Ci) }\end{array}$ & $\begin{array}{l}\text { Activity after } \\
\text { screening } \\
\text { (Ci) }\end{array}$ & $\begin{array}{l}\text { Activity in } \\
\text { refined } \\
\text { inventory as } \\
\text { of } 1993 \\
\text { (Ci) }\end{array}$ & $\begin{array}{l}\text { Activity in } \\
\text { simplified } \\
\text { inventory }{ }^{b} \text { as } \\
\text { of } 1993 \\
\text { (Ci) }\end{array}$ \\
\hline $\mathrm{Ba}-137 \mathrm{~m}$ & 253.6 & 207.8 & 207.8 & 936.3 & 1125 \\
\hline C-14 & $<1.0$ & $<1.0$ & 1.0 & - & - \\
\hline Ce-144 & 166.4 & 0.325 & - & - & - \\
\hline Co-58 & 13.2 & $\approx 0$ & - & - & - \\
\hline $\mathrm{Co}-60$ & 104.6 & 13.92 & 13.92 & 36.4 & 47 \\
\hline $\mathrm{Cr}-51$ & 1.0 & $\approx 0$ & - & - & - \\
\hline Cs-134 & 58.1 & 5.5 & 5.5 & - & - \\
\hline Cs-137 & 253.6 & 207.8 & 207.8 & 936.3 & 1125 \\
\hline $\mathrm{Fe}-59$ & 1.3 & $\approx 0$ & - & - & - \\
\hline $\mathrm{H}-3$ & 159 & 55.8 & 55.8 & - & - \\
\hline $\mathrm{I}-129$ & $<1.8 \mathrm{E}-5$ & $<1.8 \mathrm{E}-5$ & $1.8 \mathrm{E}-5$ & - & - \\
\hline Mn-54 & 13.4 & 0.046 & - & - & - \\
\hline $\mathrm{Nb}-95$ & 0.3 & $\approx 0$ & - & - & - \\
\hline Sr-90 & 190.5 & 154.3 & 154.3 & 828.9 & 1013 \\
\hline Tc-99 & $<0.05$ & $<0.05$ & 0.05 & - & - \\
\hline$Y-90$ & 190.5 & 154.3 & 154.3 & 828.9 & 1013 \\
\hline $\mathrm{Zr}-95$ & 12.1 & $\approx 0$ & - & - & - \\
\hline Total & 1418.6 & 800.8 & 800.5 & 3566.8 & 4323 \\
\hline
\end{tabular}




\section{A-10.5 Comparisons of the Three Successive Nonactinide Inventories}

The $\mathrm{CH}$ and $\mathrm{RH}$ portions of the nonactinide "refined inventory" from Tables A-8 and A-9 are also given in Tables A-14 and A-15, respectively. The combined $\mathrm{CH}$ and $\mathrm{RH}$ portions of the refined inventory (from Table A-8 plus Table A-9) are given in Table A-16. This allows a comparison of the "refined inventory" and the "inventory with additional refinements."

For completeness, the nonactinide "simplified inventory," taken from Table A-3, is also given in Table A-16.

Table A-16 shows that the trend in the estimate of the total nonactinide inventory, from the simplified inventory to the refined inventory to the inventory with additional refinements, is downward. The total activity was reduced in the second inventory by $17 \%$ and in the third inventory by a total of $81 \%$. The major reductions were in the predominant radionuclides Cs-137 and $\mathrm{Ba}-137 \mathrm{~m}, \mathrm{Sr}-90$ and $\mathrm{Y}-90$, and $\mathrm{Co}-60$. The inventory with additional refinements added five radionuclides not addressed in the two previous inventories: $\mathrm{H}-3, \mathrm{C}-14, \mathrm{Tc}-99$, and I-129, plus Cs-134.

Tables A-14 and A-15 show that, although the nonactinide activity in the $\mathrm{CH}$ waste increased by about $50 \%$ (from $200 \mathrm{Ci}$ to $307.7 \mathrm{Ci}$ ) in the inventory with additional refinements, the activity in the $\mathrm{RH}$ waste decreased by a factor of almost 7 (from $3366.8 \mathrm{Ci}$ to $493.8 \mathrm{Ci}$ ). The other substantial difference is in the presence of small activities of C-14, Tc-99, and I-129 (and $\mathrm{H}-3$ for the $\mathrm{CH}$ waste) in the inventory with additional refinements. The activities of these four radionuclides were derived from information sources other than RWMIS. 


\section{REFERENCES FOR APPENDIX A}

Atwood C. L., and M. J. Schlafman, 1993, Empirical Distributions of Radionuclides from RWMIS Data, EG\&G Idaho, Inc., EGG-RAAM-10741, April.

Card, D. H., 1977, History of Buried Transuranic Waste at INEL, EG\&G Idaho, Inc., WMP 77-3, March.

Clements, T. L., Jr., 1984, "Tritium-Contaminated Stored TRU Waste," letter to K. B. McKinley, EG\&G Idaho, Inc., TLC-6-84, May 14.

Clements, T. L., Jr., and G. R. Darnell, 1994, "Rocky Flats Plant Characterization (1954-1980)," EG\&G Idaho, Inc., Engineering Design File RWMC-761, July.

DOE, 1994, Integrated Data Base for 1993: U.S. Spent Fuel and Radioactive Waste Inventories, Projections, and Characteristics, U.S. Department of Energy, DOE/RW-0006, Rev. 9, March.

EPRI, 1987, Updated Scaling Factors in Low Level Radwaste, EPRI NP-5077, Impell Corporation, March.

Lockheed Idaho, 1995, $A$ Comprehensive Inventory of Radiological and Nonradiological Contaminants in Waste Buried in the Subsurface Disposal Area of the INEL RWMC During the Years 1984-2003, Lockheed Idaho Technologies Company, INEL-95/0135, May, 3 volumes.

Raivo, B. D., T. L. Eddy, and G. L. Anderson, 1993, Statement of Work: Commercial Transport and Treatment of Alpha-Contaminated Mixed Low-Level Radioactive Waste (draft), Attachment 1 to Solid Alpha-Contaminated Low-Level Radioactive Waste Transport/Treatment Services Request for Proposal, SP-SOW-01, June.

Seitz, R. R., and Kocher, D. C., 1993, "On Establishing Waste Concentration Limits for Low-level Radioactive Waste Disposal," Proceedings of the Symposium on Waste Management, Tucson, Arizona, March. 


\section{Appendix B}

Refined Model of Untreated

Alpha-Contaminated Low-Level Waste Stored at the INEL 
B-2 


\section{Appendix B}

\section{Refined Model of Untreated Alpha-Contaminated Low-Level Waste Stored at the INEL}

\section{B-1. BACKGROUND}

After treatment, alpha-contaminated low-level waste (ALLW) at the Idaho National Engineering Laboratory (INEL) is expected to be fairly homogeneous, depending on the operational practices at the treatment facility. By contrast, the untreated ALLW is highly heterogeneous in its physical, chemical, and radiological characteristics.

No waste description of manageable complexity for this study can describe the ALLW precisely. Therefore, an approximate model representing the radiological inventory and release characteristics of the waste was developed. Grouping the untreated waste into categories with similar characteristics was necessary, together with assuming homogeneity of the waste within a category. This appendix describes the method used.

The refined radionuclide inventory used for the untreated ALLW coincides with that developed in Appendix A, Table A-3 for the actinides and Tables A-8 and A-9 (the refined inventory) for the nonactinides. Thus, the discussion in this appendix does not involve a new inventory but a regrouping of the same refined inventory discussed in Appendix A.

\section{B-2. OPTIONS FOR MODELING THE WASTE COMPOSITION}

Several options exist for modeling the composition of the ALLW. On one extreme, the waste could be modeled as one homogeneous mass. As stated above, the untreated ALIW is so heterogeneous that such an approach is obviously unacceptable.

At the other extreme, the untreated ALLW could be modeled, in theory, on a container-bycontainer basis. Homogeneity would be assumed within each of the containers, which are estimated to number 53,400 (Raivo et al. 1993). This approach would be the most exact, but the work required would be far beyond the scope of this study. In addition, detailed container data are not available for much of the waste.

Several options exist between these two extremes. The intermediate options involve varying degrees of simplification and categorization. In one option, the untreated ALLW could be modeled by assuming homogeneity of all waste containers within each of the approximately 90 content codes that are in use for this waste (Raivo et al. 1993). (Each container of waste stored at the INEL is categorized under a specific content code, which provides a general description of the containerized waste.) Actually, the waste is not always similar from one container to another within a content code. For example, content code 111 includes Waste Isolation Pilot Plant (WIPP) certified solid wet sludge from Rocky Flats Plant and laboratory research waste from Argonne National Laboratory-East (ANL-E) (Apel et al. 1993). Thus, even the use of about 90 content codes involves grouping containers whose contents vary to some extent. And 90 groups 
of waste is still far too many to use in a parametric performance assessment (PA) study requiring multiple computer runs.

PSPI documents (e.g., Raivo et al. 1993) group the ALLW by INEL identification (ID) number. For mixed ALLW, 18 INEL ID numbers exist-groups of content codes-that are based primarily on physical similarities. Examples are cemented sludges (six content codes), resins (three), metals (five), combustibles (seven). For nonmixed ALLW, there are 8 similar ID numbers.

The generic descriptors for the waste groupings by ID number should not be taken literally. For example, the name of ID number ID-EGG-144 is "radioactive sources." It includes three content codes, all of which are remote-handled waste. However, only one of the three content codes involves waste commonly thought of as radioactive sources, i.e., a concentrated source of radioactivity that is inside a metal container and is used for radiation applications. The other two content codes involve waste commonly considered combustibles or laboratory equipment.

The waste groupings by INEL ID number were used as the starting point for the present refined modeling of the untreated waste. The INEL ID numbers were then grouped into a smaller number of waste categories. The characteristics of the waste within each category were then evaluated and compared against the characteristics of the other categories.

Waste records in the form of detailed descriptions of the waste within a content code (Apel et al. 1993, supplemented by Apel et al. 1994 as necessary) were used to arrive at appropriate categories for modeling the waste. Those descriptions provide a large amount of information on the waste, although they are incomplete for many content codes, particularly concerning the radionuclide activities and distributions.

\section{B-3. SOURCE OF INFORMATION FOR ACTINIDE CONTENT}

To develop the actinide content of the untreated ALLW, the initial plan was to use the histograms in Apel et al. 1993 that showed the number of containers vs. transuranic (TRU) activity. Those histograms cover the range of TRU activity from 0 to $100 \mathrm{nCi} / \mathrm{g}$ in decades (e.g., 0-10, 10-20, 20-30). Apel et al. 1994 eliminated the histograms for the ALLW.

The histograms in Apel et al. 1993 were examined in this study to determine if certain types of ALLW tended to be higher than others in average TRU activity. However, few instances of such a tendency were observed. Most of the distributions showed little tendency of waste packages to concentrate in the top or bottom part of the 0 to $100 \mathrm{nCi} / \mathrm{g}$ domain. Rather, most distributions showed a scatter across the domain. In addition, when the content codes were grouped under ID numbers, the resulting distributions were found to be rather similar from one ID number to another. Finally, radioactivity information was missing for a large number of the content codes, so no histograms were available for these content codes. Therefore, the histograms were not used in determining whether one waste category has a higher concentration of TRU activity than another category. 
Rather than using the histograms in Apel et al. 1993, the total masses of actinides for each content code (where known) were used as an aid in comparing the actinide activity among content codes, ID numbers, and categories. The total masses of actinides are listed in Part C of Table B-5 and Part B of Table B-6 of Raivo et al. 1993. Those data were used only for scaling the actinide content among content codes, ID numbers, and categories. The actinide inventory used was that developed in Appendix $A$ of the present report, as adapted for the untreated waste. See Section B-6 below.

\section{B-4. SOURCE OF INFORMATION FOR NONACTINIDE CONTENT}

Neither Raivo et al. 1993, nor Apel et al. 1993, provided information on nonactinide content. This was true even for the remote-handled $(\mathrm{RH})$ waste, the high radiation levels of which must be a result of significant activity of nonactinides. The approach used to estimate the nonactinide activity was that developed in Section $A-9$ of Appendix $A$, as adapted for the untreated waste. See Section B-6 below.

\section{B-5. GROUPING THE WASTE BY CATEGORY}

\section{B-5.1 Overview}

Table B-1 at the end of this appendix indicates the process of grouping the waste into three categories. (The information in Table B-1 was taken primarily from Raivo et al. 1993 and Apel et al. 1993. Apel et al. 1994, which was completed when this study was already underway, was consulted in instances in which the information could not be found in the other two sources.) In the PA computer runs performed for each category, homogeneity was assumed within a category.

Column 1 of Table B-1 lists the three categories into which the ALLW was grouped: sludges, etc.; nonsludges; and remote-handled waste. The rationale for these categories will be explained in Section B-5.3.

Column 2 lists the INEL ID numbers for the waste, e.g., ID-EGG-112. Columns 3 and 4 list the names (brief descriptions) and the content codes comprising each ID number. ID numbers for mixed ALLW and nonmixed ALLW (those whose ID numbers end with an "N") were combined into the same entry. The content codes for nonmixed ALLW are listed after those for the mixed ALLW, separated by a semicolon.

Column 5 indicates whether the waste in the ID number is contact-handled (CH) or remotehandled (RH). Column 6 lists the volume of the waste for each ID number, in $\mathrm{m}^{3}$.

Column 7 indicates the quantity of actinides in the ID number. Lumping the actinides together in this manner was a simplification necessitated by the nature of this study and was done for scaling purposes only. In reality, different content codes have different mixtures of actinides. For some content codes, all the actinides are listed as $\mathrm{Pu}-52$, the standard weapons-grade $\mathrm{Pu}$ mixture consisting of about $94 \% \mathrm{Pu}-239$ by mass, with small amounts of Pu-238, 240, 241, and 242. Other content codes are listed as having $\mathrm{Pu}-52$ plus some $\mathrm{Pu}-239$. Such entries are incomplete because $\mathrm{Pu}-239$ is not found without some accompanying $\mathrm{Pu}-240$. Some content 
codes are listed with $\mathrm{Pu}-52$ plus U-235. Again, in reality, the U-235 always has some accompanying U-234 and U-238, but the records are incomplete on this point. For many content codes, no information on the actinide content is available in the records. Because the records are incomplete in several ways, no fully defensible breakdown of actinides is possible until the waste is removed from storage and assayed. Thus, lumping the actinides together, for purposes only of scaling the actinide activity in the various categories, is considered of sufficient accuracy for this study.

The 8th column indicates what the records list for the nonactinides in the waste. No such information was found, so the nonactinides were estimated using the approach developed in Section A-9 of Appendix A, as adapted to the untreated ALLW.

The last column indicates the mechanism, on an overall basis, for modeling the release of radionuclides for each ID number.

\section{B-5.2 Waste Termed "Uncategorized Waste"}

The waste in $\mathrm{ID}$ number 287, which is called "uncategorized waste," represents a special case. This waste consists of (a) $137 \mathrm{~m}^{3}$ of content code 0 waste, which was buried at the Subsurface Disposal Area (SDA) (mostly in 1970), later retrieved, and placed into storage; and (b) 2,006 $\mathrm{m}^{3}$ of content code 9999 waste, ${ }^{a}$ which was received from waste generators and placed into storage from 1970 to 1972 , before definitive waste information was developed by the generators. The total waste volume for this ID number is almost $10 \%$ of the total ALLW. Little information is available on the waste, particularly the 1970-1972 stored waste. Therefore, the average characteristics for the waste in ID number 287 (which was generated mostly from 1970 through 1972) were assumed here to match those of waste generated after 1972.

The waste in ID number 287 was then divided into two portions. One portion was assumed to match the type of waste in category 1 , the sludges, etc. The other portion was assumed to match the type of waste in category 2 , the nonsludges. None of the waste in ID number 287 was listed as RH, so none of it was assumed to match the type of waste in category 3.

For the waste in ID number 287 , the volumetric split and the actinide inventory split between categories 1 and 2 were made so as to match the splits for the later waste, as exhibited in Table B-1. Excluding ID number 287 , the volume of category 1 waste was $3,561 \mathrm{~m}^{3}$; for category 2 waste, $18,656 \mathrm{~m}^{3}$. Therefore, the $2,142 \mathrm{~m}^{3}$ volume of ID number 287 waste was divided into $2,142 \mathrm{~m}^{3} \times 3,561 /(3,561+18,656)=343 \mathrm{~m}^{3}$ sludges and $2,142 \mathrm{~m}^{3} \times 18,656 /(3,561+18,656)=$ $1,799 \mathrm{~m}^{3}$ of nonsludges.

The actinide inventory listed in the records for ID number 287 is $15 \mathrm{~g}$. (This value may be quite low because there are no data on actinide content for the 1970-1972 waste placed into storage. The records implicitly assume $0 \mathrm{~g}$ for the actinides in this waste.) The $15 \mathrm{~g}$ was divided

a. Apel et al. 1994 revised the estimated volume to $3,008 \mathrm{~m}^{3}$ after much of the PA work had been completed. No significant effect of the revision on the PA results would be expected. For consistency with the earlier PA work reported in this document, the revised volume was not used. 
based on the relative fractions of the total actinides in the two categories, not counting ID number 287. Those values are about $568 \mathrm{~g}$ for category 1 and $2,892 \mathrm{~g}$ for category 2 .

Accordingly, $2 \mathrm{~g}$ of the actinides in ID number 287 were apportioned to category 1 and $13 \mathrm{~g}$ to category 2. The totals become about $570 \mathrm{~g}$ for category 1 and $2,905 \mathrm{~g}$ for category 2 .

\section{B-5.3 Rationale for the Categories}

The first column of Table B-1, the categories, is now discussed in more detail.

The first $5 \mathrm{ID}$ numbers relate to waste in the form of sludges, resins, and salts. They are combined into category 1: sludges, etc. The first 3 ID numbers are expected to contain more than $99 \%$ of the actinides in the first $5 \mathrm{ID}$ numbers, and their expected release mechanism is diffusion. The next $2 \mathrm{ID}$ numbers have expected release mechanisms of desorption and dissolution, respectively, but their actinide inventories are negligible by comparison with that of the first three ID numbers. Thus, the first $5 \mathrm{ID}$ numbers were modeled as sludges with release parameters matching those for content code 2 , second-stage sludge, the dominant content code in terms of actinide inventory. The 6 th entry is the sludge portion of ID number 287 . For scaling purposes only, the total actinide content of category 1 was taken to be $570 \mathrm{~g}$, and the total volume was taken to be $3,904 \mathrm{~m}^{3}$. The release mechanism was assumed to be diffusion.

All but one of the remaining ID numbers were grouped into category 2 , the nonsludges. Most of the actinides in category 2 are located on the surfaces of paper, rags, and metals. For all of these ID numbers except 141 and 288 , the expected release mechanism is surface washoff. ID number 141 includes about $894 \mathrm{~g}$ of $\mathrm{U}-235$ in $\mathrm{U}_{3} \mathrm{O}_{8}$ pellets, with a dissolution release mechanism. However, the activity involved is much less than $1 \mathrm{Ci}$. ID number 288 , which is mostly U-235 and again if of very low activity, includes about $27 \mathrm{~g}$ of actinides. For scaling purposes only, the actinide content of category 2 was assumed to be $2,905 \mathrm{~g}$, and the volume was assumed to be $20,455 \mathrm{~m}^{3}$. The release mechanism was taken to be surface washoff.

The last ID number is 144, which contains all of the RH ALLW. The waste with this ID number was assigned to category 3 , the RH waste. The volume is $31 \mathrm{~m}^{3}$, chosen so as to match the volume used elsewhere in this report and in the Radioactive Waste Management Information System (RWMIS). Information on the actinide content is inconclusive. A total of $560 \mathrm{~g}$ is identified in the reports, but that value is incomplete. The information on physical and chemical form is not detailed; a surface washoff release mechanism was assumed because most of the waste is combustibles and (apparently) nonactivated metals.

\section{B-5.4 Conclusions about Radiological Characteristics}

The Table B-1 entries for the category rollups can be used to draw some conclusions about the radiological characteristics of the waste.

One of the key questions is whether the concentrations of radionuclides differ between the two $\mathrm{CH}$ categories, i.e., categories 1 and 2 . Within the accuracy of this study, the concentrations of actinides (by volume) are essentially the same for both categories. The actinide concentration is $570 \mathrm{~g} / 3,904 \mathrm{~m}^{3}=0.15 \mathrm{~g} / \mathrm{m}^{3}$ for category 1 and $2,905 \mathrm{~g} / 20,455 \mathrm{~m}^{3}=0.14 \mathrm{~g} / \mathrm{m}^{3}$ for category 2 . 
Table B-1. Categorization of the untreated ALLW.

\begin{tabular}{|c|c|c|c|c|c|c|c|c|}
\hline Category & $\begin{array}{l}\text { INEL ID } \\
\text { no.: } \\
\text { ID-EGG-a }^{2}\end{array}$ & Name & $\begin{array}{l}\text { Content } \\
\text { codes }^{\mathrm{b}}\end{array}$ & $\begin{array}{c}\text { CH } \\
\text { or } \\
\text { RH? }\end{array}$ & $\begin{array}{l}\text { Vol } \\
\left(\mathrm{m}^{3}\right)\end{array}$ & $\begin{array}{l}\text { Quantity of actinides (from Raivo et al. } \\
\text { 1993, Apel et al. 1993, and, as } \\
\text { necessary, Apel et al. 1994) for } \\
\text { purposes of scaling only }\end{array}$ & $\begin{array}{c}\text { Nonactinide } \\
\text { activity } \\
\text { (from } \\
\text { information } \\
\text { sources at } \\
\text { left) }\end{array}$ & $\begin{array}{l}\text { Assumed } \\
\text { release } \\
\text { mechanism }\end{array}$ \\
\hline \multirow[t]{7}{*}{$\begin{array}{l}\text { 1- } \\
\text { Sludges, } \\
\text { etc. }\end{array}$} & $112,112 \mathrm{~N}$ & Cemented sludges & $\begin{array}{l}4,112,114 \\
834,835 \\
976 ; 836 \\
978\end{array}$ & $\mathrm{CH}$ & 1,301 & $\begin{array}{l}\text { c. } 63 \mathrm{~g} \text {; most is in content code } 4 \\
\text { (special setups) }\end{array}$ & None listed & Diffusion \\
\hline & $102,102 \mathrm{~N}$ & $\begin{array}{l}\text { Uncemented } \\
\text { inorganic sludges }\end{array}$ & $\begin{array}{l}1,2,7 \\
111,290 \\
292 ; 30,95 \\
113,995\end{array}$ & $\mathrm{CH}$ & 1,233 & $\begin{array}{l}\text { c. } 365 \mathrm{~g} ; \text { most is in content code } 2 \\
\text { (second stage sludge) and content code } \\
7 \text { (Bldg. } 347 \text { dry sludge) }\end{array}$ & None listed & Diffusion \\
\hline & 158 & $\begin{array}{l}\text { Uncemented organic } \\
\text { sludge }\end{array}$ & 3 & $\mathrm{CH}$ & 1,002 & c. $140 \mathrm{~g}$ & None listed & Diffusion \\
\hline & 145 & Resins & $\begin{array}{l}430,431 \\
432\end{array}$ & $\mathrm{CH}$ & 11 & $<1 \mathrm{~g}$ & None listed & Desorption \\
\hline & 146 & Salts & 5 & $\mathrm{CH}$ & 14 & $<1 \mathrm{~g}$ & None listed & Dissolution \\
\hline & $\begin{array}{c}287 \\
\text { (part-see } \\
\text { text for } \\
\text { explana- } \\
\text { tion) }\end{array}$ & Uncategorized & $0^{c}, 9999$ & $\mathrm{CH}$ & 343 & $\begin{array}{l}\text { c. } 2 \mathrm{~g} \text { in content code } 0 \text { (waste retrieved } \\
\text { from burial). No data on content code } \\
9999 \text { (waste received 1970-1972) }\end{array}$ & None listed & Diffusion \\
\hline & & $\begin{array}{l}\text { Total/Composite: } \\
\text { Sludges, etc. }\end{array}$ & & $\mathrm{CH}$ & 3,904 & c. $570 \mathrm{~g}$ & $\begin{array}{l}\text { None listed; } \\
\text { developed } \\
\text { using } \\
\text { approach in } \\
\text { Appendix A }\end{array}$ & $\begin{array}{l}\text { Diffusion } \\
\text { using } \\
\text { parameters } \\
\text { for content } \\
\text { code } 2 \\
\text { waste }\end{array}$ \\
\hline
\end{tabular}


Table B-1. (continued).

\begin{tabular}{|c|c|c|c|c|c|c|c|c|}
\hline Category & $\begin{array}{l}\text { INEL ID } \\
\text { no.: } \\
\text { ID-EGG-a }\end{array}$ & Name & $\begin{array}{l}\text { Content } \\
\text { codes }^{b}\end{array}$ & $\begin{array}{l}\mathrm{CH} \\
\text { or } \\
\mathrm{RH}\end{array}$ & $\begin{array}{l}\mathrm{Vol} \\
\left(\mathrm{m}^{3}\right)\end{array}$ & $\begin{array}{l}\text { Quantity of actinides (from Raivo et al. } \\
\text { 1993, Apel et al. 1993, and, as } \\
\text { necessary, Apel et al. 1994) for } \\
\text { purposes of scaling only }\end{array}$ & $\begin{array}{l}\text { Nonactinide } \\
\text { activity } \\
\text { (from } \\
\text { information } \\
\text { sources at } \\
\text { left) }\end{array}$ & $\begin{array}{l}\text { Assumed } \\
\text { release } \\
\text { mechanism }\end{array}$ \\
\hline \multirow[t]{8}{*}{$\begin{array}{l}\text { 2- Non- } \\
\text { sludges }\end{array}$} & 109 & Benelex, plexiglas & 302,464 & $\mathrm{CH}$ & 59 & c. $8 \mathrm{~g}$. & None listed & $\begin{array}{l}\text { Surface } \\
\text { washoff }\end{array}$ \\
\hline & $114,114 \mathrm{~N}$ & Combustibles & $\begin{array}{l}116,330 \\
336,337 \\
826,900 \\
970 ; 847\end{array}$ & CH & 5,674 & $\begin{array}{l}\text { c. } 1,223 \mathrm{~g} ; \text { most is in content code } 330 \\
\text { (dry paper and rags) }\end{array}$ & None listed & $\begin{array}{l}\text { Surface } \\
\text { washoff }\end{array}$ \\
\hline & $115,115 \mathrm{~N}$ & Concrete-brick & $\begin{array}{l}122,371 \\
375 ; 960\end{array}$ & $\mathrm{CH}$ & 880 & c. $4 \mathrm{~g}$ & None listed & $\begin{array}{l}\text { Surface } \\
\text { washoff }\end{array}$ \\
\hline & 118 & Filters & $\begin{array}{l}119,158 \\
328,335 \\
338,360 \\
376,490\end{array}$ & $\mathbf{C H}$ & 1,347 & $\begin{array}{l}\text { c. } 55 \mathrm{~g} \text {; most is in content code } 490 \\
\text { (high-efficiency particulate air and other } \\
\text { filters) }\end{array}$ & None listed & $\begin{array}{l}\text { Surface } \\
\text { washoff }\end{array}$ \\
\hline & $119,119 \mathrm{~N}$ & Glass & $\begin{array}{l}440,441 \\
442 ; 118\end{array}$ & CH & 405 & c. $1 \mathrm{~g}$ & None listed & $\begin{array}{l}\text { Surface } \\
\text { washoff }\end{array}$ \\
\hline & 120 & Glovebox gloves & $\begin{array}{l}123,339 \\
463\end{array}$ & CH & 8 & $<\lg$ & None listed & $\begin{array}{l}\text { Surface } \\
\text { washoff }\end{array}$ \\
\hline & 132 & Metals & $\begin{array}{l}117,320 \\
480,481 \\
803\end{array}$ & $\mathrm{CH}$ & 7,031 & $\begin{array}{l}\text { c. } 410 \mathrm{~g} \text {; most is in content code } 480 \\
\text { (gloveboxes, furnaces, lathes, ducting, } \\
\text { etc.) }\end{array}$ & None listed & $\begin{array}{l}\text { Surface } \\
\text { washoff }\end{array}$ \\
\hline & $134,134 \mathrm{~N}$ & Miscellaneous & $\begin{array}{l}100,101 \\
121,201 \\
241,950 \\
203,824 \\
825\end{array}$ & CH & 2,453 & $\begin{array}{l}\text { c. } 270 \mathrm{~g} ; \text { most is in content code } 100 \\
\text { (general plant waste) and content code } \\
201 \text { (noncombustible solids) }\end{array}$ & None listed & $\begin{array}{l}\text { Surface } \\
\text { washoff }\end{array}$ \\
\hline
\end{tabular}


Tabie B-1. (continued).

\begin{tabular}{|c|c|c|c|c|c|c|c|c|}
\hline Category & $\begin{array}{l}\text { INEL ID } \\
\text { no.: } \\
\text { ID-EGG-a }\end{array}$ & Name & $\begin{array}{l}\text { Content } \\
\text { codes }^{b}\end{array}$ & $\begin{array}{l}\mathrm{CH} \\
\text { or } \\
\mathrm{RH} ?\end{array}$ & $\begin{array}{l}\text { Vol } \\
\left(\mathrm{m}^{3}\right)\end{array}$ & $\begin{array}{l}\text { Quantity of actinides (from Raivo et al. } \\
\text { 1993, Apel et al. 1993, and, as } \\
\text { necessary, Apel et al. 1994) for } \\
\text { purposes of scaling only }\end{array}$ & $\begin{array}{l}\text { Nonactinide } \\
\text { activity } \\
\text { (from } \\
\text { information } \\
\text { sources at } \\
\text { left) }\end{array}$ & $\begin{array}{l}\text { Assumed } \\
\text { release } \\
\text { mechanism }\end{array}$ \\
\hline \multirow[t]{5}{*}{$\begin{array}{l}\text { 2- Non- } \\
\text { sludges } \\
\text { (cont.) }\end{array}$} & $137,137 \mathrm{~N}$ & $\begin{array}{l}\text { Nonmetal molds and } \\
\text { crucibles }\end{array}$ & $\begin{array}{l}300,301 \\
115,310 \\
370\end{array}$ & $\mathrm{CH}$ & 26 & $<1 \mathrm{~g}$ & None listed & $\begin{array}{l}\text { Surface } \\
\text { washoff }\end{array}$ \\
\hline & $141,141 \mathrm{~N}$ & Particulate wastes & $\begin{array}{l}90,150 \\
372,374 \\
990 ; 425 \\
842\end{array}$ & $\mathrm{CH}$ & 588 & $\begin{array}{l}\text { c. } 894 \mathrm{~g} \text {; most is } \mathrm{U}-235 \text { in content code } \\
150 \text { (miscellaneous waste, including } \\
\text { normal and enriched } \mathrm{U}_{3} \mathrm{O}_{8} \text { pellets) }\end{array}$ & None listed & Dissolution \\
\hline & $\begin{array}{c}287 \\
\text { (part-see } \\
\text { text for } \\
\text { explana- } \\
\text { tion) }\end{array}$ & Uncategorized & $0^{c}, 9999$ & $\mathrm{CH}$ & 1,799 & $\begin{array}{l}\text { c. } 13 \mathrm{~g} \text { in content code } 0 \text { (waste } \\
\text { retrieved from burial). No data on } \\
\text { content code } 9999 \text { (waste received } \\
1970-1972 \text { ) }\end{array}$ & None listed & $\begin{array}{l}\text { Surface } \\
\text { washoff }\end{array}$ \\
\hline & 288 & Unknown & $\begin{array}{l}10,20,102, \\
155,156, \\
161,202, \\
204,838, \\
848\end{array}$ & $\mathrm{CH}$ & 185 & $\begin{array}{l}\text { c. } 27 \mathrm{~g} \text {; most is } \mathrm{U}-235 \text { in content code } \\
102 \text { (absorbed liquids) }\end{array}$ & None listed & Desorption \\
\hline & & $\begin{array}{l}\text { Total/Composite: } \\
\text { Nonsludges }\end{array}$ & & $\mathrm{CH}$ & 20,455 & $\begin{array}{l}\text { c. } 2,905 \mathrm{~g} \text {; detailed distribution } \\
\text { developed using approach in Appendix } \\
\text { A. }\end{array}$ & $\begin{array}{l}\text { None listed; } \\
\text { developed } \\
\text { using } \\
\text { approach in } \\
\text { Appendix A }\end{array}$ & $\begin{array}{l}\text { Surface } \\
\text { washoff }\end{array}$ \\
\hline
\end{tabular}


Table B-1. (continued).

\begin{tabular}{|c|c|c|c|c|c|c|c|c|}
\hline Category & $\begin{array}{l}\text { INEL ID } \\
\text { no.: } \\
\text { ID-EGG-a }\end{array}$ & Name & $\begin{array}{l}\text { Content } \\
\text { codes }^{b}\end{array}$ & $\begin{array}{l}\text { CH } \\
\text { or } \\
\text { RH? }\end{array}$ & $\begin{array}{l}\text { Vol } \\
\left(\mathrm{m}^{3}\right)\end{array}$ & $\begin{array}{l}\text { Quantity of actinides (from Raivo et al. } \\
\text { 1993, Apel et al. 1993, and, as } \\
\text { necessary, Apel et al. 1994) for } \\
\text { purposes of scaling only }\end{array}$ & $\begin{array}{l}\text { Nonactinide } \\
\text { activity } \\
\text { (from } \\
\text { information } \\
\text { sources at } \\
\text { left) }\end{array}$ & $\begin{array}{l}\text { Assumed } \\
\text { release } \\
\text { mechanism }\end{array}$ \\
\hline \multirow[t]{3}{*}{$\begin{array}{l}\text { 3- } \\
\text { Remote- } \\
\text { handled }\end{array}$} & 144 & Radioactive sources & $\begin{array}{l}104,153 \\
154\end{array}$ & $\mathbf{R H}$ & $31^{\circ}$ & $\begin{array}{l}\text { No data in Raivo et al. } 1993 \text { or Apel et } \\
\text { al. } 1993 \text {. Apel et al. } 1994 \text { lists c. } 560 \mathrm{~g} \\
\text { ( }<<1 \text { Ci), almost entirely U-235 and } \\
\text { U-238, in content codes } 104 \\
\text { (miscellaneous combustible and } \\
\text { noncombustible alpha hot cell } \\
\text { waste-the dominant content code by } \\
\text { volume) and } 153 \text { (combustibles with } \\
\text { fuel on filters-the dominant content } \\
\text { code by actinide content). No data on } \\
\text { content code } 154 \text {, but it contains Pu-Be } \\
\text { sources, a Ra needle, and experimental } \\
\text { fuel capsules }\end{array}$ & None listed & $\begin{array}{l}\text { Highly } \\
\text { varied, little } \\
\text { information } \\
\text { available. }\end{array}$ \\
\hline & & $\begin{array}{l}\text { Total/composite: } \mathrm{RH} \\
\text { Waste }\end{array}$ & & RH & $31^{\mathrm{c}}$ & $\begin{array}{l}\text { More than } 560 \mathrm{~g} \text {; detailed distribution } \\
\text { developed using approach in Appendix } \\
\text { A. }\end{array}$ & $\begin{array}{l}\text { None listed; } \\
\text { developed } \\
\text { using } \\
\text { approach in } \\
\text { Appendix A }\end{array}$ & $\begin{array}{l}\text { Surface } \\
\text { washoff }\end{array}$ \\
\hline & & Grand total & & & $24,390^{c}$ & & & \\
\hline
\end{tabular}

\section{NOTES:}

a. INEL, ID Numbers ending in N represent ALLW that is nonmixed. All other entries represent mixed ALLW.

b. The content codes for any nonmixed ALLW are listed last in each cell of this column, after the semicolon.

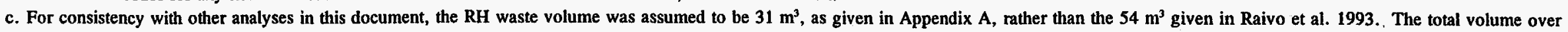
all categories is, therefore, $23 \mathrm{~m}^{3}$ less than the $24,413 \mathrm{~m}^{3}$ in Raivo et al. 1993 . This difference of less than $0.1 \%$ is not significant for developing the radiological inventory and was neglected.

d. Interestingly, the ALLW records do not list the presence of U-238 for this content code, even though it must be present if pellets of normal (unenriched) $\mathrm{U}_{3} \mathrm{O}_{8}$ are present. This is one example of the incompleteness of the radiological information about the waste. 
This result substantiates the simplifying assumption made in Appendix $A$ that the actinide activity in the $\mathrm{CH}$ ALLW is evenly spread. Thus, little accuracy would be gained by using two different concentrations of actinides for the CH ALLW in the two categories.

The actinide distribution developed in Appendix $A$ (see Table A-3) was used for all categories of untreated $A L L W$, apportioned according to the relative volumes of the three categories. It is consistent with the actinide distribution used for the treated waste.

For the nonactinide distribution, the ALLW records provide no information. Therefore, the refined actinide distribution developed in Appendix $A$ (see Tables $A-8$ and A-9) was used for the untreated ALLW.

\section{B-6. FINAL RESULTS FOR REFINED INVENTORY MODEL}

Table B-2 provides the refined inventory model for the untreated waste. It is based on the categories, volumes, release mechanisms, and key content codes of Table B-1, supplemented by information developed in Appendix A on the radionuclide distributions.

The radionuclide distributions were developed as follows. For category 3 (RH waste), the nonactinide values were taken from Table A-9 in Appendix A on RH ALLW. The actinide values were taken from Table A-3 of Appendix A, then multiplied by the volume fraction of category 3 waste to all the ALLW (31/24,413). (The minute fractional difference of less than $0.1 \%$ between the total volume of $24,413 \mathrm{~m}^{3}$ in Appendix A and the total volume of $24,390 \mathrm{~m}^{3}$ in Table B-1 was neglected.)

For categories 1 and 2 (CH waste), the approach was similar. Nonactinide values were taken from Table A-8 in Appendix A on CH ALLW, then multiplied by the fraction of $\mathrm{CH}$ volume that is category 1 $(3,904 / 24,359)$ or category $2(20,455 / 24,359)$. The actinide values were taken again from Table A-3 of Appendix A, then multiplied by the volume fraction of category 1 or 2 waste to all the ALLW $(3,904 / 24,413$ or $20,455 / 24,413$, respectively). 
Table B-2. Refined model of the untreated ALLW.

\begin{tabular}{|c|c|c|c|c|c|c|c|}
\hline Category & $\begin{array}{l}\text { Volume } \\
\left(\mathrm{m}^{3}\right)\end{array}$ & $\begin{array}{l}\text { Actinide } \\
\text { inventory } \\
\text { (Ci) }\end{array}$ & & $\begin{array}{l}\text { Nonactin } \\
\text { inventory } \\
\text { (Ci) }\end{array}$ & & $\begin{array}{l}\text { Release } \\
\text { mechanism }\end{array}$ & $\begin{array}{l}\text { Content code } \\
\text { for other } \\
\text { properties }\end{array}$ \\
\hline $\begin{array}{l}\text { 1- Sludges, } \\
\text { etc. }\end{array}$ & 3,904 & $\begin{array}{l}\text { Am-241 } \\
\text { Cm-244 } \\
\text { Pu-238 } \\
\text { Pu-239 } \\
\text { Pu-240 } \\
\text { Pu-241 } \\
\text { U-233 } \\
\text { U-238 }\end{array}$ & $\begin{array}{l}214 \\
1.28 \\
145 \\
95.7 \\
23.8 \\
384 \\
2.08 \\
0.0003\end{array}$ & $\begin{array}{l}\text { Ba-137m } \\
\text { Co-60 } \\
\text { Cs-137 } \\
\text { Sr-90 } \\
\text { Y-90 }\end{array}$ & $\begin{array}{l}8.70 \\
4.74 \\
8.70 \\
4.95 \\
4.95\end{array}$ & Diffusion & $\begin{array}{l}2 \text { (second- } \\
\text { stage sludge) }\end{array}$ \\
\hline $\begin{array}{l}2- \\
\text { Nonsludges }\end{array}$ & 20,455 & $\begin{array}{l}\mathrm{Am}-241 \\
\mathrm{Cm}-244 \\
\mathrm{Pu}-238 \\
\mathrm{Pu}-239 \\
\mathrm{Pu}-240 \\
\mathrm{Pu}-241 \\
\mathrm{U}-233 \\
\mathrm{U}-238\end{array}$ & $\begin{array}{l}1,124 \\
6.71 \\
760 \\
502 \\
123 \\
2,014 \\
10.9 \\
0.0014\end{array}$ & $\begin{array}{l}\text { Ba-137m } \\
\text { Co-60 } \\
\text { Cs-137 } \\
\text { Sr-90 } \\
\text { Y-90 }\end{array}$ & $\begin{array}{l}45.6 \\
24.9 \\
45.6 \\
25.9 \\
25.9\end{array}$ & $\begin{array}{l}\text { Surface } \\
\text { washoff }\end{array}$ & $\begin{array}{l}330 \text { (dry } \\
\text { paper and } \\
\text { rags) }\end{array}$ \\
\hline $\begin{array}{l}\text { 3- Remote- } \\
\text { handled }\end{array}$ & $31^{\mathrm{a}}$ & $\begin{array}{l}\text { Am-241 } \\
\mathrm{Cm}-244 \\
\mathrm{Pu}-238 \\
\mathrm{Pu}-239 \\
\mathrm{Pu}-240 \\
\mathrm{Pu}-241 \\
\mathrm{U}-233 \\
\mathrm{U}-238\end{array}$ & $\begin{array}{l}1.647 \\
0.010 \\
1.15 \\
0.735 \\
0.181 \\
2.950 \\
0.016 \\
0\end{array}$ & $\begin{array}{l}\text { Ba-137m } \\
\text { Co-60 } \\
\text { Cs-137 } \\
\text { Sr-90 } \\
\text { Y-90 }\end{array}$ & $\begin{array}{l}882 \\
6.8 \\
882 \\
798 \\
798\end{array}$ & $\begin{array}{l}\text { Surface } \\
\text { washoff }\end{array}$ & $\begin{array}{l}\text { None } \\
\text { appropriate; } \\
\text { assume } \\
\text { particulate on } \\
\text { filters or rags }\end{array}$ \\
\hline Total & $24,390^{\mathrm{a}}$ & $\begin{array}{l}\text { Am-241 } \\
\mathrm{Cm}-244 \\
\mathrm{Pu}-238 \\
\mathrm{Pu}-239 \\
\mathrm{Pu}-240 \\
\mathrm{Pu}-241 \\
\mathrm{U}-233 \\
\mathrm{U}-238\end{array}$ & $\begin{array}{l}1,340 \\
8 \\
906 \\
598 \\
147 \\
2,401 \\
13 \\
0.0017\end{array}$ & $\begin{array}{l}\text { Ba-137m } \\
\text { Co-60 } \\
\text { Cs-137 } \\
\text { Sr-90 } \\
\text { Y-90 }\end{array}$ & $\begin{array}{l}936 \\
36.4 \\
936 \\
829 \\
829\end{array}$ & NA & NA \\
\hline
\end{tabular}

a. For consistency with other parametric studies in this document, the volume of the RH waste was assumed to be $31 \mathrm{~m}^{3}$, as given in RWMIS and discussed in Appendix A, rather than the $54 \mathrm{~m}^{3}$ given in Raivo et al. 1993. The total volume over all categories is, therefore, $23 \mathrm{~m}^{3}$ less than the $24,413 \mathrm{~m}^{3}$ in Raivo et al. 1993. This volume difference of less than $0.1 \%$ is not significant for developing the radiological inventory and was neglected. 


\section{REFERENCES FOR APPENDIX B}

Apel, M. L., M. T. Muneta-Bradford, A. L. Rubert, J. C. Tozer, M. D. Argyle, and G. K. Becker, 1993, Waste Description Information Package for Alpha Low-Level Mixed Waste \& Alpha Low-Level Waste (draft), Attachment 2 to Solid Alpha-Contaminated Low-Level Radioactive Waste Transport/Treatment Services Request for Proposal, SP-SOW-01, July.

Apel, M. L., G. K. Becker, Z. K. Ragan, J. Frasure, B. D. Raivo, L. G. Gale, and D. P. Pace, 1994, Radiological, Physical, and Chemical Characterization of Low-level Alpha-contaminated Wastes Stored at the Idaho National Engineering Laboratory for Use in Conducting Feasibility Studies for Treatment Services, EG\&G Idaho, EGG-RWMC-11189, March.

Raivo, B. D., T. L. Eddy, and G. L. Anderson, 1993, Statement of Work: Commercial Transport and Treatment of Alpha-Contaminated Mixed Low-Level Radioactive Waste (draft)," Attachment 1 to Solid Alpha-Contaminated Low-Level Radioactive Waste Transport/Treatment Services Request for Proposal, SP-SOW-01, June. 


\section{Appendix C}

Completed Questionnaires Used to Obtain Geologic and Hydrologic Properties of Disposal Locations A, B, and C 


\section{Appendix C}

\section{Completed Questionnaires Used to Obtain Geologic and Hydrologic Properties of Disposal Locations A, B, and C}

This appendix contains the completed questionnaires used to select the geologic and hydrologic properties representative of disposal locations A, B, and C. References cited by the persons who completed the questionnaires are not included in this appendix.

The properties selected for disposal locations $D$ and $E$ were obtained from formal performance assessments (PAs) prepared recently by personnel at those respective sites. Those formal PAs are referenced in Section 3 of this report. 
C-4 
Site Properties Representative of Site A

(Radioactive Waste Management Complex at the INEL) 
C-6 
Table 0-3. Parameters used in the ground water tmozes calculattons.

Parzatar

Value Units

Reference

Soures length sarallel to flow

257 a case et ai. (1990)

Soures width sarailel to now

122

Case it 21. (2980)

Source entekness

6.1

Case of ai. (1990)

Soil denstity at soures

$1.5 \mathrm{Va}$ Case.et il. (1990)

Aeutfer density

$1.8 \mathrm{~g} \boldsymbol{\sigma o x}^{3}$

Case ot 81. (1990)

Aquifer porosity

0.10 -

Case ot 21. (1980)

Pore veloctity

$370 \quad$ a/yr case et 21. (1990)

Yoll serven thiekness

$12 \quad a$

EsRe idatho (1991)

Unsaturated zone thickenass.

178

infiltrat on pite

0.123

-

Case et 21. (1990)

Source voluentrte watar content

0.347 - Caleulazos"

Unsaturazed volumentrie watar content

$0.07=$

Caleulatass

Longitudinal disparsivity

0.9

Armets et al. (2990).

Transverse dispersivity

0.4 :

Arnest ot al. $(1990)^{5}$

Receptor distance

Water ingestion rate

100.

2.0 W Way GFR (19981)

a. Lased on a 100-yoar water travel tiat in the unsaturated zone. See diseusston in Section 4.2.2.3.

b. Based on the 100-year watar travet t1an in the unsaturated zone.

c. Yalue divided by 100 for conservatisa.

d. The value of 100 a ts genorally sesepted as the soint of conollance for performance assessenent ealeulatiens for DoE faetlitles. This distance is imasurad frow the downgradient scge of the factlity. 
Pable 0-6. Parameters used in the ground water tmpset ealeylations (values different fron Table D-3 are stown in bold).

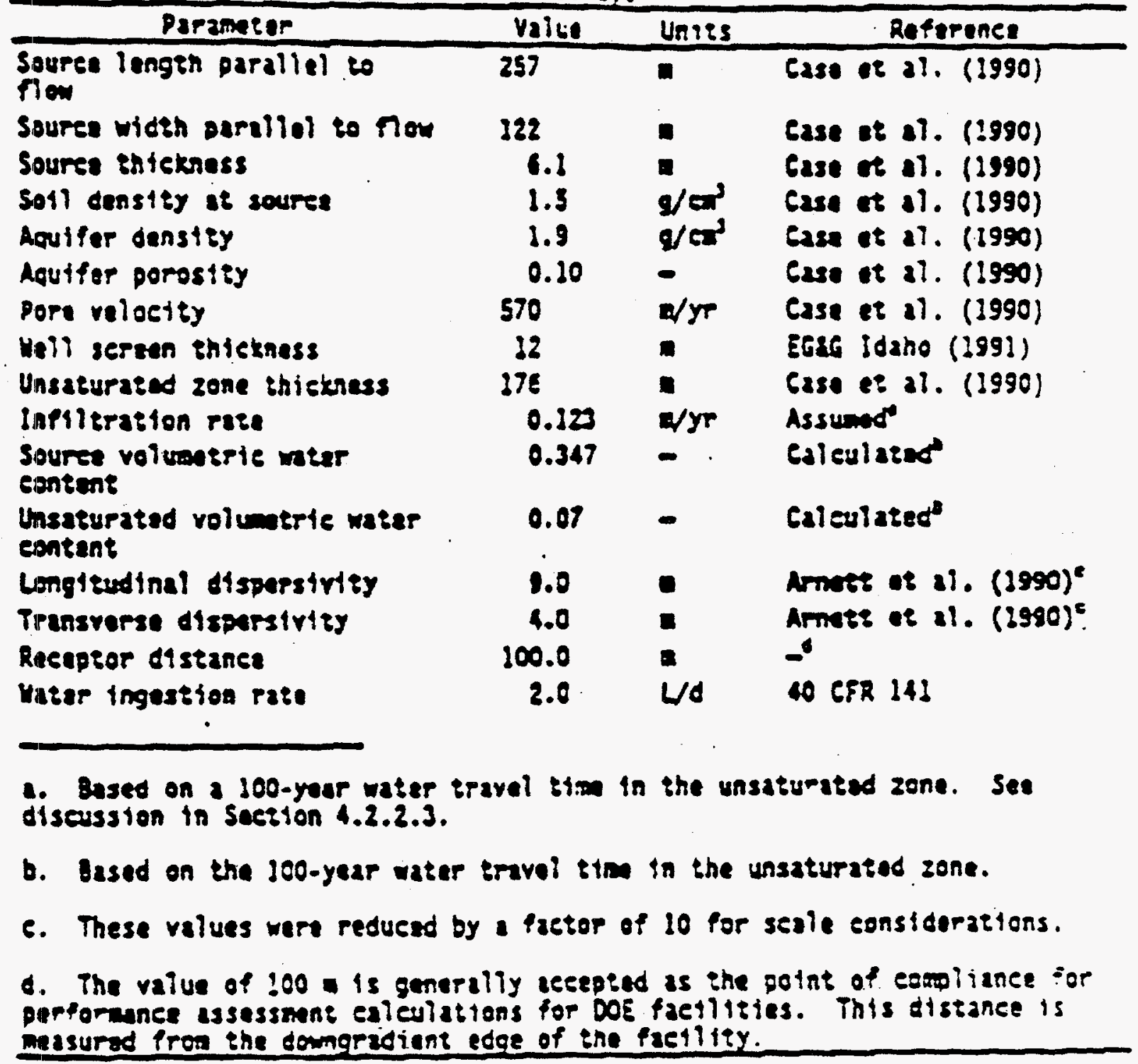


Site Properties Characteristic of Site B

(Site 14 in the Central Part of the INEL) 


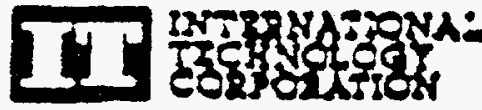

Mr. Jseit Bestelough

ECsO idato. las.

P. O. Bex 1625

Itatio Fulle ID 834is

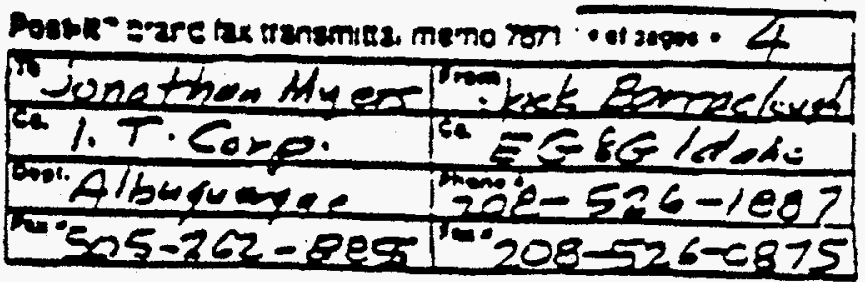

indy dy. 65y

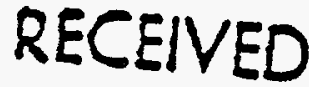

Projes: No. 3Cis2402

If CORP. AlBUQUERQUE .

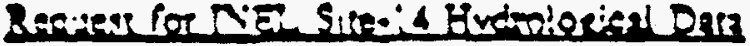

Dert Mr. Bcrsulough:

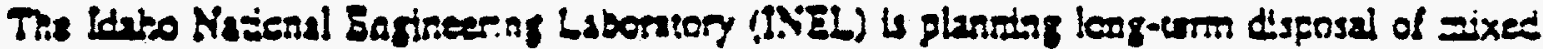

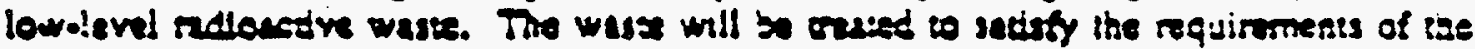

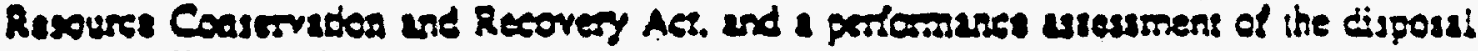

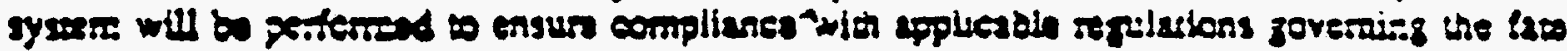
and ruspors of rudionerive consaninents.

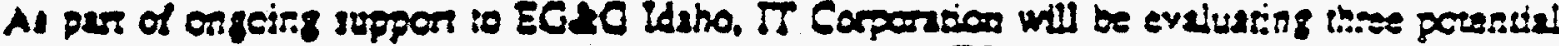

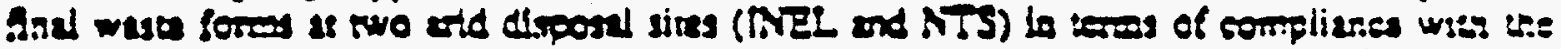

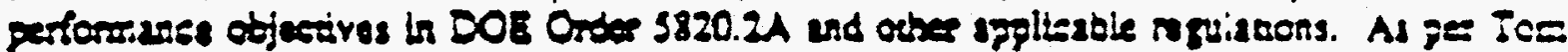

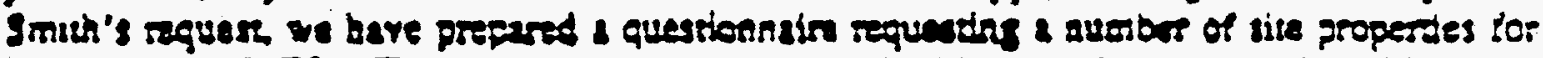

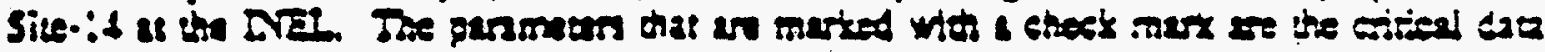

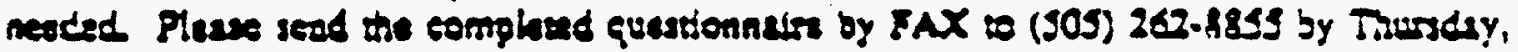
May 87. if porstele.

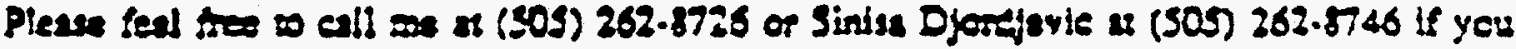

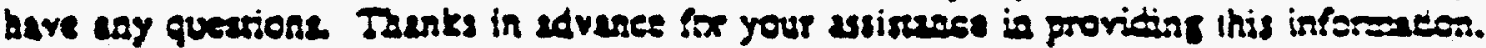

Sinewrily,

Tr CORPORATION

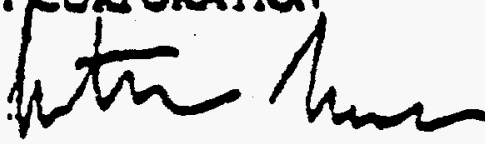

Jeanthe Myors

Misoilst

es: Sleis Diondjeris, TI Corportion Taes Senith. 8CAC lidaho. Ine.

Iogeres Cices

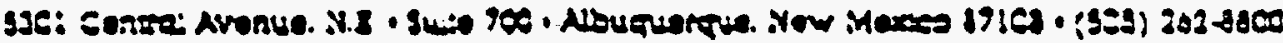

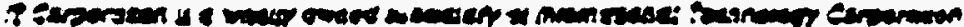




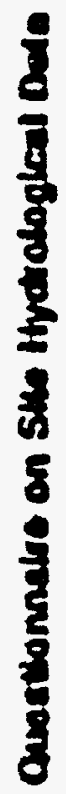

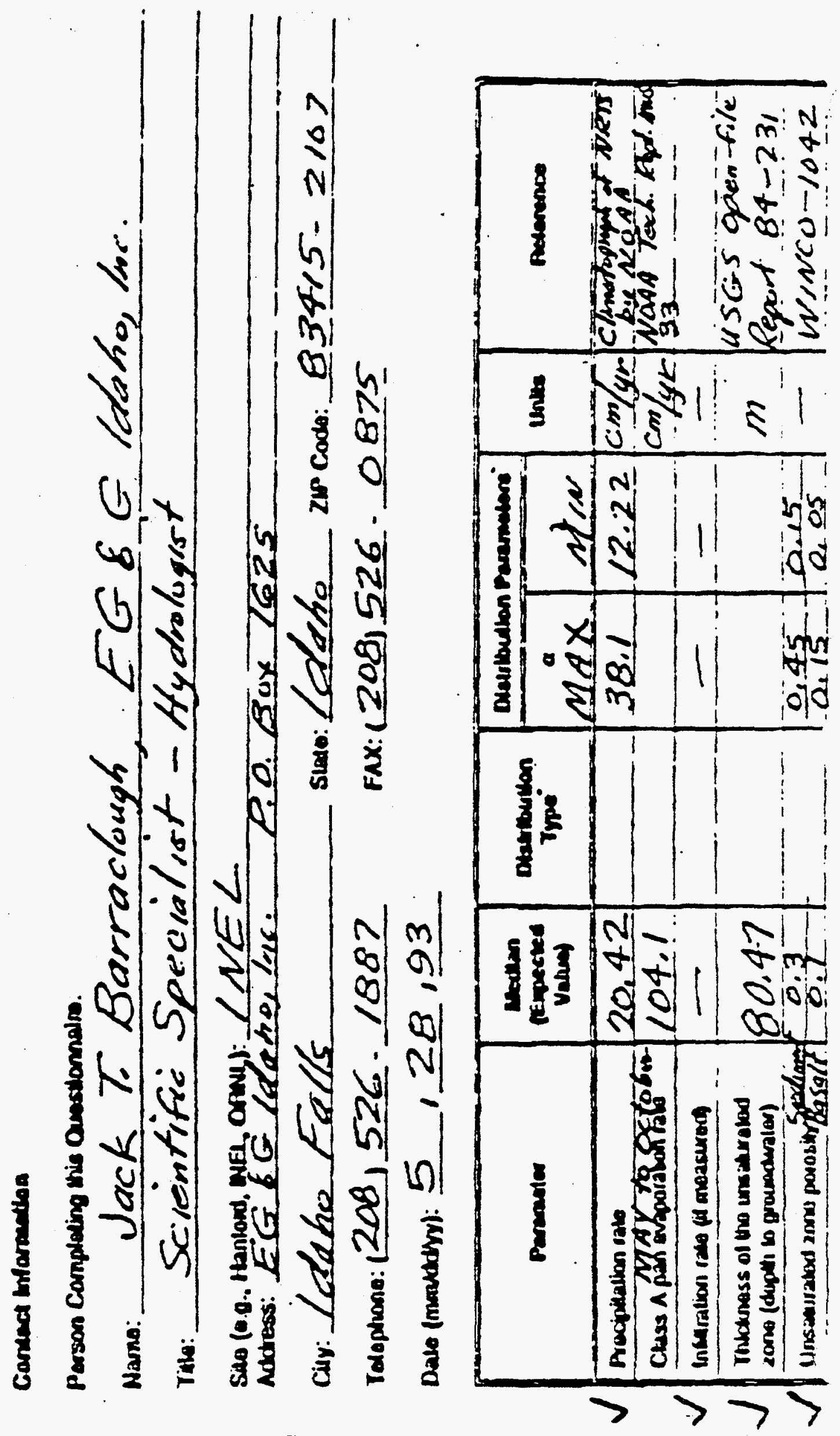




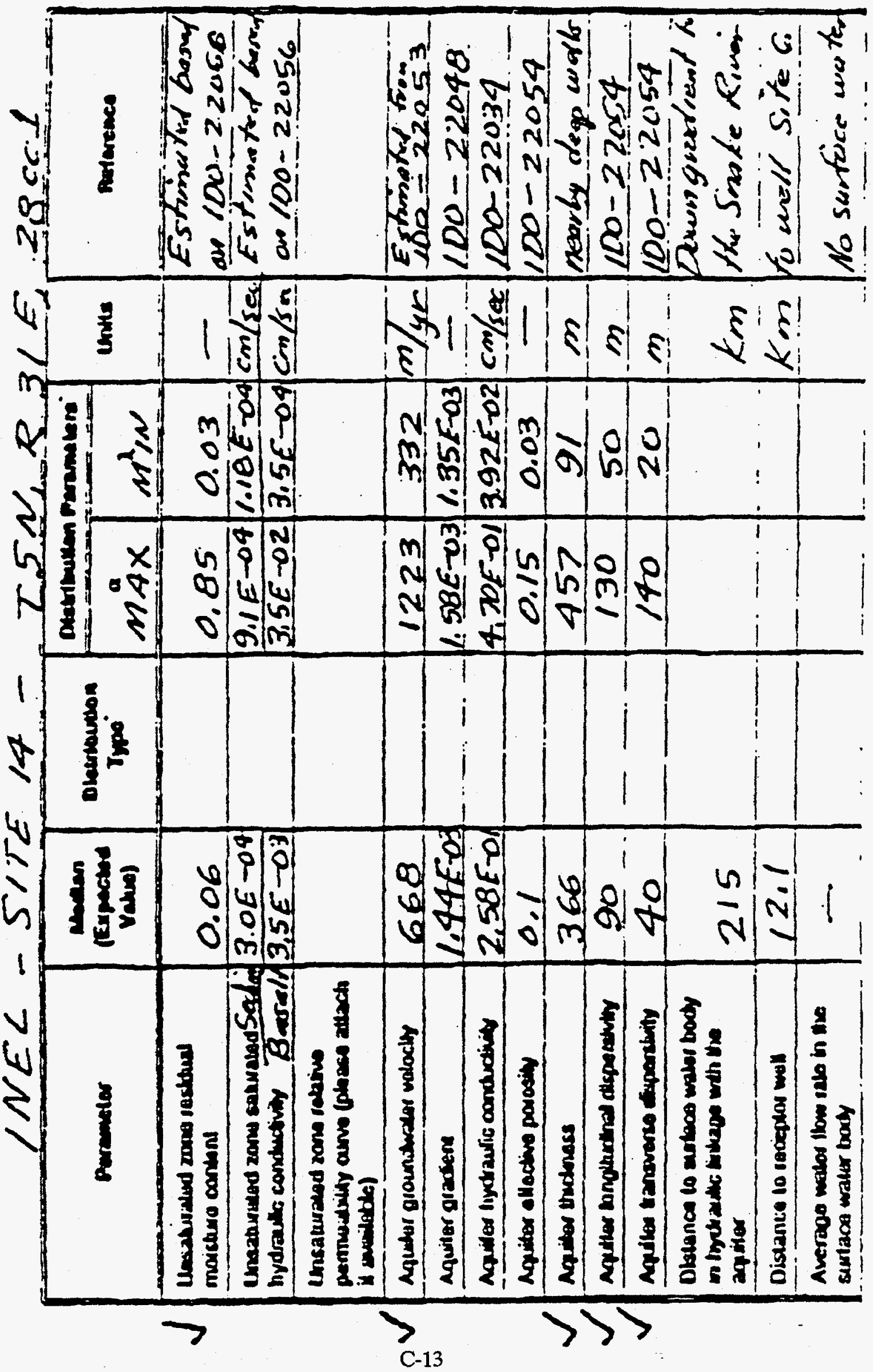




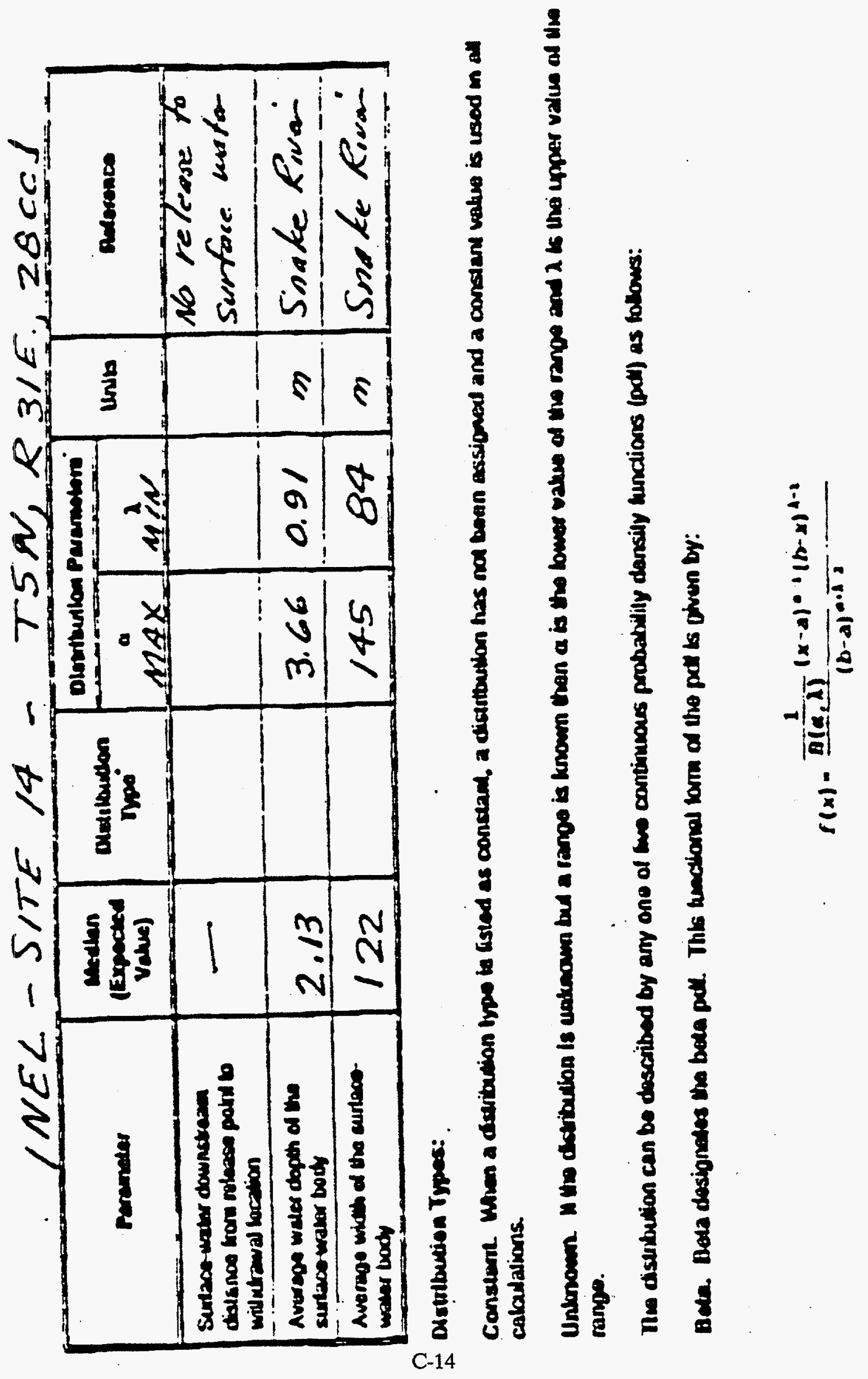


Site Properties Characteristic of Site C

(Radioactive Waste Management Site at the Nevada Test Site) 
C-16 
REYNOLDS ELECTRICAL \& ENGINEERING CO., INC. Post Ottles Box 88621
Las Vegas. NV $89183-852$

FACSIMILE MESSAGE

UNCLASSIFIED ONLY

THIS COVER SHEET IS FOR THE TRANSMITTAL OF UNCLASSIFIED MESSAGES ONLY

$$
\text { DATE: } \frac{5 / 27}{1 / 27}
$$

TIME: $8: 15$

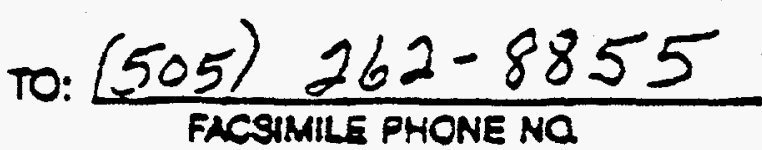

To:

VERIFICATION PHONE NO.

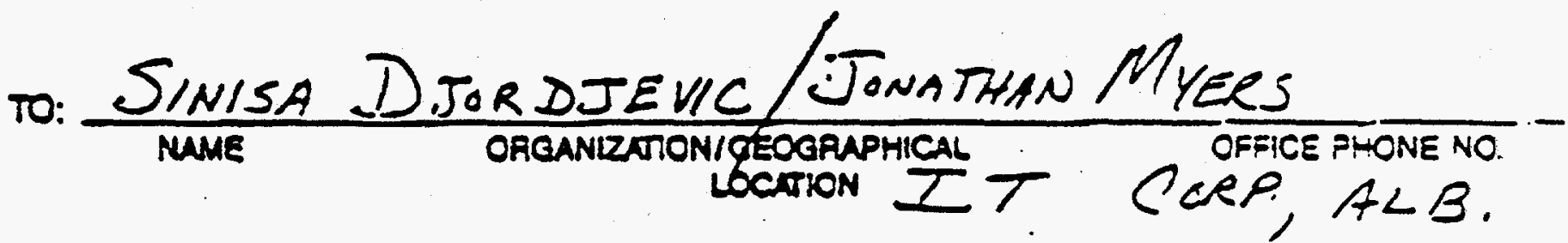

from: $\frac{\text { MAX DOLING, REEL }}{\text { NAME }}$ DEPARTMENT

THIS TRANSMITTAL CONSISTS OF

PAGES (EXCLUDING COVER SHEET)

SPECIAL INSTRUCTIONS:

UNCLASSIFIED ONLY

C-17

25.19 


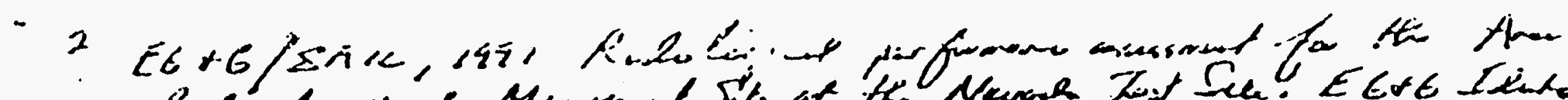

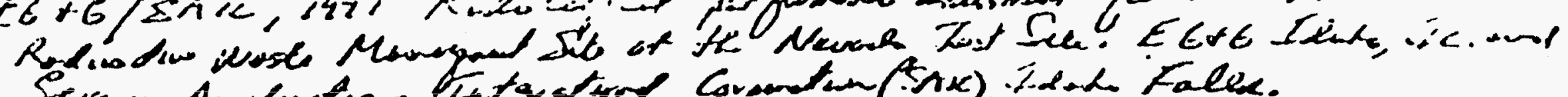

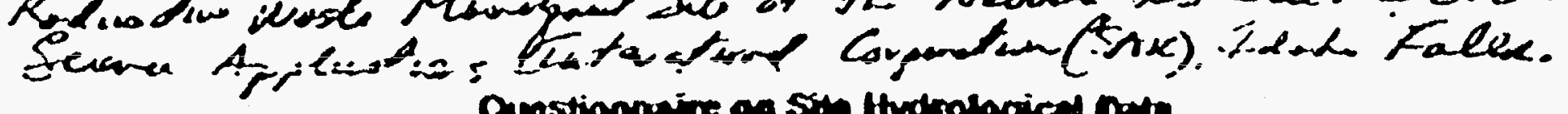

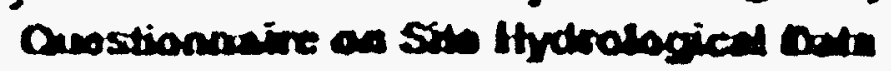

sontact bisormantion

Terson Completing this Oustionaio:

came: Dee Hammanester / Dn Blont

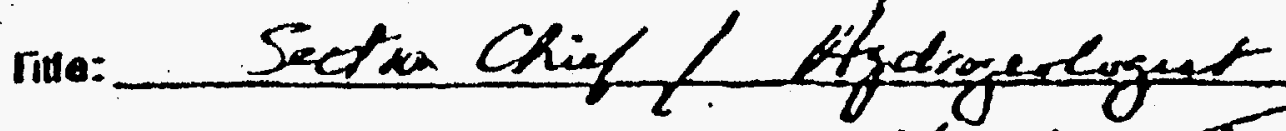

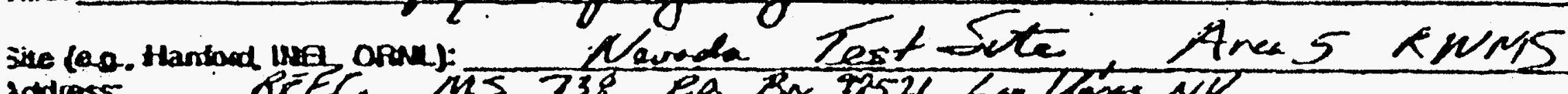

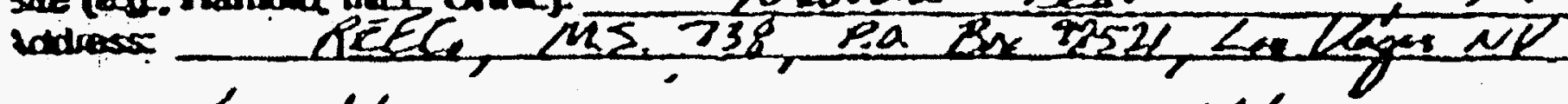

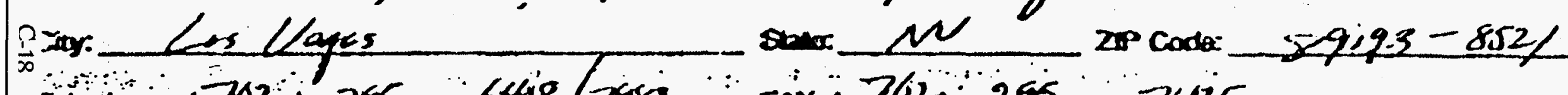

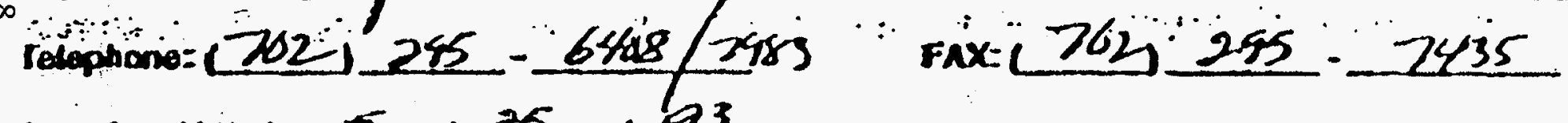
2ale (montadys): 5125,93

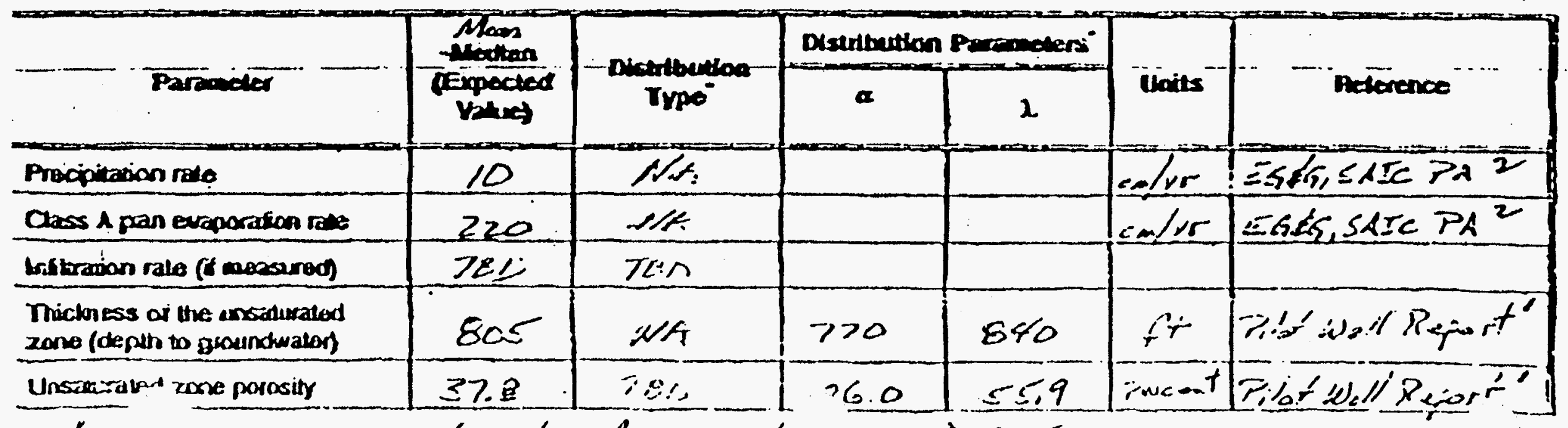




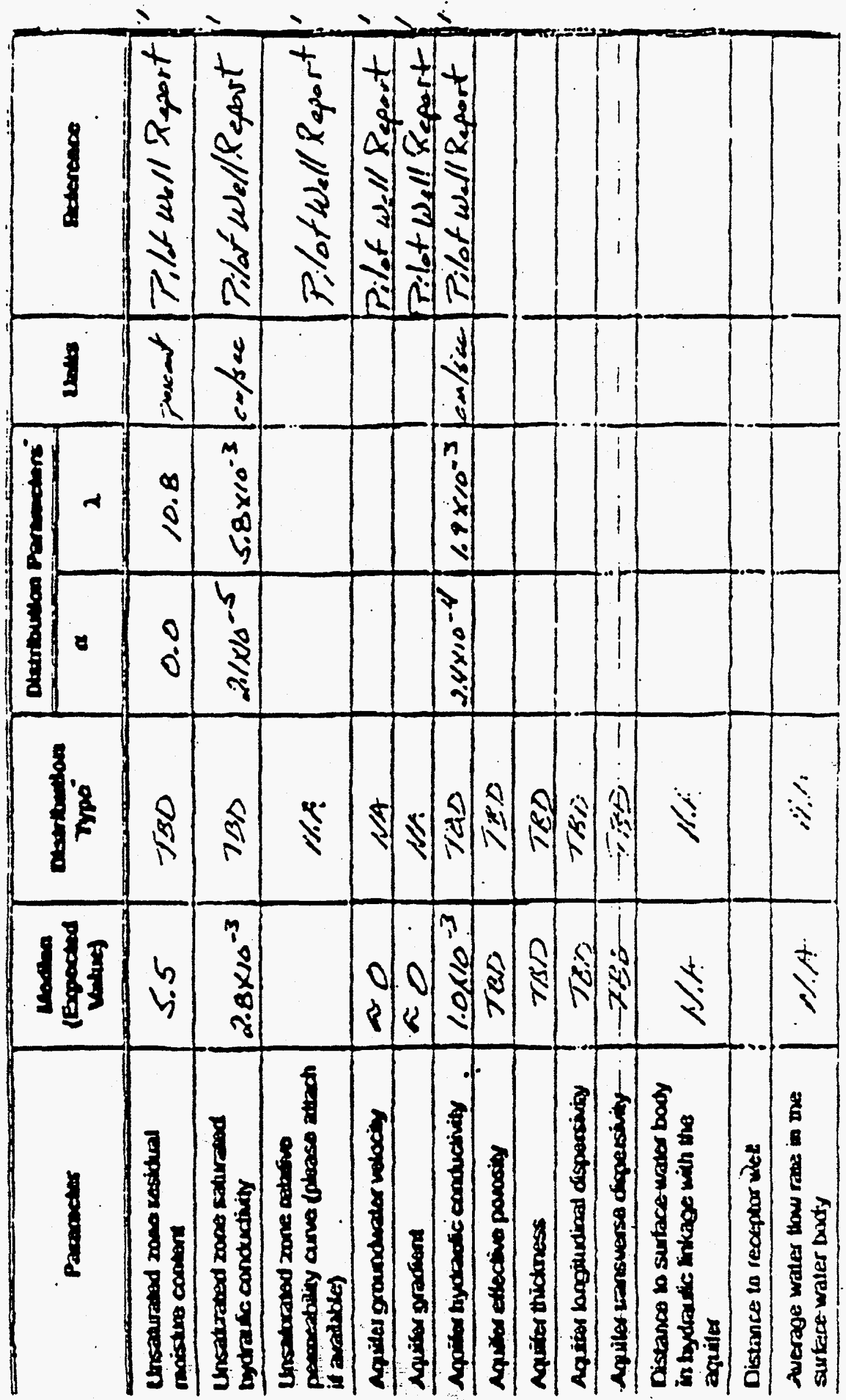




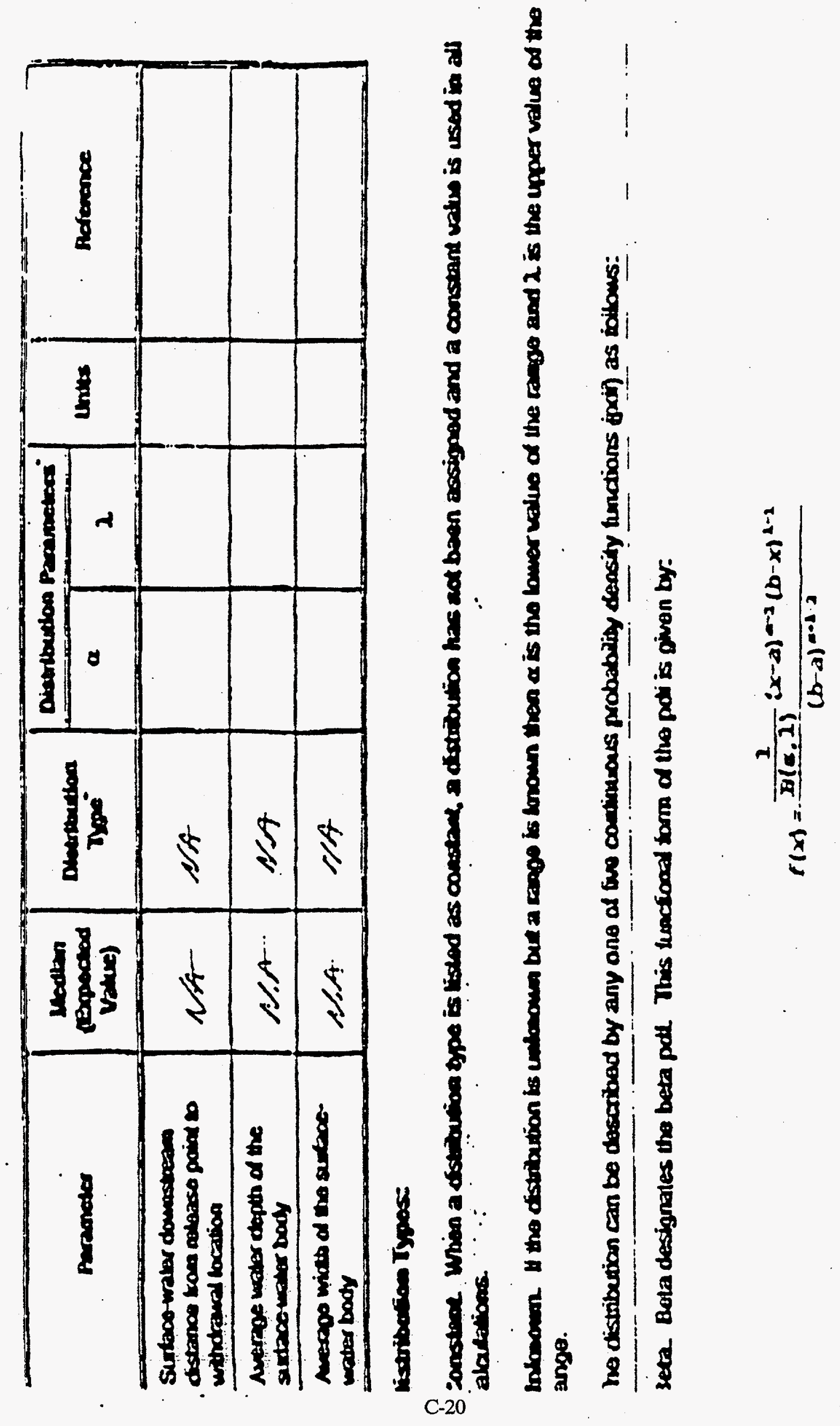




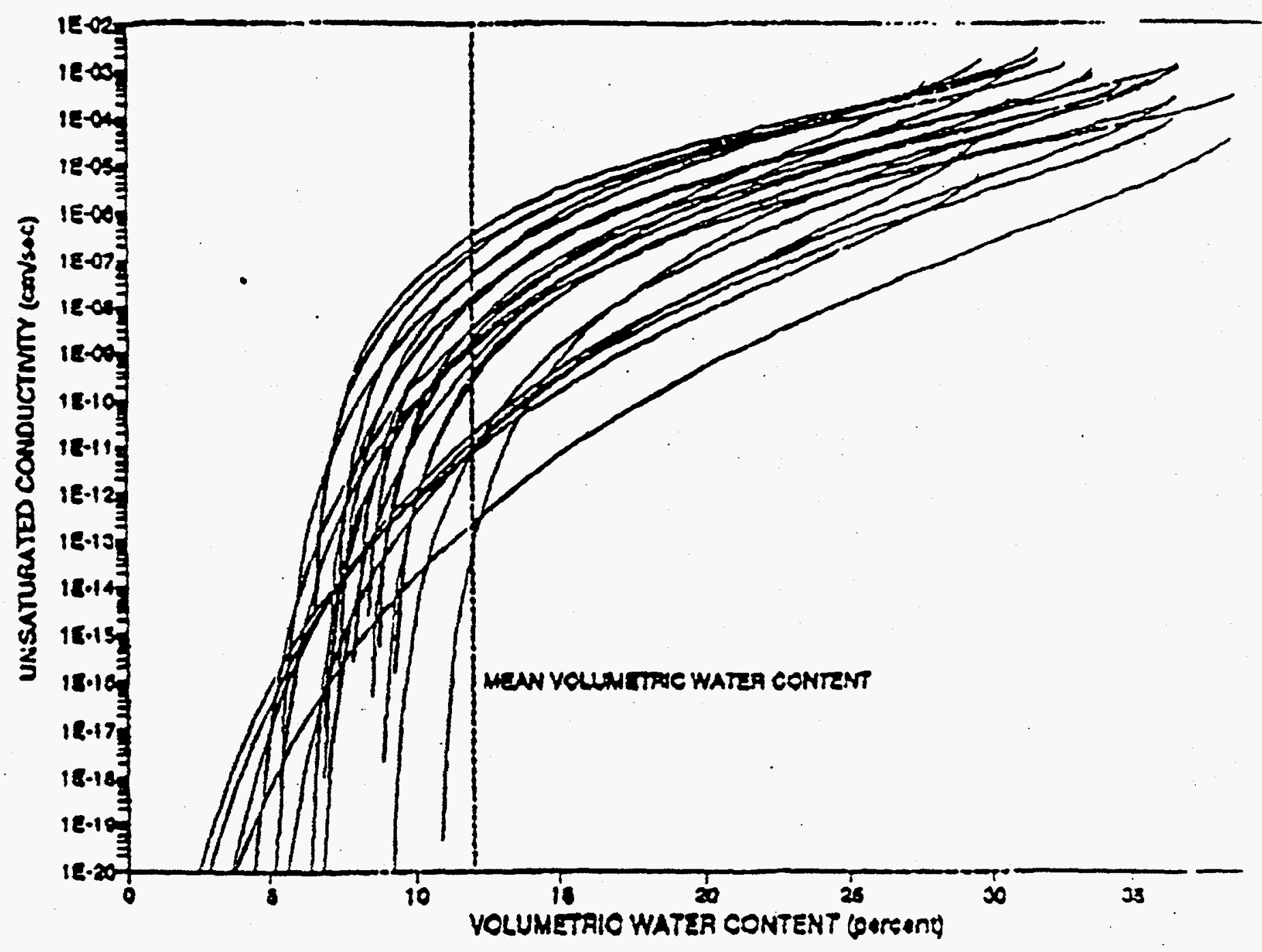

Figure 3.15 Flüed unsaturated hydraulic conducdvity tuncticns for core samples from UesPW-1. 


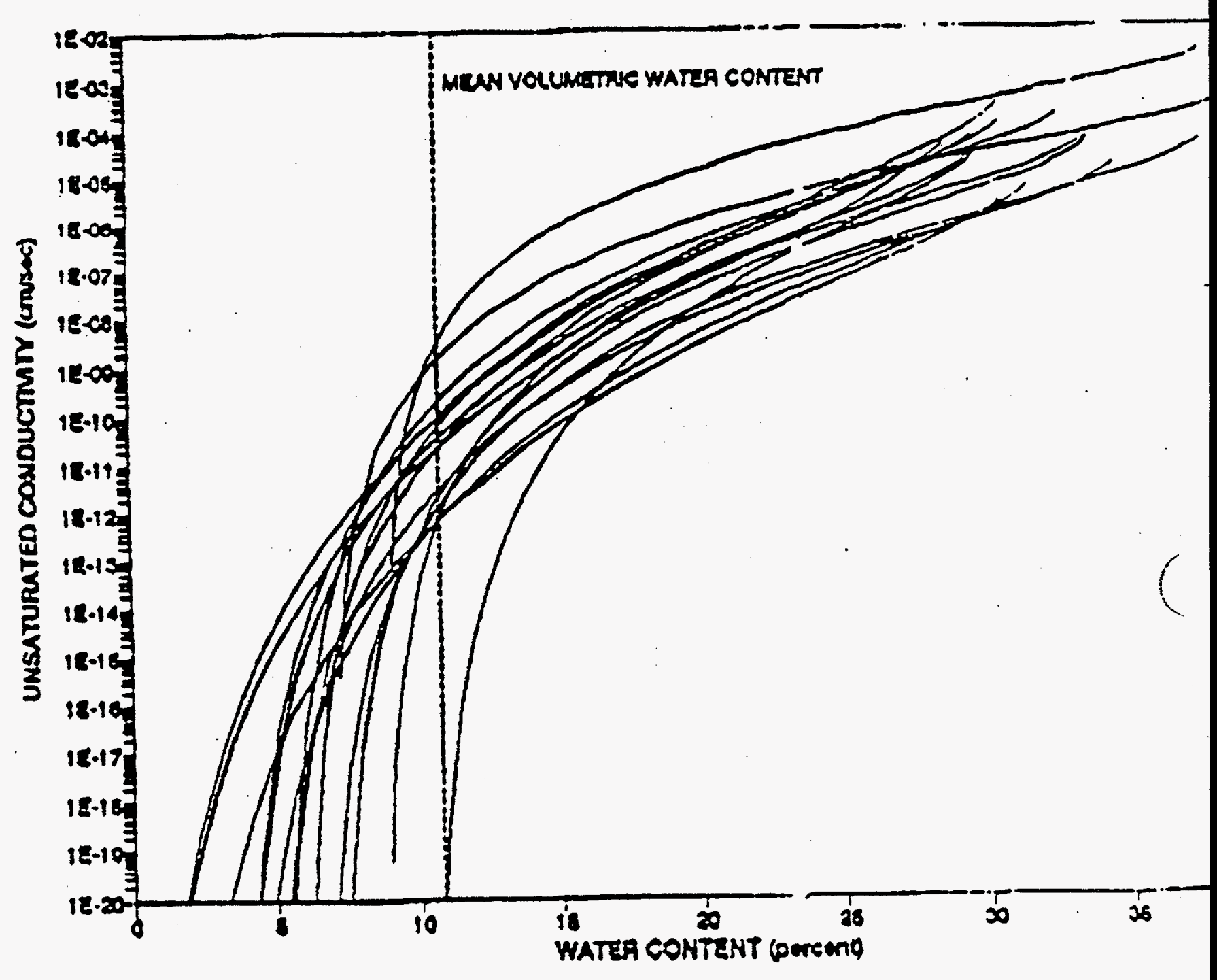

Figure 3.16 Fitted unsaturated hydraulic conductivity sunctions for cose samples from UespW-2. 


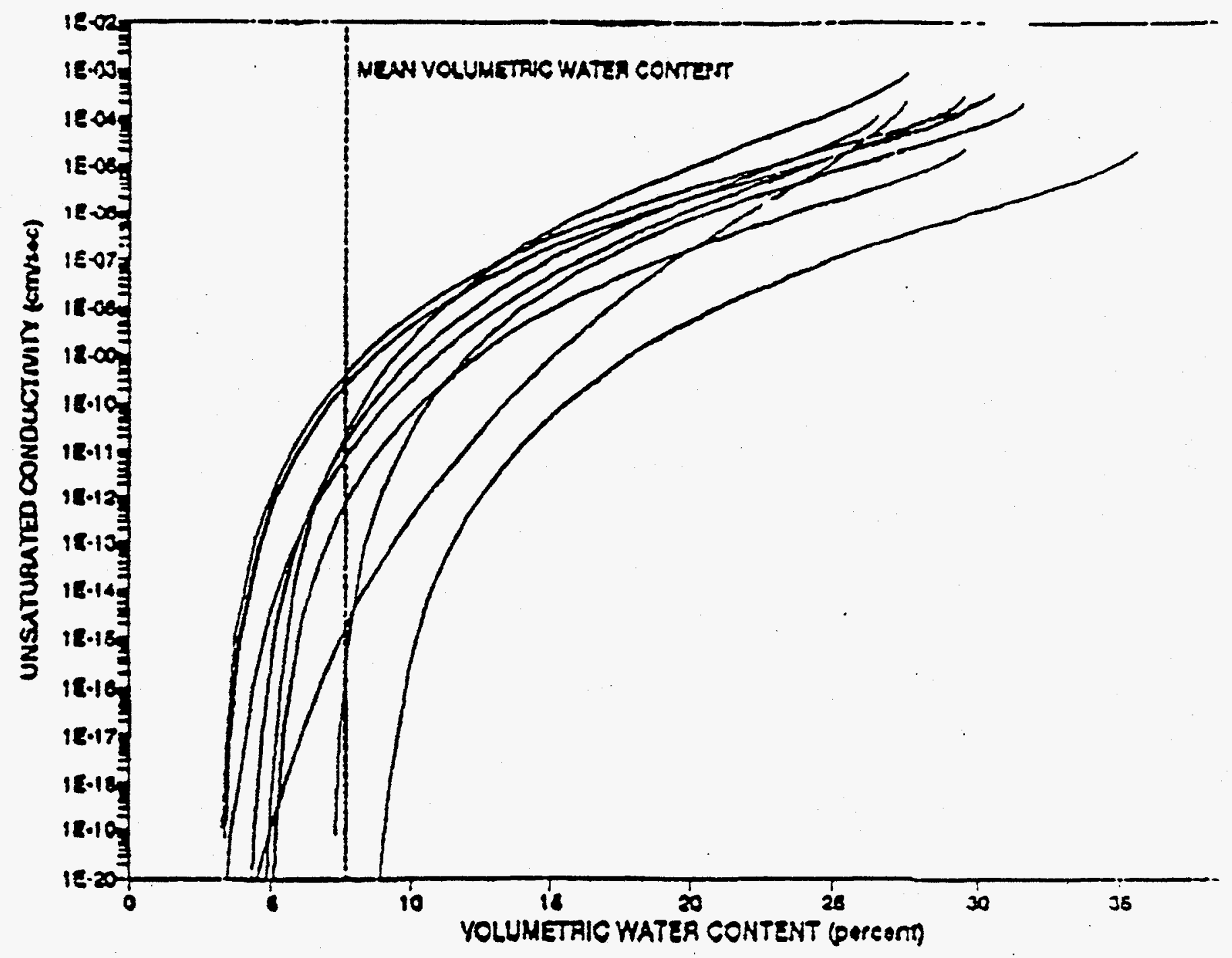

Figure 3.17 Fined unsarurated hydralle conductlvity functlons for core samples from UoSPW-3. 


\section{Appendix D}

Description of Preprocessor and Postprocessor Programs 
D-2 


\section{Appendix D}

\section{Description of Preprocessor and Postprocessor Programs}

\section{D-1. MLLWDRIV.FOR}

\section{D-1.1 Description}

MLLWDRIV.FOR is a driver preprocessor program, written in FORTRAN, that reads the input file for the Model and creates the appropriate input data files for all the codes in the Model. This program also links the individual codes or modules into the Model as explained in this section. The program first opens the input data file "MLLWDRIV.DAT" and reads in the values of the variables for a given run. The data encompass waste form, disposal facility, site, and environmental properties.

After reading the variables in the file "MLLWDRIV.DAT," the file "RAD.DAT" is created for use by the "WELLC.FOR" code. The parameters that are written to the "RAD.DAT" file include the number of radionuclides to be modeled, the element symbol identifiers, the atomic weights of the nuclides, and the nuclide retardation coefficients.

The program then creates the data file "RADUST.DAT" containing data needed to create the DUST input file using the PREDUST.FOR preprocessor. Specifically, the parameter values that are written to the RADUST.DAT file include the number of radionuclides to be simulated, the radionuclide identifiers required by the DUST code, the radionuclide half-lives (yr), the atomic weights, the saturation concentrations $\left(\mathrm{g} / \mathrm{cm}^{3}\right)$, and the radionuclide concentrations in the waste form $\left(\mathrm{Ci} / \mathrm{m}^{3}\right)$.

The program MLLWDRIV then calls the subroutine VDTHETA, passing to this subroutine the value of the infiltration rate into the disposal facility, denoted by variable RATEINFL. The subroutine VDTHETA passes back the Darcy velocity and the moisture content in the facility. Program MLLWDRIV then creates the data file required by the program PREDUST.FOR, which in turn creates the input data file for each radionuclide for the DUST code. This will be explained later in this Appendix.

The data file for the WELLC code (PREWELLC.IN) is then created. The final statements in program MLLWDRIV create the DOS batch file "PAM.BAT," which, when executed, runs the Model. Since the DUST code can calculate the source term (time-dependent flux of a radionuclide leaving the disposal facility) for only one radionuclide at a time, the DUST code must be executed once for each radionuclide. Thus, a DO loop for the number of radionuclides writes statements to the batch file to cause execution of the PREDUST, DUST, and POSTDUST codes for the required number of radionuclides. Statements are then written to the PAM.BAT batch file to cause execution of the WELLC code. A statement is then written to the batch file that causes execution of the postprocessor DECAYDOS that decays and in-grows radionuclides at the water well used by the receptor. 


\section{D-1.2 Verification}

The program MLLWDRIV.FOR is a peripheral computer code that manipulates the data read in from the master input data file (MLLWDRIV.DAT) and creates the appropriate input data files for the various codes and pre- and postprocessors of the Model.

Verification of the code was demonstrated by comparing the data in MLLWDRIV with the following input data files:

- $\quad$ PREDUST.DAT

- RAD.DAT

- RADUST.DAT

- PREWELLC.IN

- PAM.BAT.

The comparison of these files was successful and ensures that execution of the MLLWDRIV code produces the required input data files, thus verifying the MLLWDRIV code.

\section{D-2. PREDUST.FOR}

\section{D-2.1 Description}

PREDUST.FOR is a preprocessor program of the Model written in FORTRAN that prepares the input data file for the DUST code for each radionuclide analyzed. Since the DUST code can calculate the source term (time-dependent flux of a radionuclide leaving the disposal facility) for only one radionuclide at a time, the DUST code must be executed once for each radionuclide. This execution is automatically accomplished by executing the PAM.BAT DOS batch file that was created by the MLLWDRIV code, as described earlier.

The program opens the input data files "PREDUST.DAT" and "RADUST.DAT" that were created previously and reads the values of the various variables. The input data file for the DUST code entitled "DUSTMLLW.INP" is then opened, and the following ten data sets required by the DUST code are written to the file:

Data Set 1: Title and General Problem Definition

Data Set 2: Time Parameters

Data Set 3: Material Assignments/Properties

Data Set 4: Output Specifications 
Data Set 5: Facility Coordinate Data

Data Set 6: Initial and Boundary Conditions

Data Set 7: Water-Flow Parameters

Data Set 8: Container Parameters

Data Set 9: Waste Form Leaching Parameters

Data Set 10: External Sources

\section{D-2.2 Verification}

The PREDUST.FOR is a peripheral computer code that manipulates the data read in from the data files "PREDUST.DAT" and "RADUST.DAT" created by execution of the MLLWDRIV program. The program then creates the appropriate input data file, "DUSTMLLW.INP," for the DUST code for each radionuclide using data contained in the PREDUST.DAT and RADUST.DAT files, as well as values of some parameters that are hard-wired in the PREDUST code. The program also creates the input data file "POSTDUST.DAT" for the POSTDUST program.

Successful verification of the code was demonstrated by comparing the data in the input files and output files to ensure that the values were correctly transferred and in the proper format.

\section{D-3. POSTDUST.FOR}

\section{D-3.1 Description}

POSTDUST.FOR is a postprocessor program of the Model, written in FORTRAN, that converts the source-term data calculated by the DUST code into the form required by the WELLC and SURFQ codes. Each run of the DUST code writes the source-term data for a particular radionuclide XX to the file TRACEFXD.DAT. The POSTDUST code reads the flux (in units of $\mathrm{Ci} / \mathrm{cm}^{2} / \mathrm{yr}$ ) versus time (in yr) data from the TRACEFXD.DAT and multiplies each flux value by the cross-sectional area through which flow occurs within the facility. The waste form is considered impermeable relative to the backfill, and the cross-sectional area of flow corresponds to the area occupied by the backfill around the drums of waste. The resulting flux (in $\mathrm{Ci} / \mathrm{yr}$ )-versus-time data are then written to the file DSTRADXX.DAT for the particular radionuclide XX.

\section{D-3.2 Verification}

Verification of the POSTDUST postprocessor was performed through a hand-calculation by multiplying the flux values in the TRACEFXD.DAT file by the cross-sectional flow area and then comparing the results to the DSTRADXX.DAT file generated by the POSTDUST program. 


\section{D-4. DECAYDOS.FOR}

\section{D-4.1 Description}

The DECAYDOS.FOR is a postprocessor program of the Model that was written in FORTRAN that performs decay-chain calculations. The program reads the well-concentration-versus-time data in file WELLGEN.INP created by the WELLC code and accounts for the decay and in-growth of radionuclides. The resulting concentrations are multiplied by radionuclide-specific dose conversion factors to derive dose versus time profiles for each decay chain.

Based on screening of radionuclides in the alpha low-level waste (ALLW) inventory at the Idaho National Engineering Laboratory (INEL), eight radionuclides were considered for more detailed evaluations using the Model. The inventories of two of these radionuclides ( $\mathrm{Cm}-244$ and Pu-241) were combined with the inventories of their progeny ( $\mathrm{Pu}-240$ and Am-241, respectively), since the half-lives of Cm-244 and Pu-241 are short compared to the half-lives of their progeny.

The radioactive decay chains included in the current version of the Model are shown in Figure D-1. Each chain was considered to be a straight chain. (Any branching involved only very short-lived radionuclides, and the branches eventually rejoined at a common radionuclide.) Very short-lived radionuclides (for which dose data were not available in GENII) are not shown in Figure D-1 since this dose is included in the dose conversion factors for their parent radionuclides.

The decay and in-growth of radionuclides was performed within the DECAYDOS code using the following Bateman decay equations for straight-chain radioactive decay (Benedict et al. 1981):

$$
N_{i}=N_{1}^{0} \lambda_{1} \lambda_{2} \ldots \lambda_{i-1} \sum_{j=1}^{i} \frac{e^{-\lambda, t}}{\prod_{\substack{k=1 \\ k \neq j}}^{i}\left(\lambda_{k}-\lambda_{j}\right)} \quad(i>1)
$$

and

$N_{1}=N_{1}^{0} e^{-\lambda_{1} t} \quad(i=1)$

where

$$
\begin{aligned}
& N_{i}=\text { number of atoms of radionuclide } i \\
& N_{1}{ }^{0}=\text { number of atoms of the progenitor radionuclide } \\
& \lambda_{i}=\text { decay constant for radionuclide } i \\
& t=\text { time. }
\end{aligned}
$$



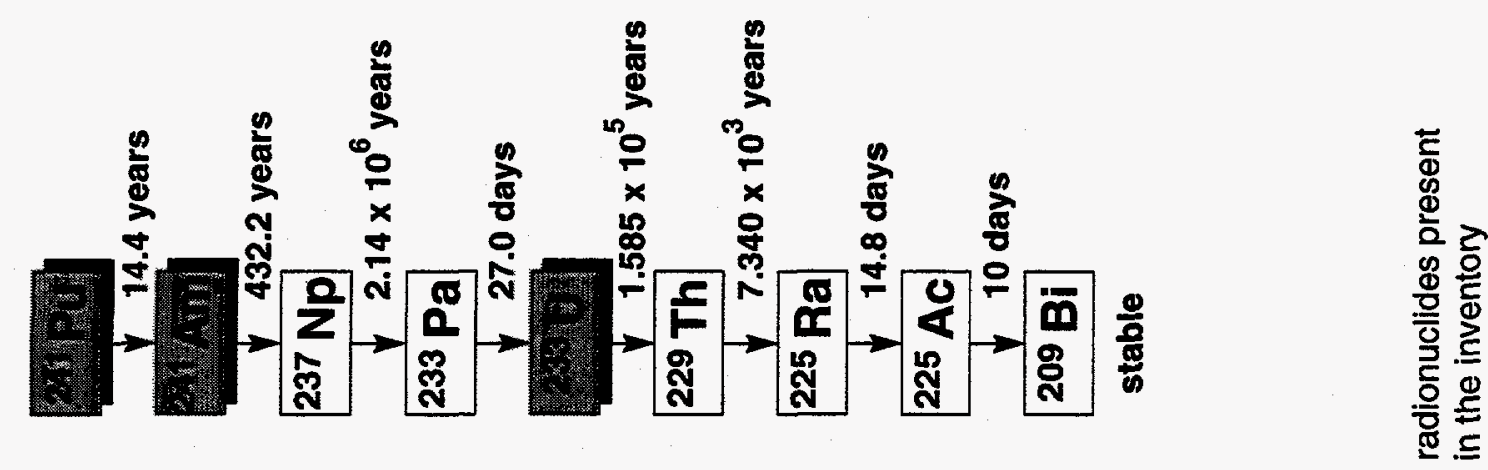

$\sum_{-\infty}^{\infty}$
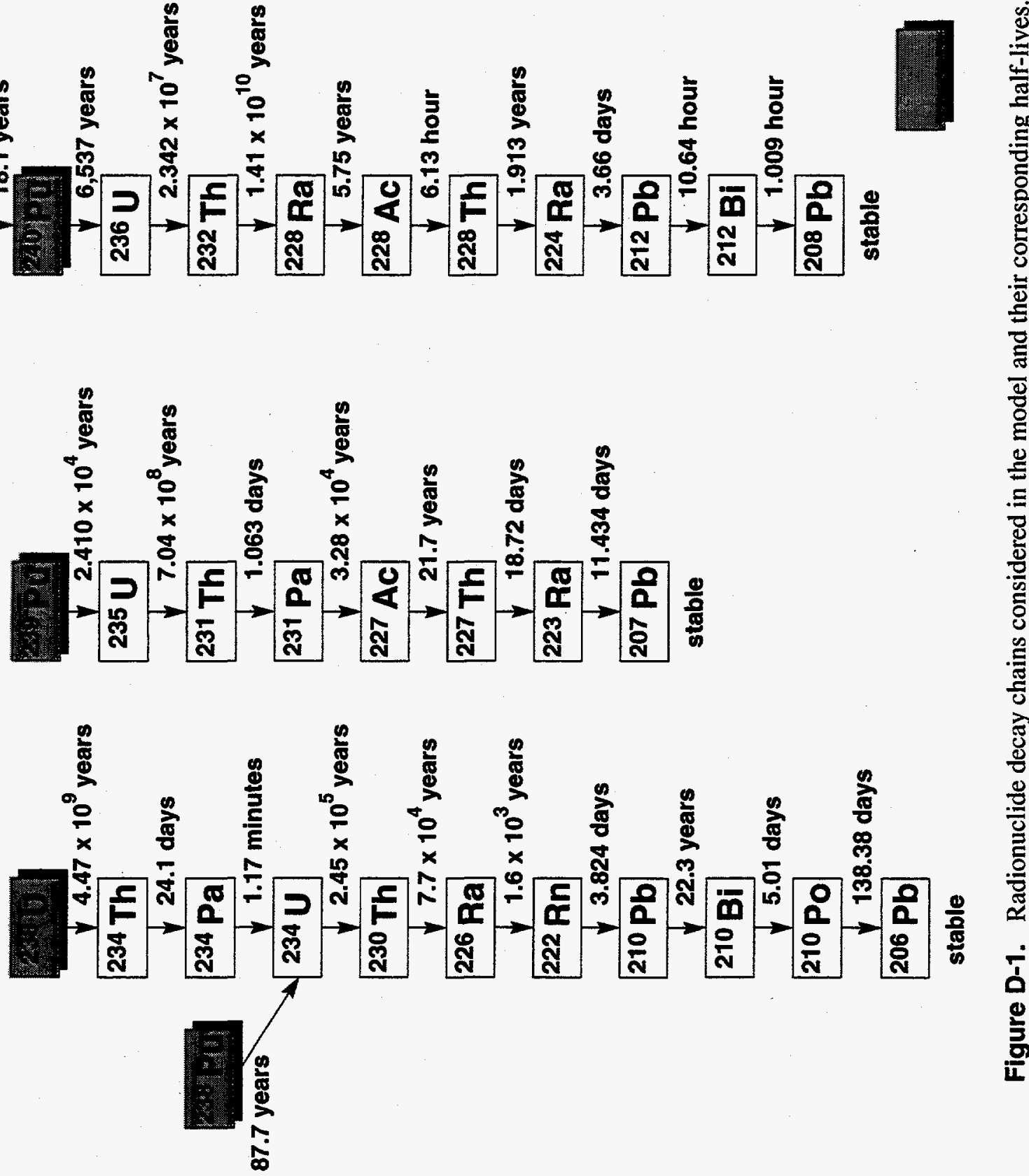

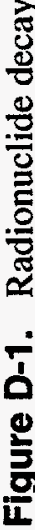


The concentrations and fluxes of the progenitors, in terms of activity, were converted into equivalent atom concentrations and fluxes of the progenitors before applying the Bateman equations. The calculated concentrations and fluxes of the parents and progeny, in terms of atoms, were then converted into units of activity concentrations and fluxes for use with the Dose Integrated Over Ten Thousand Years code.

\section{D-4.2 Verification}

The DECAYDOS code was verified by comparing the predicted results with a code specifically developed for verification using a different calculational methodology. Specifically, the verification code DECHDOSE solves a system of differential equations representing a radioactive decay chain numerically. The procedure recommended for solving sets of stiff differential equations (Press et al. 1990) served as the core of this code. The codes were shown to provide identical results when the tinne-step size in the DECHDOSE program was set to less than one year. 


\section{REFERENCES FOR APPENDIX D}

Benedict, M., T. H. Pigford, and H. W. Levi, 1981, Nuclear Chemical Engineering, 2nd ed., McGraw-Hill Book Company, New York, New York.

Press, W. H., B. P. Flannery, S. A. Teukolsky, and W. T. Vetterling, 1990, Numerical Recipes. The Art of Scientific Computing FORTRAN Version, Cambridge University Press, Cambridge, Massachusetts. 


\section{Appendix E \\ Description of Computer Programs}


E-2 


\section{Appendix E \\ Description of Computer Programs}

This appendix provides a brief description of the computer programs used, other than the preprocessor and postprocessor programs described in Appendix D.

\section{E-1. DESCRIPTION OF VS2DT}

The flow of groundwater through the disposal facility was modeled using the Variably Saturated 2-Dimensional Flow and Transport (VS2DT) code. The program uses a finitedifference approximation to the advection-dispersion equation with added retardation and decay to model both saturated and unsaturated flow and transport (Healy 1990). VS2DT is a nonproprietary computer code published by the U.S. Geological Survey (USGS) (Healy 1990).

The code is well documented and versatile and has been used to simulate variably saturated flow and solute transport under a variety of hydrogeologic conditions. Simulated regions can be one-dimensional columns, two-dimensional vertical cross sections, or axially symmetric, threedimensional cylinders.

For this project, VS2DT was used to calculate the moisture content and Darcy velocity through the facility.

\section{E-2. DESCRIPTION OF DUST}

The Disposal Unit Source Term (DUST) code (Sullivan 1993) was selected to model release and transport of contaminants to the disposal facility boundary. The code accounts for the most important processes of fluid flow, container degradation, waste-form leaching, and radionuclide transport and decay which influence release.

DUST allows waste form release to be modeled in three ways: surface washoff, diffusion release, and uniform dissolution of the waste form. All of these release mechanisms account for radioactive decay of the source.

Two different methods are available for calculating transport of contaminants through the facility: the Multi-Cell Mixing Cascade (MCMC) model and the one-dimensional Finite Difference (FD) model. The FD model is much more flexible and is capable of simulating more processes than the MCMC model. The FD model checks to ensure that radionuclide solubilities are not exceeded, whereas the MCMC model does not perform this check. The FD model also permits the water velocity through the waste to be defined as a function of time. The MCMC model only allows a constant velocity to be defined. The MCMC model does not model diffusional releases, whereas the FD model does. Thus, the FD model was used for the performance assessment (PA) source-term.

The FD model solves the transport equation with the processes of advection, dispersion, retardation, and radioactive decay (Sullivan 1993). The FD model is one-dimensional and divides the model domain into control volumes. It then transforms the advection-dispersion transport equation into a set of coupled algebraic equations using the control volumes. Then a mass balance is performed on each control volume using finite differences. 
For this project, DUST was used to provide a flux of radionuclides out the bottom of the disposal facility.

\section{E-3. DESCRIPTION OF WELLC}

The WELLC code consists of a vadose zone flow and transport routine and a saturated zone flow and transport routine. The code accepts as input the time-dependent flux of radionuclides entering the vadose zone, and returns as output the concentrations of radionuclides at a receptor well as a function of time.

The vadose zone routine considers one-dimensional advection and retardation in a variably saturated medium. Within the vadose zone, the average velocity and travel time of a nonsorbing contaminant moving from the waste zone to the water table is estimated analytically as a function of the infiltration rate, the degree of saturation, the porosity, and the thickness of the vadose zone. The travel time of each contaminant is then calculated by multiplying the vadose zone travel time by the retardation coefficient for that contaminant.

Within the saturated zone, calculations are performed using Green's function solutions to the steady, one-dimensional aquifer flow, advection-dispersion equations with added retardation. To solve the Green's function, the code requires properties of the aquifer, disposal facility, and the location of a receptor well. In addition, the mass flux into the aquifer from the vadose zone flow and transport routine is used as the source of contamination to the aquifer. The aquifer properties required are retardation coefficients, thickness, groundwater velocity, and longitudinal and transverse dispersivity. The disposal facility properties required are the length of the facility along the direction of groundwater flow, the width of the facility perpendicular to the groundwater flow direction, and the distance to a receptor well from the downgradient edge of the facility. This solution is then used over various times to develop a concentration-versus-time profile at the receptor well location.

\section{E-4. DESCRIPTION OF GENII}

The Generation-II (GENII) package (Napier et al. 1988) was used to calculate the doses for the intruder scenarios. GENII is one of the most commonly used packages in Department of Energy (DOE) low-level waste (LLW) disposal facility PAs. It implements the recommended U.S. Nuclear Regulatory Commission (NRC) exposure pathways models and performs dose calculations using the methods recommended by the International Committee on Radiation Protection.

The GENII package has the capability to calculate radiation dose to individuals and populations from both acute and chronic releases from all contributing pathways of exposure, including external exposure and ingestion. The GENII package comprises seven interrelated computer codes and their associated data libraries. The codes fall into three categories: user interface, internal and external dose factor generators (codes INTDF and EXTDF), and environmental dosimetry programs. The EXTDF module allows easy and uniform calculation of external dose-rate factors for submersion in an infinite cloud of radioactive materials, immersion in contaminated water, and direct exposure to plane or slab sources of contamination. The EXTDF code is a modification and enhancement of the well-known shielding code ISOSHLD. The INTDF code is used to make estimates of the dose equivalents in a number of target organs from the activity in a given source organ. Most of the INTDF code is used to calculate the integrated retentions of parent and progeny radionuclides in the source organs. The 
environmental dosimetry programs can be used to evaluate either short- or long-term scenarios. The short-term environmental dosimetry portion is divided into three separate but interrelated programs (ENVIN, ENV, and DOSE) that handle input organization and checking, environmental exposure, and dose calculations, respectively. The ENVIN module controls the reading of the . input files. The ENVIN code interprets the basic input, reads the basic GENII data libraries and other optional input files, and organizes the input into sequential segments based on radionuclide decay chains. The ENV module calculates the environmental transfer, uptake, and human exposure to radionuclides that result from the chosen scenario for the defined source term. The DOSE module reads the annual intake and exposure rates defined by the ENV module and converts them to radiation dose. The calculation of external dose is done with precalculated factors from the EXTDF module, and the calculation of internal dose is done with precalculated factors from the INTDF module. This portion of the GENII package is designed to analyze environmental consequences in the near term ( 0 to $100 \mathrm{yr})$ following release to the environment and was applied to evaluate the impacts of the three human-intrusion scenarios. The primary limitation of the short-term portion is that the programs are based on steady-state radionuclide concentrations in environmental media. 


\section{REFERENCES FOR APPENDIX E}

Healy, R. W., 1990, "Simulation of Solute Transport in Variably Saturated Porous Media with Supplemental Information on Modifications to the U.S. Geological Survey's Computer Program VS2D," Water-Resources Investigations Report 90-4025, U.S. Geological Survey, Denver, Colorado.

Napier, B. A., R. A. Peloquin, D. L. Strenge, and J. V. Ramsdell, 1988, GENII-The Hanford Environmental Radiation Dosimetry Software System: Conceptual Representation, PNL-6584, Vol. 1, Pacific Northwest Laboratory.

Sullivan, T. M., 1993, DUST Disposal Unit Source Term: Data Input Guide, NUREG/CR-6041, BNL-NUREG-52375, Brookhaven National Laboratory, April. 


\section{Appendix F}

Verification and Validation of Computer Programs 
F-2 


\section{Appendix F}

\section{Verification and Validation of Computer Programs}

This appendix discusses the verifications and validations of the computer programs described in Appendix E. The process of verifying, validating, and testing software was considered essential in the development of the Model. Verification is an independent assessment of the numerical correctness of the software results. Validation is an independent assessment of the theoretical correctness of the software.

The Model is made up of Nuclear Regulatory Commission (NRC) computer codes and computer codes widely used in the Department of Energy (DOE) system, as well as the pre- and postprocessors that have been developed to link the individual codes into the Model. The VS2DT, DUST, and GENII codes are considered "industry standards," and verification and validation $(V \& V)$ was performed outside the current effort. The pre- and postprocessors MLLWDRIV, PREDUST, and POSTDUST, which simply manipulate input and output files required and created by the industry standard codes, were verified by confirming that the required data and formats were properly transferred between files (see Appendix D). A number of calculations are performed within the DECAYDOS postprocessor of the Model. This program was verified/validated by comparing the results to those of an independently developed program that uses a different calculational methodology. The following describes the verification and validation that have been performed for the various codes.

\section{F-1. V\&V OF VS2DT}

The flow through the disposal facility was modeled by using the VS2DT model. VS2DT is a U.S. Geological Survey (USGS) finite difference code that can be used to model both saturated and unsaturated flow and transport (Healy 1990). Recent discussions with the Sandia National Laboratories/New Mexico (SNL/NM) staff, who are developing the NRC performance assessment (PA) methodology, indicated that VS2DT will be recommended as an alternative model to the previously recommended VAM2D model (Kozak and Olague 1993). VS2DT is a nonproprietary computer code published by the USGS. The code is well documented and versatile and has been used to simulate variably saturated flow and solute transport under a variety of hydrogeologic conditions.

A study has recently been completed to identify the "code of choice" for the SNL/NM Environmental Restoration Program to use to simulate vadose zone and contaminant transport. As part of the study, SNL/NM staff benchmarked VS2DT against VAM2D (Huyakorn et al. 1989), a proprietary finite-element flow and solute transport code that is widely used in DOE site PAs. The SNL/NM staff found that the codes gave comparable results but that VS2DT was significantly faster (McCord and Goodrich 1993).

The VS2DT code was developed by the USGS under their software quality assurance (QA) standards. It had been tested and verified previously against several analytical solutions (Healy 1990). Although several verification examples were provided in the VS2DT manual (Healy 1990), 
it was felt that some additional, independent verification was in order before an unequivocal recommendation to use the VS2DT code on this project could be given. Two verification problems were selected based on two analytical solutions. The first verification problem represented two-dimensional unsaturated flow to a water table that was solved analytically by Philip (1989). The second verification problem simulated two-dimensional saturated solute transport and was solved analytically by Javandel et al. (1984) and named "TDAST." The differences in mass between that predicted by the VS2DT code and the prediction in the analytical solution were less than $2 \%$ for each verification problem.

\section{F-2. V\&V OF DUST}

Verification and validation of the DUST code have been conducted through a number of studies. The container degradation models (general and local failure) and the waste form release models (diffusion, uniform, and surface rinse with partitioning) were independently verified by comparing the predicted results of known analytical solutions. The finite difference and multi-cell mixing cascade models were extensively tested by comparing the predicted results to known analytical solutions and by comparing the results predicted by the two models on identical problems. In all cases, there was excellent agreement among the various results.

\section{F-3. V\&V OF WELLC AND SURFQ}

Because the source codes for DISPERSE and SURFACE that were developed and recommended by Kozak et al. (1990) were unavailable, comparable codes were developed for use in the Model. The WELLC and SURFQ codes of the Model provide the concentrations of radionuclides at the well and the flux of radionuclides entering a surface-water body, respectively, as a function of time. In both codes, the calculations are performed using Green's function solutions to the steady, one-dimensional aquifer flow, advection-dispersion equations. The WELLC and SURFQ codes thus use the same equations as in the corresponding DISPERSE and SURFACE codes, respectively, and differ only in the numerical integration scheme. Specifically, in the WELLC and SURFQ codes, integration of the product of the Green's function and the source rate is performed using the Quadrature routine Adaptive integrator General purpose userdefined integer and Extended parameters list for increased flexibility (QAGE) routine of QUADPACK (Piessens et al. 1983).

The codes were tested and successfully verified through benchmarking exercises with the DISPERSE and SURFACE codes. Each subroutine of the DISPERSE and SURFACE codes was verified independently before being used in the code. The codes were then verified for selfconsistency by comparing results for a point source to results from the point-source of Green's function. The codes were also verified against the analytical Green's function for an area source of infinitesimal duration, and the codes reproduced the analytical results well. The results of the DISPERSE code were compared to those predicted by the FEMWATER and the VAM2D codes for a simple conceptual model. The effects of several parameters on the comparisons were examined for each case. The results from the three codes are qualitatively similar, but the simpler DISPERSE code produced slightly more conservative well concentrations. 


\section{F-4. V\&V OF GENII}

The GENII package was developed in accordance with American Society of Mechanical Engineers standard NQA-1 as implemented in the Pacific Northwest Laboratories Quality Assurance Manual. The design process consisted of developing and internally testing software, developing test cases, and documenting software in accordance with the design input. The GENII package has been extensively tested and verified by hand, using hand-calculation worksheets, and has been benchmarked against similar Hanford environmental dosimetry programs. The code has also undergone extensive peer reviews. Additional GENII QA-related information is provided in Chapter 5.0 of the GENII Users' Manual (Napier et al. 1988). 


\section{REFERENCES FOR APPENDIX F}

Healy, R. W., 1990, "Simulation of Solute Transport in Variably Saturated Porous Media with Supplemental Information on Modifications to the U.S. Geological Survey's Computer Program VS2D," Water-Resources Investigations Report 90-4025, U.S. Geological Survey, Denver, Colorado.

Huyakorn, P. S., J. B. Kool, and J. B. Robertson, 1989, Documentation and User's Guide: VAM2D-Variably Saturated Analysis Model in Two Dimensions (Version 5.0 with Hysteresis and Decay Transport), NUREG/CR-5352, HCL/89-01, HydroGeoLogic Inc., Herndon, Virginia.

Javandel, I., C. Doughty, and C. Tsang, 1984, "Groundwater Transport: Handbook of Mathematical Models," Water Resources Monograph Series 10, American Geophysical Union, Washington, D.C.

Kozak, M. W., and N. E. Olague, 1993, "Updated Recommendations for Low-Level Waste Performance Assessment," Proceedings of the Symposium on Waste Management, Tucson, Arizona, March, pp. 371-376.

Kozak, M. W., M. S. Y. Chu, and P. A. Mattingly, 1990, A Performance Assessment Methodology for Low-Level Waste Facilities, NUREG/CR-5532, SAND90-0375, Sandia National Laboratories, Albuquerque, New Mexico.

McCord, J. T., and M. T. Goodrich, 1993, Benchmark Testing and Independent Verification of the VS2DT Computer Code, SAND91-1526, draft, Sandia National Laboratories, Albuquerque, New Mexico.

Napier, B. A., R. A. Peloquin, D. L. Strenge, and J. V. Ramsdell, 1988, GENII-The Hanford Environmental Radiation Dosimetry Software System: Conceptual Representation, PNL-6584, Vol. 1, Pacific Northwest Laboratory, Richland, Washington.

Philip, J. R., 1989, "Multidimensional Steady Infiltration to a Water Table," Water Resources Research, Vol. 25, No. 1, pp. 109-116.

Piessens, R., E. deDoncker-Kapenga, C. W. Uberhuber, and D. K. Kahener, 1983, "QUADPACK-A Subroutine Package for Automatic Integration," Springer Series in Computational Mathematics, Vol. 1. Springer-Verlag, Berlin, Germany. 


\section{Appendix G}

Final Waste Form Characteristics 
G-2 


\section{Appendix G}

\section{Final Waste Form Characteristics}

This appendix provides the properties of untreated waste and final waste forms (FWFs) that were used.

Three categories of FWFs-cement, glass, and ceramic-were selected for evaluation. For each category, two FWFs were identified to represent realistic limits of the behavior of relatively favorable FWFs and relatively unfavorable FWFs. As used here, the term "favorable" refers to FWF behavior that tends to enhance long-term immobilization of the radionuclides.

For some properties, measured values for specific FWFs were used. Those specific FWFs are as follows: Portland cement concrete (PCC) and concrete fused under elevated temperature and pressure (FUETAP); borosilicate glass (BSG) and aluminosilicate glass (ASG); and iron-enriched basalt (IEB) and IEB with $\mathrm{TiO}_{2}$ and $\mathrm{ZrO}_{2}$ additions (IEB4). For other properties, the ranges of values represent variations that may occur in practice during treatment operations, rather than correlations with a particular FWF. For such properties, the analogy was continued by assigning the more favorable value of the property to the more favorable FWF, and the less favorable value to the less favorable FWF. For simplicity, the FWF terminology used in the property tables is "More Favorable" and "Less Favorable," for the ranges of FWFs under each of the three categories.

Table G-1 lists the values used for the FWF properties that are independent of contaminant. The specific gravity and porosity of untreated waste are also addressed. Table G-2 lists the values used for the FWF properties that are contaminant-dependent. The contaminants for which the values apply are indicated. The values listed in Tables G-1 and G-2 were compiled from various IT Corporation and Idaho National Engineering Laboratory (INEL) reports. Table G-3 lists typical chemical compositions of the FWFs.

Also included in this appendix are two letters that provide information on FWF characteristics. The first letter, from T. L. Eddy on January 18, 1995, is titled "Leach Rate Updates Based on Recent Experiments." It provides updated values for the waste form dissolution rates in Table G-1, based on data published after this performance assessment (PA) task had begun. The data from the Eddy letter that were used in the PA runs are those listed under the heading "New MCC-1" in Table 6. These data are referred to in the main body of this report as the "revised leach rates."

The second letter, from T. L. Eddy on March 14, 1995, is titled "Two-Step Leach-Rate Decay Model." It provides guidance rates in different time periods. The data that were used in the PA runs appear in Table II of the letter. Runs were made only for the IEB FWF. The step 1 value of $0.08 \mathrm{~g} / \mathrm{m}^{2}$-day was used. For conservatism, the step 2 value used was the largest for the BSG FWF. These data are referred to in the main body of this report as the "time-dependent leach rates." 
Table G-1. Final waste form properties that are independent of contaminant.

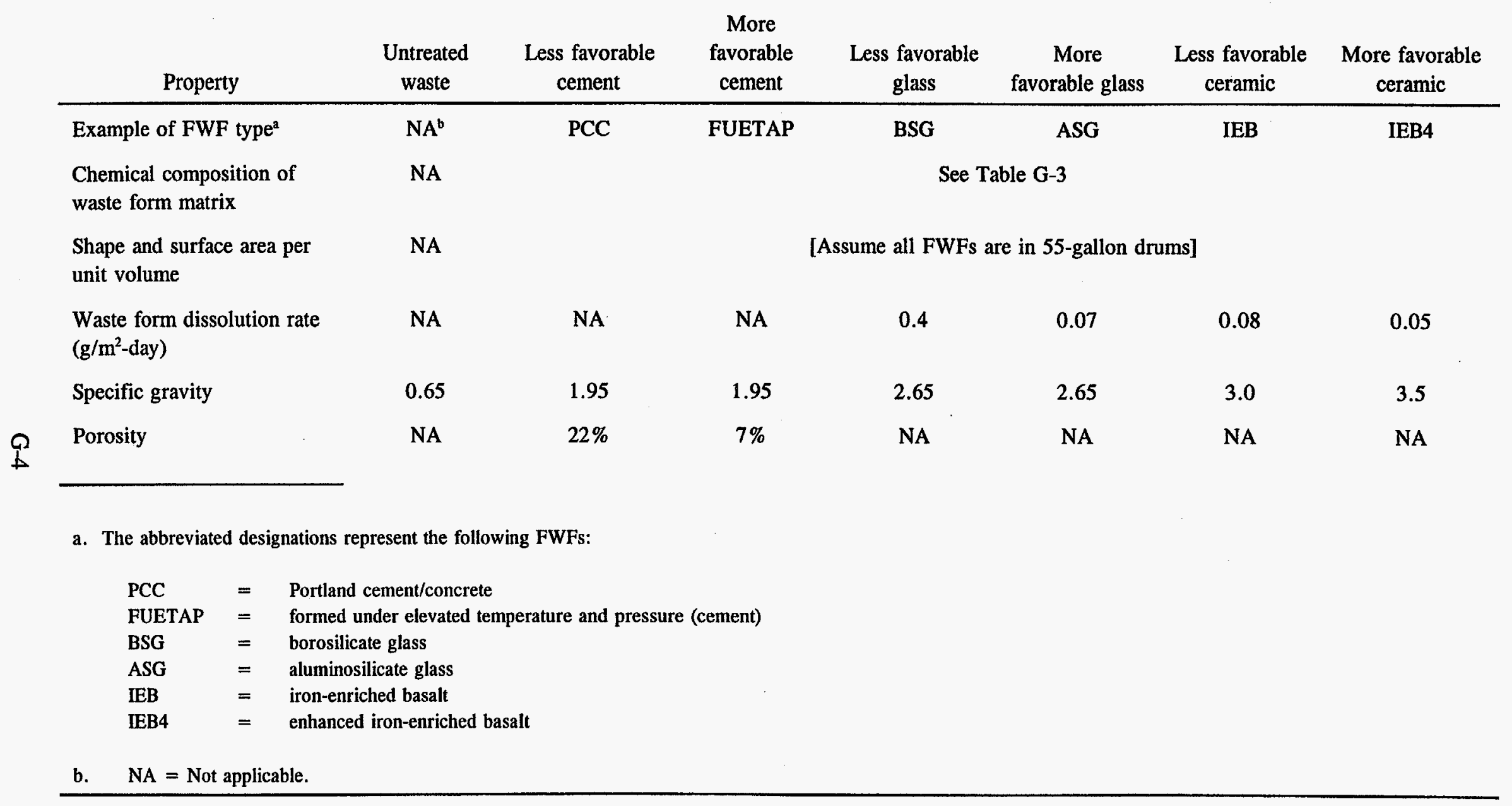


Table G-2. Final waste form properties that are contaminant-dependent.

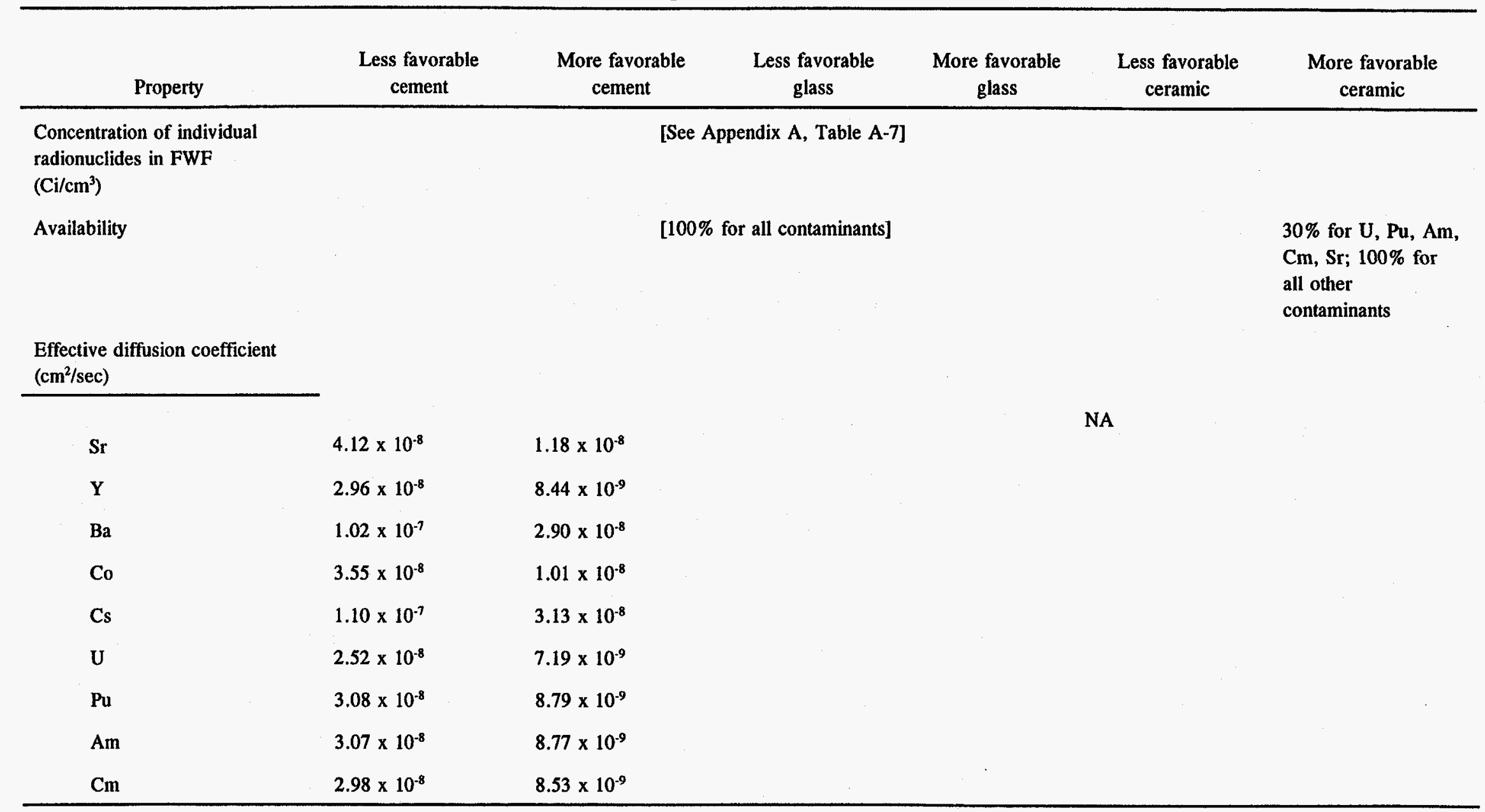


Table G-2. (continued).

\begin{tabular}{|c|c|c|c|c|c|c|}
\hline Property & $\begin{array}{l}\text { Less favorable } \\
\text { cement }\end{array}$ & $\begin{array}{l}\text { More favorable } \\
\text { cement }\end{array}$ & $\begin{array}{l}\text { Less favorable } \\
\text { glass }\end{array}$ & $\begin{array}{l}\text { More favorable } \\
\text { glass }\end{array}$ & $\begin{array}{l}\text { Less favorable } \\
\text { ceramic }\end{array}$ & $\begin{array}{l}\text { More favorable } \\
\text { ceramic }\end{array}$ \\
\hline \multicolumn{7}{|l|}{$\begin{array}{l}\text { Solubility limits } \\
\left(\mathrm{g} / \mathrm{cm}^{3}\right)\end{array}$} \\
\hline $\mathrm{Am}$ & $4.60 \times 10^{-7}$ & & & & & \\
\hline $\mathrm{Pu}$ & $4.51 \times 10^{-8}$ & & & & & \\
\hline $\mathrm{U}$ & $3.03 \times 10^{-5}$ & & & & & \\
\hline $\mathrm{Cm}$ & $\begin{array}{l}3.03 \times 10^{-5} \\
\text { (conservative value) }\end{array}$ & & & & & \\
\hline All other elements & $\begin{array}{l}1 \times 10^{-2}, \text { so as not to } \\
\text { limit releases }\end{array}$ & & & & & \\
\hline
\end{tabular}

$\frac{a}{a}$ 
Table G-3. Typical chemical composition of final waste forms (wt\%).

\begin{tabular}{|c|c|c|c|c|c|c|c|c|c|c|c|c|c|}
\hline FWF & $\mathrm{SiO}_{2}$ & $\mathrm{~B}_{2} \mathrm{O}_{3}$ & $\mathrm{Na}_{2} \mathrm{O}$ & $\mathrm{K}_{2} \mathrm{O}$ & $\mathrm{Li}_{2} \mathrm{O}$ & $\mathrm{MgO}$ & $\mathrm{CaO}$ & $\begin{array}{c}\mathrm{FeO} \& \\
\mathrm{Fe}_{2} \mathrm{O}_{3}\end{array}$ & $\mathrm{Al}_{2} \mathrm{O}_{3}$ & $\mathrm{TiO}_{2}$ & $\mathrm{ZrO}_{2}$ & $\mathrm{H}_{2} \mathrm{O}$ & Misc \\
\hline $\mathrm{PCC}^{\mathrm{a}}$ & 25.2 & & 1.9 & 1.0 & & 1.8 & 15.3 & 14.0 & 5.4 & & & 35.0 & \\
\hline FUETAP ${ }^{b}$ & 45.7 & & 1.9 & & & 1.8 & 14.5 & 19.7 & 5.2 & 3.8 & & 2.0 & 4.5 \\
\hline $\mathrm{BSG}^{\mathrm{c}}$ & 49.6 & 7.0 & 9.6 & & 4.9 & 0.7 & 1.1 & 15.8 & 4.5 & & 0.7 & & 6.0 \\
\hline $\mathrm{ASG}^{\mathrm{d}}$ & 53.2 & & 1.1 & 1.9 & & 2.8 & 12.0 & 19.0 & 9.7 & 0.4 & & & \\
\hline $\mathrm{IEB}^{\mathrm{e}}$ & 55.7 & & 2.6 & 2.7 & & 3.1 & 10.3 & 13.8 & 11.4 & 0.4 & & & \\
\hline IEB $^{f}{ }^{f}$ & 51.7 & & 2.4 & 2.5 & & 2.9 & 9.6 & 12.8 & 10.6 & 5.0 & 2.5 & & \\
\hline
\end{tabular}

a. Grandy, J. D., et al., 1993, p. 10. Assumes $40 \%$ A-Series waste loading.

b. Dole, L. R., et al., 1983 , p. 5-6. Assumes $40 \%$ A-Series waste loading, $18.7 \%$ Portland cement, $9.4 \%$ flyash, $6.4 \%$ clay, $23.6 \%$ sand, and $2 \%$ water.

c. Kong, P. C., et al., 1993, Table 12. BSG with $30 \%$ waste loading. (Document is in draft form and not yet available for public distribution.)

d. Grandy, J. D., et al., 1993, Table p. A-5, S-60 mixture.

e. Grandy, J. D., et al., 1993, A-60 mixture.

f. Grandy, J. D., et al., 1993, A-60 mixture prorated for $7.5 \% \mathrm{TiO}_{2}+\mathrm{ZrO}_{2}$. 


\section{REFERENCES FOR APPENDIX G}

Dole, L. R., G. C. Rogers, M. T. Morgan, D. P. Stintion, J. H. Kessler, S. M. Robinson, and J. G. Moore, 1983, Cement-Based Radioactive Waste Hosts Formed Under Elevated Temperatures and Pressures (FUETAP Concretes) for Savannah River Plant High-Level Defense Waste, ORNL/TM-8579, Oak Ridge National Laboratory, April.

Grandy, J. D., T. L. Eddy, and G. L. Anderson, 1993, TSA Waste Stream and Final Waste Form Composition, EGG-MS-10617, January.

Kong, P. C., G. A. Reimann, S. O. Bates, B. A. Detering, T. L. Eddy, and G. L. Anderson, 1993, Final Waste Form Option Scoping Studies for RWMC Wastes, EG\&G Idaho, Inc., EGG-WTD10363, Draft, August. 
Date: January 18,1995

To: $\quad$ T. H. Smith, MS 3960 , FAX 6-3612

From: T. L. Eddy, MS 2210

Subject: LEACH RATE UPDATES BASED ON RECENT EXPERIMENTS

Leach rates previously provided for the performance assessment were obtained from a survey of existing 28-day MCC -1 leach rate data, predominantly via Radioactive Waste Forms of the Future by W. Lutze and R. C. Ewing ${ }^{1}$, NorthHolland, 1988 and as tabulated by Eddy ${ }^{2}$. The exception being bulk leach rates and availability factors for IEB4, the more favorable ceramic.

Recent leach rate measurements obtained on the PSPI Proof Test project are now available to check the values used previously. Leach tests were made on the less-favorable and more-favorable ceramic, IEB and IEB4, respectively. Attempts to measure the leach rates of aluminasilicate glass (ASG) were unsuccessful, as such, because the ASG turned rapidly into a glass-ceramic, ASGC, even with the "fast-cooled" procedure.

The evaluation is more complicated than originally expected due to the following facts:

1. Bulk rates are desired, but were not measures directly. Usually the Si leach rate is close to the effective bulk leach rate and can be substituted.

2. The leach rates for the radionuclides are usually much (one to four orders of magnitude smaller) than the bulk or Si rate. Sometimes the "availability factor" is used to account for this large difference.

3. MCC-1 rates were obtained only for certain samples. PCT rates were obtained for all samples. A conversion method has been derived, which has relatively good accuracy when fitting over several orders of magnitude, but possibly not when at the higher values of from 0.1 to 1.0 $\mathrm{g} / \mathrm{m}^{2}-\mathrm{d}$.

'W. Lutze and R. C. Ewing, Radioactive Waste Forms of the Future, NorthHoll and, 1988.

${ }^{2}$ T. L. Eddy, "Selection of a Final Waste Form," draft paper, March 1993 and $\mathrm{Ch} .5$ of the still unpublished Final Waste Form Option Scoping Studies for RWMC Wastes, draft report, August 1993. 
4. Values were obtained for different compositions: alumina-silicate glassceramic (ASGC), IEB as A-40, and IEB4 as A-40 and $\mathrm{H} 1-0$ to $\mathrm{H} 1-100$.

5. Some of the glass which was fast-cooled (FC), became devitrified, resulting in two devitrified samples: fast-cooled and devitrified (12 $\mathrm{h}$ at $1200^{\circ} \mathrm{C}$ ) samples. Crystalline ceramic samples were slow-cooled (SC) or devitrified (DV).

6. $M C C-1$ values in $\mathrm{g} / \mathrm{m}^{2}-\mathrm{d}$ are grams leached per unit surface area of the monolith divided by the concentration of the leached oxide and the number of days. PCT values in $\mathrm{g} / \mathrm{m}^{2}-\mathrm{d}$ are grams leached per assumed surface area $\left(2000\right.$ or $\left.1955 \mathrm{~m}^{2} / \mathrm{m}^{3}=\mathrm{S} / \mathrm{V}\right)$ divided by the concentration of the leached oxide and the number of days. These are not equivalent because the effective leaching area is not known in the PCT data and the average rate will be different over the different number of days ( 7 vs. 28).

The values obtained from the recent PSPI MCC-1 leach test measurements are in Table 1. The last column contains values gleaned from work at the INEL (using a more complex devitrification cycle) as summarized in Lutze \& Ewing. ${ }^{1}$ The new PSPI MCC-1 measurements are at the high end of the range given in the last column.

\begin{tabular}{|c|c|c|c|c|c|}
\hline $\begin{array}{l}\text { ASGC } \\
S-40 \\
(F C)\end{array}$ & $\begin{array}{l}\text { ASGC } \\
S-40 \\
(D V)\end{array}$ & $\begin{array}{l}\text { IEB } \\
A-40 \\
(D V)\end{array}$ & $\begin{array}{l}\text { IEB4 } \\
\text { A-40 } \\
\text { (DV) } \\
\end{array}$ & $\begin{array}{l}\text { IEB4 } \\
\text { H1-40 } \\
\text { (DV) }\end{array}$ & $\begin{array}{l}\text { IEB \& } \\
\text { IEB4 } \\
\text { (DV) }\end{array}$ \\
\hline $\begin{array}{l}0.13 \\
0.077 \\
1.7 \\
0.78\end{array}$ & $\begin{array}{l}0.21 \\
0.14 \\
3.4 \\
0.73\end{array}$ & $\begin{array}{l}0.10 \\
0.077 \\
0.50 \\
0.44\end{array}$ & $\begin{array}{l}0.11 \\
0.11 \\
0.56 \\
0.28\end{array}$ & $\begin{array}{l}0.27 \\
0.14 \\
0.96 \\
0.74\end{array}$ & $\begin{array}{l}0.01-0.14 \\
0.03-0.13 \\
0.05 \\
0.06-0.74\end{array}$ \\
\hline
\end{tabular}

Table 2 contains the PSPI and WSL PCT measurements with measured values normalized by the leached species concentrations based on SEM/EDXS, but without other corrections or conversions.

Table 2. PCT-Method A 7-day leach rates in normalized $\mathrm{mg} / \mathrm{L}$.

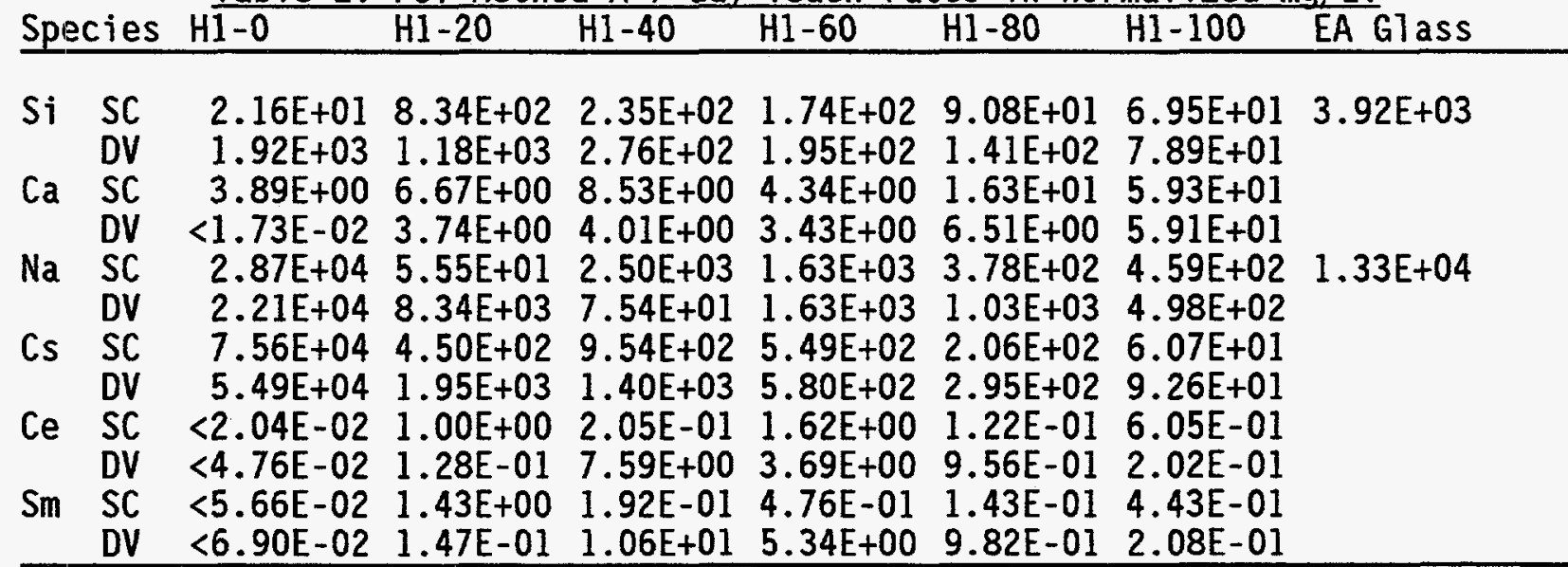


Table 3 contains PCT values in "MCC-1" units as calculated by Rick Farnsworth. I have been unable to determine how these values were calculated. The normalization used the wet chemical analysis compositions.

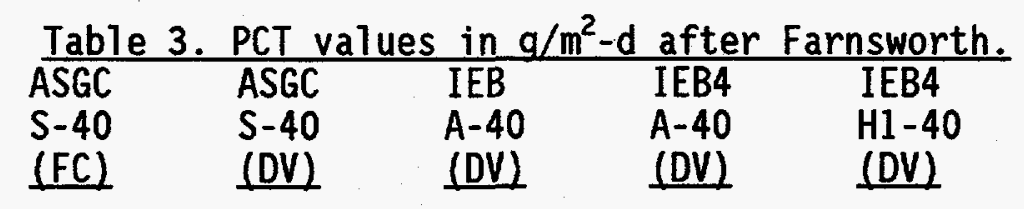

\begin{tabular}{llllll}
$\mathrm{Si} / \mathrm{Bu}$ lk & 0.0071 & 0.0070 & 0.0096 & 0.0091 & 0.020 \\
$\mathrm{Ca}$ & 0.00075 & 0.0026 & 0.00051 & 0.00079 & 0.00037 \\
$\mathrm{Na}$ & 0.12 & 0.051 & 0.070 & 0.062 & 0.0056 \\
$\mathrm{Cs}$ & 0.032 & 0.012 & 0.035 & 0.011 & 0.045 \\
\hline
\end{tabular}

Table 4 contains the PCT measured values from Table 2 and 4 converted to MCC -1 equivalent values from the first, rough, manual scheme developed by Eddy \& Grandy. 3,4 The significance of this table is that the values are based on a surface area to volume ratio (S/V) of about 500:1, in contrast to the 2000:1 prescribed by the developers of the PCT method. Second, the values in Table 4 agree very well with Farnsworth's values in Table 3.

\begin{tabular}{cccccccc} 
Table 4. $P C T$ & values & $\left(\mathrm{g} / \mathrm{m}^{2}-\mathrm{d}\right)$ & converted & to $M C C-1$ & manually & with $S / V$ & 500. \\
\hline ASGC & ASGC & IEB & IEB & IEB4 & IEB4 & IEB4 & IEB4 \\
$S-40$ & $S-40$ & $A-40$ & $A-40$ & $A-40$ & $A-40$ & $H 1-40$ & $H 1-40$ \\
$(F C)$ & (DV) & $(S C)$ & $(D V)$ & $(S C)$ & (DV) & $(S C)$ & $(D V)$
\end{tabular}

\begin{tabular}{lllllllll}
$\mathrm{Si} / \mathrm{Bu} l \mathrm{k}$ & 0.0073 & 0.0069 & 0.0099 & 0.0096 & 0.013 & 0.0099 & 0.018 & 0.021 \\
$\mathrm{Ca}$ & 0.00056 & 0.0021 & 0.00027 & 0.00043 & 0.00024 & 0.00069 & 0.00066 & 0.00031 \\
$\mathrm{Na}$ & 0.28 & 0.092 & 0.094 & 0.064 & 0.15 & 0.081 & 0.19 & 0.0058 \\
$\mathrm{Cs}$ & 0.053 & 0.070 & $0.0056^{5}$ & 0.00077 & 0.0027 & 0.023 & 0.073 & 0.11 \\
\hline
\end{tabular}

Comparing the values of Tables 3 \& 4 with those in Table 1 , one sees that the PCT values are much smaller, even though the PCT surface area is almost 2000 times larger and the average leach rate should be many times larger over the first 7 days than over 28 days.

This can be resolved by recognizing that the effective surface area is much less than 2000 or even 500 times the sample volume because of contacts between

\footnotetext{
${ }^{3}$ T.L. Eddy \& J.D. Grandy, Interoffice correspondence TLE-3-94, Feb. 2, 1994.

${ }^{4}$ T. L. Eddy, et al., "Properties of Vitrified Rocky Flats TRUW with Different Waste Loadings," Ceramic Transactions 45, Am. Cer. Soc., 1994.

${ }^{5} \mathrm{Cs}$ wt\% not measured. Assumed to be 0.50 wt\% as typical of other tests.
} 
particles and reduced diffusion rates. Eddy, Grandy, Trimberger and Anderson $^{6}$ found a S/V of approximately 25 instead of 2000 , as determined with a statistical best curve fit of PSPI, WSL and previous data including 1 anthanides (Ce \& Sm). The values of Tables 2 and 4 with $S / V=25$ are given in Table 5. The converted-PCT values in Table 5 now are in good agreement with the measured MCC-1 values in Table 1.

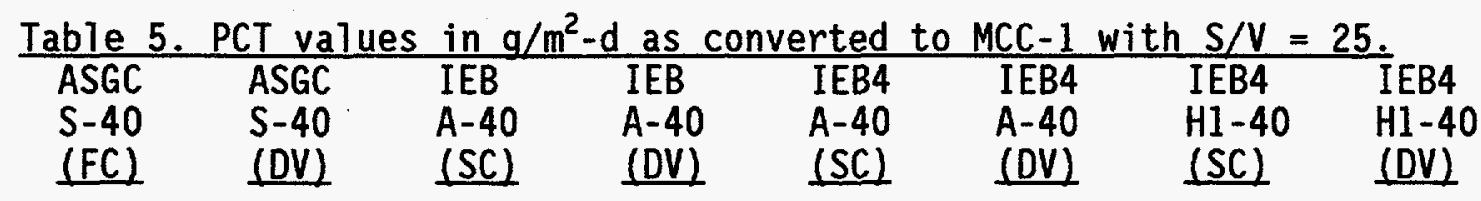

\begin{tabular}{lllllllll}
$\mathrm{Si}$ /Bulk & 0.15 & 0.14 & 0.20 & 0.19 & 0.26 & 0.20 & 0.36 & 0.42 \\
$\mathrm{Ca}$ & 0.011 & 0.042 & 0.0054 & 0.0086 & 0.0048 & 0.014 & 0.013 & 0.0062 \\
$\mathrm{Na}$ & 5.6 & 1.8 & 1.9 & 1.3 & 3.0 & 1.6 & 3.8 & 0.116 \\
$\mathrm{Cs}$ & 1.1 & 1.40 & $0.11^{7}$ & 0.015 & 0.054 & 0.46 & 1.46 & 2.16 \\
\hline
\end{tabular}

In a larger set of data for IEB4, H-0, H-20, H-40, H-60, H-80, and $\mathrm{H}-100$ relatively consistent PCT values were obtained in which if normalizing on $\mathrm{Na}$ as 1.0 , then $\mathrm{Cs}$ is $0.4, \mathrm{Si}$ is $0.1, \mathrm{Ca}$ is 0.002 , and the transuranic surrogates are 0.0003 . These values are in agreement with the values in Table 5 and Table 1.

\section{Conclusions}

A comparison of prior and new measurement values is given in Table 6 based on the $S i$ leach rate as the bulk rate. ASG(original), ASGC(FC), IEB(DV) and IEB4/A-40(DV) with the $S / V=25$ are used in the table.

Table 6: New Measurements and Prior Bulk Leach Rate Choices.

\begin{tabular}{lllllll} 
& & Prior & New & \multicolumn{2}{c}{ New } & \multicolumn{2}{c}{ Availability } \\
& & Choice & MCC-1 & & PCT & \multicolumn{2}{c}{ Prior } & $\frac{\text { Recom. }}{100 \%}$ \\
Least Favorable Glass & BSG & 0.4 & --- & -- & $100 \%$ & $10 \%$ \\
Most Favorable G1 asS ASG/ASGC & 0.07 & 0.13 & 0.15 & $100 \%$ & $100 \%$ \\
Least Favorable Ceramic & IEB & 0.08 & 0.10 & 0.19 & $100 \%$ & $100 \%$ \\
Most Favorable Ceramic & IEB4 & 0.05 & 0.11 & 0.20 & $30 \%$ & $30 \%$ \\
\hline
\end{tabular}

The new leach rate measurements, both direct $M C C-1$ and "corrected" PCT (to match the $M C C-1)$ are a factor of two larger than those from prior, other sources. Whether this is due to the 1 imited sample, the different waste form formation process, or differences in the analytical methods is not known. The

${ }^{6}$ T.L. Eddy, J.D. Grandy, B.R. Trimberger and G.L. Anderson, "Method of Comparison of PCT and MCC-1 Leach Rates," I\&EC Special Symposium, American Chemical Society Meeting, Atlanta GA, Sept. 19-21, 1994.

${ }^{7} \mathrm{Cs}$ wt\% not measured. Assumed to be $0.50 \mathrm{wt} \%$ as typical of other tests. ${ }^{8} 30 \%$ on $\mathrm{U}, \mathrm{Pu}, \mathrm{Am}, \mathrm{Cm}, \mathrm{Sr}$. All other contaminants $100 \%$. 
trend in the new PCT values is identical to the prior choice, and would be nearly numerically equal if $S / V=50$ or 60 , instead of 25 .

The IEB4/H1-40(DV) has a higher Si(bulk) leach rate than IEB4/A-40(DV) (MCC-1: 0.27 vs. 0.11 or PCT: 0.42 vs 0.20 ), but that may be in part due the lower concentration of $\mathrm{SiO}_{2}, 17.29 \mathrm{wt} \%$ vs. $21.58 \mathrm{wt} \%$ affecting norma 7 ization, and the much higher $\mathrm{Na}$ concentration, $4.78 \mathrm{wt} \%$ vs. $1.15 \mathrm{wt} \%$. Leach rates in the $\mathrm{H} 1$-series increased linearly with $\mathrm{Na}$ content and decreased with Si content. When comparing the relative amounts of each of the major waste streams, the $\mathrm{H} 1$-series is relatively small and has the most $\mathrm{Na}$. Most of the waste forms generated from the other waste streams will be more stable than the A-series waste, thus the A-series waste leach rate is best to use as a mean.

\section{Recommendations}

The recommendation is to use the same dissolution rates and availability factors as before and shown in Table 6 based on the above arguments with the following exceptions:

One recommended change is for IEB4, in which the bulk material is essentially the same as the IEB (except for less than 10 wt\% of $\mathrm{TiO}_{2}$ plus $\mathrm{ZrO}_{2}$ ) and therefore should be adjusted to equal the IEB leach rate. This equivalence of IEB and IEB4 leach rates is borne out in the measurements and focussed upon in Table 5.

At the same time the IEB4 leach rate data (not included above because no MCC - 1 measurements were reported) shows that the transuranic surrogates are even more unavailable than perceived from prior data and the availability factor could be lowered for $\mathrm{U}, \mathrm{Pu}, \mathrm{Am}, \mathrm{Cm}$, and $\mathrm{Sr}$ to $10 \%$ with good cause. This recommendation for $\mathrm{S} r$ is supported above with the results for $\mathrm{Ca}$, which is a Sr surrogate.

Distribution:

G. L. Anderson

MS 2414

P. C. Kong

MS 2210

0. L. Wiersholm

MS 3649

B. R. Raivo

MS 3765

N. R. Soelberg

MS 3625

S. M. Sorensen

MS 2210

S. 0. Bates

MS 3710 


\section{MeltTran Corporation \\ 2300 NORTH YELLOWSTONE HWY. \\ IDAHO FALIS, ID 83401 \\ PHONE: (208) 524-6358; FAX: (208) 523-1049}

March 14, 1995

Thomas H. Smith

INELUTCO, P.O. Box 1625

Idaho Falls, ID $83415-3960$

\section{Dear Tom:}

Please find attached a copy of the letter report on the "Two-Step Leach-Rate Decay Model" which I was able to complete at MeltTran.

The results indicate that the originally proposed MCC-1 leach rate values (and availability factors) can be used for the It step of 4 -year with excellent accuracy. The $2^{\text {nd }}$ step leach rates are obtained using similarity principles from long term BSG leach rates proposed by Grambow (1988). Availability factors should be usable for this period, as well.

The initial approach that I was going to try did not work out The subsequent approach resulted in a relatively simple method to extrapolate to long time periods. The accuracy of the method for long tem rates depends on the accuracy of the BSG long time value for which there is no explicit experimental information to my knowledge. Test results closest to the desired measurements are being made at Argonne National Lab by Terry Johnson and Dave Wronkiewicz. These are the steam vapor tests at elevated temperatures. The results are being compared to natural analogues.

I hope the results are appropriate for your needs. If you have any questions, please contact me at Meltiran.

Sincerely yours,

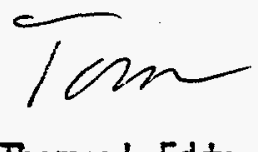

Thomas L Eddy

President

\section{Enclosure}

CC: $\quad$ Gary L Anderson, LITCO 
TNO-STEP LEACH-RATE DECAY MODEL

\author{
T. L. Eddy \\ Me TtTran Corporation \\ 2300 North Yellowstone HWY., Idaho Falls, ID 83401 \\ March 10, 1995
}

\title{
Purpose
}

The purpose of this report is to propose a two-step model for leach rates to be used in performance assessment calculations, as requested by T. H. Smith, LITCO. Th is work was initiated at LITCO and completed at MeltTran. The first step would be over short time periods and may be based on the MCC-I or equivalent Jeach rates. The second step would represent rates over many decades or centuries in the repository.

This work does not include the effect of $\mathrm{pH}$, temperature, or other sophistications of leach behavior. The leach rates presented are based on dejonized water at $90^{\circ} \mathrm{C}$ and are "normalized" to MCC-1 leach rates as previously supplied to IT Corp. for the PA.

Most of the referenced work is obtained from the monograph by Lutze \& Ewing.

\section{Glass Waste Forms}

Figure 1 shows the cumulative fractional release of different species from BSG over time for two different ground-water flow rates as calculated by Grambow, et a1. With high rates of flow $(100 \mathrm{~L} / \mathrm{y}$, dashed 1 ines $)$, the rates are interna 1 diffusion limited and form "nice and parallel" curves that represent initial release rates (at $10^{-2}=3.65$ days), logar ithmet ic long-term rates ( $>1$ year), and the transition region between them. At low flow rates $(1 \mathrm{~L} / \mathrm{y})$, the release becomes flow limited over a longer transition period up to 10 to 100 years. Also the fractional release may be "irregular" for some constituents, e.g., Al here.

The curves in Fig. 1 for glass waste forms could be approximated by a two-step leach process, approximated as shown in $\mathrm{Fig} .2$, with a constant fractional release rate to the knee of the curve followed by a logarithmetic release rate over long time periods. In Figs. 1 \& 2, the fractional amount released is the total amount leached divided by the initial amount in the glass; hence a cumulative total in per cent. (Note that different charts give different types of data.)

The performance assessment model will theoretically account for the driving leach-rate mechanisms: internal diffusion, external flow rate, etc.; therefore, the necessary dissolution rate is that for high flow rates which is internaldiffusion limited. Different leach conditions that are the responsibility of the

${ }^{2}$ W. Lutze and R. C. Ewing (Eds.), Radioactive Waste Forms for the Future, North-Holland, Amsterdam, 1988

'B. Grambow, W. Lutze, R.C. Ewing, and L.O. Werme, in Scientific Basis for Nuclear Waste Management XI, Vo T. 112, P. 531, M.J. Apted \& R.E. Westerman (eds.), Materials Research Society, Pittsburgh, PA, 1988. 
PA model are illustrated in Figure 3. They are not considered here.

\section{Ceramic Waste Forms}

Though Fig. 1 is for BSG, the characteristics should be valid for the glass phase of similar glass ceramics as considered here. It may not be valid for the crystalline ceramic phases for reasons illustrated in Fig. 4 from Reeve et $27 .^{3}$ The figure illustrates that the BSG glass instantaneous leach rate is flat over the significant time period of 75 days; whereas, in the crystalline/ceramic Syrroc-C, the leach rate of the same substances is (Cs \& Sr) decreases significantly at a semilogarithmetic rate. Other differential curves appear to decrease exponentially as shown in Figure 5." Both are with deionized water that is replaced daily and the shape does not appear to be affected significantly by temperature (Fig. 5).

A third representation is the cumulative mass flux (species) leached versus time as shown in the semilogarithmetic plot of Figure $6 .^{5}$ As suggested in the differential or instantaneous leach plots, Fig. 6 shows a trend toward linearity at long times (in days). These three types of plots help one to understand the different mechanisms at play and how to model them for the present work.

Derivation of the Two-Step Model

Since the fractional release rates are constant for about one year, they should be calculable from the MCC-1 or converted PCT values with reasonable accuracy. The latter are normalized on initial concentrations, but are usually at very short time periods compared to one year; therefore, the initial concentrations should be good approximations.

The MCC-1 normalized mass flux leach rate $L_{\text {nut }}$ is specified in $\mathrm{g} / \mathrm{m}^{2}-d$ which is actua 17y:

$$
\begin{aligned}
& \text { (grams of substance leached) (grams of waste) } \\
& \text { (grams of substance in waste) (surface area in } m^{2} \text { ) (no. of days) }
\end{aligned}
$$

This can be converted to a fractional release rate:

$$
\text { (grams of substance leached) }
$$

by dividing by total mass of the waste. Since all the "samples" have the same mass and since we really want $L_{\text {naf }}$ and not $L_{\text {naf }} / m_{\text {weste }}$, the two variables are related

3K.D. Reeve, D.M. Levins, E.J. Ramm, and J.L. Woolfrey, "The Deve lopment and Evaluation of SYNROC for High Level Waste Immobilization," Proc. IAEA/CEC/NEA Int. Symp. on the Conditioning of Radioactive Wastes for Storage and Disposal, Utrecht, The Netherlands, (IAEA Vienna) pp. 375-390, 1982.

4A.G. Solomah, Nuclear Technology, Vo1. 67, p. 311, 1983.

${ }^{5}$ V.M. Oversby and A.E. Ringwood, Radioactive Waste Management Nuclear Fuel Cycle, Vol. 2, p. 223, 1982. 
by a constant. We can plot $L_{\text {naf }}$ in the same form as in Figures 1 \& 2 with the MCC -1 (or prorated value) as the intercept on the ordinate.

The instantaneous leach rates for glass are relatively constant; therefore, the 28-day MCC-1 values for glass, e.g., BSG or ASG (but probably not ASGC) would be the values to use for the constant phase. The BSG bulk rate previously recommended for the $P A$ is $0.4 \mathrm{~g} / \mathrm{m}^{2}-d$ based on $M C C-1$. A typical forward rate of $1.5 \mathrm{~g} / \mathrm{m}^{2}-\mathrm{d}$ was used by Grambow et a $1 .^{2}$ as shown in Table I with other data used to predict Fig. 1 results. The 28 -day value should be better for the Step 1 constant value than using the (initial) forward rate based on an extrapolation to time zero. The latter represents an instantaneous maximum and not a constant rate over the first few days or months.

Table I (Table 5, p. 714, Ref. 1)

Parameters and data used in the performance analysis of borosilicate glass

(1) Materials properties: forward rate

long-term rate

$\log K$ for silica saturation

diffusion coefficient of $\mathrm{SiO}_{2}$ in the surface layer

selection of glass alteration phases

temperature

(2) Production related waste form data:

geometric surface area

factor for surface area increase

canister flling height

glass block diameter

glass density

total mass

molecular mass of the glass

void volume in the container

(3) Repository conditions:

ground water flow rate

glass surface area to solution volume ratio $(S / V)$

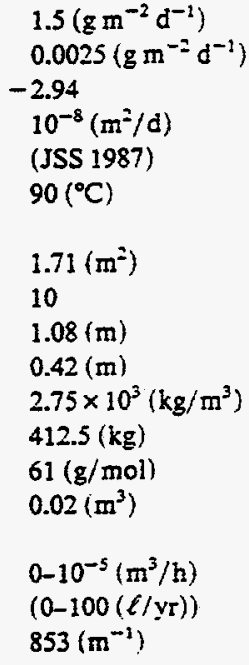

Measured long-term leach rates for glass are not available. Table I indicates the bulk leach rate value used by Grambow et a 1. in a performance ana lys is of BSG was $0.0025 \mathrm{~g} / \mathrm{m}^{2}-\mathrm{d}$.

The Step 1 period would last through the knee of the curve in Fig. 2 for the Si curve, which is similar in time to that for the other high-flow rate curves. The time $t_{1}$ is then approximately one year. Step 2 then runs at times greater than one year.

A method to relate the cumulative mass fraction release rate to the bulk leach rates is given in the appendix. The results are presented here. For Stage 2, 99\% of the fractional release of $\mathrm{Si}$ in Fig. 2 (assuming Si represents the bulk leach rate) is accomplished over 20,000 years. For BSG at $2500 \mathrm{~kg} / \mathrm{m}^{3}$, the characteristic thickness is $7.37 \mathrm{~m}$ (a volume per unit surface area). This is reasonable if the waste repository is greater than or equal to $7.34 \mathrm{~m}$ thick. Applying the characteristic thickness to Stage 1 for $1 \%$ release over 1 year yields a leach rate of $0.505 \mathrm{~g} / \mathrm{m}^{2}-\mathrm{d}$. The latter value is very close to the value of $0.4 \mathrm{~g} / \mathrm{m}^{2}-\mathrm{d}$ originally recommended for the PA calculations; therefore, 
the methods are consistent with the data.

Conclusions and Recommendations

The recommended dissolution rates for BSG glass are then:

Step 1: $\quad 0.4 \mathrm{~g} / \mathrm{m}^{2}-\mathrm{d}$ for $t=0$ to 1 year.

Step 2: $\quad 0.0025 \mathrm{~g} / \mathrm{m}^{2}-d$ for $t>1$ year.

Similar data is not available to determine the appropriate dissolution leach rates for ASG or for the ceramics. Based on the results with BSG, it is reasonable to assume that the Step 1 leach rate is the previous Ty recommended MCC-1 value. The Step 2 values can then be calculated from the ratio of the ASG (or ceramics) Step 1 to BSG Step 1 value times the BSG Step 2 va]ue, assuming the values are proportional.

The recommended ASG and ceramic values as calculated for the two-step model are given in Table II, a long with the BSG values. The availability factor should be employed for the ceramics over both Steps 1 and 2.

Table II. Recommended two-step model leach-rate values in $\mathrm{g} / \mathrm{m}^{2}-\mathrm{d}$.

Final Waste Form

Least Favorable Glass Most Favorable Glass

Least Favorable Ceramic IEB

Most Favorable Ceramic IEB4
BSG

ASG

$\frac{\text { Step } 1}{0<t<1 y}$

$\frac{\text { Step } 2}{1<t<20,000+y r}$

0.4

0.07

0.0025

0.00044

0.08

0.05

0.00050

0.00031

The major error in the assumptions for the ASG, IEB, or IEB4 final waste form is the lack of knowledge of the slope of the curves equivalent to those for BSG in Figures 1 \& 2. The slope parameters are obtained through the assumption of proportionality to the BSG values. This will influence the time for the "100\%" fractiona $]$ release, which for Step 2 leach rates that are less than the BSG value of $0.0025 \mathrm{~g} / \mathrm{m}^{2}-d$ will exceed 20,000 years, by a factor of 10 or more.

Note that though the $100 \%$ release rate mass fraction was used to calculate the slope for the 1-10\% region in the appendix, the time for the $100 \%$ release is a linear extrapolation. The actual time for a $100 \%$ release is hypothetical. 


\section{APPENDIX}

Plotting formats of interest are:

$$
\begin{array}{ll}
\text { Linear: } & y=a+b x \\
\text { Semi-log: } & y=a+b \log x \\
\text { Log-Log: } & \log y=a+b \log x
\end{array}
$$

where $a$ is the intercept and $b$ is the slope of the line plotted.

The plot for Step 2 in Figs. 1 \& 2 is Log-Log; hence,

$$
\log m_{f i}=a+b \log t=\log a_{2}+\log t^{b}=\log a_{2} t^{b}
$$

From which at times $t$ and $t_{1}$ :

$$
\frac{m_{f i}(t)}{m_{f i}\left(t_{1}\right)}=\left(t / t_{1}\right)^{b}
$$

showing that the cumulative mass fraction is proportional to the ratio of times to the power of the slope.

The differential mass fraction leached can be related to the normalized leach rate as follows.

$$
m_{s} d m_{f_{i}}=L_{\text {nef }}\left(m_{t} / m_{s}\right) d A d t
$$

where the mass of the sample, $m_{s}$, is used to give the fractional mass release the dimensions of mass. Assuming that the surface area $A$ is constant for leaching from a "slab" shaped repository, and that $L_{\text {nef }}$ is based on the initial $\mathrm{m}_{1} / \mathrm{m}_{3}$ at $t_{0}$, then integration from $t_{1}$ at the knee of the curve in Fig. 2 to $t_{2}$ at a known $m_{p_{1}}$, in this case $100 \%$, yields:

$$
\begin{aligned}
m_{f_{1}}\left(t_{2}\right)-m_{f_{1}}\left(t_{1}\right)= & \left(A / M_{s}\right)\left(m_{1} / m_{s}\right) \int L_{\text {nef }} d t \\
& =\left(A / M_{s}\right)\left(m_{1} / m_{s}\right) L_{\text {naf, ave }}\left(t_{2}-t_{1}\right)
\end{aligned}
$$

Where $L_{\text {mant,ave }}$ is the average leach rate over Step 2 .

Note that the species leach rate (un-normalized) is just:

$$
L_{\mathrm{zf}}=\left(\mathrm{m}_{\mathrm{i}} / \mathrm{m}_{\mathrm{s}}\right) L_{\text {maf }} .
$$

but for the bulk, $m_{i}=m_{3}$; hence,

$$
L_{\mathrm{mot}}=(1) \mathrm{L}_{\text {nof }} \text {. }
$$

Rearranging $(7)$ to determine $L_{\text {af }, \text { ave }}$ gives: 


$$
\begin{gathered}
L_{\text {xf, ave }}=L_{\text {naf , ave }}=\frac{\mathbb{m}_{s}\left(m_{f}\left[t_{2}\right]-m_{f f}\left[t_{1}\right]\right)}{A\left(t_{2}-t_{1}\right)} \\
L_{\text {wi,ave }}=\frac{p_{s} L_{c}\left(m_{f}\left[t_{2}\right]-m_{f i}\left[t_{1}\right]\right)}{\left(t_{2}-t_{1}\right)}
\end{gathered}
$$

where $(V / V)$ is inserted to use the FF density, $P_{s}$, and the concept of characteristic length, $L_{c}=V / A$.

Solving for the BSG Step 2 with $t_{1}=1 \mathrm{y}, t_{2}=20,000 \mathrm{y}$, and the respective mass fraction releases as $1 \%$ and $100 \%$, a BSG density of $2500 \mathrm{~g} / \mathrm{m}^{3}$ gives

$$
\begin{aligned}
& L_{\text {nf ave }}=0.000339 \mathrm{~g} / \mathrm{m}^{2}-d \text { for } L_{c}=1 \mathrm{~m} \\
& L_{\text {mf,ave }}=0.00339 \mathrm{~g} / \mathrm{m}^{2}-d \text { for } L_{c}=10 \mathrm{~m}
\end{aligned}
$$

and for the Grambow, et al. ${ }^{2}$ value of $0.0025 \mathrm{~g} / \mathrm{m}^{2}-\mathrm{d}$, the characteristic length is between 1 and $10 \mathrm{~m}$ at $7.37 \mathrm{~m}$. This value corresponds to the "minimum" thickness of the layer of waste in the repository. It is in a reasonable range, giving credence to the calculations.

Extending (10) to Step 1 , from $t_{0}=0$ with no mass release to $t_{1}$ with the other properties from above gives the mean leach rate over Step 1:

$$
L_{\text {mf ive }}=0.505 \mathrm{~g} / \mathrm{m}^{2}-\mathrm{d}
$$

This value is very close to the previously and still recommended MCC-1 value for BSE for the PSPI PA calculations. 


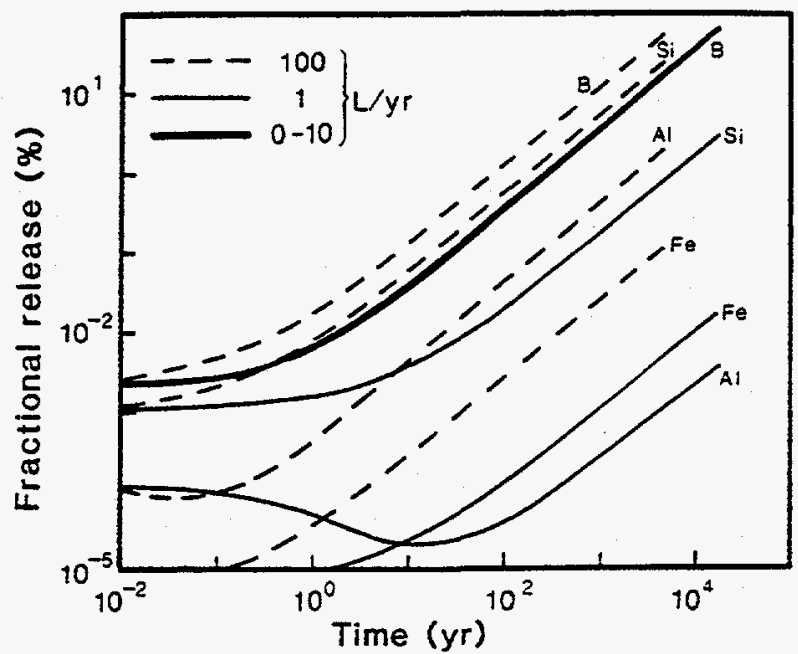

Prediction of borosilicate nuclear waste glass (ISS-A) corrosion as a function of exposure time. Effect of flow rate on the release of $\mathrm{Si}, \mathrm{B}, \mathrm{Al}$ and $\mathrm{Fe}$ (deionized water, $90^{\circ} \mathrm{C}$ ). The fractional release is the amount of the respective element in solution relative to that in the glass (for waste form dimensions see table 1 ).

Fig. 1 (Fig 1, P. 715, Ref. 1)

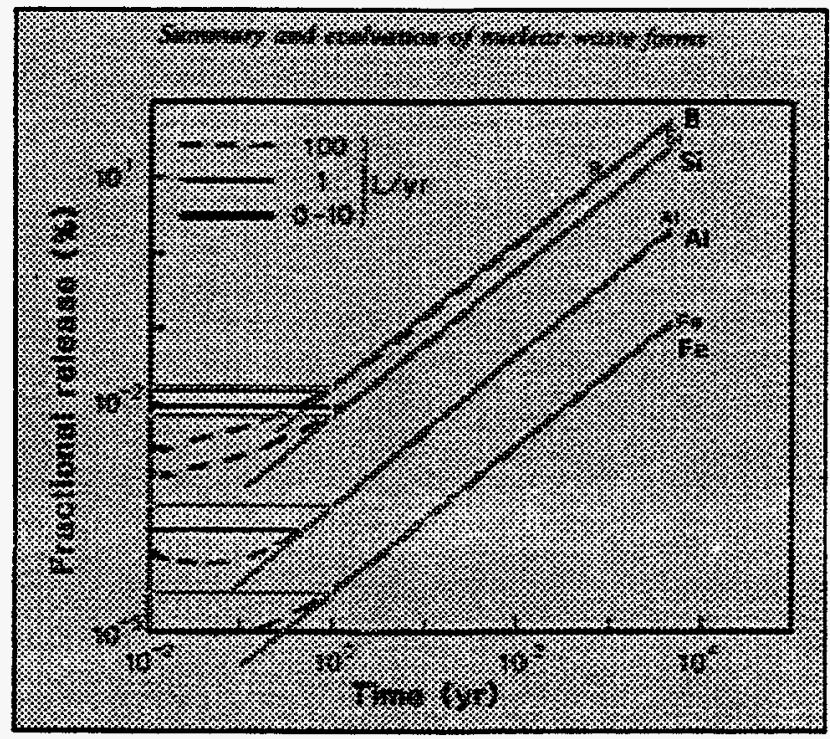

Fig. 2 is Fig 1 modified for the 2-step process. Time $t_{0}$ is at time $0, t_{1}$ is at the knee or junction of the two straight lines, and $t_{2}$ is at $t(100 \%)$. 


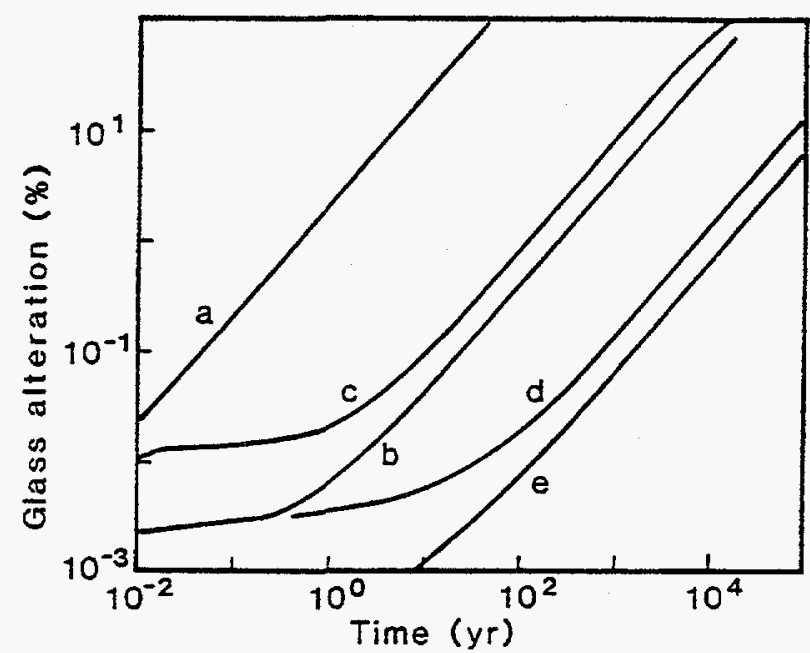

Prediction of borosilicate nuclear waste glass (JSS-A) corrosion as a function of exposure time for different release mechanisms. (a) Controlled by forward rate (table 1), (b) controlled by long-term rate (table 1 ), flow rate is $18 / \mathrm{yr}$, (c) as in (b) however the long-term rate increased by a factor of two and amorphous silica saturation allowed, (d) long-term rate equals zero, i.e., release is flow-rate controlled,

(e) as in (d) but the near field effect considered (see section 2.1.1).

Fig. 3 (Fig 2, p. 716 Ref. 1)

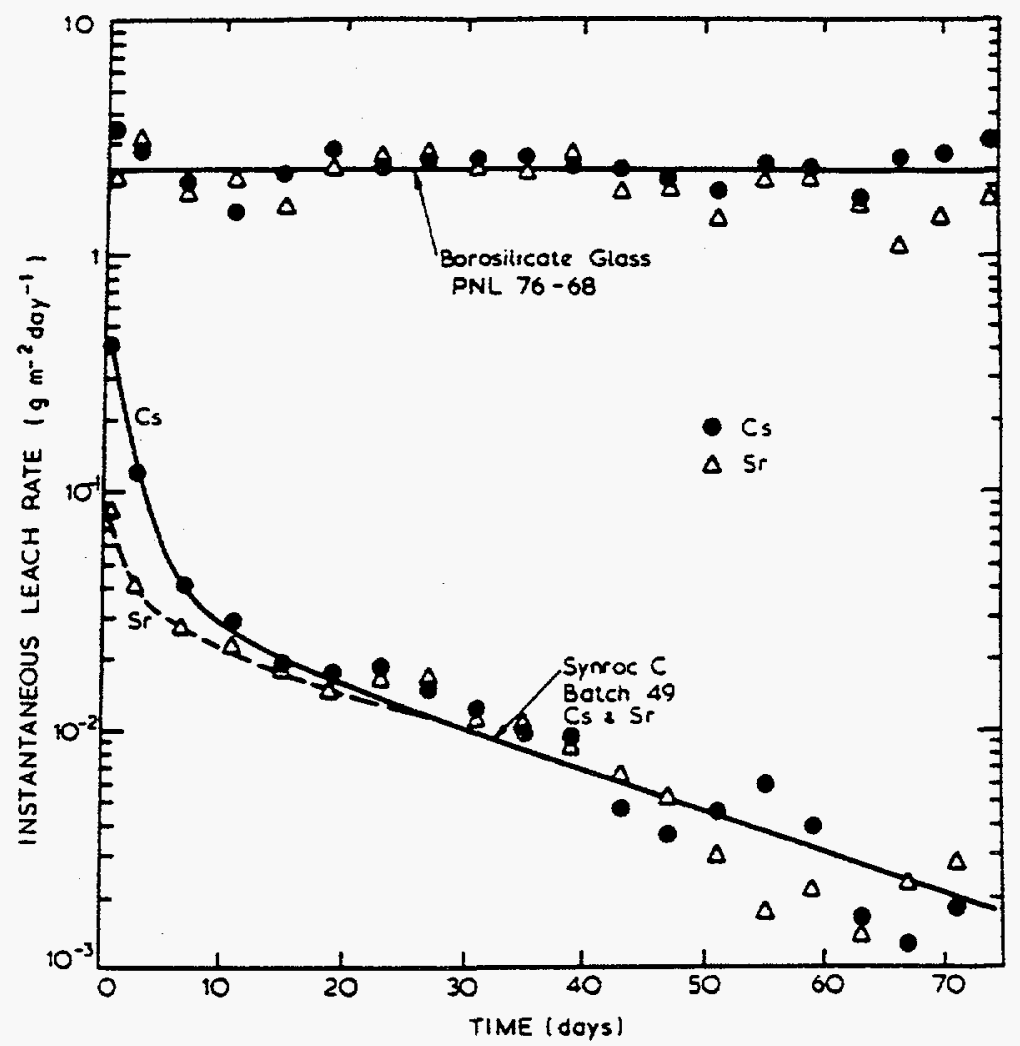

Leach results for cesium and strontium from Synroc-C (10 wt\% simulated HLW) and waste glass (PNL 76-68) at $100^{\circ} \mathrm{C}$; leachant: deionized water, replaced daily (Reeve et al. 1982).

Fig. 4 (Fig. 18, p. 263, Ref. 1) 


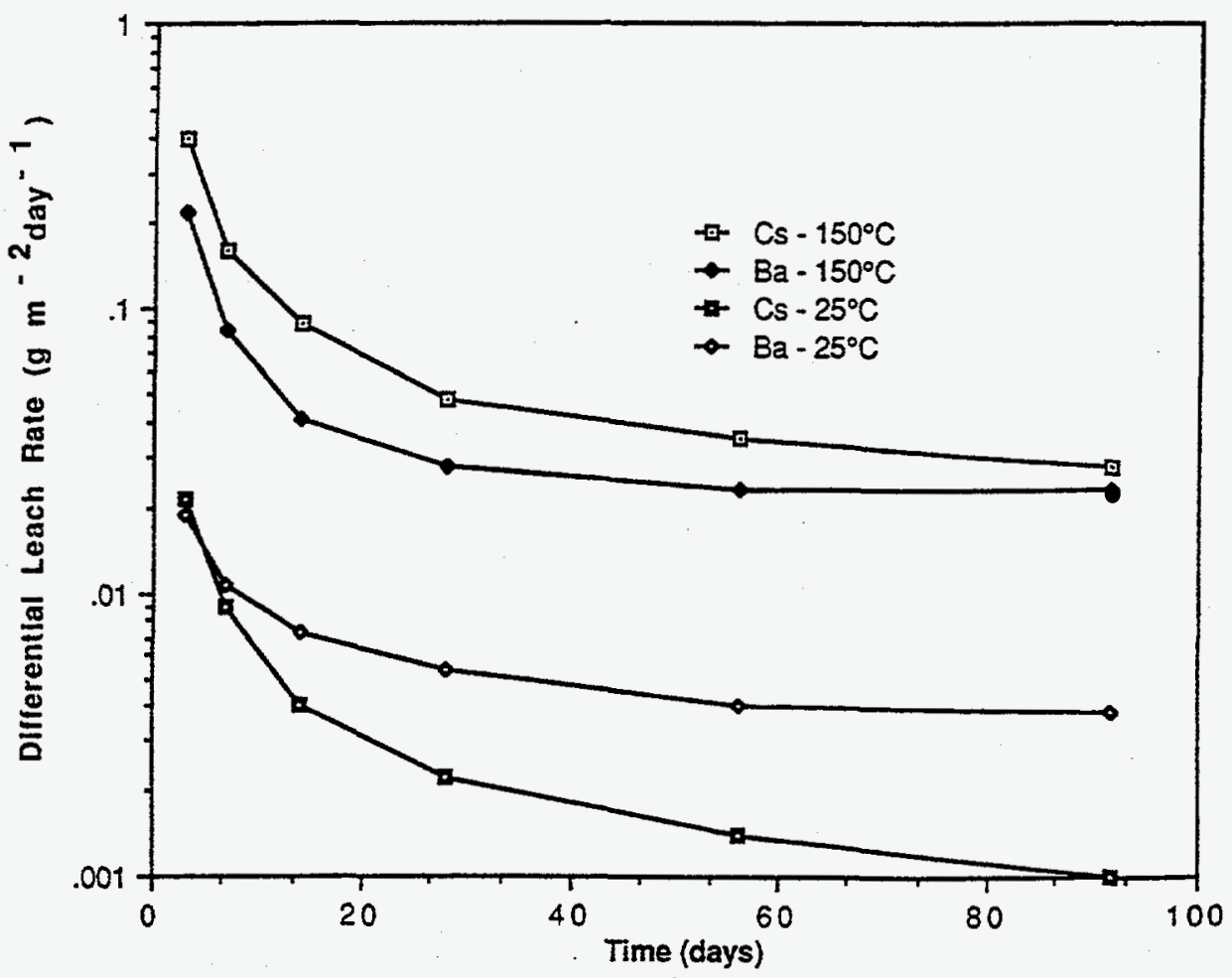

Differential leach rates of barium and cesium from Synroc-C prepared by cold-pressing and sintering ( $10 \mathrm{wt} \%$ simulated HLW) (Solomah 1983).

Fig. 5 (Fig. 15, p. 260, Ref. 1)

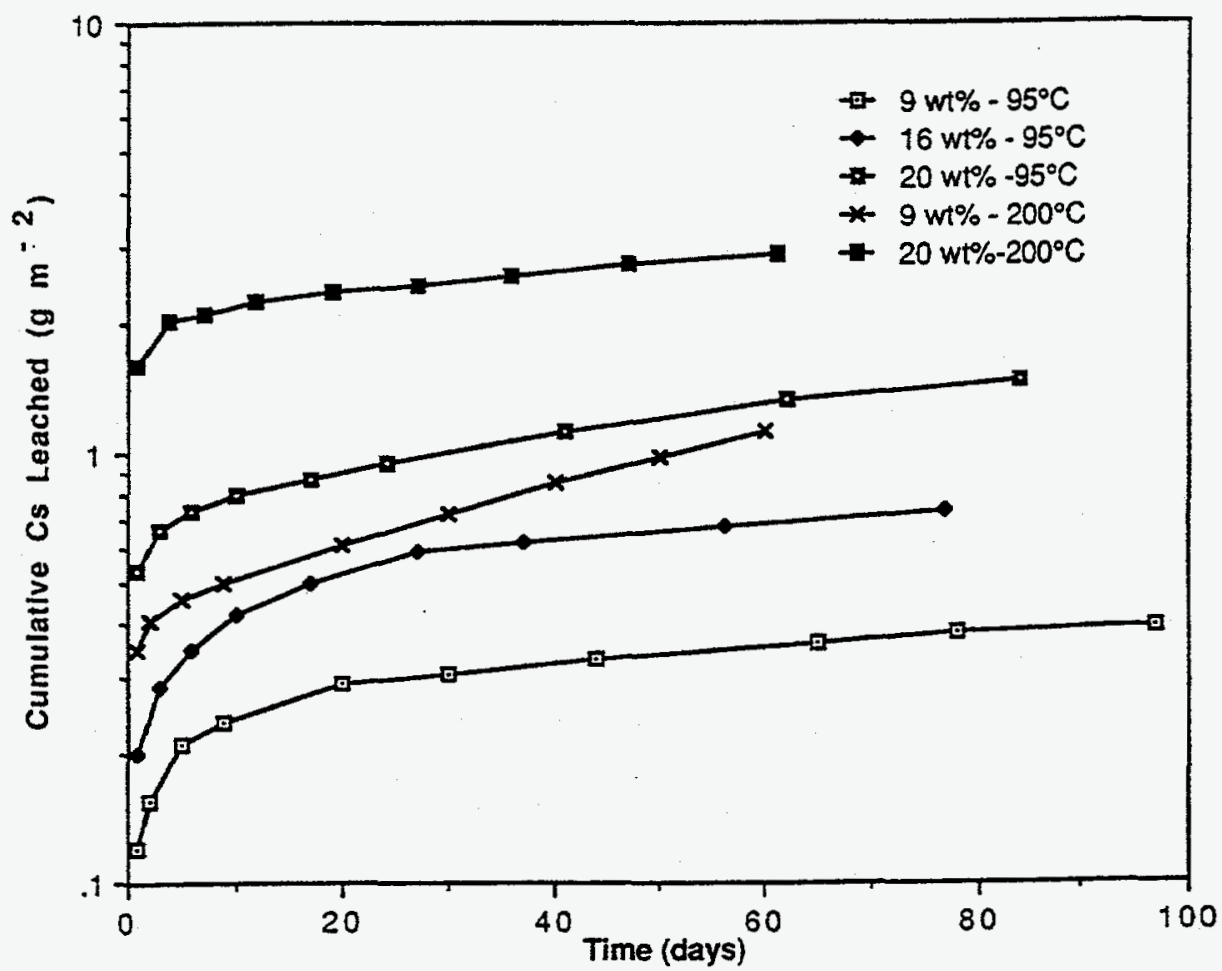

Effect of simulated HLW loading on cesium release from inactive Synroc-C [data plotted from Oversby and Ringwood (1982).

Fig. 6 (Fig. 28, p. 273, Ref. 1) 


\section{Appendix H}

Detailed Comparison of Assumptions and Parameter Values Used in Performance Assessments and Risk Assessments Related to the RWMC Subsurface Disposal Area 
H-2 


\section{Appendix $\mathrm{H}$}

\section{Detailed Comparison of Assumptions and Parameter Values Used in Performance Assessments and Risk Assessments Related to the RWMC Subsurface Disposal Area}

This appendix presents detailed comparisons of the assumptions and parameter values used in six PAs or risk assessments, including this study, related to the Radioactive Waste Management Complex (RWMC) Subsurface Disposal Area (SDA) (see Table H-1 at end of this appendix). The table containing the comparisons was compiled originally by a panel of five personnel, which included at least one participant from each assessment cited. The entries underwent several rounds of comment and revision by the panel members. Additional changes were made by authors of this report after Phases 2 and 3 of the study.

The six SDA-related assessments ${ }^{\mathrm{a}}$ whose assumptions and parameter values were compared are listed across the top of the table in columns 2 through 7. The five other assessments are Maheras et al. (1994), Loehr et al. (1994), Maheras et al. (1992), Rood (1992), and Rood (1993).

The left side (the first column) of the table lists the approximately 130 parameters, assumptions, and process models on which the studies were compared. The items are organized into the following categories:

- General (e.g., objective of assessment, type of waste addressed)

- Radionuclide inventory

- Waste characteristics (e.g., final waste form, release mechanisms, containers)

- Disposal unit characteristics (e.g., disposal depth, cover details)

- General timeline assumptions

- Undisturbed-waste scenario

- General (e.g., pathways evaluated, receptors)

- Groundwater pathway details

- Air pathway details

a. The assumptions and parameters values used in this study for Sites B, C, D, and E are listed for informational purposes only-not for comparison against the other five assessments which address the SDA only. 
- Biotransport pathway details

- Exposure route details

- Intrusion scenarios

- Regulatory standards used to compare calculated doses

- $\quad$ Results.

For a given parameter or assumption, one can compare the six assessments by scanning down the left side until the item is found, then reading across horizontally. The assumptions used by the various assessments are indicated where applicable in columns 2 through 7 . Some of the assessments did not evaluate certain pathways or scenarios, so there are fewer than six entries in some rows.

Numerous reference sources are called out in the table. These references are not given in this appendix. The interested reader should consult the assessment that cited the reference.

Two more columns appear on the right side of Table H-1. Their purpose was to help ensure that, for all important parameters, this study either (a) used single-point values that were as conservative as those in the majority of the other assessments, or (b) used a range of values including conservative values.

One of the last two columns is "degree of conservatism in the ALLW PA." This column gives a simplified, qualitative indication of how conservative the evaluations were, relative to the other five assessments. The entries in this column were based on comparing the entries in each row and reflect the judgment of the panel members. For each entry, the alpha low-level waste (ALLW) performance assessment (PA) was concluded to be conservative or nonconservative or to have used typical values, compared with the values in the five other assessments.

It is stressed that the comparisons were not for the purpose of declaring one value "right" and another value "wrong." Such conclusions are generally not appropriate for several reasons. First, among informed peers, a range of values can be considered acceptable for most parameters used in $P A s$. Second, the studies were performed for different purposes, with different intended degrees of conservatism, in different regulatory environments, and for different portions of the waste. The question here focused more on how conservative the ALLW PA value was, compared with the range of acceptable values. Thus, the comparisons presented here simply provide a perspective on the values that could be used for a given parameter. They do not imply that the value of a parameter used in a given assessment is in error.

The last column - "spread, sensitivity, and importance"-provides a simplified ranking of the importance of each parameter. The term "spread" represents the range of values used for a given parameter in the six assessments. For each parameter, a measure of the spread $(3=$ large, $2=$ moderate, $1=$ small) was agreed upon by the panel members. The measure was based on considering the size of the range in values, compared with the full range that might have been chosen. 
The term "sensitivity" is a measure of the extent to which the calculated doses depend on the parameter. Since the assessments considered different waste at different times, etc., there is no rigorous, single answer for the sensitivity. The results have different dependencies at different times for different radionuclides. Therefore, the simplified sensitivity ratings represent a collective judgment by the panel members based on (a) limited sensitivity studies in the six assessments, (b) experience with parameter sensitivities in other evaluations, and (c) professional judgment. Sensitivity was rated as $3=$ high, $2=$ moderate, $1=$ low.

The "importance" of a parameter was assumed to be determined by the spread and the sensitivity. That is, if the assessments used widely differing values of a parameter, and if the sensitivity of the result to changes in the value of the parameter was high, then the parameter was judged to be important. In this simple scheme, the importance was calculated by multiplying the spread rating by the sensitivity rating. The maximum importance rating was $3 \times 3=9$. The minimum was $1 \times 1=1$. 


\section{References for Appendix H}

Loehr, C. A., B. H. Becker, D. E. Burns, R. M. Huntley, S. M. Rood, P. Sinton, and T. H. Smith, 1994, Preliminary Scoping Risk Assessment for Waste Pits, Trenches, and Soil Vaults at the Subsurface Disposal Area, Idaho National Engineering Laboratory, EGG-WM-11181, EG\&G Idaho, Inc., May.

Maheras, S. J., A. S. Rood, and R. Shuman, 1992, "A Performance Assessment of Radioactive Waste Encapsulated in Concrete and Disposed at the INEL," engineering design file, IWPF-0028, Appendix 2, EG\&G Idaho, Inc., September.

Maheras, S. J., A. S. Rood, S. O. Magnuson, M. E. Sussman, and R. N. Bhatt, 1994, Radioactive Waste Management Complex Low-Level Waste Radiological Performance Assessment, EGG-WM-8773, EG\&G Idaho, Inc., May.

Rood, A. S., 1992, "A Performance Assessment of Radioactive Waste Encapsulated in IronEnriched Basalt and Disposed at the Idaho National Engineering Laboratory's Radioactive Waste Management Complex," Proceedings of the International Topical Meeting on Nuclear and Hazardous Waste Management, Spectrum '92, engineering design file, IWPF-0028, Appendix 3, EG\&G Idaho, Inc, August.

Rood, A S., 1993, "A Limited Performance Assessment for the Idaho Waste Processing Facility: 1993 Update Using Revised Parameters and Limited Sensitivity Analysis," engineering design file, IWPF-0044, EG\&G Idaho, Inc., September. 
Table H-1. Comparison of assumptions and parameters used in SDA-related assessments.

\begin{tabular}{|c|c|c|c|c|c|c|c|c|}
\hline $\begin{array}{l}\text { Parameter, assumption, } \\
\text { or process modeled }\end{array}$ & ALLW PA & $\begin{array}{c}\text { Concrete PA } \\
\text { (Maheras, et al. 1992) }\end{array}$ & $\begin{array}{c}\text { IEB PA } \\
(\operatorname{Rood} 1992)\end{array}$ & $\begin{array}{c}\text { IWPF PA } \\
(\operatorname{Rood} 1993)\end{array}$ & $\begin{array}{c}\text { RWMC LLW } \\
\text { Radiological PA } \\
\text { (Maheras et al. 1994) }\end{array}$ & $\begin{array}{c}\text { Preliminary Scoping Risk } \\
\text { Assessment } \\
\text { (Loehr et al. 1994) }\end{array}$ & $\begin{array}{c}\text { Degree of } \\
\text { conservatism in } \\
\text { ALLW PA }\end{array}$ & $\begin{array}{c}\text { Spread, } \\
\text { sensitivity, and } \\
\text { importance }\end{array}$ \\
\hline \multicolumn{9}{|l|}{ A. GENERAL } \\
\hline A.1. Purpose & $\begin{array}{l}\text { Early scoping of FWF } \\
\text { performance at various } \\
\text { sites }\end{array}$ & Scoping & Scoping & Scoping & $\begin{array}{l}\text { Obtain approval from DOE- } \\
\text { HQ }\end{array}$ & $\begin{array}{l}\text { Preliminary scoping risk } \\
\text { assessment to identify } \\
\text { information gaps concerning } \\
\text { potential hazards posed by } \\
\text { wastes buried in the SDA; this } \\
\text { information is intended to } \\
\text { support planning of the } \\
\text { Remedial Investigation under } \\
\text { Comprehensive Environmental } \\
\text { Response, Compensation and } \\
\text { Liability Act (CERCLA) }\end{array}$ & NA & NA \\
\hline A.2. Regulatory context & $\begin{array}{l}\text { DOE Order } 5820.2 \mathrm{~A} \text { and } \\
\text { referenced regulations such } \\
\text { as } 40 \mathrm{CFR} 141\end{array}$ & $\begin{array}{l}\text { No regulatory } \\
\text { mandates }\end{array}$ & $\begin{array}{l}\text { No regulatory } \\
\text { mandates }\end{array}$ & $\begin{array}{l}\text { No regulatory } \\
\text { mandates }\end{array}$ & $\begin{array}{l}\text { DOE Order } 5820.2 \mathrm{~A} \text { and } \\
\text { referenced regulations such } \\
\text { as } 40 \mathrm{CFR} 141\end{array}$ & $\begin{array}{l}\text { No regulatory mandate, but the } \\
\text { analysis was performed in } \\
\text { accordance with EPA guidance } \\
\text { documents; addressed } \\
\text { radiological and } \\
\text { nonradiological contaminants }\end{array}$ & NA & NA \\
\hline $\begin{array}{l}\text { A.3. Type of waste } \\
\text { addressed }\end{array}$ & $\begin{array}{l}\text { Mixed alpha LLW that is } \\
\text { currently stored at RWMC } \\
\text { TSA }\end{array}$ & $\begin{array}{l}\text { Retrieved transuranic } \\
\text { (TRU) waste and } \\
\text { intermixed LLW that } \\
\text { is currently buried at } \\
\text { RWMC SDA }\end{array}$ & $\begin{array}{l}\text { Retrieved TRU } \\
\text { waste and } \\
\text { intermixed LLW } \\
\text { that is currently } \\
\text { buried at RWMC } \\
\text { SDA }\end{array}$ & $\begin{array}{l}\text { Alpha LLW. } \\
\text { currently stored } \\
\text { at RWMC TSA }\end{array}$ & $\begin{array}{l}\text { LLW that is currently } \\
\text { buried at RWMC SDA }\end{array}$ & $\begin{array}{l}\text { Buried TRU waste and low- } \\
\text { level waste, much of which is } \\
\text { mixed, at RWMC SDA }\end{array}$ & NA & NA \\
\hline A.4. Years generated & 1970 to 1992 & $\begin{array}{l}\text { Unknown, believed to } \\
\text { be the same inventory } \\
\text { analyzed in the IEB } \\
\text { PA (TRU inventory } \\
\text { buried between } 1954 \\
\text { and 1970) }\end{array}$ & $\begin{array}{l}\text { TRU inventory } \\
\text { buried between } 1954 \\
\text { and } 1970\end{array}$ & $\begin{array}{l}\text { Some of the } \\
\text { waste is future } \\
\text { generation and } \\
\text { some is on the } \\
\text { TSA pad or } \\
\text { buried in a pit or } \\
\text { trench }\end{array}$ & $\begin{array}{l}1984-2020 \text { (projected } \\
\text { inventory from } 1994 \text { on) }\end{array}$ & $1952-1983$ & NA & NA \\
\hline $\begin{array}{l}\text { A.5. Years disposed of } \\
\text { (conceptual model) }\end{array}$ & $\begin{array}{l}\text { One instantaneous disposal } \\
\text { in } 1993\end{array}$ & $\begin{array}{l}\text { One instantaneous } \\
\text { future disposal of } \\
\text { treated waste; no } \\
\text { decay of inventory }\end{array}$ & $\begin{array}{l}\text { One instantaneous } \\
\text { future disposal of } \\
\text { treated waste; no } \\
\text { decay of inventory }\end{array}$ & $\begin{array}{l}\text { Future disposal; } \\
\text { no decay of } \\
\text { inventory. }\end{array}$ & $\begin{array}{l}\text { 1984-1993 } \\
\text { projected: } 1994-2020\end{array}$ & $1952-1983$ & NA & NA \\
\hline A.6. Other & & & & . & $\begin{array}{l}\text { DOE Order } 5820.2 \mathrm{~A} \\
\text { requirement deals only with } \\
\text { waste disposed of after } 1988\end{array}$ & & NA & NA \\
\hline $\begin{array}{l}\text { B. RADIONUCLIDE } \\
\text { INVENTORY }\end{array}$ & & & & & & & & \\
\hline
\end{tabular}


Page H-8 of $\mathbf{H - 3 3}$

\begin{tabular}{|c|c|c|c|c|c|c|c|c|}
\hline $\begin{array}{l}\text { Parameter, assumption, } \\
\text { or process modeled }\end{array}$ & ALLWW PA & $\begin{array}{c}\text { Concrete PA } \\
(\text { Maheras, et al, 1992) } \\
\end{array}$ & $\begin{array}{c}\text { IEB PA } \\
\text { (Rood 1992) }\end{array}$ & $\begin{array}{c}\text { IWPF PA } \\
\text { (Rood 1993) } \\
\end{array}$ & $\begin{array}{c}\text { RWMC LLW } \\
\text { Radiological PA } \\
\text { (Maheras et al. 1994) }\end{array}$ & $\begin{array}{c}\text { Preliminary Scoping Risk } \\
\text { Assessment } \\
\text { (Loehr et a1. 1994) }\end{array}$ & \begin{tabular}{|c|} 
Degree of \\
conservatism in \\
ALLW PA \\
\end{tabular} & $\begin{array}{c}\text { Spread, } \\
\text { sensitivity, and } \\
\text { importance }\end{array}$ \\
\hline B.1. Source of inventory & $\begin{array}{l}\text { RWMIS data, as decayed } \\
\text { to } 1993 \text { by Atwood and } \\
\text { Schlafman (1993); } \\
\text { additional refinements } \\
\text { based on data for } \\
\text { individual shipments in } \\
\text { RWMIS and on limited } \\
\text { waste information not in } \\
\text { the shipping records }\end{array}$ & $\begin{array}{l}\text { RWMIS and that } \\
\text { derived from private } \\
\text { sector participation } \\
\text { (PSP) }\end{array}$ & $\begin{array}{l}\text { RWMIS and that } \\
\text { derived from PSP }\end{array}$ & $\begin{array}{l}\text { RWMIS and that } \\
\text { derived from Joe } \\
\text { Gale }\end{array}$ & $\begin{array}{l}\text { RWMIS for historical } \\
\text { disposals, combination of } \\
\text { generator projections and } \\
\text { RWMIS extrapolations for } \\
\text { future disposals }\end{array}$ & $\begin{array}{l}\text { HDT used to generate } \\
\text { P-CIDRA, on which PSRA is } \\
\text { based }\end{array}$ & NA & $\begin{array}{l}\text { Spread small, } \\
\text { sensitivity high, } \\
\text { importance 3/9 }\end{array}$ \\
\hline $\begin{array}{l}\text { B.2. Initial Screening } \\
\text { (explain) }\end{array}$ & \begin{tabular}{|l|} 
Actinides+ progeny: \\
(a) <0.5 Ci deleted except \\
$0.1 \mathrm{Ci} \mathrm{U}-238 ;$ and (b) $<0.4$ \\
$\mathrm{Ci}$ of $\mathrm{U}-232,<0.1 \mathrm{Ci}$ of $\mathrm{U}-$ \\
234, and $<0.1 \mathrm{Ci}$ of Pu-242 \\
deleted; others: $<1 \mathrm{Ci}$ \\
deleted; and $13 \mathrm{Ci}$ of $\mathrm{Ce}-$ \\
$144,55 \mathrm{Ci}$ of $\mathrm{Cs}-134,3.4$ \\
$\mathrm{Ci}$ of $\mathrm{Kr}-85,1.79 \mathrm{Ci}$ of $\mathrm{Ni}-$ \\
$63,14 \mathrm{Ci}$ of Pm- 147 , and \\
$14 \mathrm{Ci}$ of Pr-144 deleted; \\
validity of initial screening \\
confirmed in later detailed \\
screening and detailed \\
intruder calculations; in \\
nonactinide inventory with \\
additional refinements $\mathrm{C}-$ \\
$14, \mathrm{I}-129$, and Tc-99 were \\
included even though their \\
activities were $<1$ Ci each
\end{tabular} & Unknown & |Unknown & $\begin{array}{l}\text { Unknown, fission } \\
\text { products deleted. }\end{array}$ & $\begin{array}{l}\text { None, all inventory } \\
\text { considered initially. } \\
\text { Actinides where parent }+ \\
\text { progeny have } t_{1 / 2}<10 \mathrm{yr} \\
\text { deleted; short-lived progeny } \\
+ \text { long-lived parent resulting } \\
\text { in }<1 \text { nCi deleted, all short- } \\
\text { lived daughters of long-lived } \\
\text { parents included }\end{array}$ & \begin{tabular}{|l|} 
(a) Used disposed upper bound \\
inventory estimates for \\
screening; (b) kept \\
radionuclides with half-life \\
$>1$ yr and $>1$ Ci; (c) kept \\
radionuclides whose daughter \\
has half-life $>1$ yr and $>1 \mathrm{Ci} ;$ \\
(d) kept daughter radionuclides \\
with half-lives $>1$ yr, $>1 \mathrm{Ci}$, \\
and for which the slope factor \\
of the parent does not account \\
for the daughter effects; (e) for \\
remaining radionuclides, \\
annual decay to 1994 was \\
performed, and retained \\
radionuclides with activity \\
$>1$ Ci; (f) conservative risk \\
calculations were used to \\
further screen out \\
contaminants with risk $<10^{-7}$ \\
and hazard quotient $<0.1$
\end{tabular} & $\begin{array}{l}\text { Assumptions } \\
\text { confirmed by } \\
\text { later detailed } \\
\text { screening }\end{array}$ & $\begin{array}{l}\text { Spread small, } \\
\text { sensitivity } \\
\text { varies, } \\
\text { importance } 1 / 9 \\
\text { to } 3 / 9\end{array}$ \\
\hline
\end{tabular}




\begin{tabular}{|c|c|c|c|c|c|c|c|c|}
\hline $\begin{array}{c}\text { Parameter, assumption, } \\
\text { or prooess modeled }\end{array}$ & ALLW PA & $\begin{array}{c}\text { Concrete PA } \\
\text { (Maheras, et al. 1992) }\end{array}$ & $\begin{array}{c}\text { IEB PA } \\
(\text { Rood 1992) }\end{array}$ & $\begin{array}{c}\text { IWPF PA } \\
(\operatorname{Rood~1993)}\end{array}$ & $\begin{array}{c}\text { RWMC LLW } \\
\text { Radiological PA } \\
\text { (Maheras et al. 1994) }\end{array}$ & $\begin{array}{c}\text { Preliminary Scoping Risk } \\
\text { Assessment } \\
\text { (Loehr et al. 1994) }\end{array}$ & $\begin{array}{c}\text { Degree of } \\
\text { conservatism in } \\
\text { ALLW PA }\end{array}$ & $\begin{array}{c}\text { Spread, } \\
\text { sensitivity, and } \\
\text { inportance }\end{array}$ \\
\hline $\begin{array}{l}\text { B.3. Specification of } \\
\text { wastes considered }\end{array}$ & $\begin{array}{l}\text { Remote-handled (RH) and } \\
\text { contact-handled (CH) } \\
\text { ALLW considered. } \\
\text { Assumptions for most runs: } \\
\text { (a) activity is uniformly } \\
\text { distributed, (b) } \\
\text { pretreatment activity = } \\
\text { posttreatment activity, } \\
\text { (c) baseline case has alpha } \\
\text { activity = } 100 \text { nCi/g; some } \\
\text { runs performed with a } \\
\text { "refined" inventory that } \\
\text { considered CH and RH } \\
\text { fractions separately; } \\
\text { additional runs performed } \\
\text { with higher U-233 and } \\
\text { Th-232 inventories }\end{array}$ & Unknown. See A.3 & Unknown. See A.3 & $\begin{array}{l}\mathrm{CH} \text { and RH } \\
\text { waste considered }\end{array}$ & $\begin{array}{l}\mathrm{CH} \text { and } \mathrm{RH} \text { waste } \\
\text { considered }\end{array}$ & All waste considered & $\begin{array}{l}\text { For most runs, } \\
\text { conservative for } \\
\text { CH waste, non- } \\
\text { conservative for } \\
\text { RH waste; for } \\
\text { runs with } \\
\text { refined } \\
\text { inventory, } \\
\text { typical } \\
\text { modeling } \\
\text { assumptions }\end{array}$ & $\begin{array}{l}\text { Spread } \\
\text { moderate, } \\
\text { sensitivity } \\
\text { moderate, } \\
\text { importance } 4 / 9\end{array}$ \\
\hline $\begin{array}{l}\text { B.4. Handling of decay } \\
\text { from time of generation } \\
\text { to start time of PA }\end{array}$ & $\begin{array}{l}\text { Decay }+ \text { ingrowth from } \\
\text { generation to start of PA } \\
\text { considered by using } \\
\text { decayed values from } \\
\text { Atwood and Schlafman } \\
\text { (1993) or from calculated } \\
\text { decay }\end{array}$ & $\begin{array}{l}\text { No decay accounted } \\
\text { for in the reported } \\
\text { inventory }\end{array}$ & $\begin{array}{l}\text { No decay accounted } \\
\text { for in the reported } \\
\text { inventory }\end{array}$ & $\begin{array}{l}\text { Decay is } \\
\text { accounted for } \\
\text { before treatment } \\
\text { and burial }\end{array}$ & \begin{tabular}{|l|} 
Decay was considered for \\
each year of disposal $(36 \mathrm{yr})$
\end{tabular} & Annual decay with ingrowth & $\begin{array}{l}\text { Typical } \\
\text { modeling } \\
\text { assumption }\end{array}$ & $\begin{array}{l}\text { Spread small, } \\
\text { sensitivity high, } \\
\text { importance 3/9 }\end{array}$ \\
\hline $\begin{array}{l}\text { B.5. Handling of MAP } \\
\text { and MFP }\end{array}$ & $\begin{array}{l}\text { MFP is } 50 \% \mathrm{Sr}-90 \text { and } \\
50 \% \text { Cs-137; }<1 \mathrm{Ci} \text { of } \\
\text { MAP screened out }\end{array}$ & Not discussed & Not discussed & NA & $\begin{array}{l}\text { MAP and MFP as } 50 \% \text { Sr- } \\
90 \text { and } 50 \% \text { Cs- } 137\end{array}$ & $\begin{array}{l}\text { Radioactivity previously listed } \\
\text { under generic names was } \\
\text { distributed in the HDT on a } \\
\text { waste-stream-specific basis }\end{array}$ & $\begin{array}{l}\text { Realistic } \\
\text { simplified } \\
\text { modeling } \\
\text { assumption }\end{array}$ & $\begin{array}{l}\text { Spread small, } \\
\text { sensitivity low, } \\
\text { importance } 1 / 9\end{array}$ \\
\hline $\begin{array}{l}\text { B.6. Handling of } \\
\text { unidentified beta- } \\
\text { gamma }\end{array}$ & $\begin{array}{l}\text { Unidentified beta-gamma } \\
\text { activity is } 50 \% \mathrm{Sr}-90 \text { and } \\
50 \% \mathrm{Cs}-137\end{array}$ & Not discussed & Not discussed & NA & $\begin{array}{l}\text { Unidentified beta-gamma } \\
\text { activity is } 50 \% \text { Sr-90 and } \\
50 \% \text { Cs-137 }\end{array}$ & $\begin{array}{l}\text { Radioactivity previously listed } \\
\text { under generic names was } \\
\text { distributed in the HDT on a } \\
\text { waste-stream-specific basis }\end{array}$ & $\begin{array}{l}\text { Typical } \\
\text { modeling } \\
\text { assumption }\end{array}$ & $\begin{array}{l}\text { Spread small, } \\
\text { sensitivity low, } \\
\text { importance } 1 / 9\end{array}$ \\
\hline $\begin{array}{l}\text { B.7. Handling of } \\
\text { unidentified alpha }\end{array}$ & None in inventory & None in inventory & None in inventory & Unknown & None in inventory & $\begin{array}{l}\text { Radioactivity previously listed } \\
\text { under generic names was } \\
\text { distributed in the HDT on a } \\
\text { waste-stream-specific basis }\end{array}$ & NA & NA \\
\hline $\begin{array}{l}\text { B.8. Projection of } \\
\text { future wastes }\end{array}$ & $\begin{array}{l}\text { Only stored waste } \\
\text { considered }\end{array}$ & None in inventory & None in inventory & None in inventory & $\begin{array}{l}\text { Generator forecasts and } \\
\text { extrapolated averages of } \\
\text { historical disposals }\end{array}$ & None in inventory & NA & NA \\
\hline
\end{tabular}


Page H-10 of $\mathrm{H}-33$

\begin{tabular}{|c|c|c|c|c|c|c|c|c|}
\hline $\begin{array}{l}\text { Parameiter, assumpition, } \\
\text { or prooess modeled }\end{array}$ & ALLW PA & \begin{tabular}{|c|} 
Concreite PÂ \\
(Maheras, et al. 1992)
\end{tabular} & $\begin{array}{c}\text { FBB PA } \\
\text { (Rood 1992) }\end{array}$ & $\begin{array}{r}\text { IWPF PA } \\
(\operatorname{Rood} 1993)\end{array}$ & $\begin{array}{c}\text { RWMC LLW } \\
\text { Radioiogicai PÁ } \\
\text { (Maheras et al. 1994) }\end{array}$ & $\begin{array}{c}\text { Preliminary Sooping Risk } \\
\text { Assessment } \\
\text { (Lochr et al. 1994) } \\
\end{array}$ & \begin{tabular}{|c|} 
Degree of \\
conservatism in \\
ALLW PA \\
\end{tabular} & $\begin{array}{c}\text { Spread, } \\
\text { sensitivity, and } \\
\text { importanoe }\end{array}$ \\
\hline B.9. Other & \begin{tabular}{|l|} 
The objective of developing \\
the simplified inventory \\
was to project and retain \\
the top contributors to \\
dose, not to produce a \\
comprehensive inventory
\end{tabular} & & & & \begin{tabular}{|l|} 
Assigning MAP, MFP, \\
unidentified beta-gamma \\
based on activity distribution \\
in wastes received from \\
1984-1993 was performed in \\
uncertainty analysis with \\
negligible effect on \\
estimated doses
\end{tabular} & & NA & NA \\
\hline \multicolumn{9}{|l|}{$\begin{array}{l}\text { C. WASTE } \\
\text { CHARACTERISTICS }\end{array}$} \\
\hline $\begin{array}{l}\text { C.1. Disposed of with } \\
\text { or without treatment }\end{array}$ & $\begin{array}{l}\text { With treatment; limited } \\
\text { runs with untreated waste } \\
\text { also performed }\end{array}$ & With treatment & With treatment & $\begin{array}{l}\text { With or without } \\
\text { treatment }\end{array}$ & Without treatment & Without treatment. & $\mathrm{NA}$ & NA \\
\hline $\begin{array}{l}\text { C.2. Type of waste } \\
\text { treatment }\end{array}$ & \begin{tabular}{|l|} 
Thermal treatment to meet \\
LDR. Cement (PCC, \\
FUETAP), glass (BSG, \\
ASG), and ceramic (IEB, \\
IEB4) FWFs evaluated \\
\end{tabular} & $\begin{array}{l}\text { 55-gal drums } \\
\text { solidified with } \\
\text { concrete }\end{array}$ & \begin{tabular}{|l} 
Vitrification in \\
basalt
\end{tabular} & None & None & None & NA & NA \\
\hline C.3. Final Waste Forms & \begin{tabular}{|l|} 
Cement (PCC, FUETAP), \\
glass (BSG, ASG), and \\
ceramic (IEB, IEB4) \\
FWFs evaluated. Limited \\
runs with untreated waste
\end{tabular} & Concrete & IEB & Untreated waste & Untreated waste & Untreated waste & NA & NA \\
\hline $\begin{array}{l}\text { C.4. Degradation of } \\
\text { Treated Waste Form }\end{array}$ & $\begin{array}{l}\text { Cement fracturing } \\
\text { simulated by shorter } \\
\text { diffusion path. Glass and } \\
\text { ceramic fracturing } \\
\text { simulated by increasing } \\
\text { FWF surface area }\end{array}$ & \begin{tabular}{|l|} 
Cement fracturing \\
simulated by increase \\
in porosity
\end{tabular} & Not considered & NA & NA & NA & \begin{tabular}{|l|} 
ALLW most \\
conservative \\
among studies \\
involving \\
treated waste
\end{tabular} & $\begin{array}{l}\text { Spread large, } \\
\text { sensitivity } \\
\text { medium, } \\
\text { importance 6/9 }\end{array}$ \\
\hline $\begin{array}{l}\text { C.5. Release } \\
\text { mechanisms }\end{array}$ & \begin{tabular}{|l|} 
Cement release by \\
diffusion, glass, and \\
ceramic release by \\
dissolution; unrelated waste \\
release by surface washoff \\
and, alternatively, by \\
diffusion
\end{tabular} & \begin{tabular}{|l|} 
Diffusion from \\
nondegraded concrete \\
and advection from \\
degraded concrete
\end{tabular} & $\begin{array}{l}\text { Dissolution of the } \\
\text { blocks }\end{array}$ & Sorption leaching & \begin{tabular}{|l|} 
Sorption-limited leaching, \\
corrosion of activated metals \\
and diffusion
\end{tabular} & $\begin{array}{l}\text { Corrosion release of activation } \\
\text { products from metals; surface } \\
\text { washoff for other contaminants }\end{array}$ & $\begin{array}{l}\text { Appropriate } \\
\text { approach }\end{array}$ & NA \\
\hline
\end{tabular}


Page H-11 of H-33

\begin{tabular}{|c|c|c|c|c|c|c|c|c|}
\hline $\begin{array}{l}\text { Parameter, assumption, } \\
\text { or process modeled }\end{array}$ & ALLW PA & $\begin{array}{c}\text { Concrete PA } \\
\text { (Maheras, et al. 1992) }\end{array}$ & $\begin{array}{c}\text { IEB PA } \\
(\operatorname{Rood} 1992)\end{array}$ & $\begin{array}{c}\text { IWPF PA } \\
(\operatorname{Rood} 1993)\end{array}$ & $\begin{array}{c}\text { RWMC LLW } \\
\text { Radiological PA } \\
\text { (Maheras et al. 1994) }\end{array}$ & $\begin{array}{c}\text { Preliminary Scoping Risk } \\
\text { Assessment } \\
\text { (Lochr et al. 1994) }\end{array}$ & $\begin{array}{c}\text { Degree of } \\
\text { conservatism in } \\
\text { ALLW PA }\end{array}$ & $\begin{array}{c}\text { Spread, } \\
\text { sensitivity, and } \\
\text { importance }\end{array}$ \\
\hline $\begin{array}{l}\text { C.6. Credit for waste } \\
\text { containers }\end{array}$ & None & None & None & None & $\begin{array}{l}\text { Some credit was taken for } \\
\text { waste contained in metal } \\
\text { containers (10-yr mean } \\
\text { lifetime); no credit was } \\
\text { taken for cardboard or } \\
\text { wooden boxes }\end{array}$ & $\begin{array}{l}\text { Assumed instantaneous failure } \\
\text { at beginning of release (1994) } \\
\text { for all containers/forms except } \\
\text { steel drums, which were } \\
\text { decayed according to the } \\
\text { INEL-specific drum decay } \\
\text { curve }\end{array}$ & \begin{tabular}{|l|} 
More \\
conservative \\
than RWMC \\
PA and PSRA.
\end{tabular} & \begin{tabular}{|l} 
Sensitivity \\
varies \\
depending on \\
nuclide \\
inventory; \\
importance $2 / 9$ \\
to $6 / 9$
\end{tabular} \\
\hline \multicolumn{9}{|l|}{$\begin{array}{l}\text { D. DISPOSAL } \\
\text { CHARACTERISTICS } \\
\text { DIRECTLY } \\
\text { RELATED TO } \\
\text { DISPOSAL }\end{array}$} \\
\hline $\begin{array}{l}\text { D.1. Location of } \\
\text { disposal site }\end{array}$ & $\begin{array}{l}5 \text { sites: RWMC SDA Site } \\
14 \text { (INEL), Area G (NTS), } \\
\text { E-Area Vaults Disposal } \\
\text { Facility (SRS), and } 200 \\
\text { West Burial Grounds } \\
\text { (Hanford) }\end{array}$ & RWMC SDA & RWMC SDA & RWMC SDA & RWMC SDA & RWMC SDA & NA & NA \\
\hline $\begin{array}{l}\text { D.2. Type of disposal } \\
\text { unit(s) }\end{array}$ & Pits. Vaults for SRS only & Pits & Pits & Pits & Pits and soil vaults & Pits, trenches, and soil vaults & NA & NA \\
\hline $\begin{array}{l}\text { D.3. Dimension of } \\
\text { disposal unit, parallel } \\
\text { and perpendicular to } \\
\text { groundwater flow } \\
\text { direction }\end{array}$ & $\begin{array}{l}51.8 \mathrm{~m} \times 51.8 \mathrm{~m} \\
(\text { FUETAP/PCC) } \\
31.5 \mathrm{~m} \times 31.5 \mathrm{~m} \text { (IEB4) } \\
34.1 \mathrm{~m} \times 34.1 \mathrm{~m} \text { (IEB) } \\
51.3 \mathrm{~m} \times 51.3 \mathrm{~m} \text { (BSG) } \\
36.2 \mathrm{~m} \times 36.2 \mathrm{~m} \text { (ASG) }\end{array}$ & $160 \mathrm{~m} \times 160 \mathrm{~m}$ & $77 \mathrm{~m} \times 77 \mathrm{~m}$ & $76 \mathrm{~m} \times 76 \mathrm{~m}$ & $257 \mathrm{~m} \times 122 \mathrm{~m}$ & $\begin{array}{l}\text { Rectangle of } 181 \times 647 \mathrm{~m} \\
\text { oriented with the long edge } \\
\text { perpendicular to groundwater } \\
\text { flow in the Snake River Plain } \\
\text { Aquifer }\end{array}$ & \begin{tabular}{|l|} 
RWMC PA \\
and PSRA \\
modeled actual \\
layout. Others \\
were \\
hypothetical
\end{tabular} & $\begin{array}{l}\text { Spread } \\
\text { moderate, } \\
\text { sensitivity } \\
\text { moderate, } \\
\text { importance } 4 / 9\end{array}$ \\
\hline $\begin{array}{l}\text { D.4. Depth of top of } \\
\text { waste stack } \\
\text { (belowgrade) }\end{array}$ & $1.5 \mathrm{~m}$ and $2.7 \mathrm{~m}$ & $\begin{array}{l}4.6 \mathrm{~m} \text { (this value was. } \\
\text { chosen to prevent the } \\
\text { intruder from } \\
\text { excavating the waste } \\
\text { during basement } \\
\text { construction) }\end{array}$ & $\begin{array}{l}\text { 3-m (this value was } \\
\text { chosen to prevent } \\
\text { the intruder from } \\
\text { excavating the waste } \\
\text { during basement } \\
\text { construction) }\end{array}$ & $0 \mathrm{~m}$ & $\begin{array}{l}\text { Pits: } 2.4 \mathrm{~m} \\
\text { soil vaults: } 3.3 \mathrm{~m}\end{array}$ & $\begin{array}{l}1.8 \mathrm{~m} \text { (average thickness of soil } \\
\text { cover) }\end{array}$ & $\begin{array}{l}\text { Some more, } \\
\text { some less; } \\
\text { typical } \\
\text { assumptions } \\
\text { used }\end{array}$ & $\begin{array}{l}\text { Spread big, } \\
\text { sensitivity high, } \\
\text { importance } 9 / 9\end{array}$ \\
\hline $\begin{array}{l}\text { D.5. Thickness of waste } \\
\text { layer }\end{array}$ & $6.9 \mathrm{~m}$ & $1.6 \mathrm{~m}$ & $2.4 \mathrm{~m}$ & $2.7 \mathrm{~m}$ & Pits: $6.1 \mathrm{~m}$, soil vaults: $3.0 \mathrm{~m}$ & $\begin{array}{l}2.53 \mathrm{~m} \text { (average thickness of } \\
\text { waste based on thickness in } \\
\text { units) }\end{array}$ & NA & NA \\
\hline $\begin{array}{l}\text { D.6. Mixing of waste } \\
\text { with backfill }\end{array}$ & $\begin{array}{l}\text { Waste and backfill } \\
\text { homogeneously mixed }\end{array}$ & $\begin{array}{l}\text { Waste was not mixed } \\
\text { with backfill; a 1-m } \\
\text { thick soil layer } \\
\text { underlying the waste } \\
\text { blocks was accounted } \\
\text { for }\end{array}$ & $\begin{array}{l}\text { Waste was not } \\
\text { mixed with backfill; } \\
\text { a 1-m thick soil } \\
\text { layer underlying the } \\
\text { waste blocks was } \\
\text { accounted for }\end{array}$ & $\begin{array}{l}\text { Waste } \\
\text { homogeneously } \\
\text { mixed with } \\
\text { backfill }\end{array}$ & $\begin{array}{l}\text { Most wastes mixed } \\
\text { homogeneously with backfill, } \\
\text { activated metals and } \\
\text { beryllium reflector blocks } \\
\text { remain separate but release } \\
\text { into the total backfilled soil }\end{array}$ & $\begin{array}{l}\text { Model assumed homogeneously } \\
\text { mixed with soil; actual } \\
\text { conditions are variable }\end{array}$ & $\begin{array}{l}\text { Typical } \\
\text { modeling } \\
\text { assumption }\end{array}$ & $\begin{array}{l}\text { Spread } \\
\text { medium, } \\
\text { sensitivity low, } \\
\text { importance } 2 / 9\end{array}$ \\
\hline
\end{tabular}


Page H-12 of H-33

\begin{tabular}{|c|c|c|c|c|c|c|c|c|}
\hline $\begin{array}{c}\text { Parameter, assumption, } \\
\text { or process modeled }\end{array}$ & ALLW PA & $\begin{array}{c}\text { Concrete PÁ } \\
\text { (Maheras, et al. 1992) }\end{array}$ & $\begin{array}{c}\text { IEB PÁ } \\
(\operatorname{Rood} 1992) \\
\end{array}$ & $\begin{array}{c}\text { IWPF PA } \\
(\operatorname{Rood} 1993)\end{array}$ & $\begin{array}{c}\text { RWMC LIW } \\
\text { Radiological PA } \\
\text { (Maheras et al. 1994) }\end{array}$ & $\begin{array}{c}\text { Preliminary Scoping Risk } \\
\text { Assessment } \\
\text { (Loehr et al. 1994) } \\
\end{array}$ & \begin{tabular}{|c|} 
Degrec of \\
conservatism in \\
ALLW PA \\
\end{tabular} & $\begin{array}{c}\text { Spread, } \\
\text { sensitivity, and } \\
\text { importance }\end{array}$ \\
\hline $\begin{array}{l}\text { D.7. Cover installed } \\
(y / n)\end{array}$ & $\begin{array}{l}\text { No for undisturbed } \\
\text { performance; } \\
\text { yes for intrusion scenarios }\end{array}$ & No & No & No & $\begin{array}{l}\text { Yes. Cover considered for } \\
\text { reduction of infiltration } \\
\text { during institutional control } \\
\text { period }(2020-2120)\end{array}$ & Yes & \begin{tabular}{|l} 
Typical \\
modeling \\
assumption
\end{tabular} & $\begin{array}{l}\text { Spread big, } \\
\text { sensitivity low } \\
\text { to high, } \\
\text { importance 3/9 } \\
\text { to } 9 / 9\end{array}$ \\
\hline $\begin{array}{l}\text { D.8. (if y) Degradation } \\
\text { of cover }\end{array}$ & $\begin{array}{l}\text { Instant, total erosion at } \\
\text { year 500 }\end{array}$ & NA & NA & NA & $\begin{array}{l}\text { Pits: } 2-\mathrm{m} \text { operational cover } \\
\text { has 3-m closure cover } \\
\text { added; erodes to a total } \\
\text { thickness of } 2.4 \mathrm{~m} \\
\text { soil vaults: } 5 \mathrm{~m} \text { cover erodes } \\
\text { to } 3.3 \mathrm{~m} \text { thickness }\end{array}$ & No degradation assumed & \begin{tabular}{|l} 
Typical \\
modeling \\
assumption
\end{tabular} & $\begin{array}{l}\text { Spread } \\
\text { medium, } \\
\text { sensitivity } \\
\text { medium, } \\
\text { importance 4/9 }\end{array}$ \\
\hline D.9. Other & & & & & $\begin{array}{l}\text { Dimensions of disposal unit } \\
\text { approximately match the } \\
\text { combined area of Pits } 17, \\
18,19 \text {, and } 20\end{array}$ & & NA & NA \\
\hline $\begin{array}{l}\text { E. GENERAL } \\
\text { TIMELINE } \\
\text { ASSUMPTIONS }\end{array}$ & & & & & & & & \\
\hline $\begin{array}{l}\text { E.1. Date waste } \\
\text { emplacement operations } \\
\text { end }\end{array}$ & 1993 & 1970 & 1970 & $\begin{array}{l}\text { Future disposal, } \\
\text { unknown }\end{array}$ & $\begin{array}{l}\text { Conservative date of } 2020 \\
\text { was used }\end{array}$ & 1983 & NA & NA \\
\hline \begin{tabular}{|l|} 
E.2. Period of \\
institutional control
\end{tabular} & $100 \mathrm{yr}$ & $100 \mathrm{yr}$ & $100 \mathrm{yr}$ & $\begin{array}{l}\text { NA (no intruder } \\
\text { scenarios } \\
\text { considered) }\end{array}$ & $100 \mathrm{yr}$ & $100 \mathrm{yr}$ & \begin{tabular}{|l|} 
Typical \\
assumption \\
following \\
regulatory \\
guidance
\end{tabular} & $\overline{\mathrm{NA}}$ \\
\hline $\begin{array}{l}\text { E.3. Start of modeling } \\
\text { vs. start of waste } \\
\text { emplacement }\end{array}$ & $\begin{array}{l}\text { Instantaneous waste } \\
\text { emplacement at start of } \\
\text { simulation }\end{array}$ & $\begin{array}{l}\text { Instantaneous waste } \\
\text { emplacement at start } \\
\text { of simulation }\end{array}$ & $\begin{array}{l}\text { Instantaneous waste } \\
\text { emplacement at } \\
\text { start of simulation }\end{array}$ & $\begin{array}{l}\text { Instantaneous } \\
\text { waste } \\
\text { emplacement at } \\
\text { start of } \\
\text { simulation }\end{array}$ & \begin{tabular}{|l|} 
The start of modeling \\
coincided with the start of \\
waste emplacement: 1984 to \\
2020
\end{tabular} & $\begin{array}{l}\text { Modeling starts at beginning of } \\
\text { 1994; start of waste } \\
\text { emplacement in } 1952\end{array}$ & $\begin{array}{l}\text { Typical } \\
\text { modeling } \\
\text { assumption }\end{array}$ & $\begin{array}{l}\text { Spread low, } \\
\text { sensitivity low, } \\
\text { importance } 1 / 9\end{array}$ \\
\hline E.4. Other & & & & & $\begin{array}{l}\text { Soil vault inventories were } \\
\text { considered to be mixed in } \\
\text { the pit volume for } \\
\text { groundwater pathway } \\
\text { calculational purposes }\end{array}$ & & NA & NA \\
\hline \begin{tabular}{|l|} 
F. UNDISTURBED \\
WASTE SCENARIOS
\end{tabular} & & & & & & & & \\
\hline
\end{tabular}


Page H-13 of H-33

\begin{tabular}{|c|c|c|c|c|c|c|c|c|}
\hline $\begin{array}{l}\text { Parameter, assumption, } \\
\text { or process modeled }\end{array}$ & ALLW PA & $\begin{array}{c}\text { Concrete PA } \\
\text { (Maheras, et al. 1992) }\end{array}$ & $\begin{array}{c}\text { IEB PA } \\
\text { (Rood 1992) }\end{array}$ & $\begin{array}{c}\text { IWPF PA } \\
(\operatorname{Rood} 1993)\end{array}$ & $\begin{array}{c}\text { RWMC LLW } \\
\text { Radiological PA } \\
\text { (Maheras et al. 1994) }\end{array}$ & $\begin{array}{c}\text { Preliminary Scoping Risk } \\
\text { Assessment } \\
\text { (Loehr et al. 1994) }\end{array}$ & $\begin{array}{c}\text { Degree of } \\
\text { conservatism in } \\
\text { ALLW PA }\end{array}$ & $\begin{array}{c}\text { Spread, } \\
\text { sensitivity, and } \\
\text { importance }\end{array}$ \\
\hline \multicolumn{9}{|l|}{ F.1. GENERAL } \\
\hline $\begin{array}{l}\text { F.1(a) Transport } \\
\text { Pathways }\end{array}$ & $\begin{array}{l}\text { Groundwater, airborne } \\
\text { (radon assumed to be only } \\
\text { important airborne } \\
\text { pathway, based on RWMC } \\
\text { PA) }\end{array}$ & Groundwater & Groundwater & Groundwater & $\begin{array}{l}\text { Groundwater, airborne, } \\
\text { radon }\end{array}$ & $\begin{array}{l}\text { Groundwater, air, soil, direct } \\
\text { radiation }\end{array}$ & $\begin{array}{l}\text { Typical } \\
\text { modeling } \\
\text { assumption }\end{array}$ & NA \\
\hline F.1(b) Receptors & $\begin{array}{l}\text { Located } 100 \mathrm{~m} \text { and } 215 \mathrm{~km} \\
\text { from the downgradient } \\
\text { edge of the disposal unit; } \\
\text { onsite for intrusion } \\
\text { scenarios }\end{array}$ & $\begin{array}{l}\text { Receptor located at } \\
\text { edge of source for } \\
\text { evaluation of } \\
\text { groundwater pathway }\end{array}$ & $\begin{array}{l}\text { Receptor located at } \\
\text { downgradient edge } \\
\text { ( } 38.5 \mathrm{~m} \text { from } \\
\text { center) of source for } \\
\text { evaluation of } \\
\text { groundwater } \\
\text { pathway }\end{array}$ & $\begin{array}{l}\text { Receptor located } \\
\text { at downgradient } \\
\text { edge of source } \\
\text { for evaluation of } \\
\text { groundwater } \\
\text { pathway }\end{array}$ & $\begin{array}{l}100 \mathrm{~m} \text { downgradient from } \\
\text { Pits } 17-20 \text { boundary and at } \\
\text { the site boundary }(5,500 \mathrm{~m} \\
\text { downgradient during } \\
\text { institutional control, } 100 \mathrm{~m} \\
\text { downgradient thereafter) }\end{array}$ & $\begin{array}{l}\text { Onsite future worker and } \\
\text { onsite future resident located } \\
\text { at downgradient edge of } \\
\text { combined source }\end{array}$ & $\begin{array}{l}\text { Typical or } \\
\text { slightly non- } \\
\text { conservative } \\
(100 \mathrm{~m})\end{array}$ & $\begin{array}{l}\text { Spread } \\
\text { medium, } \\
\text { sensitivity } \\
\text { medium, } \\
\text { importance 4/9 }\end{array}$ \\
\hline $\begin{array}{l}\text { F.1(c) Exposure } \\
\text { Pathways }\end{array}$ & Ingestion, inhalation & Ingestion & Ingestion & $\begin{array}{l}\text { Ingestion, } \\
\text { inhalation, } \\
\text { transfer to food } \\
\text { via irrigation (all } \\
\text { pathways) }\end{array}$ & $\begin{array}{l}\text { Consumption and irrigation } \\
\text { with groundwater }\end{array}$ & $\begin{array}{l}\text { Onsite future worker: fugitive } \\
\text { dust inhalation, soil ingestion, } \\
\text { dermal contact with soil, and } \\
\text { external radiation exposure at } \\
\text { surface; onsite future resident: } \\
\text { fugitive dust inhalation, } \\
\text { ingestion of soil, ingestion of } \\
\text { groundwater, meat, dairy } \\
\text { products, and crops, dermal } \\
\text { contact with soil, and external } \\
\text { radiation exposure at surface }\end{array}$ & \begin{tabular}{|l|} 
Less \\
conservative \\
than RWMC \\
PA and PSRA, \\
same as others
\end{tabular} & $\begin{array}{l}\text { Spread medium } \\
\text { to high, } \\
\text { sensitivity low } \\
\text { to medium, } \\
\text { importance } 2 / 9 \\
\text { to } 6 / 9\end{array}$ \\
\hline $\begin{array}{l}\text { F.1(d) Exposure } \\
\text { Scenarios }\end{array}$ & $\begin{array}{l}\text { Groundwater = leaching } \\
\text { and transport to receptor } \\
\text { well, drinking water and } \\
\text { irrigation of crops; air = } \\
\text { inhalation of radon }\end{array}$ & Drinking water & Drinking water & $\begin{array}{l}\text { All pathway } \\
\text { (drinking water, } \\
\text { ingestion of } \\
\text { contaminated } \\
\text { foods) }\end{array}$ & $\begin{array}{l}\text { All pathway (drinking water, } \\
\text { ingestion of contaminated } \\
\text { foods), groundwater, } \\
\text { inhalation of airborne dust, } \\
\text { external exposure }\end{array}$ & $\begin{array}{l}\text { Groundwater } \rightarrow \text { ingestion } \\
\text { (resident only); biotic transport } \\
\text { - suspension - air - } \\
\text { inhalation; biotic transport - } \\
\text { direct contact } \rightarrow \text { soil - } \\
\text { ingestion/contact; biotic } \\
\text { transport }- \text { radiation - } \\
\text { external exposure; radiation } \\
\text { through cover }- \text { external } \\
\text { exposure }\end{array}$ & & \\
\hline
\end{tabular}


Page $\mathrm{H}-14$ of $\mathrm{H}-33$

\begin{tabular}{|c|c|c|c|c|c|c|c|c|}
\hline $\begin{array}{c}\text { Parameter, assumption, } \\
\text { or process modeled }\end{array}$ & ALLW PA & $\begin{array}{c}\text { Concrete PÁ } \\
\text { (Maheras, et al. 1992) }\end{array}$ & $\begin{array}{c}\text { IEB PA } \\
(\operatorname{Rood} 1992)\end{array}$ & $\begin{array}{c}\text { IWPF PA } \\
\text { (Rood 1993) }\end{array}$ & $\begin{array}{c}\text { RWMC LLW } \\
\text { Radioiogical PA } \\
\text { (Maheras et al. 1994) }\end{array}$ & $\begin{array}{c}\text { Preliminary Scoping Risk } \\
\text { Assessment } \\
\text { (Loehr et al. 1994) }\end{array}$ & $\begin{array}{c}\text { Degree of } \\
\text { conservatism in } \\
\text { ALlW PA }\end{array}$ & $\begin{array}{c}\text { Spread, } \\
\text { sensitivity, and } \\
\text { importance }\end{array}$ \\
\hline \multicolumn{9}{|l|}{$\begin{array}{l}\text { F.2. } \\
\text { GROUNDWATER } \\
\text { PATHWAY DETAILS }\end{array}$} \\
\hline \multicolumn{9}{|l|}{ F.2(a). GENERAL } \\
\hline $\begin{array}{l}\text { F.2(a).1. Transport } \\
\text { pathways }\end{array}$ & $\begin{array}{l}\text { Waste zone } \rightarrow \text { vadose zone } \\
\rightarrow \text { saturated zone }\end{array}$ & $\begin{array}{l}\text { Waste zone - vadose } \\
\text { zone - saturated } \\
\text { zone }\end{array}$ & $\begin{array}{l}\text { Waste zone - } \\
\text { vadose zone - } \\
\text { saturated zone }\end{array}$ & $\begin{array}{l}\text { Waste zone - } \\
\text { vadose zone - } \\
\text { saturated zone }\end{array}$ & $\begin{array}{l}\text { Waste zone } \rightarrow \text { vadose zone } \\
\rightarrow \text { saturated zone }\end{array}$ & $\begin{array}{l}\text { Waste zone } \rightarrow \text { vadose zone } \rightarrow \\
\text { saturated zone }\end{array}$ & \begin{tabular}{|l} 
Same \\
assumptions
\end{tabular} & NA \\
\hline $\begin{array}{l}\text { F.2(a) 2. Period of } \\
\text { performance evaluated }\end{array}$ & Time to maximum dose & $\begin{array}{l}\text { Time to maximum } \\
\text { dose }\end{array}$ & $\begin{array}{l}\text { Time to maximum } \\
\text { dose }\end{array}$ & $\begin{array}{l}\text { Time to } \\
\text { maximum dose }\end{array}$ & $\begin{array}{l}10,000 \text { yr from } 1984 \text {, doses } \\
\text { from nuclides, with a peak } \\
\text { dose after that time, were } \\
\text { presented in tables for } \\
\text { informational purposes only }\end{array}$ & $\begin{array}{l}1,000 \text { yr with } 30 \text {-yr averages for } \\
10 \text { different periods; also } \\
\text { calculated peak risk resulting } \\
\text { from peak concentrations in } \\
\text { groundwater regardless of time }\end{array}$ & $\begin{array}{l}\text { Typical and } \\
\text { comprehensive }\end{array}$ & $\begin{array}{l}\text { Spread small, } \\
\text { sensitivity } \\
\text { medium, } \\
\text { importance 2/9 }\end{array}$ \\
\hline $\begin{array}{l}\text { F.2(a).3. Groundwater } \\
\text { transport screening }(y / n, \\
\text { if y explain) }\end{array}$ & $\begin{array}{l}\text { Yes, used Seitz method, } \\
\text { function of inventory, } \mathrm{K}_{d} \text {, } \\
\text { half life, dose conversion } \\
\text { factor; parents of chains } \\
\text { not screened }\end{array}$ & None & None & None & $\begin{array}{l}\text { Yes, GWSCREEN was used } \\
\text { to calculate a screening dose } \\
\text { using more conservative } \\
\text { transport parameters and } \\
\text { assumptions }\end{array}$ & Yes, see B.2. & $\begin{array}{l}\text { Typical } \\
\text { modeling } \\
\text { assumptions } \\
\text { used }\end{array}$ & $\begin{array}{l}\text { Spread large, } \\
\text { sensitivity } \\
\text { varies, } \\
\text { importance } 3 / 9 \\
\text { to } 6 / 9\end{array}$ \\
\hline $\begin{array}{l}\text { F.2(a).4. Decay and } \\
\text { ingrowth }\end{array}$ & $\begin{array}{l}\text { Accounted for at the } \\
\text { receptor well; progeny } \\
\text { travel with parent }\end{array}$ & $\begin{array}{l}\text { Accounted for at the } \\
\text { receptor well; progeny } \\
\text { travel with parent }\end{array}$ & $\begin{array}{l}\text { Accounted for at } \\
\text { the receptor well; } \\
\text { progeny travel with } \\
\text { parent }\end{array}$ & $\begin{array}{l}\text { Accounted for at } \\
\text { the receptor well; } \\
\text { progeny travel } \\
\text { with parent }\end{array}$ & $\begin{array}{l}\text { Accounted for at the } \\
\text { receptor well; progeny travel } \\
\text { with parent }\end{array}$ & $\begin{array}{l}\text { Ingrowth during transport away } \\
\text { from waste zone, progeny } \\
\text { travel with parent }\end{array}$ & $\begin{array}{l}\text { Conservative } \\
\text { approach }\end{array}$ & $\begin{array}{l}\text { Spread small, } \\
\text { sensitivity high, } \\
\text { importance } 3 / 9\end{array}$ \\
\hline
\end{tabular}


Page H-15 of H-33

\begin{tabular}{|c|c|c|c|c|c|c|c|c|}
\hline $\begin{array}{l}\text { Parameter, assumption, } \\
\text { or process modeled }\end{array}$ & ALLW PA & $\begin{array}{c}\text { Concrete PA } \\
\text { (Maheras, et al. 1992) }\end{array}$ & $\begin{array}{c}\text { IEB PA } \\
(\operatorname{Rood} 1992)\end{array}$ & $\begin{array}{c}\text { IWPF PA } \\
(\operatorname{Rood} 1993)\end{array}$ & $\begin{array}{c}\text { RWMC LLW } \\
\text { Radiological PA } \\
\text { (Maheras et al. 1994) }\end{array}$ & $\begin{array}{c}\text { Preliminary Scoping Risk } \\
\text { Assessment } \\
\text { (Loehr et al. 1994) }\end{array}$ & $\begin{array}{c}\text { Degree of } \\
\text { conservatism in } \\
\text { ALLW PA }\end{array}$ & $\begin{array}{c}\text { Spread, } \\
\text { sensitivity, and } \\
\text { importance }\end{array}$ \\
\hline \multicolumn{9}{|l|}{$\begin{array}{l}\text { F.2(b). } \\
\text { HYDROLOGIC } \\
\text { PROCESSES OR } \\
\text { PARAMETERS } \\
\end{array}$} \\
\hline $\begin{array}{l}\text { F.2(b).1 Infiltration } \\
\text { Rate }\end{array}$ & $\begin{array}{l}\text { RWMC SDA }=1.32,5, \\
\text { and } 10 \mathrm{~cm} / \mathrm{yr} ; \text { Site } 14= \\
1.2,5 \text {, and } 10 \mathrm{~cm} / \mathrm{yr} ; \mathrm{NTS} \\
=0.6 \mathrm{~cm} / \mathrm{yr} ; \mathrm{SRS}=40,80, \\
\text { and } 120 \mathrm{~cm} / \mathrm{yr} ; \mathrm{Hanford}= \\
0.5,5, \text { and } 10 \mathrm{~cm} / \mathrm{yr}\end{array}$ & & $5 \mathrm{~cm} / \mathrm{yr}$ & 4 and $10 \mathrm{~cm} / \mathrm{yr}$ & $\begin{array}{l}4 \text { to } 10 \mathrm{~cm} / \mathrm{yr}, 7 \mathrm{~cm} / \mathrm{yr} \text { were } \\
\text { used for compliance } \\
\text { determination purposes }\end{array}$ & $10 \mathrm{~cm} / \mathrm{yr}$ & $\begin{array}{l}\text { Non- } \\
\text { conservative for } \\
\text { most runs, } \\
\text { typical for runs } \\
\text { with high } \\
\text { infiltration } \\
\text { rates }\end{array}$ & $\begin{array}{l}\text { Spread high, } \\
\text { sensitivity high, } \\
\text { importance } 9 / 9\end{array}$ \\
\hline F.2(b).2 How derived & $\begin{array}{l}\text { Infiltration assumed to be } \\
6 \% \text { of precipitation (except } \\
\text { values of } 5 \text { and } 10 \mathrm{~cm} / \mathrm{yr} \text { at } \\
\text { RWMC and Site } 14 \text { ); SRS } \\
\text { value of } 40 \mathrm{~cm} / \mathrm{yr} \text { from site } \\
\text { data, plus } 80 \text { and } 120 \mathrm{~cm} / \mathrm{yr} \\
\text { for sensitivity; Hanford } \\
\text { value of } 0.5 \mathrm{~cm} / \mathrm{yr} \text { from site } \\
\text { data plus } 5 \text { and } 10 \mathrm{~cm} / \mathrm{yr} \\
\text { for sensitivity }\end{array}$ & $\begin{array}{l}\text { From Baca et al. } \\
1992, \text { assumed value } \\
\text { equal to } 20 \% \text { of } \\
\text { precipitation }\end{array}$ & \begin{tabular}{|l|} 
From Baca et al. \\
1992, assumed value \\
equal to $20 \%$ of \\
precipitation
\end{tabular} & $\begin{array}{l}\text { Same as } 1994 \\
\text { RWMC LLW } \\
\text { Radiological PA }\end{array}$ & $\begin{array}{l}\text { In situ moisture content and } \\
\text { lydraulic characterization of } \\
\text { samples from } 240-\mathrm{ft} \text { interbed } \\
\text { beneath the RWMC coupled } \\
\text { with unit gradient } \\
\text { assumption (Magnuson and } \\
\text { McElroy 1993); further } \\
\text { relied on infiltration } \\
\text { estimates from neutron } \\
\text { access tube monitoring } \\
\text { inside the SDA (McElroy } \\
\text { 1993) }\end{array}$ & $\begin{array}{l}\text { Upper end of range given in } \\
\text { Magnuson and McElroy, } 1993\end{array}$ & $\mathrm{NA}$ & $\mathrm{NA}$ \\
\hline $\begin{array}{l}\text { F.2(b).3 } \\
\text { Cover/Engineered } \\
\text { Barrier }(y / n)\end{array}$ & $\begin{array}{l}\text { No, except for SRS facility, } \\
\text { which has concrete vault } \\
\text { and cover }\end{array}$ & No & No & No & \begin{tabular}{|l|} 
Yes, maintained thick soil \\
cover during institutional \\
control had a reduced \\
infiltration rate of $1 \mathrm{~cm} / \mathrm{yr}$ \\
based on simulation study by \\
Magnuson (1993)
\end{tabular} & Yes & $\begin{array}{l}\text { Conservative } \\
\text { compared to } \\
\text { RWMC PA, } \\
\text { consistent with } \\
\text { others }\end{array}$ & $\begin{array}{l}\text { Spread } \\
\text { medium, } \\
\text { sensitivity high, } \\
\text { importance } 6 / 9\end{array}$ \\
\hline $\begin{array}{l}\text { F.2(b). } 4 \text { (if y) } \\
\text { Assumptions used in } \\
\text { degradation of cover }\end{array}$ & $\begin{array}{l}\text { Not applicable at INEL } \\
\text { and NTS sites; concrete } \\
\text { cover at SRS assumed to } \\
\text { provide complete } \\
\text { containment for } 575 \text { years }\end{array}$ & NA & NA & NA & $\begin{array}{l}\text { Barrier was conservatively } \\
\text { assumed to fail hydraulically } \\
\text { during the } 5 \text { yr after } \\
\text { institutional control ended; } \\
\text { rapid failure was assumed } \\
\text { due to high likelihood of } \\
\text { rodent burrowing }\end{array}$ & $\begin{array}{l}\text { No credit taken for cover with } \\
\text { respect to the groundwater } \\
\text { pathway }\end{array}$ & NA & NA \\
\hline $\begin{array}{l}\text { F.2(b).5 Thickness of } \\
\text { sediment underlayer in } \\
\text { disposal unit (credit } \\
\text { taken?) }\end{array}$ & No underlayer & $\begin{array}{l}1 \mathrm{~m} \text { of backfill } \\
\text { sediments }\end{array}$ & $\begin{array}{l}1 \mathrm{~m} \text { of backfill } \\
\text { sediments }\end{array}$ & No underlayer & No underlayer & No underlayer & $\begin{array}{l}\text { Typical and } \\
\text { conseivative }\end{array}$ & $\begin{array}{l}\text { Spread } \\
\text { medium, } \\
\text { sensitivity } \\
\text { medium, } \\
\text { importance } 4 / 9\end{array}$ \\
\hline
\end{tabular}


Page H-16 of H-33

\begin{tabular}{|c|c|c|c|c|c|c|c|c|}
\hline $\begin{array}{l}\text { Parameter, assumption, } \\
\text { or process modelod }\end{array}$ & ALLW PA & $\begin{array}{c}\text { Concretc PA } \\
\text { (Maheras, et al. 1992) }\end{array}$ & $\begin{array}{c}\text { IIB PA } \\
(\operatorname{Rood} 1992)\end{array}$ & $\begin{array}{c}\text { TWPF PA } \\
(\operatorname{Rood} 1993)\end{array}$ & $\begin{array}{c}\text { RWMC LLW } \\
\text { Rađdiological PA } \\
\text { (Maheras et al. 1994) }\end{array}$ & $\begin{array}{c}\text { Preliminary Sooping Risk } \\
\text { Assessment } \\
\text { (Loehr et al. 1994) }\end{array}$ & \begin{tabular}{|c|} 
Degree of \\
conservatism in \\
ALLW PA
\end{tabular} & $\begin{array}{c}\text { Spread, } \\
\text { sensitiviiy, and } \\
\text { importance }\end{array}$ \\
\hline $\begin{array}{l}\text { F.2(b).6 Movement of } \\
\text { infiltrating water } \\
\text { through waste zone } \\
(\mathrm{y} / \mathrm{n})\end{array}$ & Yes & Yes & Yes & Yes & Yes & Yes & Typical & NA \\
\hline $\begin{array}{l}\text { F.2(b).7 Steady-state } \\
\text { or transient }\end{array}$ & Steady-state & Steady-state & Steady-state & Steady-state & Steady-state & Steady-state & $\begin{array}{l}\text { Typical and } \\
\text { consistently } \\
\text { non- } \\
\text { conservative }\end{array}$ & NA \\
\hline $\begin{array}{l}\text { F.2(b).8 Constitutive } \\
\text { relationship of flow in } \\
\text { waste zone }\end{array}$ & $\begin{array}{l}\text { Same as RWMC PA for } \\
\text { the backfill, FWFs } \\
\text { considered impermeable }\end{array}$ & $\begin{array}{l}\text { From Baca et al. 1992 } \\
\text { as was originally } \\
\text { implemented in } \\
\text { GWSCREEN, this } \\
\text { implementation } \\
\text { incorrectly } \\
\text { represented residual } \\
\text { moisture content, and, } \\
\text { as a result, the } \\
\text { estimated moisture } \\
\text { contents differ from } \\
\text { those for the RWMC } \\
\text { LLW PA and the } \\
\text { IWPF }\end{array}$ & \begin{tabular}{|l|} 
From Baca et al. \\
1992 as was \\
originally \\
implemented in \\
GWSCREEN, this \\
implementation \\
incorrectly \\
represented residual \\
moisture content, \\
and, as a result, the \\
estimated moisture \\
contents differ from \\
those for the \\
RWMC LLW PA \\
and the IWPF
\end{tabular} & \begin{tabular}{|l|} 
Same as 1994 \\
RWMC LLW \\
Radiological PA
\end{tabular} & $\begin{array}{l}\text { Geometric averaging of } \\
\text { fitted van Genuchten curves } \\
\text { from four surficial sediment } \\
\text { samples hydrologically } \\
\text { characterized and reported } \\
\text { in McElroy and Hubbell } \\
\text { (1990); the geometric } \\
\text { averages were first reported } \\
\text { in Baca et al. } 1992 \text { and were } \\
\text { subsequently used as } \\
\text { surficial soil default } \\
\text { parameters in the } \\
\text { GWSCREEN model (Rood } \\
\text { 1994) }\end{array}$ & Same as RWMC PA & \begin{tabular}{|l} 
Typical and \\
consistent \\
approach
\end{tabular} & $\mathrm{NA}$ \\
\hline \begin{tabular}{|l|} 
F.2(b).9 $\quad$ Moisture \\
content (if steady-state)
\end{tabular} & \begin{tabular}{|l|} 
RWMC $=0.32(1.32$ \\
$\mathrm{cm} / \mathrm{yr}), 0.36(5 \mathrm{~cm} / \mathrm{yr}), 0.38$ \\
$(10 \mathrm{~cm} / \mathrm{yr}) ;$ Site $14=0.32$ \\
$(1.2 \mathrm{~cm} / \mathrm{yr}), 0.36(5 \mathrm{~cm} / \mathrm{yr})$ \\
$0.38(10 \mathrm{~cm} / \mathrm{yr}) ; \mathrm{NTS}=$ \\
$0.30 ; \mathrm{SRS}=0.178(40$ \\
\\
$\mathrm{cm} / \mathrm{yr}), 0.19(80 \mathrm{~cm} / \mathrm{yr})$ \\
$0.21(120 \mathrm{~cm} / \mathrm{yr})$
\end{tabular} & 0.285 & 0.285 & $\begin{array}{l}0.32 \& 0.34, \text { for } \\
0.04 \text { to } 0.10 \mathrm{~m} / \mathrm{yr} \\
\text { infiltration }\end{array}$ & $0.33 \mathrm{~cm}^{3} / \mathrm{cm}^{3}$ & 0.3 & $\begin{array}{l}\text { Typical and } \\
\text { consistent } \\
\text { approach }\end{array}$ & $\begin{array}{l}\text { Spread small, } \\
\text { sensitivity } \\
\text { medium, } \\
\text { importance 2/9 }\end{array}$ \\
\hline
\end{tabular}


Page H-17 of H-33

\begin{tabular}{|c|c|c|c|c|c|c|c|c|}
\hline $\begin{array}{c}\text { Parameter, assumption, } \\
\text { or process modeled }\end{array}$ & ALLW PA & $\begin{array}{c}\text { Concrete PA } \\
\text { (Maheras, et al. 1992) }\end{array}$ & $\begin{array}{c}\text { IEB PA } \\
(\operatorname{Rood} 1992)\end{array}$ & $\begin{array}{c}\text { IWPF PA } \\
\text { (Rood 1993) }\end{array}$ & $\begin{array}{c}\text { RWMC LLW } \\
\text { Radiological PA } \\
\text { (Maheras et al. 1994) }\end{array}$ & $\begin{array}{c}\text { Preliminary Scoping Risk } \\
\text { Assessment } \\
\text { (Loehr et al. 1994) }\end{array}$ & $\begin{array}{c}\text { Degnee of } \\
\text { conservatism in } \\
\text { ALLW PA }\end{array}$ & $\begin{array}{c}\text { Spread, } \\
\text { sensitivity, and } \\
\text { importance }\end{array}$ \\
\hline $\begin{array}{l}\text { F.2(b).10 Movement of } \\
\text { infiltrating water in } \\
\text { basalts within the } \\
\text { vadose zone }\end{array}$ & $\begin{array}{l}\text { Sediment and basalt } \\
\text { simulated by varying } \mathrm{K}_{d} \\
\text { and porosity and bulk } \\
\text { density; did not model } \\
\text { fracture flow; some runs } \\
\text { took no credit for basalt }\end{array}$ & $\begin{array}{l}\text { Water travel time was } \\
\text { accounted for only in } \\
\text { the basalts }\end{array}$ & $\begin{array}{l}\text { Water travel time } \\
\text { was accounted for } \\
\text { only in the basalts }\end{array}$ & $\begin{array}{l}\text { Water travel time } \\
\text { was accounted for } \\
\text { only in the } \\
\text { sediments }\end{array}$ & $\begin{array}{l}\text { Water travel time was } \\
\text { accounted for only in the } \\
\text { sediments }\end{array}$ & $\begin{array}{l}\text { Water travel time was } \\
\text { accounted for only in the } \\
\text { sediments }\end{array}$ & $\begin{array}{l}\text { For most runs, } \\
\text { ALLW PA was } \\
\text { non- } \\
\text { conservative; } \\
\text { long vadose } \\
\text { zone travel time } \\
\text { due to assumed } \\
\text { infiltration rate } \\
\text { and moisture } \\
\text { content; for } \\
\text { runs taking no } \\
\text { credit for } \\
\text { basalt, typical }\end{array}$ & $\begin{array}{l}\text { Spread high, } \\
\text { sensitivity high, } \\
\text { importance } 9 / 9\end{array}$ \\
\hline $\begin{array}{l}\text { F.2(b). } 11 \text { (if } y \text { ) } \\
\text { Thickness of basalt } \\
\text { layers }\end{array}$ & $\begin{array}{l}\text { RWMC = } 167 \mathrm{~m} \text { basalt } \\
\text { under } 9 \mathrm{~m} \text { sediment; no } \\
\text { basalt at Site 14, NTS, or } \\
\text { SRS; Hanford basalt below } \\
\text { water table }\end{array}$ & $176 \mathrm{~m}$ & $176 \mathrm{~m}$ & NA & NA & NA & NA & NA \\
\hline $\begin{array}{l}\text { F.2(b).12 Constitutive } \\
\text { relationship for flow in } \\
\text { basalt }\end{array}$ & $\begin{array}{l}\text { Basalt characteristic curve } \\
\text { from GWSCREEN }\end{array}$ & $\begin{array}{l}\text { From Bishop (1991) } \\
\text { basalt matrix } \\
\text { characterization data } \\
\text { as implemented in } \\
\text { Baca et al. 1992; this } \\
\text { same curve was } \\
\text { assigned as the } \\
\text { default basalt } \\
\text { moisture } \\
\text { characteristic curve in } \\
\text { GWSCREEN; relies } \\
\text { on simplistic } \\
\text { assumptions to } \\
\text { incorporate fracture } \\
\text { flow effects }\end{array}$ & $\begin{array}{l}\text { From Bishop (1991) } \\
\text { basalt matrix } \\
\text { characterization } \\
\text { data as implemented } \\
\text { in Baca et al. 1992; } \\
\text { this same curve was } \\
\text { assigned as the } \\
\text { default basalt } \\
\text { moisture } \\
\text { characteristic curve } \\
\text { in GWSCREEN; } \\
\text { relies on simplistic } \\
\text { assumptions to } \\
\text { incorporate fracture } \\
\text { flow effects }\end{array}$ & Not considered & Not considered & Not considered & NA & NA \\
\hline $\begin{array}{l}\text { F.2(b).13 Moisture } \\
\text { content of basalt (if } \\
\text { steady-state) }\end{array}$ & $\begin{array}{l}\text { RWMC = } 0.07 \\
\text { Site } 14, \text { NTS, SRS, and } \\
\text { Hanford = NA }\end{array}$ & 0.05 & 0.05 & NA & NA & NA & NA & NA \\
\hline $\begin{array}{l}\text { F.2(b).14 Movement of } \\
\text { infiltrating water in } \\
\text { sedimentary interbeds } \\
(y / n)\end{array}$ & $\begin{array}{l}\text { All sediment and interbed } \\
\text { layers lumped together }\end{array}$ & Not considered & Not considered & Yes & Yes & Yes & Typical & NA \\
\hline
\end{tabular}


Page H-18 of H-33

\begin{tabular}{|c|c|c|c|c|c|c|c|c|}
\hline $\begin{array}{l}\text { Parameter, assumption, } \\
\text { or process modeled }\end{array}$ & ALLW PA & $\begin{array}{c}\text { Concrete PA } \\
\text { (Maheras, et al. 1992) }\end{array}$ & $\begin{array}{c}\text { HEP PA } \\
\text { (Rood 1992) }\end{array}$ & $\begin{array}{r}\text { IWPF PA } \\
(\operatorname{Rood~1993)})\end{array}$ & $\begin{array}{c}\text { RWMC LLW } \\
\text { Radiological PA } \\
\text { (Maheras et al. 1994) }\end{array}$ & $\begin{array}{c}\text { Preliminary Scoping Risk } \\
\text { Assessment } \\
\text { (Loehr et al. 1994) }\end{array}$ & \begin{tabular}{|c|} 
Degree of \\
conservatism in \\
ALLW PA
\end{tabular} & $\begin{array}{c}\text { Spread, } \\
\text { sensitivity, and } \\
\text { importance }\end{array}$ \\
\hline $\begin{array}{l}\text { F.2(b).15 (if } y) \\
\text { thickness of } \\
\text { sedimentary interbeds }\end{array}$ & $\begin{array}{l}\text { RWMC = } 9 \mathrm{~m} \text {; Site } 14= \\
80 \mathrm{~m} \text { (sediment); NTS = } \\
245 \mathrm{~m} \text { (sediment); SRS = } \\
21 \mathrm{~m} \text { (sand and soil); } \\
\text { Hanford = } 75 \mathrm{~m} \\
\text { (sediment) }\end{array}$ & NA & NA & $\begin{array}{l}10.66 \mathrm{~m} \text {, based } \\
\text { on interim } \\
\text { calculations for } \\
\text { the RWMC LLW } \\
\text { PA; deeper } \\
\text { interbeds not } \\
\text { considered }\end{array}$ & $\begin{array}{l}12.5 \mathrm{~m} \text {, no credit taken for } \\
\text { A-B interbed due to location } \\
\text { of Pits 17-20; average } \\
\text { Anderson and Lewis (1989) } \\
\text { thicknesses for B-C, C-D, } \\
\text { D-E, and E-F interbeds } \\
\text { were used }\end{array}$ & $\begin{array}{l}16.46 \mathrm{~m} \text { equal to the sum of } \\
\text { the average interbed } \\
\text { thicknesses given in Anderson } \\
\text { and Lewis (1989), interbed } \\
\text { thicknesses for the A-B, B-C, } \\
\text { C-D, D-E, E-F, and F-G } \\
\text { interbeds }\end{array}$ & Conservative & $\begin{array}{l}\text { Spread small, } \\
\text { sensitivity } \\
\text { moderate, } \\
\text { importance } 2 / 9\end{array}$ \\
\hline $\begin{array}{l}\text { F.2(b).16 Constitutive } \\
\text { relationship for flow in } \\
\text { sedimentary interbeds }\end{array}$ & $\begin{array}{l}\text { Based on basalt } \\
\text { characteristic curves from } \\
\text { GWSCREEN }\end{array}$ & NA & NA & $\begin{array}{l}\text { Same as } 1994 \\
\text { RWMC LLW } \\
\text { Radiological PA }\end{array}$ & $\begin{array}{l}\text { Hydrologic characterization } \\
\text { of core samples from 110-ft } \\
\text { and 240-ft interbeds } \\
\text { reported in McElroy and } \\
\text { Hubbell (1990); these } \\
\text { samples were grouped and } \\
\text { averaged and representative } \\
\text { van Genuchten moisture } \\
\text { characteristic curves for } \\
\text { both interbeds were } \\
\text { determined (Magnuson and } \\
\text { McElroy 1993) }\end{array}$ & $\begin{array}{l}\text { Based on surficial sediment } \\
\text { characteristic curves from } \\
\text { GWSCREEN }\end{array}$ & NA & $\overline{N A}$ \\
\hline \begin{tabular}{|l|} 
F.2(b).17 Moisture \\
content (if steady-state)
\end{tabular} & $\begin{array}{l}\text { RWMC }=0.07 ; \text { Site } 14= \\
0.06 ; \text { NTS = 0.05; SRS = } \\
0.074 \text { (sand), 0.088 (soil); } \\
\text { Hanford = (0.039) }\end{array}$ & NA & NA & $\begin{array}{l}0.27, \text { as in } \\
\text { RWMC LLW PA } \\
\text { travel, this was } \\
\text { the moisture } \\
\text { content necessary } \\
\text { to match } \\
\text { cumulative } \\
\text { estimated travel } \\
\text { times across } \\
\text { sedimentary } \\
\text { interbeds }\end{array}$ & $\begin{array}{l}\text { Varied by interbed: B-C } \\
0.082 ; \text { C-D 0.38; D-E \& E- } \\
\text { F 0.40; moisture content } \\
\text { that was necessary to match } \\
\text { cumulative vadose zone } \\
\text { travel time was } 0.168\end{array}$ & 0.3 & \begin{tabular}{|l} 
ALLW PA is \\
non- \\
conservative \\
compared with \\
other analyses
\end{tabular} & $\begin{array}{l}\text { Spread large, } \\
\text { sensitivity } \\
\text { medium to } \\
\text { large, } \\
\text { importance } 6 / 9 \\
\text { to } 9 / 9 \text { (nuclide- } \\
\text { specific) }\end{array}$ \\
\hline $\begin{array}{l}\text { F.2(b).18 Cumulative } \\
\text { water travel time } \\
\text { through vadose zone }\end{array}$ & $\begin{array}{l}\text { Total (including waste } \\
\text { zone) is RWMC = 933 yr } \\
\text { for most runs; some runs } \\
\text { made with travel times as } \\
\text { short as } 6.3 \mathrm{yr} \text {; Site } 14= \\
400 \mathrm{yr} \text {, NTS }=2,246 \mathrm{yr} \\
\text { SRS }=4.52 \mathrm{yr} \text {, Hanford = } \\
560 \mathrm{yr}\end{array}$ & $176 \mathrm{yr}$ & $176 \mathrm{yr}$ & $28.7-71.9 \mathrm{yr}$ & $\begin{array}{l}\text { For the } 7 \mathrm{~cm} / \mathrm{yr} \text { infiltration } \\
\text { rate, the cumulative water } \\
\text { travel time from beneath the } \\
\text { pit to the aquifer was } 30 \mathrm{yr}\end{array}$ & $49.4 \mathrm{yr}$ & \begin{tabular}{|l|} 
ALLW PA is \\
nonconservative \\
for most runs; \\
is conservative \\
for a limited \\
number of runs
\end{tabular} & \\
\hline
\end{tabular}


Page $\mathrm{H}-19$ of $\mathrm{H}-33$

\begin{tabular}{|c|c|c|c|c|c|c|c|c|}
\hline $\begin{array}{l}\text { Parameter, assumption, } \\
\text { or process modeled }\end{array}$ & ALLW PA & $\begin{array}{c}\text { Concrete PA } \\
\text { (Maheras, et al. 1992) }\end{array}$ & $\begin{array}{c}\text { IEB PA } \\
\text { (Rood 1992) }\end{array}$ & $\begin{array}{c}\text { IWPF PA } \\
\text { (Rood 1993) }\end{array}$ & $\begin{array}{c}\text { RWMC LLW } \\
\text { Radiological PA } \\
\text { (Maheras et al. 1994) }\end{array}$ & $\begin{array}{c}\text { Preliminary Scoping Risk } \\
\text { Assessment } \\
\text { (Loehr et al. 1994) }\end{array}$ & \begin{tabular}{|c|} 
Degree of \\
conservatism in \\
ALLW PA
\end{tabular} & $\begin{array}{c}\text { Spread, } \\
\text { sensitivity, and } \\
\text { importance }\end{array}$ \\
\hline $\begin{array}{l}\text { F.2(b).19 Other } \\
\text { Unsaturated Zone }\end{array}$ & & & & & $\begin{array}{l}\text { (a) The infiltration rate at } \\
\text { depth was not reduced even } \\
\text { with a cover during } \\
\text { institutional control based } \\
\text { on an assumption of easy } \\
\text { horizontal movement within } \\
\text { the fractured basalts; (b) } \\
\text { greater than unit gradients } \\
\text { based on field measurements } \\
\text { were used to estimate } \\
\text { velocity across the C-D } \\
\text { interbed; (c) travel times } \\
\text { were estimated across } \\
\text { individual interbeds and } \\
\text { summed to determine } \\
\text { cumulative water travel time }\end{array}$ & & NA & NA \\
\hline $\begin{array}{l}\text { F.2(b).20 Aquifer } \\
\text { average linear velocity }\end{array}$ & $\begin{array}{l}\text { RWMC }=570 \mathrm{~m} / \mathrm{yr} ; \text { Site } \\
14=668 \mathrm{~m} / \mathrm{yr} ; \mathrm{NTS}=1.0, \\
0.1, \text { and } 0.01 \mathrm{~m} / \mathrm{yr} ; \mathrm{SRS}= \\
6.67 \mathrm{~m} / \mathrm{yr} ; \text { Hanford }= \\
22.0 \mathrm{~m} / \mathrm{yr}\end{array}$ & $570 \mathrm{~m} / \mathrm{y}$ & $570 \mathrm{~m} / \mathrm{y}$ & \begin{tabular}{|l|}
$890 \mathrm{~m} / \mathrm{yr}$ This \\
value was an \\
interim RWMC \\
PA value that was \\
later changed to \\
$560 \mathrm{~m} / \mathrm{y}$
\end{tabular} & $560 \mathrm{~m} / \mathrm{yr}$, Wood (1989) & $570 \mathrm{~m} / \mathrm{yr}$ & $\begin{array}{l}\text { Typical values } \\
\text { used }\end{array}$ & $\begin{array}{l}\text { Spread small, } \\
\text { sensitivity low } \\
\text { to medium } \\
\text { depending on } \\
\text { receptor well } \\
\text { location; } \\
\text { importance } 1 / 9 \\
\text { to } 3 / 9\end{array}$ \\
\hline $\begin{array}{l}\text { F.2(b).21 Aquifer } \\
\text { porosity }\end{array}$ & $\begin{array}{l}\text { RWMC = 0.10; Site } 14= \\
0.10 ; \text { NTS = NA; SRS = } \\
0.4 ; \text { Hanford }=0.1\end{array}$ & 0.1 & 0.1 & 0.1 & $\begin{array}{l}0.10 \mathrm{~cm}^{3} / \mathrm{cm}^{3}, \text { Robertson } \\
(1974)\end{array}$ & 0.1 & $\begin{array}{l}\text { Typical values } \\
\text { used }\end{array}$ & $\begin{array}{l}\text { Spread small, } \\
\text { sensitivity high, } \\
\text { importance 3/9 }\end{array}$ \\
\hline $\begin{array}{l}\text { F.2(b).22 Flooding } \\
\text { events evaluated }(y / n)\end{array}$ & No & No & No & No & $\begin{array}{l}\text { Yes, flooding was evaluated } \\
\text { as a sensitivity case; floods } \\
\text { of magnitude } 20,35 \text {, and } \\
70 \mathrm{~cm} \text {, occurring shortly } \\
\text { after termination of } \\
\text { institutional control, were } \\
\text { evaluated }\end{array}$ & No & $\begin{array}{l}\text { Only RWMC } \\
\text { PA considered } \\
\text { flooding, and } \\
\text { that was as a } \\
\text { sensitivity case; } \\
\text { ALLW PA was } \\
\text { non- } \\
\text { conservative }\end{array}$ & $\begin{array}{l}\text { Spread small, } \\
\text { sensitivity } \\
\text { medium to } \\
\text { high, } \\
\text { importance 3/9 } \\
\text { to 6/9 }\end{array}$ \\
\hline
\end{tabular}


Page H-20 of H-33

\begin{tabular}{|c|c|c|c|c|c|c|c|c|}
\hline $\begin{array}{l}\text { Parameter, assumption, } \\
\text { or process modeled }\end{array}$ & ALLW PA & $\begin{array}{c}\text { Concreie PA } \\
\text { (Mahcras, ct al. 1992) }\end{array}$ & $\begin{array}{c}\text { IEB PA } \\
(\operatorname{Rood} 1992)\end{array}$ & $\begin{array}{c}\text { IWPF PA } \\
(\operatorname{Rood} 1993)\end{array}$ & $\begin{array}{c}\text { RWMC LLW } \\
\text { Radiological PA } \\
\text { (Maheras et al. 1994) }\end{array}$ & $\begin{array}{c}\text { Preliminary Scoping Risk } \\
\text { Assessment } \\
\text { (Loehr et al. 1994) }\end{array}$ & $\begin{array}{c}\text { Degree of } \\
\text { conservatism in } \\
\text { ALLW PA }\end{array}$ & $\begin{array}{c}\text { Spread, } \\
\text { sensitivity, and } \\
\text { importance }\end{array}$ \\
\hline $\begin{array}{l}\text { F.2(b).23 Codes or } \\
\text { methodology used }\end{array}$ & $\begin{array}{l}\text { VS2DT for flow through } \\
\text { disposal facility; water } \\
\text { travel time through vadose } \\
\text { zone estimated analytically } \\
\text { as a function of the } \\
\text { infiltration rate, moisture } \\
\text { content, and vadose zone } \\
\text { thickness; saturated zone } \\
\text { had associated aquifer } \\
\text { average linear velocity }\end{array}$ & $\begin{array}{l}\text { Codes were written or } \\
\text { modified (GWMOD) } \\
\text { to perform } \\
\text { calculations for this } \\
\text { problem }\end{array}$ & $\begin{array}{l}\text { Codes were written } \\
\text { or modified } \\
\text { (GWMOD) to } \\
\text { perform calculations } \\
\text { for this problem }\end{array}$ & $\begin{array}{l}\text { GWSCREEN; } \\
\text { water travel time } \\
\text { through vadose } \\
\text { zone estimated } \\
\text { analytically as a } \\
\text { function of the } \\
\text { infiltration rate, } \\
\text { moisture content, } \\
\text { and vadose zone } \\
\text { thickness }\end{array}$ & $\begin{array}{l}\text { Source term: analytic unit- } \\
\text { gradient solutions as } \\
\text { described above; water } \\
\text { travel time through vadose } \\
\text { zone estimated analytically } \\
\text { as a function of the } \\
\text { infiltration rate, moisture } \\
\text { content, and vadose zone } \\
\text { thickness; saturated zone: } \\
\text { GWSCREEN for both } \\
\text { steady-state and flooding }\end{array}$ & DUST & $\begin{array}{l}\text { Typical } \\
\text { approach }\end{array}$ & NA \\
\hline \multicolumn{9}{|l|}{$\begin{array}{l}\text { F.2(c). SOURCE } \\
\text { ZONE TRANSPORT } \\
\text { PROCESSES }\end{array}$} \\
\hline $\begin{array}{l}\text { F.2(c).1 Include } \\
\text { sorption (if y, cite } \\
\text { sources) }\end{array}$ & $\begin{array}{l}\text { No, except for some cases; } \\
\text { these cases used } 1 / 10 \text { of } \\
\text { the } \mathrm{K}_{d} \text { of the vadose zone } \\
\text { soils at the site; additional } \\
\text { cases, representing tailored } \\
\text { backfill, used the full value } \\
\text { of the } \mathrm{K}_{d} \text { of the vadose } \\
\text { zone soils }\end{array}$ & $\begin{array}{l}\text { Yes, Case et al. } \\
(1990)\end{array}$ & $\begin{array}{l}\text { Yes, Case et al. } \\
(1990)\end{array}$ & $\begin{array}{l}\text { Yes, RWMC PA } \\
\text { (Case et al. 1990) } \\
\text { and TRACK } 2 \\
\text { guidance } \\
\text { document (DOE } \\
1993 \text { ) }\end{array}$ & $\begin{array}{l}\text { Yes, sorption coefficient } \\
\text { data in the } 1990 \text { PA (Case } \\
\text { et al.) were used; } \\
\text { comparisons and sensitivity } \\
\text { analysis were also performed } \\
\text { using data from Sheppard } \\
\text { and Thibault (1990), the } \\
\text { TRACK } 2 \text { manual (DOE } \\
\text { 1993), Baes and Sharp } \\
\text { (1984), Del Debbio and } \\
\text { Thomas (1989), and the } \\
\text { NEA Database (Ticknor and } \\
\text { Ruegger 1989) }\end{array}$ & $\begin{array}{l}\text { Yes: DOE (1993), Sheppard } \\
\text { and Thibault (1990), Baes and } \\
\text { Sharp (1983), Coughtrey et al. } \\
\text { (1987), Looney et al. (1987), } \\
\text { Del Debbio and Thomas } \\
\text { (1989), Hawkins and Short } \\
\text { (1965), Schmalz (1972) }\end{array}$ & $\begin{array}{l}\text { ALLW } \\
\text { generally } \\
\text { conservative }\end{array}$ & $\begin{array}{l}\text { Spread high, } \\
\text { sensitivity high, } \\
\text { importance 9/9 }\end{array}$ \\
\hline $\begin{array}{l}\text { F.2(c).2 Include } \\
\text { dispersion }\end{array}$ & No & No & No & No & $\begin{array}{l}\text { No, mixing cell model for } \\
\text { source term }\end{array}$ & Yes & \begin{tabular}{|l|} 
Consistent \\
conservative \\
approach
\end{tabular} & NA \\
\hline $\begin{array}{l}\text { F.2(c).3 Include } \\
\text { diffusion }\end{array}$ & No & No & No & No & No & Yes & & \\
\hline F.2(c).4 Solubility limits & $\begin{array}{l}\text { Yes - EQ3/6 limits used } \\
\text { but never reached }\end{array}$ & No & No & Yes & Yes, but never reached & Yes & NA & $\mathrm{NA}$ \\
\hline $\begin{array}{l}\text { F.2(c). } 5 \text { Codes or } \\
\text { methodology used }\end{array}$ & DUST code & \begin{tabular}{|l|} 
First-order kinetic \\
model written for \\
calculation of release \\
from source term; \\
BLT used for \\
sorption controlled \\
release form soil layer
\end{tabular} & $\begin{array}{l}\text { First-order kinetic } \\
\text { model written for } \\
\text { calculation of } \\
\text { release from source } \\
\text { term }\end{array}$ & GWSCREEN & $\begin{array}{l}\text { A custom code was written } \\
\text { to solve for the time- } \\
\text { dependent inventory and } \\
\text { release rate from the source } \\
\text { model }\end{array}$ & DUST & \begin{tabular}{|l|} 
Codes \\
appropriate for \\
types of FWFs
\end{tabular} & NA \\
\hline
\end{tabular}


Page H-21 of H-33

\begin{tabular}{|c|c|c|c|c|c|c|c|c|}
\hline $\begin{array}{l}\text { Parameter, assumption, } \\
\text { or process modeled }\end{array}$ & ALLW PA & $\begin{array}{c}\text { Concrete PA } \\
\text { (Maheras, et al. 1992) }\end{array}$ & $\begin{array}{c}\text { IEB PA } \\
\text { (Rood 1992) }\end{array}$ & $\begin{array}{c}\text { IWPF PA } \\
\text { (Rood 1993) }\end{array}$ & $\begin{array}{c}\text { RWMC LLW } \\
\text { Radiological PA } \\
\text { (Maheras et al. 1994) }\end{array}$ & $\begin{array}{c}\text { Preliminary Scoping Risk } \\
\text { Assessment } \\
\text { (Loehr et al. 1994) }\end{array}$ & $\begin{array}{c}\text { Degree of } \\
\text { conservatism in } \\
\text { ALLW PA }\end{array}$ & $\begin{array}{c}\text { Spread, } \\
\text { sensitivity, and } \\
\text { importance }\end{array}$ \\
\hline \multicolumn{9}{|l|}{$\begin{array}{l}\text { F.2(d). } \\
\text { UNSATURATED } \\
\text { ZONE TRANSPORT } \\
\text { PROCESSES }\end{array}$} \\
\hline $\begin{array}{l}\text { F.2(d).1 Include } \\
\text { sorption }\end{array}$ & Yes & Yes & Yes & Yes & Yes & Yes & \begin{tabular}{|l} 
Typical \\
consistent \\
approach
\end{tabular} & $\mathrm{NA}$ \\
\hline $\begin{array}{l}\text { F.2(d).2 Include } \\
\text { dispersion }\end{array}$ & No & No & No & No & $\begin{array}{l}\text { No, conservatively neglected, } \\
\text { plug flow model assumed }\end{array}$ & No & \begin{tabular}{|l|} 
Typical \\
consistent \\
approach
\end{tabular} & NA \\
\hline $\begin{array}{l}\text { F.2(d).3 Include } \\
\text { diffusion }\end{array}$ & No & No & No & No & No & No & \begin{tabular}{|l} 
Typical \\
consistent \\
approach
\end{tabular} & NA \\
\hline $\begin{array}{l}\text { F.2(d).4 Sorption } \\
\text { coefficients source }\end{array}$ & $\begin{array}{l}\text { Case et al. (1990), DOE } \\
\text { (1982), and DOE (1984); } \\
\text { SRS values from EAVDF } \\
\text { PA (1994), Hanford values } \\
\text { from 200W Area PA } \\
(1994)\end{array}$ & $\begin{array}{l}\text { Case et al. (1990), } \\
\text { DOE (1982), and } \\
\text { DOE (1984) }\end{array}$ & $\begin{array}{l}\text { Case et al. (1990), } \\
\text { DOE (1982), and } \\
\text { DOE (1984) }\end{array}$ & $\begin{array}{l}\text { Case et al. } \\
(1990) \text {, } \\
\text { DOE (1982), and } \\
\text { DOE (1984) }\end{array}$ & $\begin{array}{l}\text { Yes, sorption coefficient } \\
\text { data in the DOE } 1982 \text { and } \\
1984 \text { studies were used; } \\
\text { comparisons and sensitivity } \\
\text { analyses were also } \\
\text { performed using data from } \\
\text { Sheppard and Thibault } \\
\text { (1990), the TRACK 2 } \\
\text { manual (DOE 1992), Baes } \\
\text { et al. (1984) for Tc and K, } \\
\text { Del Debbio and Thomas } \\
\text { (1989), and the NEA } \\
\text { Database }\end{array}$ & $\begin{array}{l}\text { Yes, DOE (1993), Sheppard } \\
\text { and Thibault (1990), Baes and } \\
\text { Sharp (1983), Coughtrey et al. } \\
\text { (1987), Looney et al. (1987), } \\
\text { Del Debbio and Thomas } \\
\text { (1989), Hawkins and Short } \\
\text { (1965), Schmalz (1972) }\end{array}$ & $\begin{array}{l}\text { Identical values } \\
\text { used for all key } \\
\text { nuclides }(\mathrm{Pu}, \\
\mathrm{U} \text {, and } \mathrm{Ra})\end{array}$ & NA \\
\hline
\end{tabular}


Page H-22 of H-33

\begin{tabular}{|c|c|c|c|c|c|c|c|c|}
\hline $\begin{array}{l}\text { Parameter, assumption, } \\
\text { or process modeled }\end{array}$ & ALLW PA & $\begin{array}{c}\text { Concrete PA } \\
\text { (Maheras, et al. 1992) }\end{array}$ & $\begin{array}{c}\text { IFB PA } \\
\text { (Rood 1992) }\end{array}$ & $\begin{array}{c}\text { IWPF PA } \\
\text { (Rood 1993) }\end{array}$ & $\begin{array}{c}\text { RWMC LLW } \\
\text { Raäiological PA } \\
\text { (Maheras et al. 1994) }\end{array}$ & $\begin{array}{c}\text { Preliminary Scoping Risk } \\
\text { Assessment } \\
\text { (Loehr et al. 1994) }\end{array}$ & $\begin{array}{c}\text { Degree of } \\
\text { conservatism in } \\
\text { ALLW PA }\end{array}$ & $\begin{array}{c}\text { Spread, } \\
\text { sensitivity, and } \\
\text { importance }\end{array}$ \\
\hline $\begin{array}{l}\text { F.2(d).5 Codes or } \\
\text { methodology used }\end{array}$ & $\begin{array}{l}\text { 1-D analytical solution; } \\
\text { nuclide velocity calculated } \\
\text { as product of the vadose } \\
\text { zone water travel time and } \\
\text { the nuclide-specific } \\
\text { retardation coefficient for } \\
\text { the site-specific geologic } \\
\text { stratigraphy }\end{array}$ & \begin{tabular}{|l} 
1-D analytical \\
solution; nuclide \\
velocity calculated as \\
product of the vadose \\
zone water travel time \\
and the nuclide- \\
specific retardation \\
coefficient for the \\
site-specific geologic \\
stratigraphy
\end{tabular} & $\begin{array}{l}\text { 1-D analytical } \\
\text { solution; nuclide } \\
\text { velocity calculated } \\
\text { as product of the } \\
\text { vadose zone water } \\
\text { travel time and the } \\
\text { nuclide-specific } \\
\text { retardation } \\
\text { coefficient for the } \\
\text { site-specific geologic } \\
\text { stratiggaphy }\end{array}$ & $\begin{array}{l}\text { 1-D analytical } \\
\text { solution; nuclide } \\
\text { velocity } \\
\text { calculated as } \\
\text { product of the } \\
\text { vadose zone } \\
\text { water travel time } \\
\text { and the nuclide- } \\
\text { specific } \\
\text { retardation } \\
\text { coefficient for the } \\
\text { site-specific } \\
\text { geologic } \\
\text { stratigraphy; } \\
\text { implemented } \\
\text { using } \\
\text { GWSCREEN }\end{array}$ & $\begin{array}{l}\text { 1-D analytical solution; } \\
\text { nuclide velocity calculated as } \\
\text { product of the vadose zone } \\
\text { water travel time and the } \\
\text { nuclide-specific retardation } \\
\text { coefficient for the site- } \\
\text { specific geologic } \\
\text { stratigraphy; implemented } \\
\text { using GWSCREEN }\end{array}$ & GWSCREEN & $\begin{array}{l}\text { Typical } \\
\text { consistent } \\
\text { approach }\end{array}$ & NA \\
\hline $\begin{array}{l}\text { F.2(e). SATURATED } \\
\text { ZONE TRANSPORT } \\
\text { PROCESSES }\end{array}$ & & & & & & & & \\
\hline $\begin{array}{l}\text { F.2(e).1 Include } \\
\text { sorption }\end{array}$ & Yes & Yes & Yes & Yes & Yes & Yes & \begin{tabular}{|l|} 
Typical \\
consistent \\
approach
\end{tabular} & NA \\
\hline $\begin{array}{l}\text { F.2(e).2 Include } \\
\text { dispersion }\end{array}$ & Yes & Yes & Yes & Yes & Yes & Yes & $\begin{array}{l}\text { Typical } \\
\text { consistent } \\
\text { approach }\end{array}$ & NA \\
\hline $\begin{array}{l}\text { F.2(e).3 Include } \\
\text { diffusion }\end{array}$ & Yes (NTS only) & No & No & No & No & Yes & $\begin{array}{l}\text { Typical } \\
\text { consistent } \\
\text { approach }\end{array}$ & NA \\
\hline
\end{tabular}


Page $\mathrm{H}-23$ of $\mathbf{H}-33$

\begin{tabular}{|c|c|c|c|c|c|c|c|c|}
\hline \begin{tabular}{|c|}
$\begin{array}{c}\text { Parameter, assumption, } \\
\text { or process modeled }\end{array}$ \\
\end{tabular} & ALLW PA & $\begin{array}{c}\text { Concrete PA } \\
\text { (Maheras, et al. 1992) } \\
\end{array}$ & $\begin{array}{c}\text { IEB PA } \\
(\operatorname{Rood} 1992) \\
\end{array}$ & $\begin{array}{c}\text { IWPF PA } \\
(\operatorname{Rood} 1993) \\
\end{array}$ & $\begin{array}{c}\text { RWMC LLW } \\
\text { Radiological PA } \\
\text { (Maheras et al. 1994) } \\
\end{array}$ & $\begin{array}{c}\text { Preliminary Scoping Risk } \\
\text { Assessment } \\
\text { (Loehr et al. 1994) }\end{array}$ & $\begin{array}{c}\text { Degree of } \\
\text { conservatism in } \\
\text { ALLW PA }\end{array}$ & $\begin{array}{c}\text { Sprcad, } \\
\text { sensitivity, and } \\
\text { importance }\end{array}$ \\
\hline $\begin{array}{l}\text { F.2(e).4 Source of } \\
\text { information for sorption } \\
\text { coefficients }\end{array}$ & $\begin{array}{l}\text { Case et al. (1990), DOE } \\
\text { (1982), and DOE (1984); } \\
\text { SRS data from EAVDF } \\
\text { PA (1994), Hanford data } \\
\text { from 200W Area PA } \\
(1994)\end{array}$ & $\begin{array}{l}\text { Case et al. (1990), } \\
\text { DOE (1982), and } \\
\text { DOE (1984) }\end{array}$ & $\begin{array}{l}\text { Case et al. (1990), } \\
\text { DOE (1982), and } \\
\text { DOE (1984) }\end{array}$ & \begin{tabular}{|l|} 
Case et al. \\
$(1990)$, DOE \\
$(1982)$, and DOE \\
$(1984)$
\end{tabular} & $\begin{array}{l}\text { Sorption coefficient data in } \\
\text { the DOE } 1982 \text { and } 1984 \\
\text { studies were used; } \\
\text { comparisons and sensitivity } \\
\text { analyses were also } \\
\text { performed using data from } \\
\text { Sheppard and Thibault } \\
(1990) \text {, the TRACK } 2 \\
\text { manual (DOE 1992), Baes } \\
\text { et al. (1984) for Tc and K, } \\
\text { Del Debbio and Thomas } \\
\text { (1989), and the NEA } \\
\text { Database (Ticknor and } \\
\text { Ruegger 1989) }\end{array}$ & $\begin{array}{l}\text { Yes: DOE (1993), Sheppard } \\
\text { and Thibault (1990), Baes and } \\
\text { Sharp (1983), Coughtrey et al. } \\
\text { (1987), Looney et al. (1987), } \\
\text { Del Debbio and Thomas } \\
\text { (1989), Hawkins and Short } \\
\text { (1965), Schmalz (1972) }\end{array}$ & $\begin{array}{l}\text { Typical } \\
\text { consistent } \\
\text { approach }\end{array}$ & NA \\
\hline $\begin{array}{l}\text { F.2(e).5 Well screen } \\
\text { thickness }\end{array}$ & $15 \mathrm{~m}$ per Track 2 guidance & $12 \mathrm{~m}$ & $12 \mathrm{~m}$ & $12 \mathrm{~m}$ & $\begin{array}{l}100 \mathrm{~m} \text { receptor: } 12 \mathrm{~m} \text { (Seitz } \\
1991) ; \text { site boundary } \\
\text { receptor: } 76 \mathrm{~m} \text { (Robertson } \\
\text { 1974) }\end{array}$ & $15 \mathrm{~m}$ & $\begin{array}{l}\text { ALLW non- } \\
\text { conservative } \\
\text { (25\% higher) } \\
\text { than most } \\
\text { others }\end{array}$ & $\begin{array}{l}\text { Spread small, } \\
\text { sensitivity } \\
\text { medium, } \\
\text { importance } 2 / 9\end{array}$ \\
\hline $\begin{array}{l}\text { F.2(e).6 Codes or } \\
\text { methodology used }\end{array}$ & $\begin{array}{l}\text { Analytical Green's function } \\
\text { solutions to the advection- } \\
\text { dispersion equation as } \\
\text { presented in Codell et al. } \\
(1982) \text { and implemented by } \\
\text { IT }\end{array}$ & $\begin{array}{l}\text { Analytical Green's } \\
\text { function solutions to } \\
\text { the advection- } \\
\text { dispersion equation as } \\
\text { presented in Codell et } \\
\text { al. (1982) and } \\
\text { implemented in } \\
\text { modified GWMOD }\end{array}$ & $\begin{array}{l}\text { Analytical Green's } \\
\text { function solutions to } \\
\text { the advection- } \\
\text { dispersion equation } \\
\text { as presented in } \\
\text { Codell et al. (1982) } \\
\text { and implemented in } \\
\text { modified GWMOD }\end{array}$ & $\begin{array}{l}\text { Analytical } \\
\text { Green's function } \\
\text { solutions to the } \\
\text { advection- } \\
\text { dispersion } \\
\text { equation as } \\
\text { presented in } \\
\text { Codell et al. } \\
\text { (1982) and } \\
\text { implemented in } \\
\text { GWSCREEN }\end{array}$ & $\begin{array}{l}\text { Analytical Green's function } \\
\text { solutions to the advection. } \\
\text { dispersion equation as } \\
\text { presented in Codell et al. } \\
(1982) \text { and implemented in } \\
\text { GWSCREEN }\end{array}$ & GWSCREEN & $\begin{array}{l}\text { Typical } \\
\text { approach }\end{array}$ & NA \\
\hline
\end{tabular}


Page H-24 of H-33

\begin{tabular}{|c|c|c|c|c|c|c|c|c|}
\hline $\begin{array}{c}\text { Parameter, assumption, } \\
\text { or process modeled }\end{array}$ & ALLW PA & $\begin{array}{c}\text { Concrete PA } \\
\text { (Maheras, et al. 1992) }\end{array}$ & $\begin{array}{c}\text { IEB PA } \\
(\operatorname{Rood} 1992)\end{array}$ & $\begin{array}{c}\text { IWPF PA } \\
\text { (Rood 1993) }\end{array}$ & $\begin{array}{c}\text { RWMC LLW } \\
\text { Radiological PA } \\
\text { (Maheras et al. 1994) }\end{array}$ & $\begin{array}{c}\text { Preliminary Sooping Risk } \\
\text { Assessment } \\
\text { (Loehr et al. 1994) }\end{array}$ & \begin{tabular}{|c|} 
Degree of \\
conservatism in \\
ALLW PA
\end{tabular} & $\begin{array}{c}\text { Spread, } \\
\text { sensitivity, and } \\
\text { importance }\end{array}$ \\
\hline \multicolumn{9}{|l|}{$\begin{array}{l}\text { F.3. AIR PATHWAY } \\
\text { DETAILS }\end{array}$} \\
\hline $\begin{array}{l}\text { F.3(a) Air pathways } \\
\text { addressed }\end{array}$ & \begin{tabular}{|l} 
Rn-222 emission from the \\
disposal facility; other air \\
pathways were not pursued \\
based on results from \\
RWMC PA
\end{tabular} & None & None & None & $\begin{array}{l}\text { Gaseous release of } \mathrm{H}-3 \text { and } \\
\mathrm{C}-14 \text {, and resuspension of } \\
\text { contaminated surface soil }\end{array}$ & Resuspension & $\begin{array}{l}\text { Consistent } \\
\text { approach } \\
\text { except for } \\
\text { RWMC PA } \\
\text { and PSRA } \\
\text { which } \\
\text { considered } \\
\text { limited air } \\
\text { pathway }\end{array}$ & Varies \\
\hline F.3(b) Code(s) used & $\begin{array}{l}\text { Flux of Rn-222 calculated } \\
\text { through analytical equation } \\
\text { cited in Case et al. (1990); } \\
\text { concentration of Rn at } \\
\text { receptor at the downwind } \\
\text { edge of the disposal facility } \\
\text { using the Eulerian box } \\
\text { model (EPA 1991) }\end{array}$ & $\mathrm{NA}$ & NA & NA & $\begin{array}{l}\text { GENII; source term for air } \\
\text { pathway derived from biotic } \\
\text { transport of waste to the } \\
\text { surface }\end{array}$ & $\begin{array}{l}\text { Methodology from DOE } \\
\text { (1993) }\end{array}$ & NA & NA \\
\hline \multicolumn{9}{|l|}{$\begin{array}{l}\text { F.4. BIOTRANSPORT } \\
\text { PATHWAY DETAILS }\end{array}$} \\
\hline $\begin{array}{l}\text { F.4(a) Pathways } \\
\text { addressed }\end{array}$ & No & No & No & No & Yes & $\begin{array}{l}\text { Burrowing animals and insects, } \\
\text { plant uptake, and animal } \\
\text { uptake }\end{array}$ & $\begin{array}{l}\text { Consistent } \\
\text { approach } \\
\text { except for } \\
\text { RWMC and } \\
\text { PSRA,which } \\
\text { considered } \\
\text { biotransport }\end{array}$ & Varies \\
\hline F.4(b) Code(s) used & NA & NA & NA & NA & Hand calculation & DOSTOMAN & $\overline{\mathrm{NA}}$ & NA \\
\hline F.4(c) Other & \begin{tabular}{|l|} 
No animal intrusion was \\
considered because the \\
depth of the waste \\
precludes animal intrusion
\end{tabular} & & & & $\begin{array}{l}\text { Transport by this pathway } \\
\text { was considered only for } \\
\text { some plant species; no } \\
\text { animal intrusion was } \\
\text { considered because the } \\
\text { depth to the waste precludes } \\
\text { intrusion by animals }\end{array}$ & & NA & NA \\
\hline \begin{tabular}{|l} 
F.5. EXPOSURE \\
ROUTE DETAILS
\end{tabular} & & & & & & & & \\
\hline
\end{tabular}


Page H-25 of H-33

\begin{tabular}{|c|c|c|c|c|c|c|c|c|}
\hline $\begin{array}{l}\text { Parameter, assumption, } \\
\text { or process modeled }\end{array}$ & ALLW PA & $\begin{array}{c}\text { Concrete PA } \\
\text { (Maheras, et al. 1992) }\end{array}$ & $\begin{array}{c}\text { IEB PA } \\
(\operatorname{Rood} 1992)\end{array}$ & $\begin{array}{c}\text { IWPF PA } \\
(\text { Rood 1993) }\end{array}$ & $\begin{array}{c}\text { RWMC LLW } \\
\text { Radiological PA } \\
\text { (Maheras et al. 1994) }\end{array}$ & $\begin{array}{c}\text { Preliminary Scoping Risk } \\
\text { Assessment } \\
\text { (Loehr et al. 1994) }\end{array}$ & $\begin{array}{c}\text { Degree of } \\
\text { conservatism in } \\
\text { ALLW PA }\end{array}$ & $\begin{array}{c}\text { Spread, } \\
\text { sensitivity, and } \\
\text { importance }\end{array}$ \\
\hline $\begin{array}{l}\text { F.5(a) Exposure } \\
\text { pathways }\end{array}$ & $\begin{array}{l}\text { Ingestion (groundwater, } \\
\text { crops, and animal } \\
\text { products) }\end{array}$ & $\begin{array}{l}\text { Groundwater } \\
\text { ingestion }\end{array}$ & $\begin{array}{l}\text { Groundwater } \\
\text { ingestion }\end{array}$ & $\begin{array}{l}\text { All pathways, } \\
\text { drinking water }\end{array}$ & $\begin{array}{l}\text { Inhalation, ingestion (direct } \\
\text { ingestion of groundwater } \\
\text { and all pathway), external } \\
\text { exposure }\end{array}$ & $\begin{array}{l}\text { Onsite future worker: fugitive } \\
\text { dust inhalation, soil ingestion, } \\
\text { dermal contact with soil, } \\
\text { external radiation exposure; } \\
\text { onsite future resident: fugitive } \\
\text { dust inhalation, soil ingestion, } \\
\text { groundwater ingestion, } \\
\text { ingestion of meat, dairy } \\
\text { products, and crops, dermal } \\
\text { contact with soil, and external } \\
\text { radiation exposure }\end{array}$ & $\begin{array}{l}\text { ALLW PA } \\
\text { considered } \\
\text { more pathways } \\
\text { than others } \\
\text { except for } \\
\text { RWMC PA } \\
\text { and PSRA }\end{array}$ & $\begin{array}{l}\text { Spread big, } \\
\text { sensitivity low, } \\
\text { importance } 3 / 9\end{array}$ \\
\hline $\begin{array}{l}\text { F.5(b) Shielding factor } \\
\text { for external exposure }\end{array}$ & NA & NA & NA & NA & $\begin{array}{l}\text { Two factors evaluated: } 0.7 \\
\text { and } 0.36 \text { based on NRC } \\
(1977) \text { and Konz et al. } \\
\text { (1989), respectively }\end{array}$ & $\begin{array}{l}\text { Used MicroShield } \mathbf{4} 4.0 \text {; no } \\
\text { shield other than soil cover; } \\
\text { factor not reported }\end{array}$ & NA & NA \\
\hline $\begin{array}{l}\text { F.5(c) Air immersion } \\
\text { assumptions }\end{array}$ & NA & NA & NA & NA & $\begin{array}{l}\text { Exposure to contaminated } \\
\text { air for } 1 \text { yr using above } \\
\text { shielding factors }\end{array}$ & NA & NA & NA \\
\hline F.5(d) Diet assumed & $\begin{array}{l}\text { Kennedy and Strenge } \\
\text { (1992) and Aaberg and } \\
\text { Kennedy (1990); GENII } \\
\text { default values of } 2 \mathrm{~L} / \mathrm{d}, 365 \\
\text { d/yr; } 25 \% \text { vegetables home- } \\
\text { grown }\end{array}$ & $\begin{array}{l}2 \mathrm{~L} / \mathrm{d}, 365 \mathrm{~d} / \mathrm{yr} \text { for } \\
\text { direct groundwater } \\
\text { ingestion }\end{array}$ & $\begin{array}{l}2 \mathrm{~L} / \mathrm{d}, 365 \mathrm{~d} / \mathrm{yr} \text { for } \\
\text { direct groundwater } \\
\text { ingestion }\end{array}$ & \begin{tabular}{|l|}
$0.7 \mathrm{~L} / \mathrm{d}$ water \\
ingestion rate, 18 \\
$\mathrm{~kg} / \mathrm{yr}$ leafy veg, \\
$112 \mathrm{~L} / \mathrm{yr}$ milk, 85 \\
$\mathrm{~kg} / \mathrm{yr}$ beef, and \\
$176 \mathrm{~kg} / \mathrm{yr}$ produce
\end{tabular} & $\begin{array}{l}\text { For the all-pathway analysis, } \\
\text { the diet was taken from } \\
\text { Yang and Nelson, NCRP, } \\
\text { Rupp, Ng, EPA, and some } \\
\text { site-specific data; the water } \\
\text { ingestion rate was } 0.7 \mathrm{~L} / \mathrm{d} \text {, } \\
\text { beef ingestion was } 85 \mathrm{~kg} / \mathrm{yr} \text {, } \\
\text { milk ingestion was } 0.3 \mathrm{~L} / \mathrm{d} \text {, } \\
\text { produce ingestion was } 176 \\
\text { kg/yr and leafy vegetables } \\
\text { consumption was } 18 \mathrm{~kg} / \mathrm{yr} \text {; } \\
70 \% \text { vegetables home-grown }\end{array}$ & $\begin{array}{l}\text { Soil ingestion: resident adult } \\
100 \mathrm{mg} / \mathrm{d} \text {, resident child } \\
200 \mathrm{mg} / \mathrm{d} \text {, worker } 50 \mathrm{mg} / \mathrm{yr} ; \\
\text { water ingestion: resident } 2 \mathrm{~L} / \mathrm{d} \text {, } \\
\text { worker none; beef/dairy } \\
\text { ingestion: resident } 75 \mathrm{~g} / \mathrm{d} \text { beef } \\
\text { and } 300 \mathrm{~g} / \mathrm{d} \text { dairy, worker } \\
\text { none; crops ingestion: resident } \\
122 \mathrm{~g} / \mathrm{d} \text {, worker none }\end{array}$ & \begin{tabular}{|l} 
More \\
conservative \\
than IWPF and \\
RWMC PAs
\end{tabular} & $\begin{array}{l}\text { Spread } \\
\text { medium, } \\
\text { sensitivity } \\
\text { medium, } \\
\text { importance } 4 / 9\end{array}$ \\
\hline F.S(e) Code(s) used & $\begin{array}{l}\text { DITTY code of the GENII } \\
\text { Package }\end{array}$ & Spread sheet & Spread sheet & $\begin{array}{l}\text { Spread sheet to } \\
\text { calculate an } \\
\text { equivalent water } \\
\text { ingestion rate; } \\
\text { dose calculation } \\
\text { performed in } \\
\text { GWSCREEN }\end{array}$ & $\begin{array}{l}\text { Spread sheet calculation for } \\
\text { all pathway analysis and } \\
\text { GENII for atmospheric dose } \\
\text { calculations }\end{array}$ & DOSTOMAN, GWPOST & $\begin{array}{l}\text { Appropriate } \\
\text { approach }\end{array}$ & NA \\
\hline $\begin{array}{l}\text { F.5(f) Dose conversion } \\
\text { factors }\end{array}$ & DOE/EH-0071 & DOE 1988 & DOE 1988 & DOE 1988 & DOE 1988 & BEIR V & $\begin{array}{l}\text { Appropriate } \\
\text { approach }\end{array}$ & NA \\
\hline $\begin{array}{l}\text { G. INTRUSION } \\
\text { SCENARIOS }\end{array}$ & & & & & & & & \\
\hline
\end{tabular}




\begin{tabular}{|c|c|c|c|c|c|c|c|c|}
\hline 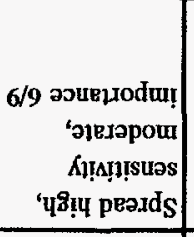 & 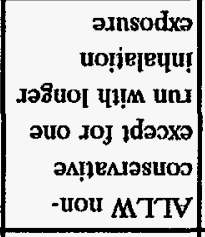 & $\mathbf{V N}$ & 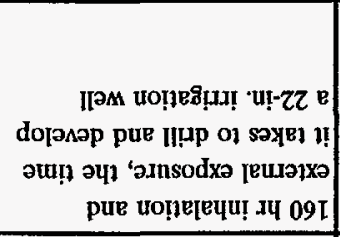 & $\mathbf{V N}$ & 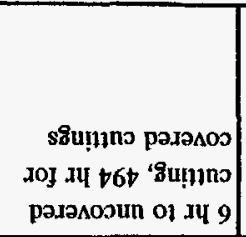 & 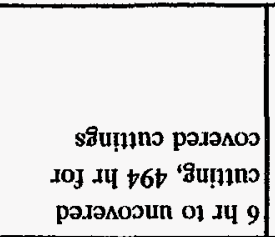 & 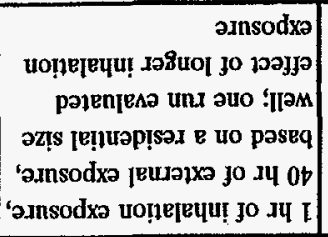 & $\begin{array}{r}\text { ajnsodxə } \\
\text { jo uoṭemnd (p) } z: 0 \\
\end{array}$ \\
\hline 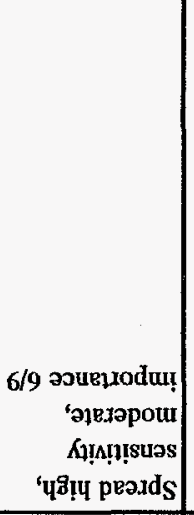 & 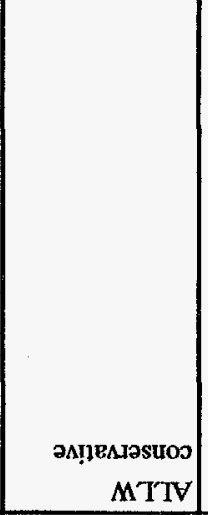 & $\mathbf{V N}$ & 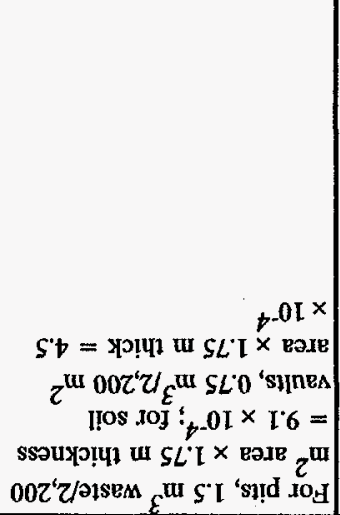 & $\mathrm{VN}$ & $\varepsilon \mathrm{II} 0^{\circ}$ & 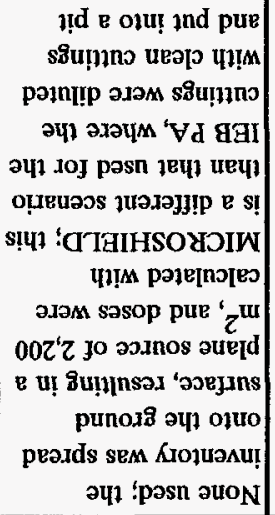 & $t I 9^{\circ} 0=\left(t \varepsilon^{\circ} 0+t S^{\circ} 0\right) / t s^{\circ} 0$ & Jołoej uonm!!̣ (o) 20 \\
\hline 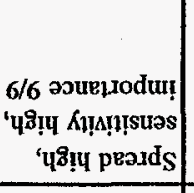 & 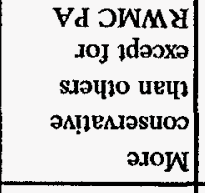 & $\mathrm{VN}$ & 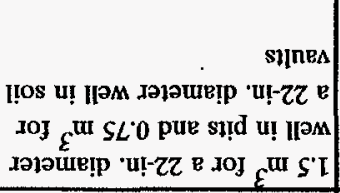 & $\mathbf{V N}$ & 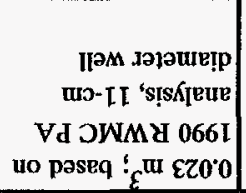 & 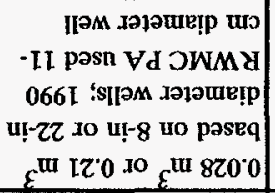 & 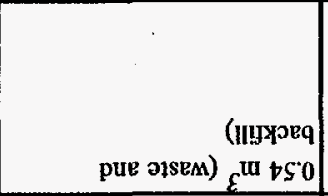 & 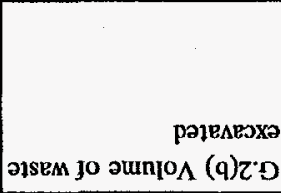 \\
\hline \multirow[t]{2}{*}{ 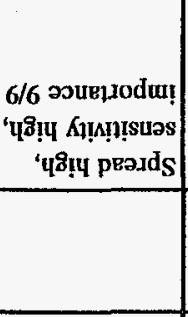 } & 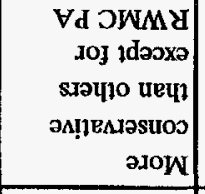 & $\forall N$ & $\varepsilon^{\mathrm{w} / \mathrm{B}} \varepsilon^{-0 I \times I}$ & $\mathrm{VN}$ & 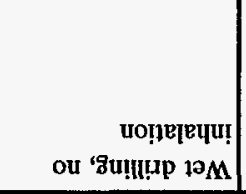 & 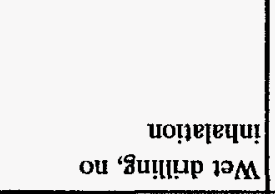 & $\varepsilon^{\mathrm{w} / \mathrm{s}}, 0 \mathrm{pl} \times 0 \mathrm{0l}$ & Su!peol isna (B)zo \\
\hline & & & & & & & & 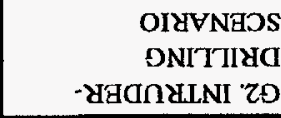 \\
\hline \multirow[t]{2}{*}{ 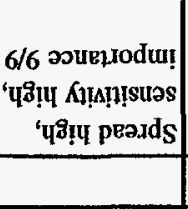 } & 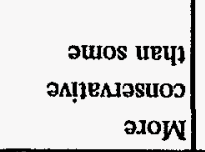 & aroN & 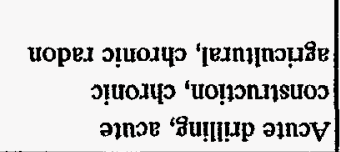 & auoN & 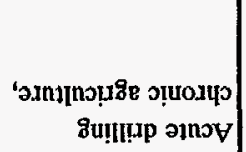 & 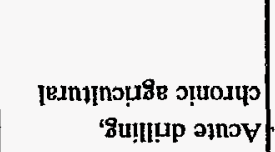 & 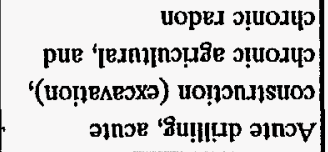 & 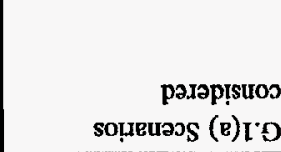 \\
\hline & & & & & & & & TVYango I.0 \\
\hline 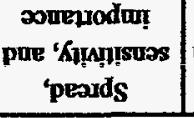 & $\begin{array}{c}\text { Vd MTTV } \\
\text { घ! ustpentasuos } \\
\text { jo əafora }\end{array}$ & 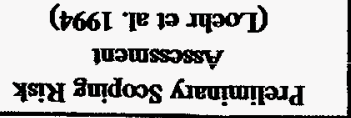 & 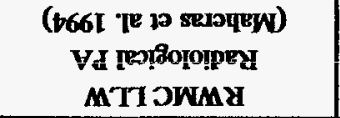 & $\begin{array}{l}\text { (E66I pooy) } \\
\text { VA IAAI }\end{array}$ & $\begin{array}{l}\text { (z66I pooy) } \\
\text { VA สभI }\end{array}$ & 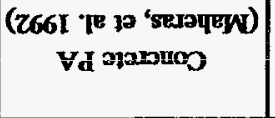 & Vd MTTV & 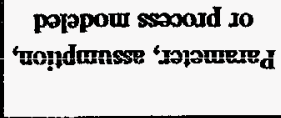 \\
\hline
\end{tabular}

$\varepsilon \varepsilon-H$ jo $92-H$ วิิอ d 
Page H-27 of H-33

\begin{tabular}{|c|c|c|c|c|c|c|c|c|}
\hline $\begin{array}{c}\text { Parameter, assumption, } \\
\text { or process modeled }\end{array}$ & ALLW PA & $\begin{array}{c}\text { Concrete PA } \\
\text { (Maheras, et al. 1992) }\end{array}$ & $\begin{array}{c}\text { IEB PA } \\
(\operatorname{Rood} 1992)\end{array}$ & $\begin{array}{c}\text { IWPF PA } \\
\text { (Rood 1993) }\end{array}$ & $\begin{array}{c}\text { RWMC LLW } \\
\text { Radiological PA } \\
\text { (Maheras et al. 1994) }\end{array}$ & $\begin{array}{c}\text { Preliminary Scoping Risk } \\
\text { Assessment } \\
\text { (Loehr et al. 1994) }\end{array}$ & \begin{tabular}{|c|} 
Degree of \\
conservatism in \\
ALLW PA
\end{tabular} & $\begin{array}{c}\text { Spread, } \\
\text { sensitivity, and } \\
\text { importance }\end{array}$ \\
\hline $\begin{array}{l}\text { G.2(e) Time of } \\
\text { intrusion }\end{array}$ & $\begin{array}{l}100 \mathrm{yr} \text { after disposal } \\
\text { facility closure for most } \\
\text { runs; also explored times } \\
\text { up to } 1,000,000 \mathrm{yr}\end{array}$ & $100 \mathrm{yr}$ & $100 \mathrm{yr}$ & NA & $\begin{array}{l}\text { The intruder may enter the } \\
\text { site any time after } \\
\text { institutional control; peak } \\
\text { was not at } 100 \mathrm{yr}\end{array}$ & NA & \begin{tabular}{|l|} 
Consistent \\
approach taken
\end{tabular} & $\overline{\mathrm{NA}}$ \\
\hline G.2(f) Code(s) used & GENII & MICROSHIELD & $\begin{array}{l}\text { PATHRAE and } \\
\text { MICROSHIELD }\end{array}$ & NA & $\begin{array}{l}\text { MICROSHIELD and } \\
\text { GENII }\end{array}$ & NA & \begin{tabular}{|l|} 
Range of \\
common codes \\
used
\end{tabular} & $\overline{\mathrm{NA}}$ \\
\hline G.2(g) Other & & & & NA & $\begin{array}{l}\text { This analysis is similar to } \\
\text { the concrete performance } \\
\text { assessment and differs from } \\
\text { the IEB PA; the major } \\
\text { difference is in how the } \\
\text { cuttings are dealt with; in } \\
\text { the IEB PA, a mud pit was } \\
\text { assumed; in later analysis, it } \\
\text { was found that drillers in the } \\
\text { local area do not use mud } \\
\text { pits, but spread the cuttings } \\
\text { out over the area }\end{array}$ & NA & NA & $\overline{\mathrm{NA}}$ \\
\hline $\begin{array}{l}\text { G.3. INTRUDER- } \\
\text { EXCAVATION } \\
\text { SCENARIO }\end{array}$ & & $\begin{array}{l}\text { The intruder } \\
\text { excavation scenario } \\
\text { was not evaluated } \\
\text { because the intruder } \\
\text { could not penetrate } \\
\text { the waste; therefore, } \\
\text { no doses from dust } \\
\text { inhalation could be } \\
\text { calculated }\end{array}$ & & & & & & \\
\hline G.3(a) Dust loading & $5.0 \times 10^{-3} \mathrm{~g} / \mathrm{m}^{3}$ & $\mathrm{NA}$ & $\mathrm{NA}$ & NA & $1 \times 10^{-3} \mathrm{~g} / \mathrm{m}^{3}$ & NA & \begin{tabular}{|l} 
More \\
conservative \\
than RWMC \\
PA
\end{tabular} & $\begin{array}{l}\text { Spread } \\
\text { medium, } \\
\text { sensitivity high, } \\
\text { importance 6/9 }\end{array}$ \\
\hline $\begin{array}{l}\text { G.3(b) Volume of waste } \\
\text { excavated }\end{array}$ & $\begin{array}{l}100 \mathrm{~m}^{3} \text { (waste and } \\
\text { backfill) of which } 75 \mathrm{~m}^{3} \\
\text { are waste }\end{array}$ & NA & NA & $\overline{N A}$ & $\begin{array}{l}60 \mathrm{~m}^{3} \text { (at the time of } \\
\text { maximum erosion, } 2.4 \mathrm{~m} \text { of } \\
\text { cover remain; therefore, } 0.6 \\
\mathrm{~m} \text { of waste is brought to the } \\
\text { surface) }\end{array}$ & NA & $\begin{array}{l}\text { Different } \\
\text { scenarios } \\
\text { considered }\end{array}$ & $\begin{array}{l}\text { Spread } \\
\text { medium, } \\
\text { sensitivity high, } \\
\text { importance } 6 / 9\end{array}$ \\
\hline
\end{tabular}


Page H-28 of H-33

\begin{tabular}{|c|c|c|c|c|c|c|c|c|}
\hline $\begin{array}{l}\text { Parameter, assumption, } \\
\text { or process modeled }\end{array}$ & ALLW PA & $\begin{array}{c}\text { Concrete PA } \\
\text { (Maheras, et al. 1992) }\end{array}$ & $\begin{array}{c}\text { IEB PA } \\
\text { (Rood 1992) }\end{array}$ & $\begin{array}{c}\text { IWPF PA } \\
\text { (Rood 1993) }\end{array}$ & $\begin{array}{c}\text { RWMC LLW } \\
\text { Radiological PA } \\
\text { (Maheras et al. 1994) }\end{array}$ & $\begin{array}{c}\text { Preliminary Sooping Risk } \\
\text { Assessment } \\
\text { (Loehr et al. 1994) }\end{array}$ & $\begin{array}{c}\text { Degree of } \\
\text { conservatism in } \\
\text { ALLW PA }\end{array}$ & $\begin{array}{c}\text { Spread, } \\
\text { sensitivity, and } \\
\text { importanoe }\end{array}$ \\
\hline G.3(c) Dilution factor & $\begin{array}{l}\left(75 \mathrm{~m}^{3} \text { waste }\right) /\left(100 \mathrm{~m}^{3}\right. \\
\text { waste and backfill }+ \\
\left.152 \mathrm{~m}^{3} \text { soil }\right)=0.298\end{array}$ & NA & NA & NA & $\begin{array}{l}\text { This factor was not used; } \\
\text { the intruder is exposed to } \\
\text { contaminated dust during } \\
\text { basement excavation and } \\
\text { extemal exposure from the } \\
\text { waste exposed at the base of } \\
\text { the basement }\end{array}$ & NA & NA & NA \\
\hline $\begin{array}{l}\text { G.3(d) Duration of } \\
\text { exposure }\end{array}$ & $80 \mathrm{hr}$ & NA & NA & NA & $64 \mathrm{hr}$ & NA & $\begin{array}{l}\text { ALLW more } \\
\text { conservative } \\
\text { than RWMC } \\
\text { PA }\end{array}$ & \begin{tabular}{|l|} 
Spread small, \\
sensitivity \\
medium, \\
importance 2/9
\end{tabular} \\
\hline $\begin{array}{l}\text { G.3(e) Time of } \\
\text { intrusion }\end{array}$ & $\begin{array}{l}500 \mathrm{yr} \text { after disposal } \\
\text { facility closure for most } \\
\text { runs; also explored times } \\
\text { up to } 1,000,000 \mathrm{yr}\end{array}$ & NA & NA & NA & $\begin{array}{l}\text { Maximum doses were } \\
\text { predicted to occur at } 10^{6} \mathrm{yr} \\
\text { from U-238 decay chain; } \\
\text { protective cover assumed to } \\
\text { last 3,000 yr }\end{array}$ & NA & \begin{tabular}{|l|} 
Consistent \\
approach taken
\end{tabular} & $\begin{array}{l}\text { Spread high, } \\
\text { sensitivity high, } \\
\text { importance 9/9 }\end{array}$ \\
\hline G.3(f) Code(s) used & GENII & NA & NA & NA & $\begin{array}{l}\text { MICROSHIELD for } \\
\text { external exposure; GENII } \\
\text { for inhalation doses }\end{array}$ & NA & $\begin{array}{l}\text { Appropriate } \\
\text { codes used }\end{array}$ & NA \\
\hline
\end{tabular}


Page H-29 of H-33

\begin{tabular}{|c|c|c|c|c|c|c|c|c|}
\hline $\begin{array}{c}\text { Parameter, assumption, } \\
\text { or process modeled }\end{array}$ & ALLW PA & $\begin{array}{c}\text { Concrete PA } \\
\text { (Maheras, et al. 1992) }\end{array}$ & $\begin{array}{c}\text { IBB PA } \\
(\operatorname{Rood} 1992)\end{array}$ & $\begin{array}{c}\text { IWPF PA } \\
(\operatorname{Rood~1993)}\end{array}$ & $\begin{array}{c}\text { RWMC LLW } \\
\text { Radiological PA } \\
\text { (Maheras et al. 1994) }\end{array}$ & $\begin{array}{c}\text { Preliminary Sooping Risk } \\
\text { Assessment } \\
\text { (Loehr et al. 1994) }\end{array}$ & $\begin{array}{c}\text { Degree of } \\
\text { conservatism in } \\
\text { AIXW PA }\end{array}$ & $\begin{array}{c}\text { Spread, } \\
\text { sensitivity, and } \\
\text { importance }\end{array}$ \\
\hline \multicolumn{9}{|l|}{$\begin{array}{l}\text { G.4. INTRUDER- } \\
\text { AGRICULTURAL } \\
\text { SCENARIO }\end{array}$} \\
\hline $\begin{array}{l}\text { G.4(a) Scenario } \\
\text { description }\end{array}$ & $\begin{array}{l}\text { Intrusion was assumed to } \\
\text { occur at } 100 \mathrm{yr} \text { (drilling) } \\
\text { and } 500 \mathrm{yr} \text { (excavation); } \\
\text { drill cuttings or excavation } \\
\text { materials are mixed with } \\
\text { soil used for crops; crops } \\
\text { are consumed by farmer } \\
\text { and livestock; farmer } \\
\text { consumes water, } \\
\text { contaminated crops, and } \\
\text { animal products; intrusion } \\
\text { times up to } 1,000,000 \mathrm{yr} \\
\text { were explored }\end{array}$ & $\begin{array}{l}\text { Contaminated drill } \\
\text { cuttings were spread } \\
\text { over the intrusion } \\
\text { site; no waste from } \\
\text { basement excavation } \\
\text { was considered }\end{array}$ & $\begin{array}{l}\text { Contaminated } \\
\text { cuttings are spread } \\
\text { over the intrusion } \\
\text { site; no waste from } \\
\text { basement excavation } \\
\text { was considered }\end{array}$ & NA & $\begin{array}{l}\text { The intruder drills a well } \\
\text { and spreads cuttings over a } \\
2,200-\mathrm{m}^{2} \text { area and mixed in } \\
\text { soil to a depth of } 0.75 \mathrm{~m} \\
\text { where crops are grown; in } \\
\text { addition, a home is } \\
\text { constructed, and the waste } \\
\text { brought to the surface } \\
\text { during basement excavation } \\
\text { is also spread out on the } \\
\text { agriculture field }\end{array}$ & NA & $\begin{array}{l}\text { ALLW PA } \\
\text { more } \\
\text { conservative } \\
\text { than all except } \\
\text { RWMC PA }\end{array}$ & $\begin{array}{l}\text { Spread high, } \\
\text { sensitivity high, } \\
\text { importance } 9 / 9\end{array}$ \\
\hline G.4(b) Dust loading & $1.0 \times 10^{-4} \mathrm{~g} / \mathrm{m}^{3}$ & $\begin{array}{l}5.53 \times 10^{-5} \mathrm{~g} / \mathrm{m}^{3} \\
\text { (weighted average) }\end{array}$ & $\begin{array}{l}5.53 \times 10^{-5} \mathrm{~g} / \mathrm{m}^{3} \\
\text { (weighted average) }\end{array}$ & NA & $\begin{array}{l}5 \times 10^{-5} \mathrm{~g} / \mathrm{m}^{3} ; \text { this is a } \\
\text { weighted average for } \\
\text { different field activities }\end{array}$ & NA & $\begin{array}{l}\text { ALLW } \\
\text { conservative }\end{array}$ & $\begin{array}{l}\text { Spread low } \\
\text { sensitivity high, } \\
\text { importance } 3 / 9\end{array}$ \\
\hline $\begin{array}{l}\text { G.4(c) Volume of waste } \\
\text { excavated }\end{array}$ & $\begin{array}{l}0.34 \mathrm{~m}^{3} \text { for drilling- } \\
\text { agricultural scenario (100 } \\
\text { yr) and } 100 \mathrm{~m}^{3} \text { for } \\
\text { excavation-agricultural } \\
\text { scenario }\end{array}$ & $\begin{array}{l}0.028 \mathrm{~m}^{3} \text { (8-in. well) } \\
\text { and } 0.21 \mathrm{~m}^{3} \text { (22-in. } \\
\text { well) }\end{array}$ & $0.023 \mathrm{~m}^{3}$ & NA & $\begin{array}{l}0.2 \mathrm{~m}^{3} \text { from well drilling } \\
\text { and } 60 \mathrm{~m}^{3} \text { from basement } \\
\text { excavation }\end{array}$ & NA & $\begin{array}{l}\text { ALLW PA } \\
\text { more } \\
\text { conservative } \\
\text { than all except } \\
\text { RWMC PA }\end{array}$ & $\begin{array}{l}\text { Spread high, } \\
\text { sensitivity high, } \\
\text { importance } 9 / 9\end{array}$ \\
\hline G.4(d) Dilution factor & $\begin{array}{l}0.34 /(375+0.34)=9.06 \times \\
10^{-4}\end{array}$ & $6.1 \times 10^{-4}$ & $1.15 \times 10^{-5}$ & NA & $\begin{array}{l}\text { The waste was spread out on } \\
\text { a } 2,200-\mathrm{m}^{2} \text { lot and mixed to } \\
\text { a depth of } 0.75 \mathrm{~m} \text {; therefore, } \\
\text { the dilution factor is } 0.036\end{array}$ & NA & $\begin{array}{l}\text { Wide range of } \\
\text { values used; } \\
\text { ALLW PA in } \\
\text { middle of range }\end{array}$ & $\begin{array}{l}\text { Spread high, } \\
\text { sensitivity high, } \\
\text { importance } 9 / 9\end{array}$ \\
\hline $\begin{array}{l}\text { G.4(e) Groundwater } \\
\text { included }(y / n)\end{array}$ & No & No & No & NA & $\begin{array}{l}\text { Yes, used all pathway doses } \\
\text { at selected times }\end{array}$ & NA & $\begin{array}{l}\text { ALLW PA } \\
\text { same as most } \\
\text { others but less } \\
\text { conservative } \\
\text { than RWMC } \\
\text { PA }\end{array}$ & \begin{tabular}{|l} 
Spread \\
medium, \\
sensitivity \\
medium, \\
importance $6 / 9$
\end{tabular} \\
\hline G.4(f) Code(s) used & $\begin{array}{l}\text { GENII was used to } \\
\text { calculate doses from } \\
\text { ingestion, inhalation, and } \\
\text { external exposure }\end{array}$ & $\begin{array}{l}\text { GENII was used to } \\
\text { calculate ingestion } \\
\text { doses; } \\
\text { MICROSHIELD was } \\
\text { used to calculate } \\
\text { external exposure }\end{array}$ & $\begin{array}{l}\text { PATHRAE, } \\
\text { MICROSHIELD }\end{array}$ & NA & $\begin{array}{l}\text { GENII for inhalation and } \\
\text { ingestion, MICROSHIELD } \\
\text { for external exposure }\end{array}$ & NA & $\begin{array}{l}\text { Appropriate } \\
\text { codes used } \\
\end{array}$ & NA \\
\hline
\end{tabular}


Page H-30 of H-33

\begin{tabular}{|c|c|c|c|c|c|c|c|c|}
\hline $\begin{array}{c}\text { Parameter, assumption, } \\
\text { or prooess modeled }\end{array}$ & ALLW PA & $\begin{array}{c}\text { Concrete PA } \\
\text { (Maheras, et al. 1992) }\end{array}$ & $\begin{array}{c}\text { mB PA } \\
(\operatorname{Rood} 1992)\end{array}$ & $\begin{array}{c}\text { IWPF PA } \\
\text { (Rood 1993) }\end{array}$ & $\begin{array}{c}\text { RWMC LLW } \\
\text { Radioiogical PA } \\
\text { (Maheras et al. 1994) }\end{array}$ & $\begin{array}{c}\text { Preliminary Scoping Risk } \\
\text { Assessment } \\
\text { (Lochr et al. 1994) }\end{array}$ & $\begin{array}{c}\text { Degree of } \\
\text { conservatism in } \\
\text { ALLW PA }\end{array}$ & \begin{tabular}{|c|} 
Spread, \\
sensitivity, and \\
importance
\end{tabular} \\
\hline G.4(g) Other & & \begin{tabular}{|l|} 
The intruder \\
agriculture dose was \\
based on two \\
different diets, one \\
from Yang and \\
Nelson and the other \\
from Rupp; two \\
different inhalation \\
rates were also \\
considered
\end{tabular} & & & & & NA & NA \\
\hline $\begin{array}{l}\text { G.5. RADON } \\
\text { EXPOSURE } \\
\text { SCENARIO }\end{array}$ & & None & None & NA & & NA & & \\
\hline $\begin{array}{l}\begin{array}{l}\text { G.S(a) Diffusion } \\
\text { coefficient }\end{array} \\
\end{array}$ & $\begin{array}{l}2.5 \times 10^{-4} \mathrm{~m}^{2} / \mathrm{s} \text { in cover } \\
2.5 \times 10^{-8} \mathrm{~m}^{2} / \mathrm{s} \text { in } \\
\text { foundation }\end{array}$ & $\mathrm{NA}$ & NA & NA & $\begin{array}{l}2.5 \times 10^{-8} \mathrm{~m}^{2} / \mathrm{s} \text { in } \\
\text { foundation }\end{array}$ & $\mathrm{NA}$ & NA & $\mathrm{NA}$ \\
\hline $\begin{array}{l}\text { G.5(b) Emanation } \\
\text { coefficient }\end{array}$ & 0.17 & $\widehat{\mathrm{NA}}$ & NA & NA & 0.17 & NA & $\begin{array}{l}\text { Typical value } \\
\text { used }\end{array}$ & \begin{tabular}{|l|} 
Spread low, \\
sensitivity \\
medium, \\
importance $2 / 9$
\end{tabular} \\
\hline \begin{tabular}{|l|} 
G.S(c) Distance from \\
bottom of basement to \\
top of waste
\end{tabular} & $0.3 \mathrm{~m}$ & $\overline{\mathrm{NA}}$ & NA & NA & $\begin{array}{l}0 \mathrm{~m} \text { for pits; } 0.3 \mathrm{~m} \text { for soil } \\
\text { vaults }\end{array}$ & NA & $\begin{array}{l}\text { ALLW less } \\
\text { conservative } \\
\text { than RWMC } \\
\text { PA }\end{array}$ & $\begin{array}{l}\text { Spread } \\
\text { moderate, } \\
\text { sensitivity } \\
\text { moderate, } \\
\text { importance } 4 / 9\end{array}$ \\
\hline $\begin{array}{l}\text { G.5(d) Dose conversion } \\
\text { method }\end{array}$ & $\begin{array}{l}\text { Methodology used in } \\
\text { RESRAD; used definition } \\
\text { of working levels per } \\
\text { Radiological Health } \\
\text { Handbook and multiplied } \\
\text { by exposure time for dose } \\
\text { to receptor; overall dose } \\
\text { conversion was } 1 \mathrm{pCi} / \mathrm{L}= \\
130 \mathrm{mrem} / \mathrm{yr}\end{array}$ & $\mathrm{NA}$ & NA & NA & \begin{tabular}{|l|} 
Methodology used in \\
RESRAD; used definition \\
of working levels per \\
Radiological Health \\
Handbook and multiplied by \\
exposure time for dose to \\
receptor; overall dose \\
conversion was 1pCi/L = \\
$130 \mathrm{mrem} / \mathrm{yr}$
\end{tabular} & NA & $\begin{array}{l}\text { Methods not } \\
\text { comparable } \\
\text { especially since } \\
\text { ALLW did not } \\
\text { calculate dose }\end{array}$ & $\begin{array}{l}\text { Spread large, } \\
\text { sensitivity } \\
\text { moderate, } \\
\text { importance 6/9 }\end{array}$ \\
\hline G.5(e) Code(s) used & RESRAD & NA & NA & NA & RESRAD & NA & NA & NA \\
\hline
\end{tabular}


Page H-31 of H-33

\begin{tabular}{|c|c|c|c|c|c|c|c|c|}
\hline $\begin{array}{l}\text { Parameter, assumption, } \\
\text { or process modeled }\end{array}$ & ALLW PA & $\begin{array}{c}\text { Concrete PA } \\
\text { (Maheras, et al. 1992) } \\
\end{array}$ & $\begin{array}{c}\text { IBB PA } \\
(\operatorname{Rood} 1992) \\
\end{array}$ & $\begin{array}{c}\text { IWPF PA } \\
(\operatorname{Rood} 1993)\end{array}$ & $\begin{array}{c}\text { RWMC LLW } \\
\text { Radiological PA } \\
\text { (Maheras et al. 1994) }\end{array}$ & $\begin{array}{c}\text { Preliminary Scoping Risk } \\
\text { Assessment } \\
\text { (Lochr et al. 1994) }\end{array}$ & $\begin{array}{c}\text { Degree of } \\
\text { conservatism in } \\
\text { ALLW PA }\end{array}$ & $\begin{array}{c}\text { Spread, } \\
\text { sensitivity, and } \\
\text { importance }\end{array}$ \\
\hline $\begin{array}{l}\text { H. REGULATORY } \\
\text { STANDARDS USED } \\
\text { TO COMPARE } \\
\text { CALCULATED } \\
\text { DOSES }\end{array}$ & $\begin{array}{l}\text { Performance was measured } \\
\text { against DOE Order } \\
5820.2 \mathrm{~A} \text { for all-pathway } \\
\text { analysis and } 40 \text { CFR } 141 \\
\text { (or DOE Order } 5400.5 \text { ) } \\
\text { for drinking water } \\
\text { standards }\end{array}$ & $\begin{array}{l}\text { Performance was } \\
\text { measured against } \\
\text { DOE Order } 5820.2 \mathrm{~A} \\
\text { for all-pathway } \\
\text { analysis and } 40 \mathrm{CFR} \\
141 \text { (or DOE Order } \\
5400.5 \text { ) for drinking } \\
\text { water standards }\end{array}$ & $\begin{array}{l}\text { Performance was } \\
\text { measured against } \\
\text { DOE Order } \\
5820.2 \mathrm{~A} \text { for all- } \\
\text { pathway analysis and } \\
40 \text { CFR } 141 \text { (or } \\
\text { DOE Order } 5400.5 \text { ) } \\
\text { for drinking water } \\
\text { standards }\end{array}$ & $\begin{array}{l}\text { Performance was } \\
\text { measured against } \\
\text { DOE Order } \\
5820.2 A \text { for all- } \\
\text { pathway analysis } \\
\text { and } 40 \text { CFR } 141 \\
\text { (or DOE Order } \\
5400.5 \text { ) for } \\
\text { drinking water } \\
\text { standards }\end{array}$ & $\begin{array}{l}\text { Performance was measured } \\
\text { against DOE Order } 5820.2 \mathrm{~A} \\
\text { for all-pathway analysis and } \\
40 \mathrm{CFR} 141 \text { (or DOE } \\
\text { Order } 5400.5 \text { ) for drinking } \\
\text { water standards }\end{array}$ & $\begin{array}{l}\text { Carcinogenic risks are } \\
\text { compared to the National } \\
\text { Contingency Plan target range } \\
\text { of } 10^{-4} \text { to } 10^{-6} \text {; } \\
\text { noncarcinogenic risks are } \\
\text { evaluated using the Hazard } \\
\text { Index (HI); if the HI for a } \\
\text { contaminant is }>1 \text {, then there } \\
\text { may be concern for potential } \\
\text { adverse health effects }\end{array}$ & $\begin{array}{l}\text { Performance } \\
\text { was compared } \\
\text { against } \\
\text { appropriate } \\
\text { regulatory } \\
\text { standards }\end{array}$ & NA \\
\hline I. RESULTS & & $\begin{array}{l}\mathrm{Pu}-239 \text {, and Am-241 } \\
\text { were the primary } \\
\text { nuclides in the } \\
\text { intruder analysis, max } \\
\text { dose=from } 64 \text { to } 82 \\
\text { mrem/y (intruder } \\
\text { agriculture) at } 100 \mathrm{yr} ; \\
\text { Cs-137 contributed } \\
\text { about } 4 \% \text { in the form } \\
\text { of external exposure }\end{array}$ & $\begin{array}{l}\text { Maximum intruder } \\
\text { dose was for Am- } \\
241 \text { ( } 4.9 \text { mrem) for } \\
\text { the agriculture } \\
\text { scenario at } 100 \mathrm{yr}\end{array}$ & & & ' & & ' \\
\hline
\end{tabular}


Page H-32 of H-33

\begin{tabular}{|c|c|c|c|c|c|c|c|c|}
\hline $\begin{array}{l}\text { Paramctcr, assumption, } \\
\text { or process modeled }\end{array}$ & ALLW PA & $\begin{array}{c}\text { Concrete PA } \\
\text { (Maheras, et al. 1992) } \\
\end{array}$ & $\begin{array}{c}\text { IBB PA } \\
\text { (Rood 1992) }\end{array}$ & $\begin{array}{c}\text { FWPF PA } \\
(\text { Rood 1993) }\end{array}$ & $\begin{array}{c}\text { RWMC LLW } \\
\text { Radiologicai FA } \\
\text { (Maheras et al. 1994) }\end{array}$ & $\begin{array}{c}\text { Preliminary Sooping Risk } \\
\text { Assessment } \\
\text { (Loehr et al. 1994) }\end{array}$ & \begin{tabular}{|c|} 
Degree of \\
conservatism in \\
ALLW PA
\end{tabular} & $\begin{array}{c}\text { Spread, } \\
\text { sensitivity, and } \\
\text { importance }\end{array}$ \\
\hline \multicolumn{9}{|l|}{$\begin{array}{l}\text { I.1. UNDISTURBED- } \\
\text { WASTE SCENARIOS }\end{array}$} \\
\hline $\begin{array}{l}\text { I.1(a) Dominant } \\
\text { pathways }\end{array}$ & $\begin{array}{l}\text { Vadose zone - } \\
\text { groundwater (migration); } \\
\text { ingestion (exposure) }\end{array}$ & Groundwater & $\begin{array}{l}\text { Groundwater for } \\
\text { dose at time periods } \\
\text { greater than } 10,000 \\
\text { yr and intruder } \\
\text { agriculture for time } \\
\text { periods less than } \\
10,000 \text { yr }\end{array}$ & All pathway & $\begin{array}{l}\text { Groundwater, all pathway } \\
\text { scenario; max. dose after } \\
\text { institutional control at } 100 \\
\mathrm{~m} \text { south of the RWMC } \\
\text { boundary; max. all pathway } \\
\text { dose } 17 \text { mrem }\end{array}$ & $\begin{array}{l}\text { Ingestion of crops and } \\
\text { groundwater are most } \\
\text { important pathways }\end{array}$ & NA & NA \\
\hline $\begin{array}{l}\text { I.1(b) Dominant } \\
\text { radionuclides }\end{array}$ & Am-241 decay chain & $\begin{array}{l}\text { U-238 and Am-241; } \\
\text { maximum dose of } 150 \\
\text { mrem/y at } 7.4 \times 10^{5} \\
\text { yr (driven primarily } \\
\text { by daughter ingrowth) }\end{array}$ & $\begin{array}{l}\text { U-238 and Am-241 } \\
\text { (Np-237 progeny } \\
\text { the primary dose } \\
\text { contributor); } \\
\text { maximum dose of } \\
420 \text { mrem/y at } 7.2 \\
\times 10^{5} \text { yr (driven } \\
\text { primarily by } \\
\text { daughter ingrowth) }\end{array}$ & $\begin{array}{l}U-233 \text { and } \\
U-235 ; \text { dose of } \\
0.2 \text { mrem (U- } \\
233 \text { ) and } 0.6 \\
\text { mrem (U-235); } \\
\text { Np-237 was the } \\
\text { only nuclide to } \\
\text { arrive at the } \\
\text { receptor before } \\
10,000 \mathrm{yr}\end{array}$ & $\mathrm{C}-14, \mathrm{H}-3$ and $\mathrm{I}-129$ & $\begin{array}{l}\text { All pathways: } \mathrm{Sr}-90 \text { risk }>10^{-4} \text {; } \\
\text { Am-241, Cs-137, } \mathrm{Pu}-239, \mathrm{Pu}- \\
240, \mathrm{Ra}-226, \mathrm{U}-235 \text { risks are } \\
\text { between } 10^{-4} \text { and } 10^{-6} \text {; } \\
\text { groundwater: } \mathrm{Am}-241, \mathrm{C}-14 \text {, } \\
\mathrm{Ni}-59, \mathrm{~Np}-237, \mathrm{U}-234, \text { and } \mathrm{U} \text { - } \\
238 \text { risks are between } 10^{-4} \text { and } \\
10^{-6} \text {; U-238 } \mathrm{HI} \text { is } 0.1 \text { to } 1.0 ; \\
\text { nonradiological: risk }<10^{-6} \\
\text { and } \mathrm{HI}<1.0\end{array}$ & NA & NA \\
\hline $\begin{array}{l}\text { I.1(c) Important } \\
\text { parameters }\end{array}$ & $\begin{array}{l}\text { Radionuclide travel time in } \\
\text { the vadose zone (effective } \\
\mathrm{K}_{d} \text { values), TRU activity } \\
\text { loading, degradation of } \\
\text { FWF, distance to receptor } \\
\text { well }\end{array}$ & $\begin{array}{l}K_{d} \text { value in soils and } \\
\text { unsaturated zone; } \\
\text { this study indicates } \\
\text { that waste } \\
\text { containment does } \\
\text { very little to improve } \\
\text { the performance for } \\
\text { long-lived actinides; } \\
\text { the sorption } \\
\text { coefficient in the } \\
\text { unsaturated zone is } \\
\text { perhaps the most } \\
\text { important parameter } \\
\text { in addition to the } \\
\text { unsaturated zone flow } \\
\text { characteristics that } \\
\text { determine the travel } \\
\text { time of the nuclides }\end{array}$ & $\begin{array}{l}\mathrm{K}_{d} \text { value in soils } \\
\text { and unsaturated } \\
\text { zone; this study } \\
\text { indicates that waste } \\
\text { containment does } \\
\text { very little to } \\
\text { improve the } \\
\text { performance for } \\
\text { long-lived actinides; } \\
\text { the sorption } \\
\text { coefficient in the } \\
\text { unsaturated zone is } \\
\text { perhaps the most } \\
\text { important parameter } \\
\text { in addition to the } \\
\text { unsaturated zone } \\
\text { flow characteristics } \\
\text { that determine the } \\
\text { travel time of the } \\
\text { nuclides }\end{array}$ & $\begin{array}{l}\mathrm{K}_{d} \text { value and the } \\
\text { infiltration rate }\end{array}$ & $\begin{array}{l}\text { Leach rates of C-14 from } \\
\text { miscellaneous waste and } \\
\text { activated metals }\end{array}$ & $\begin{array}{l}\text { Release rate parameters, cover } \\
\text { thickness, infiltration rate, mass } \\
\text { of unknown radionuclides and } \\
\text { chemicals, synergistic effects of } \\
\text { contaminants, and land use } \\
\text { scenarios }\end{array}$ & NA & NA \\
\hline
\end{tabular}


Page H-33 of H-33

\begin{tabular}{|c|c|c|c|c|c|c|c|c|}
\hline $\begin{array}{l}\text { Parameter, assumption, } \\
\text { or process modeled }\end{array}$ & ALLW PA & $\begin{array}{c}\text { Concrete PA } \\
\text { (Maheras, et al. 1992) }\end{array}$ & $\begin{array}{c}\text { IEB PA } \\
\text { (Rood 1992) }\end{array}$ & $\begin{array}{c}\text { IWPF PA } \\
(\operatorname{Rood} 1993)\end{array}$ & $\begin{array}{c}\text { RWMC LLW } \\
\text { Radiological PA } \\
\text { (Maheras et al. 1994) }\end{array}$ & $\begin{array}{c}\text { Preliminary Sooping Risk } \\
\text { Assessment } \\
\text { (Lochr et al. 1994) }\end{array}$ & \begin{tabular}{|c|} 
Degree of \\
conservatism in \\
ALLW PA
\end{tabular} & $\begin{array}{c}\text { Spread, } \\
\text { sensitivity, and } \\
\text { importance }\end{array}$ \\
\hline \multicolumn{9}{|l|}{$\begin{array}{l}\text { I.2. INTRUDER } \\
\text { SCENARIOS }\end{array}$} \\
\hline $\begin{array}{l}\text { I.2(a) Dominant } \\
\text { pathways }\end{array}$ & $\begin{array}{l}\text { Inhalation for both acute } \\
\text { and chronic scenarios }\end{array}$ & \begin{tabular}{|l|} 
Intruder agriculture \\
scenario, inhalation \\
(Am-241) \\
groundwater ingestion \\
(U-238); for external \\
exposure, Cs-137 was \\
the dominant nuclide
\end{tabular} & \begin{tabular}{|l|} 
Intruder agriculture, \\
inhalation (Am-241) \\
and external \\
exposure (Cs-137)
\end{tabular} & NA & $\begin{array}{l}\text { External exposure in the soil } \\
\text { vault chronic intruder- } \\
\text { agriculture scenario was } \\
\text { primary pathway; second } \\
\text { most important pathway had } \\
\text { equal contributions from } \\
\text { inhalation and exposure } \\
\text { during the soil vault } \\
\text { scenario }\end{array}$ & None considered & NA & $\overline{\mathrm{NA}}$ \\
\hline $\begin{array}{l}\text { I.2(b) Dominant } \\
\text { radionuclides }\end{array}$ & $\begin{array}{l}\text { Cs-137 (acute), } \\
\text { Cs-137 and Am-241 } \\
\text { (chronic) }\end{array}$ & Am-241 and U-238 & \begin{tabular}{|l|} 
Am-241 and Cs-137 \\
(see above)
\end{tabular} & NA & \begin{tabular}{|l|} 
CS-137 for dominant \\
pathway; Cs-137 and Ni-63 \\
for second most important \\
pathway; U-238 decay chain \\
for waste in pits
\end{tabular} & NA & NA & $\overline{\mathrm{NA}}$ \\
\hline $\begin{array}{l}\text { I.2(c) Important } \\
\text { parameters }\end{array}$ & $\begin{array}{l}\text { Dust loading factor, TRU } \\
\text { activily loading, time of } \\
\text { human intrusion }\end{array}$ & $\begin{array}{l}\text { Well diameter, } \\
\text { assumed diet and } \\
\text { inhalation rate }\end{array}$ & \begin{tabular}{|l|} 
Dissolution rate of \\
IEB waste form, and \\
$\mathrm{K}_{d}$ values for \\
actinides
\end{tabular} & NA & $\begin{array}{l}\text { Exposure time for dominant } \\
\text { pathway; sensitivity analysis } \\
\text { performed only for } \\
\text { dominant pathway }\end{array}$ & NA & NA & $\mathrm{NA}$ \\
\hline I.2(d) Other & & & & & $\begin{array}{l}\text { If leaching (source } \\
\text { depletion) had been } \\
\text { considered, it would have } \\
\text { affected only the maximum } \\
\text { doses for the pits and not } \\
\text { the soil vaults; the } \\
\text { maximums for the soil vaults } \\
\text { occurred at the end of } \\
\text { institutional control, while } \\
\text { those for the pits occurred } \\
\text { at } 1 \times 10^{6} \mathrm{yr}\end{array}$ & NA & NA & $\mathbf{N A}$ \\
\hline
\end{tabular}

